DOMINGO HERNÁNDEZ SÁNCHEZ

\title{
ESTÉTICA DE LA LIMITACIÓN \\ LA RECEPCIÓN DE HEGEL POR ORTEGA Y GASSET
}

EDICIONES UNIVERSIDAD DE SALAMANCA 


\section{COLECCIÓN VITOR}

45

(C)

Ediciones Universidad de Salamanca

y Domingo Hernández Sánchez

$1^{a}$ edición: Junio 2000

I.S.B.N.: 84-7800-936-1

Depósito Legal: S. 469-2000

Ediciones Universidad de Salamanca

Apartado postal 325

E-37080 Salamanca (España)

Realización:

Nemática, S.L.

Impreso en España - Printed in Spain

Todos los derechos reservados. Ni la totalidad ni parte de este libro puede reproducirse ni transmitirse sin permiso escrito de

Ediciones Universidad de Salamanca

CEP. Servicio de Bibliotecas

HERNÁNDEZ SÁNCHEZ, Domingo

Estética de la limitación. La recepción de Hegel

por Ortega y Gasset / Domingo Hernández Sánchez. $1^{\text {a }}$ ed.--

Salamanca : Ediciones Universidad de Salamanca, 2000

1 disco compacto.-- (Colección Vítor ; 45)

Tesis-Universidad de Salamanca

1.Universidad de Salamanca (España)-

Tesis y disertaciones académicas.

2.Estética de la recepción. 3. Hegel,

Georg Wilhelm Friedrich-Estética

4. Ortega y Gasset, José- Crítica e interpretación

Hegel, Georg Wilhelm Friedrich (043.2)

Ortega y Gasset, José (043.2) 


\section{RESUMEN}

\section{ESTÉTICA DE LA LIMITACIÓN \\ LA RECEPCIÓN DE HEGEL POR ORTEGA Y GASSET}

\section{Domingo Hernández Sánchez}

El trabajo examina de modo detallado la recepción de Hegel por José Ortega y Gasset, acudiendo para ello no sólo a los textos de Ortega sobre Hegel, o al conjunto de las obras publicadas de Ortega, sino especialmente a las notas de trabajo inéditas que Ortega escribió sobre Hegel. Del mismo modo, y junto a ello, la investigación en la biblioteca personal de Ortega, presente en la "Fundación José Ortega y Gasset", permite configurar un análisis en el que la relación entre Hegel y Ortega se muestra como una creación asimiladora: Hegel es recibido por Ortega con unos fines particulares y muy definidos que remiten al conjunto de su filosofía. El trabajo, dividido en cuatro partes, y abarcando desde los primeros escritos de Ortega a comienzos de siglo hasta los textos de los años cincuenta, se encuentra guiado por una categoría concreta: la limitación. En la conjunción de la recepción de Hegel por Ortega y el análisis de los conceptos de límite y limitación en Ortega se configura una particular estética de la limitación. La estética de la limitación aparece como una dialéctica de superación de limitaciones que se constituye como una estética política. Se trata de mostrar al arte como constante superación de limitaciones, pero partiendo precisamente de esas limitaciones. Del mismo modo, la política, sea en la forma del paisaje, sea en la forma del proyecto de nación, sea en la temática de Europa, se define siempre en Ortega como la conjunción de realidades e ideales, de limitaciones y superación de limitaciones. 



\section{ABSTRACT \\ AESTHETICS OF LIMITATION \\ HEGEL'S RECEPTION BY ORTEGA Y GASSET}

Domingo Hernández Sánchez

The work thorougly examinates Hegel's reception by José Ortega y Gasset, exhaustively studying not only Ortega's texts on Hegel and the whole of Ortega's published works, but also unpublished manuscripts and work notes written by Ortega about Hegel's philosophy. Both these studies and, moreover, research in Ortega's personal library located in the "Fundación José Ortega y Gasset", brings about a number of conclusions regarding the philosophical relationship between Ortega and Hegel. In particular, it is shown how Hegel is creatively assimilated by Ortega to attain definite philosophical goals as to affect Ortega's thought as a whole. The work is divided in four parts throughout Ortega's work, from the first writings at the beginning of the century until his last ones in the fifties. There is also a central conceptual guide in the work: the category of limitation. Integrating Hegel's reception by Ortega with the analysis of the concepts of limit and limitation in Ortega's philosophy, a particular aesthetics of limitation is configured. The aesthetics of limitation shows itself as a dialectic of superation of limitations, a superation which becomes a political aesthetics. The issue is showing art as a constant superation of limitations, a superation which dialectically assumes such limitations. Ortega applies this dialectical scheme to politics, be it in the form of landscape, or in the form of a nation's project, or as the european problematic: policy is allways defined by Ortega as the integration of realities and ideals, as the integration of limitations and the superation of limitations. 



\section{ÍNDICE}

Introducción. Ortega y la recepción................................................. 11

Un título y una intención............................................................................ 11

Estética de la recepción........................................................................ 13

La recepción en Ortega: los clásicos ...................................................... 17

La recepción en Ortega: lectura y reviviscencia ......................................... 20

La recepción de Hegel por Ortega........................................................... 23

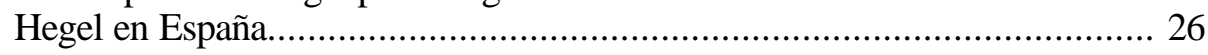

Recepción de la recepción: la estética de la limitación................................. 28

Objetivos y pretensiones ................................................................. 31

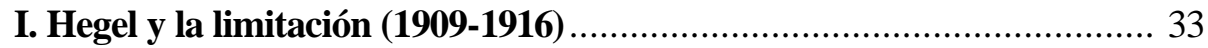

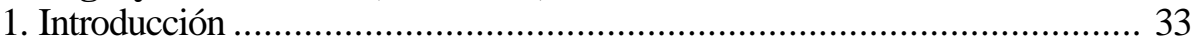

2. El liberalismo y la polémica con Maeztu ................................................ 41

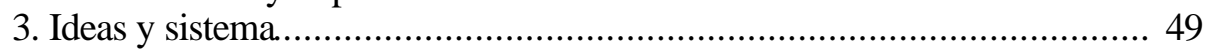

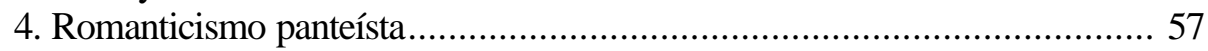

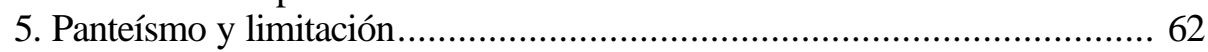

6. El respeto por el individuo: las pasiones ................................................ 68

7. La pedagogía social.......................................................................... 76

8. Mediterranismo y cultura fronteriza …............................................... 80

9. El nacionalismo y la degeneración del Volksgeist..................................... 91

10. El arte de las relaciones (1910-1912) .................................................. 100

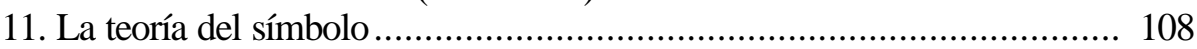

12. El paisaje y la limitación.................................................................... 119

12.1. El paisaje como percepturitio .................................................... 122

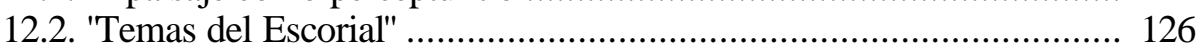

12.3. Perniciosa aproximación a Hegel...................................................... 133

12.4. Los dioses particulares.................................................................. 137

13. Límite, concepto y metáfora: Hegel y Ortega en 1914.......................... 142

13.1. Ortega y el prólogo a la Fenomenología del espíritu........................... 144

13.1.1. Límite y concepto........................................................................... 145

13.1.2. Tiempo de tránsito ................................................................. 150

13.2. El límite en Meditaciones del Quijote .......................................... 156

13.2.1. Superación de la limitación ........................................................... 157

13.2.2. El bosque: superficie y profundidad............................................... 161

13.2.3. La integración ............................................................................ 164

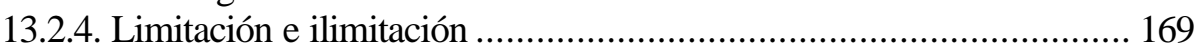

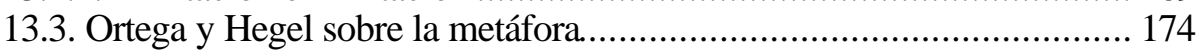

13.3.1. El 'Ensayo de estética". La metáfora en Ortega ............................. 175

13.3.2. La metáfora en Hegel................................................................ 182

II. Del límite a la historia (1916-1928) ........................................... 188

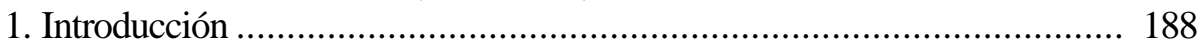

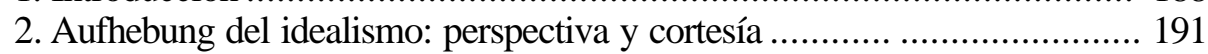

3. La nueva sensibilidad. Hegel y la tragedia de la limitación...................... 200

4. Filosofía de lo real, política realista ................................................. 207

5. El ideal objetivo frente al debe ser................................................. 213

6. Historia y felicidad........................................................................... 221

7. De la soledad a la solidaridad........................................................... 229 


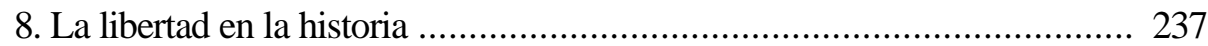

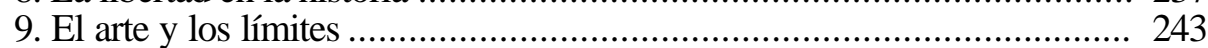

III. Los escritos de Ortega sobre Hegel (1928-1931)............................ 253

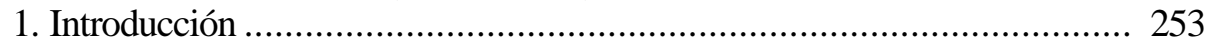

2. "La Filosofía de la historia de Hegel y la historiología"........................... 257

2.1. Contra la historia diplomática................................................... 261

2.2. Historiología y humanidades................................................... 270

2.3. Las leyes intrahistóricas..................................................... 277

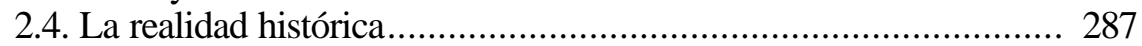

2.5. Problemas de traducción: historia y razón................................... 293

2.6. El descontento en la historia ...................................................... 303

2.7. Historia y convivencia .......................................................... 307

3. "Hegel y América" ............................................................................ 315

3.1. Heidegger y el tema de la muerte............................................... 318

3.2. El futuro en la historia: las profecías.......................................... 325

3.3. Futuro y presente: nuestro tiempo................................................. 335

3.4. Lo temporal y lo eterno........................................................... 344

3.5. El Estado en la historia ...................................................... 349

3.6. La prehistoria y los pueblos primitivos ..................................... 355

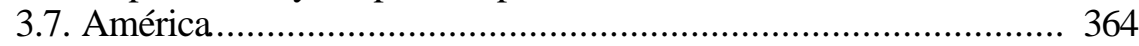

3.7.1. El futuro y la juventud ............................................ 367

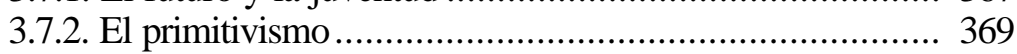

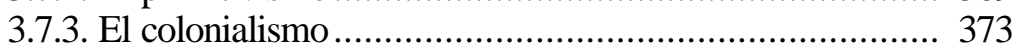

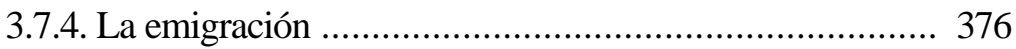

3.8. Historia y densidad de población............................................... 381

4. "En el centenario de Hegel"............................................................... 386

4.1. Vida y espíritu ...................................................................... 388

4.2. Reflexividad del espíritu y reflexividad de la vida ........................ 395

4.3. La reflexividad del Estado ...................................................... 404

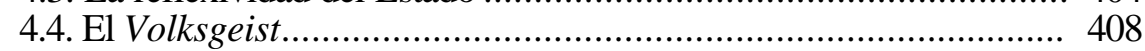

4.5. El espíritu objetivo.................................................................... 416

4.6. La geografía estético-histórica de la limitación............................. 423

4.7. Los tres paisajes .................................................................. 433

4.8. Los tres paisajes y la limitación.................................................. 440

IV. El final de la recepción: Dialéctica y Europa (1931-1950) ................ 446

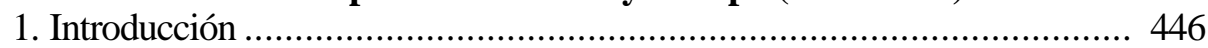

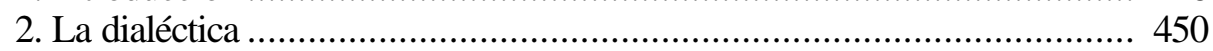

2.1. "Dialéctica e intuición": Buenos Aires, 1928 .................................. 453

2.2. Estética dialéctica y dialéctica de la colaboración ........................ 458

2.3. Dialéctica histórica.................................................................... 464

2.4. Dilthey y la continuidad de la conciencia ................................... 471

2.5. La paradoja de Hegel................................................................... 475

2.6. "Lo absoluto es objeto"........................................................ 484

2.7. El pasado filosófico: la historia de la filosofía ................................ 493

2.8. El tema del error ................................................................... 500

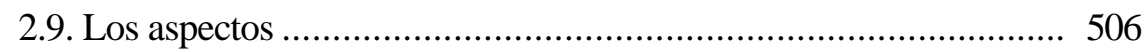

2.10. El pensamiento intuitivo ..................................................... 513

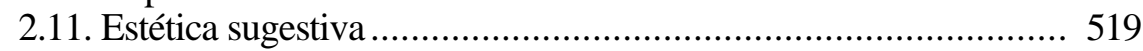

3. Estética política de la limitación........................................................ 524 
3.1. La Meditación de Europa desde La rebelión de las masas............. 527

3.2. Mobilis in mobile ............................................................ 532

3.3. Ortega versus Meinecke: el fondo ultranacional .......................... 538

3.4. Fichte y el cosmopolitismo ..................................................... 545

3.5. Cosmopolitismo contra internacionalismo.................................. 550

3.6. Fronteras políticas............................................................... 556

3.7. ...y fronteras estéticas ........................................................... 562

3.8. Imprecisión y descontento .................................................... 567

3.9. España como finis terrae. Mitos sin amaneramiento ..................... 571

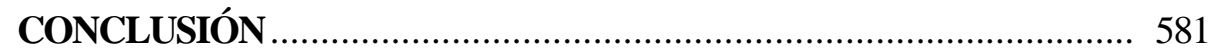

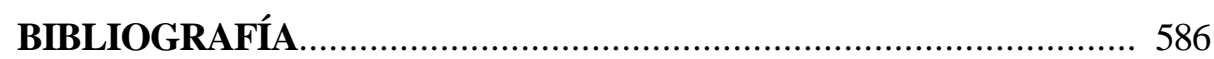




\section{ESTÉTICA DE LA LIMITACIÓN}

LA RECEPCIÓN DE HEGEL POR ORTEGA Y GASSET 


\title{
INTRODUCCIÓN: ORTEGA Y LA RECEPCIÓN
}

\begin{abstract}
"No tiene sentido exponer a Hegel, sino ver cómo nuestros problemas aparecen en él y lo que de sus visiones es instructivo para nuestros problemas"

Ortega y Gasset

"El arte es siempre creación y no elección entre lo ya creado. Es creación, no sólo parte del artista productor, sino también del contemplador. Una estética torpe nos ha habituado a reservar el nombre de artista para el que produce la obra, como si el que la goza adecuadamente no tuviese también que serlo. Producción y recepción son en arte operaciones recíprocas"
\end{abstract}

Ortega y Gasset

\section{Un título y una intención}

Expuesto como un título con un subtítulo, el encabezamiento de este trabajo, Estética de la limitación. La recepción de Hegel por Ortega y Gasset, es en realidad una declaración de intenciones. Debe ser leído superando el carácter de "simple" título, invirtiendo sus términos y apareciendo como una afirmación, la afirmación inicial de la idea que se quiere presentar: la recepción de Hegel por José Ortega y Gasset tiene lugar a través de una estética de la limitación.

Si la exposición y defensa de esa idea supondrá el conjunto del texto, la metodología sobre la que se apoya exige su explicación en el inicio. Para llevar a cabo tal explicación es necesario mostrar las relaciones entre las cinco claves que aparecen en ese título o declaración de ntenciones: Hegel, Ortega, recepción, limitación y estética, y, de un modo muy especial, definir qué se entiende exactamente por recepción, pues es ésta la que sostiene la conjunción de las otras cuatro, la que se sitúa en el centro metodológico del trabajo.

En un primer momento, recepción de Hegel por Ortega significa el modo cómo éste entiende, utiliza y aplica a sus propios intereses teóricos la filosofía de Hegel, o las partes que estudia de ella. La recepción, en este sentido, se concibe como una interpretación que 
es todo menos una exposición. Ortega nunca expone a Hegel, sino que toma de él aquello que le es útil, aquello que le sirve para completar o continuar sus propias teorías: la interpretación siempre viene marcada por los intereses particulares de la propia filosofía de Ortega. Esto no quiere decir que esa interpretación sea incorrecta (y mucho menos poco trabajada: la multitud de notas de lectura sobre Hegel dan prueba de lo contrario), pero sí que está completamente dirigida, determinada. Tomará ideas de Hegel e inmediatamente las utilizará para sus propósitos, las descontextualizará, las "orteguizará". Esa es la recepción de Ortega, es su modo de recibir, de actualizar y hacer presente a Hegel en su filosofía.

Pero esto no ocurre únicamente con Hegel, sino con todos los clásicos que utiliza Ortega en sus teorías. Por ello, no es que sea inadecuado realizar ejercicios de interpretación en el sentido de si Ortega entendió bien o mal a Hegel (en este caso), no es inadecuado, pero sí intrascendente. Lo realmente interesante, y es esto lo que tendrá este trabajo como guía metodológico, consiste en saber cómo, por qué y para qué utilizó Ortega a determinado autor, o idea de un autor, y en mucha menor medida si lo hizo entendiendo o no lo que el autor en cuestión quería dar a entender. Llevar a cabo el análisis de una recepción por parte de Ortega, en este caso la de Hegel, implica primero la necesidad de mostrar cómo interpreta Ortega al autor en cuestión, y, segundo, presentar las causas, contextos e intenciones que dirigen esa interpretación.

Pero resta la segunda parte del título o intención. Analizar la recepción de Hegel por Ortega es el primer momento, el segundo consiste en la interpretación de esa recepción. Esta interpretación tiene un tema principal que la determina: la limitación, la relación entre límite y limitación. Este tema presenta una lectura y una intención estéticas. La estética que aparece en el título no remite únicamente a las ideas sobre el arte presentes en la filosofía de Ortega, sino que expresa la interpretación propia, particular, de la recepción de Hegel por Ortega. La estética de la limitación (el título) es la tesis interpretativa que dirige el tema general del trabajo, la recepción de Hegel por Ortega (el subtítulo). La conjunción de ambos aspectos está posibilitada por la metodología del trabajo en general, metodología sostenida por los caracteres de la estética de la recepción. 


\section{Estética de la recepción}

Hablar de estética de la recepción, aunque tanto esa estética como esa recepción presenten unos contenidos e intereses determinados, supone situar la metodología del trabajo en un contexto explícito. Este contexto es el de la teoría estética de la recepción o investigación sobre la recepción, reconocida de modo concreto como teoría en la década de los años sesenta y situada alrededor de los autores de la escuela de Constanza. Con todo, los orígenes de la reflexión sobre la recepción de las obras de arte son tan antiguos como la misma reflexión estética.

$\mathrm{Si}$, pese a ello, se considera como precursores de la moderna teoría de la recepción a Valéry, a Benjamin o a Sartre1, la teoría adquiriría desde el inicio una serie de concreciones explícitas: el receptor de la obra de arte interactúa con el productor, la creación integra producción y recepción; la función de la obra sobrevive a su creador, permite dar la espalda a sus intenciones e integrar en una acogida siempre abierta el pasado y el futuro de la obra $^{2}$; la negación de una función contemplativa y pasiva en la mirada sobre la obra exige afirmar la implicación de autor y lector, escritura y lectura.

Cuando Jauss e Iser, sobre todo, con la hermenéutica de Gadamer en el fondo del primero y la fenomenología de Ingarden en el del segundo, inician la exposición teórica de la investigación sobre la recepción, lo hacen desde una intención determinada: la superación del concepto clásico de obra de arte autónoma, concluida, modélica, en la que al receptor le corresponde la contemplación en soledad 3 . Frente a ese modelo clásico, en la

1Es la tesis de R. Sánchez Ortiz de Urbina. Cfr. SÁNCHEZ ORTIZ DE URBINA, R. "La recepción de la obra de arte", en: BOZAL, V. (Ed.), Historia de las ideas estéticas y de las teorías artísticas contemporáneas, II. Madrid: Visor, 1996, p. 172 ss.

\footnotetext{
2La idea se muestra explícita en Benjamin: "Para el que se ocupa de ellas [las obras de arte] en cuanto dialéctico histórico, integran estas obras tanto su prehistoria como su historia sucesiva -una historia sucesiva por virtud de la cual se percibe también su prehistoria en tanto implicada en una transformación constante. Le enseñan que su función sobrevive a su creador; también le enseñan cómo dar la espalda a sus intenciones". BENJAMIN, "Historia y coleccionismo: Eduard Fuchs", en: BENJAMIN, W. Discursos interrumpidos, I. Filosofía del arte y de la historia. Madrid: Taurus, 1992 ( $3^{\text {a }}$ reimp.), p. 90 ss. Comentando ese texto de Benjamin escribe Jauss: "Benjamin se ha anticipado así a la estética de la recepción que se impone treinta años más tarde". JAUSS, H.R. Las transformaciones de lo moderno. Estudios sobre las etapas de la modernidad estética. Madrid: Visor, 1995, p. 179.

3JAUSS, H.R. "El lector como instancia", en: MAYORAL, J.A. (comp.), Estética de la recepción. Madrid: Arco, 1987, p. 73: "Al concepto clásico de obra de arte autónoma le corresponde la contemplación en soledad del lector como comportamiento paradigmático del receptor".
} 
recepción activa, en el proceso de lectura, el lector aprovecha los "lugares vacíos" (el concepto es de Iser) dejados por el autor, aprovecha el coeficiente de indeterminación de la obra y mantiene la posibilidad de corealización del texto o del objeto estético en general. El receptor adquiere los caracteres de un nuevo espectador, activo, dinámico, que se integra en el proceso creativo: frente a la reverencialidad pasiva la actitud activa. Se trata de la intervención activa del espectador que reclama la propia dinámica del arte contemporáneo en general, o, como afirma José Jiménez, "en lugar de contemplación y pasividad, los nuevos públicos reclaman acción y dinamismo, y así, en un sentido filosófico, podemos hablar con propiedad de la aparición de un nuevo espectador'4.

El aspecto clave de este nuevo espectador puede ser aplicado directamente a la metodología hermenéutica de la recepción de Hegel por Ortega: el Ortega espectador adquiere ante los clásicos las categorías de nuevo espectador, receptor, activo. Se trata en todo caso de fundir el carácter ajeno de los textos con las intenciones propias, privadas, "convertir la experiencia ajena de los textos en experiencia privada"5. La co-realización, el diálogo entre la teoría ajena y la propia, la superación de la interpretación de significados en la producción de significados, la sustitución de la postura contemplativa por la actividad estética del receptor 6 , todos ellos son caracteres que, utilizados en un sentido puramente metodológico, afectan tanto a la recepción de Hegel por parte de Ortega, como a la recepción de esa recepción por nuestra parte.

En este contexto, la metodología empleada se inicia en la nota de trabajo expuesta al comienzo de esta introducción: "no tiene sentido exponer a Hegel, sino ver cómo nuestros problemas aparecen en él y lo que de sus visiones es instructivo para nuestros problemas", escribía Ortega en sus notas de lectura sobre Hegel7 ${ }^{7}$ El hecho de que no tenga sentido exponer a Hegel no remite únicamente a que su momento haya pasado, a que la exposición

\footnotetext{
4JIMÉNEZ, J. "Introducción", en: JIMÉNEZ, J. (Ed.), El nuevo espectador. Madrid: Fundación Argentaria - Visor Dis., 1998, p. 14.

5ISER, W. "La estructura apelativa de los textos", en: WARNING, R. (ed.), Estética de la recepción. Madrid: Visor, 1989, p. 148.

6JAUSS, H.R. Experiencia estética y hermenéutica literaria. Ensayos en el campo de la experiencia estética. Madrid: Taurus, $1992^{2}$, p. 109: "Una estética de la recepción capaz de abarcar, en nuevas definiciones de una poiesis del sujeto receptor y por encima de las tradicionales definiciones de la postura contemplativa, la actividad estética exigida por el espectador".
}

${ }^{7}$ Archivo de la "Fundación José Ortega y Gasset", Carpetilla "Hegel - Filosofía de la historia". 
sólo habría tenido vigencia en determinado contexto histórico, sino, sobre todo, a que una mera exposición eliminaría el carácter receptivo, útil, actual que pueden conllevar sus teorías.

La mera exposición significaría situarse en el conformismo ante la tradición; buscar en los textos de Hegel "nuestros problemas", aquello que es "instructivo para nuestros problemas", implica arrancarles todo conformismo en su lectura, en el sentido de Benjamin: "En toda época ha de intentarse arrancar la tradición al respectivo conformismo que está a punto de subyugarla"8. Es la negación del conformismo la que implica la recepción determinada, la superación de la contemplación pasiva, como afirmaba el propio Benjamin sobre las placas fotográficas de Atget: "Así es como se forma su secreta significación histórica. Exigen una recepción en un sentido determinado. La contemplación de vuelos propios no resulta muy adecuada"9.

Ortega abre la teoría de Hegel, la re-lee, la utiliza únicamente cuando, sea mediante la crítica, sea mediante la coincidencia, "es instructivo para nuestros problemas". Puede hacerlo porque, tomando los textos e ideas desde el punto de vista activo del receptor, Hegel se le presenta abriendo progresivamente el sentido que ofrece su filosofía, "en la medida en la que su posible significación es entendida y leída de modo nuevo en el horizonte cambiante de la experiencia"10. Esto no significa en ningún caso que Ortega olvide la situación concreta de la filosofía de Hegel en su contexto histórico, o la necesaria dialéctica continua de los momentos, en la historia y en la historia de la filosofía. La razón histórica que confiere un sentido, un logos, y permite analizar los acontecimientos en su momento, desde el presente hacia el pasado y para el futuro, es también la que posibilita utilizar el texto ajeno, el texto clásico, con intenciones precisas de presente.

Pero para poder hacerlo, antes hay que llegar hasta él, antes hay que conocer al clásico. Visto desde el contexto de la superación del idealismo, Hegel representará para Ortega una doble cuestión: se utilizará de él lo que es instructivo para "nuestros problemas", pero también se afirmará la necesidad de la superación del imperialismo idealista del absoluto o

8BENJAMIN, "Tesis de filosofía de la historia", en: BENJAMIN, W. Discursos interrumpidos, I. Op. cit. p. 180.

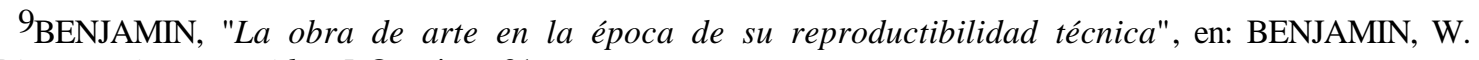
Discursos interrumpidos, I. Op. cit. p. 31. 
del espíritu. Ambos aspectos exigen primero llegar hasta Hegel, únicamente después se podrá utilizarlo o superarlo.

En otra de las notas de trabajo escribe Ortega: "El destino de nuestro tiempo es precisamente superar a Hegel, lo que implica llegar hasta él"11. Tanto la apropiación como la superación suponen el trabajo activo del receptor. En el contexto de la crítica del concepto de contemplación estética, Bürger escribe: "La recepción es una superación de obstáculos, y, por consiguiente, un trabajo", y añade: "Como cualquier otro trabajo, la recepción de las obras de arte supone un proceso de aprendizaje. En primer lugar, el receptor debe haber realizado experiencias específicas relativas a un objeto, cuando accede a una obra nueva. Por otra parte, debe haber aprendido a relacionar las experiencias estéticas específicas con experiencias históricas. Sólo cuando esto ocurre, le «dice» algo la obra"12. Es en la conjunción de ambos aspectos, el de la experiencia específica de actualidad, la intención particular de la teoría propia, y el proceso de aprendizaje, la relación con la experiencia histórica, de pasado, cuando Hegel le "dice" algo a Ortega, cuando puede ser "instructivo para nuestros problemas".

En el conjunto de estos caracteres se muestra la recepción estética como metodología del trabajo. Hegel, o el clásico en general, es considerado por Ortega como obra estética que posibilita su co-realización, como lectura que permite la posición activa y no contemplativa del receptor. El clásico como objeto estético implica la posición activa del receptor, y, con ello, se actualiza, permite utilizarlo para "nuestros problemas", se hace presente. Es la definición que el propio Ortega daba del objeto estético, "absoluta presencia"13. El objeto estético es una intimidad que se expresa ejecutándose, y esa ejecución exige en su creación la producción y la recepción.

\footnotetext{
10JAUSS, H.R. Las transformaciones de lo moderno. Op. cit. p. 179.

${ }^{11}$ Archivo de la "Fundación José Ortega y Gasset", Carpetilla "Hegel: filosofía de la historia". Conjunto de notas titulado "Detalles históricos".

${ }^{12}$ BÜRGER, P. Crítica de la estética idealista. Madrid: Visor, 1996, pp. 170-171.

13"Ensayo de estética a manera de prólogo" (1914). OC VI, 255. [Este será el modo de citar las obras de Ortega presente en todo el trabajo. En primer lugar el título del escrito, entrecomillado si es un artículo, acompañado, entre paréntesis, de su año de publicación -o de exposición, si corresponde a un curso o lección editado posteriormente. A continuación OC, que remite a: ORTEGA Y GASSET, J. Obras completas. Madrid: Alianza/Revista de Occidente, doce vols., 1983. El número romano corresponde al volumen y el arábigo a la página. Cuando el texto de Ortega no esté incluido en las Obras completas se ofrecerá la referencia exacta].
} 
No se trata únicamente de la comprensión del clásico, de la obra histórica en el sentido de Gadamer, en el que el diálogo con ella se establece en la asunción de la historicidad propia y de los prejuicios particulares, sino, sobre todo, de la utilización del inevitable círculo hermenéutico como método de trabajo. Si en Gadamer, la historia y la posibilidad de su hermenéutica se inicia en la serie de efectos en el transcurso de una tradición, la teoría de la recepción, y sería en ésta donde se situaría tanto el modo de leer Ortega a Hegel como el modo de leer nosotros a Ortega, se mostrará en la apropiación activa de la obra, con unos intereses muy particulares y sin desvirtuar, al conducirlo a un contexto propio, el sentido inicial del clásico, en este caso Hegel.

\section{La recepción en Ortega: los clásicos}

Situar la metodología del trabajo en el contexto de una teoría estética de la recepción no significa aplicar un carácter externo, elegido arbitrariamente y colocado desde fuera. El propio Ortega exige ese método en su lectura de los clásicos, Hegel entre ellos: también en Ortega hay una teoría estética de la recepción. La contemplación o lectura no es pasiva, sino activa, el arte es siempre conjunción de creación y diálogo, como se lee en la segunda cita antepuesta a esta introducción: "el arte es siempre creación y no elección entre lo ya creado. Es creación, no sólo parte del artista productor, sino también del contemplador. Una estética torpe nos ha habituado a reservar el nombre de artista para el que produce la obra, como si el que la goza adecuadamente no tuviese también que serlo. Producción y recepción son en arte operaciones recíprocas"14. En ese texto, Ortega no remite únicamente a la necesaria conjunción de producción y recepción de la obra, sino también a la relación entre pasado y presente en los modos de interpretación.

El diálogo entre el productor y el receptor crea constantemente la obra, la actualiza, sin por ello desvirtuar su situación y contextualización concretas en un determinado momento histórico. Es la conjunción de pasado y presente la que dinamiza el proceso receptivo, o, en el caso de Hegel, la que posibilita la reunión de las dos ideas expuestas por Ortega en sus

\footnotetext{
14"Nuevas casas antiguas" (1926). OC II, 550.
} 
notas de trabajo: la recepción se inicia llegando hasta Hegel, y únicamente a partir de ese momento puede continuarse el proyecto de superación o de utilización.

$\mathrm{Si}$ se intenta no una actualización o contemporaneización del clásico, de la teoría pretérita, sino un simple traslado de lo recibido, una reinstauración de lo pasado en el presente, surge el escolasticismo, la tragedia de la recepción: "no se suele percibir lo que tiene de trágico toda «recepción»"15. Es la tragedia del transporte integral de ideas, tragedia causada por la imposibilidad de hacer del pasado un presente. La teoría pasada únicamente llega hasta el presente si se la adecúa a los nuevos intereses, si se la actualiza y se aprovecha lo que de ella es útil. De este modo recibe Ortega a Hegel: en ningún momento pretende hacer presente un pasado, sino utilizar lo que de ese pasado puede ser contemporaneizado, adecuado a los nuevos intereses, a las propias teorías. La recepción de Hegel por Ortega no es una tragedia, sino la conjunción acumulativa, ampliadora, que supone el diálogo, la utilización del clásico, su salvación para conseguir la nuestra.

Esta es la idea que Ortega tiene de la recepción de los clásicos, y es la metodología que aplica a su recepción del clásico llamado Hegel, la que conecta directamente con la intención de encontrar aquello de sus visiones que sea "instructivo para nuestros problemas":

"No hay más que una manera de salvar al clásico: usando de él sin miramiento para nuestra propia salvación -es decir, prescindiendo de su clasicismo, trayéndolo hasta nosotros, contemporaneizándolo, inyectándole pulso nuevo con la sangre de nuestras venas, cuyos ingredientes son nuestras pasiones... y nuestros problemas. En vez de hacernos centenarios en el centenario, intentar la resurrección del clásico re-sumergiéndolo en la existencia"16.

El clásico es necesario siempre, pero siempre también insuficiente. Necesario porque aquello que lo convierte en clásico no es el hecho de que ofrezca soluciones o respuestas a cuestiones hasta entonces irresueltas, sino precisamente lo contrario: que los problemas que él encontró siguen presentando batalla, "nos plantee problemas, discuta y se defienda de

${ }^{15}$ La idea de principio en Leibniz y la evolución de la teoría deductiva (1947). OC VIII, 297. Ese texto, así como las páginas que lo acompañan, los repite Ortega en más de una ocasión: cfr. "Medio siglo de filosofía" (1951), en: ORTEGA Y GASSET, J. Origen y epílogo de la filosofía y otros ensayos de filosofía. Madrid: Revista de Occidente en Alianza -Obras de José Ortega y Gasset, 12-, 1981, p. 139 ss.; y "Prólogo a «El collar de la paloma», de Ibn Hazm de Córdoba" (1952). OC VII, 47 ss.

16"Pidi endo un Goethe desde dentro. Carta a un alemán" (1932). OC IV, 419. 
nosotros"17, con lo que su actualidad proviene de su problematismo, de su inconclusión, de no acabar de decir nunca lo que tiene que decir 18 . La eternidad, la persistencia de los clásicos, se inicia en la propia inconclusión de los problemas y temas que plantean. Pero, si ésa es su necesidad, también implica su insuficiencia: los problemas adquieren otras formas, solicitan respuestas adecuadas a las épocas nuevas, la urgencia y velocidad de la vida continúan presentando cuestiones a las ya iniciadas por los clásicos, cuestiones que exigen respuesta inmediata para superar el naufragio en el mundo.

Es así como surge el enfrentamiento que posibilita la recepción. Los clásicos deben perder su clasicismo y ser utilizados para ayudar a superar el naufragio, salvar al clásico utilizándolo para nuestra salvación, con plenas pretensiones de actualidad. Por ello, "es preciso citar a los clásicos ante un tribunal de náufragos"19. Ante ese tribunal responderán a las cuestiones urgentes, las cuestiones de presente, las que refieren a la teoría propia originada en el tiempo propio. Perderán su clasicismo, pero mantendrán su actualidad.

La recepción de Hegel por Ortega significa su citación ante el tribunal de náufragos: Hegel será resucitado no mediante exposiciones o interpretaciones, sino mediante su aplicación a los nuevos problemas o teorías. La resurrección del clásico en los nuevos problemas exige todos los caracteres de la teoría de la recepción: no se trata de exposiciones, tampoco de continuidad histórica o hermenéutica, sino de recepción estética en el diálogo y la co-realización de la obra, aprovechar lo que el clásico dice y lo que no dice, mostrar la lectura como aumento, completar la obra "completando su lectura"20, convertir la vista en mirada y el leer contemplativo en leer receptivo, "leer pensativo" 21.

La conexión entre el clásico y la posibilidad de su recepción, de su contemporaneización, remite directamente a una teoría de la lectura en Ortega y del decir en general. Esa teoría iba a situarse de un modo explícito en un estudio concreto, los Principios de la nueva filología, uno de los capítulos del proyecto al que remite

17"La «Filosofía de la historia de Hegel» y la historiología" (1928). OC IV, 523.

${ }^{18}$ Es una de las definiciones del libro clásico en Calvino: "Un clásico es un libro que nunca termina de decir lo que tiene que decir". CALVINO, I. Por qué leer los clásicos. Barcelona: Tusquets, 1992, p. 15.

19"Pidiendo un Goethe desde dentro. Carta a un alemán" (1932). OC IV, 399.

200RTEGA Y GASSET, J. Meditaciones del Quijote. Madrid: Cátedra, 1984 (Ed. Julián Marías), p. 84. Utilizo esta edición para Meditaciones del Quijote. A partir de aquí citado MQ. 
insistentemente Ortega y que no llegó a ver la luz, la Aurora de la razón histórica. Sin embargo, los dos principios sobre los que se sostendría la teoría los menciona Ortega en "La reviviscencia de los cuadros" y en el comentario al Banquete de Platón, dos textos del mismo año, 1946. Esos dos principios expresan la ley de deficiencia y exuberancia de bs textos: "1 $1^{\mathrm{o}}$ Todo decir es deficiente -dice menos de lo que quiere. $2^{\mathrm{o}}$ Todo decir es exuberante -da a entender más de lo que se propone" 22 .

\section{La recepción en Ortega: lectura y reviviscencia}

El clásico que se re-vitaliza al ser colocado ante los problemas y pasiones presentes, conecta con una teoría de la lectura en la que la recepción del texto aprovecha tanto la deficiencia como la exuberancia de todo decir. Si el clásico no acaba de decir nunca lo que tiene que decir, el tema se amplía a toda enunciación significativa: ningún decir concluye nunca de decir. Hegel será situado por Ortega ante ambos contextos metodológicos, el del clásico y el de la lectura, y es esto lo que exige la utilización de una muy determinada estética de la recepción para el análisis de la relación entre ambos, Hegel y Ortega.

Todo decir es deficiente y exuberante simultáneamente porque su intención es siempre querer decir tal cosa determinada, pero esa determinación no es nunca expuesta con plena suficiencia. Siempre habrá una inadecuación entre lo que se pretendía decir y lo que efectivamente se dice. Una gran cantidad de supuestos quedan tácitos, las cosas que, "por sabidas", se callan, supuestos que en el diálogo con el contemporáneo son coincidentes, pero no así si el diálogo se establece con el antepasado, con la figura histórica.

En la lectura, el problema se acentúa. El leer es una faena utópica, que tiene que contentarse con aproximaciones al objetivo inicial de entender completamente un texto. En el esfuerzo que supone la aproximación, el lector extraerá una porción de lo que el autor ha pretendido decir, pero siempre quedará un residuo ilegible. Al mismo tiempo, ese esfuerzo supondrá entender cosas que el autor no ha querido decir y que, sin embargo, en el proceso de lectura, en la recepción del texto, efectivamente dice. De este modo, "leer no puede

\footnotetext{
${ }^{21}$ Ibid. p. 124.

22"Comentario al «Banquete» de Platón" (1946). OC IX, 751.
} 
consistir sólo en recibir lo que buenamente las frases escritas quieren volcar sobre nosotros, leer no es, sin más, deslizarse sobre el texto, sino que es forzoso salir del texto, abandonar nuestra pasividad y construirnos laboriosamente toda la realidad mental no dicha en él, pero que es imprescindible para entenderlo más satisfactoriamente" 23 . Conjuntando los caracteres, "leer es interpretar" 24.

Salir del texto, abandonar la pasividad, construir lo no dicho. Ortega se refiere a la necesidad de apoderarse de la realidad vital que subyace al texto concreto, para poder entenderlo, aunque sea de un modo aproximado. Es la conjunción de filología e historia: entender un texto significa entenderlo en la función activa, vital, que cumplió al ser enunciado. Y ello exige reconstruir la vida entera del autor, pero también la de su época, y la de las vigencias de la época, o, de otro modo, conjuntar la razón histórica con la razón vital. Esta es la nueva filología que Ortega le muestra en carta a Curtius en 1938. A los dos principios, el de exuberancia y el de deficiencia, se une un tercero: entender un texto implica entender toda la realidad vital que le subyace, con lo que "se entrevé el riguroso sentido formal de principio para una nueva filología que posee la expresión: Duo si idem dicunt non est idem" 25 .

Si en este sentido, los principios de la nueva filología remiten a su conexión con la razón histórica y vital, esa conexión se establece en el contexto del primer momento: el momento de entender un texto o, en lo referente a Hegel y utilizando aquella nota de trabajo, el momento que exige llegar hasta él. Pero hay un segundo momento en el que la ley de deficiencia y exuberancia remite directamente a lo que el receptor pone en su lectura, en su actividad creadora. Lo no dicho ya no referiría únicamente a la situación vital que sostiene el texto concreto, sino a la misión receptiva y constructora del lector. Esa misión es la que aparece en la teoría receptiva de los clásicos, la que hace prescindir del clasicismo del clásico y lo sumerge en la actualidad de la vida, de la teoría propia, del momento presente. Es el segundo momento en el que, de nuevo remitiendo a Hegel y las notas de lectura, puede iniciarse tanto su superación como la utilización para "nuestros problemas".

\footnotetext{
${ }^{23}$ Ibid. 752.

${ }^{24}$ Ibid.

25 ORTEGA Y GASSET, J. Epistolario. Madrid: Revista de Occidente, 1974, pp. 111.
} 
La teoría de la recepción en Ortega se establece en la conjunción de ambos momentos, la teoría de los clásicos y la teoría de la nueva filología. Consiste en mostrar los dos sentidos de la deficiencia y excedencia de los textos: lo no dicho como aquello que hay que averiguar, uniendo filología, vida e historia, y lo no dicho como aquello que hay que crear, mediante la recepción, mediante la utilización de la obra o texto con pretensiones de actualidad. Este es el sentido de la recepción que Ortega aplica a Hegel, y es el método de trabajo necesario para entender la relación entre ambos.

La recepción estética del clásico, que primero llega hasta él, y a continuación lo salva utilizándolo para nuestra salvación, muestra el doble sentido del duo si idem dicunt non est idem: non est idem porque cambian las situaciones vitales e históricas, pero, a la vez, non est idem si la repetición se muestra en términos de recepción. Cuando Ortega explícitamente utilice caracteres que Hegel remite al espíritu para aplicarlos al concepto orteguiano de vida, como veremos, se encuentra en este segundo momento, el momento de la recepción estética, en la que el clásico renace al situarlo junto a "nuestros problemas": es la reviviscencia del clásico en el momento de su recepción.

En este sentido, la nueva filología no remite únicamente a la teoría de la lectura, sino de modo directo, y sobre todo, al contexto de la recepción en la relación entre estética e historia. No es casual que Ortega situara esa referencia a la nueva filología en "La reviviscencia de los cuadros", y no lo es porque es ahí donde se muestra su aplicación: la pintura es "un diálogo permanente entre el artista y el contemplador"26, y, por ello, "contemplar una pintura no es sólo cuestión de ojos, sino de interpretación"27. De la misma forma que los clásicos, que el objeto estético en general, y precisamente porque es objeto estético, "el cuadro nos está siempre haciendo señas". Y para entender esas señas hay que situar al cuadro en su momento histórico, como trozo de una vida, la vida de un hombre particular y concreto. Se trata de reconstruir la obra, ver el cuadro como fragmento de una vida, de una época, de una historia. Ver el pasado desde el presente, recibirlo, entender los supuestos sobre los que se sostenía y, con ello, entender al antepasado tal como él se entendió; pero "para entenderlo como él se entendió, no hay más remedio que entenderlo

\footnotetext{
26"La reviviscencia de los cuadros" (1946). OC VIII, 490.

27Ibid. p. 491.
} 
mejor"28. En ese momento confluyen estética e historia y aparece la reviviscencia de los cuadros como su recepción.

Ver bien el cuadro, entenderlo, es verlo haciéndose, ejecutándose, en la biografía de un autor y de una época. Esa es su reviviscencia, que supone la forma activa de la contemplación, con lo que "no cabe, pues, contraponer una contemplación puramente estética a una contemplación histórica del arte"29. La contemplación histórica, que muestra la reviviscencia de los cuadros, se reúne con la contemplación detenida ante la obra. La contemplación histórica es contemplación activa, que entiende al antepasado mejor que él mismo, en tanto conoce los supuestos sobre los que se apoyaba $\mathrm{y}$, simultáneamente, lo conduce hasta los problemas y temas del tiempo nuevo. La recepción del cuadro, de la obra, del clásico, incluye la reviviscencia de su pasado desde la actualidad de un presente, de un tiempo propio. Se busca revivir y recibir el cuadro, y el objeto estético en general, en la biografía del autor, en la reconstrucción de una intimidad, de un yo ajeno. Pero ese "yo" ya no está concebido desde el tópico moderno cartesiano: ahora se trata de narrar una vida, y en esa narración lo substancial es la vida, no el "yo".

La reviviscencia como recepción implica la serie de caracteres que permite entender la recepción concreta de Hegel por Ortega y la interpretación que aquí se llevará a cabo. Se trata de la conjunción de estética e historia mediante la posibilidad de basar en la contemplación activa, receptiva, la relación entre Hegel y Ortega. La reviviscencia del cuadro, del objeto estético, en la reunión de contemplación estética e histórica supone la actualización de un pasado, y, con ella, la ampliación de ese pasado, de la teoría ajena, recibida, en la aplicación a lo que es "instructivo para nuestros problemas".

\section{La recepción de Hegel por Ortega}

La recepción concreta por Ortega del clásico llamado Hegel presenta tres ámbitos diferenciables, y únicamente en su conjunción es posible entender la recepción:

\footnotetext{
28Ibid. p. 494.

29Ibid. p. 505.
} 
- El primero remite a los tres artículos que Ortega publicó sobre Hegel, "La «Filosofía de la historia de Hegel» y la historiología", "Hegel y América" y "En el centenario de Hegel". Los dos primeros fueron escritos en 1928, el tercero en 1931.

- El segundo ámbito refiere a la presencia de Hegel, explícita e implícita, en el resto de las obras publicadas, el conjunto de las obras de Ortega editadas hasta la fecha.

- El tercer ámbito consiste en el indispensable material de archivo que permite entender el subsuelo de la relación Hegel-Ortega: en primer lugar, la multitud de notas de trabajo inéditas sobre Hegel, notas de trabajo que incluyen fragmentos de lectura, interpretaciones, párrafos que luego serían publicados, simples apuntes, críticas, etc.; en segundo lugar, las ediciones de la Werke de Hegel utilizadas por Ortega, así como otras ediciones de obras de Hegel, ediciones independientes de las distintas Werke, también empleadas por Ortega: los subrayados, anotaciones y referencias que aparecen en esos ejemplares, escritos de puño y letra de Ortega, son una ayuda inestimable para conocer en determinados momentos cómo leyo a Hegel; en tercer lugar, los estudios sobre Hegel consultados por Ortega, cuya lectura posibilita saber no sólo cómo recibió a Hegel, sino, sobre todo, cuál fue el sentido particular, el lugar en la teoría propia que ocupó esa bibliografía adyacente.

Este trabajo se sostiene sobre la conexión de los tres ámbitos. Si con el método de estética de la recepción se pretende la novedad en el tipo análisis, que permite sobrepasar el habitual "Ortega entendió... Ortega no entendió... Ortega tomó esto de aquí... Ortega copió esto de allí...", la base sobre la que se apoya la interpretación intenta permanecer en los pilares de la investigación clásica: el conocimiento del conjunto de la obra de Ortega, la rigurosidad en la interpretación de los textos y el buceo en el archivo y la biblioteca del autor. El carácter novedoso que supone, en los estudios sobre Ortega, el método de una concreta estética de la recepción, se presenta acompañado del marco tradicional en la investigación de los materiales. Si, además, parte de esos materiales, como es la cantidad importante de notas de trabajo inéditas, permite añadir algo original a las investigaciones sobre el autor, el objetivo estará cumplido.

La reunión de los ámbitos de la recepción, los tres textos sobre Hegel, el conjunto de las obras de Ortega y el material de archivo, exige dividir la conexión Ortega-Hegel en cuatro momentos (que no representan etapas o secciones en la biografía filosófica de Ortega en general, sino únicamente en lo que refiere a su relación con Hegel). El primero abarca 
desde el inicio de la trayectoria intelectual de Ortega hasta Meditaciones del Quijote y Temas del Escorial, o, en años, hasta 1914-1915; el segundo muestra el trayecto que separa esos años y la publicación del primer artículo sobre Hegel, en 1928; el tercero se centra exclusivamente en los tres artículos publicados sobre Hegel; y, el último momento, el final de la recepción, abarca dos décadas, los años treinta y cuarenta, y dos temas explícitos, la dialéctica y Europa. Esos momentos corresponden a las cuatro secciones en las que se divide el trabajo.

A partir de los cambios e intereses en la interpretación desarrollados en los cuatro momentos, se muestra el progreso efectuado por Ortega en su recepción de Hegel. El método de estética de la recepción permanecerá en el conjunto, pero no así los objetivos concretos de esa recepción. Los temas y conceptos, ideas y teorías, que Ortega recibe de Hegel irán modificando las concreciones que determinan la recepción. La relación se establecerá continuamente entre Hegel y los temas o intereses concretos que, superando la referencia explícita a Hegel, condicionan la teoría de Ortega en cada momento. En el primero, Hegel aparecerá en conexión con el tema del sistema, el nacionalismo, las referencias explícitas a la Fenomenología del espíritu, etc.; el segundo mostrará cómo se produce el paso hasta los escritos publicados sobre Hegel, un paso determinado por el tema de la superación del idealismo y el interés de Ortega por la historia, en general, y la filosofía de la historia de Hegel, en particular; el tercero, con el contenido de los tres artículos en el centro del desarrollo, presentará la recepción concreta por Ortega de la teoría hegeliana de la historia, del tema de América y de la conexión entre historia y geografía, y entre espíritu y vida. Por último, el momento final mostrará de modo explícito la recepción del tema de la dialéctica y de la reaparición de Hegel junto al tema de la nación en los años cuarenta.

Si hay algo que permanece común en los cuatro momentos, eso es que, aunque la lectura de Hegel por Ortega esté basada en una teoría de la recepción, de utilización de Hegel para objetivos siempre concretos y particulares, ello no quiere decir que Ortega no leyera o no conociera a Hegel. Es precisamente la necesidad de la recepción, la exigencia de utilizarlo, recibirlo, con unos intereses muy determinados, la causa de que Ortega estudiara a Hegel. La interpretación es receptiva, interesada, pero eso no significa que sea débil o insuficiente. Como veremos, las lecturas, las notas de trabajo, los materiales utilizados, etc., prueban que 
Ortega llegó a adquirir un conocimiento lo suficientemente amplio de la filosofía de Hegel. Otra cosa es que la recepción lo condicionara para utilizar únicamente aquello que le era "instructivo para nuestros problemas".

\section{Hegel en España}

Esta recepción no ha sido suficientemente analizada. De hecho, el estudio concreto de la relación entre Ortega y Hegel en general apenas ha sido estudiada. Esta ausencia fue el primer objetivo que llevó a realizar este trabajo. Únicamente cuatro o cinco artículos (presentes en la bibliografía), todos ellos centrados en puntos concretos de los escritos de Ortega sobre Hegel, han sido dedicados a estudiar el tema. Mención especial merece el libro de Xabier Insausti ${ }^{30}$, el primero y único hasta ahora dedicado de un modo más o menos concreto a la relación entre Hegel y Ortega (y Unamuno). Pero los intereses del autor son determinados: se centran únicamente en los tres artículos publicados sobre Hegel y se limitan a analizar de un modo breve la relación entre Hegel y Ortega basada en esos textos. Insausti no se ocupa en su obra más que de un modo rápido del resto de la filosofía de Ortega en relación con Hegel, y su objetivo no consiste en averiguar realmente para qué utilizó Ortega a Hegel, sino en mostrar en tono expositivo qué es lo que decía Ortega sobre Hegel.

Si se supera la relación explícita con Ortega y se piensa en el estudio de la recepción general de Hegel en España, los problemas no son menores. A pesar de la multitud de excelentes investigadores españoles actuales que han dedicado obras amplias y reconocidas a estudiar la filosofía hegeliana en concreto, ninguno de ellos ha dirigido sus intereses hacia la recepción de Hegel en la filosofía española en general, y menos en la de Ortega en particular.

Sobre la recepción de Hegel en España, pueden mencionarse dos obras, la de Manuel Pizán, Los hegelianos en España y otras notas críticas 31 , en la que lo dedicado a los

\footnotetext{
30INSAUSTI, F.-J. Miguel de Unamunos und José Ortega y Gassets Philosophie im Zusammenhang mit ihrer Hegel-Rezeption. San Sebastián: Zorroaga, 1993.

31PIZÁN, M. Los hegelianos en España y otras notas críticas. Madrid: Edicusa, 1973.
} 
hegelianos no es el libro completo, sino únicamente el primer artículo, es decir, veinte páginas (en las que no menciona a Ortega), y la de Lacasta Zabalza, Hegel en España 32 , dedicada ésta sí a la recepción de Hegel.

Lacasta, aunque analiza de un modo más detallado y mucho amplio la recepción de Hegel en España desde sus inicios, en aquellos autores que Pizán únicamente menciona o trata rápidamente en su artículo (la escuela sevillana en general, Benítez de Lugo, Fabié, Montoro, etc.), se detiene en un momento concreto: la segunda mitad del siglo XIX, y en un tema determinado: el pensamiento jurídico 33 . Sus intereses se centran sobre todo en el análisis de la escuela de Sevilla y los orígenes del hegelianismo hispánico, en el marco de la Restauración y en la influencia de Hegel en Pi y Margall y en Castelar. Sólo en la primera sección introductoria dedica unas páginas rápidas (concretamente cinco) a "los hombres de 1914", en las que pasa de puntillas sobre Ortega.

En lo que refiere a la relación concreta entre Hegel y Unamuno, tema que sobrepasa el objetivo de mi trabajo, el análisis de la recepción se encuentra en un momento más avanzado que el de la relación con Ortega. Aunque las referencias bibliográficas tampoco son demasiadas, sí superan en número a las dedicadas a examinar la recepción de Hegel por Ortega 34 . De todos modos, también está por hacer el análisis exhaustivo de la relación entre Hegel y Unamuno, planteado desde la recepción, desde aquello que a Unamuno le sirvió de Hegel, y manejando materiales determinados que sostengan esa recepción.

32LACASTA ZABALZA, J.I. Hegel en España. Un estudio sobre la mentalidad social del hegelianismo hispánico. Madrid: Centro de Estudios Constitucionales, 1984.

${ }^{33}$ En el contexto del siglo XIX, así como el de la influencia hegeliana en la filosofía del derecho español, iniciada ya en la escuela de Sevilla, o el de la relación entre Hegel y el krausismo, las referencias bibliográficas aumentan. Ver, por ejemplo: DÍAZ, E. La filosofía social del krausismo español. Madrid: Edicusa, 1973; ELÍAS DE TEJADA, F. El hegelianismo jurídico español. Madrid: Ed. Revista de Derecho Privado, 1944; GARCÍA CASANOVA, J.F. La filosofía hegeliana en la España del siglo XIX. Madrid: Juan March, 1978; GARCÍA CUE, J.R. La recepción del hegelianismo en la filosofía jurídica de la Universidad de Sevilla. La obra de Benítez de Lugo. Sevilla: Universidad, 1982; RIVERA DE VENTOSA, E. Influencia del sistema de Hegel en el ideario de Castelar. Granada: Anales de la Cátedra Francisco Suárez, 1970, etc.

\footnotetext{
${ }^{34}$ Sobre la relación entre Hegel y Unamuno, además del libro de Insausti citado más arriba, pueden mencionarse las siguientes obras: PIZÁN, M. El joven Unamuno. Influencia hegeliana y marxista. Madrid: Ayuso, 1970; MORÓN ARROYO, C. "Unamuno y Hegel", en: SÁNCHEZ BARBUDO (ed.), Miguel de Unamuno. Madrid: 1974, pp. 151-179; RIVAS, P. "El Volksgeist de Hegel y la intrahistoria de Unamuno", en: Cuadernos de la Cátedra Miguel de Unamuno, 1971, pp. 23-33; RIVAS, P. "Unamuno y Hegel", en: Cuadernos de la Cátedra Miguel de Unamuno, 1978, pp. 55-89; RIVAS, P. "Unamuno lector de Hegel", en: Revista de Occidente, 1987, pp. 108-125.
} 
Puede decirse, de un modo general, que la recepción de Hegel en España ha sido analizada más o menos detalladamente en lo que refiere a los orígenes, centrados en la escuela de Sevilla, y en el pensamiento jurídico; únicamente iniciada respecto a Unamuno; totalmente ausente en lo que remite al pensamiento filosófico español actual; y, por lo que respecta a Ortega, apenas presentada. Llenar el hueco que supone la ausencia de un estudio detallado de la relación entre Hegel y Ortega es el objetivo de este trabajo. Para ello, la estética de la recepción situada como método de trabajo permitirá no sólo mostrar la conexión explícita entre ambos autores, sino, además, ofrecer una interpretación de esa conexión, así como superar las referencias a Hegel y acudir constantemente a los temas concretos de la filosofía de Ortega que las rodean, las explican y muestran su aplicación. De este modo, el análisis de la recepción es completado con una recepción de la recepción.

\section{Recepción de la recepción: la estética de la limitación}

El método de estética de la recepción utilizado para analizar la relación Ortega-Hegel exige atender no sólo a la presencia de Hegel en Ortega, sino también a los temas concretos que, superando la referencia explícita a Hegel, determinen esa relación. En el fondo, la estética de la recepción aplicada al caso concreto de la conexión entre Hegel y Ortega implica: 1. Conocer de un modo riguroso cómo interpretó Ortega a Hegel, 2. Extender el marco y presentar detalladamante por qué y para qué lo interpretó como lo hizo, con lo que queda en una posición no sólo secundaria, sino también irrelevante e inconsecuente, hablar de si Ortega entendió o no a Hegel; 3. Mostrar los temas y contextos que, superando la referencia explícita a Hegel, permiten confeccionar la red en la que se sitúa como un punto más la propia recepción de Hegel.

En este tercer momento se presenta la recepción de la recepción, que puede considerarse como el hilo conductor que dirige la interpretación de Hegel por Ortega. Este hilo conductor remite a un tema determinado: el límite y la limitación, tema nunca analizado de un modo concreto en la bibliografía sobre Ortega. En la primera de las épocas marcadas, la que concluye en 1914-1915, el origen del trayecto lo mostrará una de las meditaciones no escritas por Ortega, el Ensayo sobre la limitación, que mantenía una relación explícita con 
Hegel; en la segunda, se mostrará el desarrollo tanto de Hegel como del tema de la limitación en el contexto que lleva hasta los escritos sobre Hegel; en la tercera, el tema del límite y la limitación aparecerá en un momento determinante, el que conecta con la relación entre geografía e historia a partir de la recepción por Ortega de la Filosofía de la historia de Hegel; en la cuarta, el tema de la limitación estará situado tanto en el marco de la dialéctica como en el de Europa y la idea de nación.

El tema de la limitación se constituye como una dialéctica, la dialéctica entre el límite y la limitación. El juego establecido remite insistentemente a la misma dinámica: la afirmación de limitaciones y la superación del carácter restrictivo de esa limitación, al constituirse tal limitación como límite y permitir la superación de sí misma. Es en este momento cuando la recepción de la recepción deviene recepción estética: el arte se mostrará constantemente en Ortega como superación de limitaciones, por un lado, y la limitación se concentrará en el tema del paisaje, por el otro. El paisaje como limitación y el arte como superación de limitaciones no sólo presentarán la dialéctica de límite y limitación en el ámbito estético, sino que, además, implican un aspecto determinante: el talante político de esta estética. La estética de la limitación como recepción de la recepción es en realidad una estética política de la limitación, y Hegel se encontrará en el centro del desarrollo.

En 1906 afirmaba Ortega que "la estética es una cuestión política"35. Un año después, en carta a Rosa Spottorno, explicaba la afirmación: "Estos días pienso mucho en los problemas españoles; cada vez me convenzo más de que nuestra salvación tiene que estar en una fórmula cultural que sea a un tiempo política y asimismo que sea estética"36. En 1910 concretará el tema: "A los españoles nos toca la justificación por la estética"37. Esta estética política es una estética de la limitación. Es la limitación la que conjuga los caracteres políticos y estéticos: por un lado la atención a la limitación española, al paisaje propio, a la "forma española de mirar las cosas", por el otro la constante necesidad de superar esa limitación, de mantener la particularidad propia en las relaciones con otras

\footnotetext{
35"Las fuentecitas de Nuremberga" (1906). OC I, 428.

${ }^{36}$ Cartas de un joven español (1891-1908). Madrid: El Arquero, 1991 (Ed. Soledad Ortega), carta 181, p. 570.

37"Adán en el paraíso" (1910). OC I, 477
} 
limitaciones, en la ampliación de mundo, de realidad. El arte, que se presenta en Ortega como creación de mundos nuevos, como ampliación de limitaciones y habitualidades, se sitúa en el centro del proceso. La dialéctica de límite y limitación configurará la estética política que Ortega mostraba como salvación para los problemas españoles.

En la unión de Hegel con el tema de la limitación se establece la recepción estética de la recepción de Hegel por Ortega. De este modo, la recepción de la recepción mantiene un movimiento constante: de Hegel a los temas donde Ortega lo utiliza, de esos temas a su conexión con otros temas en la filosofía de Ortega que los determinan. Hegel y la limitación se presentan como hilos conductores, pero su referencia explícita será constantemente superada. Es en este sentido en el que la recepción estética amplía la recepción de Hegel que lleva a cabo el propio Ortega: si Ortega amplía a Hegel situándolo en un marco propio, nosotros ampliaremos a Ortega y su recepción al situarlos en el contexto estético de la limitación. Es un contexto estético, pero no se detiene únicamente en las ideas de Ortega sobre arte: la estética de la limitación remite a todo momento en el que la dialéctica entre límites y limitaciones se presenta ejerciendo su dinámica.

Por esto, el marco político será una de las determinaciones principales, y, con ello, el tema del paisaje adquirirá un papel crucial: el paisaje como marco estético de una vida, pero también como limitación política que hay que sostener, el paisaje como dialéctica de límite y limitación, en su constante superación de sí mismo y referencia a más allá de sí, a otros paisajes, a paisajes futuros. Si la recepción de Hegel por Ortega vendrá determinada en nuestro análisis por el tema de la limitación, también éste será dirigido por aquél. La conexión se establece en tres puntos: Ortega, Hegel y la limitación, y a partir de las referencias entre ellos se superará el marco concreto de cada uno para dar sentido a los tres.

La estética de la limitación, que es estética por mostrar insistentemente la superación de la limitación, por referir al talante simbólico, metafórico, ambiguo, en el que el sentido se supera a sí mismo y se convierte en límite, en referencia a más allá de sí, supone la conjunción de la estética de la recepción exigida como método con la recepción estética presentada como interpretación de esa recepción. Hegel y la limitación, en su conexión, darán lugar a una interpretación particular de la filosofía de Ortega en su conjunto, una interpretación basada en ambos aspectos y mostrada como estética política de la relación entre límite y limitación. 


\section{Objetivos y pretensiones}

El tema del trabajo consiste en analizar la recepción de Hegel por José Ortega y Gasset. El método para llevarlo a cabo se sostiene sobre los caracteres de una particular estética de la recepción. A la recepción de Hegel por Ortega se le añade una interpretación concreta basada en el tema de la limitación y del límite, que se constituye como estética de la limitación. Los materiales para llevar a cabo el trabajo son el conjunto de las obras de Ortega, las notas de trabajo presentes en el archivo de la "Fundación José Ortega y Gasset" y el manejo constante de la biblioteca del propio Ortega.

Esos son los puntos que definen el conjunto del trabajo. Con ellos se pretende alcanzar sobre todo tres objetivos:

- Primero, y principal, llenar el vacío que supone la ausencia de un trabajo riguroso y con pretensiones de totalidad sobre la relación entre Hegel y Ortega.

- Segundo, mostrar la aplicación del método de la recepción en la investigación sobre la filosofía de Ortega. Se pretende con ello salir de la serie de comentarios expositivos de su obra que, en gran parte de los casos, no aportan nada nuevo. Del mismo modo, el método de recepción implica ir más allá de muchos de los exámenes de la relación de Ortega con otros filósofos, exámenes basados habitualmente o en la crítica a Ortega, o en la simple enunciación de coincidencias, o en pretensiones que se alejan de Ortega, en muchos casos hasta olvidarlo.

- Y tercero, analizar un aspecto fundamental para entender la filosofía de Ortega, como es el tema de la limitación. Este tema no ha sido nunca analizado en concreto en la bibliografía sobre Ortega. El vacío no es grave únicamente por no atender a los propios intereses de Ortega, cuando éste desde muy temprano tenía planteado escribir un Ensayo sobre la limitación, sino, sobre todo, porque es en el tema de la limitación donde quizá mejor se perciba una de las mayores originalidades de Ortega: la conjunción de estética y política.

En la reunión de estos tres objetivos se mueven todas las pretensiones del trabajo. Ortega, Hegel y la limitación aparecerán en la dinámica de la referencia constante entre 
unos temas y otros. La estética de la recepción como método y la estética de la limitación como recepción de esa recepción mostrarán el hilo que determina la constante dinámica de referencias.

Para llevar a cabo este trabajo he contado con ayudas inestimables: la Universidad de Salamanca me ha permitido realizar el proyecto con los medios ofrecidos por una Beca de Formación de Profesorado Universitario y Personal Investigador -Complemento de la Universidad de Salamanca; el Departamento de Filosofía y Lógica y Filosofía de la Ciencia, así como la Facultad de Filosofía en general, me han dado todo el apoyo necesario para hacer posible el trabajo; la "Fundación José Ortega y Gasset" me ha permitido, con todo tipo de facilidades y ayudas, la consulta de los archivos de Ortega y el uso de su biblioteca personal; y, de un modo muy especial, mi tutor y drector del trabajo, José Luis Molinuevo, que, en todos los aspectos, ha hecho posible este proyecto. A todos ellos mi más profundo agradecimiento. 


\section{HEGEL Y LA LIMITACIÓN (1906-1916)}

\section{Introducción}

En la contraportada de la primera edición de Meditaciones del Quijote, en 1914, Ortega anunciaba los títulos de las posteriores meditaciones que seguirían a éstas. Ya en los años previos tenía pensados los temas a tratar en ellas, pues se conocen varias listas de los proyectos previstos por Ortega. Se conoce esa lista encontrada por Garagorri entre los papeles del manuscrito de Anatomía de un alma dispersa (texto de 1912, según Inman Fox, y no de 1910, como indican Garagorri y el propio Ortega) y se conoce también las notas de trabajo editadas recientemente por Molinuevo, que incluyen varios proyectos y listas de meditaciones y que modifican de forma explícita las conclusiones que se podrían deducir desde la nota transcrita por Garagorri38.

Entre las listas hay diferencias, unos títulos desaparecen o se modifican, hay cambios de orden, etc. Algunos de los proyectos anunciados sí fueron concluidos (los dedicados a Baroja y a Azorín, por ejemplo), pero unos cuantos se unieron formando un grupo de propósitos abandonados por Ortega que, aunque seguramente partes o pensamientos que les correspondían pasaran a formar parte de otras obras, nunca llegaron a conformarse como texto propio. Entre estas meditaciones no escritas hay una que permanece en todas las listas. Es el "Ensayo sobre la limitación".

El tema de la limitación aparecerá constantemente en los escritos publicados que rodean a Meditaciones, incluida esta obra, así como en trabajos realizados años antes de 1914, la fecha de publicación de esas "salvaciones" sobre el Quijote. La limitación a que se refiere

\footnotetext{
${ }^{38}$ Sobre los proyectos y listas de "Meditaciones", ver: el estudio introductorio de J. Marías a su edición de Meditaciones (MQ, 29 ss.); la introducción y los anejos de Garagorri a la suya, que incluyen esa lista de las meditaciones previstas (ORTEGA Y GASSET, J. Meditaciones del Quijote. Con un apéndice inédito. Madrid: Revista de Occidente en Alianza -Obras de José Ortega y Gasset, 17-, 1994³, pp. 11 n. y 166); las reconstrucciones de E. Inman Fox, que ordena, con las meditaciones escritas, el proyecto original de Ortega (ORTEGA Y GASSET, J. Meditaciones sobre la literatura y el arte (La manera española de ver las cosas). Madrid: Castalia, 1987, p. 27 ss.); por último, y podría decirse que de un modo definitivo en torno a los proyectos y listas de "meditaciones", ver las notas de trabajo editadas por Molinuevo, que incluyen varias
} 
Ortega queda indicada en el ensayo introductorio, "Lector", que escribió para toda la serie de meditaciones: "Somos héroes, combatimos siempre por algo lejano y hollamos a nuestro paso aromáticas violas. / En el Ensayo sobre la limitación, se detiene el autor con delectación morosa a meditar sobre este tema. Creo muy seriamente que uno de los cambios más hondos del siglo actual con respecto al XIX, va a consistir en la mutación de nuestra sensibilidad para las circunstancias"39. La limitación, que iba a permanecer como tema de un ensayo específico, alude a la circunstancia particular, a lo cercano, al paisaje, a la limitación española y con un destino propio que convergerá en un modo español de mirar las cosas.

La limitación, ya desde este momento inicial, introductorio, permite vislumbrar la conexión de dos caracteres que no sólo se mantendrán unidos en Ortega, sino que, además, tal conexión podría incluso conformarse como una de sus mayores originalidades: es la conexión de estética y política. Esa conexión aparecerá constantemente en los capítulos que formarán esta primera sección.

Además de la mención explícita en Meditaciones al Ensayo sobre la limitación y a su contenido, hay otra pista que permite seguir la trayectoria de ese ensayo no escrito. Esa pista es la referencia a Hegel. Tal referencia tiene dos vertientes. La primera se encuentra en las propias Meditaciones, aunque ya no en la introducción general, sino en la meditación preliminar. Se trata de la conexión entre límite y concepto, y el texto de Ortega, que aparecerá a menudo en esta sección, es el siguiente:

"Hegel escribe que donde está el límite de una cosa no está esta cosa. Según esto los límites son como nuevas cosas virtuales que se interpolan e interyectan entre las materiales, naturalezas esquemáticas cuya misión consiste en marcar los confines de los seres, aproximarlos para que convivan y a la vez distanciarlos para que no se confundan y aniquilen. Esto es el concepto: no más, pero tampoco menos. Merced a él las cosas se respetan mutuamente y pueden venir a unión sin invadirse las unas a las otras" 40.

Esta unión entre Hegel, el tema del concepto y el del límite, como veremos, supera en cierto sentido el que iba a ser el contenido del Ensayo sobre la limitación. Éste tendrá como objetivo examinar la circunstancia española, vista desde un lugar que posibilite tanto su

notas sobre esos proyectos de Ortega ("Sobre Cervantes y El Quijote desde el Escorial. (Notas de trabajo de José Ortega y Gasset) ". En: Revista de Occidente, n 156, mayo 1994, pp. 36-54).

${ }^{39} \mathrm{MQ}, 66$.

40MQ, 146-147. 
conocimiento como la necesidad de sentirla, y, con ello, ampliarla, hacerla crecer, mejorarla. Ese lugar será el tema del paisaje, que encontrará un comentario explícito en Temas del Escorial, escrito de 1915, aunque con muchas referencias a textos y temas de años anteriores. De todos modos, la conexión entre esos límites y conceptos de Meditaciones y la limitación referida al tema del paisaje y a España será determinante, porque permitirá ver no sólo lo que podría haber sido el contenido del Ensayo sobre la limitación, sino también la ampliación del tema hacia otros contextos. El tema de la limitación refiere al tema del paisaje, pero va mucho más allá y, como veremos, mantiene una unión indisoluble con el tema de la nación, con el tema del arte, con el tema del concepto, etc., y, en general, con campos que unen teoría y práctica, estética y política, filosofía y ética.

En lo que refiere al concepto, de lo que hablará Ortega es del concepto como visión completa de las cosas, el concepto como instrumento para asegurar (nunca sustituir) la espontaneidad vital, el concepto como seguridad que permita una cultura progresiva, firme, que acabe con la discontinuidad, con el carácter salvaje y fronterizo de la cultura española hasta ese momento, en lucha constante por la posesión, por la seguridad. La limitación tendrá precisamente como enemigo un carácter cercano, la cultura fronteriza: "la cultura salvaje, la cultura sin ayer, sin progresión, sin seguridad; la cultura en perpetua lucha con lo elemental, disputando todos los días la posesión del terreno que ocupan sus plantas. En suma, cultura fronteriza"41. Los límites y los conceptos, entonces, se mantendrán como instrumentos de seguridad, como instrumentos de posesión, de huida de lo no firme, de agarrar, permitiendo ver esto la alusión de Ortega a la etimología alemana de Begriff.

La segunda referencia en la pista que establece la conexión entre Hegel y el Ensayo sobre la limitación se encuentra entre las notas de trabajo editadas por Molinuevo, concretamente en dos. La primera es tajante: "Leer Hegel - Sin éste no podré atacar bien el problema de la justificación del «presente» y el «límite»". La segunda es más amplia, y permite vislumbrar aspectos diversos; escribe Ortega, remitiendo a los dioses particulares del último Schelling, teoría que será examinada más adelante: "El paisaje funda la unidad entre el hombre y Dios. Dios como el complemento de la limitación - El paisaje-milieu la limitación - Cada paisaje un Dios: el desierto es monoteísta - Los dioses indios, al trasluz, 
Galton - «Dioses momentáneos» - La limitación como la ilimitación - Hegel-Schelling: los dioses particulares" 42 . Si las conclusiones que pueden deducirse de estas notas se unen con las ideas explicitadas en las obras publicadas, podrá alcanzarse una conexión entre temas claves (Hegel, limitación, finitud, paisaje, etc.) que permitirá una lectura de Ortega en la que su recepción de Hegel se mantendrá como un hilo de discurso importante para su interpretación.

En concreto, entonces, en esta primera sección, centrada en el tema de la limitación y que, de un modo más general, pretende investigar la primera recepción de Hegel por Ortega, se intenta contestar a una pregunta que puede expresarse de varias maneras: ¿por qué necesita Ortega a Hegel para el tema del límite y del presente? ¿por qué a Hegel precisamente? ¿a qué Hegel, a qué obras, a qué temas de Hegel se refiere? Contestar a estas cuestiones es el objetivo de esta sección, y para ello se examinarán no sólo las referencias a Hegel, sino también los temas que las rodean: interesa Hegel, pero también el tema de la limitación, y será la unión de ambos la que dirigirá esta primera sección. El contexto referirá a los primeros escritos de Ortega, ocupando un espacio que iría desde los primeros años de Ortega como filósofo, hasta 1915, aproximadamente, el año posterior a la publicación de Meditaciones del Quijote.

La razón de tratar ese espacio concreto de tiempo, más que la intención de colocar "etapas" o "secciones" en la filosofía de Ortega (intención ya suficientemente explorada, y explotada, en la bibliografía orteguiana), se asienta exclusivamente en la conexión con Hegel: si en este primer momento la recepción de Hegel por Ortega remitirá, como veremos, al sistema, al concepto o a la limitación, por ejemplo, a partir de 1915 o 1916 la conexión se centrará casi exclusivamente en el tema de la historia, que culminará con los escritos publicados de Ortega sobre Hegel al final de los años veinte y comienzos de los treinta. Sólo en una época final, alrededor de los años cuarenta, surgirán otros temas y conexiones con Hegel, que no aparecen demasiado en los escritos publicados, pero sí en las notas inéditas o apuntes de lectura de Ortega, y que remitirán, por ejemplo, a la dialéctica y al tema de la nación.

\footnotetext{
$41_{\mathrm{MQ}, 155 .}$

42"Sobre Cervantes y El Quijote desde el Escorial. (Notas de trabajo de José Ortega y Gasset)". Op. cit. pp. 47 y 50 , respectivamente.
} 
La conexión entre Ortega y Hegel, ya desde los primeros años de la filosofía de Ortega, se mostrará como ambigua. Aparecerán temas y expresiones que Ortega parece no soportar, pero junto a ellos surgirán talantes y formas puramente hegelianos a los que Ortega no puede renunciar. Incluso, como veremos, en relación con el tema del límite aparecerá esa "necesidad de leer a Hegel" enfrentada a cierta "perniciosa aproximación a Hegel"43. Esta dualidad es algo más que un carácter que, aunque deberá ser examinado explícitamente, se muestre únicamente en este momento de la biografía filosófica de Ortega. La ambivalencia o ambigüedad que representa permanecerá en multitud de temas que conforman la recepción de Hegel por Ortega. Constantemente, sea en el tema de la historia, o de la dialéctica, o de la limitación, y sea en la época que sea, permanecerá esa dualidad, un cierto carácter de "con Hegel no, pero sin Hegel tampoco", que, a pesar de la dificultad que supone para el análisis, permitirá entender la relación entre Hegel y Ortega a partir de una teoría de la recepción. Una recepción que no sólo remite a la acogida de Hegel por Ortega, sino también al modo de recibir nosotros al propio Ortega.

Una de las primeras apariciones de Hegel en los escritos publicados de Ortega se encuentra en una carta a su padre desde Marburgo con fecha del 21 de enero de 1907. En esa carta Ortega recomienda a su padre que vuelva a escribir, y no artículos, o en periódico, sino libros, obras pulidas. Para ello considera inevitable la lectura de los clásicos y de "libros serios de filosofía". Le recomienda el Kant de Ryssen y el Platon de Prat, y añade: "La Estética de Hegel está en casa y su Filosofía de la historia -libro que más que ningún otro te conviene- creo que está traducido al italiano. Como introducción a Hegel acaba de publicar un buen libro el notabilísimo italiano Benedetto Croce: Cio che è vivo e cio che $e$ morto nella filosofia di Hegel"44.

En la biblioteca de Ortega presente en la "Fundación José Ortega y Gasset" no se encuentra esa Estética mencionada, con toda seguridad la edición francesa de Benard (las ediciones de la Estética en la biblioteca de Ortega son la de Meiner -incompleta- y la de la

\footnotetext{
43"Temas del Esocrial" (1915), en: Notas de andar y ver. Viajes gentes y países. Madrid: Revista de Occidente en Alianza -Obras de José Ortega y Gasset, 32-, 1988, p. 45.

${ }^{44}$ ORTEGA Y GASSET, J. Cartas de un joven español (1891-1908). Madrid: El Arquero, 1991 (Ed. Soledad Ortega), carta 90, pp. 279-280.
} 
Jubiläumausgabe, de edición posterior a esa fecha ${ }^{45}$ ), pero sí el libro de Croce, que Ortega debía estar utilizando durante esa época. Pues bien, en su ejemplar del libro de Croce, Ortega subraya el siguiente texto: "La coscienza moderna non può nè accettar tutto Hegel, nè tutto rifiutarlo, come si soleva cinquant'anni fa: essa si trova, verso di lui, nella condizione del poeta romano verso la sua donna: nec tecum vivere possum, nec sine te ${ }^{146}$. Puede decirse que la relación explícita entre Hegel y Ortega $\mathbf{e}$ expresa en términos muy similares. El desarrollo de este "con Hegel no, pero sin él tampoco", recorrerá el conjunto de la recepción de Hegel por Ortega.

Para intentar cumplimentar estas intenciones introductorias llevaré a cabo un análisis bidireccional en el que los objetos de estudio sean tanto las referencias a Hegel, como los temas (y sus contextos) donde se encuentran esas referencias. Por ello, comenzaré analizando las primeras apariciones de Hegel en Ortega, apariciones en temas y textos muy concretos de alrededor de 1908 y que, en general, remitirán al concepto de sistema. Pero será un sistema muy particular. A Ortega, más que el contenido del sistema hegeliano le interesan sus caracteres generales: la unión de particularidades, la evolución y el desarrollo, las connotaciones de progreso, de mejora, etc.

Esos caracteres revertirán en Ortega en dos direcciones, por un lado en un cierto panteísmo y romanticismo del hen kaí pan que mantiene en estos primeros años, por el otro todo lo referente al tema de España: la necesidad de educación, de cultura, de ciencia, etc., necesarios para conseguir el progreso y la mejora del país. Y es por este lado, como se examinará, por donde aparecerá una ramificación determinante del tema de la limitación que ya comienza ahora, en estos primeros años, y que llegará en Ortega hasta los escritos de los años cuarenta, especialmente en La meditación de Europa: es el tema de la nación, el tema de la relación entre España y Europa y, en general, la posición en el mundo de la circunstancia española, la limitación española. En ese tema, Hegel, Schelling y demás aparecerán en Ortega mediante el concepto de Volksgeist, que en este momento aludirá a la

\footnotetext{
45 $\mathrm{Al}$ no indicar nada Ortega, podría parecer que se refiere a una edición en castellano, pero la traducción de la Estética de Hermenegildo Giner de los Ríos es de 1908 (ver, sobre esto, LACASTA ZABALZA, J.I. Hegel en España. Un estudio sobre la mentalidad social del hegelianismo hispánico. Madrid: Centro de Estudios Constitucionales, 1984, p. 53). La Estética de Hegel que "está en casa" sería el Cours d'Esthethique traducido por Benard: HEGEL, Cours d'Esthethique. 5 vols. Trad. M. Ch. Benard. París: Mancy-Raibois, 1840-1851.
}

${ }^{46}$ CROCE, B. Ciò che è vivo e ciò che è morto della filosofia di Hegel. Bari: Laterza, 1907, p. 206. 
degeneración del talante nacional, abierto, internacional, en nacionalismo, cerrado, agresivo.

Ahora bien, esa limitación española, que requiere mejoras inmediatas, encontrará en el tema del arte y la estética un compañero inseparable. La estética política que intentará llevar a cabo Ortega se mostrará de un modo clarísimo en estos pimeros años, porque no sólo coincidirán cronológicamente escritos sobre arte o sobre política que no pueden ser separados, sino, sobre todo, porque los contenidos y las exigencias serán similares. El arte no sólo mostrará la limitación, la materia y el paisaje españoles, sino que, además, deberá cumplir su misión intelectiva y pedagógica de ampliar esa limitación, deberá crear ideales, mostrar ilimitaciones, tocar almas y sentimientos que reviertan en un talante práctico.

Uno de los temas que conjuntará odos esos caracteres es el que Ortega tenía en mente para el Ensayo sobre la limitación, el tema del paisaje, que expresará no sólo la materia española, sino también la necesidad de su mejora. Como veremos, Hegel aparecerá aquí y allá en momentos determinantes, siempre en conexión con el tema de la limitación, sea en lo referente al paisaje, sea en lo referente al concepto. Incluso, como trataré de demostrar, los análisis orteguianos del símbolo y la metáfora, temas fundamentales no sólo para entender el Ortega de este periodo, sino también para entender el tema de la limitación, tendrían en Hegel un tratamiento similar en sentidos determinados, que permite ampliar la conexión entre ambos autores.

Es necesario, para cualquier estudio o escrito sobre Ortega que se quiera llevar a cabo, mantener muy clara, muy cuidada, la base que representan los escritos y temáticas de estos primeros años. Aunque parte de las temáticas o los conceptos o los análisis de Ortega puede que permanezcan con los años, o que mantengan tratamientos similares, o que parezca que simplemente se "amplían", es muy difícil mantener la seguridad de la verosimilitud de tal conexión. En concreto: en Ortega no se puede mezclar, si no se ha llevado a cabo un análisis meticuloso del recorrido, un exto de estos primeros años con un escrito de los años treinta, por ejemplo, aunque incluso las palabras empleadas por el filósofo sean muy similares. Los contenidos, las intenciones y los contextos serán diferentes.

Por ello, y es especialmente importante en lo que se refiere a estos primeros años, los que irían hasta 1915, aproximadamente, se mantendrá un extremado cuidado en lo que refiere a las fechas, aunque ello suponga perder ciertas ampliaciones de temas a tratar. Esta 
rigurosidad en el tratamiento cronológico, biográfico, contextual, es indispensable en cualquier escrito sobre Ortega. 


\section{El liberalismo y la polémica con Maeztu}

Volviendo a la obra de Croce citada, en otro de los textos subrayados por Ortega puede leerse: "Un certo romanticismo filosofico, che è una condizione (benchè nient'altro che una condizione) per bene intendere Hegel e tutti i filosofi del suo periodo'47. No es casual que Ortega enfatizara esa idea: el cariz romántico es importantísimo en este momento. Nos encontramos ante los primeros textos de Ortega, en la primera década del siglo. El libro de Croce es de 1907, también lo es la carta a su padre donde Ortega aconseja su lectura. El Hegel que aparecerá en estos primeros años está unido a ese romanticismo de una forma explícita. Es más, puede afirmarse que ese Hegel romántico procede de manuales, de historias de la filosofía, de las lecciones escuchadas en Alemania, pero no de una lectura concreta del propio Hegel: Ortega no lee a Hegel de un modo detenido hasta algunos años más tarde.

No será difícil demostrar esto acudiendo a los textos, pero también hay algunas curiosidades que pueden servir como complemento. Los tres primeros viajes de Ortega a Alemania son de 1905, 1907 y 1911; sin entrar en cuánto tiempo necesitó o dejó de necesitar Ortega para aprender alemán, en las ediciones de las obras de Hegel presentes en la biblioteca de la Fundación sólo hay una fecha, esa fecha es "Marburgo, 1911" y se encuentra escrita por Ortega al comienzo de la Enciclopedia... en la edición italiana de Croce. Por otro lado, en la Fundación hay tres ediciones, aparte de obras independientes, de la Werke de Hegel: la de Lasson, la de Glockner y la iniciada en 1832 por Michelet, siendo la segunda la única completa 48 . Si se toma únicamente la última, que Ortega compraría de segunda mano, en el interior del volumen XIII, las Lecciones sobre historia de la filosofía, he encontrado una referencia que puede ayudar a situar fechas: una postal dirigida a Ortega por Hugo Hallwig desde la Treuner Buchhandlung agradeciendo el hecho de que Ortega le "envíe" clientes. La postal es del 13 de febrero de 1912.

47CROCE, B. Ciò che è vivo e ciò che è morto della filosofia di Hegel. Bari: Laterza, 1907, p. 205.

${ }^{48}$ HEGEL, Sämtliche Werke. Jubiläumsausgabe in 20 Bänden. In neuer Anordnung herausgegeben von H. Glockner. Stuttgart: Frommanns Verlag, 1927-1929; HEGEL, Sämtliche Werke. Hrsg. G. Lasson. Leipzig: Meiner, 1923 ss.; HEGEL, Werke. Vollständige Ausgabe durch einen Verein von Freunden des Verewigten. Berlin: Verlag von Duncker \& Humblot, 1832 ss. 
Sin entrar de un modo concreto en determinar exactamente cuándo comenzó Ortega a leer a Hegel, lo que es cierto es que al inicio de la segunda década del siglo se encuentra ocupado con él, incluso años antes, como veremos por la aparición de Hegel en los escritos sobre la polémica con Maeztu, aparecen referencias explícitas a Hegel, sobre todo a la Fenomenología del espíritu, concretamente al prólogo. Esa ocupación procedía de la necesidad de leer a Hegel para el tema del sistema, del concepto, del Volksgeist, etc., contenidos y tratamientos que, en todo caso, preceden a la lectura de la Filosofía de la historia que Ortega llevará a cabo en los años veinte, y que conducirán hasta esa "necesidad de leer a Hegel para entender el tema del límite".

Si el Ortega de 1908 encuentra en el recuerdo de sus 18 años "nuestra época de «nietzscheanos»; atravesábamos a la sazón, jocundamente cargados con los odrecillos olorosos de nuestra juventud, la zona tórrida de Nietzsche"49, si Nietzsche trajo el primer cargamento de orgullo, de ímpetu, que salvaba del achabacanamiento patrio, si los primeros artículos publicados de Ortega, esas Glosas de 1902, tienen un clarísimo sabor nietzscheano. Si en 1906, Ortega estaba "en, de, con, por, sin sobre Kant y espero ser el primer español que lo ha estudiado en serio'50, si primero desde Berlín y luego desde Marburgo al lado de Cohen, Ortega asumirá los planteamientos neokantianos, tanto en el plano filosófico como en las posibilidades que ofrecen para la actuación en España, teoría y práctica: "el error de nuestro agarbanzamiento consiste en creer que la teoría y la práctica son cosas distintas", escribía a su padre desde Marburgo en $1906^{51}$. Si Nietzsche primero y Kant, a través del neokantismo, después, representarían momentos ineludibles en el joven Ortega, las primeras apariciones de Hegel (determinadas por esas otras referencias), por contra, en los escritos de Ortega no tienen lugar hasta 1908. También la primera referencia

\footnotetext{
49"El sobrehombre" (1908). OC I, 91.

50 ORTEGA Y GASSET, J. Cartas de un joven español (1891-1908). Madrid: El Arquero, 1991 (Ed. Soledad Ortega), carta 83, pp. 255.

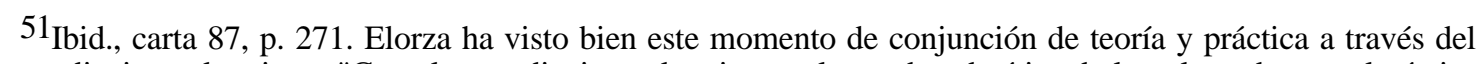
aprendizaje neokantiano: "Con el aprendizaje neokantiano, a la sombra de ética de la voluntad pura, el tríptico parece desplegarse definitivamente: la teoría analiza la realidad, la conoce en su objetividad; la práctica se apoya de modo inmediato en esa teoría, siendo movida por la voluntad e incardinándose en el mundo social a través de la política". ELORZA, A. La razón y la sombra. Una lectura política de Ortega y Gasset. Barcelona: Anagrama, 1984, p. 34. O, de otro modo, "el neokantismo como ilustración", del que hablaba Cerezo: CEREZO GALÁN, P. La voluntad de aventura. Aproximamiento crítico al pensamiento de Ortega y Gasset. Barcelona: Ariel, 1984, p. 18.
} 
de Ortega a Fichte aparece en 1908, después de su segundo viaje a Alemania ${ }^{52}$. No es casual.

En junio de 1908 Ortega escribe "¿Hombres o ideas?", artículo que será comentado y criticado por Maeztu, y cuyos comentarios volverán a ser examinados por Ortega en "Algunas notas", otro texto del mismo año. Puede afirmarse que en esos textos se encuentra la primera aparición de Hegel en los escritos publicados de Ortega. ¿¿Hombres o ideas?" es un artículo crucial en esta etapa de la biografía intelectual de Ortega, o, más que el artículo en sí, el tema que representa. Y no sólo ese texto, sino también los que le acompañan en esa época. Ortega introduce el artículo en una obra de 1916, Personas, obras, cosas, y en el prólogo aclara aspectos determinantes:

"Van en este volumen reunidos los trabajos menos imperfectos de entre los que he publicado durante la corriente de nueve años. [...] Mi mocedad no ha sido mía, ha sido la de mi raza. Mi juventud se ha quemado entera, como la retama mosaica, al borde del camino que España lleva por la historia. Hoy puedo decirlo con orgullo y con verdad. Esos mis diez años jóvenes son místicas trojes henchidas sólo de angustias y esperanzas españolas. / En todo lo esencial puedo hacerme actualmente solidario de los pensamientos que este volumen transporta. Sólo hallo una excepción grave, a que responden dos o tres advertencias por mí deslizadas al pie de otras tantas páginas: me refiero al valor de lo individual y subjetivo. Hoy más que nunca tengo la convicción de haber sido el subjetivismo la enfermedad del siglo XIX, y en grado superlativo, la enfermedad de España. Pero el ardor polémico me ha hecho cometer frecuentemente un error de táctica, que es a la vez un error substancial. Para mover guerra al subjetivismo negaba al sujeto, a lo personal, a lo individual todos sus derechos. Hoy me parecería más ajustado a la verdad y aun a la táctica reconocérselos en toda su amplitud y dotar a lo subjetivo de un puesto y una tarea en la colmena universal" 53 .

El tema del subjetivismo, o, mejor, la táctica ante él, tanto la que ahora, en 1916, considera errónea, como la que aquí presenta, va a ser determinante. Pero este inicio, esta primera aparición concreta de Hegel en Ortega, que se presenta exactamente en "Algunas notas", la réplica de Ortega a la respuesta de Maeztu a "¿Hombres o ideas?", es tan importante que hay que determinar el contexto. En mayo de 1908 Ortega escribe "El cabilismo, teoría conservadora", Maeztu glosa el artículo en Nuevo mundo y en junio del mismo año Ortega contesta con "̈Hombres o ideas?". Maeztu replica al artículo de Ortega, y éste, de nuevo, responde en agosto mediante "Algunas notas".

${ }^{52}$ Cfr. MOLINUEVO, J.L. "Salvar a Fichte en Ortega", en: Azafea, III, 1990, p. 107. 
Maeztu vuelve a responder en septiembre desde Nuevo mundo y Ortega contesta con "Sobre una apología de la inexactitud" desde Faro y en el mismo mes. En general, lo que está en juego es el idealismo, el idealismo político que en este momento defiende Ortega y que dejaba claro en 'La reforma liberal", artículo que reaparecerá en "̈Hombres o ideas?". Ya ahí, en "La reforma liberal" muestra Ortega claramente la conexión entre sistema e idea. Esa conexión es la que conducirá a Hegel tanto en "̈Hombres o ideas?", como, sobre todo, en "Algunas notas". No deja de ser curioso: el liberalismo, o, mejor, esta caracterización que el Ortega de 1908 hace del liberalismo, entendiéndolo como sistema de la revolución, revolución ideal, realización del ideal moral, será la que conduzca hasta la primera aparición explícita de Hegel en sus escritos.

"La reforma liberal" se iniciaba ya con la temática de hombres-ideas: "Es tan grande la energía de las ideas que no cabe dentro de la mecánica, y ha sido menester abrir todas las compuertas del mundo natural a fin de que se espacie en la región de las posibilidades limitadas. La existencia de esta energía ideal nos permite dormirnos todas las noches con un poco de dulzor en el corazón y algunos aromas de esperanza en la fantasía: sin ella sería el optimismo un vicio, aun falta de braveza intelectual" 54 . Ahora bien, las ideas políticas, que son las que en este momento interesan a Ortegan, necesitan tomar carne, habitar un cuerpo. La idea debe expandirse, debe emocionar, debe llegar a formarse un arte de las emociones sociales que permita a la idea realizarse.

Años más tarde, desde Meditaciones, Ortega continuará concretando este carácter real de la idea; incluso, también en 1914, en 'Vieja y nueva política", mostrará a la cultura como esa conexión de idea y realización: "Lo general no es más que un instrumento, un órgano para ver claramente lo concreto; en lo concreto está su fin, pero él es necesario. Mientras sean para los españoles sinónimos la idea general y lo irreal, lo vago, todo empeño de renacer fracasará. Porque cultura no es otra cosa sino esa premeditada, astuta, vuelta que se toma con el pensamiento -que es generalizador- para echar bien la cadena al cuello de lo concreto" 55 . Pero conviene no adelantar acontecimientos.

\footnotetext{
${ }^{53}$ Personas, obras, cosas (1916). OC I, 419-420.

54"La reforma liberal" (1908). OC X, 31.

55"Vieja y nueva política" (1914). OC I, 284.
} 
Ese arte de las emociones sociales, esa misión estética de conceder carácter emotivo a la idea, es tarea de los periódicos, pero también del político. El propio Ortega, viéndose a sí mismo como articulista, como formando parte de esos periódicos, parece definir su propia misión: "El periódico no es ciencia, sino arte; arte de las emociones sociales. Como en algún modo el político, los periódicos están encargados de dar a la idea carne de emoción para que se expanda y se haga emotiva"56. Es la conexión, entonces, de tres factores, de tres componentes: la idea, la política y la estética. La relación entre los tres aspectos aumentará, modificará y detallará su contenido, pero de un modo u otro permanecerá. Es el idealismo estético y político que mantiene el Ortega de estos años. 'La reforma liberal" se refiere de un modo explícito, mediante esa conjunción de idea, política y arte, el arte de las emociones sociales, al liberalismo, a la necesidad de resucitar en España el liberalismo como idea para que ésta pueda tomar cuerpo en un verdadero partido liberal.

El tema es el liberalismo, pero el contexto es mucho más amplio: la necesidad de rehacer España, la necesidad de educación, de pedagogía, de cultura, de ideas. Por ello, cuando Ortega escriba 'La conservación de la cultura", un mes después de 'La reforma liberal", comentando este texto dirá que "no era sino un ensayo de pedagogía política, en el sentido moral de esta palabra", pero es que, además, dejará claro que "la función central de la política debe ser la educación"57. Se trata del ideal moral, el ideal que falta a España: España carece de ideas políticas, y esas ideas son necesarias. El problema es que si no se aceptan, en general, las ideas como tales, difícilmente serán aceptadas sus concreciones, sus realizaciones. Se olvida que "el Ideal y la realidad son dos mundos adyacentes"58. España no tenía ideas políticas, y el papel del liberalismo era justamente dárselas: "el nuevo liberalismo es un deber; no es una comodidad. Y anticipar ideales y educar según ellos los corazones, constituye la misión impersonal, que sin ensoberbecer, obliga, impuesta por el Demiurgo que ordena la Historia a los pensadores de cada pueblo. Por eso no queremos reformar las costumbres sino cultivar las ideas" 59 .

\footnotetext{
56"La reforma liberal" (1908). OC X, 32-33.

57"La conservación de la cultura" (1908). OC X, 43.

58 Ibid. p. 42.

${ }^{59}$ Ibid. pp. 44-45.
} 
La misión del liberalismo, teniendo claro que Ortega, como él mismo insiste en recalcar, mantiene intenciones que no son de política, sino de Política, consiste en traer esas ideas, esos ideales morales, políticos, que conducen a emociones universales y cosmopolitas. "Mi liberalismo lo exige: me importa más Europa que España, y España sólo me importa si integra espiritualmente Europa. Soy, en cambio, patriota, porque mis nervios españoles, con toda su herencia sentimental, son el único medio que me ha sido dado para llegar a europeo. $\mathrm{Ni}$ tristeza, ni melancolía me produce ser español: es más, creo que España tiene una misión europea, de cultura, que cumplir'60. España y Europa, entonces, pero reunidos en torno a ese ideal moral, de cultura, de educación, que sólo si España lo recibe para sí podrá conducirle a su misión europea. La relación entre España y Europa será siempre de ida y vuelta: España tiene una misión europea, pero sólo podrá desempeñarla si antes introduce en sí misma los caracteres de esa Europa llena de ciencia, de conceptos, de ideas, que Ortega ha visto en sus viajes. A partir de aquí se conjuntan el liberalismo y, en general, el idealismo político y estético que Ortega defiende.

Cuando Ortega defina ahora, en 'La reforma liberal", al liberalismo como el "sistema de la revolución"61, tomando tal definición de Stahl (el filósofo que teorizó la acción conservadora alemana y que censuraba así el liberalismo62), pero concediéndole una valoración opuesta, estará no sólo concretando su teoría del liberalismo en este momento, sino, además, forjando el contexto que, al unir los conceptos de sistema, idea y desarrollo o transformación, permitirá entender las referencias a Hegel en "¿Hombres o ideas?" y en "Algunas notas". Unicamente analizando ese contexto es posible entender esta primera aparición de Hegel en la obra de Ortega.

\footnotetext{
60 Ibid. p. 45.

${ }^{61}$ Definición que seguirá manteniendo dos años más tarde: "Sin miedo a ninguna mala interpretación, puede repetirse ahora lo entonces dicho, puede afirmarse que los partidos liberales son partidos fronterizos de la revolución o no son nada". "Lerroux, o la eficacia" (1910). OC X, 157.

${ }^{62}$ No hay que olvidar que Friedrich Stahl, alumno de Schelling, fue convocado por Federico Guillermo IV a Berlín, en 1840, con el fin de realizar un estudio sobre la influencia de la filosofía hegeliana en el derecho. Con la llegada de Federico Guillermo IV al poder de Prusia, el cambio en la materia de política cultural supuso el traslado de las simpatías oficiales desde el hegelianismo hasta los representantes de la Escuela Histórica. El propio Schelling fue también llamado a Berlín para acabar con "la mala simiente del hegelianismo". Ver sobre esto: SCHNÄDELBACH, H. Filosofía en Alemania, 1831-1933. Madrid: Cátedra, 1991, p. 48 n.
} 
El liberalismo, entonces, como "sistema de la revolución", pero sin olvidar que "sistema es una idea: sistema de la revolución significa, pues, idea de la revolución o revolución ideal"63, con lo que "llamo liberalismo a aquel pensamiento político que antepone la realización del ideal moral a cuanto exija la utilidad de una porción humana, sea esta una casta, una clase o una nación. La dirección conservadora, por el contrario, se desentiende de exigencias ideales, niega su valor ético y se atiende en este punto a lo ya logrado, cuando no fomenta el regreso a formas superadas de constitución política'64. Este es el carácter del ideal que se va a mantener: ninguna concreción, ningún régimen social o político es completa o definitivamente justo, sino que siempre habrá una posibilidad de mejora, una posibilidad de ampliación, que, al no haberse alcanzado todavía, va más allá de lo concretado, de lo realizado, de la constitución escrita. Es un derecho ideal, un derecho a la transformación para ir más allá, en busca de algo mejor, algo todavía no conseguido, un derecho, entonces, sobreconstitucional, pues va más allá de la constitución escrita, dada: "A ese derecho sobreconstitucional que es a su vez un sagrado deber, llamo revolución"65.

Con ello se unen ese deber sagrado de la revolución, el ideal, el progreso y la educación. Sólo dos años antes, en el discurso para los Juegos Florales de Valladolid, que escribió Ortega para que lo presentara su padre, José Ortega Munilla, puede leerse: "El más grande deber de cada generación es labrar un ideal nuevo, fresco, fructífero a la generación que sobreviene. Esto y no otra cosa es el progreso. [...] La labor de los que ya somos viejos labor que a nosotros mismos nos salvará del pesimismo- ha de ser hundirnos en esa alba cantera de la sinceridad y de la ciencia y arrancándonos grandes bloques de mármol virgen cincelar en ellos un magno ideal de exaltación, un ideal político. / La misión educativa consiste en hacer fecundo ese ideal año tras año, lentamente porque no es tarea de un momento ni fácil inyectar de ideal el aparato de una raza marchita"66.

Ese deber de la revolución es el que caracterizaría la libertad que parece haber acompañado siempre al liberalismo. Una libertad que no es la del laissez faire, laissez

63"La reforma liberal" (1908). OC X, p. 34.

64 Ibid. pp. 34-35.

65 Ibid. p. 35.

66"Discurso para los Juegos Florales de Valladolid". En: ORTEGA Y GASSET, J. Cartas de un joven español (1891-1908). Op. cit. pp. 771-772. 
passer, sino la libertad para amonestar constantemente la ley escrita, para condenar todo estancamiento, para buscar constantemente la mejora, para inventar. Es una labor de futuro, no de pasado, con lo que concuerda con la labor del ideal, "el ideal, cuando lo es, ni es fantasía ni es ensueño: es la anticipación de la realidad futura"67, y con la propia idea de "patria": "La patria no es nunca una cosa hecha, cumplida, histórica, hieratizada y perfecta, sino un perpetuo problema, una tarea nunca acabada, una futura realidad, un conflicto entre posibilidades presentes"68. Es el patriotismo enérgico69, el de la patria como Kinderland y no Vaterland de Nietzsche: "El patriotismo enérgico: amar la patria es hacerla y mejorarla. Un problema a resolver, una tarea a cumplir, un edificio a levantar: esto es patria. La conocida frase de Nietzsche lo ha formulado exactamente: Patria no es la tierra de los padres -Vaterland-, sino tierra de los hijos -Kinderland"70.

La idealidad como anticipación no destruye, no aniquila la realidad, sino que la modifica, la mejora, la reforma. Es aquí donde, según Ortega, concluiría la acción del liberalismo y comenzaría la de su instrumento, el partido liberal, que tendría como misión "adecuar trozo a trozo el ideal a la realidad y hallar las fórmulas para insertar en ella la mayor porción posible de ideal. De este modo quedan sistematizadas las revoluciones"71. Pues bien, está sistematización de las revoluciones, que se inicia en el contexto presentado y significa la adecuación de idea y realidad, conducirá a Ortega hasta Hegel.

67"La reforma liberal" (1908). OC X, p. 37.

68"Viaje de España" (1910). OC I, 527.

${ }^{69}$ Alain Guy definía ese patriotismo enérgico como sigue: "El verdadero patriotismo: este último no debe ser "extático", es decir, no debe quedar inmovilizado en una beata admiración del pasado nacional, con la intención de eternizarlo creyéndolo impecable. Por el contrario debe ser "enérgico", es decir, debe incitar a los españoles a mejorar su país en todos los planos, superando todo lo que conserva de arcaico y de preterido para lograr un progreso auténtico". GUY, A. "Ortega y Gasset: su visión de Europa", en: Aporía, n 21-24, 19831984, p. 26.

70"Nueva revista" (1910). OC I, 144.

71"La reforma liberal" (1908). OC X, p. 37. 


\section{Ideas y sistema}

Con la serie de ideas expuestas como fondo, Ortega escribe "El cabilismo, teoría conservadora", el artículo que supondrá la crítica de Maeztu contestada por Ortega con "¿Hombres o ideas?". España no es ni individualista ni colectivista, sino cabilista, banderista, esto es, su carácter es el de los bandos, donde cada hombre se reúne en torno a un jefe cuyos intereses defenderá siempre que coincidan con los suyos. La política europea, la política de partidos, no existe en España, y no existe porque un partido reúne en torno a una idea política, y en España no hay ideas políticas. "Hoy en España no hay partidos políticos, sino bandos, cuadrillas. No hay ideas políticas"72, escribe Ortega contra la afirmación de Azorín de que los partidos políticos los hacen hs personas, que los partidos no son ideas, sino hombres. Este es el inicio de "¿Hombres o ideas?".

Pero antes de pasar a este texto es importante comentar el carácter de individualismo que Ortega no encuentra en España, y es importante porque es un primer modo de mostrar los rasgos de limitación: "Individualismo es pasión por la peculiaridad, es heroico cultivo de nuestra fisionomía personalísima, de nuestros rasgos genuinos, de nuestra acción señera"73. Ortega habla incluso de "henchir la individualidad", como más adelante hablará de "henchir la limitación". España no ha tenido ni tiene conciencia de su individualidad, de su limitación, de su destino. No ha tenido ni tiene conciencia de sí misma, de sus temas individuales, de sus nomini singulari.

Por esto, misión que Ortega se encargará de llevar a cabo, la necesidad de henchir esa individualidad, henchir esa limitación, por eso la necesidad de examinar todos esos nomini singulari, autores o temas, mitos o figuras, Don Quijote, Don Juan, El Greco... o, en general, los proyectos que más adelante deberían haber formado el conjunto de Meditaciones. El tema de la limitación, entonces, comienza bastantes años antes de Meditaciones, y acompaña de forma ineludible a todos esos caracteres de educación, de progreso, de cultura, de idealismo político y estético que en este momento se presentan como indispensables, e incluso "¿Hombres o ideas?" conducirá de forma concreta al Renan, donde la limitación aparecerá enfrentada a un enemigo, por lo menos a primera

\footnotetext{
72"El cabilismo, teoría conservadora " (1908). OC X, 61.

${ }^{73}$ Ibid. p. 59.
} 
vista, inexpugnable: el panteísmo, el panteísmo de este Ortega romántico y muy cercano al hen kaí pan.

Ortega, en "¿Hombres o ideas?", intenta dejar las cosas claras desde el comienzo:

"No, querido Ramiro; el intelectualismo (?), el idealismo que yo defiendo, no llevan a creer que las ideas andan solas. / Un hábito mental que no he logrado dominar me impele a ver todos los asuntos sistemáticamente. Creo que entre las tres o cuatro cosas inconmoviblemente ciertas que poseen los hombres, está aquella afirmación hegeliana de que la verdad sólo puede existir bajo la figura de un sistema. De aquí la enorme dificultad que encuentra lo verdadero para resplandecer en un artículo o en un discurso parlamentario. En virtud de esta convicción, he procurado exponer, con un poco de rigor sistemático, la doctrina del Idealismo político: tal fue la intención de un artículo que vio la luz en Faro con el título de "La reforma liberal", trabajo que ha leído usted con cariño, pero que ha olvidado al punto. Venía a decir allí que las ideas políticas no se satisfacen viviendo quietas en los libros, como las ideas científicas, sino que habían de incorporarse en un hombre que supiera convertirlas en emociones. La psicología idealista es la primera en afirmar que al hombre sólo le mueven los afectos, las pasiones, que se llaman también emociones precisamente porque incitan, porque mueven los músculos, al paso que idea significa mirar, ver, contemplar, espejar, especular"74.

Ese sistematismo no refiere únicamente a una cuestión de estilo, de exposición. La sistematización de las revoluciones remitía al sistema como idea, a la idealización de las revoluciones y la necesidad de la transformación y desarrollo continuos. Este sistema como idea, y con ella como evolución, como desarrollo, no sólo remite a Hegel de un modo implícito, sino que en "Algunas notas", cuando Ortega replique a la respuesta de Maeztu, explicitará de modo concreto la relación con Hegel.

La afirmación hegeliana que menciona Ortega se encuentra en el prólogo a la Fenomenología. Ortega utiliza en este momento la edición de Lasson de 1907, y el texto lo subraya al margen. Se trata de lo que el propio Hegel considera su propuesta filosófica: "Die wahre Gestalt, in welcher die Wahrheit existiert, kann allein das wissenschaftliche System derselben sein. Daran mitzuarbeiten, dass die Philosophie der Form der Wissenschaft näherkomme - dem Ziele, ihren Namen der Liebe aum Wissen ablegen zu können und wirkliches Wissen zu sein - ist es, was ich mir vorgesetz". En la misma página Ortega encontrará esa definición del límite que utilizará en Meditaciones: "Ebenso ist die Verschiedenheit vielmehr die Grenze der Sache; sie ist da, wo die Sache aufhört, oder sie

74" ¿Hombres o ideas?" (1908). OC I, 439-440. 
ist das, was diese nicht ist"75. No es casual que ambas ideas, la del límite que utilizará en Meditaciones y la conexión de sistema y verdad que menciona ahora en "¿Hombres o ideas?", se encuentren tan cercanas una de otra. Tanto el tema del sistema, o de la idea, como el del límite, caminan de forma paralela en la recepción que Ortega hace de Hegel en este momento.

En el párrafo citado Ortega no es demasiado justo con el concepto de sistema. El "sistema", en "La reforma liberal", no remitía únicamente al rigor con que examinaba la doctrina del idealismo político, sino que se presenta en ese lberalismo como "sistema de revolución" que permitía la pregunta de Ortega: "¿Qué prefieren: un sistema de revolución o revolucionarios sin sistema?"76, así como la concreción del sistema como idea, y, con ella, la teoría del ideal como cambio, modificación de lo real, libertad para inventar. Cuando la teoría pasaba a la práctica y adecuaba el ideal a lo real, misión ya del partido liberal, las revoluciones quedaban "sistematizadas". El sistema, pues, como idea, incluye teoría y práctica, revoluciones y desarrollos, progresos y libertades. Así, si en "̈Hombres o ideas?" parece huir Ortega en cierta medida de la categoría de sistema, de modo inmediato la concretará, al responder a la crítica de Maeztu, y hará regresar ideas procedentes de esa "sistematización de las revoluciones".

Las ideas políticas han de ser convertidas en emociones. Se trata del arte de las emociones sociales que aparecía en 'La reforma liberal": la idea no puede permanecer en la simple vista, en la mirada, en la contemplación, sino que ha de incluir algo que permita su realización, su efectivización. Debe ser una mirada, una vista que emocione, que incluya esa emoción y dé lugar a que la simple contemplación torne en realización. La idea política, estética, al entenderse como mirada, como vista, adquiere posibilidades de realización precisamente al incluir la emoción, el arte de la emoción social, al incluir la incitación, el movimiento. De nuevo, entonces, la conjunción de estética y política, que supone la

\footnotetext{
${ }^{75}$ Cito por la edición que maneja Ortega en este momento: HEGEL, Phänomenologie des Geistes. Jubiläumsausgabe, Hrsg. G. Lasson. Leipzig: Verlag der Dürr'schen Buchhandlung, 1907, p. 5. La edición castellana traduce, respectivamente: "La verdadera figura en que existe la verdad no puede ser sino el sistema científico de ella. Contribuir a que la filosofía se aproxime a la forma de la ciencia -a la meta en que pueda dejar de llamarse amor por el saber para llegar a ser saber real: he ahí lo que yo me propongo", y: "Asimismo, la diversidad es más bien el límite de la cosa; aparece allí donde la cosa termina o es lo que ésta no es". Fenomenología del espíritu. Trad. W. Roces. Madrid: F.C.E., 1988 ( $7^{\text {a }}$ reimp.), pp. 9 у 8, respectivamente.

76"La reforma liberal" (1908). OC X, p. 36.
} 
aparición de los otros dos componentes, la educación y la moral. Educación para ser capaces de adquirir esas ideas, moral para ser capaces de realizarlas.

En este momento, Ortega cree coincidir con Maeztu, y escribe: "la historia es para ambos la realización progresiva de la moralidad; es decir, de las ideas. Y al actuar políticamente seguiremos al hombre cuyo programa más se aproxime a nuestra idea del bien, sea él quién sea, y con él, llegado el caso, nos hundiremos prietamente abrazados a nuestra idea"77. La idea, entonces, unida a la moralidad, a la cultura, a la educación, a la historia, difícilmente andará sola. Pero, a la vez, esa unión de aspectos, esa conjunción de medios y objetivos reunidos con el fin de realizar la idea, de salvar España concediéndole ideas, de las que carece, e ideas que a través de una labor de cultura y educación puedan realizarse, puedan dar lugar a un progreso, a un desarrollo, exige la sistematización de esa serie de aspectos reunidos para tal fin. Es aquí donde, tras las críticas de Maeztu, definirá Ortega en "Algunas notas" la posición real que ocupaba Hegel a través de esa afirmación de que la verdad sólo puede existir con la figura del sistema.

Pero el sistema del que está hablando Ortega es muy especial. Es un sistema de unificación, en el que las dimensiones morales, políticas y estéticas deben reunirse con el fin común de educar y culturizar España, en todos los sentidos. En lo referente a la estética, Ortega, antes de iniciar el diálogo con Hegel, trata de ser lo más concreto posible, y escribe: "No comprendo bien el horror hacia el arte por el arte que acomete a algunos pensadores españoles contemporáneos. La estética es una dimensión de la cultura, equivalente a la ética y a la ciencia"78. Se trata de la unificación de dimensiones que, mediante su reunión en un sistema que incluya teoría y práctica, idea y realización de tal idea, sea considerada como instrumento de salvación para el problema de España.

En el fondo se encuentra el idealismo neokantiano, estético y político, estético-político, que, precisamente por aunar ambos factores, puede llevar a cabo su misión de educación, de germen de progreso. Es el idealismo que Ortega, sí, fue a buscar a Alemania ("yo fui a Alemania para henchir de idealismo algunos tonelillos"79), pero que, una vez encontrado, exigía su realización y su práctica en España, necesariamente adecuadas, entonces, tanto a

\footnotetext{
77" ¿Hombres o ideas?" (1908). OC I, 441.

78"Algunas notas" (1908). OC I, 113.
} 
los problemas como a las posibilidades y características propias del país (ése era el sueño de Ortega: " $¡ Y$ yo que soñaba en convertirme desde Alemania en importador de idealismo, que es lo que aquí hace falta", escribe a Navarro Ledesma ${ }^{80}$ ).

Ortega responderá de un modo tajante a las críticas de Maeztu por el miedo de éste a la "excesiva sistematización de las ideas". En el fondo, el contexto se encuentra determinado por aquel cuasi-lema que Ortega escribía dos años antes: "La estética es una cuestión política, como lo es toda fuerza capaz de poner sobre el mundo un ideal"81. Ese era el idealismo estético-político, que tendrá como consecuencia el claro acercamiento del Ortega de estos primeros años al panteísmo romántico, pero también esta conceptualización del sistema que realiza en "Algunas notas". Es necesario citar completo el texto de Ortega:

"La afirmación de Hegel no sólo no excluye la del desarrollo, sino que, omo usted sabe, Hegel ha construido más hondamente que nadie el sistema de la evolución. Exigir un sistema como yo hago no tiene nada que ver con el escolasticismo de la Sorbona. La verdad para Hegel no se exhausta jamás; la Idea evoluciona mañana, como hoy y ayer; es, como dirían Kant y Fichte, una tarea, un problema infinitos. Pero en cada instante es preciso que la verdad del mundo sea un sistema, o lo que es lo mismo, que el mundo sea un cosmos o universo. / Sistema es unificación de los problemas, y en el individuo unidad de la conciencia, de las opiniones. Esto quería yo decir. [...] No es decente mantener en el alma compartimientos estancos, sin comunicación unos con otros; los cien problemas que constituyen la visión del mundo tienen que vivir en unidad consciente. Cabe, naturalmente, no tener listo un sistema; pero es obligatorio tratar de formárselo. El sistema es la honradez del pensador. Mi convicción política ha de estar en armonía sintética con mi física y mi teoría del arte. / No entiendo, pues, lo que usted llama conceder demasiada importancia a los sistemas. Estos no han de ser más o menos importantes: han de ser y basta. De su falta proviene el doloroso atomismo de la raza española, su disgregación. Es preciso que el alma nuestra marche con perfecta continuidad desde "Los borrachos", de Velázquez, hasta el cálculo infinitesimal, pasando por el imperativo categórico. Sólo mediante el sistema pondremos bien tenso el espíritu de nuestra raza como un tinglado de cuerdas y estacas sirve al beduino para poner tirante la tela feble de su tienda" 82 .

El sistema que tiene en mente Ortega posee una referencia claramente política, práctica, así como un objetivo explícito: atacar el atomismo y la disgregación española, en todos los

79"Las dos Alemanias" (1908). OC X, 24.

${ }^{80}$ ORTEGA Y GASSET, J. Cartas de un joven español (1891-1908). Op. cit. carta 184, p. 580.

81"Las fuentecitas de Nuremberga" (1906). OC I, 428.

82"Algunas notas" (1908). OC I, 114-115. 
sentidos. Las ideas, el ideal moral, estético y político del que carecía España exigen la función unificadora del sistema. Con ello, el tema del sistema concuerda con el tema de la limitación, la individualidad y el destino propiamente españoles: sólo el sistema, que une los compartimientos estancos, que comunica política, estética, filosofía y ciencia, con una finalidad moral y cultural, puede forjar una limitación que no excluya ningún elemento.

Es el sistema, este sistema como armonía y tarea, el que permite la evolución y el desarrollo, y, con ellos, la posibilidad de que la limitación española adquiera carácter de límite, esto es, permita el contacto con los contextos, la ampliación que significaba aquel liberalismo como "sistema de la revolución" a partir del cual se impedía la culminación de las mejoras, de las posibilidades de progreso y crecimiento.

Por todo ello, Ortega acude a Hegel en este momento, pues de él puede tomar un sistema que, sí, se mantiene como comunicación y armonía, pero, a la vez, permite la evolución y el desarrollo. El referente está siendo el prólogo a la Fenomenología, y, si se quiere concretar la edición exacta, Ortega está manejando la de Lasson de 1907. Puede decirse incluso que Ortega todavía no ha leído detenidamente la Filosofía de la historia, y que, por ello, una de las críticas más habituales que llevará a cabo 20 años más tarde surgirá precisamente cuando se encuentre con "la enorme limitación del pensamiento hegeliano: su ceguera para el futuro"83.

Si en este momento, para Ortega, el sistema de Hegel se caracteriza por ser el sistema de la evolución, la evolución de la idea "mañana, como hoy y ayer", años más tarde, con la Filosofía de la historia en la mano, escribirá (y son las notas de las que surgirían los escritos sobre Hegel): "El mayor defecto de la filosofía de la historia de Hegel - como de toda su filosofía - es que en ella no queda lugar para el futuro. Todas las determinaciones están calculadas en vista del presente como el término de la evolución. Esta es la dimensión de ingenuidad del hegelismo: es lo que le hace ser un sistema cerrado - y por lo mismo sin evolución, sin porvenir"84. Pero Ortega todavía no ha llegado a esto. El idealismo de estos primeros años le exige acudir a un sistema de evolución, de desarrollo, que pueda aplicarse a la misión de educación y de progreso para España, una misión que debe efectivizar

\footnotetext{
83"Hegel y América" (1928). OC II, 573.

${ }^{84}$ Archivo de la "Fundación José Ortega y Gasset", Carpetilla "Hegel: filosofía de la historia".
} 
aquella labor del ideal, la anticipación de la realidad futura, y, con ello, dejar abierta la posibilidad del porvenir.

Si la referencia concreta es el prólogo a la Fenomenología, basta una mirada a los subrayados y anotaciones de Ortega a la edición que está manejando para mostrar la recepción de Hegel en este momento. Ahí se verá que lo que interesa a Ortega son el sistema y la evolución, el desarrollo, la posibilidad de progreso, con las vistas puestas en las intenciones expuestas en "Algunas notas", pero también el mismo tema tratado, si se quiere, de un modo más teórico, más filósofico, entendiendo las referencias de Hegel al todo, al sistema, de un modo romántico y panteísta. Las dos lecturas concuerdan en este momento: la armonía y la unificación que para Ortega supone el sistema conducen tanto a la lucha contra la disgregación española, como al hen kaí pan. Los contextos son inseparables.

Ortega está leyendo el prólogo a la Fenomenología, pero de un modo muy concreto. Si se mantiene la vista en lo que viene examinándose hasta aquí, y de forma explícita en el texto citado de "Algunas notas", se entenderá perfectamente por qué el interés de Ortega hacia determinados textos o ideas hegelianos. Desde el inicio en su lectura del prólogo Ortega se centra en el tema de lo general, de lo universal, del todo, y la posibilidad de su desarrollo. Es comprensible que le extrañen las críticas de Maeztu; deben recordarle las preocupaciones por la confusión que puede surgir al entender mal la filosofía y que Hegel mencionaba al comienzo del prólogo.

El texto, subrayado por Ortega, dice: "Auch weil die Philosophie wesentlich im Elemente der Allgemeinheit ist, die das Besondere in sich schliesst, so findet bei ihr mehr als bei anderen Wissenschaften der Schein statt, als ob in dem Zwecke oder den letzten Resultaten die Sache selbst und sogar in ihrem vollkommenen Wesen ausgedrückt wäre, gegen welches die Ausführung eigentlich das Unwesentliche sei"85. Esa Ausführung es crucial para Hegel, y también para Ortega, en el uso que le está dando en este momento. El "todos somos desarrollistas"86 no deja lugar a dudas, pero se trata de un desarrollo que comienza en un todo, un sistema que incluya sus propias posibilidades de evolución, con

\footnotetext{
85HEGEL, Phänomenologie des Geistes. Op. cit. p. 3. La traducción de Roces es la siguiente: "Además, por existir la filosofía, esencialmente, en el elemento de lo universal, que lleva dentro de sí lo particular, suscita más que otra ciencia cualquiera la apariencia de que en el fin o en los resultados últimos se expresa la cosa misma, e incluso se expresa en su esencia perfecta, frente a lo cual el desarrollo parece representar, propiamente, lo no esencial". Fenomenología del espíritu. Op. cit. p. 7.
} 
una finalidad definitiva, "y esa realidad definitiva es... una Idea, amigo Maeztu"87, pero una idea que suponga el sistema y su apertura, su evolución.

El desarrollo es lo esencial, y, en el contexto donde lo sitúa Ortega, refiere al progreso que debe causar el ideal político-estético a inculcar en España. El sistema, el todo, el conjunto unificado de todos los instrumentos, esa armonía de política, física y estética, debe poder desarrollarse, con una explícita finalidad pedagógica, cultural y moral. La unión se establece entre los medios y los fines, entre los instrumentos y los objetivos que persiguen. No es extraño, entonces, que, recibiendo a Hegel de este modo determinado, Ortega haga suya la afirmación de que la verdad sólo puede existir bajo la forma del sistema, y puede hacerlo porque, en el mismo lugar del prólogo, acaba de leer la conjunción entre desarrollo y resultado que supone el sistema: "Denn die Sache ist nicht in ihrem Zwecke erschöpft, sondern in ihrer Ausführung, noch ist das Resultat das wirkliche Ganze, sondern es zusammen mit seinem Werden"88.

Incluso, de un modo más claro, remitiendo explícitamente a esa verdad que sólo puede existir bajo la figura de un sistema, llama la atención en la edición de la Fenomenología que está manejando Ortega un texto subrayado con más fuerza que los demás, con cuatro o cinco líneas de trazos gruesos al margen: "Das Wahre ist das Ganze. Das Ganze aber ist nur das durch seine Entwicklung sich vollendende Wesen.'89. En la utilización que está haciendo Ortega ahora de esa idea, el todo remite tanto a la armonía del sistema como unificación de problemas, convicciones y compartimientos, como a un todo romántico, ese panteísmo que encontrará en Renan y que, a través de Spinoza, conectará tres caracteres básicos: el panteísmo, el salvarnos en las cosas y el tema de la limitación. La clave está en entender que ambas direcciones no están separadas, sino que se reúnen en ese anhelo orteguiano de conjuntar teoría y práctica que pretendía utilizar para lograr una España nueva: es la idea como tarea lo que está entendiendo Ortega.

86"Algunas notas" (1908). OC I, 115.

${ }^{87}$ Ibid.

88HEGEL, Phänomenologie des Geistes. Op. cit. p. 5. "En efecto, la cosa no se reduce a sufin, sino que se halla en su desarrollo , ni el resultado es el todo real, sino que lo es en unión con su devenir". Fenomenología del espíritu. Op. cit. p. 8.

${ }^{89}$ HEGEL, Phänomenologie des Geistes. Op. cit. p. 14. "Lo verdadero es el todo. Pero el todo es solamente la esencia que se completa mediante su desarrollo". Fenomenología del espíritu. Op. cit. p. 16. 


\section{Romanticismo panteísta}

La idea, la teoría, el sistema, etc., todos ellos son elementos del afán educador, moralizador o culturalizador del Ortega de este momento. Por ello esta primera recepción de algunas ideas de Hegel. Sólo un año después de todos estos artículos, en 1909, escribía Ortega: "Por una idea diéramos nuestra escasa fortuna; por una teoría, nuestra vida; por un sistema, yo no sé que diéramos por un sistema"90. Con ello, la evolución, el despliegue, el progreso, esos caracteres de movilidad que toma del concepto hegeliano de sistema, mucho más que del sistema hegeliano como tal, adquieren los dos sentidos: son rasgos de movimiento, de avance, pero movimiento y avance a la búsqueda de mejoras, de perfeccionamientos, de ideales.

La clave que une al sistema y a la limitación es la equiparación de Ortega entre que "la verdad del mundo sea un sistema" (y esto es lo que toma de Hegel) con el hecho de que "el mundo sea un cosmos o universo", del texto citado más arriba 91 . El "lo que es lo mismo" que Ortega interpone entre ambas ideas es lo que une a Hegel y a Ortega en 1908. Pero la exposición es doble: por un lado el sistema como unión de compartimientos estancos, por el otro el todo en referencia a cierto panteísmo romántico, el todo en todo, cada cosa en conexión con las demás, el poder de las relaciones. Es una tarea de unificación, de temas y problemas, teorías y prácticas, medios y objetivos. Ya al comienzo del mismo año, 1908, Ortega dejaba claras sus intenciones: "La acción humana por excelencia es la unificación; por eso romper la unidad o no buscarla nos parece una mengua de lo humano"92, y las referencias son tanto político-educativo-morales, como estético-filosóficas, el todo que Ortega toma de Hegel lo recibe tanto como sistema como cosmos.

Cuando Maeztu replica a "Algunas notas", Ortega contesta con "Sobre una apología de la inexactitud". En ese artículo explicita Ortega el tema que viene a aglutinar todo este contexto: la ciencia, la cultura, la teoría, como posibilidad ineludible para solucionar el problema de España. Escribe, y concreta así las diferencias: "Maeztu no admite, como yo, un medio que nos podemos proporcionar para hacer hombres buenos, como el que compra

\footnotetext{
90"Al margen del libro «Los Íberos»" (1909). OC I, 494.

91"Algunas notas" (1908). OC I, 114-115.

92"Las dos Alemanias" (1908). OC X, 23.
} 
una pócima en la botica: ciencia"93. Ortega no menciona ni a Hegel ni al sistema, pero continúa manteniendo en la base el mismo pensamiento culturalizador y pedagógico, práctico. Tampoco olvida la discusión de si son antes bs hombres o las ideas, no la olvida, pero sí la concentra alrededor de la misión de la ciencia como perfeccionamiento y adiestramiento de los individuos.

No abandona Ortega el tema de hombres o ideas, pero cada vez irá concretando más los aspectos. El comienzo del "Renan", sólo un año posterior a la polémica con Maeztu, (y texto que interesa especialmente por conjuntar lo que se ha mantenido como segunda referencia de ese todo, ese sistema, que tomaba Ortega de Hegel, el panteísmo romántico, y aspectos determinantes del tema de la limitación), es tajante: "En general, no concibo que puedan interesar más los hombres que las ideas, las personas que las cosas"94, escribe Ortega. No es casual que el "Renan" continúe a "¿Hombres o ideas?" en Personas, obras, cosas. Ese comienzo da razón de ello. Ortega tocaba únicamente de pasada el tema de hombres e ideas en "Sobre una apología de la inexactitud" porque para tratarlo con rigurosidad deberían resolverse los problemas principales de la metodología histórica, saber si la historia es producto de individualidades o de corrientes ideales. En el "Renan" el tema se concentrará en la crítica a lo subjetivo que, en las notas añadidas de 1916, así como en la introducción a Personas, obras, cosas, Ortega considerará como equívocos.

La conjunción del tema, esto es, del todo-sistema-idea en sus dos vertientes, la éticomoral-política, y la estético-filosófica, se vierte en lo que Ortega llama la potencia suma de energía cultural, "la de crear realidades universales"95. Esas realidades conjuntan las intenciones del idealismo panteísta de este Ortega de la primera década del siglo. El arte trágico, la poesía como flor del dolor, que mantenía en 1906, ya reflejaban el mismo contexto: "Sobre la totalidad de una vida, con su nacimiento y su muerte, gravita a la vez, forzosamente, en más remota esfera, el doliente corazón silencioso del Uno-Todo"96. Este Uno-Todo, estos rasgos panteístas, que adquirirán concreciones mayores, se verán truncados porque, a pesar de las críticas de Ortega al subjetivismo en este momento, no

\footnotetext{
93"Sobre una apología de la inexactitud" (1908). OC I, 120.

94"Renan" (1909). OC I, 443.

95Ibid. p. 444.
} 
puede abandonar al individuo, no puede dejar de dotar al individuo con "un puesto y una tarea en la colmena universal", como escribirá en 1916, en el prólogo a Personas, obras, cosas.

El panteísmo del "Renan" tiene diversas direcciones: Dios como prototipo de la originalidad, en cuanto es "padre y manadero de todas las cosas"; la verdad como contradicción de lo subjetivo, en cuanto habla de las propiedades de las cosas, no de la intimidad de quien la pensó; lo subjetivo como error, en cuanto no es parte del mundo, no empuja a nuestra salvación en las cosas, etc. Es esa teoría de la imitación de las cosas, teoría de relaciones y contactos, pero también de virtudes y eternidades: salvarnos en las cosas, imitarlas, porque ellas contienen el secreto del universo, hacen patente todo lo oculto, mientras que lo subjetivo sería perecedero y equívoco. Es ese panteísmo naturalista, con referencias a Spinoza, Goethe, Fichte, Schelling, etc., que incluso parece coincidir, sobre todo por reflejar las teorías más juveniles, más de primera época, con textos concretos de aquel intercambio epistolar entre Hegel, Schelling y Hölderlin. Incluso las referencias a Spinoza son las mismas:

"Un espíritu cuyas operaciones todas crearan verdad objetiva carecería de subjetividad, de morada interior: sería idéntico a la Naturaleza, y por corresponder a Dios esa absoluta veracidad, vióse obligado Spinoza a identificarlo con aquélla y exclamar: Natura sive Deus: la Naturaleza o, lo que es lo mismo, Dios... De donde sacamos la grave enseñanza de que Dios es el ser sin intimidad. / Al hombre, en cambio, fue otorgado este don angustioso de mantener frente al universo ilimitado un pequeño recinto secreto, donde sólo él entra plenamente; lo íntimo, el yo"97.

La oposición entre ese universo ilimitado y la limitación del hombre, dirigirán el tema en este momento. Ahora bien, la misión de lo subjetivo como camino hacia Dios, hacia la absoluta objetividad; la conciencia de que esa meta es imposible y sólo permite la aproximación; el diluirnos en Dios y, directamente, perder "la lepra de la subjetividad" (idea que Ortega, en nota de 1916, considerará, sin más, como blasfemia); las referencias a Spinoza y al Uno-Todo, la natura sive Deus, el amor a la verdad, a las cosas, a través de un

\footnotetext{
96"Poesía nueva, poesía vieja" (1906). OC I, 52.

97"Renan" (1909). OC I, 445.
} 
Platón que es el que realmente está en el fondo de las "ideas" que utiliza Ortega, etc. 98 , todo ello remite de forma explícita a otros marcos más generales.

Refiere para decirlo concretamente, por ejemplo al diálogo entre Jacobi y Lessing, ese diálogo ya clásico que tuvo lugar en Wolfenbüttel y Braunschweig en 1780: "[Lessing] Die orthodoxen Begriffe von der Gottheit sind nicht mehr für mich; ich kann sie nicht geniessen. Hen kaí pan! Ich weiss nicht anders [...]. [Jacobi] Da wären Sie ja mit Spinoza ziemlich einverstanden. [Lessing] Wenn ich mich nach jemand nennen soll, so weiss ich keinen andern"99. Remite al final de la carta de Schelling a Hegel desde Tubinga en febrero de 1795: "No hay un Dios personal y nuestra suprema aspiración es la destrucción de nuestra personalidad, la transición al ámbito absoluto del Ser, transición que con todo no es posible por los siglos de los siglos; o sea, sólo acercamiento práctico al Absoluto y, por tanto, inmortalidad"100. Refiere también a ese fragmento de Novalis que Ortega subraya en su edición francesa: "Tout objet aimé est le centre d'un paradis"101, idea que reaparecerá en Meditaciones del quijote con la doctrina del concepto y del amor como conexión. Son, en general, a todas esas referencias de romanticismo, panteísmo e idealismo que Ortega está retomando en este momento y que concuerdan en el plano teórico con las intenciones prácticas del sistema-todo que tomaba de Hegel en "Algunas notas".

Tampoco es casual que la similitud entre esas ideas coincidan en momentos iniciales, juveniles, si se quiere, tanto de Ortega como de, por ejemplo, Hegel, Schelling y Hölderlin. Y no es casual porque parte de las intenciones eran las mismas, y, sobre todo, una de ellas: la conexión entre la necesidad de una revolución filosófica y las intenciones de que esa

\footnotetext{
98"Los últimos fundamentos de la verdad, en fin, llámanse en Platón "Ideas", es decir, intuiciones, puntos de vista". "Renan" (1909). OC I, 448. "La palabra idea procede de Platón. [...] El idealismo verdaderamente habría de llamarse realismo". "Adán en el paraíso" (1910). OC I, 486. En el manuscrito de la "Introducción al idealismo", conferencia de 1912, puede leerse: "El idealismo es el de la idea de Platón. Idealismo es lo contrario de lo que hoy se tiene por idealismo". Archivo de la "Fundación José Ortega y Gasset", Rollo 1, tomo XVI. Y está la referencia de Meditaciones, el ver que es mirar, la mirada con los conceptos: "Platón supo hallar para estas visiones que son miradas una palabra divina: las llamó ideas". MQ, 115-116.
}

99"F.H. Jacobi über seine Gespräche mit Lessing", en: LESSING, G.E. Werke, VIII. Darmstadt: Wissenschaftliche Buchgesellschaft, 1996, pp. 563-564. Traducción: "[Lessing] Los conceptos ortodoxos de la divinidad no son más para mí; no puedo sacarles provecho. Hen kaí pan! No sé otra cosa [...]. [Jacobi] Ahí estaría usted bastante de acuerdo con Spinoza. [Lessing] Si debo nombrarme junto a alguien, no conozco a ningún otro".

100 HEGEL, G.W.F. Escritos de juventud. Ed. J.M. Ripalda. México: F.C.E., 1984 (2ª reimp.), p. 60. 
revolución afecte también a ámbitos supuestamente ajenos a la filosofía. ¿¿Quién es capaz de enterrarse en el polvo de la antigüedad, cuando la marcha de $s u$ tiempo le vuelve a levantar y arrastrar consigo a cada momento?", escribe Schelling a Hegel desde Tubinga, y añade más adelante: "Actualmente trabajo en una Ética a lo Spinoza. Sentaré los primeros principios de toda filosofía, en los cuales se unen la razón teórica y práctica"102. Hegel le contesta con un lema que Ortega aceptaría sin problemas: "Repitamos constantemente tu consiga: «iNo nos quedemos atrás!»"103.

El espinozismo que merodea por ese contexto, o, por lo menos, el interés que muestran Schelling y Hölderlin, sobre todo, no refiere únicamente a causas teóricas. En abril de 1795 , Hegel escribe a Schelling sobre la fuerza vivificadora de las ideas, fuerza que Ortega intenta presentar en todos los artículos que han sido examinados. Escribe Hegel: "Esta fuerza vivificadora de las ideas -incluso cuando siguen siendo limitadas como patria, Constitución, etc.- levantará los ánimos y éstos llegarán a sacrificarse por ellas, mientras que actualmente el espíritu de las Constituciones ha contraído una alianza con el egoísmo individual y en él basa su imperio"104. Y no se trata únicamente de la conexión en intenciones, sino, además, de conexión de épocas: Molinuevo ha visto bien, en lo referente a Fichte, pero que puede servir también ahora, ese paralelismo de tiempos, tiempos de reconstrucción nacional y de búsqueda de identidad, tanto en la Alemania de la época, como en la España del momento de Ortega 105. Más adelante aparecerá una unión más concreta entre Hegel y Ortega en lo referente a la época.

${ }^{101}$ NOVALIS, Les disciples a Saïs et Les Fragments. Trad. et int. M. Maeterlinck. Bruxelles: Laconblez, 1914, p. 105.

102 HEGEL, G.W.F. Escritos de juventud. Op. cit. p. 53.

${ }^{103}$ Ibid. p. 56.

104 Ibid. p. 61.

${ }^{105}$ Cfr. MOLINUEVO, J.L. "Salvar a Fichte en Ortega", en: Azafea, III, 1990, p. 108: "Más allá de las diferencias específicas Ortega ve un paralelismo esencial entre los rasgos de la época que describe Fichte y la suya propia, entre una Alemania en crisis, conmocionada por las guerras napoleónicas y que busca su identidad nacional, y una España que ve agudizada su enfermedad endémica por el fracaso de la Restauración y la catástrofe del 98. En ambos casos se trata de un proceso de reconstrucción nacional, porque Alemania y España son un proyecto, no una realidad". 


\section{Panteísmo y limitación}

En el "Renan" y la serie de artículos que lo rodean, el tema de la limitación es determinante. Para examinarlo era necesario concretar el contexto en el que se sitúa, con la intención de mostrar la relación entre la limitación y el panteísmo, la manera renaniana de acercarse a las cosas, pero también la de Ortega en estos momentos.

Después de exponer la teoría de lo verosímil, del vivir en zig-zag, de esa cultura centúrida de Renan que intenta armonizar verdad y ficción, y para ello se instala en el mundo de lo verosímil, mundo de arte, religión, poesía, mito, Ortega muestra cómo este mundo, ilimitado, está construido con metáforas. La contrapartida es la historia, llena de hechos, de figuras, de héroes, una historia, por tanto, dominada por la variación, pero también por la limitación. El enfrentamiento se produce, entonces, entre la ilimitada variedad de lo metafórico, de lo verosímil, y la limitada variedad de la historia. Es en este momento cuando Ortega escribe:

"Hay un término en Platón y en alguno de sus sucesores muy poco estudiado todavía, y capaz, en mi opinión, de un fecundo desarrollo; me refiero a la palabra que para ellos definía la vida: pleonexia, es decir, aumento, henchimiento. Vivir es crecer ilimitadamente; cada vida es un ensayo de expansión hasta el infinito. El límite nos es impuesto; es una resistencia que nos opone otra vida que a nuestro lado, e incitada por análoga energía, ensaya su acaparamiento del universo. Cada cosa -afirma Spinoza- aspira a perseverar en su ser. No, no; la fórmula no es suficiente; cada cosa viva aspira a ser todas las demás. La biología exige que instituyamos la categoría del henchimiento. Dios, inmutable, perseverando en su ser hasta el fin de los tiempos, es un objeto teológico; la biología comienza con la historia natural de Luzbel, la bestia del empireo que aspiró a ser Dios. / Hace veintiséis siglos que Anaximandro enseñaba a los marineros de Mileto la doctrina de que el límite es un gran castigo impuesto por una severísima justicia. Nos limitamos los unos a los otros; nos distinguimos, nos diferenciamos, y, como advierte Stendhal, diferencia engendra odio; somos progenie del odio y de la enemistad. Homines ex natura hostes. De aquí que la labor filosófica por excelencia sea buscar tras esas crueles diferencias y limitaciones una sustancia colectiva, homogénea e idéntica. El magno deber del sabio, historiador o moralista, es intentar la reconstrucción de la unidad fundamental, es ir adobando, tras de la variedad de los hombres, la unidad humana"106.

Este modo de enfocar el tema, dirigido por connotaciones panteístas y spinozistas, pero también fichteanas, es la primera aparición de la limitación en los escritos de Ortega.

106"Renan" (1909). OC I, 454-455. 
Estamos en 1909. No sólo es la primera aparición, sino también la primera versión. Las connotaciones refieren al contexto presentado: la vida como la expansión al infinito, cada cosa como aspiración a ser todas las demás, la limitación como crueldad y la exigencia de la unidad, etc., todas ellas refieren al romanticismo panteísta y nietzscheano, así como al idealismo estético, político y moral de talante neokantiano, pero además con las alusiones explícitas ya mostradas que conlleva Ortega en estos años. Las alusiones al "vivir es más vivir" de Nietzsche son claras, idea que Ortega ya ha venido utilizando desde años anteriores, y que continuará haciendo 107 .

Ésta es la conexión entre el panteísmo y la limitación, o, mejor, lo que cada uno conlleva: la crueldad de la limitación y la exigencia de unidad. La unión de intenciones, la teórica y la práctica, es evidente: no es necesario recordar aquel "la acción humana por excelencia es la unificación", de "Las dos Alemanias", presentándose con ello las dos direcciones que mantenían en su base las referencias al sistema-todo hegeliano en la polémica con Maeztu. Pero el tema es más grave de lo que parece, porque la conexión entre el panteísmo y la limitación se dirige directamente a la esencia del problema: si todo es todo, si todo está en todo, si cada cosa expresa el resto de las cosas, entonces se produce la coincidencia paradójica entre el panteísmo y la limitación, esto es, "la limitación como la ilimitación", precisamente la frase que encontramos en esas notas de trabajo desde El Escorial, pero con un añadido: "La limitación como la ilimitación -Hegel-Schelling: los dioses particulares"108. La referencia a esos "dioses particulares" aparecerá más adelante, pues Ortega utiliza la idea, y aclara el contexto, en un texto de 1915 (aunque el tema, en la referencia explícita a Schelling, proviene de varios años antes, por ejemplo de "Anatomia de un alma dispersa", en el capítulo titulado "Un pensamiento de Schelling), La guerra, los pueblos y los dioses", donde se mostrará la relación con Schelling y su Filosofía de la mitología, y con temas determinantes: la nación, los pueblos. De nuevo la aparición de Hegel, la unión de limitación e ilimitación, de finito e infinito.

\footnotetext{
${ }^{107}$ La referencia a la idea de Nietzsche se encuentra, por ejemplo, en: "Discurso para los Juegos Florales de Valladolid" (1906), en: Cartas de un joven español. Op. cit. p. 752; "El sobrehombre" (1908). OC I, 94; "La voluntad del Barroco", en: Meditaciones del Quijote. Con un apéndice inédito. Op. cit. p. 155; "En un banquete en su honor en Pombo" (1922). OC VI, 227, etc.

108"Sobre Cervantes y El Quijote desde el Escorial. (Notas de trabajo de José Ortega y Gasset)". Op. cit. p. 50 .
} 
El cambio se producirá en el momento que Ortega perciba que la limitación y la diferencia no sólo no son crueldades, sino que, todo lo contrario, posibilitarán gran parte de sus intenciones tanto teóricas como prácticas. La vida como expansión en este momento es entendida como agresividad, como imposición de la limitación, de la diferencia, a la fuerza. Es la vida agresiva de la naturaleza, pero también la individualidad coercitiva de pueblos y épocas, que pretenden perpetuar su propia limitación. La única forma de armonía, y, a la vez, ampliación y enriquecimiento de la individualidad sería "invadir la inagotable diversidad de seres". Es la interpretación panteísta y unificadora de la multitud de vidas de Empédocles, y es aquí donde Ortega, a través de Renan, muestra una primera solución al problema: "Claro está que no podemos ser otro sin dejar momentánteamente de afirmar nuestros rasgos distintivos; sólo negándonos parcialmente llegamos a confundirnos con el prójimo y a comprenderle; sólo una disimulación de lo que espontáneamente somos y una simulación de lo que es nuestro hermano nos reunirá y nos hará confluir como las aguas de dos manantiales. Ahora bien, disimulo y simulación se dicen en griego: Ironía"109.

La ironía para solucionar el problema de la limitación, pero teniendo claro este primer contexto: las limitaciones son de individualidades, de prójimos. La limitación, en este sentido negativo que ahora presenta Ortega, se esquivaría negándola parcialmente, disimulando, ironizando. Únicamente cuando esas ironía y simulación dejen de ser tales, cuando los contactos se produzcan no en la negación de la limitación, sino en su conversión en límite, en su henchimiento por contactos, Ortega podrá dar un paso más. Las limitaciones se referirán a paisajes, a circunstancias, a naciones; las relaciones, ampliaciones o coexistencias se referirán a conceptos, salvaciones, reabsorciones. Pero eso se producirá más adelante.

En este momento, la agresividad y crueldad de la limitación son algo natural, son insuperables como tales. La armonía, irónica, aparecerá cuando a la naturaleza suceda la cultura. "Si la vida natural es hostilidad, la cultura hace a los hombres amigos"110. Es el optimismo de la paz sobre la tierra, la unidad de los hombres en formación, la historia como proceso en que se organiza la unidad humana, etc. La solución es una solución estética: sólo el arte, los mitos, los símbolos, son capaces de alcanzar esa "pedagogía de la unidad

109"Renan" (1909). OC I, 456. 
humana"; los clásicos son testimonios de la unidad ideal del hombre, la cultura es pedagogía de unidad. Continúan, pues, las dos direcciones del discurso, perfectamente entrelazadas. Todavía resuena aquella definición del idealismo que Ortega daba en 1906: "Idealismo es el amor tan ferviente de la realidad, que adentramos ésta en nosotros, y en lo más íntimo quilificada nos da un humor de quintaesencia que al correr de arteria en arteria y vena en vena nos mueve a ver todo como divinamente adobado y nos hace sentir un aroma trascendente de las cosas"111. Es el idealismo cultural, el idealismo con vuelta, la cultura como medio para echar mano a lo concreto. Esa conjunción permanecerá, pero con modificaciones que abandonarán el talante panteísta para remitir a un todo basado precisamente en limitaciones, un todo cohesionador, asentado en la potencia conectora del concepto. El idealismo, que "adoba todo divinamente", coincide ahora con el panteísmo del "Renan" y con las intenciones salvadoras que deberían cumplir el arte y la cultura.

La conjunción de caracteres se presenta, entonces, con toda su fuerza. Estética y cultura, arte y política, ideal y educación. En el fondo se encuentra aquel arte de las emociones sociales, necesario para llenar de vida, de realidad, a la idea política. Ahora, si se trata de mostrar esa armonía cultural, irónica y estética, idealista y panteísta, sería más conveniente acudir a la estética espacial (que, como veremos, es determinante para el tema del paisaje), una de las aficciones más intensas de Ortega, o, mejor, Rubín de Cendoya, uno de los complementarios 112 .

La estética espacial se demora en la disposición de líneas y límites, ritmos y composiciones, que "dan un alma armónica al espacio. Por lo demás, añade a veces, arte espacial no es solamente arquitectura: en ésta son el mármol, la piedra, la madera, el hierro o el adobe vehículos esenciales de la expresión estética, al paso que aquel arte sólo echa mano de aire, de líneas y de sombras, para con estas vagas cosas ponernos en el corazón esas mismas emociones irisadas que unos hombres nos sugieren en sus cuadros o con sus versos, y otros, más sentimentales, con los rubios violines"113. Las emociones irisadas de

110

111"Las fuentecitas de Nuremberga" (1906). OC I, 427.

112Sobre estos "complementarios" de Ortega, ver: CARPINTERO, H. "Ortega y sus complementarios", en: Revista de Occidente, $\mathrm{n}^{\circ} 192$, mayo 1997, pp. 59-77.

113" Sobre «El Santo»" (1908). OC I, 434. 
aquí se unen con las emociones sociales de allá. La armonía de la cultura irónica en el "Renan" remite a esa otra armonía del espacio, de líneas y sombras. No se trata, de que el arte o la estética se "añadan", se "introduzcan", en campos éticos o políticos, sino de que los caracteres son muy similares en ambos marcos, esto es, que ya se han introducido. Lo que trata Ortega es de dejarlo ver, de mostrarlo, utilizarlo.

El panteísmo de Renan, o el influjo de Spinoza y Fichte114, sólo entendido desde este contexto puede concebirse de un modo adecuado. Si se cuestiona no de dónde toma Ortega ese panteísmo (referentes ya mostrados y más o menos claros), no cómo lo entiende, sino para qué lo utiliza, qué sentido tiene, entonces la respuesta es la misma que a la pregunta de por qué utilizaba el sistema de Hegel en los textos de la polémica con Maeztu: porque todos estos caracteres, sistema, uno-todo, armonía, idea, cultura, etc., le permiten conjugar las dos direcciones que pretende mantener unidas, la filosofía, la estética, la teoría, y el problema de España, la política, la educación, el progreso.

Todos esos rasgos romántico-idealistas-panteístas, el cada cosa expresa el resto de las cosas, el placer estético como descarga de emociones, o, en general, el panteísmo como exclusión de todo desdén, exclusión de toda exclusión, pueden interpretarse a partir de la idea que mueve a Ortega en este momento, idea que, precisamente, coincide con los jóvenes Schelling, Hegel o Hölderlin, la idea de conjuntar la circunstancia filosófica y la circunstancia epocal, nacional, y no en el sentido de que todo el mundo es hijo de su tiempo, sino en el sentido de mostrar, de conseguir, que ese tema de su tiempo sea el mismo por partida doble, en la teoría y en la práctica.

No es de extrañar, entonces, que el tema de la limitación comience desde estos contextos a situarse como, por lo menos, especial, pues también conjuga las dos direcciones, limitación de objetos o ideas, pero también de épocas o naciones. Lo único que hay que tener en cuenta es que en este momento, Ortega, y coincide perfectamente con las aclaraciones de su introducción a Personas, obras, cosas, todavía separa entre limitación y armonía, no ve bien la conjunción, la necesaria conjunción de ambos aspectos. Incluso,

\footnotetext{
${ }^{114}$ Sobre las relaciones entre Fichte y Ortega, ver la serie de artículos de Molinuevo sobre el tema: "Salvar a Fichte en Ortega", en: Azafea III, 1990, pp. 103-150; "Fichte y Ortega (II). Héroes o ciudadanos. El mito de Don Quijote", en: Daimon, 1994, no 9, pp. 341-358, y la tercera parte, de próxima aparición, "Fichte y Ortega (III). Superación del idealismo". Para el tema que nos ocupa, ver sobre todo "Salvar a Fichte en Ortega", Op. cit. pp. 121 ss.
} 
recordando de un modo fácil y explícito a Novalis y sus Himnos a la noche, Ortega mantiene el tono hasta el final: "La orden del día era separación, límite, hostilidad. La orden de la noche nos hunde en la profunda unanimidad de las cosas"115. Y Novalis: "Más celestiales que esos astros fúlgidos / en las lejanías, / nos parecen los ojos infinitos que la Noche abre en nosotros" 116 .

115"Renan" (1909). OC I, 465.

116 NOVALIS, Himnos a la noche. Trad. J.Ma Valverde. Barcelona: Icaria, 1985, pp. 29-31. 


\section{El respeto por el individuo: las pasiones}

Si todo esto se produce alrededor de 1908, y si lo que interesa de un modo especial es llegar a un momento clave, entre 1912 y Meditaciones, para examinar mejor tanto a Hegel como el tema de la limitación, entonces es necesario acercarse de un modo más detallado. Se trataría ahora de concentrar la atención en torno a 1910 y 1911.

1910 es el año de Adán en el paraíso, aunque no sólo. Es también el año de "La pedagogía social como programa político", texto que, por las referencias a Hegel, interesa especialmente. De nuevo se producirá una bifurcación entre el tema de Hegel y el tema de la limitación: hay alusiones a ambos en este año, pero ninguna en la que aparezcan juntos. $\mathrm{Y}$, sin embargo, las referencias a Hegel van a coincidir en un aspecto clave con el contexto de la limitación, el tema del individuo, del respeto, que puede considerarse como un primer momento de la conversión del yo solitario en yo solidario, o, sin más, en la armonización del individuo y el todo.

La conferencia "La pedagogía social como programa político", leída en marzo de 1910 en la Sociedad "El Sitio", de Bilbao, es un texto clave, pues aglutina temas y problemas que se presentan desparramados en cantidad de artículos de la época. Es una especie de resumen del Ortega de la primera década de siglo. El tema de la pedagogía, de la educación, importantísimo en este momento, ya ha venido apareciendo, y con los mismos referentes: es la pedagogía social, pero también la pedagogía política, la pedagogía de la unidad. Se trata de una de las direcciones que explican el contacto entre el tema del sistema, el todo, y el problema de España. España no existe como nación, y hay que construirla exigiendo la búsqueda de una España futura dirigida por un patriotismo activo y con base de mejora, de progreso, de tarea de transformación que abra España a Europa 117.

\footnotetext{
${ }^{117}$ Elorza ha expresado claramente esta conjunción de la exigencia de transformaciones y la relación España-Europa: "La tensión ideal que en todo momento introduce esa exigencia de transfo rmaciones que debe ser el resultado del análisis. Un componente dinamizador del pensamiento nacionalista de Ortega que, también desde un principio, le lleva a alcanzar dos resultados principales: una visión proyectiva del hecho nacional, lo que vincula a éste con una concepción democrática, no tradicionalista, y por otra parte, una perspectiva de superación, de europeización que a su vez contiene el doble elemento de la apertura cultural de España a Europa como eje de la regeneración social y una aún indeterminada articulación de cada hecho nacional con esa unidad de ámbito más amplio y enriquecededor que es Europa". ELORZA, A. La razón y la sombra. Una lectura política de Ortega y Gasset. Barcelona: Anagrama, 1984, p. 45.
} 
Se trata, de nuevo, del carácter de idea, de ideal, ideal político, ese carácter que incluye los dos sentidos de progreso: movimiento y mejora. Por ello es necesario transformar la realidad caduca, inoperante, en el sentido de ese ideal de mejora, con lo que la educación ocupa un lugar determinante, siempre que se trate de una educación basada, de nuevo, en cierto ideal pedagógico que determine lo que el hombre debe ser y ofrezca los instrumentos para conseguirlo. El problema está en que no es tan fácil saber lo que debe ser el hombre, o, sin más, qué es el hombre, y escribe Ortega: "No ignoráis que una de las creaciones más sabias y fecundas de Hegel es su cristología, su interpretación laica del símbolo cristiano. Cristo es, según él, el ensayo más enérgico que se ha realizado para definir al hombre. / La historia entera, señores, la historia política especialmente, no es otra cosa en su última sustancia que la serie de luchas y de esfuerzos por la definición del hombre"118.

La referencia a Hegel es más importante de lo que parece a primera vista, porque, teniendo en cuenta las connotaciones panteístas ya examinadas, y conociendo la teología social, teología laica, que va a apoyar Ortega, comienza a intuirse la dirección que seguirá el desarrollo: el individuo se constituye como tal en la sociedad, en la colectividad, e interpretando así la referencia a Hegel, Cristo como el ensayo más enérgico para definir al hombre porque es la conexión explícita de hombre y Dios, y, aplicándole las connotaciones sociales y socialistas orteguianas, "el individuo se diviniza en la colectividad. ¿No es tal el sentido de la humanización de Dios, del verbo haciéndose carne?"119. En este sentido se entiende la referencia a Hegel 120 .

Sólo un mes antes de la conferencia en Bilbao, en febrero de 1910, Ortega había publicado dos artículos, cuyos temas serán ampliados y matizados en esa conferencia, 'La teología de Renan" y "Catecismo para la lectura de una carta". Este segundo es una defensa explícita de las escuelas laicas (criticando duramente a Menéndez Pelayo), en las que no se excluiría la enseñanza religiosa, pero sí la que se llevara a cabo según la dogmática de una escuela determinada. Las escuelas laicas, por ejemplo, no excluyen la

118" La pedagogía social como programa político" (1910). OC I, 510.

119ibid. p. 520.

${ }^{120}$ Según Morón Arroyo, la interpretación laica del símbolo cristiano, que aquí refiere a Hegel, permaneció en Ortega hasta el final. MORÓN ARROYO, C. El sistema de Ortega y Gasset. Madrid: Alcalá, 1968, p. 419: "En 1910 pedía el derecho a una «interpretación laica» del símbolo cristiano, citando a Hegel. No hay constancia en sus escritos de que jamás cambiase de opinión". 
teodicea; no hay ningún problema con la teodicea, "ábranse, pues, en cada barrio escuelas donde se preparen los nuevos corazones, según la Teodicea de Spinoza, Voltaire, Lessing, Rousseau, Kant, Hegel, Strauss (joven), Renan, etc."121. Estos son los nombres, y la conclusión de Ortega: escuela laica no es escuela sin religión, sino escuela sin Iglesia.

Ahora bien, en lo referente a Hegel, Ortega no está pensando únicamente en las connotaciones religiosas, sino también en las históricas. Ya ha comenzado a estudiar la Filosofía de la historia, en la primera edición manejada por él, la de Reclam, y está teniendo muy en cuenta las palabras de Hegel en la introducción: "Unsere Betrachtung ist insofern eine Theodizee, eine Rechtfertigung Gottes"122. Por ello la aparición de Hegel en este momento en lo referente al tema del individuo, uniendo los tres contextos: individuo y Dios, individuo e historia, individuo y sociedad; por ello la anterior conexión de la cristología con la historia como búsqueda de la definición del hombre. Y, si en la conferencia de Bilbao ha mostrado de forma concreta esa divinización del individuo en la sociedad, en 'La teología de Renan", utilizando al propio Renan, presentará la divinización de la historia y la culturización de Dios.

Por un lado, "Renan miraba todas las cosas bajo la especie de lo histórico, mas como para él lo histórico es lo divino, lo que tiene en sí mismo su valor y su perenne justificación, su filosofía de la historia es, en realidad, una teología"123. Hasta ahí Renan, pero si Dios es la proyección del ideal, de cuanto de valioso encuentra el hombre, si Dios es todo, ilimitado, infinito, y si "el siglo XVIII, el siglo de Leibniz, Newton, Hume y Kant, ha hecho imposible el trato mano a mano con nada que, siendo real, pretenda ser ilimitado y absoluto"124, entonces se produce una descomposición mediante la cual esos ideales proyectados, esos valores últimos, justicia, sabiduría, fortaleza, etc., se disuelven en la serie de actos humanos que presentan esos valores, con lo que "Dios queda disuelto en la historia de la humanidad; es inmanente al hombre: es, en cierto modo, el hombre mismo padeciendo

121" Catecismo para la lectura de una carta" (1910). OC X, 136.

${ }^{122}$ Cito por esa misma edición. El texto está subrayado por Ortega: HEGEL, Vorlesungen über die Philosophie der Geschichte. Hrsg. F. Brunstäd. Leipzig: Reclam, s.a., p. 49. Traducción: "Nuestro tratamiento es de este modo una teodicea, una justificación de Dios".

123" La teología de Renan" (19 10). OC I, 134.

124 Ibid. 
y esforzándose en servicio de lo ideal. Dios, en una palabra, es la cultura. [...] Podría decirse que Dios es el conjunto de las acciones mejores que han cumplido los hombres"125.

Esta es la conexión de historia y divinidad, o, mejor, la divinización de cultura, historia y sociedad, así como la explicación de las alusiones a la teodicea y a la cristología. En este sentido deben leerse las referencias a Hegel en este momento. En la base continúa encontrándose cierto momento del tema de la limitación, el de la conexión entre individuo y todo, sea Dios, historia o sociedad, dependiendo naturalmente de los contextos y las intenciones. En lo referente a la historia, todos esos valores, esas acciones mejores que se van sucediendo, hay que reconquistarlas, conservarlas: "un inglés, al nacer, no trae disuelto en la sangre el binomio de Newton, ni un alemán la Crítica de la razón práctica. Ambas cosas son, ciertamente, espíritu condensado; pero ningún espíritu individual puede atribuírselas: son lo que Hegel llama asimilárselo para que aquella riqueza latente adquiera vida actual" 126 .

Este es el papel del individuo, que puede ser traducido: se trata de ensanchar su limitación asimilando, actualizando lo alcanzado por otras limitaciones, otras individualidades. En este Hegel-Renan está pensando ahora Ortega: "Renan exclama imperativamente que no renunciemos al pasado, que lo conservemos, y su obra aparece como inmenso pebetero, del cual se eleva, ondeando, el incienso del respeto"127. Va a ser este tema del respeto el que ponga en contacto las relaciones del individuo con la historia y con la colectividad, con el otro, con los otros. Las limitaciones comienzan a dejar de ser entendidas como crueldades y pasan a concebirse como solidaridades, como exigencias precisamente por su limitación, por su diferencia. El respeto que debe guiar al individuo no se refiere, entonces, únicamente a los otros, también se refiere a los otros pasados, a la historia, a eso que hay que actualizar.

No es de extrañar, entonces, que, si Ortega en este momento en lo referente a Hegel tiene en mente sobre todo el prólogo a la Fenomenología (y sólo ahora, en 1910 y 1911, comienza a estudiar atentamente la Filosofía de la historia), entendiéndolo tanto en el sentido que se ha mostrado, con las referencias panteístas y del romanticismo alemán, como

125 Ibid. p. 135.

126 Ibid. 
en éste de la conexión del individuo con unas "totalidades divinizadas" mucho más cercanas, tomara de ese prólogo la idea según la cual "der einzelne muss auch dem Inhalte nach die Bildungsstufen des allgemeinen Geistes durchlaufen"128, pero entendiéndolo en el sentido que le interesa.

El individuo, el recorrido, las fases de formación, y, ahora ya, el respeto entre las individualidades, las limitaciones, su solidaridad y no su disolución en el todo, son las concreciones que están dirigiendo el desarrollo, tanto en lo referente a Hegel como a las temas mismos que ocupan a Ortega. El respeto, que ya en 1908 y junto a Goethe, expresaba la emoción religiosa 129 , que avanzará hasta convertirse en la virtud socializadora por excelencia, uniendo, de nuevo, sociedad y religión, en tanto "es para mí el respeto la virtud socializadora por excelencia, la emoción religiosa (de religare, atar). Si toda la energía humana no se consume en las luchas individuales, si algo de ella sobrequeda y rebasando todas las querellas momentáneas labra silenciosamente obras más perennes que el individuo, es decir, obras sociales, débese al respeto"130, ese mismo respeto lo encontrará Ortega también, directamente, en la Filosofía de la historia de Hegel:

"¿No habéis leído la Filosofía de la historia de Hegel? Es un libro de magnífica poesía que nos enseña a buscar en nuestros actos más ínfimos el fondo general de lo humano: nos enseña el respeto a la humanidad y, como consecuencia, el respeto a nosotros mismos, al contrario que las obras de un romanticismo cutáneo, las cuales nos incitan a erigirnos en tipo ejemplar humano. Por eso, cuando a los veinte años salimos de casa de los padres en busca de una novia floreciente, debíamos llevar, ya que en el bolsillo derecho los versos de Bécquer, en el izquierdo la Filosofía de la Historia de Hegel, aunque sólo fuera como contrapeso" 131 .

Son cruciales esas enseñanzas que en este momento le ofrece a Ortega la Filosofía de la historia: enseña a buscar en cada uno de nuestros actos la referencia de lo humano en general, enseña el respeto a la humanidad y enseña el respeto a nosotros mismos. La enseñanza consiste, entonces, en ayudar a encontrar la relación explícita entre el individuo

127 Ibid. p. 136.

${ }^{128}$ El texto está subrayado por Ortega. HEGEL, Phänomenologie des Geistes. Op. cit. p. 20. "También el individuo singular tiene que recorrer, en cuanto a su contenido, las fases de formación del espíritu universal". Fenomenología del espíritu. Op. cit. p. 21.

${ }^{129}$ Cfr. "Sobre «El Santo»" (1908). OC I, 436.

130" Fuera de la discreción" (1909). OC X, 95. 
y la humanidad, con un instrumento, la historia, y una exigencia determinante, el respeto. La limitación, el individuo como limitación, en lugar de la crueldad que expresaba más arriba, se sitúa ahora en la categoría del respeto ${ }^{132}$. Y es la historia la que exige esa categoría, respeto a la humanidad y, como consecuencia, respeto a nosotros mismos.

Ortega no olvida las referencias de Hegel en la introducción a la Filosofía de la historia a la conexión historia-individuo, a esa importancia de las pasiones: en su edición de Reclam (es la edición que está manejando Ortega en estos momentos iniciales; la de Lasson, que utilizará habitualmente, es de 1920) están subrayados con fuerza los textos clásicos de Hegel, "...dass nichts Grosses in der Welt ohne Leidenschaft vollbracht worden ist. [...] Leidenschaft ist auch nicht ganz das passende Wort für das, was ich hier ausdrücken will. Ich verstehe hier nämlich überhaupt die Tätigkeit des Menschen aus partikulären Interessen, aus speziellen Zwecken oder, wenn man will, selbstsüchtigen Absichten"133.

Esta referencia a las pasiones no es gratuita: no se trata únicamente del papel del individuo, del particular en la historia, sino también de cómo se lleva a cabo ese papel. No hay que olvidar que también en 1910 Ortega ha determinado que "la política se hace con pasiones"134. Veinte años más tarde, utilizando de nuevo a Hegel, concretará: "En su Filosofía de la Historia universal dice Hegel que todo lo importante que se ha hecho en la Historia lo ha hecho, sin duda, la pasión -pero bien entendido, añade-, la pasión... fría. Cuando la pasión es simple hervor, frenesí y calentura, no sirve para nada"135.

\footnotetext{
131"La pedagogía social como programa político" (1910). OC I, 514.
}

132En una lección de la Escuela Superior de Magisterio decía Ortega: "El respeto, señoritas, es la emoción filosófica. [...] La filosofía nace del respeto y enseña respeto: la filosofía es la ciencia general del respeto". Archivo de la "Fundación José Ortega y Gasset", Lección en la Escuela Superior de Magisterio, fecha 15 de diciembre de 1909 (?).

${ }^{133}$ HEGEL, Vorlesungen über die Philosophie der Geschichte. Op. cit. p. 59. Gaos, siguiendo la edición de Lasson, y, por lo tanto, sin coincidir exactamente con la de Brunstäd para Reclam, traduce: "La palabra pasión no es, empero, justa para lo que quiero expresar aquí. Me refiero aquí, en general, a la actividad del hombre, impulsada por intereses particulares, por fines especiales, o, si se quiere, por propósitos egoístas. [...] Nada grande se ha realizado en el mundo sin pasión". HEGEL, Lecciones sobre la filosofía de la historia universal. Ed. J. Gaos. Madrid: Alianza, 1994 (5 $5^{\text {a }}$ reimp.), p. 83.

134"Lerroux o la eficacia" (1910). OC X, 156

135 Misión de la Universidad. Madrid: Revista de Occidente en Alianza -Obras de José Ortega y Gasset, 22, 1983, p. 18. El texto corresponde al capítulo I de Misión de la universidad para la primera edición, de 1930. Este capítulo, y la dedicatoria que le antecede, se omitieron en reediciones posteriores y no se encuentran en las Obras completas. Un año más tarde, en la "Rectificación de la república", Ortega volverá a incidir en esa pasión fría: cfr. Rectificación de la República (1931). OC XI, 401. El texto de Hegel a que refiere, texto 
Individuo e historia, individuo y sociedad, el hombre como individuo de la humanidad, pero contando con los dos caracteres, la pasión y el respeto, siendo este segundo el que debe enfriar a la primera. Y no sólo eso, no sólo las referencias de la pasión tanto al individuo como a la política, sino que, además, la pasión remite a la cultura, la cultura como creación de ideales y emociones: "Cultura es algo más que eso, más que la forma de las pasiones e ideas humanas; es creación de pasiones nuevas y de ideas nuevas"136. Es este momento de creación, o, si se quiere, de tarea, de idea, el que une individuo y sociedad, el que enfría las pasiones y las convierte en emociones, en germen de progreso, de evolución, de respeto. Y es, a la vez, esta unión de creación y cultura en lo referente a pasiones e ideas la que en este momento orteguiza la enunciación clásica hegeliana: "Es sind zwei Momente, die in unseren Gegenstand eintreten; das eine ist die Idee, das andre sind die menschlichen Leidenschaften; das eine ist der Zettel, das andre der Einschlag des grossen Teppichs der vor uns ausgebreteten Weltgeschichte". 137 Mediante la conexión de los dos aspectos, esto es, por un lado ideas y pasiones, y, por otro, su creación, su evolución, aglutina Ortega en este momento las referencias a las Lecciones sobre filosofía de la historia y al prólogo de la Fenomenología.

Se reúnen así, en lo referente a las intenciones de Ortega en este momento, el individuo que, según el prólogo a la Fenomenología, recorre la formación del espíritu, y la conexión individuo-historia de las Lecciones. Mas adelante, la relación con Hegel en el tema del individuo se modificará, aunque seguirá siendo determinante. Incluso, en una de sus notas de lectura de las Lecciones escribirá: "Mi contraposición a Hegel: para él el individuo es la

subrayado por el propio Ortega en su edición de Lasson (la de Reclam únicamente la utiliza en los primeros años) es el siguiente: "Der politische Mensch ist nicht Enthusiast; er muss die klare Besonnenheit haben, die man den Enthusiasten gewöhnlich nicht zuschreibt. Die Leidenschaft ist die Bedingung, dass aus dem Menschen etwas Tüchtiges hervorkommt; also ist sie nichts Unmoralisches. Wenn diese Begeisterung wahrhafter Natur ist, so ist sie zugleich eine kalte". HEGEL, Vorlesungen über die Philosophie der Weltgeschichte. Band II-IV. Hrsg. G. Lasson. Hamburg: Meiner, 1923, p. 80.

136" Alemán, latín, griego" (1911). OC I, 208.

137HEGEL, Vorlesungen über die Philosophie der Geschichte. Hrsg. F. Brunstäd. Leipzig: Reclam, s.a., p. 59. La traducción (mía, por no coincidir el texto de la edición Reclam con la de Lasson que sigue Gaos) sería: "Son los dos momentos que se presentan en nuestro objeto: uno es la idea, el otro las pasiones humanas, el primero es la urdimbre, el otro la trama de la gran alfombra de la historia universal desplegada ante nosotros". Comentando este texto escribía H.-C. Lucas: "Este entretejimiento (pues el "estar entretejido" salta a la vista con particular viveza gracias a la metáfora de la alfombra) que vincula lo individual con lo universal se cumple, con preferencia, mediante espíritus de los pueblos individualmente destacados y a través de individualidades personales: los llamados pueblos y personas de alcance histórico-universal". LUCAS, H.-C. "Individuo, historia y estado en Hegel", en: Pensamiento, vol. 50, n 196, 1994, p. 8. 
exterioridad del proceso real - para mí al revés"138. Ahora, alrededor de 1910, todavía no se ha producido esa contraposición, por la simple razón de que Ortega está buscando otros objetivos. La misma idea, que en la conexión individuo-sociedad refiere Ortega a Natorp, esto es, que "el individuo aislado no puede ser hombre, el individuo humano, separado de la sociedad -ha dicho Natorp- no existe, es una abstracción", en la conexión ndividuo-historia la encuentra en Hegel, "denn das Individuum ist ein solches, das da ist, nicht Mensch überhaupt, denn der existiert nicht, sondern ein bestimmter"139.

Si sólo existe el individuo socializado, la comunidad (familia, ciudad, Estado), si la referencia no es sólo espacial, sino también temporal, entonces esa comunidad no es sólo social, sino también histórica. En este segundo momento se sitúa la referencia a Hegel, y la conexión con el primero, el individuo-sociedad, se encuentra en esa base que debe referir a ambos: el respeto al individuo, a la limitación, sea en la comunidad histórica, sea en la comunidad social, y, precisamente por ello, el ataque directo al individualismo (a un individualismo en sentido negativo que no se base en el respeto), y, con él, a la pedagogía individual.

138Archivo de la "Fundación José Ortega y Gasset", Carpetilla "Hegel: filosofía de la historia".

139HEGEL, Vorlesungen über die Philosophie der Geschichte. Op. cit. p. 59. "El individuo es, como tal, algo que existe; no es el hombre en general (pues no existe), sino un hombre determinado". HEGEL, Lecciones sobre la filosofía de la historia universal . Op. cit. p. 83. 


\section{La pedagogía social}

Ortega acude a Platón, a Pestalozzi y a Natorp para definir la pedagogía social que pretende. Se trata de unir la política y la pedagogía, al tener ambas el mismo ideal, el de la transformación de la sociedad, en este caso la española, con lo que la política deviene pedagogía social, y el problema de España un problema pedagógico. La labor debe ser una tarea de cultura, de producir cosas, de trabajo.

En este momento toma Ortega de Pestalozzi esa "educación para el trabajo", que es por y para el trabajo, y que se asienta en una comunidad como cooperación en la que sus miembros son trabajadores. Por esto la conexión entre cultura y socialismo: "Socializar al hombre es hacer de él un trabajador en la magnífica tarea humana, en la cultura, donde cultura abarca todo, desde cavar la tierra hasta componer versos"140. Se muestra así el socialismo de Ortega, un socialismo que debe entenderse, antes que del concepto mismo, a partir de sus caracteres: cooperación, cultura, trabajo, pedagogía social, etc., cuando todos estos rasgos no sólo no terminan con el idealismo, con la condición del ideal como tarea futura, sino que la exigen, la incluyen.

Ya años antes de este texto, en el discurso para los Juegos Horales de Valladolid, Ortega había insistido en la conexión de socialismo e idea, cultura, y lo hacía allí con un rasgo importante: mostrando la imposibilidad de olvidar a Hegel en las teorías de Marx. Era la indicación que el joven Ortega hacía a su padre para aclararle cómo debía "representar" este tema en su lectura (el discurso fue preparado por Ortega, pero leído por su padre, Ortega Munilla): "Peroración emotiva describiendo brevemente, con imágenes vistas, reales de lo que sería un movimiento exasperado de proletarios en estado salvaje aún - no se olvide que el socialismo es en cuanto doctrina un producto de cultura y civilización extrema (Karl Marx sacó de su maestro Hegel la teoría fundamental del socialismo «concepción materialista de la historia»): ¿qué resultará si se pone en manos de quien vive sentimental, moral e intelectualmente tres o cuatro siglos retrasado?"141.

140" La pedagogía social como programa político" (1910). OC I, 517.

141" Discurso para los Juegos Florales de Valladolid". En: ORTEGA Y GASSET, J. Cartas de un joven español (1891-1908). Op. cit. pp. 769. 
La referencia a Hegel es importante, porque muestra de un modo más claro la conexión entre el socialismo obrero y la escuela, la educación. Sería esta escuela, esta, con el concepto que utilizará más adelante, pedagogía social, la que introducirá el ideal de progreso, de futuro, de evolución: "Hay que cambiar al obrero de revolucionario en evolucionista: esto sólo se consigue en la escuela"142. Esa evolución era, precisamente, la que definía la forma de entender el sistema de Hegel por parte de Ortega, un sistema no sólo como conjunción o conexión, sino también como progreso, como evolución, y esa evolución era una de las causas de la polémica con Maeztu alrededor de Hegel. La evolución, entonces, como sinónimo de cultura, enfrentada a ese estado salvaje, que refiere a la naturaleza y su base instintiva, sin ideas, sin proyectos.

Es el mismo carácter de contrapeso que la misión de Hegel frente al "romanticismo cutáneo" que aparecía más arriba. Si ahí Ortega sitúa a Hegel como representante de un respeto por la humanidad y, con ella, el individuo, frente a la constante defensa del "tipo ejemplar de lo humano" que llevaría a cabo ese otro romanticismo (frente al de las referencias panteístas de corte spinozista), el cutáneo, superficial, inoperante ${ }^{143}$, ahora Hegel aparece como adalid de la idea, del ideal, de la teoría, frente a un socialismo que fuera "únicamente" práctica, acción, revolución. Si se tiene en cuenta que ese carácter de "idea" no remite únicamente a la teoría, a la cultura, a la ciencia y educación que necesariamente deben introducirse en España, sino que, además, remite al sistema, y con él a la colectividad, a la conexión de particularidades, entonces no es de extrañar su relación explícita con el tema de la unidad humana, que uniría (según las referencias de Ortega) al Hegel de las Lecciones sobre filosofía de la historia con el Hegel del sistema, y a ambos con el tema de la educación: "El signo de la inmoralidad es el rompimiento de la unidad

\footnotetext{
142Ibid.

${ }^{143}$ Es a este romanticismo al que se dirigen las críticas de Ortega, y no a ese otro del hen kaí pan. Éste último refiere a sistemas, a unidades, a colectividades, como se ha visto; el cutáneo refiere a "tipos ejemplares de lo humano", al "viejo liberalismo individualista". En 1908 escribía Ortega, y condensa esta temática: "Pensando de esta manera, ¿resultará extraño que abomine de toda fe en lo espontáneo de la raza? Los "solidarios" y D. Gumersindo de Azcárate creen que todos los males provienen de la legislación vigente en España desde los Reyes Católicos: suprimámosla y presenciemos la restauración espontánea de las energías sociales. Esta es una aplicación en menor escala del razonamiento anarquis ta que hay en el fondo de todo el viejo liberalismo individualista: el hombre en estado nativo es bueno; la sociedad reglamentada le hace malo; destruid ésta y renacerá sobre sus ruinas la bondad humana como un jaramago inmortal. Esto es la médula del romanticismo, y en mi vocabulario romanticismo quiere decir pecado". "Pidiendo una biblioteca" (1908). OC I, 83-84.
} 
humana y es inmoral el jurisperito justinianeo cuando conoce dos hombres distintos: el libre y el hombre-cosa, el esclavo. Pues bien: la existencia de cultos e incultos, la división de la escuela, es mucho más inmoral porque escinde más a sabiendas la unidad humana. / La pedagogía social que exige la educación por y para la sociedad, exige también la socialización de la educación"144.

La sociedad como única educadora, la correlación entre individuo y sociedad, son los caracteres en los que está incidiendo Ortega. Con ello, la temática de la limitación alcanza un primer punto álgido, un punto que, en cierto modo como contradicción, viene apareciendo desde hace tiempo: se trata del tema del individualismo, o, mejor, de lo que ello significa, es decir, ¿en qué quedamos? ¿en unidad humana, en conexión explícita entre España y Europa, en la idea y la cultura como vínculo del conjunto de la humanidad, o en el henchimiento de la limitación, en el individualismo como limitación y sólo a partir de su expansión lograr los vínculos necesarios? La polémica se instala entre dos polos: o unidad sin limitaciones particulares en su interior o unidad a partir de limitaciones. La conexión entre ambos momentos será la única posible, conexión que explicará, como veremos, desde el tema España-Europa, hasta el tema del paisaje y del concepto: la unidad con, desde y a través la limitación.

El tema del nacionalismo estará en la base, y con él el de España-Europa. Si ahora, en 1910, Ortega culmina 'La pedagogía social como programa político" con las exigencias de europeización, con las referencias a la obra de Costa Reconstitución y europeización de España, con la ineludible regeneración española como deseo y "la europeización es el medio de satisfacerlo"145, si la referencia a Europa proviene de la necesidad de cultura, de ciencia, de comunidad, desde años anteriores venía insistiendo en que esto no significa la pérdida de caracteres propios o, sin más, la pérdida de nuestra limitación. En 1908 escribía, incluyendo la conexión con el tema de la educación: "El problema español es un problema educativo; pero éste, a su vez, es un problema de ciencias superiores, de alta cultura. El verdadero nacionalismo, en lugar de aferrarse a lo espontáneo y castizo, procura

\footnotetext{
144" La pedagogía social como programa político" (1910). OC I, 518.

145Ibid. p. 521.
} 
nacionalizar lo europeo"146. Es un viaje de ida y vuelta, como los de Ortega a Alemania: necesidad de Europa, sí, pero porque necesitamos ciencia y cultura para nuestra propia limitación española. Si la tuviéramos ya aquí, el contacto con Europa sería muy diferente.

146" Pidiendo una biblioteca" (1908). OC I, 85. 


\section{Mediterranismo y cultura fronteriza}

En el mismo año que "La pedagogía social como programa político", 1910, Ortega escribe 'El «pathos» del sur", comentando el libro Primavera griega, de Hauptmann. En ese artículo Ortega concreta de un modo importante el tema de la europeización, y escribe:

"Cuando yo hablo de europeización, empero, no deseo en manera alguna que aceptemos la forma alemana de la cultura: ¿para qué? Ya hay ahí cuarenta millones de alemanes. Pero esa forma de la cultura es susceptible de que se la supere o, por lo menos, de que se enriquezca la amplitud humana poniendo otra al lado tan enérgica, tan fecunda, tan progresiva como ella. Yo ambiciono, yo no me contento con menos que con una cultura española, con un espíritu español. Y esto no existe; por mi parte, dudo que haya existido"147.

El concepto clave es el de "superación", pero, y por eso interesa mostrarlo en este contexto, se trata de una superación hegeliana. En "Alemán, latín y griego", Ortega será todavía más explícito: "Puede creérseme si digo que nadie habrá sentido y seguirá sintiendo mayor antipatía espontánea hacia la cultura germánica que yo. La patética protestante, la pedantería, la pobreza intuitiva, la insensibilidad plástica y literaria, la insensibilidad política del alemán medio mantienen firme a toda hora mi convicción de que no se trata de una cultura clásica, de que el germanismo tiene que ser superado. Pero nótese bien: tiene que ser superado; hoy no lo está"148.

La superación se producirá en dos direcciones: primero, tomando la ciencia y la cultura que necesita España, aprendiendo, educando, y, segundo, llevándolas hasta la limitación española, dirigiéndolas hacia eso que sí tenemos, un pathos del sur, una limitación propia, pero que hasta ahora ha carecido de cultura, de concepto, de conexión. La superación de la forma alemana de cultura es, entonces, absorción, asunción, o, dicho de un modo más claro, utilización, con unos fines muy concretos dirigidos hacia la ampliación, hacia el henchimiento de la limitación española. Ese henchimiento es el que dará lugar a un espíritu español que, primero, sea consciente de sus caracteres más propios, $\mathrm{y}$, segundo, sea capaz de completarlos añadiéndoles lo que les falte, en este caso la forma de ciencia y de cultura.

En 'El «pathos» del sur" Ortega concreta qué entiende por ese pathos: "¿El pathos del Sur!... Tinte espléndido del cielo, energía plástica de los colores, vivacidad en los

$147 " E l \ll p a t h o s »$ del sur" (1910). OC I, 501. 
movimientos; propensión a exteriorizar un erotismo hiperbólico, cierta espontaneidad de la retina para recibir sistematizadas las formas corporales de las cosas; gestos gráciles, expresivos y rápidos; la aptitud para la mentira; la jacarandosidad, el ocio; estas notas y otras por este orden que no trascienden de lo fisiológico, constituyen el pathos del Sur, el mediterranismo"149. Aparece entonces el enfrentamiento, si se compara con el texto anterior, la cultura germánica frente al mediterranismo: frente a la insensibilidad plástica la energía plástica, frente a la pobreza intuitiva el erotismo hiperbólico, frente a la pedantería la expresividad y espontaneidad de la retina. Son dos modos distintos de mirar, dos estéticas, dos caracteres, dos pathos.

La cultura mediterránea, el mediterranismo, tendrá su exposición en el capítulo 6 de la meditación preliminar de Meditaciones, pero su origen es bastante anterior a 1914, el año de publicación de Meditaciones. Al mismo tiempo, la cultura mediterránea implica otro carácter, un carácter definitorio de ese mediterranismo: es la cultura fronteriza. También en Meditaciones anuncia Ortega cierta 'Estética de «Myo Cid»" que debería haber consistido en "un ensayo panorámico sobre la cultura de España interpretada como cultura fronteriza"150. Con esa Estética de «Myo Cid» ocurre igual que con el Ensayo sobre la limitación, y curiosamente ambos referidos a un tema muy similar: queda únicamente el anuncio. El tema de la limitación y el tema de la cultura fronteriza deben ser interpretados conjuntamente.

La limitación española, la limitación que hay que henchir mediante la conexión con la cultura y ciencia germánicas y europeas, remite a la cultura fronteriza y mediterránea. Ya en 1910 anuncia Ortega, eso sí, sin definir sus caracteres, lo peculiar de la cultura mediterránea: "La cultura es, dondequiera, una: el griego y el escita, el francés y el prusiano trabajan ciertamente en una obra común. Pero hay una forma de cultura peculiar al Sur de Europa, un modo mediterráneo de amar a Dios, de contar los cuentos, de andar por las

148" Alemán, latín y griego" (1911). OC I, 209.

149" El «pathos» del sur" (1910). OC I, 499.

$150 \mathrm{MQ}, 155$. 
calles, de mirar a las mujeres y de decir que dos y dos son cuatro"151. El problema consiste en lo siguiente: la limitación española es una limitación mediterránea, fronteriza, en lo que refiere a contenidos, a modos de ser; esto, a su vez, remite a otro problema, el tema del nacionalismo y, en general, la relación entre España y Europa, la europeización. Se trata ir a Europa para salvar España, salir de la limitación española precisamente para poder henchirla, o, directamente: "yo no sé otro medio de salvar a España que librarme de ella; es decir, que España sea otra cosa de lo que fue y de lo que es: que no me duela"152.

Es siempre el mismo problema de limitación: salir de la limitación precisamente para verla como tal limitación, y, además, lograr aumentarla, corregirla, henchirla. Pero es necesario ir por partes. Primero hay que establecer qué es eso del mediterranismo y a continuación mostrar su carácter de "cultura fronteriza". Ambos rasgos son lo que constituye la limitación española, con lo que se exige un tercer paso: presentar cómo se mueve, cómo se desarrolla esa limitación tan peculiar, o, dicho de un modo más claro, analizar a partir de estos contextos el tema del nacionalismo y el tema de la relación entre España y Europa. Ambos temas, el mediterranismo y la cultura fronteriza, adquirirán caracterizaciones más propias en Meditaciones, pero interesa ya desde este momento, y como viene llevándose a cabo, analizar el contexto que conducirá hasta ahí.

Los caracteres del mediterranismo que Ortega ofrece en "El «pathos» del sur" son los que definen el tema. Si se atiende a esos rasgos nos encontramos con colores, movimientos, espontaneidad de la retina, gestos, mentiras, etc., rasgos que, en ningún caso, "trascienden de lo fisiológico". Son, todos ellos, caracteres que refieren a superficies y perfiles, a impresiones y miradas, reflejos y sensaciones. Por ello, la mejor exposición se encontrará en el tema del arte, de la estética. Pero, si se parte únicamente de esta primera enunciación de los caracteres, hay algo que permanece en el fondo del conjunto: se trata de algo físico, corporal, que no puede ni pensarse ni conceptualizarse a sí mismo porque le faltan los elementos que lo harían posible, los elementos de cultura, de concepto. Ortega no quiere acabar con esos rasgos, entre otras cosas porque son también los suyos, pero sí conferirles

151" Al margen del libro Colette Baudoche, de Maurice Barrès" (1910). OC I, 469. No hay que olvidar que Ortega incluye "la novelita de Barrès entre los romances fronterizos" (Ibid. p. 472), y que esos romances cantaban los combates que tenían lugar en la equívoca línea de la frontera.

152" La herencia viva de Costa" (1911). OC X, 173. 
el poder de verse como tales, dotarles de un alma, de un concepto, y esto sólo podrá conseguirse con los medios que ofrece la cultura.

Esa cultura no está en España, sino que hay que salir a buscarla a Europa, a Alemania, pero siempre teniendo en cuenta de que no se trata de una oposición, de un viaje únicamente de ida, sino de ida y vuelta. Escribe Ortega: "Yo también he pecado una vez, y a la sabiduría conceptual de los germanos oponía la sabiduría meridional de mi corazón, que es -decía yo - un canto rodado del Mediterráneo, pulido durante treinta siglos por el riente mar y que se sintió una vez rozado por la quilla llena de ovas de la barca de Ulises"153. Lo que oponía Ortega a la cultura germánica era una cultura mediterránea que parecía llegar hasta la Grecia clásica. Pero la afinidad entre España y Grecia no es de cultura, sino que remite a esos caracteres del pathos del sur, esto es, es algo puramente físico y fisiológico. En lo que refiere a la cultura, la afinidad de Grecia no es con la sabiduría meridional, del corazón, sino con la alemana, del concepto. Lo verdaderamente griego no es el pathos del sur, que lo vincularía con nosotros como mediterráneos, sino su cultura, que lo vincula directamente con la sabiduría del concepto, y, por ello, "un alemán se halla más cerca de Grecia que cualquiera de nosotros con nuestro brillante pathos meridional" 154 .

Ahora bien, esto no supone que tengamos que renunciar a nuestro propio pathos, sino que debemos constituirlo como una forma de cultura: "Nos enorgullecemos de ser una raza del Sur. Yo no pienso, ni mucho menos, que esto equivalga a una desdicha: sólo deseo que el Sur signifique algo más que una situación geográfica, algo más que una temperatura en el aire, algo más que unos grados de fiebre en las mujeres; sólo deseo que el Sur signifique una forma de cultura"155. Por ello no se acepta la forma alemana de cultura, sino la que, eso sí, procedente de Europa, habría que aplicarle a nuestro mediterranismo, ese pathos del sur que se sitúa en gestos e impresiones, en caracteres más que nada fisiológicos, en formas de amar, de mirar, incluso de andar.

Cuando retome estos caracteres para Meditaciones, Ortega lo expresará de un modo tajante, y también mucho más pulido: "El Mediterráneo es una ardiente y perpetua

$153 " E l$ «pathos» del sur" (1910). OC I, 499.

${ }^{154}$ Ibid. p. 501. 
justificación de la sensualidad, de la apariencia, de las superficies, de las impresiones fugaces que dejan las cosas sobre nuestros nervios conmovidos"156. La cultura mediterránea es, entonces, una cultura impresionista, que exige su completamiento, pero siempre sin renunciar a su propia esencia. Se exige la seguridad de la cultura, pero sin olvidar que tal cultura, el concepto, es sólo una parte, la parte que asegura, que da firmeza, en este caso a ese mediterranismo caracterizado por impresiones y gestos, miradas y espontaneidades, y, como tales, inseguridades.

Esta parte de inseguridad del mediterranismo es lo que en Meditaciones llamará Ortega cultura fronteriza, "la cultura salvaje, la cultura sin ayer, sin progresión, sin seguridad; la cultura en perpetua lucha con lo elemental, disputando todos los días la posesión del terreno que ocupan sus plantas. En suma, cultura fronteriza"157. La cultura fronteriza es la parte de inseguridad, la cultura sin cultura, sin concepto, que afecta al pathos del sur: la cultura fronteriza que aparece en Meditaciones es el mediterranismo sin concepto. En una nota añadida a ese texto citado remite Ortega a cierta "Estética de «Myo Cid»", aunque sólo lo hace en la primera edición de Meditaciones. La "Estética de «Myo Cid»" también aparece, como el "Ensayo sobre la limitación", en todas las listas que tenemos de meditaciones previstas, e incluso, tanto en la lista que exponía Ortega en la contrapartada de la primera edición de Meditaciones, como en alguna de las expuestas en las notas editadas por Molinuevo, ambas meditaciones previstas aparecen una siguiendo a la otra, primero la "Estética de «Myo Cid»", después el "Ensayo sobre la limitación"158. Esto no es casual.

Sólo existen en las obras publicadas de Ortega dos referencias a la "Estética de «Myo Cid»", ambas a pie de página en Meditaciones. Una remite a la cultura fronteriza, la otra aparece en el contexto del amor como conexión, como sentido de las cosas al expresar su lugar en el centro de una trama desde la cual parten las distintas relaciones con otras cosas. Es el concepto como rito erótico, la meditación como ejercicio amoroso, que veremos más adelante, precisamente por estar conectada estrechamente

155Ibid. p. 500.

156 MQ, 136.

${ }^{157} \mathrm{MQ}, 155$. 
la primera edición escribe Ortega: "Un amplio desarrollo de estas relaciones entre el pensar, la atención y el amor, así como de las distancias entre el amor y el impulso sexual -puede verse en el libro en preparación La estética de «Myo Cid»-, cap. VI: «Diálogo del amor a orillas del Duero»"159; en ediciones sucesivas sustituirá esa nota por otra que dice: "Sobre esas relaciones entre el pensar, la atención y el amor, así como sobre las distancias y el impulso sexual, puede verse mi libro Meditaciones de Don Juan y El Espectador, tomos I y II". Pasaré por alto lo que concierne a esas relaciones y distancias (aunque no lo referente al concepto, que veremos más adelante), pero no así el tema de la cultura fronteriza.

La cultura fronteriza, por su parte, en su expresión explícita sólo aparece en Meditaciones y en la Introducción a Velázquez (¡30 años después de Meditaciones!), referido directamente a la conexión entre España y Europa. La "cultura fronteriza" del Velázquez la examinaremos mucho más adelante; pero, continuando con el contexto en el que nos estamos moviendo, 1910 y 1911, hay un texto que parece referir a esa 'Estética de «Myo Cid»": es "Tierras de Castilla". El artículo aparece fechado en 1911, aunque Garagorri indica que el manuscrito original precisa la fecha del viaje a que alude el texto en agosto de 1913160, que sería publicado en La Prensa, de Buenos Aires, en 1914. De todos modos, en "Arte de este mundo y del otro" Ortega alude al viaje a Sigüenza (viaje en que se basa "Tierras de Castilla"), remitiendo de forma explícita al Cid, a la catedral y a sus torres, como en "Tierras de Castilla", e indica que el viaje fue realizado "hace un año". "Arte de este mundo y del otro" fue publicado por partes en El Imparcial en 1911161.

${ }^{158}$ Cfr. Meditaciones del Quijote. Con un apéndice inédito. Madrid: Revista de Occidente en Alianza Obras de José Ortega y Gasset, 17-, 1994³, p. 11 n.; y "Sobre Cervantes y El Quijote desde el Escorial. (Notas de trabajo de José Ortega y Gasset)". En: Revista de Occidente, no 156, mayo 1994, p. 41.

${ }^{159} \mathrm{MQ}, 145$.

${ }^{160}$ Cfr. Notas de andar y ver. Viajes, gentes y países. Madrid: Revista de Occidente en Alianza -Obras de José Ortega y Gasset, 32-, 1988, p. 42, nota.

${ }^{161}$ Lo que está claro es que es entre 1911 y 1913. Soledad Ortega lo explica como sigue: "Entre el año 1911 y 1913, los cuatro consuegros -es decir, los Ortega Munilla-Gasset y los Spottorno -Topete, pasan más de un verano en una casa alquilada en Sigüenza, con el joven matrimonio y su hijito Miguel. [...] En la ocasión de esos veranos se sitúa la excursión realizada por mi abuelo Ortega y mi padre, cuyos testimonios gráficos aprecen en este álbum y los relatados, en forma literaria rara vez superada, primero en "Notas de andar y ver" y más tarde en "Notas del vago estío". José Ortega y Gasset. Imágenes de una vida 1883-1955. Precedido de un relato de Soledad Ortega. Madrid: Ministerio de Educación y Ciencia / Fundación José Ortega y Gasset, 1983, pp. 33-34. 
La conexión entre "Tierras de Castilla" y la no escrita Estética de «Myo Cid» se basa en que "Tierras de Castilla" consiste en las meditaciones que Ortega-Rubín de Cendoya realiza por Sigüenza y Berlanga de Duero, en "viaje sentimental sobre una mula torda de altas orejas inquietas. Son las tierras que el Cid cabalgó. Son, además, las tierras donde se suscitó el primer poeta castellano, el autor del poema llamado Myo Cid"162. Las meditaciones llevadas a cabo en el viaje están acompañadas por la referencia al Cid y al poema, y es precisamente mediante el poema como introduce Ortega caracteres referentes al alma castellana del XII muy similares a los que más arriba remitían al pathos del sur: "El Myo Cid es un balbuceo heroico, en toscas medidas de paso de andar, donde llega a expresarse plenamente el alma castellana del siglo XII, un alma elemental, de gigante mozalbete, entre gótica y celtíbera, exenta de reflexión, compuesta de ímpetus sobrios, pícaros o nobles"163. Esos caracteres del alma castellana del XII se han desarrollado como hemos visto: la ausencia de reflexión aquí es muy similar a la no trascendencia del fisiologismo que caracterizaba al pathos del sur, los ímpetus sobrios, transformados en cultura de superficies o impresionismo cultural, se mantendrán hasta el contexto de Meditaciones.

Pero la alusión a la frontera de modo explícito se muestra más adelante. Ya incide Ortega en que Sigüenza fue durante bastante tiempo lugar fronterizo, avanzada "tierra de musulmanes", y está además la remisión a ese territorio fronterizo, no sólo referido a Sigüenza, sino sobre todo a su catedral, catedral que simultaneaba su función con la de castillo y cuyas torres muestran la indecisión de la dirección (¿catedral o castillo, cielo o tierra?) ${ }^{164}$. Este carácter fronterizo es el que aprovecha Ortega para hablar de antítesis, para mostrar la condición antitética de la vida de cada cual, siempre situada entre religión y ciencia, entre virtud y placer, entre arte y pensamiento. El problema es que hay que preferir, hay que elegir entre esas posibilidades (y ya aquí despunta un inicio de lo que más adelante será todo el tema de la elección de las posibilidades, de la vocación y el destino). La vida,

162" Tierras de Castilla. Notas de andar y ver" (1911). OC II, 43.

163Ibid. p. 44. La misma idea, casi con las mismas palabras, la encontramos también en Pío Baroja: anatomía de un alma dispersa (1912). OC IX, 480.

${ }^{164}$ En " Notas del vago estío" insistirá Ortega en el carácter intermedio, fronterizo, de castillos y catedrales: "En la fauna visual que el viajero persigue, representan catedrales y castillos una especie intermedia entre la pura naturaleza y la pura humanidad". "Notas del vago estío" (1935). OC II, 420. 
así, se muestra como tragedia, tener que elegir un polo abandonando el otro, tener que colocarse de un lado de la frontera sin poder pasar al otro.

Es en este momento cuando se da un tipo explícito de integración: "No, no prefiramos; mejor dicho, prefiramos no preferir. No renunciemos de buen ánimo a gozar de lo uno y de lo otro: Religión y ciencia, virtud y placer, cielo y tierra... Cierto que hasta ahora no se han resuelto las antítesis; pero cada hombre debe pensar que es él el llamado a resolverlas"165. Esta integración de antítesis debe leerse en conexión con todo el tema de la relación entre España y Europa, entre el hombre mediterráneo y la cultura germánica. Es el deseo de integración que en Meditaciones, teniendo en cuenta todo el contexto que viene examinándose, será concretado de modo explícito: "Representamos en el mapa moral de Europa el extremo predominio de la impresión. El concepto no ha sido nunca nuestro elemento. No hay duda que seríamos infieles a nuestro destino si abandonáramos la enérgica afirmación de impresionismo yacente a nuestro pasado. Yo no propongo ningún abandono, sino todo lo contrario: una integración"166.

Continuando en "Tierras de Castilla", insiste Ortega en otro tipo de integración. Comentando la estatua que escenifica el enterramiento de un joven guerrero, la antítesis adquiere un carácter artístico, pues el joven es guerrero de oficio, pero su cuerpo revela un temperamento débil, una "sonrisa dialéctica", escribe Ortega, unos hábitos intelectuales. De ahí la antítesis que anhela la integración: ¿Ha habido alguien que haya unido el coraje a la dialéctica?"167. En conjunto, las antítesis que aparecen en este texto remiten ya al deseo de integración, deseo que en Meditaciones encontrará su presencia explícita: el coraje y la dialéctica, la tierra y el cielo, celtíberos y góticos, todo ello se mostrará en Meditaciones, con las modificaciones requeridas, como relación entre cultura de superficies y cultura de profundidades.

La clave está en ver que años antes de Meditaciones Ortega había preparado el camino que le conduciría hasta ahí. Ahora bien, si es cierta esta conexión, si la Estética de «Myo Cid» tiene algo que ver con "Tierras de Castilla", si la cultura fronteriza que debería haber ocupado a esa estética tiene algo que ver con la serie de integraciones que aparecen en

165" Tierras de Castilla. Notas de andar y ver" (1911). OC II, 46.

$166_{\mathrm{MQ},} 165$. 
"Tierras de Castilla", entonces debe haber alguna confusión, porque la cultura fronteriza que Ortega menciona en Meditaciones tiene carácter negativo: es la cultura mediterránea cuando todavía no ha logrado la conexión con el concepto, o, mejor, la conexión del concepto. Por contra, las fronteras que aparecen en "Tierras de Castilla" son fronteras de conexión, de integración, de preferir no preferir.

No hay tal confusión. La meditación preliminar de Meditaciones, lugar del que proceden las referencias aparecidas, incluye la unión, el pulido estilístico y la aclaración de una serie de ideas y temáticas que venían siendo tratadas desde años anteriores. No sólo gran parte de los temas que examina ya han sido presentados en artículos anteriores, sino también los contenidos de algunas meditaciones aludidas, así como, en general, la postura de Ortega, sus intenciones y propósitos. Ahora bien, a pesar de haber tratado ciertos temas, como el de la limitación o el de la cultura fronteriza, en artículos anteriores, Ortega no los había concluido: sólo había presentado ciertos rasgos, que pueden corresponder al principio, al intermedio o al final de su idea. Sólo si hubiera concluido sus meditaciones previstas podríamos ver a qué corresponde cada una de las huellas dejadas en artículos anteriores.

Puede aventurarse una hipótesis: la integración que aparece junto al Cid en 'Tierras de Castilla" era el final del tema de la cultura fronteriza, tema que, en Meditaciones, será presentado en sus momentos, esto es, la cultura fronteriza como falta de seguridad y de concepto, primero, y, segundo, la necesidad de integración, de unión con ese saber conceptual, es decir, la renuncia a la preferencia, la conjunción del pathos del sur con la seguridad de la cultura germánica. Esta parte final es la que tiene una primera versión en "Tierras de Castilla".

A partir de este momento empieza a verse en sus diferentes pasos el trayecto mantenido por Ortega en lo referente a este tema. Los anhelos de sistema, de idea, incluso el tema general del panteísmo, mantenidos en las dos direcciones, la teórica y la práctica, muestran un primer momento de integración, de unidad, en el que las limitaciones y las diferencias son entendidas como crueldades, así como un inicio de la superación de este carácter negativo de la limitación diferenciadora. Sólo cuando comienza a surgir el tema del respeto por el individuo, la constancia de la limitación, la concienciación de que tal limitación necesita henchirse, pero sin renunciar a sí misma, se inicia un proceso en el que los deseos

167" Tierras de Castilla. Notas de andar y ver" (1911). OC II, 47. 
de integración, de preferir no preferir, de no renunciar a nada, adquieren ya un nivel diferente. En este nivel las limitaciones se mantienen como tales, pero precisamente para completarse, para unirse con otras limitaciones a través de las cuales puedan las primeras aumentar su contenido.

Refiriendo todo esto al tema de España, la cultura mediterránea y fronteriza exige su conexión con la sabiduría conceptual, científica, intelectual, si se quiere, que posibilite a la propia limitación española convertirse, sin más, en cultura, una cultura asentada en los caracteres más propios de esa limitación que, sin desvirtuarlos, permita conferirles la fuerza necesaria para posibilitar el progreso y desarrollo, el aumento, el crecimiento. Las distintas integraciones tienen contenidos diversos, pero todas el mismo fin: individuo y sociedad, coraje y dialéctica, España y Europa, diferencia o limitación y unidad, superficie y profundidad, impresión y concepto, etc., sea del modo que sea, se trata siempre de permitir el talante de progreso, de ideal, de evolución, de mejora, que sólo podrá llevarse a cabo si tales binomios se presentan, primero, integrados, y, segundo, unidos mediante una integración que no sitúe las particularidades como crueldades, sino como objetivos de henchimiento, henchimiento de individualidades, henchimiento de limitaciones. Si esto es así, las referencias a Hegel son, incluso, más cercanas de lo que el propio Ortega pudo darse cuenta, siempre que se interprete a Hegel no desde "finales" o "principios", sino desde la fuerza de los momentos situados entre ellos.

Pero Ortega no está pensando precisamente en ese Hegel. Es más, como consecuencia de todo lo dicho puede intuirse fácilmente que, en un tema situado constantemente alrededor de limitaciones e integraciones y que, además, remite con insistencia a la relación entre España y Europa, el problema del nacionalismo ocupará un lugar fundamental, esto es, el problema del enfrentamiento entre el nacionalismo exclusivista y la unidad europea a la que tiende Ortega 168 . Pues bien, en estos años iniciales de la segunda década de siglo, el tema del nacionalismo, en la interpretación de Ortega, incluye la referencia a Hegel, o, más que a

\footnotetext{
168 La tesis general de ese enfrentamiento la ha expresado de forma clara Th. Mermall: "La posibilidad de una Unidad Europea en la que el nacionalismo morboso, exclusivista y xenófobo quedaría desplazado por formas jurídicas de unidad, basadas en una cultura común, sin desdibujar el carácter particular y diferencial de cada pueblo". MERMALL, Th. "Abstracto/concreto: clave retórica para la comprensión de Ortega", en: Revista canadiense de estudios hispánicos, vol. XXI, 1, 1996, p. 187.
} 
Hegel, al talante general de romanticismo que, según Ortega, uniría, por ejemplo, al propio Hegel, a Schelling y a Herder. 


\section{El nacionalismo y la degeneración del Volksgeist}

Del tema del nacionalismo hay que presentar dos factores: por un lado la referencia a Hegel, por el otro a la limitación, pues si, como se verá, la propuesta orteguiana, ese socialismo integrador y cultural, europeísta y nacional, no puede separarse en ningún momento del tema de la relación entre España y Europa, entonces, de nuevo, el nacionalismo se constituirá como un problema de limitaciones. Las referencias que interesan, por unir a Hegel con el tema del nacionalismo, de España y Europa, se encuentran en dos textos del mismo año, 1911, el primero publicado en marzo, "Observaciones", el segundo en septiembre, "Alemán, latín y griego".

"Observaciones" examina, de nuevo, el tema de la europeización en relación con Costa, y consiste en aclarar ciertas alusiones a Ortega de Julio Cejador en un artículo titulado "Costa, rectificado". Ortega sitúa a Costa en lo que él considera su contexto ideológico e histórico, con el fin de concretar su relación con él. Es este contexto el que permite la referencia a Hegel. Escribe Ortega:

"Cuando Costa educaba sus broncos ideales juveniles, sus ciclópeas imaginaciones de Titán mozo, reinaba en Europa una manera de ver el mundo que, procedente de Herder, Schelling y Hegel, había adquirido entre juristas y filológos el nombre de historicismo. Queríase ver en la historia el campo de la experiencia metafísica, el lugar donde daba sus revelaciones el Espíritu Universal. Estas revelaciones son lo que se llamó espíritus de los pueblos" 169.

Es esta introducción del espíritu del pueblo, del Volksgeist, lo que interesa. El análisis del tema de la europeización se asentará ahora alrededor de ese concepto, aunque, como veremos (y por eso importa mostrarlo ya aquí), el tema conducirá a un lugar clave que será tratado al final de este trabajo, la "Meditación de Europa". Para Ortega, en este momento alrededor de 1911, el tema del Volksgeist tiene una dirección inequívoca: la temática de la relación entre España y Europa, en el contexto de la necesaria culturización de España. La unificación en torno a la razón, a la idea de progreso, a la ciencia, la unidad en torno a la nivelación de las diferencias que había supuesto el siglo XVIII, fueron las causantes de que surgiera un momento complementario, el romanticismo, que permitiera diversificar las universalidades: "El siglo XVIII, preocupado de la unificación, de lo que en las cosas hay

169" Observaciones" (1911). OC I, 166. 
de común, necesitó de otra edad complementaria, preocupada nuevamente de lo que en las cosas hay de diferente. La filosofía romántica amó lo diferencial, lo distintivo, lo peculiar: sobre el fondo Humanidad, que la edad anterior había preparado, hizo destacar en toda su fuerza las siluetas individuales de los pueblos"170. Esas siluetas individuales son las que se consolidarían como espíritus de los pueblos. El concepto de Volksgeist que entiende Ortega parte de este fondo romántico, en el que llevando las cosas a un extremo máximo, se buscarán las diferencias extremas, las religiones, las costumbres, las tradiciones. "Los pueblos cobraron, gracias a este impulso, la conciencia de su personalidad diferencial, y en un supremo arranque se organizaron en nacionalidades políticas"171.

Según Ortega, Costa se situaría en el contexto de este romanticismo del Volksgeist, y, por ello, dedicará su labor al estudio del pueblo español en sus diferencias y tradiciones, a una historia particular sin contacto con otras diferencias, otras limitaciones, otros "espíritus" del pueblo. El romanticismo del Volksgeist, y Costa con él, habría olvidado toda posibilidad de una unidad superior, de una unificación que, sí, partiendo de limitaciones y diferencias, permitiera tanto el orden como la conexión entre ellas: "Me parece Costa el símbolo del pensador romántico, una profética fisonomía que ungida de fervor histórico místico conjura sobre la ancha tierra patria el espíritu popular, el Volksgeist que pensaron Schelling y Hegel, el alma de la raza sumida en un sopor, cuatro veces centenario. Y claro está, no acudió, porque el espíritu popular no existe más que en los libros de una filosofía superada, supuesto que fuera alguna vez bien entendido"172.

Por esto, si la reconstitución de España que propugnaba Costa consistía en la vuelta a lo más íntimo y nativo, a lo más espontáneo del país, no es de extrañar que la europeización que mantenía Ortega se situara en un polo exactamente opuesto. Pero hay que entender esto bien. Lo que le preocupa a Ortega, lo que le molesta del romántico Volksgeist es su degeneración, su mala intelección, esto es, que sea interpretado como defensa de casticismos, costumbrismos y tradicionalismos. Lo que molestaba a Ortega era que "aquel amor hacia lo peculiar, sugerido por el hegelianismo, degeneró en un empirismo histórico

\footnotetext{
170 Ibid.

${ }^{171}$ Ibid. p. 167.

172Ibid. p. 169.
} 
que se afanaba exclusivamente por dotar a lo transitorio e individual de una importancia eterna"173.

No hay problema con la individualización, con la particularización y diferenciación del Volksgeist, o, de otro modo, con la limitación de cada pueblo, en este caso la española, pero sí que lo hay si eso se mantiene como definitivo. No hay problema con la limitación, siempre que ésta pueda salir de sí misma, ser capaz de ver lo que le falta y lograr contactos con otras limitaciones que le resulten provechosos; en el caso de España en este momento, indispensables. Por ello, Ortega siempre mantendrá cierta ambivalencia en torno al Volksgeist: por un lado, "el espíritu popular no existe más que en los libros de una filosofía superada", por otro, como escribirá (y subrayará) en sus notas de lectura de la Filosofía de la historia, "Volksgeist como sensibilidad vital"174, pudiéndose leer esto en referencia a Meditaciones: "Es, en definitiva, cada raza un ensayo de una nueva manera de vivir, de una nueva sensibilidad"175, pero también a El tema de nuestro tiempo: "Ideología, gusto y moralidad no son más que consecuencias o especificaciones de la sensación radical ante la vida, de cómo se sienta la existencia en su integridad indiferenciada. Esta que llamaremos «sensibilidad vital» es el fenómeno primario en historia y lo primero que habríamos de definir para comprender una época"176.

A partir de ahí surgirá el tema de las generaciones como variaciones de la sensibilidad vital. Pero esto es adelantar acontecimientos. Por lo que respecta al contexto en el que nos estamos moviendo, el problema consiste en que la degeneración del Volksgeist, entendiendo ésta como la fácil y peligrosa mistificación de casticismos e individualidades, primero, impide ver lo valioso del concepto, o, en nuestro sentido, causa la malinterpretación de la limitación, haciendo creer que tal limitación consiste, únicamente, en permanecer, inmóviles, junto a lo más peculiar y propio; y, segundo, puede ser fuente de nacionalismos exacerbados que únicamente conduzcan a consecuencias muy peligrosas, a, utilizando la expresión de Ortega, el nacionalismo como agresión.

173Ibid. pp. 167-168.

${ }^{174}$ Archivo de la "Fundación José Ortega y Gasset", Carpetilla "Hegel - Filosofía de la historia".

$175 \mathrm{MQ}, 170$.

176 El tema de nuestro tiempo (1923). OC III, 146. 
Es el Volksgeist como padre del nacionalismo el que ataca Ortega. En "Alemán, latín y griego", comentando la situación francesa, escribe: "Creyeron, pues, en la posibilidad de un renacimiento francés sin necesidad de aquel rodeo humillante; una renovación de las energías étnicas. Taine, de Inglaterra; Renan, de Alemania, trajeron las ideas de la restauración: Hegel el Restaurador, el justificador, el romántico, les invitaba a construirse una ideología nacionalista y conservadora, a renegar de Voltaire y la Revolución, a restaurar el feudalismo. De estos polvos vienen los lodos nacionalistas actuales"177. Es este Hegel romántico el que molesta a Ortega, o, de un modo más concreto, la degeneración de la idea de nación en nacionalismo, la malinterpretación de la idea de nación.

Cuando en 1915 escriba Ortega que "la idea de «nación» es hija de los románticos. Más concretamente: es hija del romanticismo alemán. Herder, Schelling y Hegel han sido los profetas de la nacionalidad, del «espíritu del pueblo», como ellos decían"178, repitiendo las ideas que ha mantenido desde años antes, ya ha dejado constancia de cuál es el problema: que lo nacional degenere en nacionalista. Sus propuestas de reconstrucción nacional no admiten tal nacionalismo, es más, ese socialismo nacional, que Ortega tomaba de Lassalle entre otros, no puede admitirlo. En el manuscrito de la conferencia que pronuncia Ortega sobre Lassalle en 1912 escribía: "Yo creo en el socialismo de Lassalle [...]. Creo en la posibilidad y en la necesidad de un socialismo constructor de naciones, verdaderamente internacionalizador de naciones"179.

Más que el tema del socialismo en concreto, interesa en este momento esa internacionalización de naciones, el internacionalismo en sí mismo, más que como táctica socialista: el internacionalismo, "un movimiento de las naciones hacia la nación única, hacia la nación de naciones"180. De nuevo el tema de la limitación, la nación como limitación, y la posibilidad de que sea conjuntada en una unidad global, sin negar los caracteres propios, pero sin degenerar en ningún tipo de casticismo o nacionalismo excluyente. Esta unidad global que pide el nacional, pero impide el nacionalista, es la misma que olvidaba el romanticismo del Volksgeist: por ello la conexión entre el espíritu

\footnotetext{
177"Alemán, latín, griego" (1911). OC I, 208.

178" La guerra, los pueblos y los dioses" (1915). OC I, 412.

${ }^{179}$ Archivo de la "Fundación José Ortega y Gasset", bandeja A.
} 
del pueblo y el nacionalismo, por ello el "de aquellos polvos vienen estos lodos". Y por ello, como veremos en la última sección del trabajo, llegará un momento en que Ortega superará el carácter de internación por el de ultranación, el internacionalismo superado en el cosmopolitismo.

El nacionalismo, aunque pueda parecer que se sitúa sosegadamente en el recinto del pueblo al que se refiere, es una táctica agresiva: "Nacionalismo es un concepto agresivo: el nacionalista piensa no tanto en su nación como contra las otras naciones. El nacional, por el contrario, se preocupa sólo de una labor constructora dentro del ámbito político en que vive"181. El nacional, entonces, piensa en su nación con las otras naciones, en su limitación con las otras limitaciones, en su "espíritu del pueblo" con los otros espíritus del pueblo. En "Vieja y nueva política" insistirá Ortega en que no se confunda su concepto de "nacional" con el de "nacionalista", repitiendo el mismo argumento: "No se entienda, por lo frecuente que ha sido en este mi discurso el uso de la palabra nacional, nada que tenga que ver con el nacionalismo. Nacionalismo supone el deseo de que una nación impere sobre las otras"182. De otro modo: el nacional está abierto, el nacionalista está cerrado, en el mejor de los casos, y, en el peor, esa cerrazón se convierte en agresión.

Si se entiende, entonces, el tema del nacionalismo y del Volksgeist en relación con el tema de la limitación, en todos los sentidos que vienen examinándose, las conclusiones serían las siguientes: el nacionalismo es una degeneración de la limitación propia, pues no piensa en su henchimiento a través del contacto y la relación, sino que, simplemente, piensa contra, sin mantener la labor constructora que supone la ampliación de la limitación, como pueblo, como nación, en su contacto y conexión con otros modos de ver, con otras sensibilidades vitales. El Volksgeist, en su caso, mantiene una parte negativa y otra positiva, la primera lo conduce a casticismos y romanticismos inútiles que causan la degeneración de la limitación nacional en limitación nacionalista; la segunda permite entenderlo como sensibilidad vital, que únicamente mediante dos direcciones, la conciencia de la propia limitación y la conciencia de la necesidad del aumento de la propia limitación, a través de

180"Miscelánea socialista" (1912). OC X, 202.

${ }^{181}$ Ibid. p. 203.

182" Vieja y nueva política" (1914). OC I, 299. 
relaciones y completamientos de aquello de lo que se carece (de cultura, de ciencia, en el caso de España), puede hacer posible el progreso y la evolución.

El lugar de España y del tema de la europeización en este contexto es fácil de determinar: la limitación española, sin renunciar a ella en ningún momento, exige su propia ampliación, su propio crecimiento, y para conseguirlos es necesario acudir, en primer término, a la culturización, a la sabiduría del concepto, que en este momento se encuentra en Europa. Eso por un lado. Por el otro, tal salida a Europa no refiere únicamente al tema de la salvación o la reconstrucción nacional, sino que afecta a toda esa teoría del internacionalismo, de la necesidad de una unidad nacional que permita los contactos y que, mediante ellos, posibilite la ampliación y mejora de las naciones, de las particularidades, de las limitaciones, y lo haga por una simple cuestión de completamiento, de inclusión de caracteres ajenos que posibiliten el crecimiento. En este sentido, el socialismo nacional e internacionalista que postula Ortega mantiene las dos direcciones: la mejora de España a través de Europa y la formación de una "internación" que haga funcionar el viaje de ida y vuelta, esto es, no sólo Europa hacia España, sino también España hacia Europa.

En una carta a Curtius (y que será examinada de un modo concreto en la última sección del trabajo), un cuarto de siglo más tarde respecto al contexto en que nos hemos movido, escribirá Ortega: "La realidad española es, desde el punto de vista europeo, una realidad anómala. Lo es hasta tal punto que representa esencialmente una realidad límite de lo europeo. Esto hace que los fenómenos españoles no puedan ser suficientemente pensados con las categorías habituales de la historia europea y por esto yacen ahí «ignorados» -como cadáveres insepultos. Por otro lado, son éstos total y puramente europeos, precisamente son la variedad más extrema de lo europeo, muy próxima a lo «completamente otro». ¿No sería una gran tarea el ensayo de integrar en la historia europea esta su manifiesta diferencia?"183. La integración, en este momento, tendría la dirección de España en Europa, pero para llegar hasta ahí habría primero que conseguir la de Europa en España. En este segundo sentido es en el que se mueven ahora los anhelos de Ortega, pero siempre sin olvidar el primero: sólo si España incluye Europa podrá Europa incluir España.

Los tres caracteres, el mediterranismo, la cultura fronteriza y el nacionalismo, no sólo exigen su conjunción, sino que, además, esa conjunción puede explicarse de un modo lo

183Epistolario. Madrid: Revista de Occidente, 1974, pp. 104-105. 
suficientemente claro mediante el tema de la limitación. La limitación española se expresa de un modo fundamental en el carácter de mediterranismo, ese talante que huye de lo trascendental y se mantiene en impresiones, en gestos, en sensibilidades. Por el hecho de que tal carácter es tal como es, la limitación española no puede henchirse, no puede conectarse con otras limitaciones que le permitan ampliar su contenido. Ese rasgo negativo de la limitación, la limitación sin posibilidad de salir de sí misma, es la cultura fronteriza: la parte de inseguridad que, al no poseer el talante de sujeción, de concienciación, tanto causa el desconocimiento de la propia limitación como impide el movimiento de progreso, de mejora.

Lo que exige la cultura fronteriza es el poder integrador, de preferir no preferir, que aglutine los caracteres básicos y propios de la limitación española con aquellos medios que hagan posible su evolución, su henchimiento. Esos medios se encuentran en la cultura y ciencia europeas, en el concepto. Por ello, para evitar el casticismo y tradicionalismo en que podría convertirse el mediterranismo si no consigue cumplir los anhelos de integración, es necesario, por la parte negativa, la negación de todo talante nacionalista, y por la positiva, la aspiración a una unidad en la que las limitaciones, y la limitación española con ellas, estén conectadas por relaciones que posibiliten la mejora, la ampliación y henchimiento, tanto de cada una de ellas como del conjunto. Es en este momento cuando la limitación nacionalista de cierto Volksgeist romántico debe perder su carácter de limitación restrictiva y dejar paso a la limitación como límite, como contacto y relación, en la que la sensibilidad vital de todo Volksgeist se sitúe en el marco de una unidad más amplia, internación, si se quiere, en la que dicha sensibilidad vital crezca por sí misma... pero por contacto.

En este momento la cultura fronteriza perdería su connotación negativa y pasaría a convertirse en un cultura límite en la que fueran las relaciones y conexiones las que definieran su propio carácter de "fronteriza". La temática de la europeización, de la relación entre España y Europa, adquiriría su razón de ser en el interior de este proceso: se trataría de conjugar la idea de nacionalidad con la visión europeísta184.

${ }^{184}$ T. López de la Vieja ha incidido en esta idea: "Ortega y Gasset no piensa, en efecto, en un "cuerpo político" en los términos de comunidad política o solidaridad interna a un grupo homogéneo. El fondo común 
Todavía antes de 1914, la fecha de publicación de Meditaciones, el mediterranismo es expuesto por Ortega en otro texto del mismo año, 1911, que la mayoría de artículos que vengo manejando. Ese artículo es "Arte de este mundo y del otro". La presencia del tema del hombre mediterráneo en un contexto referido al arte, a la estética, no es ni mucho menos casual. La estética ocupa un lugar primordial tanto en el proceso que intento exponer, como en el tema de la limitación en concreto. Si ya Ortega en 1906 afirmaba que la estética es una cuestión política, si tanto en 1908 como en 1910 insistía en que "a los españoles nos toca la justificación por la estética"185, si el mejor modo de exponer el mediterranismo, o la sensibilidad vital del español, es a través del arte y la estética, todo esto no remite únicamente a la limitación española en el sentido de conformar el modo español de mirar, o la estética española en general, sino, sobre todo, a la manera de hacerlo: construyendo una teoría de las relaciones y de las posibilidades que, como hemos visto, es indispensable tanto para la política como para la teoría filosófica que lleva de la mano.

Si se quiere responder de un modo más concreto a la cuestión de por qué Ortega acude al arte, a la estética, o, sin más, qué significa que la estética sea una cuestión política, puede hacerse mediante la conjunción de una serie de aspectos:

- El arte no sólo manifiesta la sensibilidad vital de un pueblo, esto es, presenta sus rasgos, gestos y maneras más propios, sino que, además, despierta esa sensibilidad al dotarla de intimidad: "Esto es lo más grande, lo más glorioso que puede hacer por el porvenir de su raza un artista hispano: ponerla en contacto consigo misma, sacudirla y herirla hasta despertar totalmente su sensibilidad. Dotarla de intimidad"186. La intimidad que proporciona el arte refiere a la posibilidad de presentar las cosas en el momento de su ejecución, su momento inicial: "Tal idioma es el arte: esto hace el arte. El objeto estético es una intimidad en cuanto tal" 187 , y puede hacerlo porque "las cosas del arte" son mostradas en su nacimiento, formando parte de un mundo nuevo, creado: "Sólo conocemos bien lo

europeo ha sido compatible con el hecho diferencial de los distintos países. Su idea de nacionalidad corresponde, por tanto, a una visión de europeísmo universalista, superior al particularismo de las regiones y de las tradiciones". LÓPEZ DE LA VIEJA, M ${ }^{a}$ T. "Nacionalidad y cuerpo político", en: LÓPEZ DE LA VIEJA, Ma T. (Ed.), Política de la vitalidad. España invertebrada de José Ortega y Gasset. Madrid: Tecnos, 1996, p. 141.

185"Adán en el paraíso" (1910). OC I, 477. Ver también "Algunas notas" (1908). OC I, 113.

186" ¿Una exposición Zuloaga?" (1910). OC I, 140.

187"Ensayo de estética a manera de prólogo" (1914). OC VI, 256. 
que hemos visto nacer. Esta intimidad súbita en que la obra de arte nos pone con las cosas proviene de que nos hace asistir a su generación"188. Si se tiene en cuenta que para Ortega un pueblo es una intimidad, un repertorio de secretos 189 , es fácil deducir la conexión: el arte no sólo muestra la intimidad de un pueblo, también la despierta, la obliga a reaccionar.

- Esa sensibilidad que expresa el arte no se refiere únicamente a pueblos, sino también a épocas. El arte muestra los temas y problemas de cada época, la historia del arte muestra la historia del hombre. En "Alrededor de Goethe" escribirá Ortega que el arte "precede siempre al porvenir histórico"190, pero ya cuarenta años antes lo ha dejado claro: "Aquellos temas primarios del arte pueden servirnos como confesionarios de la historia. Al enfrentarse con ellos cada época y ensayar su interpretación, declara las últimas disposiciones, la contextura radical de su ánimo. Y eligiendo un tema, persiguiendo las variaciones que en la historia del arte ha sufrido, vemos dibujarse la fisionomía moral de las edades"191.

- El arte es la mejor expresión de caracteres que afectan a la práctica, a la política. Si el problema se sitúa alrededor de la conexión individuo-sociedad, si se trata de conseguir progresos, evoluciones, mejoras, si se trata de alcanzar la solidaridad y el respeto para con el individuo, entonces el fondo se concentrará alrededor de ideas como "ampliación", "conexión", "relación", "creación de realidad", etc. El arte, como creador de mundos, como aumento de posibilidades, como manifestación de la naturaleza exuberante y simbólica de los objetos, será el encargado de presentar tales caracteres. Mostrar esto mediante textos de Ortega escritos en el mismo contexto en que nos hemos movido, 1910-1911, es el objetivo del siguiente capítulo.

188" Azorín: primores de lo vulgar" (1916). OC II, 175.

189 "Un pueblo es, como una persona, aunque de otro modo y otras razones, una intimidad -por tanto, un sistema de secretos que puede ser descubierto". "En cuanto al pacifismo" (1938). OC IV, 308; "La vida colectiva de un pueblo, de una nación, es una intimidad y, en cierto modo, un secreto". Una interpretación de la historia universal. En torno a Toynbee (1948-1949, curso). OC IX, 21; etc.

190"Alrededor de Goethe" (1949). OC IX, 604.

191"Tres cuadros del vino" (1911). OC I, 50-51. 


\section{El arte de las relaciones (1910-1912)}

En julio de 1907 escribe Ortega desde Marburgo a Rosa Spottorno: "Estos días pienso mucho en los problemas españoles; cada vez me convenzo más de que nuestra salvación tiene que estar en una fórmula cultural que sea a un tiempo política y asimismo que sea estética; una labor científica aislada no tiene, por desgracia sentido en un estado tan vil de espíritu como el nuestro; una acción política tampoco; hay que unir ambas tendencias y ambos impulsos; para mí esta síntesis es el socialismo"192. Las referencias conjuntan ideas de los capítulos anteriores: por un lado el afán de sistema en el sentido de la polémica con Maeztu, esto es, conseguir la integración de todos los medios que posibiliten la mejora y el progreso; por el otro, con la remisión al socialismo, se trata de encontrar un talante unificador no sólo en el sentido de agrupar medios, sino también de que la unificación refiera tanto a esos medios como a sus contenidos, esto es, el socialismo exige la unificación de medios porque él mismo es entendido por Ortega como síntesis, cooperación, cultura.

Es por esto por lo que el factor unitivo afecta a todos bs contextos, tanto al políticopráctico, como al estético-teórico-filosófico, y, por ello, en el fondo del talante de Ortega, y remitiendo al global de los temas, se encuentra una teoría de las relaciones. Tal teoría de las relaciones se sitúa en todos los temas examinados: desde la correción de Ortega a ciertas ideas mantenidas por él en el prólogo a Personas, obras, cosas, que exigían el reconocimiento de los derechos del individuo para dotarle de una tarea en la "colmena universal"193, hasta el carácter internacionalizador que atacaban el nacionalismo agresivo y el romanticismo del Volksgeist, pasando por la necesidad de unión de compartimentos estancos en la España del momento, la superación de la limitación como crueldad, el individuo divinizado en la sociedad, el tema del sistema, el tema del respeto, la pedagogía como la base de la unidad, el necesario contacto entre limitaciones para evitar el nacionalismo y su agresión o, en general, el juego dialéctico entre limitación y límite que permita la ampliación y el contacto.

192ORTEGA Y GASSET, J. Cartas de un joven español (1891 -1908). Op. cit. carta 181, p. 570.

${ }^{193}$ Cfr. Personas, obras, cosas (1916). OC I, 420. 
Si todo esto se presenta en Ortega de un modo coherente en todos los niveles, y este es el hilo que se ha seguido hasta aquí, el de mostrar que ciertos rasgos unitivos y relacionales se encuentran en todos los contextos, se exige una base que afecte directamente a las cosas, a los objetos, a lo real. Se exige que ellos mismos se sitúen en la misma dialéctica de límite y limitación en la que las relaciones tanto configuran su limitación propia como suponen el paso de ésta al carácter de límite en los contactos con otras cosas.

Se trata, entonces, de que el respeto por el individuo, o por la limitación en general, esté íntimamente unido con el respeto... por las cosas. Llevar a cabo esa exigencia es una misión estética, y esa misma misión explica el hecho de que la estética sea una cuestión política: solidaridad con el otro y solidaridad con las cosas, respeto por el otro y respeto por las cosas. El tema, tanto el estético como el político, es de unidades y relaciones, de limitaciones y límites. En 1910, en "Adán en el paraíso", escribe Ortega:

\footnotetext{
"Hay, pues, pintores que pintan cosas, y pintores que, sirviéndose de cosas pintadas, crean cuadros. Lo que constituye este mundo de segundo plano, al cual llamamos cuadro, es algo puramente virtual: un cuadro se compone de cosas; lo que en él hay además, no es ya una cosa, es una unidad, elemento indiscutiblemente irreal, al cual no puede buscarse en la naturaleza nada congruo. La definición que obtenemos de cuadro es tal vez harto sutil: la unidad entre unos trozos de pintura. Los trozos de pintura, mal que bien, podíamos sacarlos de la llamada realidad, copiándola, pero ¿y esa unidad de dónde viene? ¿Es un color, es una línea? El color y la línea son cosas; la unidad no. / Pero, ¿qué es una cosa? Un pedazo del universo; nada hay señero, nada hay solitario ni estanco. Cada cosa es un pedazo de otra mayor, hace referencia a las demás cosas, es lo que es merced a las limitaciones y confines que éstas le imponen. Cada cosa es una relación entre varias. Pintar bien una cosa no será, pues, según antes suponíamos, tan sencilla como copiarla: es preciso averiguar de antemano la fórmula de su relación con las demás, es decir, su significado, su valor" 194 .
}

La virtualidad del cuadro y su irreal unidad amplían la realidad, suponen el crecimiento, el henchimiento de las limitaciones, el poder creador de mundos. Y si cada cosa refiere a otras cosas, esto es, su limitación está determinada por otras limitaciones, el único modo de encontrar la unidad irreal que puede ser pintada parte de conocer cómo se relaciona, cómo está determinada su limitación. Ahora bien, la dialéctica entre relación y limitación es, de nuevo, la dialéctica entre límite y limitación, pues la limitación de la cosa sólo puede ser lo que es mediante el contacto, mediante la relación con otras cosas, esto es, cuando la

194" Adán en el paraíso" (1910). OC I, 474-475. 
limitación se convierte en límite. Con ello, en el fondo el tema se sitúa en torno a un problema de crecimiento, de ampliación de limitaciones, de henchimiento de limitaciones, exactamente la misma temática que viene siendo encontrada en otros contextos, desde la unidad entre individuo y sociedad hasta la internación como unidad de naciones.

El arte es el encargado de mostrar el juego de límites y limitaciones en las cosas, porque es el único que puede conseguir su crecimiento, su significado metafórico y simbólico que les permite ser más de lo que son. Más adelante veremos que el concepto tiene la misma función: la diferencia está en que en el arte esas unidades, mundos creados, son... irreales, esto es, la superación de la limitación que efectúa el arte es la superación de la realidad. Lo que tienen en común el tema de las relaciones, esa unidad irreal del cuadro y la virtualidad de su mundo particular, el tema de la metáfora y el símbolo, como veremos, etc., consiste en que todos ellos remiten a la posibilidad de ampliación, de crecimiento, de evolución de las cosas, a que todo es más de lo que es, a que las posibilidades son las que confieren el carácter de realidad, a que las limitaciones no pueden separarse del límite, del carácter fronterizo y relacional.

Ya en 1906 escribía Ortega que "es, pues, el arte una actividad de liberación. ¿De qué nos liberta? De la vulgaridad"195. Esa vulgaridad tiene dos sentidos. Por un lado la vulgaridad de la realidad de todos los días, de lo que no es más que lo que parece, la realidad, por decirlo así, "oficial", con la que queramos o no estamos obligados a contar, o, de otro modo, la vulgaridad de la limitación cuando no sale de sí misma, refiriendo esto tanto a cosas como a naciones; por el otro lado, la vulgaridad de la realidad española del momento, una realidad sin ideales, sin ideas, sin futuro. El arte libera de ambas vulgaridades, y puede hacerlo porque crea mundos, crea realidades, esto es, ofrece la posibilidad de evolución: remite a los ideales.

La superación de limitaciones que supone el arte, primero, se establece como una teoría de las relaciones, pues se trata de encontrar el "significado" de las cosas, esto es, cómo entran en conexión unas con otras formando una realidad. Ese significado o valor no es único, sino que depende de la conexión o relación encontrada. Por ello, "no existe, por lo tanto, esa supuesta realidad inmutable y única con quien poder comparar los contenidos de

195" Poesía nueva, poesía vieja" (1906). OC I, 51. 
las obras artísticas: hay tantas realidades como puntos de vista"196. Hay tantas realidades como puntos de vista, y cada uno de ellos, cada realidad y cada punto de vista, forma un sistema individualizado, una unidad, donde "cada elemento del sistema necesita de todos los demás: es la relación mutua entre los otros. Según esto, la esencia de cada cosa se resuelve en puras relaciones"197.

Este sistema debe ser leído teniendo muy en cuenta todo lo que aparecía más arriba en torno a la polémica con Maeztu. La voluntad de sistema de "Adán en el paraíso", expresada claramente en ese texto, puede que Ortega la haya recogido de Cohen198, pero su aplicación refiere a todo el tema de la evolución, de la necesidad de mejora y progreso a través del contacto entre particularidades, al sistema como conjunción de dispersiones, o, sin más, al problema de España. La estética política no debe olvidarse en ningún momento.

El arte libera de la vulgaridad superando limitaciones. Primero intenta encontrar el significado de las cosas, y, para ello, exige conocer sus posibilidades de conexión, de relación, esto es, su sistema. El sistema que está entendiendo aquí Ortega es, sin más, un sistema de relaciones, y el carácter de evolución y progreso que debe acompañarle aparece cuando se percibe que las relaciones y conexiones no son más que medios de crecimiento, de ampliación, de henchimiento. Cada cosa está constituida por una infinitud de relaciones, la vida es un conjunto de relaciones, cada individuo es la totalidad de las relaciones que le afectan. El arte trataría de mostrar esta totalidad, pero es imposible, por lo menos de un modo real. Es imposible de un modo real, humano, porque esa totalidad es infinita, eterna, divina: "los dioses son el sentido superior que las cosas poseen si se les mira en conexión unas con otras", con lo que "decir que no hay dioses es decir que las cosas no tienen, además de su constitución material, el aroma, el nimbo de una significación ideal, de un sentido. Es decir que la vida no tiene sentido, que las cosas carecen de conexión"199.

\footnotetext{
196" Adán en el paraíso" (1910). OC I, 475.
}

${ }^{197}$ Ibid. p. 481.

${ }^{198}$ Estoy pensando en Orringer. ORRINGER, N. Ortega y sus fuentes germánicas. Madrid: Gredos, 1979, p. 57: "Conjeturas aparte, no deja lugar a dudas la presencia en "Adán en el Paraíso" de una fuerte voluntad de sistema. Lo demuestran, por un lado, la atención especial consagrada por el lector Ortega a doctrinas claves del sistema kantiano explicadas en Kants Begründung der Aesthetik y, por otro, su deuda con Cohen tanto en lo que concierne al contenido como en lo tocante a la forma del ensayo de 1910".

199" Tres cuadros del vino (Tiziano, Poussin y Velázquez)" (1911). OC II, 57-58. 
Si expresar ese carácter divino es imposible de un modo humano, si el arte para Ortega es expresar el punto de vista de la totalidad, con lo que adquieren valor estético connotaciones que veíamos más arriba en otros contextos, como el "preferir no preferir" o la "renuncia a la renuncia", si alcanzar la totalidad de las relaciones, la totalidad de las cosas y de los sistemas es imposible, precisamente por esto "es el arte ante todo artificio: tiene que crear un mundo virtual. La infinitud de relaciones es inasequible; el arte busca y produce una totalidad ficticia, una como infinitud"200. La totalidad ficticia, esa ficción de totalidad, es plural, refiere a la inexistencia de la realidad inmutable y al necesario individualismo de cada sistema, de cada punto de vista, de cada mundo creado. Por ello, es esta creación de mundo, creación de realidad 201 , la que precisamente pone en contacto arte y vida: "la vida es lo individual"202, pero también "arte es individualización"203, y sin olvidar nunca que individuo significa siempre infinitud de relaciones.

El enfrentamiento se presentará entre la copia y la creación. Es el problema del realismo: "comúnmente se entiende por realismo - de res- la copia o ficción de una cosa; la realidad, pues, corresponde a lo copiado; la ilusión, lo fingido, a la obra de arte"204. El realismo es la "estética cómoda", que no inventa, que no crea, que no ilusiona 205 . Pero entendiendo esto bien: ese realismo como estética cómoda es el realismo concebido "comúnmente" y es ese realismo el que se presenta como "la negación del arte"206. Es la negación del arte porque no crea ni ilusiona, porque simplemente copia, cuando el arte por sí mismo es creación, cuando no es nada cómodo, sino que el placer estético "es lo que más se parece a

\footnotetext{
200"Adán en el paraíso" (1910). OC I, 484.

${ }^{201}$ En Meditaciones, todo el tema de la creación, de la creación de realidad, se ampliará hasta alcanzar multitud de referencias: cada raza es "un ensayo de una nueva manera de vivir, de una nueva sensibilidad" (MQ, 170); la aventura "quiebra como un cristal la opresora, insistente realidad. Es lo imprevisto, lo impensado, lo nuevo. Cada aventura es un nuevo nacer del mundo" (MQ, 207); el héroe supone una volición, un querer, "creador de un nuevo ámbito de realidades" (MQ, 235), etc.

202" Adán en el paraíso" (1910). OC I, 482.

203 Ibid. p. 486.

204 Ibid. p. 485.

${ }^{205}$ Cfr. "Del realismo en pintura" (1912). OC I, 566.

206 Ibid. p. 568.
} 
una indigestión"207. Y es una indigestión porque supera las limitaciones creando mundos nuevos, mostrando la vulgaridad de la limitación, porque consiste en "desarticular las formas triviales"208, y, con ello, "el arte tiene que desarticular la naturaleza para articular la forma estética"209.

Esa forma como desarticulación es la que, primero, amplía las cosas mediante los juegos de conexiones y, segundo, amplía la realidad en general al poner en contacto con lo irreal, lo posible, lo virtual, el ideal. La desarticulación de lo trivial llena a las cosas de emoción, de dinamismo, las muestra en su aspiración a ser más de lo que son, más de lo que parecen. Por ello, frente al realismo se sitúa el impresionismo, porque es éste el que presenta las relaciones, el que muestra la existencia dinámica de vida y cosas: "no hay nada más opuesto al realismo que el impresionismo. Para éste no hay cosas, no hay res, no hay cuerpos, no es el espacio un inmenso ámbito cúbico. El mundo es una superficie de valores luminosos. Las cosas, que empiezan aquí y acaban allá, son fundidas en un portentoso crisol, y comienzan a fluir las unas por dentro de los poros de las otras"210.

Las cosas conectadas unas con otras y mostrando su ampliación a través de la fusión, asumiendo limitaciones y superándolas por contacto. Con ello surge un nuevo espacio, y reaparece la estética espacial que veíamos más arriba. El espacio de la estética espacial es "construcción de coexistencia", y el arte que revierte en esa construcción "es síntesis merced a este poder particular y extraño de hacer que cada cosa penetre a las demás y en ellas perdure"211. Si uno de los caracteres del arte primitivo consiste en que no reproduce el espacio que habita entre las cosas, y que, por ello, cada cosa permanece "aislada en sí misma, libertada de su conexión difusa con las demás"212, la estética espacial parte precisamente de la creación del espacio, parte precisamente de la creación de las conexiones, y, con ellas, de mundos, de realidad.

\footnotetext{
${ }^{207}$ Cfr. "Del realismo en pintura" (1912). OC I, 566.

208" La estética de «El enano Gregorio el Botero»" (1911). OC I, 540.

209" Adán en el paraíso" (1910). OC I, 487.

210 Cfr. "Del realismo en pintura" (1912). OC I, 568.

211"Adán en el paraíso" (1910). OC I, 488.

212" Arte de este mundo y del otro" (1911). OC I, 196.
} 
Por ello la estética espacial es una estética política, porque se asienta en la conexión de individualidades, en la creación de espacios mostrando la posibilidad de ampliación de realidad a partir de la creación de relaciones, liberando de trivialidades y vulgaridades, buscando ideales 213 . Y por ello, también, esta estética espacial permite la unión ineludible entre una estética de la limitación y una estética del límite: se trata de crear espacios, paisajes, circunstancias, mundos, limitaciones, pero hacerlo mostrando las coexistencias, las convivencias, las relaciones, los límites. La estética espacial conjuga el límite y la limitación, y puede hacerlo porque parte del espacio como medio de coexistencia:

"El espacio es el medio de la coexistencia: si a un mismo tiempo existen varias cosas, débese al espacio. De aquí que cada pincelada en un cuadro tenga que ser el logaritmo de todas las demás; de aquí que un cuadro es tanto más perfecto cuanto más referencias haga cada centímentro cuadrado del lienzo al resto de él. Es la condición de la coexistencia, la cual no se reduce a un mero yacer una cosa junto a otra. La Tierra coexiste con el Sol, porque sin la Tierra el Sol se desbarataría, y viceversa: coexistir es convivir, vivir una cosa de otra, apoyarse mutuamente, conllevarse, tolerarse, alimentarse, fecundarse y potenciarse" 214.

La condición de coexistencia, entonces, se sitúa como esencia tanto del arte como de la vida. La estética espacial refiere, así, tanto al espacio del arte como al espacio de la vida, pues las potenciaciones y fecundaciones a que dan lugar las relaciones corresponden a toda unidad donde las limitaciones, las partes que entran en contacto, asuman también su condición de límite, su posibilidad de ir más allá de sí mismas. Con ello, el arte adquiere la categoría de eternidad: "Y ahora tráigase a la memoria cuanto he dicho para dar a este pobre concepto de Vida fluidez estética. Vida es cambio de sustancias; por tanto, con-vivir, coexistir, tramarse en una red sutilísima de relaciones, apoyarse lo uno en lo otro, alimentarse mutuamente, conllevarse, potenciarse. / Pintar algo en un cuadro es dotarlo de condiciones de vida eterna"215. Por esto Leonardo "trabajaba para la eternidad"216, por esto los dioses significaban el sentido superior de las cosas al verlas en conexión, por esto

213MOLINUEVO, J.L. "Estudio introductorio", en: ORTEGA Y GASSET, J. El sentimiento estético de la vida (Antología). Ed. J.L. Molinuevo. Madrid: Tecnos, 1995, p. 18: "El arte es político, ya que aspira a expresar la totalidad de las relaciones en que consiste y se expande el individuo, que nunca está dada, y que es preciso crear, destruyendo lo real, construyendo lo ideal".

214" Adán en el paraíso" (1910). OC I, 487.

$215_{\text {Ibid. p. } 491 .}$

216" La Gioconda" (1911). OC I, 557. 
el arte expresa el ideal y por esto realismo e idealismo se muestran inoperantes en su sentido clásico.

Si el realismo, mal entendido, es copia de lo real, para poder conformarse como arte debería "copiar" la totalidad de lo real, todas las relaciones, y eso es imposible, pues es una idea, un dios, una virtualidad, con lo que "desde este punto de vista no habría inconveniente en llamar al realismo más exactamente idealismo". Pero, por el otro lado, la idea debe aplicarse a lo concreto, debe buscar la unidad y la totalidad a partir de las cosas, son éstas las que deben hacerla posible, precisamente para apoderarse de ellas y romper su vulgar limitación, con lo que "el idealismo verdaderamente habría de llamarse realismo"217. El resultado consiste en cierto realismo poético 218 o cierto realismo trascendente 219 a partir del cual las cosas quedan situadas en ese espacio al que alude la estética espacial, un espacio que salva las cosas, que nos salva en las cosas, pero que puede hacerlo si y sólo si esas cosas se superan a sí mismas como tales, crecen, se amplían, se convierten en aspiración, esto es, si asumen su función metafórica, su función de símbolos.

217" Adán en el paraíso" (1910). OC I, 486.

218NAVARRO CORDÓN, J.M. "Meditación del arte", en: Revista de Occidente, no 156, 1994, p. 90: "La meditación orteguiana del arte, a la que le ha llevado la urgencia de orientarse, se propone trastocar del todo el estado de cosas y el régimen impuestos por el realismo, el idealismo y esa interpretación inglesa del arte: el arte como uso y comodidad. Tal meditación requiere un nombre o expresión que recoja su sentido y oriente nuestra lectura; lo encontramos en el mismo Ortega: realismo poético".

${ }^{219}$ ORTEGA Y GASSET, "Sobre Cervantes y el Quijote desde el Escorial. Notas de trabajo". En: Revista de Occidente, $\mathrm{n}^{\circ}$ 156, mayo 1994, p. 51: "El Quijote es todo trascendencia: y éste es su mérito: el realismo trascendente. Lo leyeron hombres intrascendentes". 


\section{La teoría del símbolo}

La función simbólica 220 de las cosas es crucial en este momento, y lo es no sólo porque se constituye como una de las claves de la meditación de Ortega sobre la estética, sino también porque coincide en más de un sentido con la teoría hegeliana del símbolo, así como con las de dos de los referentes ineludibles para entender el concepto de símbolo en la estética de Hegel: Creuzer y Bachofen. Quede la metáfora, que es "una representación simbólica"221, para un capítulo posterior, y centrémonos ahora en el carácter general, más amplio, de simbolización.

En el Renan ya presentaba Ortega que "arte es simbolización"222, y podía hacerlo mediante las referencias al panteísmo romántico spinozista que vimos más arriba: el arte es simbolización porque el artista toma un "trozo de realidad" y expresa con él "el resto del mundo, o al menos grandes extensiones de él"223. La encargada de realizar el paso desde la trivialidad del objeto hasta su conformarse como símbolo, como representante del resto del mundo, sería la imaginación, una imaginación panteísta que encuentra en cada cosa el resto del universo. Sólo dos años más tarde Ortega repetirá el argumento, casi con el mismo texto, y, sin embargo, las connotaciones son diferentes, entre otras cosas porque ya ha escrito "Adán en el paraíso" y ha concretado la teoría de las relaciones. Escribe Ortega:

"Un cuadro verdadero se sirve de lo que en él está expreso como de un plano inclinado para hacernos resbalar y lanzarnos vertiginosamente a un trasmundo donde los dolores duelen más y alegran más las alegrías, y todo tiene una vida potenciada, densísima e incalculable: un lugar de maravilla donde todo se comprueba, donde cada cosa es un símbolo. Y ¿qué es un símbolo sino aquel poder supremo que infundiéndose en una cosa hace que en ella vivan todas las demás, o al menos una gran parte?" 224.

Las connotaciones han cambiado porque ha desaparecido el talante panteísta, aunque permanezcan caracteres muy similares. Lo que está en la base ahora es la teoría de la

\footnotetext{
220 Me interesa en este momento esa función simbólica y, sobre todo, su conexión con las teorías estéticas que se están examinando. El tema no tiene demasiado que ver con otro que afecta igualmente al concepto de símbolo, el del conocimiento simbólico. Sobre éste último, cfr. ACERO, J.J. "La doctrina del conocimiento simbólico en Ortega", en: Teorema, vol. XIII / 3-4, 1983, pp. 445-493.
}

${ }^{221}$ La razón histórica (Buenos Aires, 1940). OC XII, 168.

222" Renan" (1909). OC I, 464.

223 Ibid. 
potenciación, de la ampliación de mundo y realidad a través del arte: permanecen ciertos rasgos del "todo en todo", pero siempre que éstos sean entendidos a partir de los juegos de relaciones y de la dialéctica de límite y limitación. De un modo más claro: el símbolo es el mejor representante para mostrar las posibilidades de crecimiento, de evolución, y lo es porque el símbolo en sí mismo se constituye como virtualidad de referencia a otras cosas, como superación de la cosa misma simbolizada, o, de otro modo, el símbolo es un representante espléndido de la superación de la limitación.

Así, cuando Ortega defina el símbolo, de nuevo, en la cuarta conferencia del año 28 en Buenos Aires continuará manteniendo la misma idea, casi con las mismas palabras: "Un símbolo es un trozo presente de realidad en cuya forma se refleja otra realidad ausente, a veces todo el universo"225. Ahora bien, para que el símbolo pueda "hacer que en una cosa vivan todas las demás", para que lo presente refleje lo ausente, esa cosa presente debe poseer ya en su interior la posibilidad de la ampliación, debe tener ese carácter estético que incluye la virtualidad, la aspiración, el crecimiento, debe poseer un germen de pluralidad y ambigüedad en su propio significado.

Bachofen, el autor que estudiará Ortega mediante el símbolo de Ocnos el Soguero, y que se constituye como determinante para entender ciertas referencias de Ortega a lo largo de su filosofía a la vida primitiva y la mitología arcaica, insiste en la pluralidad y ambigüedad de significado que acompaña a todo símbolo. Es el poder evocador, misterioso, vacilante, del símbolo, que va a permitir constantemente la referencia de lo simbolizado a más allá de sí. Este sentido lo expresaba Bachofen en su Introducción a la mitosimbólica como sigue: "Las palabras convierten lo infinito en finito, pero los símbolos transportan al espíritu más allá de las fronteras de la finitud, del devenir, hasta el reino de lo infinito, al reino del ser. Los símbolos evocan, son cifras inagotables de lo indecible, son tan misteriosos como necesarios"226.

Esta teoría del símbolo, que lo considera en su sentido más vacilante, más oscilador, tiene su origen en Friedrich Creuzer, maestro de Bachofen, y determinante para entender la

224" La estética de «El enano Gregorio el Botero»" (1911). OC I, 543-544.

225 ORTEGA Y GASSET, J. Meditación de nuestro tiempo. Las conferencias de Buenos Aires, 1916 y 1928. Ed. J.L. Molinuevo. Madrid: F.C.E., 1996, p. 244. 
Estética de Hegel. Es más, ese carácter misterioso del símbolo, enigmático, en cuanto la pluralidad de sus referencias es inabarcable, permanecerá en Hegel de un modo muy similar: "El símbolo propiamente dicho es en sí enigmático, por cuanto la exterioridad con que un significado universal debe acceder a la intuición sigue siendo todavía distinta del significado que tiene que representar y está por tanto siempre sometido a duda en qué sentido debe tomarse la figura. [...] Los símbolos propiamente dichos son, antes y después, problemas irresueltos"227. El símbolo, entonces, como enigma, debido a la imposibilidad de determinar con precisión aquello a lo que se refiere 228 .

En su Symbolik und Mythologie der alten Völker, besonders der Griechen escribía Creuzer: "Oscilación [Schweben], indiferencia entre forma y esencia, son propias al símbolo; en el símbolo, la simple luz de la idea se disgrega en un cromático rayo de significatividad"229. En el símbolo, tanto para Creuzer como para Bachofen, se logra el paso de la finitud a la infinitud. La base de tal teoría se asienta en el carácter de excedencia, de pluralidad, de poder del símbolo, el cual, sostenido por sus rasgos de oscilación y vacilación, posibilita que en una única cosa convivan las demás. El símbolo se establece, entonces, no sólo como presencia que remite a una ausencia, sino como desnivel entre ambos marcos, pues la unicidad de lo presente remite a la pluralidad de lo ausente, o, de otro modo, la limitación de lo presente remite mediante sus posibilidades de ampliación, de conexión, a su esencia fronteriza, límite, junto a la cual conecta con la pluralidad de lo ausente.

El objeto del arte como símbolo mantiene todos estos caracteres, y se concreta en un marco propio al permitir el paso al "trasmundo", a la vida potenciada: se trata del rasgo en que la superación de la limitación se constituye como el momento en que las cosas

226 BACHOFEN, J. J. Mitología arcaica y derecho materno. Ed. A. Ortiz-Osés, trad. B. Ariño. Barcelona: Anthropos, 1988, p. 41.

${ }^{227}$ HEGEL, Vorlesungen über die Ästhetik. I. Hrsg. E. Moldenhauer, K. Michel. Frankfurt/M.: Suhrkamp, $1992^{3}$, p. 509. Traducción: HEGEL, Lecciones sobre la estética. Ed. A. Brotóns. Madrid: Akal, 1989, p. 292. (A partir de aquí, Ästhetik y Estética, respectivamente).

${ }^{228}$ También Trías ha insistido en esto: "Lo paradójico del símbolo estriba en que "aquello otro" a lo cual alude y con lo cual se relaciona no puede ser determinado con claridad y precisión; subsiste como palabra enigmática (de doble filo; o que se esconde al mostrarse). Eso a lo cual el símbolo se refiere (su referente) es un Enigma". TRÍAS, E. Lógica del límite. Barcelona: Destino, 1991, pp. $36-37$ n.

${ }^{229}$ CREUZER, F. Symbolik und Mythologie der alten Völker, besonders der Griechen. Leipzig und Darmstadt: Carl Wilhelm Leske, 1822, § 30, p. 24. 
adquieren un significado distinto del habitual, en que todo puede referir a todo. No es de extrañar, entonces, que Ortega, en su edición Meiner de las Lecciones sobre la filosofía de la historia de Hegel, subraye ese texto en el que éste, comentando la religión egipcia, escribe: "Wir bewegen uns auf dem Boden der Symbole, so dass alles eine von ihm selbst unterschiedene Bedeutung hat, diese Bedeutung selbst aber wieder nur eine partikuläre Vorstellung sein kann und diese wieder Symbol des Symbols wird"230. Pero las conexiones más explícitas en torno a este tema del símbolo se encuentran en las Lecciones sobre la estética.

Hegel entiende el símbolo en su Estética del modo siguiente: "Símbolo en general es una existencia exterior inmediatamente presente o dada para la intuición, que sin embargo no debe tomarse tal como se presenta inmediatamente, por sí misma, sino entenderse en un sentido más amplio y general. En el símbolo por tanto hay que distinguir al punto dos cosas: en primer lugar, el significado, y luego la expresión del mismo"231. Es ese sentido "más amplio y general" el que conlleva toda la serie de matices. Creuzer 232 ya había definido claramente el estado de indecisión y ambigüedad que acompaña a todo símbolo. En el Sileno hablaba de una "peculiar posición intermedia suspendida entre lo finito y lo infinito"233 y la Symbolik partía del estado de suspensión, de ese Schweben del símbolo como indecisión u oscilación entre forma y esencia, que permite su exceso de contenido, su poder evocador y multiplicador.

230HEGEL, Vorlesungen über die Philosophie der Weltgeschichte. Band II-IV. Hrsg. G. Lasson. Hamburg: Meiner, 1923, p. 476. Gaos traduce: "Nos movemos aquí en el terreno de los símbolos, de suerte que todo tiene una significación distinta de sí mismo y esta significación puede ser a su vez una mera representación particular y se convierte también en símbolo del símbolo". HEGEL, Lecciones sobre la filosofía de la historia universal. Op. cit. p. 369.

231 Ästhetik, 394. Estética, 225.

232Sobre Hegel y Creuzer, ver, por ejemplo: HOFFMEISTER, J. 'Hegel und Creuzer", en: Deutsche Zeitschrift für Philosophie, 8, 1930, pp. 260-282. Por lo que refiere al tema concreto del símbolo en las lecciones de Hegel sobre estética, la relación con Hegel es determinante. A lo largo de su dedicación a la estética, Hegel modifica el concepto de símbolo: si en la época de Heidelberg el símbolo refería al hombre, a la forma humana, como expresión de la idea en el arte clásico, en los primeros años de Berlín, por contra, se produce un cambio de interpretación y aparece ya la forma de arte simbólica como Vorkunst, que es la que ha llegado hasta nosotros. Puede decirse que entre las posibles causas que explican ese cambio de Hegel en la interpretación del símbolo ocupa un lugar importante la aparición de la segunda edición del trabajo de Creuzer sobre mitología. Cfr. SCHNEIDER, H. "Eine Nachschrift der Vorlesung Hegels über Ästhetik im Wintersemester 1820/1821 ", en: Hegel-Studien, 26, 1991, p. 91.

${ }^{233}$ CREUZER, F. Sileno. Idea y validez del simbolismo antiguo. Introd. F. Duque, trad. A. Brotóns. Barcelona: Serbal, 1991, p. 88. 
Estos rasgos permanecerán en la teoría hegeliana del símbolo, aunque para Hegel ocuparán una posición negativa, esto es, de momento a asumir, a superar. Es conveniente, sin embargo, examinar tales caracteres sin pensar en su situación como momento dialéctico, pues precisamente lo que Hegel entiende como rasgo a superar, Creuzer (y Ortega) lo muestra como elemento central del concepto de símbolo: se trata de ese carácter de ambigüedad, de posibilidad de pluralidad, ese irse de las manos y "hurtarse a la mirada", como escribía el propio Creuzer en la Symbolik, el carácter que impide la fijación y la captación concreta del símbolo como una determinidad más.

Hegel, en las Lecciones sobre la filosofía de la historia universal, comentando el complicado aparato simbólico egipcio, muestra al símbolo como dirigido por el principio de "reunión e inversión [Vereinigung und Verkehrung]"234. Esa Verkehrung no sólo remite a la reciprocidad en la referencia contenido-figura, sino también al trastorno, al mareo que provoca el hecho de no poder sujetar la movilidad del símbolo. Es muy similar a esa "indigestión" que según Ortega produce el placer estético, en tanto remite a virtualidades, a pluralidades, a ideales. Para Hegel, el símbolo es signo, esto es, denota, refiere a algo diferente, pero no de una forma arbitraria, indiferente, como es el caso del signo 235 , sino que en la figura exterior se abarca ya el contenido interior a representar.

Esta conexión no arbitraria en el símbolo de sus dos elementos es la que causa la posibilidad de ambigüedad y ampliación en su interpretación: no se da arbitrariedad en la relación, pero tampoco una adecuación completa. Hay siempre un excedente de propiedades, un horizonte de eventualidades, que escapa a la más pura referencia directa, y es que "aunque, por un lado, el contenido que es el significado y la figura empleada para su denotación concuerden en una propiedad, sin embargo, por otro lado, también la figura

${ }^{234}$ HEGEL, Lecciones sobre la filosofía de la historia universal. Op. cit. p. 376. Vorlesungen über die Philosophie der Weltgeschichte. Hamburg: Meiner, 1923, p. 486.

235 Estética, 226. Ästhetik, 394: "El símbolo es ante todo un signo [Zeichen]. Pero en la mera denotación [Bezeichnung] la conexión entre el significado y su expresión no es más que una asociación enteramente arbitraria". Esta arbitrariedad como rasgo inherente al signo, y por la cual se distingue del símbolo, llegará hasta Saussure: "El símbolo tiene por carácter no ser nunca completamente arbitrario; no está vacío: hay un rudimento de vínculo natural entre el significante y el significado". SAUSSURE, F. Curso de lingüística general. Ed. T. de Mauro, trad. A. Alonso. Madrid: Alianza, 1991 [2 $2^{\mathrm{a}}$ reimp.], p. 140. 
simbólica contiene para sí todavía otras determinaciones de todo punto independientes de aquella cualidad común una vez significada por ella"236.

La relación se establece entonces a través de una propiedad que, en cierto momento y para cierto observador externo, coincide en el significado y en el significante. La figura posee otras propiedades que no son utilizadas para la referencia y el contenido otros caracteres que no se ven directamente aludidos; si la relación referencial del símbolo cambiara su punto de partida o de llegada, cambiaría también la interpretación del símbolo como tal. La correspondencia es unívoca, pero no el cúmulo de posibilidades. En este sentido, la ambigüedad del símbolo no es algo secundario, sino que su propia esencia es ser de por sí ambiguo, estar suspendido entre los extremos fluctuando en su plurivocidad: puede decir siempre más de lo que dice, tiene más que decir.

En su inaccesibilidad, en su origen de continuo desplazado, el símbolo hace posible la interpretación, da juego a su lectura, no detiene, no fija la mirada, sino que de forma constante remite a un otro, entendiendo esto no como la remisión de figura a contenido, sino como el envío de una interpretación a un posible cambio en la dirección de referencia: el símbolo se muestra así superándose a sí mismo, los juegos de propiedades se trastocan, una leve modificación puede originar el cambio total en su lectura. Hegel mismo es consciente de esta hermenéutica del símbolo propiciada por su carácter ambiguo: "Pero si el símbolo determinado es claro por costumbre para aquellos que se encuentran en tal círculo convencional del representar [Vorstellen], por el contrario, con todos los demás que no se mueven en el mismo círculo o para quienes éste pertenece al pasado, las cosas suceden de modo absolutamente diferente"237. Lo que hay que tener claro, así, es que este caudal de posibilidades no es algo externo, añadido, al símbolo mismo, sino que proviene ya de su carácter más esencial.

La teoría del símbolo de Ortega se sitúa junto a toda esta serie de caracteres. La vida potenciada y el rasgo de ampliación, de las cosas que se superan a sí mismas mediante la referencia a todas las demás, surge por tanto a través de los juegos de conexiones, pero, sobre todo, a partir de la unidad que forman cada uno de esos juegos y que remite al mundo irreal, creado, ampliado, del arte, a ese trasmundo donde se unen finito e infinito. El 
símbolo, constituyéndose como posibilidad de referencia de una cosa a otras, supera la limitación de lo presente, la vulgaridad de la limitación, y refleja una ausencia en la que las posibilidades son infinitas, ideales. Es el mundo del arte, la conjugación del símbolo y el límite 238 . Si para Bachofen el símbolo rompe las barreras de la finitud, si su pluralidad es tan amplia que se convierte en misterio, en enigma, si para Creuzer el símbolo se disgrega en un "cromático rayo de significatividad", si para Hegel en el símbolo todo tiene una significación distinta de sí mismo, entonces no es de extrañar que también Ortega utilice ese poder simbólico de las cosas para mostrar todo el juego de posibilidades de ampliación, de crecimiento, de idealidad y mejora.

La clave se encuentra en ese poder evocador y multiplicador del símbolo, que puede que maree, puede que indigeste, como el placer estético, pero lo hace por conducir a un mundo en el que la pluralidad de relaciones y el excedente de posibilidades campean a sus anchas. El símbolo, que imposibilita la fijación de la mirada, que se sitúa en esa estética espacial en la cual los espacios se crean y las limitaciones devienen límites, también rompe la vulgaridad, también desarticula lo trivial y expresa el absurdo de la limitación. Es la idea que Ortega encontraba en la Gioconda:

"Al enseñar a cada hombre lo absurdo de su limitación, al mostrarle que el universo es más comprensivo que su oficio, que su sistema, que su temperamento, que su pueblo, realizaba una influencia socializadora incitando a cada cual a desear ser el prójimo. El descontento es la emoción idealista, nos arroja de nuestro círculo de realidad -oficio, carácter, familia, nación, cultura, intereses- y nos lleva a buscar otra cosa que no tenemos, que no palpamos, pero que nos atrae: lo ideal. / Merced al idealismo los hombres viven fundidos en sociedad, es decir, buscándose el uno al otro, aspiran el uno a ser el otro, haciendo que cada prójimo sea un momento nuestro aguijón" 239.

\section{Estética, 229. Ästhetik, 399.}

${ }^{238}$ Trías ha insistido de un modo constante en la conexión entre símbolo y límite: "Lo carácterístico de la modernidad ha sido la represión o inhibición del simbolismo [...]. De Creuzer a Hegel, o de Schelling a Nietzsche, de éste a Freud y al surrealismo, sin olvidar al gran movimiento simbolista, esta dimensión del arte fue pensada y reflexionada, y es menester repensarla y reconquistarla para la elaboración de una estética del límite". TRÍAS, E. Lógica del límite. Barcelona: Destino, 1991, p. 71. En Los límites del mundo definía el decir simbólico como sigue: "Usa como metáfora lo que nombra, describe o narra: lenguaje que hace referencia siempre a lo que desborda el límite, pero a través de la palabra con la que se da nombre a los aconteceres e historias que forman la trama tribal, comunitaria, social o individual de este mundo". TRÍAS, E. Los límites del mundo. Barcelona: Ariel, 1985, p. 83.

239" La Gioconda" (1911). OC I, 556. 
De nuevo se conjuntan todos los caracteres, esto es, aparece la función socializadora, moral y política del arte. La conjunción se produce alrededor de una idea común: mostrar lo absurdo de la limitación, sea en lo referente a las relaciones entre individuo y sociedad, al respeto por el prójimo, a la internación como unidad de naciones o a la superación de la limitación en el arte mediante el aumento de realidad y la creación de espacios, de mundos. El descontento como emoción idealista parte de este absurdo de la limitación: el descontento, tanto muestra la limitación, como pide un paso al límite, a las relaciones y conexiones, que ya incluyen la atracción del ideal.

Esa teoría del descontento permanecerá en Ortega. También Don Juan y Don Quijote, como símbolos, son "los dos maestros españoles del descontento"240, también la historia del hombre "es obra del descontento, que es una especie de amor sin amado y un como dolor que sentimos en miembros que no tenemos. Esta emoción idealista, haciéndonos percibir que somos imperfectos, nos hace rodar en busca de lo que nos falta, y así vamos por la tierra y avanzamos por el tiempo y es nuestro corazón una proa siempre en ruta al más allá"241. El descontento, que reaparecerá más adelante con el Ungenügsamer, el insatisfecho, de Goethe, se inicia ya en estos escritos sobre el arte de en torno al año 10 como superación de la limitación.

En 1926, Ortega concretará ese descontento de un modo explícito alrededor del arte y repitiendo el texto citado: "¿Puede tener el arte más alta misión en la vida que ésta de permitimos una evasión visual de lo cotidiano, de lo que ya somos y ya sabemos? Tal vez lo que vale más en el hombre es el instinto de exploración: ese afán de fuga que le lleva a escapar de sí mismo, esa oscura inquietud que le acomete, de pájaro emigrante atraído por toda palpitación de horizontes. Alguien ha dicho que vivir es querer vivir más, apetito de ampliación, un descontento difuso y sin tristeza, divino descontento que es como un amor sin amado y un como dolor que sentimos en miembros que no tenemos" 242 .

\footnotetext{
240" Impresiones de un viajero" (1916). OC VIII, 371.

$241_{\text {Ibid. pp. 370-371. }}$

242ORTEGA Y GASSET, J. "La verdad no es sencilla" (1926), en: La deshumanización del arte y otros ensayos de estética. Madrid: Revista de Occidente en Alianza -Obras de José Ortega y Gasset, 10-, 19886 , p. 230.
} 
El arte como evasión de lo cotidiano y superación de la limitación, como divino descontento, une no sólo las funciones política y socializadora, sino que también conecta con la vida como apetito de ampliación. La clave está en no olvidar que la superación de la limitación no consiste en dejar atrás esa limitación, en negarla, sino en ampliarla, henchirla. Cuando Ortega comente, de nuevo, el pathos del sur en "Arte de este mundo y del otro" y muestre la conmoción sentida al hallarse en la catedral gótica, en un pathos que no es el suyo, el pathos trascendental o del norte, comenzará también con el tema de la limitación:

"Sin embargo, estas conmociones son oportunas; aprendemos en ellas nuestra limitación, es decir, nuestro destino. Con la limitación que ha puesto en nuestros nervios una herencia secular, aprendemos la existencia de otros universos espirituales que nos limitan, en cuyo interior no podemos penetrar, pero que resistiendo a nuestra presión nos revelan que están ahí, que empiezan ahí donde nosotros acabamos. De esta manera, a fuerza de tropezones con no sospechados mundos colindantes, aprendemos nuestro lugar en el planeta y fijamos los confines de nuestro ámbito espiritual, que en la primera mocedad aspiraba a henchir el universo" 243 .

La limitación española, basada en la sensibilidad para lo concreto y material, para lo finito, se encuentra situada frente a un pathos en el que dominan lo trascendente y lo infinito. Se aprende la limitación por contacto, por oposición, pero al aprenderla también se concibe su superación: "la salud es la liberación de todo pathos, la superación de todas las fórmulas inestables y excéntricas"244. El arte, a través de su función simbólica y su estética espacial, plantea de un modo mucho más general la posibilidad de superación de las limitaciones, y muestra que esa superación precisamente se lleva a cabo partiendo de las propias limitaciones, que la desarticulación de lo trivial y la superación de la vulgaridad sólo se pueden llevar a cabo desde dentro, asumiéndolas, partiendo de ellas, concibiéndolas.

El hombre del sur no acepta las preocupaciones ascendentes del hombre gótico, sospecha del misticismo que suplanta este mundo por el otro, irreal, trascendente. Desea permanecer en la tierra, en la vida, y, sin embargo, sólo podrá hacerlo de un modo coherente si es capaz de conferirles el carácter de ideal, de emoción, de idea, de cultura. Se admite el componente de mediterranismo: "yo llamo este fondo último de nuestra alma mediterranismo, y solicito para el hombre mediterráneo, cuyo representante más puro es el español, un puesto en la galería de los tipos culturales. El hombre español se caracteriza por

243" Arte de este mundo y del otro" (1911). OC I, 188. 
su antipatía hacia todo lo trascendente; es un materialista extremo. Las cosas, las hermanas cosas, en su rudeza material, en su individualidad, en su miseria y sordidez, no quintaesenciadas y traducidas y estilizadas, no como símbolo de valores superiores..., eso ama el hombre español"245. Se admite ese componente, pero interpretando bien la ironía de Ortega: se admite la limitación, pero se exige su superación, la superación por contacto que permita que las cosas devengan símbolo, de valores superiores, sí, de ideales, pero que nunca desaparezcan como tales cosas.

El arte español "busca siempre lo trivial, lo intrascendente", quiere "salvar las cosas en cuanto cosas, en cuanto materia individualizada", siente "jamor a lo trivial, a lo vulgar!"246, y, sin embargo, la conciencia más propia de esa limitación consiste en salvar las cosas como símbolos, salvarnos en ellas, desarticulando su vulgaridad, amando lo trivial, sí, pero amándolo desarticulándolo, convirtiéndolo en símbolo de valores supremos. Esta es la conciencia de la limitación, y con ella aparece su superación: amor a lo trivial, pero siempre que conlleve un esfuerzo para "desarticular las formas triviales"247, salvar las cosas en cuanto materia, pero siempre que esa materia conlleve la conciencia de su fuerza viva: "hay en cada cosa una aspiración a ser más que materia, a ser lo que los físicos laman fuerza viva"248.

Sólo así ese realismo, en sentido negativo, puede ser convertido en el realismo poético que supere la limitación, la limitación española, pero también la limitación de las cosas. Es ese realismo mal entendido que permanece en la materia sin buscar la fuerza viva el que causaba la pregunta de Ortega: "¿No es el realismo una limitación?"249. La superación de esa limitación, en todos los sentidos examinados, es la que dotará a la realidad de las cosas "de moción y de emoción, de vital dinamismo"250. Esa realidad como emoción y dinamismo es la realidad del realismo poético.

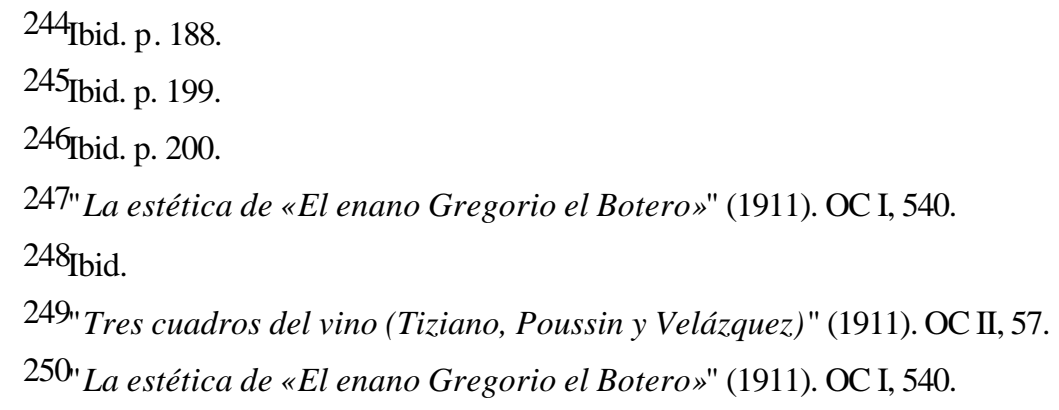


Si el problema de España es que no ha querido superar su limitación, que se ha "resistido a Europa"251, y, con ello, los españoles morirán "sobre su tierra por aspirar a conservarse idénticos" 252 , es mediante el arte, que ejercita la función simbólica de las cosas, que constantemente se muestra en una estética espacial basada en la creación de mundos y en la conversión de limitaciones en límites, que incluye las funciones política, moral y socializadora, como podrá España aprender no sólo a ser consciente de su propia limitación, sino, sobre todo, a incluir la posibilidad de su henchimiento y superación. Esta labor pedagógica y política de la estética no puede olvidarse en ninguno de los temas tratados.

251 Ibid. p. 543.

252Ibid. p. 544. 


\section{El paisaje y la limitación}

Una vez analizado el tema de las relaciones en lo referente al arte y la estética en estos escritos en torno a 1910, con la aparición en el centro del proceso tanto de la limitación como de su superación, y una vez mostrada la función ético-moral-socializadora del arte y del conjunto de la teoría de las relaciones, es necesario examinar un tema determinante para completar el desarrollo. Es el tema del paisaje. Puede asegurarse que el tema del paisaje iba a ser una de las directrices del no escrito 'Ensayo sobre la limitación". Es necesario tratarlo en este momento por varias razones: primero, porque me situaré en el puente cronológico que conduce a esa fecha clave en Ortega que es 1914, esto es, me situaré entre 1912 y 1915; segundo, porque el tema del paisaje conjunta estética y política de un modo explícito: el paisaje, como limitación, será la patria, el destino, pero también se mostrará como el espacio estético de una estética espacial dominada por los juegos de límites y limitaciones; $\mathrm{y}$, tercero, porque el tema incluye referencias concretas a Hegel que interesa examinar.

El texto clave va a ser "Temas del Escorial", de 1915, que, aunque posterior a Meditaciones, debe leerse desde las huellas existentes en años anteriores: el tema del paisaje presente en él entendido desde aquella 'Pedagogía del paisaje" de 1906, la teoría de la limitación, desde todo lo que venimos viendo, la unión de estética y política, desde aquella "estética como función política" iniciada ya en 1906 en "Las fuentecitas de Nuremberga". Puede decirse que "Temas del Escorial" comienza mucho antes de 1915, y esos inicios interesan de un modo determinante para entender el tema de la limitación. Por ello, "Temas del Escorial" será leído junto a un complemento indispensable, esas notas de trabajo "Sobre Cervantes y El Quijote desde el Escorial", notas que se sitúan entre 1912 y 1915 y que, precisamente, contienen la referencia clave para unir a Hegel con el tema de la limitación, una referencia más clara que las presentes en Meditaciones: "Leer Hegel - Sin éste no podré atacar bien el problema de la justificación del «presente» y el «límite»"253, escribe Ortega.

Esas notas de trabajo donde se encuentra la referencia a Hegel citada están stuadas en el contexto de las "salvaciones" que Ortega pensaba llevar a cabo. Si entre ellas hay varias

253"Sobre Cervantes y El Quijote desde el Escorial. (Notas de trabajo de José Ortega y Gasset)". En: Revista de Occidente, n 156, mayo 1994, p. 47. 
notas que remiten explícitamente a Meditaciones, así como al conjunto de proyectos que Ortega tenía en mente, no es menos explícita la remisión a "Temas del Escorial", con lo que la situación cronológica de esas notas se puede concretar en ese periodo que va desde 1912 a $1915^{254}$. Durante esos años, y contando con todas las ramificaciones de la temática que vienen examinándose, Ortega habría decidido escribir de un modo concreto el "Ensayo sobre la limitación".

En el archivo de la "Fundación José Ortega y Gasset" hay una carpeta que únicamente contiene una nota. El título escrito por Ortega en la portada de esa carpeta es "Ensayo sobre la limitación". La única nota que contiene está formada por el título, subrayado, "Ensayo sobre la limitación" y, debajo, tres líneas escritas por Ortega: "Escenario: viaje a Plasencia y Coria con Baroja - Basterra - Sánchez Rivero"255. No es mucho, pero podía ser menos. En 'Ideas sobre Pío Baroja", Ortega alude a ese viaje: "Va para dos años, próximamente, que hice con Baroja un viaje a la Sierra de Gata. Iba yo movido no más que por esa percepturitio de que habla Leibniz, ese entusiasmo visual, ese deleite incalculable de revolcar la retina sobre paisajes no vistos aún"256.

Si se tiene en cuenta que, aunque publicado en el primer Espectador, en 1916, Ideas sobre Pío Baroja" parece versar sobre Los recursos de la astucia, que Baroja publica en 1915 y que, de todos modos, parte de las ideas proceden de las meditaciones que, según las reconstrucciones de Inman Fox, Ortega dedica a Baroja alrededor de 1912 ("Anatomía de una alma dispersa", "La agonía de la novela" y "La voluntad del Barroco") ${ }^{257}$, puede concluirse que, de nuevo, todo remite, en este caso el viaje a la Sierra de Gata, a ese espacio que iría de 1912 a 1915, los mismos años donde se sitúan los proyectos de meditaciones y, de un modo concreto, esas notas Sobre Cervantes y El Quijote desde el Escorial' donde aparecía la conexión entre Hegel y el tema del límite.

\footnotetext{
${ }^{254} \mathrm{El}$ compilador de las notas, J.L. Molinuevo, lo expresa de un modo claro: "La fecha de la escritura de estas notas puede situarse entre 1912 y $1915^{\prime \prime}$. Ibid. p. 34.

255Archivo de la "Fundación José Ortega y Gasset", Rollo 21, caja 18, Carpetilla "Ensayo sobre la limitación".

256" Ideas sobre Pío Baroja" (1916). OC II, 78.

${ }^{257} \mathrm{Cfr}$. ORTEGA Y GASSET, J. Meditaciones sobre la literatura y el arte (La manera española de ver las cosas). Ed. E. Inman Fox. Madrid: Castalia, 1987, p. 257 n.
} 
Por lo que se refiere a Hegel, en el capítulo siguiente examinaré de un modo concreto lo concerniente al tema del límite en relación estricta con el tema del concepto, que aparecerá sobre todo en Meditaciones. Ahora me interesa ofrecer otra versión, la que afecta a la limitación como paisaje. Es la relación entre la limitación y el paisaje la que se va a examinar, y, con ella, cierta aparición de Hegel al comienzo de Temas del Escorial que me parece determinante. La conexión se establecería, aunque parezca extraño, entre el escenario del viaje a Plasencia y Coria, un paisaje, por tanto, que aparecía en las dos líneas de la única nota presente en la carpetilla titulada "Ensayo sobre la limitación", y esa necesidad de leer a Hegel que mostraba la nota de trabajo editada por Molinuevo. De un modo más concreto: el "Ensayo sobre la limitación" se sitúa en la relación entre dos caracteres, la limitación y el paisaje. Examinar esa relación es el objetivo de este capítulo, y puede hacerse porque "Temas del Escorial" permite conocer cuál es el contenido de esa relación. 


\subsection{El paisaje como percepturitio}

En 1906, en 'La pedagogía del paisaje", Ortega presentaba la primera enseñanza que le ofrecía el paisaje: "Este paisaje me hace encontrar dentro de mí algo personalísimo, específico: ahora conozco que soy algo firme, inmutable, perenne; frente a estos altos montes azules yo soy al menos un «celtíbero»"258. El paisaje permite tomar conciencia de lo que se es, tomar conciencia de la limitación. Es el paisaje el que muestra lo positivo y lo negativo del espacio propio, el que muestra la limitación desde los dos puntos de vista: saber que es la limitación que corresponde a cada cual, esto es, sentirla, saberse dentro de un paisaje que es el nuestro, pero también ver sus caracteres, tanto las deficiencias como las bondades.

Conocer el paisaje, entonces, significa conocerse a sí mismo a través del conocimiento del espacio propio, un conocimiento de identidad, pero también de identificación. Por ello Ortega promete llevar a cabo, frente a la pedagogía social de Natorp, "otra más modesta, pero más jugosa: «Pedagogía del paisaje»"259. El conocimiento del paisaje, y con ello de la limitación, se sitúa en las dos direcciones, el conocimiento del espacio y el del individuo que lo ocupa, y por ello, desde aquí, se inicia la intención de Ortega que no sólo se refiere a la circunstancia, o al punto de vista, sino también a esa razón topográfica o geográfica 260 que conectará, por ejemplo, con los escritos de Ortega sobre Hegel. Tal intención se concentra en un aserto: "Dime el paisaje en que vives y te diré quién eres"261.

La tarea de conocimiento es una tarea práctica: conocer la limitación para mejorarla, para conseguir hacerla plena, pero también es una tarea moral y teórica. La enseñanza que ofrece el paisaje no sólo confiere identidad, sino que, además, permite conocer las posibilidades para realizar, plenificar esa identidad: "El paisaje no excluye nunca la teoría:

258" La pedagogía del paisaje" (1906). OC I, 54.

259 Ibid.

260" Introducción a un "Don Juan»" (1921). OC VI, 128: "Siendo la tierra escenario de la existencia humana, de cada uno de sus puntos se desprenden sutiles alusiones a un cierto tipo de vida que en él sería posible. Es lo que yo llamo la razón geográfica de cada lugar. En todo paisaje hallamos preformado un estilo peculiar de vida".

261"La pedagogía del paisaje" (1906). OC I, 55. 
el paisaje es pedagogo", escribirá Ortega en $1909^{262}$. La teoría incluida en el paisaje 263 es la teoría necesaria para adquirir mejoras y progresos, es una teoría para la práctica, como toda teoría: "no hay más teoría que una teoría de una práctica, y una teoría que no es esto, no es teoría, sino simplemente una inepcia", escribirá Ortega en la conferencia "Vieja y nueva política"264. La teoría que incluye el paisaje remite al tema de España en el sentido en que lo venimos entendiendo: la pedagogía del paisaje está íntimamente unida con la pedagogía social, la pedagogía política y la pedagogía de la unidad, todas ellas entendidas en el contexto de la necesidad de educación para España.

Es por ello por lo que "las dos grandes virtudes que ha de formar en el hombre la pedagogía son la sinceridad y la serenidad"265, y es por ello por lo que "el interés exclusivo del paisaje no basta, a la larga, y es preciso un interés moral e histórico"266. Sinceridad para aceptar el paisaje y la limitación propios, pero también para construirlos (es "sinceridad constructora, organizadora"267); serenidad para conseguir henchirlos y plenificarlos, mejorarlos; interés moral para llevar la teoría que incluye el paisaje en una dirección práctica e interés histórico para asumir y superar no sólo la limitación espacial, sino también la temporal 268 . En una de las notas de trabajo explicará Ortega de un modo claro esta conexión entre paisaje y moral, concretando con ello precisamente el significado de las "meditaciones":

"Hay que moralizar el paisaje entretejiendo en su urdimbre nuestras almas. / Las meditaciones son como las raíces que va tendiendo nuestra alma sobre un paisaje. ¿Cómo elevar un árbol sobre una tierra sin

\section{2" Al margen del libro «Los Íberos»" (1909). OC I, 494.}

${ }^{263}$ Thomas Mermall lo expresa así: "El paisaje en Ortega es un lugar desde el cual se piensa, una circunstancia que no sólo suscita fuerte emoción, ni la mera descripción bella, sino que también provoca el análisis y conduce de manera ineluctable a la teoría". MERMALL, Th. "El paisaje pedagógico de Ortega y Gasset", en: Aporía, no 21-24, 1983-1984, p. 109.

264" Vieja y nueva política" (1914). OC I, 290.

265" La pedagogía del paisaje" (1906). OC I, 56.

$266_{\text {Ibid. }}$

267" Variaciones sobre la circum-stantia", en: Meditaciones del Quijote. Con un apéndice inédito. Madrid: Revista de Occidente en Alianza -Obras de José Ortega y Gasset, 17-, 19943, p. 137. "Variaciones sobre la circum-stantia" es el título dado por Garagorri a las páginas que continuarían a "Anatomía de un alma dispersa".

268"No sólo vivimos siempre en un paisaje espacial, sino también en un paisaje temporal", escribirá Ortega en los años 40: Origen y epílogo de la filosofía (1946). OC IX, 370. 
raíces? Todo país, además de los puntos cardinales, necesita de una orientación moral. Y esas largas miradas de orientación son las meditaciones" 269.

Las meditaciones sobre el paisaje como orientación moral implican una tarea de compromiso. Aceptar el paisaje, aceptar la limitación, no significa detenerse en su contemplación, sino comprometerse para su mejora y progreso. Tejer la urdimbre del paisaje con nuestras almas remite a un trabajo de construcción: el paisaje hay que hacerlo, plenificarlo, conferirle una propuesta de futuro. Las meditaciones, entendidas en el sentido de esa parte teórica del paisaje sostenida por una intención práctica, incluirían los dos objetivos: conocer el paisaje y darlo a conocer, pero también mostrar las posibilidades de evolución y las virtuales mejoras, la construcción del paisaje pleno. Es en este sentido en el que la historia del paisaje es una historia hacia adelante, basada en rasgos de futuro.

Cuando en esas tres líneas presentes en la carpeta Ensayo sobre la limitación" Ortega remitía al viaje a Coria como escenario nos daba una pista clave, pues en la reaparición del viaje en "Ideas sobre Pío Baroja" basaba la intención del viaje en la percepturitio de Leibniz, esto es, en paisajes aún no vistos, paisajes deseados. Lo que Ortega tiene en mente es el paisaje futuro, el no visto, el que hay que hacer, y concuerda así con todo el tema de España que viene apareciendo. Se trata de aceptar el paisaje y la limitación para superarlos, henchirlos, y esto no significa otra cosa que mejorarlos.

La percepturitio surge en "Ideas sobre Pío Baroja" una página antes de la remisión al viaje a la Sierra de Gata, y define el momento clave: 'Percepturitio, es decir, une tendence à nouvelles perceptions, una como sensibilidad para lo que aún no está ante nosotros, para lo ausente, desconocido, futuro, remoto y oculto. Este apetito, esta conación e impulso ros hace rodar más allá de nosotros mismos, aumentarnos, superarnos"270.

\footnotetext{
269" El estilo de una vida (Notas de trabajo)". Antología y edición de J.L. Molinuevo. En: Revista de Occidente, $\mathrm{n}^{\circ} 132$, mayo 1992, p. 54.

270"Ideas sobre Pío Baroja" (1916). OC II, 77. En una de las notas de Epílogo, del año 43, y en otro contexto, aunque aludiendo al tema clave del futuro, escribirá Ortega: "Futuriciones. Término. Llamo así al deseo, la esperanza, el temor - los actos mentales en que el Futuro nos es - En ellos "somos por anticipado" y salimos de "lo que somos ya" y de lo que el mundo nos es - por tanto, de los pensamientos que ya tenemos y se refieren a lo que es = es ya - y vamos a nuevos pensamientos en que imaginamos con vaguedad o con precisión lo que será. Leibniz hace que en su mónada no haya sólo percepciones - sino también - lo que con un hirsuto neologismo llama "percepturitio ou tendance à des nouvelles perceptions". Pero es raro que no vea cómo estas percepciones nuevas lo son porque el "ser" que perciben será también "nuevo" - esto es - el Porvenir". ORTEGA Y GASSET, J. Notas de trabajo. Epílogo... Ed. J.L. Molinuevo. Madrid: Alianza/Fundación José Ortega y Gasset, 1994, p. 91, nota 109.
} 
El paisaje, entonces, tomado desde su futuro, desde la posibilidad de superación, el paisaje como límite móvil271. Puede y debe sustituirse "paisaje" por "España". El paisaje como tarea futura, como paisaje que hay que hacer, concuerda con todo el tema del ideal como proyecto, como superación de limitaciones, y, a través de él, con el tema del arte y la estética: construir paisajes, "hacer paisaje", implica la creación de mundos y realidades que suponía el contacto íntimo del arte con el ideal.

Es la dinámica del paisaje que Ortega encontraba en los cuadros de Zuloaga, y precisamente por ello le interesaban más esos paisajes que las figuras que el pintor situaba en su interior: "Zuloaga pinta según un arte las figuras, y según otro los paisajes. En aquéllas acentúa la animalidad y la materia; en éstos insiste sobre lo que tienen de espíritu, de energía, de vitalidad belicosa"272. Si las figuras de Zuloaga conducen hasta el problema español, si muestran esa España que se resiste a Europa, que no quiere superar su limitación y que morirá "por instinto de conservación"273, los paisajes presentan la fuerza viva que, unida a esa labor de futuro, a ese paisaje que incluye la pedagogía y la moral, puede hacer posible la mejora y el progreso. El paisaje como limitación, de por sí, incluye la posibilidad de su propia superación, en cuanto la aceptación del paisaje propio implica ya el compromiso moral de la meditación y, con ella, de la construcción o re-construcción de ese paisaje. Es en este sentido como la re-creación del paisaje coincide con la creación de realidad y de mundo por medio del arte.

271MOLINUEVO, J.L. "Ortega sin Weimar (1914-1918)". En: Revista de Occidente, no 156, mayo 1994, p. 60: "El paisaje es para Ortega el límite móvil de una existencia. Se compone de lo que se percibe y de lo que se desea percibir, y en este sentido al menos cabría caracterizarlo como una percepturitio".

272" La estética de «El enano Gregorio el Botero»" (1911). OC I, 541.

273 Ibid. p. 543. 


\section{2. "Temas del Escorial"}

A partir de estas ideas es posible entrar de un modo adecuado en "Temas del Escorial". Es conveniente ofrecer, precediendo al comentario que una todos los caracteres, una serie de pistas textuales. Así, aunque debe circularse hacia delante y hacia atrás en el escrito, el párrafo clave es el siguiente:

"Significa, pues, el paisaje de cada uno la esfera de sus capacidades, todo lo que puede aspirar a ser, y, al propio tiempo, el coto cerrado del cual no puede salir jamás. El paisaje es nuestra limitación, nuestro destino. Ya el ser hombre, el pertenecer a esta aventurera especie nos limita el horizonte. Pero dentro del horizonte humano padecemos además una nueva limitación. Somos de una casta determinada, acaso de las más determinadas, somos españoles y donde quiera que vayamos proyectaremos en torno nuestro un paisaje español. / ¡Ay de quien crea frívolamente que le basta con querer, para libertarse de su limitación española! ¡Ay del que crea que la manera de ser más, de aumentar su personalidad consiste en ser infiel a su limitación! No puedo detenerme en hablar de esto que sería un tema de alto interés. Sólo diré, que, a mi juicio, la única manera de llegar más allá de nuestra limitación, es henchir ésta por completo, es ser plenamente lo que la naturaleza quiso que fuéramos. / Señores, el patriotismo es ante todo la fidelidad al paisaje, a nuestra limitación, a nuestro destino"274.

Puede decirse que este texto concentra gran parte de las ideas que vienen siendo presentadas. Con las ideas biológicas de Von Uexküll sobre el medio, Ortega puede justificar la dialéctica del paisaje-limitación y su superación: ya no se trata de que cada individuo nazca, caiga, en un escenario único dominante que exige la adaptación de los individuos, sino que individuo y medio se compenetran y la vida sería el diálogo entre ambos. Ortega sustituye "medio" por "paisaje" y puede concretar aún más la situación: "No hay un yo sin un paisaje, y no hay paisaje que no sea mi paisaje o el tuyo o el de él. No hay

274" Temas del Escorial" (1915), en: Notas de andar y ver. Viajes, gentes y países. Madrid: Revista de Occidente en Alianza -Obras de José Ortega y Gasset, 32-, 1988, p. 51. El artículo merece un comentario. En 1915 el Ateneo madrileño organizó una serie de conferencias bajo el título Guía espiritual de España. El texto "Temas del Escorial" corresponde a los manuscritos preparatorios de la intervención de Ortega, que fueron publicados por la revista Mapoche, de Santiago de Chile, en 1965 tomo IV, $\mathrm{n}^{\circ}$ 1, vol. 10-. Partes del texto fueron utilizadas por Ortega en varios artículos: en el Espectador - II (1917) publicó "Muerte y resurrección" (OC II, 149), que es la sección final de estos "Temas del Escorial"; en el Espectador - VI (1927), incluyó una "Meditación del Escorial" (OC II, 553) con partes de esos "Temas del Escorial". Para acabar de rizar el rizo, Garagorri, en su edición de Misión de la Universidad (Madrid: Revista de Occidente en Alianza -Obras de José Ortega y Gasset, 22-, 1983, p. 139), publica, como apéndice inédito, una de las partes de "Temas del Escorial" (concretamente, "¿Qué es un paisaje?") que luego, en su edición de Notas de andar y ver, repetiría formando parte del íntegro "Temas del Escorial". 
un paisaje en general"275. No hay un paisaje en general del mismo modo que, como veíamos más arriba, no existe la supuesta realidad inmutable "con quien comparar los contenidos de las obras artísticas", no existe esa realidad, sino que hay tantas como puntos de vista. No hay ni paisaje en general ni realidad inmutable: los paisajes y los puntos de vista son individuales, con lo que el único modo de comprender el paisaje del otro es viéndolo desde ese otro, no desde nosotros mismos.

En este momento, de nuevo, aparece el componente político y moral, la conexión con el otro, aparece la teoría de las relaciones, sea de individuos, sea de paisajes, y aparece el "yo soy yo y mi circunstancia" convertido en "yo soy yo y mi paisaje" y, con ello, en "yo soy yo y mi limitación". La clave está en tomar a cada individuo con su paisaje, y esa es la manera cervantina de acercarse a las cosas: "No existe, pues, otra manera de comprender íntegramente al prójimo que esforzarse en reconstruir y adivinar su paisaje, el mundo hacia el cual se dirige y con quien está en diálogo vital. Y viceversa, sólo veremos bien un paisaje que no sea d nuestro buscando con lealtad la pupila que le corresponde, la atalaya única con él orgánicamente enlazada. / Esta es, señores, la manera cervantina de acercarse a las cosas: tomar a cada individuo con su paisaje, con lo que él ve, no con lo que nosotros vemos - tomar a cada paisaje con su individuo, con el que es capaz de sentirlo plenamente"276.

En las notas de trabajo se ve mejor la conexión entre el paisaje y la circunstancia. Escribe Ortega: "yo y mi circunstancia como las dos partes de mí mismo: Yo integral suma de acciones y reacciones con el paisaje. No hay yo sin un paisaje y todo paisaje es $m i$ o $t u$ o $s u$ paisaje"277. La pregunta es por qué en este momento el paisaje sustituye a la circunstancia, y la respuesta puede ser la siguiente: porque en este momento, a Ortega le interesa además la justificación del momento presente, de la situación actual histórica que está sucediendo, y el paisaje puede concentrarse mejor alrededor de este contexto. Esa situación es la de la guerra. De nuevo, en las notas se ve mejor el origen de lo que luego será fundido en "Temas del Escorial": "La circunstancia -La lucha por conservar un

275 Ibid. p. 50.

276Ibid. pp. 50-51.

277"Sobre Cervantes y El Quijote desde el Escorial. (Notas de trabajo de José Ortega y Gasset)". Op. cit. pp. 50-51. 
paisaje- Guerra actual -La fidelidad al paisaje, la forma más fuerte (psíquicamente la más fuerte) del patriotismo"278.

Esa nota queda expresada de una forma definitiva en el texto como sigue: "Señores, el patriotismo es ante todo la fidelidad al paisaje, a nuestra limitación, a nuestro destino. Mirad cómo ahora los hombres de Europa luchan por conservar cada cual su paisaje"279. El paisaje como patriotismo no refiere únicamente al tema de la limitación, a las posibilidades de mejora, de "paisaje prometido", sino también al problema de la justificación del presente. Justificación que no significa justificación de la guerra, sino justificación del momento histórico. En la nota sobre Hegel escribía Ortega: "Leer Hegel Sin éste no podré atacar bien el problema de la justificación del «presente»". ¿A qué se refería? ¿qué tiene que ver Hegel con esa justificación del presente que, en el contexto que ocupa a Ortega, remite a la primera guerra mundial?

Al inicio de "Temas del Escorial" hay una aparición de Hegel que es fácil pasar por alto y que, sin embargo, es determinante. Ortega comienza su escrito preguntándose si tiene sentido una meditación sobre el Escorial, sobre el paisaje, cuando simultáneamente tienen lugar los horrores de la primera guerra mundial. Le preocupa verse como el poeta que canta a su canario en mitad de los episodios más crueles de la Revolución Francesa. Pero, a la vez, le preocupa que, al intentar evitar esa posición, pueda caer en una situación fingida. Su decisión es firme: cuando no se sabe bien qué hacer, lo mejor es ser sinceros. Pues bien, inmediatamente después de enunciar estos problemas, todavía en la introducción al texto y justamente antes de meterse de lleno en el tema del paisaje, escribe Ortega:

"En 1807, aquellos días mismos en que el cañón de los soldados napoleónicos tronaba sobre la campiña de Jena, dentro de la ciudad, en su aposento, Hegel, tranquilamente, concluía de escribir la Fenomenología de la conciencia. En este libro prodigioso se hablaba de todo menos de Napoleón el Grande, menos de lo que entonces ocurría, y no obstante, ese libro es una de las simientes para otra Alemania que en 1870 se vengó de Napoleón el Grande derrotando a Napoleón el Pequeño. ¿Podemos llamar inactual la actitud de Hegel? / Como veis no es cosa fácil ésta que voy a intentar: no es fácil hablar con dignidad del Escorial mientras un incendio incalculable cierra la línea toda del horizonte. Y habéis de auxiliarme con una

278 Ibid. p. 50.

279" Temas del Escorial" (1915). Op. cit. pp. 51-52. 
peculiar benevolencia, porque si no me conviene encontrarme junto al poeta que canta a su canario, me sería mucho más perniciosa la aproximación a Hegel" 280.

"Hegel ha terminado de escribir la Fenomenología del espíritu bajo el estruendo de los cañones de la batalla de Jena", escribía Rosenkranz en su Hegels Leben ${ }^{281}$, con palabras muy parecidas a las que utiliza Ortega. Por un lado, entonces, la necesidad de leer a Hegel para entender el problema de la justificación del presente, por el otro la perniciosa aproximación a él. ¿Qué significa esto? Una última pista antes de intentar solucionar estos problemas. En una de las notas de trabajo, Ortega, comentando el estilo de Cervantes, escribe: "El problema del estilo de Cervantes es el mismo que el de mis salvaciones y el de mi futura filosofía - salvar el presente. Sentido del presente, de lo momentáneo. Cómo sin lo sobremomentáneo - sin pasado y futuro - el presente no tiene sentido, pero cómo, no obstante, conserva su valor independiente, es algo más que un vaso donde lo eterno se va vertiendo. Yo trato de volver a unir el alma y el cuerpo - yo aspiro a Dyonysoplatón"282.

Ortega acude al tema del paisaje porque éste puede sentirse, puede sentirse plenamente. El patriotismo es la fidelidad al paisaje porque esa fidelidad es una fidelidad sentida, una fidelidad que identifica, que es interna. Si el tema del paisaje y de la limitación es en realidad el tema del patriotismo (mejor: "eficaz patriotismo"283), de ese carácter nacional, no nacionalista, que intentaba inculcar Ortega, entonces es necesario situarlo en el contexto en el que Ortega está escribiendo el texto, y ese contexto es el de la primera guerra mundial, o, de un modo más claro, el de la relación de España con la guerra. Hay una pista crucial que permite entender esto: es la referencia de Ortega a esa "composición de lugar" de Ignacio de Loyola. El patriotismo eficaz, que no es otra cosa que el henchimiento, la superación de la limitación, sólo puede llevarse a cabo recorriendo "los paisajes esenciales de nuestra España", por una razón sencilla: como ya hemos visto, el mediterranismo, el impresionismo del español, está centrado en las imágenes, en lo sensible, en la materia, y es

\footnotetext{
280 Ibid. p. 45.

${ }^{281}$ ROSENKRANZ, K. Georg Wilhelm Friedrich Hegels Leben. Darmstadt: Wissenschaftliche Buchgesellschaft, 1988, p. 228.

282" El estilo de una vida (Notas de trabajo)". Op. cit. p. 53.

283" Temas del Escorial" (1915). Op. cit. p. 45.
} 
esa materia la que intenta Ortega representar con el paisaje: "no abandonemos, pues, los españoles la materia, partamos del paisaje"284.

Expresado de otro modo, y teniendo en cuenta que, en este momento, materia, paisaje e imágenes son términos casi sinónimos: el español no puede renunciar a las imágenes, no puede renunciar a la materia, a su limitación, pero es que "nadie nos pide que renunciemos a lo visible y tangible en beneficio de un mundo de abstracciones. Bien sabía esto aquel sutilísimo vasco, Ignacio de Loyola, cuando en sus Ejercicios espirituales nos exige que antes de la meditación hagamos lo que él llama la composición de lugar. Si hemos de pensar en el cielo o en el infierno, Ignacio de Loyola quiere que los veamos primero como paisajes, porque sólo de esta manera los traeremos cerca de nosotros y alcanzarán sobre nosotros eficacia"285. La composición de lugar, entonces, como composición del paisaje. Hacer lugar, hacer paisaje, hacer espacio: la composición de lugar, la meditación del paisaje y la estética espacial no pueden separarse.

En "Política de la neutralidad", un texto de 1915, Ortega expone sus ideas sobre la guerra, y escribe: "Es cosa evidente que España sólo podía justificar y compensar su ausencia de la contienda europea dedicando en estos meses a su interna restauración la misma exaltada energía y la misma vertiginosidad que esos pueblos grandes están gastando en defenderse los unos de los otros. / El señor Dato, y con él todos los demás grupos políticos, han faltado trágicamente al patriotismo. Han desaprovechado esta incomparable ocasión de suscitar la vena de ardor nacional que aún quede viva en nuestro pueblo. El primer efecto de la guerra fue aquí, como en todas partes, un despertamiento del instinto nacional (cosa muy diferente del nacionalismo). Pudieron llamarnos a una obra común y entusiasta en que transitoriamente convivieran fundidos todos los españoles, harto separados de ordinario por eso que denominan ideas políticas"286.

Unas páginas más adelante, Ortega utiliza a San Ignacio y sus Ejercicios espirituales, entendiéndolos directamente como táctica para "abrir los pechos españoles". Escribe: "La clave de este libro y de esta táctica consiste en apoyar todas las meditaciones sobre lo que él llama «composición de lugar». Nada de ideas, de razonamientos -con esto no se hace

\footnotetext{
284 Ibid. p. 47.

285Ibid. pp. 45-46.
} 
mucho en España-. Imágenes, imágenes materiales, a ser posible, visiones. ¡Oh, quién pudiera traer a expresión material, visible y tangible estos destinos que a nuestra patria prepara el nuevo capítulo de la guerra! Pero es inútil intentarlo. [...] Pedimos, sn embargo, a todos los españoles que se esfuercen un momento en hacerse la «composición de lugar»" 287.

La conexión con "Temas del Escorial" es evidente, y permite ofrecer una conclusión: con el tema del paisaje, Ortega intenta transformar en imagen, en materia, la energía nacional que, según él, en el resto de Europa llevará a cabo la guerra. "Temas del Escorial", con el tema del paisaje a la cabeza, es la composición de lugar que ofrece Ortega para intentar henchir la energía vital del español, el patriotismo, el "ardor nacional" que, según él, estaba inculcando la guerra europea, entendido todo esto en el sentido que viene examinándose desde el comienzo: patriotismo como plenitud de la limitación, lo que implica su superación; nacionalización como internacionalización; y composición de lugar, en el sentido del hacer paisaje, hacer espacio, que implica ya la estética espacial vista más arriba.

Ortega, en 1914, pensaba que con la guerra se iniciaba una nueva etapa, y España se la estaba perdiendo, lo que significaba que había que, de un modo u otro, conseguir consecuencias similares, conseguir plenificar esos instintos nacionales que, aunque basados en juegos de contactos, deben partir de la aceptación de la limitación propia. Para Ortega, en Europa se estaba cociendo algo muy gordo y España no se inmutaba: "El español inmutable. Entramos en una época de tal modo azarosa que no puede compararse su periculosidad con circunstancia ninguna del pasado: esto que comienza como comienza es el momento inicial de un nuevo orden de todo, dentro del cual no regirán las normas hasta ahora válidas [...]. No obstante, el español, inmutable. [...] Del otro lado de la guerra, más allá de esa enorme, pavorosa cortina de llamaradas que ahora va a cubrirnos el horizonte, comienza una edad suculenta y fertilísima para lo esencialmente humano"288.

Ortega, que ha dicho por activa y por pasiva que España necesita la cultura, el concepto, el contacto con Europa, la unión de materia y espíritu, va a utilizar el tema del paisaje, de la

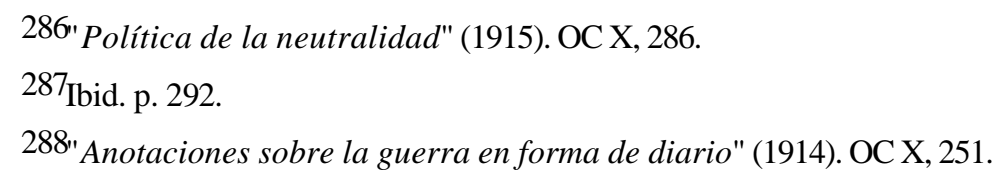


limitación, en representación de la materia, y, al hacerlo, ofrecer las posibilidades de su superación. Pero esto hay que hacerlo con mucho cuidado: se trata de inculcar el ánimo nacional, no el nacionalista, se trata de huir del poeta que canta a su canario, pero mucho más de la "perniciosa aproximación a Hegel". 


\subsection{Perniciosa aproximación a Hegel}

Es en el contexto de la guerra como se puede entender el carácter perjudicial de Hegel. En 1870, Prusia vence a Napoleón III y logra unir en un imperio a todos los estados alemanes. Bismarck utiliza a la perfección la idea de la "Nación unitaria" y la creciente conciencia nacional, conciencia a la que ayudan tanto el Volksgeist como los rasgos unitarios y nacionalistas a partir de los cuales podía ser interpretado. Para Ortega, Hegel y el romanticismo del Volksgeist, como vimos, se encuentra en el centro de esas ayudas 289.

En un primer aspecto, Hegel es perjudicial porque ayuda al nacimiento de nacionalismos imperialistas que olvidan el talante nacional e inter-nacional; en segundo lugar, porque, al igual que el poeta que canta a su canario, no hace nada por el presente, no lo salva, pero nada más lejos del carácter inofensivo del poeta: Hegel, olvidando el presente, determinará el futuro, un futuro agresivo y nacionalista. Por esto es perniciosa la aproximación a él, y por ello su presencia al comienzo de "Temas del Escorial". Ortega quiere salvar el presente, introducir el carácter nacional a través de la materia y el paisaje, pero quiere hacerlo sin nacionalismos ni patrioterismos: el paisaje como destino y patriotismo incluye siempre la posibilidad de su superación, de su mejora por contacto.

Esta atención al presente por medio del paisaje, que expresa "la presencia" en el sentido temporal y en el espacial, refiere también al futuro: "volvamos los ojos, pues, a nuestros paisajes, que en ellos está la pauta de nuestro porvenir"290. Pero esa referencia, precisamente por partir de la atención al presente, de su salvación, no es una referencia defensiva y agresiva: el futuro permanece como ideal, como paisaje pleno que limite y supere su limitación. La percepturitio, los paisajes aún no vistos, únicamente deseados, prometidos, ideales, ésa es la referencia al futuro a través del tema del paisaje.

\footnotetext{
289 Insausti ha mostrado que esta lectura de Hegel ha sido una etiqueta habitual hasta los años 50. No entro en ello, sino en la recepción que Ortega hace de su propia lectura. Insausti escribe: "[...] stellt sich Ortega in eine Tradition, die Hegel als den "preussischen Staatsphilosophen", als den "Machtstaatslehrer", als den "Nationalsozialisten" usw. zu etikettieren pflegt. Es war dies aber die Lesart, die obwohl "einseitig, historisch verzerrt und ungerecht", bis in die fünfziger Jahre unseres Jahrhunderts herrschend gewesen ist". INSAUSTI, F.-J. Miguel de Unamunos und José Ortega y Gassets Philosophie im Zusammenhang mit ihrer HegelRezeption. San Sebastián: Zorroaga, 1993, p. 127. La cita que toma Insausti es de la obra de H.-H. Ottmann, Individuum und Gemeinschaft bei Hegel. Bd. 1. Hegel im Spiegel der interpretationen. Berlin-New York, 1977, Vorwort.

290" Temas del Escorial" (1915). Op. cit. p. 53.
} 
Hegel, como ayuda para la construcción de un imperio que pretende la dominación continental, es uno de los enemigos a batir: frente al nacionalismo agresivo ofrece Ortega el concepto de paisaje, que mantiene rasgos limitadores y nacionalizadores, pero que, por definición, exige el contacto con el otro, exige el diálogo vital. La manera cervantina de acercarse a las cosas, el tomar a cada individuo con su paisaje, tanto limita como supera la limitación, tanto expresa el carácter nacional basado en ideales de progreso, como asienta esos caracteres en la necesidad de contacto con otros paisajes, con otros individuos.

Ahora bien, si esto es así, ¿por qué necesitaba Ortega a Hegel para el problema de la justificación del presente? Si la "perniciosa aproximación" se expresa por una confrontación de contenidos, basada precisamente en distintos modos de entender el futuro (Ortega quiere un paisaje pleno, conseguido desde el interior, pero basado en contactos y diálogos; Hegel, según Ortega, conducirá hasta el nacionalismo agresivo del imperio prusiano), la necesidad de leer a Hegel para entender la justificación del presente puede entenderse en un primer momento (en el capítulo siguiente mostraré otra referencia de esta "justificación") desde la Filosofía de la historia.

Cuando Ortega escriba el 'Hegel y América", en 1928, explicará esta justificación, y no refiriéndola precisamente al presente, sino al pasado: "Hay en la filosofía histórica de Hegel la ambición de justificar cada época, cada etapa humana, evitando la indiscreción del vulgar progresismo que considera todo lo pasado como esencial barbarie", y "sólo desde el presente, y en función de lo que es para nosotros nuestra vida, cabe, según Hegel, justificar las edades pretéritas; sólo desde el espíritu de nuestro pueblo cabe dignificar a los espíritus de los pueblos antiguos"291. Ortega necesita a Hegel para entender la justificación del presente para ser capaz de "colocar" la época que está viviendo en el conjunto de la historia, esto es, en la conexión entre pasado y futuro. No hay que olvidar que Ortega entiende la época que surgirá de la guerra como una nueva etapa donde no servirán los valores pasados.

Ahora bien, el hecho de que "necesite" leer a Hegel no significa que vaya a aceptar eso que lee. Todo lo contrario. Por un lado estará esa perniciosa aproximación que ya hemos visto, por el otro el problema clásico de Ortega con Hegel: no hay lugar para el futuro, el presente es el término de la evolución, etc. Serán estos problemas los que expliquen 
precisamente el interés de Ortega por el tema de América: es el tema del futuro el que está estudiando Ortega, como veremos. En este sentido, no es nada casual que el sexto Espectador culmine con "Meditación del Escorial" (texto formado por algunos capítulos de "Temas del Escorial") y el séptimo comience con "Hegel y América", aunque la diferencia entre ambos sea de 13 años. El enfrentamiento es el que hemos visto: el paisaje es un presente que incluye un futuro, el "Hegel y América" consiste en mostrar un presente sin futuro, el presente absoluto del, según Ortega, sistema sin evolución de Hegel, justo lo contrario de lo que el propio Ortega afirmaba de Hegel en aquella polémica con Maeztu que examinaba al comienzo 292 . Es más, el choque entre la "perniciosa aproximación" y la "necesidad de leer a Hegel", adquiere caracteres similares: la aproximación era perniciosa porque suponía no atender el presente, y, sin embargo, ayudar a forjar un futuro equivocado, esto es, justo lo opuesto a las intenciones de Ortega; es necesario leerlo para darle sentido a un presente, sentido para un futuro y respecto a un pasado, y, con ello, separarse del propio Hegel al entender que su "historia" carece de evolución, de progreso, de futuro.

Conjuntando toda esta serie de caracteres, la relación entre el paisaje y la limitación quedaría como sigue. Con el concepto de "paisaje" Ortega pretende inculcar el talante nacional que permita el progreso de España. Para hacerlo recurre a ese concepto porque es el que puede utilizar para expresar la materia, las imágenes, lo visible, ineludibles en el mediterranismo e impresionismo del pathos del sur, y, además, recurre al paisaje porque con él puede expresar la limitación española, en todos los sentidos, sin caer en la "perniciosa aproximación a Hegel", esto es, salvando el presente, no pasando por encima de él y conduciendo a un futuro agresivo y vengador.

El paisaje permite a Ortega reunir todas sus intenciones: por un lado expresa la materia, las imágenes, pero exige su plenitud, y esa plenitud requiere una síntesis, una misión unitiva que "consista en ensayar una síntesis suprema, no conseguida todavía por el hombre, entre las cosas y las ideas, entre la materia y el espíritu"293. Es la explicación de

291" Hegel y América" (1928). OC II, 565.

292"Hegel ha construido más hondamente que nadie el sistema de la evolución". "Algunas notas" (1908). OC I, 114-115.

293" Temas del Escorial" (1915). Op. cit. p. 53. 
la estética política, de la necesidad de acudir al arte para introducir el espíritu en la materia, es la misión del Dyonisoplatón, "unir esas dos hermanas enemigas: la pasión y la filosofía, la sensación y la idea"294, es la misión que conjunta la necesidad del arte con los anhelos de mejora para España: se trata de crear espacios, construir paisajes, unir la sensación y la idea con un fin eminentemente práctico, que, como el paisaje mismo, exige la teoría, el concepto, la meditación, incluyendo éstos el componente moral examinado, la moral que la meditación vertía sobre el paisaje.

Por todo esto el paisaje consiste en la fidelidad a la limitación, pero también en el compromiso para que esa fidelidad sea la del aumento, la del henchimiento. Como el paisaje exige el contacto, la relación, meternos en la pupila del otro para poder ver su paisaje, el compromiso con el paisaje es también el compromiso con el diálogo, y, con él, con la superación de la limitación. Cuando Ortega, como veíamos más arriba, conjuntaba el objetivo de salvar el presente, lo momentáno, con la aspiración al Dyonisoplatón, que une alma y cuerpo, significando esto la necesidad del contacto entre lo momentáneo y lo sobremomentáneo, expresaba esa superación de la limitación mediante una conclusión crucial: la limitación incluye la ilimitación.

${ }^{294}$ Ibid. p. 47. 


\subsection{Los dioses particulares}

Lo limitado de cada paisaje, su carácter individual, exige el necesario diálogo, ilimitado, con otros paisajes; lo limitado de la materia, de lo sensible, exige el necesario carácter ilimitado del espíritu; lo limitado de cada mundo creado, de cada espacio individual formado en esa estética espacial del objeto artístico, exige lo ilimitado de las relaciones, lo ilimitado del ideal, lo ilimitado de la creación de realidad. Son todos caracteres de ampliación que remiten a la dialéctica entre límite y limitación: lo limitado de la limitación, lo ilimitado de los contactos a través del carácter límite.

De nuevo en las notas de trabajo, Ortega explica esta serie de conexiones con la referencia a Hegel, y ahora también a Schelling: "El paisaje funda la unidad entre el hombre y Dios. Dios como el complemento de la limitación - El paisaje- milieu la limitación - Cada paisaje un Dios: el desierto es monoteísta - Los dioses indios, al trasluz, Galton - «Dioses momentáneos» - La limitación como la ilimitación -Hegel-Scheling: los dioses particulares"295.

Es posible concretar la nota con la referencia a esos dioses particulares (en el capítulo siguiente examinaré la referencia a Hegel y la conexión limitación-ilimitación en otro sentido; y en el capítulo de la segunda sección titulado "Perspectiva y cortesía" aparecerá la explicación de ese "desierto monoteísta"). La temática no está tratada en "Temas del Escorial", sino en "La guerra, los pueblos y los dioses" (y previamente en "Pío Baroja: anatomía de un alma dispersa", en 1912. Utilizo 'La guerra, los pueblos y los dioses" por unir el tema con el contexto de la guerra, que ya ha sido comentado), un texto del mismo espacio cronológico en el que nos encontramos, 1915, y que une los temas que nos ocupan con los del origen de los pueblos y las naciones, esto es, el tema de la limitación con el de la nación, unión que, en el fondo, es la que se encuentra en la base de todo el contexto.

Con la Filosofía de la mitología de Schelling en la mano, Ortega remite el origen de los pueblos a los procesos de diferenciación en las maneras de pensar, en las lenguas, en las costumbres, en los mitos. La masa homogénea que supondría la humanidad primigenia se ramifica al disgregarse las lenguas, y éstas lo hacen al dividirse la concepción del dios, la

\footnotetext{
295" Sobre Cervantes y El Quijote desde el Escorial. (Notas de trabajo de José Ortega y Gasset)". Op. cit. p. 50.
} 
concepción mítica. Con Schelling afirmará Ortega: "Una mitología es un pueblo. La mitología en que nacemos es nuestra fatalidad y nuestro determinismo"296. Si se disgregan los mitos, la concepción de los dioses, se produce la separación de los pueblos: "El Dios único se partió en Dioses y la humanidad quedó disgregada, separada por grietas hondísimas, y cada aglomeración de hombres se sintió compacta y unificada por la creencia en uno de esos Dioses y despegada, hostil hacia otra cualquiera que pensaba otro Dios. La duda del Dios común llevó a la invención de Dioses particulares, y en esta invención se hicieron los pueblos; estas invenciones son los pueblos"297. Y estos son los dioses particulares que aparecen en la nota 298 .

Los dioses particulares, entonces, como representantes de la pluralidad de pueblos, esto es, pluralidad de mitos, pluralidad de paisajes, pluralidad de limitaciones. Pero la hostilidad entre las diferencias, entre las diferentes particularidades, ya ha sido examinada por Ortega: es la hostilidad nacida a partir del romanticismo del Volksgeist, de los inicios del nacionalismo presente en ese talante, es la "perniciosa aproximación a Hegel". Con la pluralidad del diálogo exigido a partir de la individualidad de los paisajes, de las limitaciones, Ortega apuesta por la superación de la limitación a todos los niveles, una limitación que si permanece en sí misma necesariamente se constituirá como agresividad. Se mantiene la pluralidad, pero ya basada en el diálogo, se mantienen los talantes nacionales, que no nacionalistas, pero ya basados en los caracteres de internacionalidad.

La limitación como ilimitación proviene tanto de la necesidad del dialogo entre paisajes, entre individualidades, como de la necesaria presencia del espíritu en la materia, de la fuerza del "dyonisoplatón". El paisaje funda la unidad entre hombre y dios porque inicia el proceso de conjunción entre materia y espíritu, entre la limitación del paisaje y la

296" La guerra, los pueblos y los dioses" (1915). OC I, 415. Las mismas ideas las repite Ortega en "Temas de viaje" (1922). OC II, 380-383 y en "Pío Baroja: Anatomía de un alma dispersa" (1912). OC IX, 487-491.

297 Ibid. p. 415.

298 Las ideas de Schelling que está utilizando Ortega se encuentran en la tercera lección de la Introducción a la filosofía de la mitología. Como ejemplo sirva el siguiente texto: "Was ist doch ein Volk, oder was macht es zum Volk? Unstreitig nicht die blosse räumliche Koexistenz einer grösseren oder kleineren Anzahl physisch gleichartiger Individuen, sondern die Gemeinschaft des Bewusstseyns zwischen ihnen. Diese hat in der gemeinschaftlichen Sprache nur ihren unmittelbaren Ausdruck; aber worin sollen wir diese Gemeinschaft selbst oder ihren Grund finden, wenn nicht in einer gemeinschaftlichen Weltansicht, und diese wieder, worin kann sie einem Volk ursprünglich enthalten und gegeben sein, wenn nicht in seiner Mythologie?". 
ilimitación tanto de los contactos como de ese espíritu a introducir en la materia. "Dios es el complemento de la limitación" no quiere decir otra cosa que la limitación, el paisaje, exige el contacto con lo ilimitado del espíritu, con lo ilimitado de esos caracteres de progreso que deben mantenerse siempre inacabados. El progreso no tiene un fin.

Se trata de afirmar la limitación, henchirla, y hacerlo evitando las negaciones, o, mejor, convirtiendo esas negaciones en negaciones hegelianas. Se trata de negar la España muerta, "contar hacia atrás la historia de España"299, pero hacerlo sin olvidar que "negar no es una abstracta y simple negación"300. O, de otro modo: la preocupación patriótica que suponen toda la serie de "salvaciones", de "meditaciones" previstas por Ortega, remite a este patriotismo de "Temas del Escorial" en el que la fidelidad al paisaje y a la limitación significa su plenificación y henchimiento. Negar la España caduca, sí, pero "la negación aislada es una impiedad [...]. El hombre pío y honrado contrae cuando niega la obligación de edificar una nueva afirmación"301.

El patriotismo como fidelidad al paisaje y a la limitación adquiere, de nuevo, caracteres de la dialéctica hegeliana, entendida, eso sí, como una dialéctica sin final, en tanto los progresos y evoluciones no pueden tener fin, con lo que aparecería una contradicción en Ortega: afirma por un la lado la negación de la negación aislada (evolución constante, por tanto), y, por el otro, la ausencia de evolución en el sistema de Hegel. "La negación ha de ser seria: en serio no puede negarse una cosa sino en virtud de otra que se afirma", escribía Ortega en $1910^{302}$, y directamente admitiendo la referencia a Hegel: "Prefiero el método de Hegel para quien lo verdaderamente afirmativo nace de negar la negación"303.

Esa necesidad de progreso, de paisaje entendido como percepturitio, como paisaje futuro, esas negaciones afirmativas o transitivas, son las que implican también los errores para el avance, las que remiten al ensayo y error, y al "tened el valor de equivocaros", que SCHELLING, F.W.J. Philosophie der Mythologie. Erster Band: Einleitung in die Philosophie der Mythologie. Darmstadt: W.B., 1976, pp. 62-63.

299" Sobre Cervantes y El Quijote desde el Escorial. (Notas de trabajo de José Ortega y Gasset)". Op. cit. p. 39.

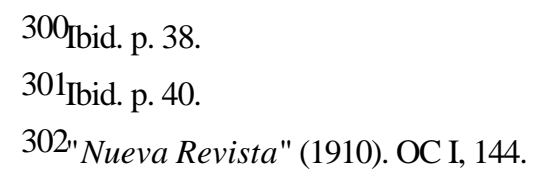


Ortega toma de Hegel e incluye en el inicio del Espectador, precisamente en 1916 304 . Es la imposibilidad del error absoluto, que Ortega subraya en su edición del Differenzschrift 305 , es la afirmación de que el miedo a errar es ya un error, que, de nuevo, Ortega subraya con fuerza en la Fenomenología 306 . Todos ellos son caracteres de futuro, y esos rasgos de porvenir, de paisaje prometido, atraviesan de parte a parte el tema de la limitación y su superación, atraviesan de parte a parte el tema de España. Son rasgos de evolución que Ortega encuentra en Hegel (y que le vienen muy bien para sus intenciones), por mucho que cuando examine la filosofía de la historia hegeliana defina a su autor como el filósofo de un sistema sin evolución, sin posibilidad de futuro.

La negación de la negación aislada debe entenderse en este sentido de "preocupación patriótica". "Habiendo negado una España nos encontramos en el paso honroso de hallar otra"307: son los experimentos de nueva España, son los deseos de ampliar las limitaciones, sabiendo que la experimentanción niega tanto la afirmación como la negación en sentido dogmático 308 , que la experimentación remite inexorablemente a la ampliación. La individualidad y particularidad de los paisajes, de las naciones, de los espacios creados, más que a la limitación remiten al deseo de ampliarla. Es lo que Ortega llamaba el verdadero individualismo, el "ensayo de ampliar nuestros límites"309. Esa ampliación, precisamente por el hecho de implicar a individualidades, a limitaciones, remite a toda la

\footnotetext{
303" Variaciones sobre la circum-stantia", en: Meditaciones del Quijote. Con un apéndice inédito. Op. cit. p. 140.

304" Verdad y perspectiva" (1916). OC II, 21.

305 "Insofern jedes Wissen zugleich eine Identität ist, insofern gibt es keinen absoluten Irrtum". HEGEL,
} Differenz des Fichteschen und Schellingschen Systems der Philosophie, en: Erste Drückschriften. Sämtliche Werke I. Hrsg. G. Lasson. Leipzig: Meiner, 1928, p. 76.

306"Diese Furcht zu irren schon der Irrtum selbst ist". HEGEL, Phänomenologie des Geistes. Jubiläumsausgabe. Hrsg. G. Lasson. Leipzig: Verlag der Dürr'schen Buchhandlung, 1907, p. 51.

$307 \mathrm{MQ}$, p. 89.

${ }^{308}$ CEREZO, P. "Experimentos de nueva España", en: LÓPEZ DE LA VIEJA, M ${ }^{\mathrm{a}}$ T. (Ed.), Política y sociedad en José Ortega y Gasset. En torno a «Viaje y nueva politica». Barcelona: Anthropos, 1997, p. 102: "Experimentar es lo más opuesto a la mera afirmación o negación dogmáticas de España".

309ORTEGA Y GASSET, J. "La voluntad del Barroco" (1915), en: Meditaciones del Quijote. Con un apéndice inédito. Op. cit. p. 158. Sobre la situación de "La voluntad del Barroco" en el conjunto de las meditaciones previstas por Ortega, ver las notas de Inman Fox y Garagorri en sus respectivas ediciones: ORTEGA Y GASSET, J. Meditaciones sobre la literatura y el arte (La manera española de ver las cosas). Op. cit. p. 237, y ORTEGA Y GASSET, J. Meditaciones del Quijote. Con un apéndice inédito. Op. cit. pp. 123 y 143. 
teoría de la conexión y del concepto presente de un modo explícito en Meditaciones. Esa teoría de la conexión une tanto el contexto de las relaciones en el arte (tratado en el capítulo anterior) con el tema de la paisaje y la limitación (tratado en este capítulo), como las referencias a Hegel concernientes al tema concreto del límite con la teoría de la metáfora. Examinar esos caracteres, y concluir así esta sección, es el objetivo del capítulo siguiente. 


\section{Límite, concepto y metáfora: Hegel y Ortega en 1914}

Meditaciones del Quijote reúne y concentra gran parte de los temas tratados hasta este momento, pensando sobre todo al ensayo introductorio "Lector..." y a la meditación preliminar. Sin embargo, es imposible entender correctamente Meditaciones sin conocer los escritos anteriores de Ortega, los textos que conducen hasta ahí y que contienen gran parte de las ideas que, depuradas, estilizadas y concretadas, formarán parte de Meditaciones.

$\mathrm{Si}$ se tiene en cuenta que los proyectos de meditaciones y salvaciones sólo fueron efectivizados en una mínima parte, pero que varios de los temas anunciados fueron tratados aquí y allá y más o menos profundamente, y que ese ensayo introductorio "Lector... " fue escrito para toda la serie de meditaciones, las escritas y las no escritas, entonces podrá entenderse la conexión de Meditaciones con los textos anteriores: Meditaciones concreta y aclara, precisamente al conjuntarlas, gran parte de las ideas del Ortega del momento, pero, a la vez, y justo porque muchas de esas ideas o temáticas todavía o habían sido analizadas detalladamente (y muchas tampoco lo serán: el tema de la limitación, por ejemplo), es necesario tener en cuenta todo el proceso que conduce hasta ahí. Examinar ese proceso, en lo referente a Hegel, a la limitación y a los temas que los rodean, ha sido el objetivo de los capítulos anteriores.

Ahora se trata, siguiendo un esquema similar al de Ortega con Meditaciones, de conectar, ampliar y concretar gran parte de los temas examinados. Con todo, situarnos en esta fecha clave de 1914, el año de publicación de Meditaciones del Quijote, implica la imposibilidad de pasar por alto otros dos escritos de ese mismo año: el Ensayo de estética a manera de prólogo y Vieja y nueva política. De nuevo, la conjunción se establecerá entre estética y política, pudiéndose utilizar Meditaciones como el hilo conductor que guíe esa conjunción. Será precisamente en Meditaciones donde aparecerá la referencia a Hegel en contacto con el tema del límite, pero ahora ya incluido en una nuevo contexto que viene a englobar los anteriores: el tema del concepto. Conectando los tres factores claves, Hegel, el límite y el concepto, es necesario comenzar por el texto donde Ortega hace explícita esa conexión. Escribe Ortega:

\footnotetext{
"Si la impresión de una cosa nos da su materia, su carne, el concepto contiene todo aquello que esa cosa es en relación con las demás, todo ese superior tesoro con que queda enriquecido un objeto cuando entra a formar parte de una estructura. / Lo que hay entre las cosas es el contenido del concepto. Ahora bien, entre
} 
las cosas hay, por lo pronto, sus límites. / ¿Nos hemos preguntado alguna vez dónde están los límites del objeto? ¿Están en él mismo? Evidentemente, no. Si no existiera más que un objeto aislado y señero, sería ilimitado. Un objeto acaba donde otro empieza. ¿Ocurrirá, entonces, que el límite de una cosa está en la otra? Tampoco, porque esta otra necesita, a su vez, ser limitada por la primera. ¿Dónde, pues? / Hegel escribe que donde está el límite de una cosa no está esta cosa. Según esto los límites son como nuevas cosas virtuales que se interpolan e interyectan entre las materiales, naturalezas esquemáticas cuya misión consiste en marcar los confines de los seres, aproximarlos para que convivan y a la vez distanciarlos para que no se confu ndan y aniquilen. Esto es el concepto: no más, pero tampoco menos. Merced a él las cosas se respetan mutuamente y pueden venir a unión sin invadirse las unas a las otras"310.

Esta es la referencia concreta que une a Hegel con el tema del límite en Ortega, exceptuando esas notas de trabajo donde aparecía "la necesidad de leer a Hegel para entender el tema del límite". Partiendo de ese texto, se llevara a cabo un comentario en tres fases: primero es necesario mostrar de dónde toma Ortega la referencia a Hegel, así como ciertas conexiones entre Ortega y la Fenomenología del espíritu; a continuación se analizará el tema del límite y la limitación en Meditaciones del Quijote, así como las referencias al tema de la ilimitación, donde también aparecerá Hegel; por último, se examinará en el tema de la metáfora y en una posible conexión entre Hegel y Ortega al respecto, basada en el sentido de la metáfora como creación y aumento de realidad.

310MQ, 145-147. 


\subsection{Ortega y el prólogo a la Fenomenología del espíritu}

La idea de Hegel sobre el límite no la toma Ortega de la Ciencia de la lógica, como sería de esperar si se piensa en el capítulo del primer libro titulado "Bestimmung, Beschaffenheit und Grenze", sino de la Fenomenología del espíritu. Es con el prólogo a la Fenomenología, más que con la temática de la Grenze en la Lógica, con lo que tiene que ver la referencia de Ortega. El texto concreto de la Fenomenología, subrayado por Ortega en su edición de Lasson de 1907, dice: "Ebenso ist die Verschiedenheit vielmehr die Grenze der Sache; sie ist da, wo die Sache aufhört, oder sie ist das, was diese nicht ist"311. Ya han sido tratadas más arriba las conexiones entre Ortega y el tema del todo, o el sentido que Ortega ofrecía del concepto de sistema, ideas que también tomaba del prólogo a la Fenomenología. El sistema era entendido como conjunción de medios, de objetivos y de contenidos. La teoría y la práctica, la estética y la política, el espíritu y la materia, etc., no pueden ser separados si se quieren conseguir el progreso y la evolución de España.

Esas conexiones o conjunciones deben referir también a las cosas, a lo real, a las circunstancias y limitaciones, a paisajes y naciones. Ya se ha mostrado el tema de las relaciones en el contexto del arte y el de la dialéctica de la limitación tanto en sus connotaciones estéticas como en las que afectan directamente al tema del paisaje. Pues bien, en Meditaciones del Quijote Ortega intentará llevar a cabo una teoría de las conexiones en todos los sentidos. Y para ello acude al concepto, un concepto entendido como conexión y esquema, como expresión de límites y limitaciones que asegure, que no deje escapar las cosas de entre las manos.

Todo esto requiere muchas explicaciones, porque los temas, de nuevo, se mezclan, se confunden. Para empezar, ¿por qué remite Ortega a Hegel en este momento? No es casual que la referencia a Hegel la tome del prólogo a la Fenomenología y no de los capítulos sobre la Grenze de la Lógica. Y no es casual por una razón sencilla: en este momento a Ortega le interesa de Hegel el tema del concepto más que el del límite. O, de otro modo, le interesa el tema del límite desde el del concepto. Le interesa $s u$ recepción de esos temas. No

311HEGEL, Phänomenologie des Geistes. Jubiläumsausgabe, Hrsg. G. Lasson. Leipzig: Verlag der Dürr'schen Buchhandlung, 1907, p. 5. La edición castellana traduce: "Asimismo, la diversidad es más bien el límite de la cosa; aparece allí donde la cosa termina o es lo que ésta no es". Fenomenología del espíritu. Trad. W. Roces. Madrid: F.C.E., 1988 (7 $7^{\mathrm{a}}$ reimp.), p. 8. 
se trata de que los entienda mal o bien, sino de que los utiliza, los recibe, con unas intenciones muy particulares, $\mathrm{y}$, en este momento, esas intenciones son claras: "conviene a todo el que ame honrada, profundamente la futura España, suma claridad en este asunto de la misión que atañe al concepto"312. Siempre el tema de España en el centro de cualquier desarrollo.

\subsubsection{Límite y concepto}

Afirmar que Ortega toma esa idea de la Fenomenología y no de la Lógica es fácil de demostrar, a pesar de que Marías en su edición de Meditaciones cite el texto correspondiente del primer libro de la Lógica ${ }^{313}$ : en primer lugar, el tema del límite en Meditaciones está tratado en relación con el tema del concepto, basado en juegos de sistemas y conexiones, esto es, no tiene demasiado que ver con la dialéctica de algo y otro a partir de la cual se constituye el análisis de la Lógica de Hegel, y sí con temas examinados en el prólogo a la Fenomenología.

En segundo lugar, Ortega era un "subrayador profesional", que subrayaba y escribía al margen de todo o casi todo lo que leía. En ninguna de las tres ediciones de la Lógica presentes en la "Fundación José Ortega y Gasset", y las tres manejadas por Ortega, hay la más mínima anotación o subrayado en los capítulos de la Lógica sobre el límite (ni sobre la limitación), frente a lo cual se encuentra el hecho de que sí está fiertemente subrayado ese párrafo de la Fenomenología, concordando además los contenidos e intereses de Ortega con la temática que más arriba vimos sobre el sistema y el todo.

Por último, de las tres ediciones de la Lógica manejadas por Ortega, dos son posteriores a 1914, fecha de publicación de Meditaciones (el Werke de Hegel editado por Lasson comienza en el 23 y el de Glockner en el 27), con lo que Ortega no podía haberlas manejado, y la que resta, la del Werke iniciado por Michelet en 1832, contiene subrayados y anotaciones en alemán, pero no son de Ortega (éste debió comprar la edición de segunda mano; sus subrayados y anotaciones al margen en esa edición, en azul y rojo, como

312MQ, 148.

313MQ, 146-147 n. 
habitualmente, no aparecen en los capítulos sobre el límite y la limitación). Este hecho de los subrayados o no subrayados no implica que Ortega no hubiera leído los textos que no subraya, pero sí permite ver sobre qué recae su énfasis en cada lectura determinada.

Todo esto, aunque puedan parecer rasgos adyacentes, es importante por el tema general: es importante saber que Ortega no toma el tema del límite de la Lógica sino de la Fenomenología, porque interesa demostrar que la dialéctica del límite tal como la trata Hegel en la Lógica a Ortega no le interesa demasiado, y sí, por contra, su relación con el tema del concepto en la Fenomenología, más concretamente en el prólogo 314 . Lo que le interesa de la dialéctica del límite y de la limitación son los temas que hemos visto más arriba: la superación de limitaciones, en el contexto del paisaje y del arte, esto es, de España y de la estética, de la estética política, y la dialéctica limitación-ilimitación, de aquella nota citada donde aparecía la referencia a los dioses particulares de Schelling, y que, como veremos, procede de otro contexto, y no de los análisis concretos de Hegel sobre la Grenze en la Lógica.

Lo que viene a decir Hegel sobre la Grenze es, primero, que el límite de algo expresa tanto el no ser del otro como la cualidad misma del algo, es decir, que las cosas en cuanto limitadas expresan una relación con un otro que mantiene dos direcciones, la negación del otro y la afirmación cualitativa de sí mismas 315 . Segundo, que el límite es la mediación entre algo y otro, pues ambos mantienen su existencia tanto más allá uno del otro como más allá de su límite 316 . Y, tercero, que el límite expresa tanto la unidad como la diferencia entre algo y otro, con lo que cada cosa constantemente se separa de sí misma y se muestra

\footnotetext{
${ }^{314}$ No haber visto esto, que la referencia no es a la Lógica sino a la Fenomenología, es el causante de la sorpresa de Mariano Álvarez al examinar este tema en un artículo reciente: ÁLVAREZ GÓMEZ, M. "El concepto de cosa en Ortega", en: PAREDES MARTÍN, Ma del C. (ed.), El hombre y su medio. Perspectivas ecológicas desde Ortega y Gasset. Salamanca: Universidad, 1998, p. 47: "Esa relación con las demás cosas, aparece ahora caracterizado como «lo que hay entre las cosas», como «sus límites». [...] A quien Ortega cita es a Hegel y sorprende por de pronto lo que le atribuye: «Hegel escribe que donde está el límite de una cosa no está esta cosa» [...]. Lo que Ortega atribuye a Hegel según la afirmación antes citada no parece pertinente pero sí lo es en cambio lo que en su lenguaje y estilo dice a continuación".
}

315HEGEL, Wissenschaft der Logik, I Hrsg. E. Moldenhauer und K. Michel. Frankfurt/M.: Suhrkamp, 19902, -Werke, 5- p. 136: "Sie ist wesentlich ebenso das Nichtsein des Anderen, so ist Etwas zugleich durch seine Grenze. Indem Etwas begrenzend ist, wird es zwar dazu herabgesetzt, selbst begrenzt zu sein; aber seine Grenze ist, als Aufhören des Anderen an ihm, zugleich selbst nur das Sein des Etwas; dieses ist durch sie das, was es ist, hat in ihr seine Qualität".

\footnotetext{
316 Ibid. p. 137: "Sie [die Grenze] ist die Mitte zwischen beiden, in der sie aufhören. Sie haben das Dasein
} jenseits voneinander und von ihrer Grenze". 
siempre en relación con las otras cosas: es la inquietud del algo en su límite, mostrarse en la contradicción de referir de continuo a un otro, a más allá de si 317.

En general, puede decirse que la Grenze de la Ciencia de la lógica presenta la necesaria unidad en las cosas, en los algos, entre su diferenciación y su relación con respecto a las otras cosas: diferencia, distinción, y relación, conexión, son constitutivas de la esencia de las cosas 318 (incluso puede decirse que la Grenze, en general, es una categoría lógica que muestra al límite mismo como dialéctico, en tanto remite a la contradicción de mantener al algo tanto en sí mismo como en su negación 319 ). Sólo en este sentido general podría encontrarse la conexión entre Meditaciones y la Grenze de la Lógica: la diferencia y la relación que expresa la Grenze la mostraría Ortega en esa misión que "consiste en marcar los confines de los seres, aproximarlos para que convivan y a la vez distanciarlos para que no se confundan y aniquilen" 320 , o, de otro modo, los límites no significarían más que "la relación en que un objeto se halla respecto de los demás"321.

Ahora bien, no es la relación entre algo y otro lo que interesa a Ortega, o esa inquietud [Unruhe] del algo en su límite, sino precisamente el concepto como expresión de finales y comienzos, de límites, si se quiere, pero con el sentido de apresar, de asegurar la fugacidad de las cosas. De hecho, precisamente de lo que quiere huir Ortega es de esa inquietud del algo en su límite (y, como se verá más adelante, la quietud que introduce el concepto también puede encontrar una referencia en la Fenomenología): esa inquietud, para Ortega, se encontraría en la materia, en la carne de las cosas, en las impresiones e imágenes que interesan al español, al pathos del sur, y precisamente por ello acudir al concepto, para

317Ibid. p. 138: "Die Unruhe des Etwas in seiner Grenze, in der es immanent ist, der Widerspruch zu sein, der es über sich selbst hinausschickt".

318HÖSLE, V. Hegels System. Der Idealismus der Subjektivität und das Problem der Intersubjektivität. Hamburg: Meiner, 1988, p. 168: "Gerade in der Grenze zeigt sich, dass dem Etwas die Unterscheidung von und die Beziehung auf das Andere konstitutiv ist".

${ }^{319}$ OHASHI, R. Zeitlichkeitsanalyse der Hegelschen Logik. Zur Idee einer Phänomenologie des Ortes. Freiburg/München: Alber, 1984, p. 75: "Hegels Dialektik konnte deswegen die "Grenze" als eine logische Kategorie entdecken, weil die Grenze selbst das Dialektische ist; sie macht einerseits die Realität des Daseins aus und andererseits auch dessen Negation. Sie selbst ist und ist nicht. Sie enthält in sich den Widerspruch und erweist sich somit als dialektisch".

320MQ, 147.

${ }^{321} \mathrm{MQ}, 151-152$. 
acabar con eso, para conferirle un espíritu a esa carne, un concepto limitador que asegure la inquietud del límite.

A Ortega, los límites le interesan como expresión de conexiones, sí, pero no conexiones de algo y otro, sino conexiones que expresen las relaciones de cada cosa con todas las demás, su situación en un sistema, en una estructura. Es de la relación entre sistema y concepto de la que está hablando Ortega, entendiendo ambos siempre en un sentido muy particular, y, de nuevo, por eso la referencia es a la Fenomenología y no al primer libro de la Lógica. Para Ortega, "el concepto expresa el lugar ideal, el ideal hueco que corresponde a cada cosa dentro del sistema de las realidades. Sin el concepto, no sabríamos bien dónde empieza y dónde acaba una cosa; es decir, las cosas como impresiones son fugaces, huideras, se nos van de entre las manos, no las poseemos. Al atar el concepto unas con otras las fija y nos las entrega prisioneras"322. Para Hegel, "die wahre Gestalt, in welcher die Wahrheit existiert, kann allein das wissenschaftliche System derselben sein. [...] Indem die Wahrheit behauptet wird, an dem Begriffe allein das Element ihrer Existenz zu haben"323.

Las intenciones y los significados de "concepto" y "sistema" no son los mismos en Hegel y en Ortega: Ortega utiliza, aprovecha lo que es útil para sus intereses. En este caso, el concepto como referencia a las conexiones, a dar cohesión a las cosas colocándolas en su lugar del sistema de realidades, expresa esa relación entre concepto y limitación precisamente a partir de la necesaria fusión de superficialidad y profundidad, fusión que debe ser utilizada para superar el talante fronterizo, inseguro, materialista, de la cultura mediterránea.

El concepto como sinónimo de profundidad, de cohesión de las fugaces impresiones superficiales, parece ya estar insinuado en un párrafo que Ortega subraya en el prólogo a la Fenomenología. Allí escribía Hegel, frente a teorías edificadoras que envuelvan lo concreto y determinado en las "nebulosidades de divinidades indeterminadas": "Wie es aber eine leere Breite gibt, so auch eine leere Tiefe, wie eine Extension der Substanz, die sich in endliche Mannigfaltigkeit ergiesst, ohne Kraft, sie zusammenzuhalten, so eine gehaltlose Intensität, welche, als lautere Kraft ohne Ausbreitung sich haltend, dasselbe ist, was die 322MQ, 152. 
Oberflächlichkeit. Die Kraft des Geistes ist nur so gross als ihre Äusserung, seine Tiefe nur so tief, als er in seiner Auslegung sich auszubreiten und sich su verlieren getraut"324.

Sacando el texto de su contexto, aunque no tanto como pueda parecerlo, la idea la recoge Ortega para su afán integrador entre la cultura de superficies, la impresionista, mediterránea, española, y la cultura de profundidades, idealista, europea: se trata de encontrar una profundidad con la fuerza necesaria para cohesionar, que se distinga de la superficialidad precisamente por este carácter conector, estructural, y que posibilite, sin desvirtuar ninguno de los polos, la integración de profundidades y superficies. El concepto sería para Ortega esa profundidad llena con fuerza para mantener las conexiones, con poder para cohesionar.

El concepto, que es el órgano del meditador, el órgano de la profundidad, el que, como representante de ciencia y progreso, hay que traer hasta la cultura mediterránea, impresionista, sensualista de España, ese concepto supone un esfuerzo. "Las impresiones forman un tapiz superficial, donde parecen desembocar caminos ideales que conducen hacia otra realidad más honda. La meditación es el movimiento en que abandonamos las superficies, como costas de tierra firme, y nos sentimos lanzados a un elemento más tenue, donde no hay puntos materiales de apoyo. [...] Cuando meditamos tiene que sostenerse el ánimo a toda tensión; es un esfuerzo doloroso e integral"325, o, de otro modo, "la «realidad»-la fiera, la pantera- cae sobre nosotros de una manera violenta, penetrándonos por las brechas de los sentidos mientras la idealidad sólo se entrega a nuestro esfuerzo"326. Es el esfuerzo del concepto, el esfuerzo y la concentración que exige la profundidad del concepto. Ortega conocía del prólogo a la Fenomenología la necesidad de asumir "die

323HEGEL, Phänomenologie des Geistes. Op. cit. 5. Traducción: "La verdadera figura en que existe la verdad no puede ser sino el sistema científico de ella. [...] La verdad sólo tiene en el concepto el elemento de su existencia". Fenomenología del espíritu. Op. cit. p. 9.

324 Ibid. p. 8. Traducción: "Pero, así como hay una anchura vacía, hay también una profundidad vacía; hay como una extensión de la sustancia que se derrama en una variedad finita, sin fuerza para mantenerla en cohesión, y hay también una intensidad carente de contenido que, como mera fuerza sin extensión, es lo mismo que la superficialidad. La fuerza del espíritu es siempre tan grande como su exteriorización, su profundidad solamente tan profunda como la medida en que el espíritu, en su interpretación, se atreve a desplegarse y a perderse". Fenomenología del espíritu. Op. cit. p. 11.

$325_{\mathrm{MQ}, 126 .}$

$326_{\mathrm{MQ}}, 140$. 
Anstrengung des Begriffs", el esfuerzo del concepto, la necesidad de la "Aufmerksamkeit auf den Begriff", la atención al concepto 327.

Si para Hegel ese esfuerzo del concepto expresa la obligación de atender a las determinaciones lógicas, que fundamentan tanto el objeto material como la realidad del yo, e implica la abstención de inmiscuirse en el propio ritmo de los conceptos, Ortega lo entiende por su parte de un modo muy determinado: la realidad, concebida en este caso en su referente a la cultura de superficies, a la impresión y materia, nos es dada, "penetra" en nosotros, nos es dada hecha, mientras que la profundidad e idealidad del concepto hay que hacerla, crearla. La meditación, como medio para mostrar conexiones, para formar estructuras y encontrar relaciones entre cosas, esto es, para conceptualizar, supone el esfuerzo exigido a toda tarea creadora, a toda tarea constructora. Y, sin embargo, este "esfuerzo del concepto" es posterior a una serie de determinaciones que también pueden entenderse a partir de cierta conexión de Ortega con el prólogo a la Fenomenología.

\subsubsection{Tiempo de tránsito}

Para comenzar, las otras dos referencias a Hegel en Meditaciones también pueden entenderse a partir del prólogo a la Fenomenología. En la primera Ortega parece remitir a la Lógica. Escribe: "Sería la ambición postrera de la filosofía llegar a una sola proposición en que se dijera toda la verdad. Así las mil y doscientas páginas de la Lógica de Hegel son sólo preparación para poder pronunciar, con toda plenitud de su significado, esta frase: «La idea es lo absoluto». Esta frase, en apariencia tan pobre, tiene en realidad un sentido literalmente infinito. $\mathrm{Y}$ al pensarla debidamente, todo este tesoro de significación explota de un golpe y de un golpe vemos esclarecida la enorme perspectiva del mundo. A esta iluminación máxima llamaba yo comprender. Podrá ser tal o tal otra fórmula un error, podrán serlo cuantas se han ensayado; pero de sus ruinas como doctrinal, renace indeleble la filosofía como aspiración, como afán"328.

Si se tiene en cuenta que el contexto en el que escribe Ortega ese párrafo es el de la distinción entre enudición y filosofía, entre la simple acumulación de hechos y la pura

${ }^{327}$ HEGEL, Phänomenologie des Geistes. Op. cit. 39.

$328 \mathrm{MQ}, 59-60$. 
síntesis que expresa el vigor, la aspiración hacia la comprensión, hacia la intelección, hacia la verdad, y que para ello la conjunción afecta al fin común que une a las distintas filosofías, a los distintos sistemas y máximas, ese fin comprensivo e intelectivo, entonces hay que recordar, de nuevo, el comienzo de la Fenomenología. Es la crítica de Hegel a aquellas opiniones que, ante una idea o una filosofía, únicamente piensan en su carácter de verdad o falsedad. Esa opinión "begreift die Verschiedenheit philosophischer Systeme nicht so sehr als die fortschreitende Entwicklung der Wahrheit [...]. Aber ihre flüssige Natur macht sie zugleich zu Momenten der organischen Einheit, worin sie sich nicht nur nicht widerstreiten, sondern eins so notwendig als das andere ist, und diese gleiche Notwendigkeit macht erst das Leben des Ganzen aus"329. La ambición de la filosofía hacia la verdad, de Ortega, y el desarrollo progresivo de la verdad, de Hegel, mantienen caracteres muy similares. No hay que olvidar que Ortega ha leído en el prólogo a la Fenomenología las conexiones, ya citadas, entre el sistema y el concepto y la verdad.

La otra referencia de Ortega a Hegel en Meditaciones se encuentra también (precisamente) en el tratamiento del tema del concepto, y expresa la diferencia entre ambos, Hegel y Ortega. Es un contexto en el que éste insiste en que, a pesar de la necesidad del concepto, de la necesidad de esa misión de la meditación y el concepto que posibilita la situación de las cosas en sus relaciones, en un sistema de realidades, el concepto nunca conseguirá darnos lo que ofrece la impresión: la carne de las cosas. Ésta no sería la misión del concepto, pues para eso ya está la impresión, sino que su oficio consiste en apresar, en agarrar y ofrecer la posesión de las cosas. En ese contexto escribe Ortega: "muy lejos nos sentimos hoy del dogma hegeliano, que hace del pensamiento sustancia última de toda realidad. Es demasiado ancho el mundo y demasiado rico para que asuma el pensamiento la responsabilidad de cuanto en él ocurre. Pero al destronar la razón, cuidemos de ponerla en su lugar"330.

329HEGEL, Phänomenologie des Geistes. Op. cit. 4. Roces traduce: "No concibe la diversidad de los sistemas filosóficos como el desarrollo progresivo de la verdad [...]. Pero, en su fluir, constituyen al mismo tiempo otros tantos momentos de una unidad orgánica, en la que, lejos de contradecirse, son todos igualmente necesarios, y esta igual necesidad es cabalmente la que constituye la vida del todo". Fenomenología del espíritu. Op. cit. p. 8.

330MQ, 153. 
También en el prólogo a la Fenomenología ha leído Ortega: "Hierin ist es begriffen, dass das Sein Denken ist"331. La diferenciación que introduce Ortega, más que enfrentarse al propio Hegel, expresa claramente su intención integradora: nada de materia sin espíritu, nada de impresión sin concepto, nada de realidad sin pensamiento, pero poniendo cada cosa en su lugar, esto es, sin invasiones de campos. Este momento integrador, como hemos visto, a pesar de todas las referencias teóricas o filosóficas que pueda tener, no debe en ningún momento dejar de entenderse sin tener en cuenta el tema de España: es la cultura mediterránea, impresionista y sensualista la que necesita el concepto, pero siempre sin desvirtuar su limitación más propia.

Si todo esto es así, si puede afirmarse que Ortega toma de su lectura del prólogo a la Fenomenología una serie de ideas que "traduce" a su situación y a sus intenciones, también podría encontrarse en este prólogo la explicación de aquella nota en la que Ortega escribía: "Leer Hegel - Sin éste no podré atacar bien el problema de la justificación del «presente» y el «límite»"332. Más arriba aparecía la conexión con Temas del Escorial y la referencia a la guerra, entendiendo ésta como situación actual, como "presente". Si la referencia al límite parte de la Fenomenología, y no de la Lógica, la justificación del presente también debería encontrarse aquí. Ya se mostró cómo Ortega entendía la época alrededor de 1914, con los comienzos de la guerra mundial, como una época de transición, de gestación de nuevas ideas y nuevos problemas, y que los valores hasta entonces válidos no tendrían demasiado sentido a partir de ese momento.

En otro contexto, con otra intención y, desde luego, refiriendo a épocas distintas (la de Ortega y la de Hegel), pero con la misma sensación de tránsito en la expresión, Ortega lee en el prólogo a la Fenomenología: "Es ist übrigens nicht schwer zu sehen, dass unsere Zeit eine Zeit der Geburt und des Übergangs zu einer neuen Periode ist", y, dentro del mismo párrafo, subraya Ortega en su edición de la obra de Hegel: "Der Leichtsinn wie die Langeweile, die im Bestehenden einreissen, die unbestimmte Ahnung eines Unbekannten

331 HEGEL, Phänomenologie des Geistes. Op. cit. 37. Traducción: "Es aquí donde se concibe que el ser es pensamiento". Fenomenología del espíritu. Op. cit. 37.

332" Sobre Cervantes y El Quijote desde el Escorial. (Notas de trabajo de José Ortega y Gasset)". Op. cit. p. 47. 
sind Vorboten, dass etwas anderes im Anzuge ist" 333 . Las referencias a Hegel al comienzo de Temas del Escorial y la necesidad de leerlo para entender el problema de la "justificación del presente" encontrarían su unión a partir de estos textos, sin olvidar nunca que Ortega lleva las ideas a su propia situación. La justificación del presente vendría entendida a partir de su traducción en "justificación de una étapa de tránsito", sean cuáles sean los términos del tránsito, y en ese sentido general Hegel y Ortega coinciden.

La explicación ofrecida en más arriba sobre aquella "perniciosa aproximación" a Hegel sólo ahora encontraría su complemento. Si Ortega suponía perniciosa la aproximación a Hegel por el hecho de que éste habría ayudado a crear en un futuro situaciones agresivas y nacionalistas, ahora puede ampliarse la explicación de esa "perniciosidad": precisamente porque las situaciones, con causas y contenidos diferentes, eran similares en cuanto al carácter de transición, Ortega no puede admitir que Hegel no sólo no intentara "salvar el presente", sino que incluso ayudara a labrar un futuro negativo, y más siendo consciente del propio rasgo transitorio del momento. Es por esto por lo que, sí, traduce ciertas ideas que encuentra en la Fenomenología, pero la aplicación va a ser muy diferente.

En general, entonces, Ortega ha leído en el prólogo a la Fenomenología que el elemento y contenido de la filosofía "no son lo abstracto o irreal, sino lo real, lo que se pone a sí mismo y vive en sí, el ser allí en su concepto"334; que el concepto es "la significación de la representación sensible"335; que "la ciencia sólo puede, lícitamente, organizarse a través de la vida propia del concepto"336; que "el concepto es el propio sí mismo del objeto, representado como su devenir"337; y que, en general, "a los verdaderos pensamientos y a la penetración científica sólo puede llegarse mediante la labor del concepto"338. Todo esto lo va a traducir a sus propios intereses, le va a dar el significado adecuado para sus objetivos

333HEGEL, Phänomenologie des Geistes. Op. cit. 9. Traducción: "No es difícil darse cuenta, por lo demás, de que vivimos en tiempos de gestación y de transición hacia una nueva época. [...] La frivolidad y el tedio que se apoderan de lo existente y el vago presentimiento de lo desconocido son los signos premonitorios de que algo otro se avecina". Fenomenología del espíritu. Op. cit. 12.

${ }^{334}$ Fenomenología del espíritu. Op. cit. pp. 31-32.

335 Ibid. p. 34.

336 Ibid. p. 35.

${ }^{337}$ Ibid. p. 40.

338Ibid. p. 46. 
de teoría estética, política y pedagógica, pero caracteres cruciales, orteguizados, como el esfuerzo del concepto, la fuerza cohesionante de esa profundidad llena, el concepto representando y limitando, estructurando, el devenir del objeto, o, en palabras de Ortega, de lo material y sensible, todo eso va a permanecer.

Ortega no podía citar a Hegel, no podía dar la más mínima pista de conexión con uno de los, supuestamente, representantes claros de ese "idealismo mucilaginoso"339 al que quiere enfrentarse. Y, sin embargo, las referencias están ahí, y no sólo porque las apariciones de Hegel en Meditaciones puedan encontrarse en el prólogo a la Fenomenología, sino porque, como he intentado mostrar, las conexiones de contenido son fáciles de rastrear 340 .

Esto no sólo no quiere decir que Ortega "copiara" o "repitiera" ideas de Hegel, sino que se dirige completamente contra este tipo de lecturas. Orringer ha mostrado la conexión de Ortega con Schapp en este tema del concepto ${ }^{341}$. Las pruebas de Orringer están ahí y a ellas hay que remitirse. Pero lo que es claro es que esa conexión no es la única: Ortega, en este tema y en muchos otros, recibe y traduce multitud de ideas y textos que no sólo conocía muy bien (el prólogo a la Fenomenología, quizá el texto clave para entender a Hegel, por ejemplo), sino que, precisamente por eso, porque las recibe y las traduce, las convierte en suyas, les da un significado y contenido propios, con unas intenciones tan claras como personales. Puede que Schapp esté presente en la teoría del concepto de Meditaciones, pero también lo está Hegel, y muchos otros. No sólo no es justo, sino tampoco correcto, presentar a Ortega "copiando" textos o ideas. Detrás de esa "copia" hay mucho trabajo, y, delante, una gran tarea de construcción, de re-creación.

Ahora bien, falta una segunda parte. Después de mostrar las referencias a Hegel, recibidas por Ortega, hay que presentar la recepción de Ortega, esto es, cómo utiliza esas referencias, hay que presentar de un modo más claro la teoría del concepto de Ortega. En el prólogo a la Fenomenología hay un texto que Ortega señala al margen con una gruesa línea

$340 \mathrm{Si}$ todo esto es así, puede afirmarse, de un modo general, que, como escribe Regalado, "Ortega es uno de los muchos herederos del pensamiento de Hegel que recuperó su prestigio durante los años que preceden a la Gran Guerra" (REGALADO, A. El laberinto de la razón: Ortega y Heidegger. Madrid: Alianza, 1990, p. 84), pero lo que está claro es que Ortega empieza a utilizar a Hegel bastantes años antes de sus escritos publicados sobre él (el primero, "La «Filosofía de la historia de Hegel» y la historiología" es de 1928), y no precisamente con la Filosofía de la historia.
}

${ }^{341}$ ORRINGER, N. Ortega y sus fuentes germánicas. Madrid: Gredos, 1979, p. 157 ss. 
roja. Ese texto dice: "Erst was vollkommen bestimmt ist, ist zugleich exoterisch, begreiflich und fähig, gelernt und das Eigentum aller zu sein"342. Esa determinación plena, que no sólo estructure singularidades y materialidades, sino que además pueda ser aprendida y apropiada por todos, en el caso de Ortega por todos los representantes del pathos del sur, es la que debe llevar a cabo la profundidad cohesionadora del concepto.

La labor pedagógica, que enseña, y teórico-práctica, que apropia, que asegura, es la misión del concepto en Meditaciones. Esa labor de determinación plena era presentada por Hegel después de mostrar su situación en una época de gestación y de transición; esa labor también la exige Ortega desde una época marcada por caracteres muy similares.

342 HEGEL, Phänomenologie des Geistes. Op. cit. p. 10. Traducción: "Sólo lo que se determina de un modo perfecto es a un tiempo exotérico, concebible y susceptible de ser aprendido y de llegar a convertirse en patrimonio de todos". Fenomenología del espíritu. Op. cit. p. 13. 


\subsection{El límite en Meditaciones del Quijote}

Manteniendo la coherencia con los temas tratados, es posible entender la teoría del concepto de Meditaciones desde un contexto formado por límites y relaciones, pero siempre sin olvidar que los temas que examina Ortega "todos, directa o indirectamente, acaban por referirse a las circunstancias españolas"343. El carácter de "salvaciones", su comportarse como ensayos de amor intelectual, con las necesarias connotaciones spinozistas, la búsqueda de la plenitud en temas, en cosas, en individuos, todo ello hace de las meditaciones que presenta Ortega, tanto de las escritas como de las no escritas, un medio para conseguir expresar las dos intenciones que más arriba aparecían en aquel texto de Temas del Escorial: se trata de aceptar la limitación española, pero hacerlo hinchiéndola, conferirle el necesario talante de profundidad, de concepto, de cultura, que pueda hacer de ella una limitación plena y abierta que se acepte a sí misma como tal pero simultáneamente permita su propia ampliación.

Cuando Ortega afirma que "la morada íntima de los españoles fue tomada tiempo hace por el odio, que permanece allí artillado, moviendo guerra al mundo"344, ya remite con ello a un problema de limitaciones: el odio concentra su atención en un punto, no permite los contactos, y más si es guerra al mundo, si no permite ni la salida de la limitación propia ni el contacto con las limitaciones ajenas. Es el problema de la nación y el nacionalismo que viene apareciendo desde el comienzo: España está encerrada en sí misma, no ama, no desea el contacto con el otro. El amor es el símbolo que emplea Ortega para mostrar un carácter necesario, el de la ampliación de la individualidad, el que permite los contactos y las conexiones, con cosas, con individuos, con naciones: el carácter de apertura 345.

Con la teoría del amor ya aparece esa necesidad de estructura que va a recaer sobre el concepto: "va ligando el amor cosa y cosa y todo a nosotros, en firme estructura

345Pedro Cerezo ha insistido en esto: "El amor es básicamente para Ortega la disposición de la apertura a lo otro de sí". CEREZO, P. "Meditaciones del Quijote o el estilo del héroe", en: V.V.A.A. (J.L. Molinuevo, coor.), Ortega y la Argentina. México: F.C.E., 1997, p. 38.
} 
esencial"346. La estructura amorosa conexiona, cohesiona, amplía límites, como presentaba Ortega en el texto citado más arriba de "La voluntad del Barroco"347 definiendo así el "verdadero individualismo", y puede ampliarlos porque no sólo se basa en una ligazón con las cosas, sino también con los individuos. Es una ligazón íntima, sentida, como lo era la del paisaje, que precisamente en su intimidad permite la ampliación, el hacer nuestros los caracteres de lo otro y de los otros. Es un afán de comprensión, pero una comprensión que apropia, que aprende $\mathrm{y}$, con ella, crece. Ese crecimiento remite a todo tipo de individualidad, a todo tipo de limitación: el afán de plenitud, de crecimiento por comprensión y estructuración es el objetivo, expresa la intención de henchimiento para los individuos, y, con ellos, también para España. El amor como estructura incluye la necesaria superación de la limitación a través del crecimiento causado por el contacto, por las relaciones, por las conexiones.

\subsubsection{Superación de la limitación}

Ya se ha visto cómo uno de los referentes de este crecimiento por contacto remite al tema de Europa, a la necesaria conexión entre España y Europa para conseguir cubrir las deficiencias del pathos del sur. Pero Ortega va más lejos aún: se trata también de un crecimiento moral, de rechazar toda ética que recluya "en un sistema cerrado de valoraciones", o, de otro modo, que impida "la ampliación y enriquecimiento de la experiencia moral"348. Esa negación del sistema cerrado no debe referirse únicamente a la experiencia moral. Si el concepto coloca a cada cosa en un sistema que "asegure", "agarre" la realidad de las cosas, ese sistema debe también basarse en límites que permitan la ampliación y el enriquecimiento. Por ello el contacto entre el concepto y el límite, por ello el concepto entendido como conexión.

El sistema abierto de la moral debe ser también el sistema abierto del concepto y, a la vez, el sistema abierto de la estructura en la cual las individualidades, sean cosas, personas

346 MQ, p. 49.

347ORTEGA Y GASSET, J. "La voluntad del Barroco" (1915), en: Meditaciones del Quijote. Con un apéndice inédito. Op. cit. p. 158.

${ }^{348} \mathrm{MQ}$, pp. 54-55. 
o naciones, posean una esencia lo suficientemente porosa como para admitir los contactos. Este sistema abierto supuestamente se enfrentaría con el, también supuestamente, cerrado, concluido sistema hegeliano, aunque sea de ese modo como lo entiende el propio Ortega 349 . Pero no es así. El sistema hegeliano no permite un final, las referencias son siempre múltiples, su carácter es el del círculo, como insistía el propio Hegel, que no sólo muestra la imposibilidad de encontrarle un final, sino también la de hallar una conclusión para los contactos 350 . O referido al propio Ortega, y acudiendo a esa segunda parte de la contradicción mencionada más arriba, ese sistema abierto de Hegel sería el de la imposibilidad del error absoluto, el de la negación transitiva, que sí interesa, y mucho, a Ortega.

Ese sistema abierto es el que pretende Ortega. El concepto como estructura y conexión se situará en este carácter abierto, hospitalario, tolerante, pero sin pasar nunca por alto que esa tolerancia afecta a muchos otros aspectos, naciones, individuos, cosas, y que puede concretarse bajo la expresión de "superación de la limitación". Esa superación, que permite crecimientos y ampliaciones, tiene su base en esta tolerancia que Ortega presenta en Meditaciones: "La verdadera tolerancia, la actitud propia de toda alma robusta"351. Es una teoría del aumento, teoría que Ortega recalcaba en "Vieja y nueva política": la nueva política tiene que poseer como único menester "el aumento y fomento de la vitalidad española"352, la política en general es "el conjunto de labores cuyo fin sea el aumento del pulso vital de España"353. Es el mismo llamamiento que hace Ortega en Meditaciones, el "llamamiento a una amplia colaboración ideológica sobre los temas nacionales"354, colaboración que, en 'Vieja y nueva política", se expresará como socialidad, como unión de

\footnotetext{
349 No hay más que recordar aquella nota de lectura ya citada: "Dimensión de ingenuidad del hegelismo: es lo que le hace ser un sistema cerrado". Archivo de la "Fundación José Ortega y Gasset", Carpetilla "Hegel: filosofía de la historia".

350 KIMMERLE, H. "Über Derridas Hegeldeutung", en: GETHMANN-SIEFERT, A. (Hrsg.), Philosophie und Poesie. Otto Pöggeler zum 60. Geburtstag. Bd. 1. Frommann-Holzboog: 1988, p. 431: "Das System der Philosophie, das aus dem Sichwissens des Wissens abzuleiten ist, lässt sich nicht stimmig zum Abschluss bringen".

$351_{\mathrm{MQ}, \text { p. }} 52$.

352" Vieja y nueva política" (1914). OC I, 275.

353 Ibid. p. 278.

${ }^{354} \mathrm{MQ}$, p. 61.
} 
ámbitos y objetivos: "Vamos a crear entre ellos fuertes lazos de socialidad. [...] Vamos a tender una red de nudos de esfuerzo por todos los ámbitos españoles, red que a la vez será órgano de propaganda y órgano de estudio del hecho nacional" 355 . Siempre, pues, los dos factores que explican todos los caracteres cohesionantes, estructura, colaboración, socialidad, sistema, etc.: la conjunción de la limitación, del estudio de ella, con la posibilidad de su ampliación, mediante relaciones, contactos, redes, lazos de socialidad... tanto en el interior de esa limitación, entre sus componentes, sean individuos o paisajes, como en su exterior, las otras limitaciones.

El primer momento, el de la atención a la limitación propia, es el que explica la insistencia de Ortega en las cosas mínimas, en los paisajes, en la circunstancia, en todo aquello que "revela la intimidad de una raza"356. Esa revelación de la intimidad es la revelación de la limitación más propia, más íntima. El "yo soy yo y mi circunstancia" se reúne con el "yo soy yo y mi paisaje" y el "yo soy yo y mi limitación", yendo así más allá del que habitualmente se considera el origen de esas ideas, el biologismo de Von Uexküll y demás, aunque el propio Ortega admitiera su influencia357. Ocurre igual que con todas las influencias que recibe Ortega: son, en el momento mismo de recibirlas, re-creadas, orteguianizadas, re-hechas.

El conocimiento de la limitación, con un afán implícito de superación, sea limitación de cosa, de individuo o de nación, exige la conciencia plena de la circunstancia, entendida como paisaje o como cosa mínima, exige el conocimiento de los espacios, el conocimiento de cercanías, teniendo siempre en cuenta la estética espacial que viene apareciendo: ese conocimiento de espacios es ya, de por sí, aumento y creación de espacios, por contactos, por ampliaciones, por ideales. Cuando Ortega remite al no escrito "Ensayo sobre la limitación" para presentar que en él se atiende sobre todo a lo cercano, al cambio en la "sensibilidad para las circunstancias"358 ya tiene en cuenta esa dialéctica entre limitación y su superación, esa dialéctica de relaciones que más arriba hemos visto tanto en el tema del

\footnotetext{
355" Vieja y nueva política" (1914). OC I, 286.

$356_{\mathrm{MQ}, \mathrm{p} .} 62$.

${ }^{357}$ Cfr. "Prólogo a «Ideas para una concepción biológica del mu ndo», de J. von Uexküll" (1922). OC VI, 308.

358MQ, p. 66.
} 
arte (en los artículos de alrededor de 1911) como en el del paisaje, siendo el paisaje sin duda alguna la concepción de la limitación que Ortega tenía en mente para su ensayo.

Ahora bien, a ese primer momento de atención a la limitación propia, a la circunstancia, al paisaje, sigue el necesario henchimiento o superación: lo inmediato, la vida individual, la materia, etc., deben adquirir una unidad, un logos, un espíritu. Es el sentido cultural y conceptual que conceda significación a lo inmediato y circunstante: "Y como espíritu, logos no son más que «sentido», conexión, unidad; todo lo individual, inmediato y circunstante parece casual y falto de significación"359. Se trata de una unidad compacta, que dé cohesión a las particularidades de lo real. En este sentido, no está de más recordar que Ortega había leído (y subrayado con fuerza) en el libro de Croce sobre Hegel mencionado la necesidad de que "la realtà diventa tutta unita, un'unità compatta (gediegene Einheit) $)^{1360 .}$

En Ortega, la conexión, la unidad, el sentido, bdos ellos son elementos de significación para los siempre problemáticos caracteres de individualidad, de materialidad, de inmediatez, etc., insistiendo siempre en el talante integrador. Una integración que crea, al dotar con un sentido, al mostrar las conexiones, creación que refiere a esa "vuelta táctica" en la que, primero, se atiende a la limitación más inmediata, para, en segundo lugar, ampliarla al encontrarle un sentido, una estructura, un concepto. Es esta unión que conecta a la limitación con su superación, con su colocación en una estructura, en un sistema, en el mundo, la que explica la relación entre la circunstancia y la limitación: "hemos de buscar a nuestra circunstancia, tal y como ella es, precisamente en lo que tiene de limitación, de peculiaridad, el lugar acertado en la inmensa perspectiva del mundo"361.

Encontrar el lugar acertado a la limitación, a nuestra circunstancia, consiste en encontrar su modo de relacionarse, que posibilite su afirmación, pero también la ampliación y crecimiento. Encontrar el lugar acertado refiere, así, tanto a la composición de lugar de Ignacio de Loyola que convertía en paisaje, en algo cercano e íntimo aquello sobre lo que se iba a meditar, esto es, que conseguía la aceptación de la limitación propia, como, de un modo general, a encontrar el lugar adecuado para España en Europa. Es por ello por lo que

359MQ, p. 69.

${ }^{360}$ CROCE, B. Ciò che è vivo e ciò che è morto della filosofia di Hegel. Bari: Laterza, 1907, p. 51. 
la composición de lugar requiere un concepto, una cultura, un sentido, requiere que "la reabsorción de la circunstancia"362 como destino del hombre no signifique otra cosa que la donación de un sentido a esa circunstancia para que encuentre su lugar en un determinado espacio. La circunstancia, de un modo más general, la limitación, no puede separarse ni de las composiciones de lugar ni de las estéticas espaciales. Es siempre el mismo trayecto: aceptar y comprender la limitación propia, conferirle el sentido que le permita encontrar su lugar y su espacio adecuados, alcanzar mediante ese sentido la ampliación de la limitación, la creación de espacios nuevos.

\subsubsection{El bosque: superficie y profundidad}

La conexión entre limitación y sentido, o entre circunstancia y espíritu, o entre paisaje y significación, con todas las determinaciones que vienen siendo examinadas, es también la dialéctica entre superficie y profundidad, entre materia y concepto, entre cultura germánica y cultura mediterránea. El talante de ampliación y de creación de realidad, precisamente al profundizar, al encontrar lo oculto de las cosas, su sentido, permanecerá en todos esos binomios. Cuando Ortega comienza la Meditación preliminar con la metáfora del bosque 363 ya está pensando en estos caracteres. El hecho de que el bosque se encuentre siempre más allá de donde nos encontramos, el hecho de que es siempre una posibilidad, que podríamos internarnos en él por otros caminos, que podríamos verlo desde otros lugares, todo ello remite a su carácter de ocultación, de ser más de lo que parece, de apertura.

El bosque, como metáfora, cumple las condiciones que más arriba veíamos en el símbolo: remitir a lo oculto, esencia ambigua, posibilidad de ampliación, etc. Es la conjunción de profundidad y superficie, de espíritu y materia, de concepto e impresión. La ocultación del bosque, su profundidad, su sentido, son los que lo constituye con una esencia móvil que presenta siempre caracteres de novedad: "La invisibilidad, el hallarse oculto no es un carácter meramente negativo, sino una cualidad positiva que, al verterse sobre una

$$
\begin{aligned}
& 361_{\mathrm{MQ}} \text {, p. } 75 . \\
& \text { 362 MQ, p. } 75 . \\
& 363_{\mathrm{MQ}} \text {, pp. } 99 \mathrm{ss} .
\end{aligned}
$$


cosa, la transforma, hace de ella una cosa nueva"364. Esa ocultación, ese carácter de profundidad es el que amplía la materia, la impresión, lo superficial.

La integración se produce del mismo modo que venimos encontrando en toda la dialéctica de la limitación y su superación: la limitación superficial, material, se amplía, se supera, desde la profundidad y la ocultación, pero siempre que revierta sobre aquélla; la profundidad de la superficie expresa los dos sentidos del genitivo. El carácter integrador es constante: "De la misma suerte que lo profundo necesita una superficie tras de que esconderse, necesita la superficie o sobrehaz, para serlo, de algo sobre que se extienda y que ella tape"365, o, de otro modo, la profundidad necesita a la superficie para manifestarse, la superficie necesita a la profundidad para tener algo que manifestar.

Esa profundidad que aumenta, que conecta mostrando las distintas posibilidades, confiriendo un sentido a las cosas, es algo que pone el sujeto, el meditador, al estructurar las distintas impresiones, las distintas superficies. "Toda esta profundidad de lontananza existe en virtud de mi colaboración, nace de una estructura de relaciones que mi mente interpone entre unas impresiones y otras"366. La estructuración es, entonces, una colaboración, y, como tal, supone el esfuerzo del trabajo a dos manos. Superficies y profundidades, mundo patente y mundo latente, impresiones y conceptos, exigen en su conjunción el esfuerzo que conlleva toda exploración de posibilidades, toda conjunción de sentidos. Es el esfuerzo del concepto que más arriba refería a Hegel, un esfuerzo que, en Ortega, ni quita ni pone realidad a ninguno de los dos mundos, el de las impresiones y el de los sentidos, pero que supone el trabajo de la creación de estructuras.

Es el esfuerzo en la colaboración que remite a los mismos intereses expresados por Ortega en 'Vieja y nueva política", el esfuerzo que requiere la colaboración entre todos los medios posibles para llevar a cabo la salvación de España. La relación entre los dos contextos la muestra Ortega cuando en "Vieja y nueva política" también incide en la necesaria conexión de lo concreto y lo general: "La dignidad del hábito mental [...] es moverse no sólo en cosas concretas, sino saber que para llegar a ellas fina y acertadamente

$$
\begin{aligned}
& { }^{364} \mathrm{MQ}, \text { p. } 103 . \\
& 365_{\mathrm{MQ}} \text {, } 105 . \\
& 366_{\mathrm{MQ}} \text {, p. } 108 .
\end{aligned}
$$


hay que tomar la vuelta de las orientaciones generales"367. La colaboración, entonces, y con ella el esfuerzo que supone, siempre trabaja en bandas diversas, pero dirigidas por el mismo fin: colaboración, conexión, estructuración, para la profundización en las cosas y, con ella, conseguir la mejora y el progreso, por comprensión, por conocimiento, por meditación. Por teoría pero también por práctica: no hay que olvidar que en el mismo año de Meditaciones del Quijote Ortega ha presentado su "Vieja y nueva política" y, con ella, la Liga de educación política española. Una educación política, un nivel pedagógico, que en Meditaciones presenta los rasgos de una pedagogía de la alusión.

La "pedagogía de la alusión"368 que Ortega encuentra en el símbolo del bosque es la pedagogía de la ampliación, la pedagogía simbólica que más adelante remitirá al tema de la metáfora 369 . Es la pedagogía colaboradora que, con ello, muestra su coherencia con la pedagogía social que examinábamos más arriba: la alusión es la de superficies a profundidades, es la alusión a posibilidades, a la ampliación de limitaciones, a la cooperación 370 . La verdad como revelación y el concepto como conexión parten de las alusiones de unas cosas a otras, de unos conceptos a otros, parten de las alusiones de presencias a ausencias, de claridades a oscuridades. Desvelar o revelar el sentido de las cosas es mostrar su poder alusivo, mostrar su intimidad, su concepto, y, con ello, hacer posible las estructuraciones y las conexiones. El esfuerzo del meditador por conseguir llevar lo más lejos posible la serie de alusiones es el esfuerzo de la creación de realidades, es el esfuerzo de la ampliación, el esfuerzo del concepto en la colaboración e integración de materias y sentidos.

\footnotetext{
367" Vieja y nueva política" (1914). OC I, 284.

$368_{\text {MQ, p. } 109 .}$

369MOLINUEVO, J.L. El idealismo de Ortega. Madrid: Narcea, 1984, p. 37: "La pedagogía de la alusión y el reflejo es, en realidad, una pedagogía de la ilusión y la metáfora".

370 Mermall ha insistido en esta función pedagógica como cooperación del símbolo del bosque: "El propósito de Ortega aquí no es sólo ilustrar un principio epistemológico, sino también infundir valores espirituales y promover, inspirado en el eros platónico, el amor, la cooperación y la armonía entre españoles, todo lo cual otorga al simbólico bosque una función pedagógica". MERMALL, Th. "En torno al estilo filosófico de Ortega", en: Revista de Occidente, n 192, mayo 1997, p. 53.
} 


\subsubsection{La integración}

El deseo de integración entre materia y sentido, entre impresión y concepto, lo refiere Ortega explícitamente al tema de la cultura mediterránea y su necesaria conexión con la cultura del concepto, la cultura germánica. Es el tema que, en sus inicios, ya hemos examinado más arriba, el de la necesaria integración entre pathos del norte y pathos del sur, la cultura germánica, de profundidades, y la mediterránea, de superficies. Ortega ya ha insistido en la necesidad de integración entre ambos pathos, y ha podido hacerlo partiendo de las profundidades y superficies, como representantes respectivos de conceptos e impresiones, sentidos y materias, antes de referirlas a símbolo de culturas.

Partiendo del enfrentamiento de Menéndez Pelayo entre las "nieblas germánicas" y la "claridad latina", Ortega negará la existencia de una "cultura latina" y la sustituye por la "cultura mediterránea". Ésta precede a las ideas de Europa y África, a lo que se ha venido entendiendo como ribera del norte y ribera del sur en el mundo mediterráneo. La cultura mediterránea es previa, es Roma, considerada como pueblo mediterráneo; únicamente la ilusión de los europeos de creerse hijos del espíritu helénico era lo que enmascaraba el sueño de tener lazos con los dioses griegos. Ya se ha visto cómo mostraba Ortega que Grecia, representando el origen del concepto, de la idea, tiene su conexión con la cultura germánica, y no con el materialismo impresionista del sur. La cultura mediterránea es la cultura que, procedente de Roma y Cartago, se constituye como cultura costera: "La onda de específica cultura empieza, tal vez, en Roma, y de allí se transmite bajo la divina vibración del sol en mediodía a lo largo de la faja costera"371.

La cultura mediterránea nace, así, como cultura costera, y esa franja costera, limítrofe por esencia, es anterior a los que posteriomente serán considerados como sus términos, Europa y África: "No se advirtió que cuando la cultura mediterránea era una realidad ni Europa ni África existían. Europa comienza cuando los germanos entran plenamente en el organismo unitario del mundo histórico. África nace entonces como la no-Europa, como to éteron de Europa. Germanizadas Italia, Francia y España la cultura mediterránea deja de ser una realidad pura y queda reducida a un más o menos de germanismo"372. Grecia revierte

$$
\begin{aligned}
& 371 \mathrm{MQ}, \text { p. } 131 . \\
& 372 \mathrm{MQ} \text {, p. } 132 .
\end{aligned}
$$


en la cultura germánica, la cultura del concepto, el mediterranismo pasa a representar el talante realista, impresionista, materialista.

"El Mediterráneo es una ardiente y perpetua justificación de la sensualidad, de la apariencia, de las superficies, de las impresiones fugaces que dejan las cosas sobre nuestros nervios conmovidos"373 y, por ello, el hombre mediterráneo ve más claro que el pensador germánico, que mantiene su claridad en el concepto: el mediterráneo se demora en "el placer de la visión, de recorrer, de palpar con la pupila la piel de las cosas"374. Es una cultura del tacto, de la superficie, que no penetra, que no profundiza, que no conceptualiza. El concepto, como órgano de la profundidad, debe estructurar las impresiones, debe cohesionar las visiones, deber dar un sentido a las superficies. El concepto, como órgano de la estructura y la relación, debe unir las individualidades, debe conferirles un sentido que las saque de su aislamiento. Es el texto clásico de Ortega:

\footnotetext{
"¡Cuán poca cosa sería una cosa si fuera sólo lo que es en el aislamiento! ¿Qué pobre, qué yerma, qué borrosa! Diríase que hay en cada una cierta secreta potencialidad de ser mucho más, la cual se liberta y expansiona cuando otra u otras entran en relación con ella. Diríase que cada cosa es fecundada por las demás, diríase que se desean como machos y hembras, diríase que se aman y aspiran a maridarse, a juntarse en sociedades, en organismos, en edificios, en mundos. Eso que llamamos "Naturaleza" no es sino la máxima estructura en que todos los elementos materiales han entrado. Y es obra de amor naturaleza, porque significa generación, engendro de las unas cosas en las otras, nacer la una de la otra donde estaba premeditada, preformada, virtualmente inclusa" 375 .
}

Preguntar por el sentido de las cosas es preguntar por sus conexiones, por su posición en una estructura de contactos, y la formación de esa estructura, erótica, amorosa, es la función del concepto. Por esto la conexión entre límites y conceptos: las cosas que al relacionarse muestran "la potencialidad de ser mucho más", rompen sus limitaciones y se conectan mediante el concepto, que acerca y distancia, une y separa. Por esto la referencia al texto de la Fenomenología que unía concepto y límite: el límite de la cosa como diversidad, apareciendo fuera de la cosa, en la relación que posibilita el concepto como esquema, como sistema de uniones, uniones sin invasiones, $\mathrm{y}$, por ello, construyendo relaciones, pero también diversidades.

\footnotetext{
373 MQ, p. 136.

${ }^{374} \mathrm{MQ}$, p. 138.
} 
Si en el primer contacto de visión las cosas "se ensanchan, se estiran, se descoyuntan como si fueran de una corporeidad gaseosa"376, esa visión, que remite a materias y superficies, impresiones y sensaciones, poco a poco se aquieta, va adquiriendo un orden, entrando en una red de relaciones, adquiriendo un sentido: "Este aquietamiento y fijeza de los contornos procede de nuestra atención que las ha ordenado, es decir, que ha tendido entre ellas una red de relaciones"377. La idea recuerda mucho a otro texto que también subraya Ortega en el prólogo a la Fenomenología. Allí escribe Hegel: "Das Wahre ist so der bacchantische Taumel, an dem kein Glied nicht trunken ist; und weil jedes, indem es sich absondert, ebenso unmittelbar [sich] auflöst, ist er ebenso die durchsichtige und einfache Ruhe" 378 . Por esto precisamente la conexión entre concepto y límite tomada de la Fenomenología y no de la Lógica: se trata de conseguir esa quietud, no la inquietud del algo en su límite. Las relaciones, el orden, el aquietamiento, el descoyuntarse del objeto antes de entrar en el orden de las relaciones, del texto de Ortega, recuerdan a esa disolución de los miembros al disociarse, a la intención de conseguir esa quietud de la conjunción del texto de Hegel.

El tema en Ortega es de cosas y conceptos, de impresiones y sentidos, pero las referencias al tema de España y Europa, al tema de la nación y el nacionalismo, a la relación entre individuo y sociedad, etc., son ineludibles. También éstos dependen de un juego de relaciones, de mantener la diversidad, pero, a la vez, permitir la relación. Es por ello por lo que el conjunto, de un modo amplio, puede entenderse a partir de la dialéctica de la limitación y su superación, una superación que significa ampliación, crecimiento, potenciación, nunca suplantación.

La unión entre límite y concepto que presenta Ortega es, entonces, determinante, pues supone los juegos de conexiones desde aproximaciones y distancias, desde fronteras, pero precisamente con un fin limitador en el que los conceptos apresen, limiten (en el sentido de

378 HEGEL, Phänomenologie des Geistes. Op. cit. p. 31. Traducción: "Lo verdadero es, de este modo, el delirio báquico, en el que ningún miembro escapa a la embriaguez, y como cada miembro, al disociarse, se disuelve inmediatamente por ello mismo, este delirio es, al mismo tiempo, la quietud translúcida y simple". Fenomenología del espíritu. Op. cit. p. 32.
} 
limitación -Schranke-) aquello que han presentado en las estructuras basadas en juegos de conexiones, de límites (en el sentido de límite -Grenze-). La conexión entre límite y limitación se presenta de un modo explícito: los límites, los conceptos, que unen y conexionan las cosas, también, al conectarlas, las limitan, las individualizan, les dan su sentido propio. Se trata, en el fondo, del mismo proceso que el de la reabsorción de la circunstancia o el de la constante superación de la limitación: entender la limitación como límite y el límite como limitación, entender las particularidades, del tipo que sean, como limitaciones que son límite, individualidades que deben ampliarse en sus conexiones y contactos.

Por esto, el concepto no puede nunca suplantar a la impresión, nunca podrá ofrecer la carne de las cosas. La función del concepto es unir límites y limitaciones en las cosas: "el concepto será el verdadero instrumento u órgano de la percepción y apresamiento de las cosas. / Agota, pues, su misión y su esencia, con ser no una nueva cosa, sino un órgano o aparato para la posesión de las cosas"379. El concepto expresa la limitación al dar un sentido, al poseer, al asegurar, al agarrar la inquietud y fugacidad de la impresión, pero lo hace mediante juegos de límites, conectando y relacionando con otras cosas, con otras impresiones. Si todo esto es así, entonces, se presenta como necesario que el 'Ensayo sobre la limitación", referido a al paisaje y la "sensibilidad para las circunstancias", adquiera su sentido más profundo al unirse con esta teoría orteguiana del concepto como límite. Los temas no son los mismos, pero se complementan, son ineludibles. Por ello, la cultura como seguridad, partiendo de ese carácter limitador del concepto, se enfrentará a la cultura fronteriza que representa España, "la cultura salvaje, la cultura sin ayer, sin progresión, sin seguridad"380.

En ningún modo suplantación, sino integración: se trata entonces de convertir esa cultura fronteriza, materialista, impresionista y sensualista, en cultura de límites y limitaciones entendidos desde el tema del concepto, desde la dialéctica de la limitación y su superación. El concepto como instrumento, que no sustituye la espontaneidad vital, pero sí la asegura confiere a esa cultura fronteriza no sólo el poder de profundizar, de dotar con un sentido a sus imágenes e impresiones, sino que, además, puede concederle la situación en un mundo,

379 MQ, pp. 152-153. 
su composición de lugar: asegurándole una limitación, pero desde el límite que permita la conexión con otras limitaciones, con otras culturas. La integración que persigue Ortega se expresaría de este modo a partir de límites y limitaciones, a partir del concepto en su poder cohesionante y creador de estructuras nuevas, sistemas nuevos, posibilidades, espacios.

Si todo esto es así, si para llevar a cabo esta teoría del concepto, con referencias ineludibles al tema de España, a la conexión de teoría y práctica, Ortega ha tomado y reescrito ciertos temas o ideas del prólogo a la Fenomenología, entonces será posible conjuntar esas ideas de Hegel con la recepción de Ortega. El límite unido al tema del concepto expresaría la diversidad y la unidad, la unidad de sentidos, la diversidad de las particularidades. Ortega entiende ese "donde está el límite de una cosa no está esa cosa" refiriendo únicamente al concepto y a su poder para poner en contacto, para cohesionar, pero, a la vez, mediante esa cohesión conferir identidad y particularidad propia a lo conectado. La verdad, manteniendo su existencia, su forma, en el sistema y el concepto remite en Ortega, primero, a ese sistema abierto en el que las limitaciones son también entendidas como límites, y, segundo, a esa verdad como revelación, como encontrar en lo oculto la posibilidad de la alusión, que permite al concepto entenderse como estructura, como esquema, en su forma de representación de los sentidos, de lo profundo, de lo oculto.

El esfuerzo que supone esa búsqueda de alusiones y estructuras, el esfuerzo de la meditación, conectaría con el esfuerzo del concepto de Hegel, pero entendiendo ese esfuerzo como la tarea, la labor ardua que supone la creación de conexiones, la búsqueda de los nuevos espacios a partir de las relaciones entre cosas. Así, esa profundidad que permite la cohesión, mencionada por Hegel, queda entendida en Ortega como la profundidad a la que llega el concepto para cohesionar las impresiones y fugaces materialidades de las cosas. Es esa quietud que expresaba Hegel, esa quietud en la que el concepto, en su relación con la verdad, aquieta la pluralidad de determinaciones e individualidades. Es ese aquietamiento, como objetivo de verdad y concepto, de sentido y profundidad, el que puede permitir la determinación más amplia, el que puede conferir sentido a las cosas, y, a través de ello, llegar a dotar de un logos la impresionista cultura mediterránea.

El "patrimonio de todos", que mencionaba Hegel, permanece en Ortega remitiendo tanto al afán pedagógico y práctico, como a los deseos de integración, y teniendo siempre en 380MQ, p. 155 
cuenta que esos deseos de integración vienen exigidos por una época de tránsito, de gestación, en la que si no se llevan a cabo las relaciones, las uniones con otras limitaciones, con otras naciones, la limitación española puede quedarse fuera de sitio, anclada en sus propias deficiencias. Ese carácter de transición y de gestación que mantiene la época era el mismo tanto para Hegel como para Ortega.

\subsubsection{Limitación e ilimitación}

Ahora bien, si el tema del concepto refiere, en un sentido muy determinado, tanto a los límites como a las limitaciones, ¿dónde queda el tema de la ilimitación? ¿dónde queda esa "limitación como ilimitación"381 que aparecía en aquella nota de trabajo? ¿tiene algo que ver con el tema del concepto, o con el prólogo a la Fenomenología? Ya apareció más arriba la conexión de este tema con la referencia de Ortega en la misma nota a los dioses particulares de Schelling, y a la relación con el tema de la nación y del paisaje. Pero hay también una referencia a Hegel, que no procede de la Fenomenología sino de la "Pequeña lógica" de la Enciclopedia.

En la biblioteca de la "Fundación José Ortega y Gasset" hay dos ediciones de la Enciclopedia de Hegel con fecha de edición anterior a 1914. Una es la edición italiana de Croce, de 1907, y en la primera página, con letra de Ortega, puede leerse: "Marburgo, octubre 1911". La otra es la de Lasson de 1905. Llama la atención que, en ambas ediciones, Ortega subraya el mismo texto de Hegel del parágrafo 60. Es un parágrafo en el que Hegel analiza ciertos temas de la filosofía de Kant y muestra lo que para él son sus defectos. El texto sobre el que hace hincapié Ortega tanto en su edición italiana como en la original alemana, citado en toda su extensión, dice así:

"Es ist darum die grösste Inkonsequenz, einerseits zuzugehen, dass der Verstand nur Erscheinungen erkennt, und andererseits dies Erkennen als etwas Absolutes zu behaupten, indem man sagt, das Erkennen könne nicht weiter, dies sei die natürliche, absolute Schranke des menschlichen Wissens. Die natürlichen Dingen sind beschränkt, und nur natürliche Dinge sind sie, insofern sie nichts von ihrer allgemeinen Schranke wissen, insofern ihre Bestimmtheit nur eine Schranke für uns ist, nicht für sie. Als Schranke,

${ }^{381}$ Cfr. "Sobre Cervantes y El Quijote desde el Escorial. (Notas de trabajo de José Ortega y Gasset)". Op. cit.p. 50. 
Mangel wird etwas nur gewusst, ja empfunden, indem man zugleich darüber hinaus ist. Die lebendigen Dinge haben das Vorrecht des Schmerzes vor den leblosen; selbst für jene wird eine einzelne Bestimmtheit zur Empfindung eines Negativen, weil sie als lebendig die Allgemeinheit der Lebendigkeit, die über das Einzelne hinaus ist, in ihnen haben, in dem Negativen ihrer selbst sich noch erhalten und diesen Widerspruch ist nur in ihnen, insofern beides in dem einen Subjekt ist, die Allgemeinheit seines Lebensgefühls und die gegen dasselbe negative Einzelheit. Schranke, Mangel des Erkennens ist ebenso nur als Schranke, Mangel bestimmt durch die Vergleichung mit der vorhandenen Idee des Allgemeinen, eines Ganzen und Vollendeten. Es ist daher nur Bewusstlosigkeit, nicht einzusehen, dass eben die Bezeichnung von etwas als einem Endlichen oder Beschränkten den Beweis von der wirklichen Gegenwart des Unendlichen, Unbeschränkten enthält, dass das Wissen von Grenze nur sein kann, insofern das Unbegrenzte diesseits im Bewusstsein ist" 382 .

El tema es la teoría kantiana del conocimiento, pero, refiriendo a Hegel, surgen varias cuestiones si se introduce la intervención de Ortega. El carácter de limitación de las cosas está siendo entendido como Mangel, como falta, como privación, o, en general, como finitud. Que esa limitación remita a la ilimitación supone la entrada en escena del sujeto, y ya se vio cómo Ortega incidía en el nivel subjetivo del concepto, aunque su objeto fueran las cosas, aunque sea imposible separar materia y concepto. Para Hegel la limitación implica la ilimitación en el sentido de que tener conciencia de ella supone la simultánea conciencia de la ilimitación de la idea.

382 HEGEL, Enzyklopädie der philosophischen Wissenschaften. Hrsg. G. Lasson. Leipzig: Verlag der Dürr'eschen Buchhandlung, 1905, § 60, pp. 85-86. En la edición italiana también manejada por Ortega la referencia es: Enciclopedia delle Scienze Filosofiche in compendio. Trad. B. Croce. Bari: Laterza, 1907, § 60, p. 63. La reciente edición de Valls traduce: "Es por ello la mayor inconsecuencia conceder, por un lado, que el entendimiento sólo conoce fenómenos y, por otro lado, afirmar este conocimiento como algo absoluto cuando se dice que el conocer no puede ir más allá, que ése es el límite absoluto, natural, del humano saber. Las cosas naturales son limitadas y solamente son tales, [o sea,] cosas naturales, mientras no saben nada de sus límites generales, mientras su determinidad es un límite sólopara nosotros, no para ellas. Algo se sabe comolímite o falta, es más, algo se siente como límite o falta solamente cuando uno, al mismo tiempo, está más allá [de ello]. Las cosas vivas tienen el privilegio del dolor por encima de las cosas que carecen de vida; incluso [se puede decir que] las cosas vivas sienten una determinidad particular como algo negativo, porque en cuanto vivas tienen en ellas mismas la universalidad de la vitalidad que está por encima del singular; en lo negativo de sí mismas se conservan, y esta contradicción la sienten como algo que existe en ellas. Esta contradicción está en ellas solamente en la medida en que las dos cosas se encuentran en un único sujeto, la universalidad de su sentimi ento vital y la singularidad negativamente enfrentada a este sentimiento. Límite, falta de conocimiento, se determinan solamente como límite o falta por comparación con la idea disponible de la universalidad, de algo entero y perfecto. Es mera inconsciencia, por tanto, no caer en la cuenta de que ya la señalización de algo como finito o limitado incluye la prueba de la presencia efectiva de lo infinito e ilimitado, que el saber acerca de barreras sólo puede darse cuando lo que carece de barreras está de este lado, en la conciencia". Enciclopedia de las ciencias filosóficas. Ed. y trad. R. Valls Plana. Madrid: Alianza, 1997, $\S 60$, pp. 162-163. 
Incluso, saliendo de ese texto en concreto y remitiendo a la dialéctica de finitud e infinitud de la Ciencia de la lógica, que es la referencia ineludible de ese texto de la Lógica de la Enciclopedia 383 , lo que viene a decir Hegel es que finitud e infinitud no presentan una oposición irresoluble, sino que forman una unidad. Si lo finito y lo infinito se toman siendo cada uno de ellos por sí, de modo autónomo, entonces lo infinito sería algo finito, no el todo, luego hay que admitir su unidad con lo finito. Es decir, que afirmar que lo infinito es sólo una de las dos dimensiones significa negar su infinitud, con lo que debe incluir la finitud como momento.

Y desde el punto de vista de la finitud, si se separa a ésta de lo infinito, entonces poseerá una autonomía, se mostrará independiente en la relación consigo mismo, autonomía e independencia que son propias de lo infinito. En general, la finitud contiene la infinitud como momento, como su otro, y ésta se constituye como un ir más allá sobre y a través de lo finito ${ }^{384}$. La Schranke, limitación, que analiza Hegel en la Lógica tiene que ver precisamente con esta dialéctica entre finitud e infinitud ${ }^{385}$, mientras que el límite, la Grenze, se refiere a la dialéctica entre algo y otro 386.

En general, y sin entrar en los temas hegelianos de buena y mala infinitud, de progreso al infinito, etc., la consecuencia estriba en que no hay una infinitud que primero sea infinita y luego devenga finita, sino que los dos momentos están incluidos. Es el texto que, precisamente, subrayará Ortega en su edición de la Lógica: "Die Antwort auf die Frage, wie das Unendliche endlich werde, ist somit diese, dass es nicht ein Unendliches gibt, das vorerst unendlich ist und das nacher erst endlich $\mathrm{zu}$ werden, zur Endlichkeit

383Un ejemplo claro de esa referencia es que ese "Vorrecht empfindender Natur ist, Schmerz zu empfinden" se encuentra en la Lógica en la nota que precede al capítulo "Übergang des Endlichen in das Unendliche". HEGEL, Wissenschaft der Logik, I Hrsg. E. Moldenhauer und K. Michel. Frankfurt/M.: Suhrkamp, $1990^{2}$, -Werke, 5- p. 146.

384Ibid. p. 160: "[...] ist die Endlichkeit nur als Hinausgehen über sich; es ist also in ihr die Unendlichkeit, das Andere ihrer selbst, enthalten. Ebenso ist die Unendlichkeit nur als Hinausgehen über das Endliche; sie enthält also wesentlich ihr Anderes und ist somit an ihr das Andere ihrer selbst. Das Endliche wird nicht vom Unendlichen als einer ausser ihm vorhandenen Macht aufgehoben, sondern es ist seine Unenlichkeit, sich selbst aufzuheben".

385Ibid. p. 151: "Die Endlichkeit ist nämlich die als Schranke gesetzte Schranke. [...] In der Unendlichkeit ist die Befriedigung vorhanden, dass alle Bestimmtheit, Veränderung, alle Schranke und mit ihr das Sollen selbst verschwunden, als aufgehoben, das Nichts des Endlichen gesetzt ist". 
herauszugehen nötig habe, sondern es ist für sich selbst schon ebensosehr endlich als unendlich"387. A esta conexión de limitación e ilimitación, o de finitud e infinitud, en este caso, refiere Ortega en esa nota, pero la aplicación y contenido que utilizará es diferente.

Entender el concepto como límite, según Ortega en Meditaciones, supone, primero, entender al concepto como posibilidad de asegurar, de apresar las cosas, esto es, de limitarlas, y, a la vez, hacerlo mediante las relaciones, esto es, desde la eficacia del límite. La conjunción de limitación e ilimitación es entendida en Ortega a partir de la conjunción que establece el concepto en las cosas, limitación al apresar su fugacidad, ilimitación por los contactos y relaciones. Por ello, la ilimitación divina, la ilimitación basada en la soledad, no interesa a Ortega: al dios le resulta indiferente el carácter de ampliación, de ensanchamiento, de relación, porque no tiene ni un otro al que tender ni un espacio donde efectuar tal ampliación, y por ello no tiene límites 388 . A Ortega no le interesa la ilimitación sin límites, sino la ilimitación por los límites, la ilimitación por contacto, y, con ello, la ilimitación como posibilidad de ampliación, como carácter abierto.

En Ortega, es el concepto el que une limitación e ilimitación, y, con ello, salva las cosas, es decir, el amor como conexión une limitaciones, y, al unirlas, supone la ilimitación. Así, ese dolor como privilegio de las cosas vivas que menciona Hegel, mostrando con ello su finitud y limitación, aparece en Ortega re-interpretando otra expresión de Hegel, también subrayada fuertemente por Ortega, la ternura por las cosas 389 . Es la ternura por ese dolor, por esa limitación, la que llevará a Ortega a unir limitación e ilimitación mediante el concepto, pero teniendo muy en cuenta que Ortega, al igual que Hegel, no quierer perder esa finitud, no quiere perder ese dolor, no quiere perder la limitación más propia.

386SCHAEFER, A. "Begriff der Grenze und Grenzbegriff in Hegels Logik", en: Zeitschrift für philosophische Forschung, Band 27, 1973, p. 81: "Die Grenze trennt und verbindet Endliches, die Schranke Endliches und Unendliches".

${ }^{387}$ HEGEL, Wissenschaft der Logik, I Hrsg. Lasson. Leipzig: Meiner, 1923, p. 143. Traducción: "La respuesta a la pregunta de cómo lo infinito deviene finito, es, por tanto, ésta: que no hay un infinito que sea primero infinito y sólo posteriormente tenga la necesidad de devenir finito, de traspasar hasta la finitud, sino que él es ya por sí mismo tanto finito como infinito".

388"Dios no tiene fronteras, límites". Una interpretación de la historia universal. En torno a Toynbee (1948-49, curso). OC IX, 209. Ó: "Dios no está limitado por nada fuera de él". Unas lecciones de metafísica (1932-33, curso). OC XII, 207. Indirectamente, la alusión está también en el texto de Meditaciones donde se une concepto y límite: "Si no existiera más que un objeto aislado y señero, sería ilimitado". MQ, p. 146.

389"Zärtlichkeit für die weltlichen Dingen". HEGEL, Enzyklopädie der philosophischen Wissenschaften. Op. cit. $\S 48$, p. 73. 
En Ortega, la ternura por las cosas deviene amor, y, aparece con él, al entenderlo como poder cohesionador, el concepto como conexión. Es la necesidad de salvar las cosas, precisamente, lo que introduce el tema del concepto, y, con él, tanto la limitación como la ilimitación. La ilimitación en Ortega es, entonces, una ilimitación por contacto, por poder cohesionador, por relaciones, que, precisamente al mantenerse en el juego de conexiones, en ningún momento rompe con la limitación. O, de otro modo: a Ortega, la ilimitación le interesa sobre todo como posibilidad, como ampliación.

Pero habría otro carácter de ilimitación, aquél que encontrábamos más arriba en el arte. Ilimitación también de relaciones, pero sobre todo de ideales, de posibilidad de crear espacios nuevos, infinitos. Se trataba, además, del símbolo como superación de la limitación. Este tema de la conexión de la limitación y de la ilimitación, entendido ahora en relación al tema del concepto, exige la transición hasta otra temática ineludible: la de la metáfora. La metáfora entendida como símbolo, como poder creador, como alusión, como ilimitada capacidad de transformación, surgiendo con ella la ilimitación que ya mencionaba Ortega en el Renan: la ilimitación de lo verosímil, el universo ilimitado, y "ese universo ilimitado está construido con metáforas"390. Por todo esto, Meditaciones del Quijote no puede ser leído sin tener en cuenta otro texto del mismo año, el Ensayo de estética a manera de prólogo. Además, pueden encontrarse ciertas conexiones entre el tratamiento orteguiano de la metáfora y el que lleva a cabo Hegel en la Estética.

390"Renan" (1910). OC I, 454. 


\subsection{Ortega y Hegel sobre la metáfora}

La metáfora, del mismo modo que el símbolo, expresa la superación de la limitación. Y lo hace precisamente presentando eso que Hegel llama el "modo de enlace de lo doble", esto es, enlace entre literalidad y metáfora, entre expresión y significado. Ese modo de enlace es posibilidad de creación, de ampliación, y, con ello, supera limitaciones, crea relaciones, forja espacios nuevos. Si Ortega entiende el concepto y el límite como formas virtuales que se interponen entre las cosas uniendo y separando, conectando y limitando, también la metáfora se va a mantener en este juego: ella también separa y une, limita y supera la limitación, ella también, como el concepto, y como el amor, entendido como conexión, es una virtualidad, y hay que reservar energía para su manejo: "reservemos buena parte de nuestra seriedad para el cultivo del amor, de la amistad, de la metáfora, de todo lo que es virtual"391.

Es esa virtualidad y ese mundo ilimitado de la metáfora los que conectan con el tema del concepto como superación de la limitación, como ilimitación por conexiones, por afán de evolución y aumento de realidad. Es el momento en que cada cosa puede ser muchas, el momento de indecisión y ambigüedad, que, como vimos en el tema del símbolo, se encuentra indisolublemente unido con lo real y material. La metáfora expresa las cosas en su indecisión, las presenta en el momento en que las alusiones y las alegorías inician su función de aumento y creación. En una de las notas de trabajo Ortega llamaba a este momento la "hora apocalíptica", la hora del crepúsculo: "Es el crepúsculo. Y no por nada estupendo. Es la hora de la indecisión de las formas de las cosas. Cada una puede ser muchas, cada una es como un vientre que tiene en sí preformadas cosas innumerables. Es la hora de las comparaciones, la hora metafórica, alegórica. $\mathrm{Y}$ esto es el pensar apocalíptico"392. La conexión es evidente con aquel texto, ya citado, de Meditaciones en el que Ortega escribía que "hay en cada una [cosa] cierta secreta potencialidad de ser mucho más, la cual se liberta y expansiona cuando otra u otras entran en relación con ella. Diríase

391" Para la cultura del amor" (1917). OC II, 143.

392" El estilo de una vida (Notas de trabajo)". Antología y edición de J.L. Molinuevo. En: Revista de Occidente, $\mathrm{n}^{\circ} 132$, mayo 1992, p. 61. 
que cada cosa es fecundada por las demás"393. Ese texto conducía al tema del concepto, y ya presentaba todo el tema de la ampliación de mundo, todo el juego de conexiones. Por esto, el tema de la metáfora y el del concepto no pueden ser separados.

\subsubsection{El "Ensayo de estética". La metáfora en Ortega}

Ortega comienza el Ensayo de estética a manera de prólogo dejando claro que el tema en cuestión es el del enriquecimiento de mundo, el del aumento de realidad. Los verdaderos poetas son esos hombres que "enriquecen el mundo, aumentan la realidad", que presentan las cosas y los significados en relaciones nuevas, en conexiones dinámicas que hacen posible la superación de las limitaciones: "sometidas a este virtual dinamismo las cosas adquieren un nuevo sentido, se convierten en otras cosas nuevas"394.

La conexión con el tema de España, y, con ello, la estética política, sigue estando vigente. Sólo hay que comparar con Vieja y nueva política", con el aumento de vitalidad española exigido para hacer eficaz el Estado y, en lo referente al mismo tema del dinamismo: "vida española, digámoslo lealmente, señores, vida española, hasta ahora, ha sido posible sólo como dinamismo. / Cuando nuestra nación deja de ser dinámica cae de golpe en un hondísimo letargo y no ejerce más función vital que la de soñar que vive"395. El dinamismo es el mismo, el de la estética, introduciendo nuevos sentidos y aumento de realidades, y el del tema de España, exigido para crear una nueva sensibilidad, una nueva política.

Ese dinamismo mantiene un carácter determinante: se trata de crear espacios y realidades, pero salvando las cosas, esto es, aceptando lo real y, precisamente por ello, llevarlo a su plenitud, al mayor número de significados, de posibilidades, de conexiones; y, en el tema de España, dinamizar la política, dinamizar la vida española, la nueva sensibilidad, pero haciéndolo desde la limitación española, esto es, dinamizar esa limitación, dinamizar el paisaje, dinamizar el contorno: "La nueva manera de pensar conduce a un afán de dinamismo y a la exigencia de intervenir con nuestra voluntad en el

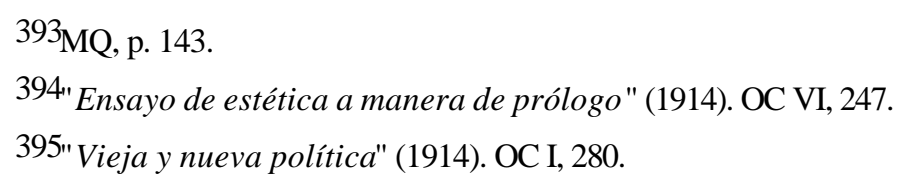


contorno"396. El dinamismo, sea el del poeta o el del político, es un dinamismo de intervención: buscar la plenitud, intervenir en las cosas, forzarlas para que ofrezcan todas sus posibilidades, enamorarlas, y ése era el comienzo de Meditaciones: "Cada cosa es un hada que revista de miseria y vulgaridad sus tesoros interiores y es una virgen que ha de ser enamorada para hacerse fecunda"397. Ése es el momento de intervención, la unión de la teoría del amor con la del concepto, siempre a la búsqueda de plenitud y fecundidad, del mismo modo que lo hace el poeta, del mismo modo que debe hacerlo esa nueva política basada en el afán de dinamismo.

Ahora bien, ese momento de intervención, como es el del dinamismo de la nueva política, como lo era el del concepto, que exigía el esfuerzo sin remilgos del sujeto, de la meditación, se expresa en el arte como todo lo contrario a cualquier tipo de utilitarismo. El yo como lo ejecutivo, la ejecutividad del yo, se presenta directamente contra este utilitarismo: "Usar, utilizar sólo podemos las cosas. Y viceversa: cosas son los puntos donde se inserta nuestra actividad utilitaria. Ahora bien: ante todo podemos situarnos en actitud utilitaria, salvo ante una sola cosa, ante una única cosa: Yo"398. El yo como ejecutividad significa el momento de verificación, de intimidad, de perfecta compenetración con algo.

El yo, que precisamente por ser en su ejecutarse no puede convertirse en cosa, expresa el momento de intimidad, de mirar desde el interior, desde dentro de sí mismo. Por ello la imposibilidad del carácter utilitario del yo, porque no podemos situarnos ante él, sino que se presenta en su intimidad, y, por ello mismo, la negación del arte como utilitarismo: la intimidad del yo en su ejecución no sólo refiere al hombre, "Yo significa, pues, no este hombre a diferencia del otro ni mucho menos el hombre a diferencia de las cosas, sino todo -hombres, cosas, situaciones-, en cuanto verificándose, siendo, ejecutándose"399, y el objeto estético es esa intimidad de ejecución, esa intimidad que es el ser verdadero, el ser

\footnotetext{
396Ibid. p. 307.

397 MQ, p. 47.

398" Ensayo de estética a manera de prólogo" (1914). OC VI, 250.

399 Ibid. p. 252.
} 
pleno de cada cosa. "Tal idioma es el arte: esto hace el arte. El objeto estético es una intimidad en cuanto tal -es todo en cuanto $y o^{\prime \prime} 400$.

Este entender las cosas como yo, como intimidad, salva a las cosas en el momento en que parte de la aceptación de lo real, del amor hacia ellas, pero precisamente por ello deseando su plenitud, deseando encontrar el ideal precisamente por partir de su aceptación. Es el idealismo estético como máxima forma de realismo. Al expresar a las cosas en su intimidad, en su ejecutividad, el arte exige su significado más pleno, exige su salvación precisamente porque las busca en el mayor número de relaciones, de conexiones con otras cosas, las intenta encontrar en su carácter de totalidad. Y, para hacerlo, necesita del medio esencial para mostrarlas en su momento de expansión y de ampliación. Ese medio es la metáfora, y con ella aparece toda una teoría de la limitación: ser más de lo que se es (superar la limitación) precisamente desde sí mismo, desde la aceptación de lo real (aceptación de la limitación), mostrar la diversidad de significados partiendo de la identidad más propia, de la intimidad, expresar la plenitud, el henchimiento, desde la concentración en el carácter más individual.

Es el mismo talante que viene apareciendo constantemente en el campo de la política y de la sociedad, o en el tema general de la limitación española: la superación de la limitación buscando sus ideales, buscando su plenitud, esto es, aceptando la limitación, pero aceptándola plenamente, en su momento de ampliación, de henchimiento, de contacto.

La metáfora, como objeto estético, expresa ese dialéctica de la limitación al mostrarse como transparencia, pero transparencia de sí misma. La metáfora muestra la dualidad, la referencia de una realidad a otra, de un significado a otro, y es, con ello, transparente, la mirada atraviesa algo que no le molesta para ver su objeto; pero, a la vez, eso hacia lo que se dirige la mirada es el objeto mismo metaforizado, sólo que transformado, recreado, plenificado. De otro modo: la metáfora expresa la limitación más plena precisamente al aumentar el significado de lo limitado, y, con ello, superar la limitación ampliándola; la limitación en la metáfora es constantemente superada, ampliada, su carácter de transparencia no permite la limitación de la superficie, la mirada no se detiene ${ }^{401}$. Es en

${ }^{401}$ Comentando La mariée mise à nu par ses célibataires, même, pintura sobre vidrio de Duchamp, escribía José Jimenez: "La obra tiene un anverso y un reverso, y nuestra mirada no se ve limitada por su superficie,
} 
este sentido en el que el objeto estético, metafórico, se expresa en una dialéctica de limitaciones.

La doble condición de la transparencia permite definir al objeto artístico como "un objeto que reúne la doble condición de ser transparente y de que lo que en él transparece no es otra cosa distinta sino él mismo. / Ahora bien: este objeto que se transparenta a sí mismo, el objeto estético, encuentra su forma elemental en la metáfora. Yo diría que objeto estético y objeto metafórico son una misma cosa, o bien, que la metáfora es el objeto estético elemental, la célula bella"402.

Utilizando como ejemplo la imagen de López Picó, "el ciprés es como el espectro de un llama", Ortega presenta su teoría de la metáfora. El objeto metafórico no es ni el ciprés, ni el espectro, ni la llama, sino el objeto nuevo que surge del encuentro de esos elementos. Aparece una teoría de las relaciones, una teoría que expresa, en primer lugar, la semejanza de los elementos, el cierto parecido existente entre el ciprés y la llama, pero esa semejanza, ese parecido, es algo inesencial, insignificante. Si lo que consigue la metáfora es, partiendo de una semejanza insignificante, afirmar la identidad absoluta entre los elementos, entonces, precisamente por la inesencialidad de la semejanza, los elementos se repelen, "de suerte que la semejanza real sirve en rigor para acentuar la desemejanza real entre ambas cosas. Donde la identificación real se verifica no hay metáfora. En esta vive la conciencia clara de la no-identidad'403.

Esta conjunción de identidad y no identidad es determinante, pues muestra la identidad en la diferencia, la ampliación de significados, de limitaciones, precisamente al conectar, al relacionarse con diferencias, con otras cosas. La metáfora deviene así entendida como la plasmación de una vida transitiva, ejecutada en el carácter de transitividad ${ }^{404}$. Se trata de un proceso de diseminación del objeto, que, con todo, permanece en sí mismo, como escribirá Hegel, recordando esa transparencia de Ortega en la que lo que transparece es el

sino que se desplaza a través de ella". JIMÉNEZ, J. "El artista poeta: Marcel Duchamp", en: MOLINUEVO, J.L.(Ed.), Arte y escritura. Salamanca: Universidad, 1995, p. 27.

402" Ensayo de estética a manera de prólogo" (1914). OC VI, 257.

403Ibid. p. 258.

${ }^{404}$ MOLINUEVO, J.L. "Literatura y filosofía en Ortega y Gasset", en: Revista de Occidente, $\mathrm{n}^{\circ}$ 132, mayo 1992, p. 81: "La metáfora es la identidad ideal de lo realmente distinto. Es la plasmación de una vida necesariamente transitiva, pero que se convierte en ejercicio amoroso al aceptar en sí mismo lo otro... de sí mismo". 
objeto mismo: se trata de la unión de identidad y diferencia a través de las relaciones entre cosas.

De nuevo el tema de las relaciones, de la ampliación de cosas en su conexionarse con otras, y, también de nuevo, el tema de la unión de limitaciones, sean significados, cosas o naciones, como superación de la limitación. La diferencia está en que si en el concepto la limitación era superada mediante contactos, mediante límites, y, con ello, la superación era asunción, concienciación de la limitación misma, ahora, en el arte, en la metáfora, tal superación supone la aniquilación del objeto real para conducir al objeto estético. También se trata de encontrar el significado pleno, como era la intención del concepto, pero el modo es distinto: el arte no puede abandonar su carácter de pantonomía, de totalidad, y, con él, de entenderse como ficción, como como si.

La metáfora aniquila las cosas reales, precisamente para encontrarles su significado pleno, ideal, "la llama abandona sus límites reales"405, que la constituyen como llama, como llama y nada más, para ampliarse, para ser más y alcanzar un significado ideal que conforme el objeto estético. Ese objeto se conforma, así, como la superación de la limitación, superación de la realidad, de la materialidad, precisamente para conferirle su significado más pleno, ideal. Es el imperativo de vida múltiple, la existencia metafórica como la expresión de no renunciar a nada, la plenitud como expresión de la totalidad de las relaciones. El fondo es siempre el mismo: aunque el arte y la metáfora consigan de forma directa lo que en el concepto únicamente puede constituirse como pretensión (la totalidad, el ideal, la superación de la limitación de un modo pleno, etc.), la re-creación de mundos, la re-creación de espacios, la re-creación de objetos permanecen en todas las ramificaciones ofrecidas por Ortega. Así, en la metáfora:

"El resultado de esta primera operación es, pues, el aniquilamiento de las cosas en lo que son como imágenes reales. Al chocar una con otra rómpense sus rígidos caparazones y la materia interna, en estado fundente, adquiere una blandura de plasma, apto para recibir una nueva forma y estructura. La cosa ciprés y la cosa llama comienzan a fluir y se tornan en tendencia ideal ciprés y tendencia ideal llama. Fuera de la metáfora, en el pensar extrapoético, son cada una de estas cosas término, punto de llegada para nuestra conciencia, son sus objetos. Por esto, el ir hacia una de ellas, excluye el ir hacia la otra. Mas al hacer la metáfora la declaración de su identidad radical, con igual fuerza que la de su radical no-identidad, nos induce a que no busquemos aquella en lo que ambas cosas son como imágenes reales, como términos

405" Ensayo de estética a manera de prólogo" (1914). OC VI, p. 259. 
objetivos; por tanto, a que hagamos de éstas un mero punto de partida, un material, un signo más allá del cual hemos de encontrar la identidad en un nuevo objeto, el ciprés a quien, sin absurdo, podemos tratar como una llama" 406 .

La ruptura de los caparazones es ya una metáfora de la ruptura de la limitación, de su superación entendida como plenitud, y la formación de nuevas estructuras incluye el mismo talante de creación y ampliación que ya suponía el concepto como estructura de conexión, como límite. De nuevo la superación de las limitaciones se produce partiendo de caracteres límite, fronterizos: el objeto ideal, como plenitud a alcanzar, se inicia al entender la realidad de las cosas, su significado habitual, como punto de partida, como límite a partir del cual puede comenzarse una serie de contactos que conduzcan a la formación de un objeto nuevo, un espacio nuevo. Se trata de un ir más allá, un ir a lo otro, un "demorarse en lo diverso", como escribirá Hegel, que permita afirmar tanto identidades como diferencias, con la intención de crear objetos y espacios nuevos que, además de constituirse como tales, mantengan su esencia en la ampliación de los habituales.

El nuevo mundo que crea el arte asume los mismos caracteres de integración que vienen apareciendo desde el inicio, integración de realidad e idealidad, identidad y diferencia, individualidad y conexión. Y la misma integración continúa manteniéndose entre estética y política: el arte como creación de ideales, pero también la Liga de la Educación Política España que presenta Ortega en el mismo año, 1914, se funda para que existan "como en otros tiempos, breves y sencillos ideales políticos, capaces de encender en llama de fe viva los corazones de todo un pueblo'407. Esta necesidad de crear ideales es la que hace del arte un arte político, una estética política.

Ahora bien, además de la metáfora como unión de identidad y diferencia, Ortega avanza otro paso, al conectar con el objeto estético como intimidad, como ejecutividad, que veíamos más arriba. El objeto desrealizado por la metáfora se transforma en actividad íntima, se transforma en yo, se transforma en sentimiento. De nuevo el poder de intervención que aparecía anteriormente, pero, de nuevo, esa intervención es, primero, integradora, y, segundo, creadora. La imagen, la metáfora, se presenta como ejecutándose, como intimidad, en el momento en que expresa una vida propia, una autoconfirmación. Es

\footnotetext{
$406_{\text {Ibid. }}$

407" Vieja y nueva política" (1914). OC I, 285.
} 
una relación nueva, un mundo nuevo, y, como tal, con un funcionamiento y unas leyes propios.

Si esto es así, no puede menos de integrar mi intervención, como sentimiento, con las leyes propias de su espacio, la integración del yo con las cosas 408 . De nuevo la misma relación que mantenía el concepto con las cosas materiales a partir de las cuales formaba estructuras y mundos nuevos: la diferencia es que en el arte esa novedad pretende directamente el carácter de ideal, de totalidad de relaciones. La intervención del yo, como intimidad, en este caso se reduce a colocar los objetos, los significados, en un cierto lugar a partir del cual ellos solos forman un espacio nuevo: ese lugar es el lugar sentimental y "la metáfora, pues, consiste en la transposición de una cosa desde su lugar real a su lugar sentimental"409.

La composición de lugar que aparecía más arriba, referida al hecho de hacer espacio, hacer paisaje, remite ahora al lugar sentimental. La metáfora también es una composición de lugar, pero en dos fases: primero, la intervención del yo como intimidad supone la ejecutividad propia de la imagen, esto es, crea su lugar sentimental, $y$, segundo, con ese lugar sentimental propio, la ejecutividad de la metáfora en sí misma construye su propio espacio, su propia ley de relación, "cada metáfora es el descubrimiento de una ley del universo"410, o, de otro modo, la composición de lugar de la metáfora, su hacer espacio y paisaje, es la composición del lugar sentimental. La metáfora integra, de este modo, la intimidad del yo y la intimidad de la propia imagen, del nuevo mundo creado. También el concepto integraba su funcionamiento como estructura, como esquema, formando nuevos espacios de relación, con la ampliación de los objetos a integrar, y también el concepto partía de su intelección como límite, esto es, identificando y diferenciando.

Es ese proceso de identidad y diferencia el que, tanto en el concepto como en la metáfora, supone la ampliación y creación de mundos, la superación de las limitaciones. Es un proceso de diversificación, de demora en las diferencias, de identificación de lo no-

\footnotetext{
${ }^{408}$ En el prólogo a su edición de La deshumanización del arte y otros ensayos de estética escribe Valeriano Bozal: "Ejecutividad hace referencia a la realización del yo en el hacerse, por tanto a la relación del yo con las cosas". BOZAL, V. "Prólogo", en: ORTEGA Y GASSET, J. La deshumanización del arte y otros ensayos de estética. Madrid: Espasa Calpe, $1993^{3}$, p. 23.

409" Ensayo de estética a manera de prólogo" (1914). OC VI, 261, n.

410 Ibid.
} 
idéntico 411 , que, precisamente por ello, permite la construcción de nuevas conexiones. Pues bien, esta conjunción de la diversificación, por un lado, y de la ampliación de realidad, por otro, aparece también en el tratamiento hegeliano de la metáfora. Es más, si en Ortega la conexión se produce entre metáfora y concepto, en Hegel se producirá nada más y nada menos que entre metáfora y espíritu.

\subsubsection{La metáfora en Hegel}

Hegel define el sentido de la metáfora del modo siguiente: "Como sentido y fin de la dicción metafórica en general ha de considerarse por tanto [...] la necesidad y el poder del espíritu y del ánimo, que no se satisfacen con lo simple, lo habitual, lo trillado, sino que van más allá para pasar a lo otro, demorarse en lo diverso y ensamblar en uno lo doble"412. Demorarse en lo diverso, bei Verschiedenem zu verweilen, no sólo es el sentido de la metáfora, sino también una capacidad y una necesidad del espíritu.

La demora en lo diverso, la huida respecto a la individualidad de lo simple, es una característica que aglutina la potencia y la necesidad del espíritu, en tanto que éste no sólo puede demorarse, extenderse en lo complejo, sino que además necesita hacerlo, necesita retrasarse en la llegada hasta sí mismo. Es el carácter de demora, pues, el que establece el contacto entre espíritu y metáfora.

Si la metáfora e demora en lo diverso, juega con lo uno y lo doble, con la expansión de los significados, el espíritu, por su parte, necesita encontrarse en las determinaciones que recorre, exige su propio desgarramiento, su demora en lo negativo. Este carácter de demora, expresado con el mismo verbo, sich verweilen, aparece en Hegel tanto en la Estética referido a la metáfora, como en la Fenomenología referido al espíritu: "El espíritu sólo conquista su verdad cuando es capaz de encontrarse a sí mismo en el absoluto desgarramiento. El espíritu no es esta potencia como lo positivo que se aparta de lo

\footnotetext{
${ }^{411}$ Es la expresión que utiliza P. Cerezo: "Por decirlo en una forma dialéctica, en la metáfora se lleva a cabo la identificación de lo no-idéntico". CEREZO, P. La voluntad de aventura. Aproximamiento crítico al pensamiento de Ortega y Gasset. Barcelona: Ariel, 1984, p. 418.

412HEGEL, Lecciones sobre la estética. Ed. A. Brotóns. Madrid: Akal, 1989, p. 298. Original: HEGEL, Vorlesungen über die Ästhetik. I. Hrsg. E. Moldenhauer, K. Michel. Frankfurt/M.: Suhrkamp, 1992 3 , p. 520. (A partir de aquí, Estética y Ästhetik, respectivamente).
} 
negativo [...], sino que sólo es esta potencia cuando mira cara a cara a lo negativo y permanece cerca de ello [indem er dem Negativen ins Angesicht schaut, bei ihm verweilt]. Esta permanencia es la fuerza mágica que hace que lo negativo vuelva al ser [Dieses Verweilen ist die Zauberkraft, die es in das Sein umkehrt]"413.

Espíritu y metáfora se apoyan en el mismo rasgo fundamental: ambos huyen de lo simple, ambos se mantienen en el camino de ida y vuelta entre sí mismos y lo otro de sí, la metáfora entre la figura exterior y lo significado, el espíritu entre su ser absoluto y lo para él negativo, sus momentos, su otro. No es casual, pues, que Hegel utilice el mismo verbo, Verweilen, demorar, para mostrar el carácter más propio de espíritu y metáfora. Es éste un carácter que refiere al sistema hegeliano en su conjunto: el sistema se demora en sus diferencias, la conjunción de necesidad y libertad del todo sólo puede darse a través de la "diversificación y determinación de sus distinciones'414.

Hegel expone en concreto el demorarse de la metáfora mediante el examen de lo que considera formas múltiples en el modo de enlace de lo doble. Encuentra tres fundamentos: el reforzamiento, la espiritualización de lo externo y lo que llama "placer lujurioso de la fantasía". Estos caracteres, intentos de dar razón de sí de la metáfora, no son más que muestras del afán por explicar lo doble, esto es, de responder a la cuestión de por qué utilizamos algo que separa lo impropio y lo propio, expresión y significado, literalidad y metáfora 415 . No hay que olvidar que Hegel viene siendo entendido comúnmente como representante por excelencia de la lectura tradicional de la metáfora, la metáfora secundarizada, derivada frente al concepto, y en este sentido, si es correcto lo dicho respecto a Ortega, éste iría más lejos, en cuanto une concepto y metáfora en el afán de ambos por crear mundos y superar limitaciones. Con todo, el proceso de diseminación, de

\footnotetext{
413HEGEL, Fenomenología del espíritu. Op. cit. p. 24. Original: HEGEL, Phänomenologie des Geistes. Hrsg. E. Moldenhauer, K. M. Michel. Frankfurt/M.: Suhrkamp, $1989^{2}$, p. 36. Heidegger, en "El concepto de experiencia de Hegel", ha insistido en este carácter del desgarramiento como esencial en el movimiento de lo absoluto: "Es la penosa tarea de soportar el dolor y el desgarro bajo cuyo signo se encuentra la relación infinita en la que se consuma la esencia de lo absoluto". HEIDEGGER, M. Caminos de bosque. Trad. H. Cortés y A. Leyte. Madrid: Alianza, 1995, p. 130. Original: HEIDEGGER, M. Holzwege. Frankfurt/M.: Klostermann, $1994^{7}$, p. 138.

414HEGEL, Enciclopedia de las ciencias filosóficas. Ed. y trad. R. Valls Plana. Madrid: Alianza, 1997, § 14, p. 117.

$415 "$ ¿Por qué esta expresión duplicada? [...] ¿por qué lo metafórico, que en sí mismo es dualidad?". Estética, 298. Ästhetik, 520.
} 
diferenciación en lo otro de sí parece ya apuntar a la superación de esa crítica habitual a Hegel.

El proceso de diseminación en lo otro de sí del estado de ánimo en la forma artística, representado ahora mediante la metáfora, lo expone Hegel claramente en un manuscrito de sus lecciones sobre estética: "La metáfora tiene, como ya se ha notado, el poder de unir lo diverso. Esta unión tiene por un lado el aspecto de refuerzo. El ánimo está inquieto, agitado, y expresa así también su movimiento, lo pone de relieve; demuestra de esta forma su poder para diseminarse [sich so zu zerstreuen], para traspasar hasta las representaciones más extrañas y, con todo, permanecer junto a sí. La metáfora sirve habitualmente para dar a conocer este movimiento del ánimo'416. Es ese poder para unir lo diverso, así como el traspaso hasta lo otro (diferenciación) y la permanencia junto a sí (identificación) lo que une a Hegel y a Ortega en este contexto, aunque varíen los caracteres.

Mediante esos fundamentos que utiliza Hegel para mostrar el enlace de lo doble podrá entenderse de forma más clara el proceso de diseminación y diversificación en la demora. La metáfora, en su sentido de reforzamiento, refiere, más que al objeto sensible en sí metaforizado, a ese ánimo agitado que huye de lo inmediatamente intuido, de lo habitual y cercano. Es el afán por encontrar lo nuevo en lo ya conocido, hallar lo que cada repetición tiene de original. La metáfora no se deja engañar por lo intuido, por lo presentificado; ve en lo habitual lo desconocido, encuentra mediante su rebuscar en lo más íntimo de toda esencia la forma de huir de lo siempre igual.

Es así como amplía, como disemina el significado inagotable de cada figuración: la metáfora hace infinito todo significado, la metaforización de lo intuido no repite el mismo significado con figura distinta, sino que añade siempre algo nuevo, incluye una marca que amplía la significación habitual: "se trata de la conmoción del ánimo que, en lugar de lo inmediatamente intuido, pone al punto otra imagen y difícilmente puede terminar con este buscar y encontrar modos de expresión de su vehemencia siempre nuevos"417. La novedad es de continuo inherente a la demora en lo múltiple, con lo que la metáfora no es sólo el juego de literalidad y significado de una expresión, sino que introduce constantemente en

416HEGEL, Vorlesungen über Ästhetik. Berlin 1820/1821. Eine Nachschrift. I. Textband. Hrsg. Helmut Schneider. Frankfurt/M.: Peter Lang, 1995, p. 133. Traducción mía.

${ }^{417}$ Estética, 299. Ästhetik, 521. 
su significado la ampliación de sentido, la creación de novedades y relaciones inéditas. Éste es el carácter de reforzamiento que conlleva la metáfora: la expansión de lo simple, inmeditamente intuido, el ir más allá respecto a lo presentificado.

El sentido de espiritualización de lo externo como expresión de la duplicidad de lo figurado, refiere a la fuerza del espíritu para encontrarse a sí mismo en su exterior. Este carácter se desprende del carácter ya tratado de demora del espíritu mismo en la multiplicidad, en la exterioridad. La clave está en el tercer fundamento en el modo de enlace de lo doble, ese "placer lujurioso de la fantasía", que tiene la misma base que la condición de reforzamiento: "La expresión metafórica puede igualmente derivar del placer meramente lujurioso de la fantasía que no puede presentar un objeto en su figura peculiar ni un significado en su simple carencia de imagen, sino que demanda sobre todo una intuición; o bien del ingenio de un arbitrio subjetivo que, para huir de lo habitual, se entrega al estímulo picante que no se ha satisfecho antes de llegar al descubrimiento de rasgos afines en lo aparentemente más heterogéneo y, por tanto a la combinación sorprendente de lo más remoto' 418 .

Ese placer consiste en el anhelo por ir más allá de la mera literalidad, en concederle una imagen a todo significado, no con el fin de entenderlo mejor, sino de ampliar su sentido, de matizar los detalles que de la expresión se pretenden en cada caso, de la huida de lo habitual. Lo peculiar de esta idea no se encuentra en el anhelo de lo distante, sino en la certeza de que la originalidad se incluye como huella de lejanía en lo más familiar. La metáfora no sólo amplía significados o concreta detalles, sino que además se encarga de remarcar el sentido figurado, simbólico, que habita en la raíz misma de toda realidad, incluida la más común: la duplicidad que la metáfora supone mediante el juego expresiónsignificado es posible gracias a que ya de hecho en el interior de las cosas se encuentra la capacidad de expandirse, de ir más allá de sí mediante el contacto con otras determinaciones, de superarse modificando su sentido habitual. La metáfora no haría más que dar cuenta de esta originalidad de las cosas.

Tal carácter de originalidad, de ser más de lo que parece, lo expone Hegel como algo no inmediatamente perteneciente a la cosa: "La metáfora es siempre una interrupción en el curso de la representación y una constante dispersión [Zerstreuung], pues suscita y 
yuxtapone imágenes no inmediatamente pertenecientes a la cosa y al significado y que asimismo pasan por tanto también de éstos a lo afín y heterogéneo'419. No inmediatamente pertenecientes, pero sí de forma mediata, esto es, yendo más allá de lo meramente presentificado en la intuición. La dispersión o diseminación que produce la metáfora tiene, por tanto, su origen en el carácter ya de por sí metafórico, de demora, de no satisfacerse, detenerse en lo simple, carácter inherente a la esencia misma tanto de la cosa como de su significado. El sentido de dispersión, de diseminación, es, pues, algo que precede a la metáfora habitual; ésta viene permitida por la huella de demora, de posibilidad de ampliación ya incluida en las cosas. Es el significado de plenitud que intenta alcanzar Ortega, alcanzar esa ampliación de las cosas para salvarlas, pero porque ellas mismas lo permiten, porque su idealidad es la plenitud de su realidad.

El arte como irrealización en Ortega parte de esta premisa: se irrealizan, se aniquilan las estructuras reales, pero porque se las intenta llevar a su plenitud. La nueva objetividad, el nuevo mundo que supone el objeto estético se inicia en el "previo rompimiento y aniquilación de los objetos reales" 420 , la estructura irreal del arte supera la estructura real de las cosas, pero ambas son "dos caras de un mismo proceso"421. La intervención del carácter de intimidad, de tomar las cosas en su ejecutividad, en su significado pleno, es lo que Ortega entiende como estilo. El estilo es la manera en que cada artista desrealiza las cosas, y, con ello, es un carácter subjetivo.

La integración se produce de este modo entre sujeto y objeto, pero a varios niveles: el sujeto desrealiza lo real, pero porque esto real, primero, lo permite, y, segundo, lo exige, si es que se quiere llegar a su significado pleno. Esta es la integración yo-cosas que supone el arte: "no se olvide que esa subjetividad sólo existe en tanto que se ocupa con cosas, que sólo en las deformaciones introducidas en la realidad aparece. Más claro: el estilo procede de la individualidad del «yo», pero se verifica en las cosas"422. En este sentido, la salvación de las cosas deviene una salvación por las cosas que es una salvación en las

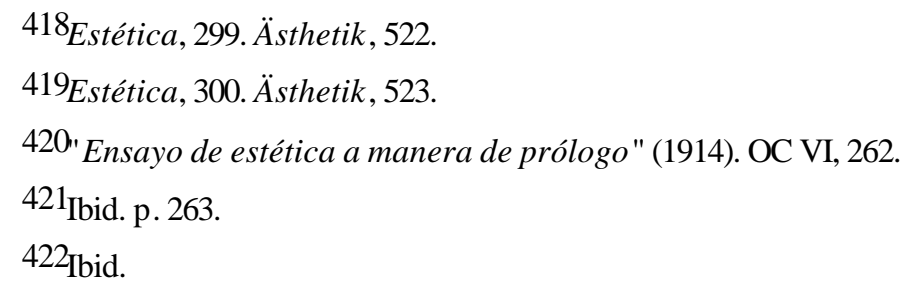


cosas. El carácter de idealidad que introduce el arte, sea hallado por el sujeto, sea partiendo de una desrealización, se inicia en la posibilidad permitida por las cosas para su propia ampliación. En este sentido concuerdan el tema de la metáfora y el tema del concepto, pero también Hegel y Ortega.

La metáfora puede ser concebida como el carácter límite de los objetos, de los significados, en tanto permite tanto la identificación limitadora como la diversidad que supera esa limitación. Si el límite era entendido por Ortega en Meditaciones, partiendo de aquel texto recogido en el prólogo a la Fenomenología, como aquello que está donde no está la cosa, como aquello que aproxima y distancia, también la metáfora cumple los mismos caracteres: está con la cosa, pero remitiendo a fuera de ella, superando su significado habitual, su cotidianeidad, y lo hace aproximando mediante relaciones con otras cosas, pero también distanciando, mostrándose en ese juego de identidad y no-identidad entre los objetos equiparados en la metáfora.

La demora en lo diverso es un modo de expresar esta unidad de identidad y diferencia, unidad que en Hegel era entendida como la coexistencia entre la diseminación en lo extraño y la permanencia junto a sí. La metáfora, partiendo de su existencia irónica, de referir siempre a un otro, a más allá de sí, expresa el carácter de desrealización del arte asentando la dialéctica de la que éste parte: desrealización para la idealización, esto es, para la realización plena. $\mathrm{O}$, entendido en el sentido que venimos utilizando, superación de la limitación, pero para que esa limitación adquiera su máxima potencia. Esta superación, en todos los contextos, refiere a una superación por relaciones, por contactos, y es precisamente ese talante el que conecta indisolublemente estética y política, teoría y práctica. La creación de espacios, de mundos, las composiciones de lugar, son el otro momento determinante. Este talante creador, amplificador, refiere tanto al tema del paisaje, como al del concepto, como al de la metáfora y el arte, o, en general, a la temática de la limitación. La limitación se supera a sí misma, se plenifica, entendiéndose a sí misma como límite y poniendo en contacto las particularidades, sean esas particularidades significados, cosas o naciones. 


\section{DEL LÍMITE A LA HISTORIA (1916-1928)}

\section{Introducción}

En 1915 Ortega leía la conferencia "Temas del Escorial", en 1928 publica "La «Filosofía de la historia de Hegel» y la historiología" y el 'Hegel y América". El objetivo de esta segunda sección es examinar la relación con Hegel y el tema de la limitación que Ortega mantiene entre esas dos fechas, marcadas por los dos primeros viajes a Argentina, en 1916 y en 1928. Es un momento particular de la recepción, un momento intermedio que conducirá hasta la publicación de los tres artículos sobre Hegel y que se muestra como determinante, pues permite ver cómo, por qué y para qué llega Ortega hasta esos tres textos. $\mathrm{Si}$ en la primera sección, el primer momento de la recepción, la clave se encontraba en la relación entre el límite y el paisaje, con el contexto estético del símbolo y la metáfora en el centro, en esta segunda se mostrará la ampliación de esa relación en un sentido concreto, el que exige la inclusión del tema de la historia, el que conduce hasta él.

En 1916 Ortega viaja a Argentina y aparece el primer Espectador. Es el año de la formación de la Liga Espartaquista en Alemania, pero también de la publicación de La metamorfosis de Kafka y de la Introducción al psicoanálisis de Freud. En España el gobierno está en manos del conde de Romanones. 1917 es para Ortega el año del segundo Espectador, también el de la fundación de El Sol, con Nicolás Urgoiti. En Europa, Estados Unidos ha entrado en la guerra y se ha producido la revolución rusa; en España es el año de las Juntas Militares de Defensa, de la Asamblea de Parlamentarios en Barcelona, de la huelga general revolucionaria. Al año siguiente termina la primera guerra mundial, y en 1919 tiene lugar el Tratado de Versalles, a la vez que la creación en Alemania del Partido Nacional-Socialista. Spengler ha publicado La decadencia de Occidente, y Ortega está totalmente dedicado a sus artículos sobre la situación política española: entre 1918 y 1919, el gobierno español pasa por las manos de Maura, García Prieto, Romanones, de nuevo Maura, Sánchez de Toca y Manuel Allendesalazar. La situación es, como poco, confusa: por un lado está la escalada del terrorismo en Barcelona, por el otro el ingreso de España en la Sociedad de Naciones. 
A finales de 1920 Ortega comienza España invertebrada, que aparecerá completo al año siguiente. En 1920 ha escrito 'El «Quijote» en la escuela" y "Los hermanos Zubiaurre", así como multitud de artículos políticos, con lo que continuará la conexión pedagogía-artepolítica; en 1921 aparecerá el tercer Espectador, pero también un texto fundamental como es el prólogo a la Historia de la filosofía de Vorländer. 1920 es el año de la muerte de Galdós, el del gobierno de Eduardo Dato y el del nacimiento del Partido Comunista de España. Paul Valery ha publicado El cementerio marino, Unamuno La tía Tula. En 1921 tiene lugar el desastre de Annual en Marruecos, y los gobiernos de Allendesalazar y Maura. $\mathrm{Al}$ año siguiente muere José Ortega Munilla, padre de Ortega. Es el año de los prólogos (a Freud, a Rickert, a von Uexküll, etc.), pero también el del comienzo de El tema de nuestro tiempo, que verá la luz al año siguiente. Joyce publica el Ulises, Mussolini alcanza la jefatura del gobierno. 1923 es el año de El tema de nuestro tiempo, también de la fundación de Revista de Occidentey, sobre todo, del golpe de estado de Primo de Rivera.

Entre 1924 y 1925 Ortega escribe y publica, por partes, La deshumanización del arte e ideas sobre la novela. También otros textos fundamentales, como "Las dos grandes metáforas", "Kant: reflexiones de centenario" y "Sobre el origen deportivo del Estado". 1924 es el año de la muerte de Lenin, al que sucederá Stalin; al año siguiente Hitler publicará Mein Kampf. Entre 1925 y 1927 verán la luz los números cuatro, cinco y seis del Espectador, en 1927 escribe Ortega Mirabeau o el político", se publica El espíritu de la letra, y aparecen los primeros artículos que luego pasarán a formar parte de La rebelión de las masas. 1927 es también el año de Ser y tiempo y del estreno de Le chien andalou. En 1928 tiene lugar el segundo viaje de Ortega a Argentina y la publicación de los escritos sobre Hegel. Es el año de la huelga general de estudiantes, del Romancero gitano de Lorca, de la fundación del Opus por Escrivá de Balaguer, del descubrimiento de la penicilina...

Si se quiere concretar todo en tres puntos, los años que van desde 1916 a 1928 son, en Europa, los del final de la primera guerra y el comienzo de los talantes que luego darán lugar a la segunda; en España, una situación política confusa y peligrosa que culminará con la dictadura de Primo de Rivera; en Ortega, los años de El Espectador, de la mayor parte de los escritos políticos, de los dos primeros viajes a Argentina, de España invertebrada, El tema de nuestro tiempo y La deshumanización del arte, o, de otro modo, y por temas, España, razón vital y arte. 
Durante estos años, las referencias a Hegel por Ortega son breves y no demasiado numerosas. Son casi insinuaciones, preparaciones de lo que más adelante serán los temas centrales en su recepción: la historia, el concepto de espíritu objetivo, etc. Son insinuaciones que, con todo, mostrarán una importancia determinante si se las analiza junto al contexto en el que se presentan. Hay, sin embargo, un carácter que llama la atención: en una de las temáticas claves, la de la superación del idealismo, Ortega utilizará constantemente, para mostrar su anhelo de integración, un procedimiento de Aufhebung, de superación conservadora, con remisión explícita a Hegel. Esto es importante: la superación del idealismo que pretende llevar a cabo Ortega funciona mediante un mecanismo de Aufhebung, el mecanismo clave de la dialéctica hegeliana.

Ortega utiliza a Hegel, pero lo hace recibiéndolo, aplicándolo a sus propias teorías, a sus propias ideas. La explicación se encuentra en la característica, presentada ya en la introducción, que sirve para todo este trabajo y lo sostiene sobre una teoría de la recepción: Ortega en ningún momento, ni siquiera en los escritos publicados, expone a Hegel. Esa no es su pretensión. De lo que se trata es de utilizar aquello que le es útil, instructivo, para sus propias intenciones, y, en este caso, la Aufhebung como asimilación integradora respondía perfectamente a las que Ortega tenía para su superación del idealismo. 


\section{Aufhebung del idealismo: perspectiva y cortesía}

En el primer Espectador, en 1916, publicó Ortega un texto titulado 'Conciencia, objeto y las tres distancias de este. Fragmentos de una lección", y al título agregaba una nota: "La lección, cuyos son estos fragmentos, corresponde al curso dado en otoño de 1915 y enero, febrero y marzo del corriente en el Centro de Estudios Históricos"423. Ese curso llevaba por título "Sistema de psicología", y refiere al texto editado póstumamente Investigaciones psicológicas. Puede afirmarse que ese escrito se enmarca en el tema de la superación del idealismo, ese idealismo entendido como subjetivismo, ese idealismo "mucilaginoso" que mencionaba ya en Meditaciones. La superación se referirá a este idealismo como subjetivismo.

En la lección VI del curso sobre psicología presenta Ortega el carácter integrador que debería acompañar a la superación del idealismo-subjetivismo, un idealismo entendido por Ortega con todas las connotaciones negativas del estereotipo. Escribe: "Se trata, pues, nada menos que de un nuevo reparto de jurisdicciones entre el sujeto y el objeto. No tiene sentido una vuelta al realismo de los antiguos, pero tampoco nos es posible permanecer dentro del quid pro quo en que el subjetivismo se funda. No puede supeditarse el sujeto al objeto -como hace Aristóteles- ni el objeto al sujeto -como hace en parte Kant, resueltamente Fichte. ¿Qué pues? [...] Tendremos que buscar un equitativo régimen para el sujeto y el objeto, y acaso tengamos que verlos como aquellas divinidades que los etruscos llamaban Dii consentes, dioses conjuntos, de quienes decían que sólo podían nacer y morir juntos"424. La propuesta de Ortega es clara: ni reducción del sujeto al objeto ni reducción del objeto al sujeto, sino la fusión de ambos, una fusión que, con todo, no confunda, que, al igual que el concepto y su conexión con los límites, incluya acercamiento y separación, unión y diferencia. Eso es lo que expresa la metáfora de los dii consentes, una metáfora que se mantiene en el talante integrador que debería reunir al realismo y sensualismo del hombre mediterráneo, del español, y al idealismo y trascendentalismo del europeo, del pathos del norte.

423" Conciencia, objeto y las tres distancias de éste. Fragmentos de una lección" (1915). OC II, 61, n. 424"Investigaciones psicológicas" (1915). OC XII, 388. 
Si la superación del subjetivismo remite a la superación de la divinización del yo que ha caracterizado según Ortega a toda la época moderna ("El idealismo, el subjetivismo es el modo radical de enfrentarse con la vida que llena la edad moderna. [...] Esto ha sido el idealismo subjetivista con más o menos claridad: una divinización del yo'425), pero esa superación no debe significar destrucción, sino punto de apoyo, preparación para otro talante, entonces tal superación exige mantener los rasgos de Aufhebung: "Como Hegel sostenía, en la evolución del pensamiento toda destrucción es una superación y toda superación es una conservación. Porque la nueva idea que supera a la antigua la lleva en sí perpetuamente, como la cantidad mayor lleva en sí las menores, y gracias a ello es mayor. $\mathrm{Al}$ revés que en la generación biológica en la ideológica las ideas recien nacidas llevan en su vientre a sus madres"426. Es el doble sentido de Aufheben que mencionaba Hegel en aquella nota clásica de la Lógica: "Aufheben hat in der Sprache den gedoppelten Sinn, dass es soviel als aufbewahren, erhalten bedeutet und zugleich soviel als aufhören lassen, ein Ende machen'427.

Esta superación hegeliana del idealismo es lo que Ortega considerará el "tema de nuestro tiempo". En ¿Qué es filosofía? lo afirmará de un modo tajante: "la superación del idealismo es la gran tarea intelectual, la alta misión histórica de nuestra época, «el tema de nuestro tiempo»"428. El problema está en que, primero, es necesario afirmar que ese idealismo que pretende superar Ortega remite a un cliché, a una etiqueta bajo la cual entiende una pluralidad de autores y temáticas que superan ampliamente el rótulo de "idealismo": racionalismo, irracionalismo, intelectualismo, filosofía de la cultura, etc. Esa pluralidad es la que causará que la superación de Ortega sea, por un lado, ambigua, y, por el otro, nunca total, pues el idealismo estético y ético que hemos venido viendo en la sección anterior de un modo u otro permanecerá. Pero, en segundo lugar, la superación, siempre hegeliana, exige concretar qué es exactamente lo que quiere superar Ortega, esto es, olvidar por un

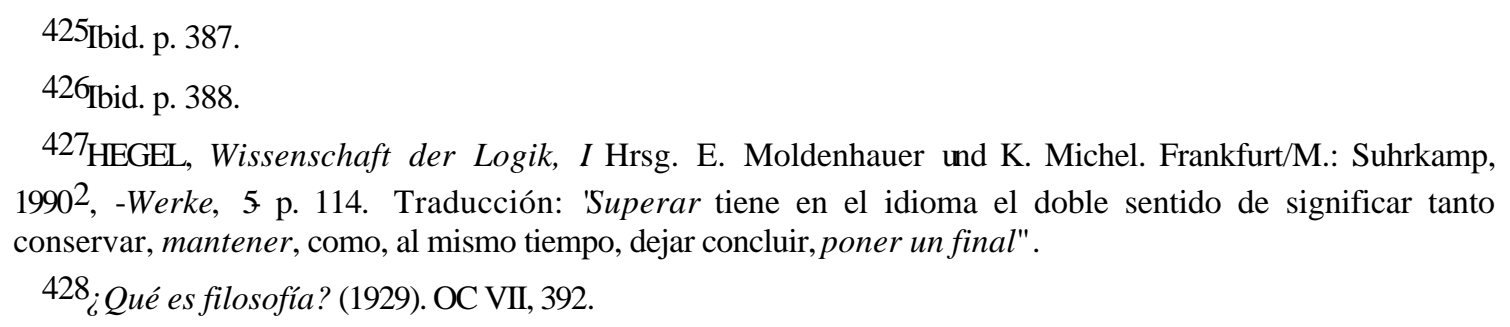
$1990^{2}$, -Werke, 5 p. 114. Traducción: 'Superar tiene en el idioma el doble sentido de significar tanto conservar, mantener, como, al mismo tiempo, dejar concluir, poner un final".

428. ¿Qué es filosofía? (1929). OC VII, 392. 
momento la etiqueta de "idealismo" que Ortega coloca al objeto de esa superación y permanecer en tal objeto en sí mismo.

Si la superación es hegeliana, entonces Ortega ha debido quedarse con algo. No sólo remite esa superación conservadora a un talante histórico, de no olvidar el pasado o utilizar los errores como medios de impulso, sino también a conservación de contenidos. Si se exigen constantemente los caracteres de integración, si la metáfora es la de los dii consentes, si la superación es hegeliana, puede afirmarse que lo que intenta superar Ortega es aquello que, según su lectura del "idealismo", es el máximo carácter de éste: la divinización del yo, el subjetivismo. Es el mismo rasgo que viene apareciendo desde Meditaciones y años antes: la intimidad del sujeto debe exigir la intimidad con las cosas.

La integración es de sujeto y objeto, de yo y cosas. En su concepto de vida Ortega expresará esta integración íntima de yo y mundo, de yo y circunstancia 429 . Y, sin embargo, esa misma integración, esa misma intimidad, por el hecho de basarse en caracteres de fidelidad (a las cosas, a las circunstancias, a los paisajes), requerirá los talantes de plenitud, de insatisfacción, el deseo de ampliar el significado de las cosas, superar las limitaciones mediante metáforas o símbolos, esto es, la teoría del ideal como descontento, que veíamos más arriba referida al arte, con lo que el idealismo estético que pretende tanto mostrar las limitaciones como llevar las cosas a su plenitud permanecerá de un modo u otro.

El conjunto de las Investigaciones psicológicas remite desde el inicio al tema de la superación entendida como integración. La primera superación integradora será la del clasicismo, la de los clásicos, en tanto toda investigación exige el aumento, la ampliación de la ciencia y del objeto sometido a análisis. La superación debe incluir la creación, la renovación: "El aprendizaje mismo lleva en sí la exigencia de concluir y transformarse en creación independiente. Estudiar a un clásico, aprender de un clásico, quiere decir a la postre intentar hacer lo que él hizo; superar el clasicismo anterior, transformar, ampliar,

\footnotetext{
429Molinuevo ha insistido en esto: "A este idealismo disecado va a oponer Ortega un concepto hegeliano de superación. Superar -insiste repetidamente en ello - es «heredar y añadir». Encuentra positiva la exigencia idealista de que no hay mundo si no es para una conciencia, lo que le permite dar un paso más adelante afirmando que tampoco hay hombre sin mundo. Le parece un hallazgo el nuevo concepto moderno de ser como intimidad, porque de él arranca su Idea de la Vida (sic), «intimidad consigo y con las cosas». ¿Es esto, realmente, una superación?, ¿merece la pena?". MOLINUEVO, J.L. El idealismo de Ortega. Madrid: Narcea, 1984, p. 15.
} 
renovar la ciencia"430. Es una superación, entonces, asentada en caracteres de creación, pero también de integración. Es una ampliación de limitaciones, ir más allá de lo ya conseguido, pero sin perder de vista eso superado: se trata de utilizarlo, precisamente para no caer en los mismos errores.

Y esto se refiere tanto a métodos o modos de investigación como a los contenidos mismos. Cuando Ortega defina el subjetivismo como "la interpolación o intromisión de lo psíquico entre el yo que conoce y lo físico", y añada que "es condición esencial para el próximo porvenir de la filosofía y por tanto de la cultura que se extirpe este error, que se corrija fundamentalmente lo que en esta teoría hay de error'431, ya está pensando no sólo en el error, la divinización del yo, la divinización de lo psíquico, sino también en su solución: "la inseparabilidad de subjetividad y objetividad en cuanto realidades no implica su inseparabilidad e indistinción como fenómenos. / Y conste, sobre todo, esta segunda proposición que es, a mi entender, punto de partida para el próximo porvenir de la filosofía $\mathrm{y}$, en consecuencia, de la manera de ver el mundo que impere mañana: lo psíquico y lo físico se nos dan como fenómenos distintos, con la misma inmediatez. No se puede reducir lo uno a lo otro' 432 .

Integración, sí, pero siempre sin reducciones, sin invasiones. Se admite que la conciencia es referirse a un objeto, con todos los componentes fenomenológicos e intencionales del Ortega del momento, se admite que "objeto es todo aquello a que cabe referirse de un modo $\mathrm{u}$ otro. $\mathrm{Y}$ viceversa: conciencia es referirse a un objeto'433, pero siempre desde una integración equitativa entre ellos, desde la superación de los rasgos parcializadores de realismo y subjetivismo, esto es, desde la metáfora integradora de los dii consentes. Es por ello por lo que la superación del idealismo es una superación hegeliana: permanece el hecho de que no hay objeto si no es para una conciencia, no hay mundo si no es para un sujeto, pero tampoco hay hombre sin mundo, nunca hay yo sin circunstancia, la

\footnotetext{
430"Investigaciones psicológicas" (1915). OC XII, 341.

${ }^{431}$ Ibid. p. 358.

${ }^{432}$ Ibid. p. 360.

433 Ibid. p. 378.
} 
conciencia no es más que un lado de la relación de ese "fenómeno fundamental de dirigirse un sujeto a un objeto, o viceversa de hallarse un objeto ante un sujeto' 434.

Si esta conciencia como parte, como uno de los lados de la integración, es lo que permanece, lo que se asume, aquello que hay que negar refiere al talante más parcializador del subjetivismo: el escepticismo, el relativismo. Escribe Ortega: "Llamo subjetivismo (relativismo) a toda teoría del conocimiento donde el carácter de verdad se hace dependiente, en una forma u otra, de la constitución del sujeto que conoce. [...] Hecha esta afirmación nominal afirmo primero: que todo subjetivismo (relativismo) es escepticismo. Segundo: que el escepticismo es una proposición absurda"435. Ahora bien, esto supone un problema importante, porque no refiere únicamente al tema del relativismo o escepticismo como tales, sino que implica una teoría crucial para Ortega y sobre la que deberá insistir para que no se confunda con el relativismo escéptico: es la teoría de la perspectiva.

El escepticismo tiene un valor positivo, el hecho de que con la duda se inicia el recorrido que conducirá hasta la verdad, "tenemos que llegar a la verdad por la duda y a la filosofía por el escepticismo", escribe Ortega 436, cuando esto no supone la anulación de la verdad, sino su multiplicidad, su carácter perspectivista y circunstancial, esto es, múltiple, con lo que todo concordará con el proceso seguido: la perspectiva es otro modo de entender la limitación, y lo que ello significa, perspectivas limitadas, sí, pero que requieren su integración con otras, requieren aprender a mirar desde la pupila del otro, sabiendo que la de cada cual es insustituible.

La pluralidad de opiniones o la relatividad de la verdad, los clásicos tropos de Agripa para mostrar la fuerza del escepticismo, no tienen como consecuencia que no haya verdad, sino que plantean el problema particular de cómo es posible esa diversidad. Si la verdad es la adecuación entre pensamiento y realidad, y Ortega ha negado el carácter divinizador y exclusivista del yo que implicaba el subjetivismo, entonces puede llevar a cabo una conversión de ese subjetivismo mediante la cual la pluralidad de opiniones deviene pluralidad de perspectivas. Negar el carácter exclusivista del sujeto implica negar el carácter exclusivista de la verdad, la verdad para mí es verdad en absoluto. La integración

\footnotetext{
${ }^{434}$ Ibid. p. 392.

435 Ibid. p. 422.
} 
de sujeto y objeto, de yo y mundo, implica la pluralidad de perspectivas, de aspectos, de paisajes, de pupilas.

Surge, de nuevo, ahora en torno a la teoría de la verdad y la perspectiva, el talante de integración, de conexión, que suponía en la teoría del paisaje ponernos en la pupila del otro. La limitación que conlleva el paisaje es la misma que la que posee la perspectiva, la diversidad y la diferencia van a exiger la unidad e integración de las perspectivas, una integración que, como siempre, respeta las particularizaciones y limitaciones. Así, "donde yo estoy en efecto nadie está, y el mundo envía hacia mí una perspectiva, toma un aspecto que sólo yo puedo ver. Pero esto no quiere decir que el mundo no sea como yo digo y veo. Todos los aspectos y perspectivas lo son verdaderamente del objeto' 437 .

En este momento contactan la teoría de la perspectiva, la teoría del paisaje y la teoría de la limitación. En El tema de nuestro tiempo Ortega lo afirmará de un modo explícito: "la realidad, como un paisaje, tiene infinitas perspectivas, todas ellas igualmente verídicas y auténticas. La sola perspectiva falsa es esa que pretende ser la única"438, lo que implica la negación del "paisaje arquetipo": "ese paisaje arquetipo no existe ni puede existir. La realidad misma es tal, que sólo puede ser vista bajo una determinada perspectiva"439. Ya en Meditaciones había insistido en ello: "el ser definitivo del mundo no es materia ni es alma, no es cosa alguna determinada - sino una perspectiva'440. La conclusión, de nuevo, consiste en ver que, en el fondo, se encuentra el tema de España y, con él, el de la limitación. Es la amplitud del tema de la limitación que viene apareciendo desde el comienzo: esa limitación refiere a paisajes, conceptos, perspectivas, naciones, individuos...

Ortega acude a la misma teoría del medio que más arriba aparecía eferida al tema del paisaje, pero ahora ya conjuntando todos los caracteres, esto es, medio, individuo, España, integración, etc. Incluso las conexiones con aquellas notas sobre la limitación donde se exponía el "dios como complemento de la limitación" parecen claras:

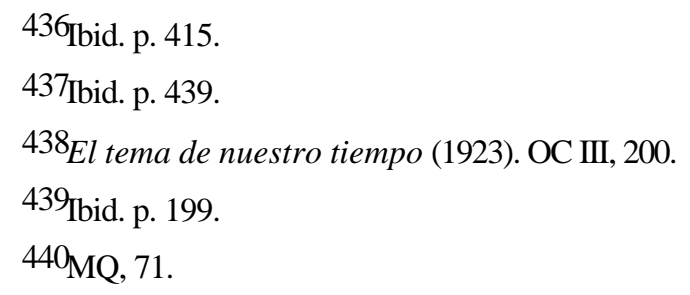


"El ser crea su medio - lo selecciona, lo recorta. Cada individuo necesario. El foco. / El individuo como un órgano y un tentáculo del universo. La raza. - La nación. / La vertiente española del mundo. / Los haces verdaderos o trozos del mundo se constituyen en las razas, en las épocas, en los individuos. Y el universo no lo es en nadie porque individuo es «punto de vista exclusivo». La historia es interindividual como integración de esos trozos de mundo. Dios como la integración, correlato del universo -omnitudo veritatum es la exclusión de toda exclusión. Dios exigencia derivada de la lógica. Si no, la física no existe. / En suma, quien no se obstine en contrasentidos, en lugar de decir «la verdad es la verdad para mí», tendrá que decir la «verdad para mí» es verdad en sí, absoluta"441.

Es esta teoría de la perspectiva, entendida como particularización e individuación integradora de mundos y sujetos, de realidades y miradas, la que verdaderamente supera la divinización del yo que implicaba el idealismo en el sentido de Ortega. Las perspectivas son también ejemplos de limitaciones, como lo es este individuo que se muestra como necesario. Al respeto por el individuo que más arriba encontrábamos en la pedagogía social se une ahora otro carácter integrador: la cortesía, cortesía para con las distintas limitaciones, para con los distintos paisajes, para con las distintas perspectivas. Es en la cortesía donde la perspectiva deviene límite, donde el talante individualizador de la perspectiva remite a su necesaria integración con otras.

Se trata de la ley de cósmica cortesía que Ortega mencionaba en la 'Introducción a un Don Juan": "Cada cosa nos impone tácitamente una peculiar distancia y una determinada perspectiva. Quien quiera ver el universo como es tiene que aceptar esta ley de cósmica cortesía"442. La cortesía para aceptar las perspectivas de los otros, la cortesía para poder poner nuestra pupila en lugar de la del otro, la cortesía, de un modo sencillo, como una táctica de convivencia, de conversación entre perspectivas, entre limitaciones. Es la "corrección" que hace Ortega al versículo de San Juan, entendiendo logos como conversación: "En el comienzo era la cortesía... y luego empezó la conversación"443.

La integración se produce, entonces, entre exclusividades, entre puntos de vista o perspectivas particulares, limitadas. Dios como exclusión de toda exclusión es el ideal, la conjunción ideal de las realidades particulares. La verdadera representación divina en este sentido es la de la nota citada más arriba, la de "cada paisaje un Dios: el desierto es

\footnotetext{
441"Investigaciones psicológicas" (1915). OC XII, 439.

442" Introducción a un Don Juan" (1921). OC VI, 133.

443" Diálogos superfluos" (1918). OC X, 431.
} 
monoteísta"444. Ese desierto monoteísta lo aclara Ortega en un texto del periodo que nos ocupa, "Abenjaldún nos revela el secreto". Hablando del puritanismo, del wehabismo, de los caracteres agresivos del mahometismo, escribe Ortega: "La fe mahometana es constitutivamente polémica, guerrera. Consiste, ante todo, en creer que los demás no tienen derecho a creer lo que nosotros no creemos. Mas bien que monoteísmo, el nombre psicológicamente exacto de esta religión sería «no-politeísmo». [...] En este sentido hay que entender la frase de Renan: «El desierto es monoteísta». El desierto lo que es, como tipo de vida humana, es agresivo y soberbio. El beduino sólo se entusiasmará con una idea que le invite a devastar ciudades'445. Ese desierto monoteísta, como ejemplificación de la limitación agresiva, de la perspectiva soberbia que se cree única, es al que debe oponerse la teoría de la perspectiva, de la verdad múltiple. "Cada paisaje un dios" significa "cada perspectiva un dios": las particularidades remiten a su limitación, pero, sobre todo, también a la cortesía que haga posible la convivencia.

A la frase de Renan de "el desierto es monoteísta" hay que añadirle el dicho que Ortega repite por doquier, el dicho de los beduinos en el oásis: "bebe y deja tu sitio a otro". La teoría de la perspectiva, del paisaje o de la limitación es una teoría del respeto y de la cortesía partiendo, precisamente, del juego de unas limitaciones que se convierten en límites, en contactos. La cortesía no sólo permite ser capaz de ver a las situaciones, a los objetos, a los individuos, en todas sus facetas, en sus caras múltiples, sino que además exige la convivencia entre esa multiplicidad.

Es la cortesía como sabiduría de perspectiva, que tiene el mismo objetivo que toda superación (hegeliana) de las limitaciones, la creación de espacio, la ampliación del mundo: "Tenemos que preparar el nuevo progreso con una sabiduría de perspectiva. De otro modo, no lograremos una verdadera ampliación del orbe"446. Es esta sabiduría de perspectiva, basada en la cortesía para con las limitaciones, la que reúne la particularización del desierto monoteísta con el dios como exclusión de toda exclusión. Si se quiere concretar más aún: la teoría de la perspectiva no puede separarse de una propuesta de integración entre identidad

\footnotetext{
444" Sobre Cervantes y El Quijote desde el Escorial. (Notas de trabajo de José Ortega y Gasset)". Op. cit. p. 50 .

445" Abenjaldún nos revela el secreto (Pensamientos sobre África menor)" (1927). OC II, 683.

446" Para la cultura del amor" (1917). OC II, 141.
} 
y convivencia, sea de individuos, sea de naciones. En el caso de España, esa propuesta quedará plasmada en España invertebrada.

El conjunto de los caracteres de integración y perspectiva, superando el marco de las Investigaciones psicológicas tiene su expresión más concentrada en un texto del primer Espectador, "Verdad y perspectiva". En ese texto, necesario para entender la cita anterior de Investigaciones psicológicas, Ortega concreta todas las insinuaciones ya comentadas que allí eran simples apuntes:

"La verdad, lo real, el universo, la vida -como queráis llamarlo-, se quiebra en facetas innumerables, en vertientes sin cuento, cada una de las cuales da hacia un individuo. Si éste ha sabido ser fiel a su punto de vista, si ha resistido a la eterna seducción de cambiar su retina por otra imaginaria, lo que se ve será un aspecto real del mundo. / Y viceversa: cada hombre tiene una misión de verdad. Donde está mi pupila no está otra: lo que de la realidad ve mi pupila no lo ve otra. Somos insustituibles, somos necesarios. «Sólo entre todos los hombres llega a ser vivido lo humano» -dice Goethe. Dentro de la humanidad cada raza, dentro de cada raza cada individuo, es un órgano de percepción distinto de todos los demás y como un tentáculo que llega a trozos de universo para los otros inasequibles. / La realidad, pues, se ofrece en perspectivas individuales. Lo que para uno está en último plano, se halla para otro en primer término. El paisaje ordena sus tamaños y sus distancias de acuerdo con nuestra retina, y nuestro corazón reparte los acentos. La perspectiva visual y la intelectual se complican con la perspectiva de la valoración. En vez de disputar, integremos nuestras visiones en generosa colaboración espiritual, y como las riberas independientes se aunan en la gruesa vena del río, compongamos el torrente de lo real" 447 .

No es casual que ese texto sea el inicio de El Espectador, y no lo es porque la pretensión de Ortega está clara: conjuntar en un hilo común las diversas ramas, que pueden parecer diferentes, de su vida intelectual, dejar muy claro que la integración refiere tanto a perspectivas, como a individuos, como a naciones, como a puntos de vista. Ese párrafo aglutina todos los caracteres: las facetas innumerables de lo real, el talante individual, limitador, de cada punto de vista, la necesidad de integración de las individualidades, la conexión de paisaje y perspectiva, la colaboración aglutinadora en todos los aspectos, etc.

447" Verdad y perspectiva" (1916). OC II, 19. 


\section{La nueva sensibilidad. Hegel y la tragedia de la limitación}

Hay otro escrito de Ortega, del mismo año que "Verdad y perspectiva", que no sólo completa las Investigaciones psicológicas, sino también todos los caracteres que venimos viendo. Ese escrito corresponde a las lecciones ofrecidas por Ortega en su primer viaje a Argentina en 1916, curso titulado 'Introducción a los problemas actuales de la filosofía", y que es el complemento ineludible para entender las Investigaciones psicológicas. Es conveniente comenzar por las referencias a Hegel, una remitiendo, de nuevo, a esa superación del idealismo como Aufhebung, otra, importante para nuestro tema, en el contexto del tema de la limitación.

La segunda conferencia en Buenos Aires del año 16 culmina con el mismo tema y los mismos textos que aparecían en el curso sobre psicología. Se trata de la superación del idealismo subjetivista, de nuevo remitiendo a los dii consentes, a la propuesta de no renunciar a nada y, también, insistiendo en que esa superación debe ser hegeliana: "Hegel sostenía que en la evolución del pensamiento destrucción quiere decir superación, y superación quiere decir conservación. La nueva idea que llega, tiene perpetuamente dentro de sí la antigua idea"448. Las mismas palabras, entonces, que en Investigaciones psicológicas. El resultado de esa integración, de esa superación, será la mirada jánica, bifronte, del dyonisoplatón que más arriba veíamos uniendo cuerpo y alma, pasión e idea, hombre del sur y hombre del norte. Es esa integración la que deberá conseguir el nacimiento de una nueva sensibilidad, la sensibilidad para las circunstancias, para las perspectivas, para las limitaciones, que trata de encontrar lo ideal precisamente en lo real, en la fidelidad a las cosas.

La nueva sensibilidad es expresada muy claramente por Ortega en la conferencia ofrecida en el teatro Odeón de Buenos Aires el 15 de noviembre de 1916. Es la nueva sensibilidad que ofrece el comienzo de siglo: "El 1900 no significa sólo una cifra que varía en el calendario, es una nueva sensibilidad en los corazones" 449 . Hay que recordar que en Meditaciones había presentado el no escrito Ensayo sobre la limitación como "la mutación

\footnotetext{
448 Meditación de nuestro tiempo. Ed. J.L. Molinuevo. México/Madrid: F.C.E., 1996, p. 65.

449" El novecentismo" (1916), en: Meditación del pueblo joven y otros ensayos sobre América. Madrid: Revista de Occidente en Alianza -Obras de José Ortega y Gasset, 11-, 1981, p. 15.
} 
de nuestra sensibilidad para las circunstancias"450. Esa nueva sensibilidad es la que parte de la integración de cuerpo y alma, de realismo e idealismo, materia e idea, parte de ella y revierte en la fidelidad a las cosas, buscando en ellas su plenitud, su ideal. Es una fidelidad a la limitación entendida en la forma de su superación, cuando el cambio supone una modificación en la atención: atención para las cosas y para las circunstancias, pero también para la convivencia entre ellas.

De ahí la remisión al arte, y no sólo entendido como superación de la limitación, como integración de realidad e idealidad, sino a una vida que ya es arte. El arte nuevo será este arte de convivencia, esta nueva sensibilidad entendida como nueva forma de cultura. Es el sentido estético del vivir que Ortega definía en "Para un museo romántico": "El arte supremo será el que haga de la vida misma un arte. [...] La forma soberana del vivir es convivir, y una convivencia cuidada, como se cuida una obra de arte, sería la cima del universo. [...] Se inicia una nueva forma de cultura -la vida selecta y armoniosa-; despierta un arte nuevo: la vida como arte" 451 .

Por todo esto el cambio de sensibilidad, asentado en la fidelidad a las cosas, supone también un cambio en la atención: "una nueva época no es sino un nuevo régimen de la atención"452. La atención es ahora para lo cercano, para lo próximo, sabiendo que en ello se encuentra la posibilidad del ideal. Es la fidelidad a lo real, a la limitación, si se quiere, pero siendo consciente de la posibilidad de su superación, de su posible plenitud: "la vida es limitada, por tanto es preciso cargarla de realidades' 453 , y es precisamente en esas realidades, asentadas en su aspiración de plenitud, donde la fidelidad que les dedica la nueva sensibilidad busca todo tipo de dinamismo, de progreso, de vida ascendente. A ello remite Ortega utilizando a Nietzsche: "Tenía razón Nietzsche al anunciar que el tiempo nuevo preferiría una moral dinámica y creadora a una moral de esclavitud y de inercia -a la humildad la nobleza, a la renuncia la energía, a la discreción el entusiasmo. En suma, como él dice, a las virtudes de la vida en decadencia las fuertes virtudes de la vida

\footnotetext{
$450 \mathrm{MQ}, 66$.

451" Para un museo romántico" (1921). OC II, 519.

452" El novecentismo" (1916). Op. cit. p. 16.

453Ibid. p. 19.
} 
ascendente"454. El arte de la vida, o, mejor, la vida como arte, basada en el cambio de atención, en la fidelidad a las cosas, se asienta en este carácter ascendente, en el entusiasmo que posibilitará el dinamismo, la convivencia entre las limitaciones, entre las distintas perspectivas: "yo diría que la nueva sensibilidad aspira a un arte, a una moral y a una vida que, como los torsos del Buonarroti, tengan un maraviglioso gesto di muoversi" 455 . Es el mismo dinamismo que más arriba veíamos tanto en la estética como en la política.

La fidelidad a las cosas, a lo más cercano, incluye entonces la posibilidad de acercamiento a lo lejano. Por ello la constante conexión con el arte y la metáfora: "La metáfora es un acto intelectual por medio del cual podemos llegar a apoderarnos de lo que está más lejos de nuestra costumbre. Con lo más próximo, con lo que mejor dominamos intelectivamente, nos aproximamos a lo más lejano'456. Ya vimos más arriba (en el capítulo "Ortega y Hegel sobre la metáfora") las conexiones de esta teoría de la metáfora con la de Hegel en la Estética, entendiendo la figura metafórica y simbólica como superación de la limitación. No es casual, entonces, que en las mismas lecciones de Buenos Aires Ortega vuelva a utilizar a Hegel en relación con el tema de la limitación. El contexto es ahora el de la teoría del medio, de la perspectiva, de los mundos innumerables:

"Para el organismo nacer, estar compuesto con una determinada estructura, con unos ciertos órganos es ya romper violentamente el mundo y quedar abrazado a uno solo de sus trozos. Ved por dónde viene la más reciente biología a inyectar nuevo sentido en los versos centenarios de nuestro Calderón: «Porque el delito mayor del hombre es haber nacido». Sí, del hombre en cuanto organismo vivo, como de todo otro animal es nacer limitarse, podar la realidad. Aquí fundaba Hegel su idea de la tragedia: todo individuo es limitación y como no sabe que hay mundos innumerables junto a él, cree que es el todo" 457 .

Será la teoría de la perspectiva, de esa vida como arte basada en juegos de convivencia, de conexiones, la que mostrará la posibilidad de los mundos innumerables. Es el carácter de la individualidad insustituible que aparecía en el texto citado de "Verdad y perspectiva": la quiebra del mundo en facetas plurales basada en la multiplicidad de individuos, de paisajes, de limitaciones. La exposición del tema de la tragedia en la Estética de Hegel ejemplifica

\footnotetext{
454Ibid. p. 23.

455 Ibid. pp. 23-24.

456 Meditación de nuestro tiempo. Op. cit. p. 159.

457 Ibid. pp. 82-83.
} 
para Ortega la limitación del individuo en su carácter de insustituible, único, pero mostrando el resultado negativo, trágico, que significaría la ausencia de integración. En un añadido lateral al margen de esa referencia a la tragedia en Hegel escribe Ortega: "Como para Calderón, para Hegel todo individuo que nace es tragedia que nace. ¿Tendrán razón? Otro día lo veremos"458. La referencia, entonces, no es únicamente al tema de la tragedia, sino también al del individuo.

Será precisamente el tema del individuo uno de los principales motivos de enfrentamiento entre Ortega y Hegel. Más adelante se mostrará de un modo detallado en el contexto de la filosofía de la historia (más arriba aparecía, en este sentido, en el tema de las pasiones), y en sus notas de lectura sobre Hegel insiste en ello constantemente. Un ejemplo: "En la concepción de la historia de Hegel hay una nota prusiana, dura, gengis-khanesca, molokista - que hace rodar la carroza histórica sobre los individuos, aplastándolos no sólo sin piedad sino sin percibirlo siquiera. El individuo se siente hormiga. No tiene por sí papel. Para tenerlo tiene que desindividualizarse, servir a lo general"459. Sin embargo, la referencia a la teoría de la tragedia de las lecciones de Buenos Aires debe interpretarse también en otro sentido.

El contexto es aquí el del tema de la perspectiva y, con él, el de la limitación. Diez años antes de las conferencias en Buenos Aires escribía Ortega un texto muy similar en una carta a Unamuno sobre Cervantes, y que no fue enviada. Esa carta, redactada en Marburgo, es de febrero de 1907. No hay que forzar demasiado la lectura de ese texto para, primero y en particular, ver la conexión con la tragedia hegeliana de la limitación que aparece ahora en las lecciones de Argentina, y, segundo y en general, ver los inicios de lo que luego se convertirá en la teoría de la perspectiva o del punto de vista. Escribe Ortega a Unamuno: "Todas las realidades son trágicas porque ninguna es realidad: y esto, porque ninguna es la sola realidad sino la únicamente mía. La tragedia consiste en que el individuo necesita convertir su realidad en la realidad. Como él la crea cree que él la es, que él es todo'460.

\footnotetext{
458 Ibid. p. 83 n.

459Archivo de la "Fundación José Ortega y Gasset", Carpetilla "Hegel: filosofía de la historia". Conjunto de notas titulado "Detalles históricos".

${ }^{460}$ Epistolario completo Ortega-Unamuno. Ed. L. Robles. Madrid: El Arquero, 1987, p. 169, carta AII.
} 
La teoría de la tragedia en Hegel expresa de un modo particular el sentimiento de limitación que utiliza Ortega. Para Hegel, el tema de la tragedia "propiamente dicho es lo divino", lo divino entendido "tal como interviene en el mundo, en la acción individual", con lo que esa divinidad mundanizada queda caracterizada como lo ético (das Sittliche), pues lo ético es "lo divino en su realidad mundana"461. Es a los caracteres de totalidad que expresan la divinidad y la eticidad a los que se enfrenta la limitación del individuo. La acción individual quiere imponer sus fines, sus intenciones, con lo que se produce la oposición que da origen al desenlace trágico.

Se trata de la solución, el desenlace de la colisión entre individuo y todo, la que presenta los verdaderos caracteres trágicos, la destrucción de la individualidad: "la justicia eterna se ejerce sobre los fines y los individuos de tal modo que restaura la sustancia y la unidad éticas [die sittliche Substanz und Einheit] con la destrucción de la individualidad perturbadora de su calma"462. La unilateralidad de lo particular, o, en el sentido de Ortega, la limitación del individuo, debe renunciar a sus pretensiones de totalidad, en tanto ésta no admite el carácter particular de su acción. El individuo no reconoce su limitación, no es capaz de superarla, y no puede hacerlo porque su propia tragedia consiste en no poder salir de sí mismo, en no ser capaz de convertir las limitaciones en límites.

En la tragedia, el individuo debe renunciar a sus objetivos: "Lo que por tanto se supera en el desenlace trágico es sólo la particularidad unilateral que no ha podido encajar en esta armonía y que en la tragicidad de su acción, no pudiendo abdicar de sí misma y de sus propósitos, se ve en toda su totalidad expuesta a la ruina o al menos obligada a renunciar"463. Ahora bien, si en la teoría hegeliana de la tragedia se produce una cierta sublimación del final trágico, de la muerte, al posibilitarse así el paso a la armonía de individuo y totalidad 464 , la solución de Ortega al problema de la limitación del individuo

461 HEGEL, Lecciones sobre la estética. Ed. A. Brotóns. Madrid: Akal, 1989, p. 856. Original: HEGEL, Vorlesungen über die Ästhetik. III. Hrsg. E. Moldenhauer, K. Michel. Frankfurt/M.: Suhrkamp, 19933 , p. 522. (A partir de aquí, Estética y Ästhetik, III, respectivamente).

${ }^{462}$ Estética, p. 857; Ästhetik, III, p. 524.

463 Ibid.

${ }^{464}$ Villacañas ha incidido en esto: "La propia teoría de la tragedia de Hegel encuentra la manera de sublimar la muerte en la positividad de la unidad que aparece sobre ella". VILLACAÑAS, J.L. Tragedia y teodicea de la historia. El destino de los ideales en Lessing y Schiller. Madrid: Visor, 1993, p. 16 n. 
viene representado por la teoría de la perspectiva, esto es, no la unidad armónica de la muerte, del final tágico, sino los caracteres de integración que supone la necesaria unión de puntos de vista.

Ortega, de este modo, supera la tragedia de la limitación del hombre al convertir esa limitación en límite, en "dulce frontera". En un texto perteneciente al mismo espacio temporal en el que nos movemos, el comentario a El obispo leproso de Miró, Ortega concretaba esta conversión, esta superación de la tragedia de la limitación de un modo explícito. El párrafo debería ser mantenido siempre al lado de la referencia a la limitación del individuo en la tragedia hegeliana: "Complazcámonos en reconocer nuestra limitación: así, a la vez, la superamos. Es el mayor privilegio del hombre este de poder asomarse, como a unas bardas, a sus propios límites y ver que él termina dlí, pero no el mundo. De este modo, el límite trágico queda transfigurado en dulce frontera. Nos tranquiliza -si somos generosos- pensar que donde nosotros concluimos empiezan otras cosas, y que en ellas acaso se encuentren esos pedazos que a nosotros nos faltan' 465 .

El reconocimiento de la limitación como superación mantiene los mismos caracteres de Aufhebung que la superación del idealismo. Es una superación que es integración, que lleva en su interior la ley de cortesía, de convivencia, de fidelidad a las cosas que implica la nueva sensibilidad. La transfiguración del límite trágico, la limitación, en dulce frontera, el límite, expresa la conclusión de Ortega al problema de la individualidad. En esa transfiguración se reúnen los tres textos citados, la referencia a Hegel en las lecciones de Argentina, la referencia a la tragedia en la carta a Unamuno y la referencia al propósito de continuación, de integración, que implica ese privilegio del hombre como superación de la limitación.

Si quiere expresarse de un modo general puede hacerse del modo siguiente: la teoría de la perspectiva supone tanto la particularización e insustituibilidad del individuo, como la necesaria conexión de las limitaciones; esto implica la superación hegeliana del idealismo subjetivis ta porque la intención concreta estriba en la fidelidad a las cosas y las leyes de cortesía, que no permiten ni la divinización del yo ni la del objeto por separado; el resultado es una serie de connotaciones de unidad e integración que deben remitir a la vida

465" «El obispo leproso», novela, por Gabriel Miró", en: El espíritu de la letra (1927). OC III, 544. 
ascendente, al dinamismo, al progreso, a la conexión de idealidad y realidad sin abstracciones y utopismos.

De ahí la implicación del arte y la metáfora, pues éstos tanto superan limitaciones como muestran leyes de convivencia, de cortesía y respeto para con, y entre, las cosas. El conjunto expresará la fidelidad a las cosas en la fidelidad a sus ideales. Es la idea que Ortega exponía de modo explícito en "Estética en el tranvía", texto también de 1916: "Cada cosa al nacer trae su intransferible ideal" 466 , o, de otro modo, "dondequiera nos es fecunda esta idea, que descubre en la realidad misma, en lo que tiene de más imprevisible, en su capacidad de innovación ilimitada, la sublime incubadora de ideales, de normas, de perfecciones"467. La fidelidad a lo real, así, es también fidelidad a su capacidad para la ampliación de mundo, para la evolución y el progreso.

466" Estética en el tranvía" (1916). OC II, 37.

467Ibid. p. 38. 


\section{Filosofía de lo real, política realista}

La unidad integradora, la mirada jánica del dyonisoplatón que reúne en la fidelidad a las cosas también la fidelidad a sus posibilidades de plenitud, de superación de limitaciones, de progreso, es precisamente la que se enfrenta al "progresismo" de la modernidad materialista y positivista del XIX. Es crucial en este sentido que, en el escrito ya clásico de Ortega, también de 1916, "Nada moderno y muy siglo $X X "$ incidiese precisamente en la imposibilidad de progresos, de superaciones, enmascarada en el supuesto talante de "progresismo" que caracterizaba al siglo anterior: "Una de las singularidades de ese siglo fue la de precaverse a tiempo contra todo tipo de superación"468, o, de otro modo, "el siglo XIX no consiente a los futuros ser de otro modo que él y pretende imponerles, no sólo sus preocupaciones, sino hasta el rango que en su ánimo gozaban. El siglo progresista no concibe que se dé el progreso en otra forma que en estado de alma progresista" 469.

La nueva sensibilidad se asienta precisamente en el talante dinamizador de la vida ascendente, en la necesaria convivencia e integración de las múltiples realidades para posibilitar ideales de evolución. Es otra de las explicaciones de por qué acude Ortega a la superación hegeliana para mostrar su relación con el idealismo subjetivista: el hecho mismo de la superación es ya un carácter de la nueva sensibilidad, del dinamismo que suponen los caracteres de integración.

La misma razón explica uno de los temas recurrentes de Ortega en estos años: la crítica a los neos -, a las filosofías restauradoras, entre ellas el neohegelianismo 470 . El contexto es siempre el mismo: al positivismo y materialismo del XIX, sostenidos por el cientificismo utilitarista, responde una serie de filosofías que pretenden recuperar lo propio de la

470 En la biblioteca de la "Fundación José Ortega y Gasset" se encuentra un librito, seguramente manejado por Ortega, por referir a todo el talante neokantiano de sus maestros en Marburgo, que aclara las direcciones del neohegelianismo. Es importante tener en cuenta la fecha de ese escrito, 1927, justo un año antes de los textos de Ortega sobre Hegel. La obra es: LEVY, H. Die Hegel-Renaissance in der deutschen Philosophie mit besonderer Berücksichtigung des Neukantismus. Philosophische Vorträge, Kant-Gesellschaft. Leipzig: PanVerlag Rolf Heise, 1927. Los autores tratados en la obra de Levy, por capítulos, de un modo u otro determinan el contexto de la filosofía alemana que estudió Ortega: Dilthey, Spranger, Husserl, Litt, Freyer, Troeltsch, Simmel, Cohen, Natorp, Cassirer, Hartmann, Liebert, Windelband, Rickert, Lask, Bauch, Kroner y Jonas Cohn.
} 
filosofía, y, para ello, vuelven a los clásicos, regresan "a la escuela": "Volvemos atrás, volvemos a Kant, a Fichte, a Hegel. Son las filosofías que yo llamo restauradoras"471. Pero el problema va mucho más allá de una crítica a la repetición, una crítica a la actualización de un pasado que, aunque integrado, debe ser superado. El problema remite también al tema de la nueva sensibilidad que busca Ortega: la nueva época, si lo es realmente, debe mantener su originalidad, sea en el talante, sea en la filosofía, debe crear una nueva tesitura, una "predisposición peculiar"472, y esa nueva predisposición, que incluya en la fidelidad a lo real la superación del subjetivismo, es un "predisposición para las cosas"473.

Es esta predisposición peculiar, esta nueva sensibilidad, la que exige de la nueva época su filosofía original. Comentando la obra de Rickert Ciencia cultura y ciencia natural, y dentro del mismo contexto de crítica a las filosofías anacronistas y restauradoras de los neos-, escribía Ortega: "Cada época, si es de plenitud, necesita su propia, original filosofía" 474 . La intención de Ortega es que su época, en todos los sentidos, sea una época de plenitud, y por ello la necesidad de crear una nueva filosofía, de integración, de convivencia, de superación de limitaciones.

La crítica a los neos- se constituye como la necesidad de superar las filosofías de la cultura que aquéllos habían supuesto, pero también debe mostrar la propuesta de Ortega: la fidelidad a lo real, la nueva síntesis de la vida, la conexión de historia y culturas, en plural. La crítica a los neos- remitirá tanto a la superación del idealismo como a la fidelidad a las cosas, dos de los rasgos ineludibles de la nueva sensibilidad. En 1924, en "Las ideas de León Frobenius", Ortega ordenará todas estas referencias:

"Todas ellas eran y se llamaban filosofías de la cultura, no filosofías de lo real. Son síntesis urgentes, arbitrarias, de una convencional estructura, sórdidas utopías en que se confunde la sinuosa y espléndida realidad con los míseros esquemas del llamado idealismo. A esta fauna filosófica pertenece la filosofía neo-hegeliana de Croce, la neo-fichtiana de Rickert y la neo-kantiana de mis maestros marburgueses. El neo prefijado a muchas de ellas anuncia su arcaísmo. Son trajes de viejos sistemas arreglados para otros cuerpos. En su hora tuvieron sentido, porque la generación anterior había perdido por completo la técnica

471 Meditación de nuestro tiempo. Op. cit. p. 98.

472 Ibid. p. 133.

473Ibid. p. 135.

474" Prólogo a Cien cia cultural y ciencia natural de Enrique Rickert" (1922). OC VI, 306. 
de la filosofía y era menester reaprenderla. Pero, a la vez, se revela en ellas la incapacidad de construir originalmente la nueva síntesis de la vida" 475 .

Es esa filosofía de lo real la que pretende Ortega, la que quedará expresada en El tema de nuestro tiempo como conexión de cultura y vida, y que en el texto citado adquiere los caracteres de "nueva síntesis de la vida" que no alcanzaban las filosofías de la cultura, los neos-. La cultura que admitirá Ortega será, primero, plural, y de ese modo contactará con la historia: "el pluralismo de las culturas es, pues, una y misma cosa con el método propio de nuestra ciencia histórica"476, y, segundo, íntimamente unida con la vida, mostrándose como una parte (un "rincón", llegará a escribir Ortega 477 ), conectando el imperativo cultural y el vital: "la vida debe ser culta, pero la cultura tiene que ser vital"478.

La misma fidelidad a las cosas, la filosofía de lo real, que no acepta la divinización de la cultura de las filosofías restauradoras, es también la que exige el ataque a Hegel, en tanto éste según Ortega llevaría a cabo la suplantación de lo concreto por lo abstracto. En una carta a Unamuno, tampoco enviada, con fecha de diciembre de 1917, escribía Ortega: "En Hegel hallamos a la intemperie ese pecado de suplantación: porque, él mejor que nadie, vio que lo abstracto no es real. Y esto le llevó a no contentarse con la actitud media de Kant. Hegel siente la forzosidad de concretar lo abstracto -pero esto lo hace sacando lo real de b ideal, disolviendo lo concreto en la abstracción" 479 . En sus notas de lectura de la Filosofía de la historia de Hegel expresará Ortega esta idea de un modo más directo: "A pesar de su efectiva abstracción (Hegel se cree el concretista por excelencia) [...]. La enfermedad del alma moderna es en su raíz la pérdida de la sensación de realidad'480.

\footnotetext{
475" Las ideas de León Frobenius" (1924). OC III, 253.

$476_{\text {Ibid. p. } 252 .}$

477"Estas fueron las filosofías restauradoras que florecieron hacia 1900 (neokantismo, neohegelianismo). Pero la verdad es que la cultura representa dentro del universo muy poca cosa, cualquiera que sea el patetismo con que los pensadores alemanes de la generación anterior la hayan embadurnado. Inclusive dentro del hombre, es la cultura sólo un rincón". "Max Scheler. Un embriagado de esencias (1874-1928)" (1928). OC IV, 509.

${ }^{478}$ El tema de nuestro tiempo (1923). OC III, 169.

${ }^{479}$ Epistolario completo Ortega-Unamuno. Op. cit. p. 182, carta AIV.

${ }^{480}$ Archivo de la "Fundación José Ortega y Gasset", Carpetilla "Hegel: filosofía de la historia". Conjunto de notas titulado "Detalles históricos".
} 
La pérdida de la sensación de realidad es la que trata por todos los medios de superar Ortega. La sensación de realidad, la filosofía de lo real, la fidelidad a las cosas, todos ellos son caracteres de la nueva sensibilidad. Si, para Ortega, Hegel concreta lo abstracto "sacando" lo real de lo ideal, el proceso de Ortega será exactamente el inverso: alcanzar lo ideal en lo real, encontrarle sus posibilidades de plenitud. Aun así, utilizará precisamente a Hegel para concretar ese proceso. Si, como veremos, en "La «Filosofía de la historia de Hegel» y la historiología" insistirá en que "la característica del pensar, su forma constitutiva, consiste en adoptar la forma de los objetos, hacer de éstos su principio y norma'481, en las notas inéditas sobre Hegel, Ortega concretará esa idea: "La ley del pensar está en las cosas. ¡La hora de la evasión! Estábamos en estado de sitio dentro de nosotros. Al mundo, al cosmos!'482.

Esta hora de la evasión sólo puede entenderse en los caracteres de nueva sensibilidad que Ortega viene presentando desde años anteriores a la publicación de los escritos sobre Hegel. La evasión es la superación del subjetivismo, y Ortega está utilizando a Hegel, entre otros, precisamente para llevar a cabo esa evasión. Critica lo que entiende negativo de Hegel, la abstracción de lo concreto, pero no puede menos de utilizar, en su propio sentido, esa ley del pensar como la hora de la evasión. Se trata de superar a Hegel, pero, primero, hay que llegar hasta él, y, segundo, utilizar todo lo que de él sea útil. De nuevo en las notas de lectura presenta Ortega la misma idea: "El destino de nuestro tiempo es precisamente superar a Hegel, lo que implica llegar hasta él" 483 .

En este tema de la relación entre lo concreto y lo abstracto aparece otro ejemplo de la ambiguiedad de la conexión Ortega-Hegel, esa ambigüedad que muestra por un lado la necesidad de superación, de crítica de abstraccionismos, y por el otro la recepción de todo aquello que sea útil. Se trata del ataque de Ortega al liberalismo abstracto, ese liberalismo que sólo quiere la libertad y olvida otras muchas cosas. En 'Entreacto polémico", una serie de artículos políticos de 1925 en polémica con Romanones, escribe: "Tampoco el socialismo quiere la libertad ante todo, la libertad sola, porque ha aprendido de Carlos

\footnotetext{
481" La «Filosofía de la historia de Hegel» y la historiología" (1928). OC IV, 538-539.

482Archivo de la "Fundación José Ortega y Gasset", Carpetilla "Hegel: Dialéctica".

${ }^{483}$ Archivo de la "Fundación José Ortega y Gasset", Carpetilla "Hegel: filosofía de la historia". Conjunto de notas titulado "Detalles históricos".
} 
Marx, el cual lo aprendió de Hegel, que la libertad sin más no es más que un abstracto. Decía este filósofo que en el proceso histórico, donde se ha elaborado la liberación humana, «el liberalismo es la tendencia que se aferra a la abstracción; sobre él triunfa siempre lo concreto, y lo mantiene en perpetua bancarrota ${ }^{\prime 4} 484$.

La tesis de Ortega es la habitual: la libertad no se puede querer sola, sino que hay que concretarla, nacionalizarla, conducirla hasta una política nacional. No se trata de no querer la libertad, sino de querer muchas cosas más (el dinamismo, la evolución, la mejora de las instituciones, etc.): "Mi iliberalismo consiste, no en desear menos libertades que ustedes, sino en desear a la vez muchas otras cosas"485. Se trata, entonces, de sustituir el liberalismo abstracto por una política realista, con lo que, de nuevo, aparecerá el tema del enfrentamiento entre idealidad y realidad.

Si pasamos por alto a Marx, la aparición de Hegel en ese momento refiere al final de la Filosofía de la historia. Es el capítulo sobre la revolución francesa y sus consecuencias, con el que Hegel cierra sus lecciones. Para Hegel, la revolución francesa es paradigmática sobre todo en lo que tiene de posibilidad para la entrada de principios nuevos, de renovaciones, pero nunca si es entendida como "revolución permanente". En este sentido se ha dicho que Hegel puede concebirse como filósofo de la revolución y de la reforma, pero nunca como un filósofo de la revolución permanente 486 . En el fondo se encuentran críticas muy similares a las efectuadas por Ortega a ese liberalismo abstracto que todo lo basa en la Libertad, con mayúscula, y olvida la concreción de los caracteres. Si esto es así, no es de extrañar que Ortega utilice, siempre con unos intereses muy personales, ideas encontradas en esas páginas finales de la Filosofía de la historia, donde lee textos como los siguientes: "El liberalismo ha dominado sobre todo en las naciones latinas, o sea, el mundo católicoromano: Francia, Italia, España y Portugal. Pero ha sufrido la bancarrota en Francia, luego Französische Revolution die paradigmatische Revolution, weil durch sie neuen Prinzipien in die geschichtliche Welt getreten sind. Danach bleibt für ihn allein der Weg der Reformen, die sich an diesen neuen Prinzipien auszurichten haben. Insofern ist er gleichzeitig Philosoph der Revolution und der Reform, aber eben keineswegs ein Philosoph der permanenten Revolution".
} 
en España, en Italia [...]. La libertad del espíritu, tal como se ha expresado en los países latinos, los principios mismos de esta libertad, son principios abstractos [...]. La abstracción del liberalismo ha recorrido así, desde Francia, el mundo románico. [...] Con este formalismo de la libertad, con esta abstracción, los liberales no dejan consolidarse nada en la organización. A las distintas disposiciones del gobierno, opónese en seguida la libertad; pues aquellas son una voluntad particular, o sea, arbitrariedad" 487.

Este carácter abstracto del liberalismo es el que va a atacar Ortega. Su propuesta es la de una política realista, que huya de utopismos y abstraccionismos y que no se detenga en la aceptación de la realidad, sino que la construya, la haga: "De aquí que el verdadero sentido de la política realista, más que en aceptar la realidad, consiste en hacerla. [...] Política realista es política de realización'488. Estamos ante la constitución política de la unión entre la fidelidad a lo real y los deseos de plenitud, de mejora, de insatisfacción constante que deben sostenerla. Se sustituyen los ideales como utopismos por deales que comienzan y se detienen en lo real, en su ampliación.

Es la aplicación política de los talantes que más arriba hemos visto tanto en la filosofía como en el arte, conectando directamente con el "pensamos con las cosas" referido a Hegel y la hora de la evasión o superación del subjetivismo: "El político idealista vivía perpetuamente en posición falsa. El realismo es más exigente: nos invita a que transformemos la realidad según nuestras ideas; pero, a la vez, a que pensemos nuestras ideas en vista de la realidad, a que extraigamos el ideal, no subjetivamente de nuestras cabezas, sino objetivamente de las cosas. Toda cosa concreta -una nación, por ejemplocontiene, junto a lo que es, el perfil de su posible perfección. Y este ideal, el de la cosa, no el nuestro, es el verdaderamente respetable. El ideal subjetivo anda siempre cerca de ser un capricho o manía" 489 . El texto es concluyente en lo referente al tema de los ideales en Ortega: se niega el ideal subjetivo precisamente para afirma el ideal objetivo, el ideal de la cosa, de lo concreto.

\footnotetext{
${ }^{487}$ HEGEL, Lecciones sobre la filosofía de la historia universal. Ed. J. Gaos. Madrid: Alianza, 1994 (5ª reimp.), pp. 696-697.

488" Entreacto polémico" (1925). OC XI, 63.

489 Ibid. p. 64.
} 


\section{El ideal objetivo frente al debe ser}

La política realista sólo puede entenderse si se la sitúa junto a la filosofía de lo real, así como en el contexto de la nueva sensibilidad y de la fidelidad a las cosas. Y puede y debe decirse también al revés, que la fidelidad a las cosas y la filosofía de lo real sólo pueden entenderse a partir de esa política realista que suponga la evolución y la reforma de España. Es algo en lo que vengo insistiendo desde el comienzo: en Ortega, la teoría, o filosofía, o cómo se quiera expresar, es inseparable de sus ideas políticas.

$\mathrm{Si}$ en este momento esa "cosa concreta que contiene junto a lo que es el perfil de su posible perfección" es una nación, puede mostrarse fácilmente la ampliación de los sentidos a todo tipo de limitación, de circunstancia, o, en general, de realidad y concreción. El propio Ortega lo expresará casi con las mismas palabras sólo un año más tarde respecto a los artículos políticos comentados: "Toda circunstancia y toda realidad contiene una posible perfección, y este margen de perfeccionamiento de la circunstancia es lo que el buen artífice vital llama ideal y se esfuerza en henchir"490. Ese henchimiento del ideal lo hemos visto ya en múltiples ocasiones: el henchimiento de la individualidad 491 , el henchimiento como pleonexia $^{492}$, el henchimiento de la limitación 493 , etc. Es un ideal que supone la vida y su necesaria evolución, que se sostiene sobre lo real, y que, con ello, refiere a todos los contextos.

El ideal no subjetivo es, así, el instrumento de encanto, de entusiasmo, de excitante para la vida, y Ortega precisamente encontrará ese significado que le conviene en las nuevas teorías de la biología que muestran la vida como un diálogo con el contorno en el que éste constantemente excita y activa su funcionamiento. Quizá la mejor expresión de esta unidad entre ideal y vida, que conduce tanto a la política realista como al henchimiento de la

490" Reforma de la inteligencia" (1926). OC IV, 494.

491"El cabilismo, teoría conservadora" (1908). OC X, 60: "En una raza banderista no cuidará cada hombre celosamente de henchir su individualidad".

492" Renan" (1909). OC I, 454-455: "Pleonexia, es decir, aumento, henchimiento".

493"Temas del Escorial" (1915), en: Notas de andar y ver. Viajes, gentes y países. Madrid: Revista de Occidente en Alianza -Obras de José Ortega y Gasset, 32-, 1988, p. 51: "La única manera de llegar más allá de nuestra limitación, es henchir ésta por completo". 
limitación (en todos los sentidos) en sus referencias biológicas 494 se encuentre en el epílogo al libro de Victoria Ocampo De Francesca a Beatrice. Escribe Ortega:

"Así como la presión atmosférica, la temperatura, la sequedad, la luz excitan, irritan nuestras actividades corporales, hay en el paisaje figuras corpóreas o imaginarias cuyo oficio consiste en disparar nuestras actividades espirituales que, a su vez, arrastran en pos el aparato corporal. Esos excitantes psíquicos son los ideales, ni más ni menos. Cese, pues, la vaga, untuosa, pseudomística plática de los ideales. Son éstos, en resolución, cuanto atrae y excita nuestra vitalidad espiritual, son resortes biológicos, fulminantes para la explosión de energías. Sin ellos la vida no funciona. Nuestro contorno, que está poblado, no sólo de cosas reales, sino también de rostros extraterrenos y hasta imposibles, contiene un repertorio variadísimo de ellos. Los hay mínimos, humildes, que casi no nos confesamos; los hay gigantescos y de histórico tamaño, que ponen en tensión nuestra existencia entera y a veces la de todo un pueblo y toda una edad. Si el nombre de ideales quiere dejarse sólo para estos mayúsculos no hay inconveniente con tal de recordar que lo que tienen de ideales no es lo que tienen de grandes, no es su trascendencia objetiva, sino lo que tienen de común con los más pequeños estímulos del vivir: encantar, atraer, irritar, disparar nuestras potencias. El ideal es un órgano de toda vida encargado de excitarla. Como los antiguos caballeros, la vida, señora, usa espuela"495.

El ideal, si se reúnen los caracteres presentados, queda caracterizado como la capacidad de las cosas, de lo real, para innovarse ilimitadamente, para perfeccionarse. Ese perfeccionamiento parte de las posibilidades que lo real concreto mismo ofrece para su transformación, sea entendida tal concreción como cosa, como circunstancia, como nación... o, en general, como limitación. En este sentido, los ideales se constituyen como estimulantes, como excitantes, como encantos, y, con ello, el arte y toda capacidad simbólica o metafórica adquieren un sentido, tanto teórico como práctico, como instrumento de idealización. El ideal se mantiene en su papel de encantamiento para originar transformaciones y progresos. El objetivo no es la realización efectiva de ese ideal, sino la previa excitación, la capacidad de henchimiento de lo real: "Es condición de todo ideal no ser posible realizarlo. Su papel consiste más bien en erguirse más allá de la realidad, influyendo simbólicamente sobre ésta, a la manera que la estrella influye sobre la

494La relación de Ortega con la biología está tratada, sobre todo, en la obra de M. BENAVIDES LUCAS, De la ameba al monstruo propicio. Raíces naturalistas del pensamiento de Ortega y Gasset. Madrid: Ediciones de la Universidad Autónoma, 1988. Para el tema que nos ocupa ahora, ver especialmente las páginas 185 y ss.

495" Epílogo al libro De Francesca a Beatrice" (1924). OC III, 325. 
nave'496. Esa influencia simbólica mantiene los rasgos del símbolo que vimos más arriba: la conexión de idealidad y realidad, la ampliación, la creación de mundo, etc.

El ideal como margen de perfeccionamiento, entonces, deviene superación de las limitaciones de las cosas y, con ello, se consolida en el marco de creación de realidad. En ningún momento va a permitir Ortega que el ideal suplante a lo real, que el "cómo deben ser las cosas" suplante al "cómo son realmente". La anterioridad del es respecto al debe se muestra imprescindible. La concreción más explícita de este tema se encuentra en España invertebrada, en el capítulo titulado "La magia del «debe ser»", capítulo determinante no sólo en este tema sino en todo el contexto de la filosofía de Ortega. Ahí reaparece el ideal como perfeccionamiento: "El ideal de una cosa, o, dicho de otro modo, lo que una cosa debe ser, no puede consistir en la suplantación de su contextura real, sino, por el contrario, en el perfeccionamiento de ésta"497. El enfrentamiento se produce ahora entre el "es" y el "debe", enfrentamiento ya presentado en las lecciones sobre psicología de 1915 mediante el plante de Ortega ante sus maestros neokantianos:

\footnotetext{
"Tengo que acusar al psicólogo tradicional de que inventa las cosas en lugar de averiguarlas, de que no las busca tal y como ellas son y se presentan [...], sino que decreta de antemano cómo las cosas deben y tienen que ser, y con esta sentencia pertrechado va a los objetos y queda, claro es, ciego para cuanto da a su sentencia en rostro. Largo tiempo he vivido yo-y añado que para mi aprendizaje filosófico lo considero una ventura- largos años he vivido yo ejercitando una filosofía -la neo-kantiana- para la cual, declarada y resueltamente, las cosas no son comoson sino como deben ser" 498 .
}

En España invertebrada, el binomio ser-debe ser afecta a todos los contenidos: "No se habla más que de si la constitución política, desde un punto de vista moral o de justicia, debe ser o no debe ser aristocrática. En vez de analizar previamente lo que es, las condiciones ineludibles de cada realidad, se procede desde luego a dictaminar sobre cómo deben ser las cosas. Este ha sido el vicio característico de los «progresistas», de los «radicales»y, más o menos, de todo el espíritu llamado «liberal»y «democrático»'499. Ese progresismo es aquél que, precisamente, imposibilitaba todo progreso y superación; ese

\footnotetext{
496" Notas de vago estío" (1925). OC II, 434.

${ }^{497}$ España invertebrada. Bosquejo de algunos pensamientos históricos (1921). OC III, 101.

498" Investigaciones psicológicas" (1915). OC XII, 447.

${ }^{499}$ España invertebrada. Bosquejo de algunos pensamientos históricos (1921). OC III, 100.
} 
espíritu liberal refiere al liberalismo abstracto sostenido por el ideal subjetivo, y no el objetivo de la política realista; esas condiciones ineludibles de cada realidad provienen de la fidelidad a las cosas de la nueva sensibilidad.

El progresismo que desde el siglo XVIII caracterizaría al pensamiento social está asentado en la búsqueda de cómo debe ser la sociedad, en el mundo mágico de lo perfecto, de lo deseable y olvida la pregunta por la realidad, por cómo es la sociedad realmente. Para Ortega, esas ensoñaciones éticas o jurídicas del XVIII o XIX lo que pretenden es "operar mágicamente sobre la historia"500, suplantar la realidad histórica por el ideal de una perfección que no ha existido, por la parcialidad de atender exclusivamente a la significación moral y jurídica del debe ser.

La teoría de Ortega en este momento es muy explícita, de una claridad obsesiva: "Sólo debe ser lo que puede ser, y sólo puede ser lo que se mueve dentro de las condiciones de lo que es. [...] Toda recta sentencia sobre cómo deben ser las cosas presupone la devota observación de su realidad"501. Culmina Ortega diferenciando su ideal objetivo como perfeccionamiento, frente a todo utopismo mágico del idealismo progresista y subjetivista, y para ello recurre al mandamiento pindárico: "Volvamos la espalda a las éticas mágicas y quedémonos con la única aceptable, que hace veintiséis siglos resumió Píndaro en su ilustre imperativo «llega a ser lo que eres». Seamos en perfección lo que imperfectamente somos por naturaleza. Si sabemos mirarla, toda realidad nos enseñará su defecto y su norma, su pecado y su deber"502. Quedan concentrados de este modo la fidelidad a las cosas, la crítica del idealismo subjetivista, el ideal objetivo y como posibilidad de estímulo en lo real, etc. Llama la atención, con todo, ciertas conexiones entre el tratamiento que hace Ortega y algunas ideas de Hegel en la Lógica, precisamente en la nota en que examina el Sollen 503 en su sentido ético.

La figura dialéctica que en la Lógica se sitúa al lado de la Schranke, la limitación, es el Sollen. Hegel define el Sollen del modo siguiente: "Dieses Ansichsein hiermit ist als die

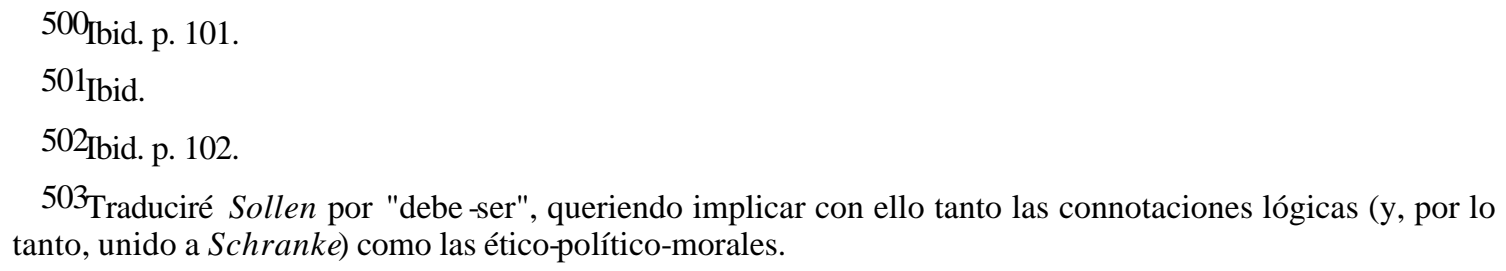
tanto, unido a Schranke) como las ético-político-morales. 
negative Beziehung auf seine von ihm auch unterschiedene Grenze, auf sich ds Schranke, Sollen"504. El debe-ser, en Hegel, tiene rasgo de categoría lógica, y se sitúa en el marco de la finitud, o, mejor, en el marco de la relación entre lo finito y lo infinito. Con ello, se muestra como algo más que un postulado ético-político, aunque Hegel, en una amplia nota, mostrará esas connotaciones, refiriendo sobre todo a Kant y a Fichte. El Sollen contiene un doble aspecto: por un lado va más allá de la negación impuesta por la limitación, va más allá del límite del algo; por otro, al mantenerse en el algo mismo, al no ser más que debeser, es también una determinación negativa. No es necesario entrar demasiado en los caracteres lógicos del Sollen 505 . Baste con saber que se sitúa en el marco de la finitud, y que constituye, en su capacidad para ir más allá de la limitación("als Sollen geht nun aber ferner das Endliche über seine Schranke hinaus"506), un momento crucial en el paso de lo finito a lo infinito. En este momento interesa más la nota que añade Hegel a ese capítulo "Die Schranke und das Sollen", titulada sencillamente en el índice "Das Sollen".

En dicha nota, Hegel muestra la parcialidad de un Sollen referido únicamente a la ética, y acentúa la anterioridad de los conceptos de Schranke y Sollen en su posición de determinaciones del Dasein con respecto a todo tratamiento posterior del tema, es decir, acentúa la preeminencia del es ante el debe. La crítica que efectúa Hegel, pensando sobre todo en Kant (del mismo modo que Ortega), se dirige contra aquellas concepciones del Sollen que lo sitúan más allá del campo de la finitud, esto es, que separan la realidad efectiva y la idea, en términos hegelianos, y la cosa concreta y el ideal, en términos de Ortega. Esas concepciones son las del debe ético y político.

Es, pues, la finitud del Sollen lo que está defendiendo Hegel, está criticando la magia del debe-ser, el olvido de cómo son realmente las cosas que efectúa el "sabihondo" (besserwisses) Sollen de la moral: "Diejenigen, welche das Sollen der Moral so hoch halten und darin, dass das Sollen nicht als Letztes und Wahrhaftes anerkannt wird, meinen, dass

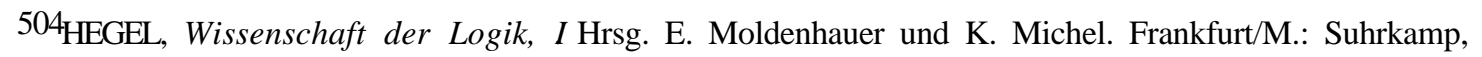
$1990^{2}$, -Werke, 5- p. 143. Traducción: "Con esto, este ser-en-sí como referencia negativa respecto a su límite, distinto de él, respecto hacia sí mismo como limitación, es debe-ser".

505Esos caracteres están examinados detalladamente en: ÁLVAREZ GÓMEZ, M. "Fundamentación lógica del deber ser en Hegel", en: FLÓREZ, C. y ÁLVAREZ GÓMEZ, M. (eds.), Estudios sobre Kant y Hegel. Salamanca: I.C.E., 1982, pp. 171-201. 
die Moralität zerstört werden solle, sowie die Räsoneurs, deren Verstand sich die unaufhörliche Befriedigung gibt, gegen alles, was da ist, ein Sollen und somit ein Besserwissen vorbringen zu lönnen, die sich das Sollen darum ebensowenig wollen rauben lassen, sehen nicht, dass für die Endlichkeit ihrer Kreise das Sollen vollkommen anerkannt wird"507.

No es gratuita esta conexión entre Hegel y Ortega. La idea central de ese texto citado está también expresada por Hegel en el sexto parágrafo de la Enciclopedia. La edición manejada por Ortega, la de Lasson de 1905, presenta subrayado con trazo fuerte el 'Sollen" que contiene el siguiente texto: "Aber die Abtrennung der Wirklichkeit von der Idee ist besonders bei dem Verstande beliebt, der die Träume seiner Abstraktionen für etwas Wahrhaftes hält und auf das Sollen, das er vornehmlich auch im politischen Felde gern vorschreibt, eitel ist, als ob die Welt auf ihn gewartet hätte, um zu erfahren, wie sie sin solle, aber nicht sei; wäre sie, wie sie sein soll, wo bliebe die Altklugheit seines Sollens?"508. Por todo lo visto, por todo el tema del ideal objetivo, del ideal como perfecionamiento, la fidelidad a las cosas, etc., Ortega tampoco puede admitir ningún sueño de abstracción: el es, para él, es siempre anterior al debe. Tanto Ortega como Hegel muestran la necesidad de mantener al debe-ser en sus límites, y de ahí la preeminencia del es en Ortega, de ahí la reivindicación de la finitud del Sollen en Hegel.

Incluso si se coloca el tema directamente en relación explícita con Kant, los argumentos son similares: "No pasará mucho tiempo sin que el gesto de Kant, decretando cómo debe

506HEGEL, Wissenschaft der Logik, I Op. cit. p. 144. Traducción: "Como debe-ser además pasa lo finito más allá de su limitación".

507Ibid. pp. 147-148. Traducción, quizá demasiado forzada: "No reconocido el debe-ser de la moral como último y verdadero, aquéllos que lo encumbran opinan que la moralidad estaría abocada a destruirse. Del mismo modo los razonadores, cuyo entendimiento se concede la constante satisfacción de poder aducir contra todo lo que existe un debe-ser, y con ello un saberlo todo, por esta razón tampoco quieren dejarse arrebatar el debe-ser. No ven, tanto unos como otros, que, para la finitud de su círculo, el debe-ser está plenamente reconocido".

508HEGEL, Enzyklopädie der philosophischen Wissenschaften. Hrsg. G. Lasson. Leipzig: Verlag der Dürr'eschen Buchhandlung, 1905, § 6, p. 37. Valls traduce: "Pero a quien le es especialmente querida la separación entre realidad efectiva e idea es al entendimiento que tiene por verdaderos los sueños de su abstracción y se envanece con el deber [moral] que él receta muy a gusto especialmente en el terreno político, como si el mundo hubiese tenido que aguardarle a él para saber cómo debe ser, sin serlo; porque si el mundo fuese ya como debe ser, ¿qué lugar habría para la precoz sabihondez de su deber ser?". HEGEL, Enciclopedia de las ciencias filosóficas. Ed. y trad. R. Valls Plana. Madrid: Alianza, 1997, § 6, p. 107. 
ser la sociedad, parezca a todos un torpe ademán mágico", escribe Ortega ${ }^{509}$, y Hegel, en sus lecciones sobre historia de la filosofía refiriendo a Kant: "Der Mensch soll moralisch sein, es bleibt beim Sollen stehen. [...] Es bleibt daher bie diesem gerede von Moralität. Was aber moralisch ist, oder an ein System des sich verwirklichenden Geistes wird nicht gedacht"510. En general, entonces, el "si sabemos mirarla, toda realidad nos enseñará su defecto y su norma, su pecado y su deber" de Ortega 511 , quedaría en Hegel, con las diferencias oportunas: "Aber in der Wirklichkeit selbst steht es nicht so traurig um Vernünftigkeit und Gesetz, dass sie nur sein sollten"512.

Ni Ortega ni Hegel pueden admitir el carácter abstracto e idealizado del debe-ser: Ortega porque exige la realidad previa, exige la fidelidad a las cosas que, precisamente, conceden un ideal objetivo, ideal de perfeccionamiento, no utópico; Hegel porque necesita la finitud del Sollen, su determinación concreta como categoría lógica para posibilitar precisamente el traspaso de finito a infinito. Es por ello por lo que ambos, con intenciones diferentes, aunque no tanto como pueda parecerlo, critican la preeminencia del debe. Lo que no hay que olvidar es que, en Ortega, esa preeminencia del es ante el debe refiere tanto a temas puramente teóricos o filosóficos como políticos, esto es, al tema de España, por lo que no es de ningún modo casual la aparición del problema en España invertebrada.

El tratamiento de la preeminencia del es ante el debe en España invertebrada permite ver también la relación con el tema de la historia. Ortega lo muestra utilizando su propio devenir filosófico: "Sometido al influjo de las inclinaciones dominantes en nuestro tiempo, yo he vivido también durante algunos años ocupado en resolver esquemáticamente cómo deben ser las cosas. Cuando luego he entrado de lleno en el estudio y meditación del pasado histórico, me sorprendió superlativamente hallar que la realidad social había sido en ocasiones mucho más deseable, más rica en valores, más próxima a una verdadera

${ }^{509}$ España invertebrada. Bosquejo de algunos pensamientos históricos (1921). OC III, 99.

510HEGEL, Vorlesungen über die Geschichte der Philosophie, III. Hrsg. E. Moldenhauer und K. Michel. Frankfurt/M.: Suhrkamp, 1993², -Werke, 20- p. 369. La edición castellana traduce: "El hombre debe ser moral; pero no se pasa del deber ser, y todo queda reducido a esta cháchara sobre lo ético; no se nos dice qué sea lo ético, no se piensa para nada en un sistema del espíritu que se realiza". Lecciones sobre la historia de la filosofía, III. Ed. E.C. Frost. México: F.C.E., 1981 (3ª reimp.), p. 447.

511España invertebrada. Bosquejo de algunos pensamientos históricos (1921). OC III, 102.

512 HEGEL, Wissenschaft der Logik, I. Op. cit. p. 148. Traducción: "Pero en la realidad misma la racionalidad y la ley no permanecen tan pobres que únicamente deban ser". 
perfección, que todos mis sórdidos y parciales esquemas"513. El pasado histórico permite ver a Ortega que el es es superior al debe. Si España invertebrada es el intento de ir a lo más profundo de la historia de España, de un modo general el tema de la historia debe englobar todos los caracteres que venimos viendo: el de la integración, el de la conexión de perspectivas, el de la superación de la limitación, etc.

En aquel texto citado más arriba ya aparecía la historia reuniendo las diversas perspectivas, los trozos de mundo: "la historia es individual como integración de esos trozos de mundo"514. España invertertebrada mostrará directamente los cambios históricos como cambios de perspectiva: "los cambios históricos son principalmente cambios de perspectiva"515. La historia como aprendizaje de limitaciones, de puntos de vista, de modos de ver el mundo, incluyendo el necesario sentido de evolución y progreso, de mejora, debe partir precisamente de la preeminencia del es ante el debe, de la imposibilidad de que el ideal suplante lo real.

${ }^{513}$ España invertebrada. Bosquejo de algunos pensamientos históricos (1921). OC III, 100.

514"Investigaciones psicológicas" (1915). OC XII, 439.

515España invertebrada. Bosquejo de algunos pensamientos históricos (1921). OC III, 123. 


\section{Historia y felicidad}

La unión de historia y perspectiva, basada siempre en la fidelidad a lo real, exige la integración de las distintas limitaciones. El tema conecta con el contexto tratado más arriba de la aceptación de la limitación propia. España invertebrada intenta mostrar las causas de la decadencia española, pero la temática es mucho más general, en tanto esa decadencia partiría de olvidar la limitación propia, la limitación de raza, la perspectiva. En "Sobre la muerte de Roma" Ortega insistirá en ello: "Las causas internas de toda gran decadencia histórica no son más que esto: las limitaciones nativas, iniciales. Cada raza ha llegado al área histórica con su destino preformado, su curva prescrita, y no ha habido manera de reformar su trayectoria. La salvación sólo podría venir si en un cierto momento esa raza tuviese la clara conciencia de su limitación y se esforzase en corregirla con heroico denuedo, tanto más heroico cuanto que habría de ejercitarse sobre su propio ser. Este es hoy el problema de Europa en general, y de España en particular. $\mathrm{O}$ vemos bien nuestras limitaciones y nos resolvemos a subsanarlas, o moriremos sin remisión"516.

La conciencia de la limitación, la "captación" de las limitaciones, como faltas, implica los dos caracteres, por un lado el de la fidelidad a lo real, por el otro el de la necesidad de conexión con otras limitaciones. La fidelidad a lo real, el tema de la superación del idealismo subjetivista es, también, un tema histórico, que exige no sólo esa fidelidad, sino al mismo tiempo la conexión de perspectivas y limitaciones, de ámbitos de realidad.

El tema afecta al problema de la historia en general, y en concreto a la relación entre Ortega y Hegel. Es más, puede decirse que alrededor de este contexto se inicia la relación de Ortega con la filosofía de la historia de Hegel. Si en 1910 la teoría de Hegel enseñaba a Ortega "el respeto a la humanidad y, como consecuencia, el respeto a nosotros mismos"517, en los años en que nos movemos ahora, cuando se ha llevado y se está llevando a cabo la exposición de la teoría de la perspectiva, la de la superación del idealismo subjetivista, la de la crítica al debe, Ortega comienza a ver los problemas.

No es casual que sólo un año después de España invertebrada, en esos artículos políticos de 1922 titulados "Ideas políticas", Ortega incida en que "en tiempo de Hegel [...]

516" Sobre la muerte de Roma" (1926). OC II, 545.

517"La pedagogía social como programa político" (1910). OC I, 514. 
comulgaban amplias masas sociales en la fe de que hemos venido al mundo para realizar ciertas formas jurídicas. Se componían filosofías de la historia mostrando la larga y ondulante línea de las aventuras humanas como un proceso progresivo de realización del Derecho. [...] Estamos en otra edad"518. Esa otra edad es la de la nueva sensibilidad, la que no considera a la ética o al derecho como abstracciones, como representantes del debe-ser, sino que los mantiene como "instrumentos al servicio de las necesidades reales". 519 Sólo un párrafo más arriba, Ortega ha mostrado la causa de esta crítica, la base del problema: "No confundamos las cosas. El sentido del ideal consiste en orientar nuestra voluntad, no en suplantar las realidades"520. Esa filosofía de la historia basada en la realización del ideal, con Hegel a la cabeza, iría contra todas las ideas de Ortega. Y, sin embargo, continúa la ambigüedad, ambigüedad que únicamente quedará concretada en los capítulos siguientes, al examinar de un modo detenido los textos de Ortega sobre Hegel.

Con todo, ya en estos años previos, la ambigüedad de la relación con la filosofía de la historia de Hegel inicia su camino. Si por el lado negativo se encuentra ese intento de realización del ideal, basado en el progresismo que, precisamente, imposibilita todo progreso, por el positivo, y refiriendo de un modo concreto a la historia de la filosofía, "Hegel elevó la historia de la filosofía al rango de ciencia. [...] Es, pues, la historia madurada en ciencia la última gran conquista llevada a cabo por Occidente. Articuladas históricamente, aparecen ahora las variaciones filosóficas como una ejemplar continuidad. [...] La historia, sea de esto o de lo otro, del cuerpo vivo o de una nación, de un arte o de una ciencia, consiste primariamente en el establecimiento de estas líneas o series de evolución"521. El valor de la continuidad, del progreso, de la evolución queda como positivo, pero no así el final de esos movimientos. Ésta es, en el fondo, la valoración y la crítica de Ortega a Hegel, en el contexto de la filosofía de la historia, a un nivel muy general, que ya comienza a intuirse años antes de los escritos sobre Hegel.

Las razones son todas las que venimos viendo, que pueden concretarse en una: no hay nada más importante para Ortega que el progreso, que la evolución, pero siempre si están

\footnotetext{
518"Ideas políticas" (1922). OC XI, 24.

519 Ibid.

$520_{\text {Ibid. }}$
} 
basados en perfeccionamientos, en ideales objetivos, no en subjetivismos utopistas. De Hegel admiraba muchas cosas, pero no podía soportar sus finales, su ausencia de futuro. Insiste Ortega en su referencia ineludible: "Hegel vio muy bien que en todo lo vivo -la idea o la carne- superar es negar; pero negar es conservar" 522 , pero hay que añadir una "pequeña" diferencia, pues la conservación que mantiene Ortega, sí, refiere al talante histórico, evolutivo, pero también al integrador, al que une las particularidades, las limitaciones, con intenciones claras de futuro. Y, para Ortega, ese futuro en la filosofía de la historia de Hegel no existe, por mucho que en aquellos textos de 1908, examinados al comienzo, insistiera en ver el sistema de Hegel como el sistema de la evolución 523 . En realidad, el proceso es tan llamativo como paradójico: Ortega intenta superar a Hegel con un procedimiento de Aufhebung, Ortega intenta superar hegelianamente a Hegel.

En el prólogo a La decadencia de Occidente de Spengler, Ortega concretará sus críticas, y mostrará las claves de interpretación: "Desde hace tiempo se aspira a una interpretación histórica de la historia. Durante el siglo XIX se seguía una propensión inversa. Así, Hegel describe el desarrollo de los sucesos humanos como resultado automático de la dialéctica abstracta de los conceptos"524. Esa interpretación histórica de la historia no permite la base idealizada, la que determine cómo deba ser esa interpretación desde fuera de ella. Pero, a la vez, esa interpretación histórica de la historia culminará en Ortega en claves como las de la razón narrativa y la razón histórica, y, en estos años, en la razón vital, en la unión de historia, cultura y vida que expresará en El tema de nuestro tiempo. No hay que olvidar, con todo, que esos "conceptos" hegelianos, que ahora critica en su relación con la historia, años antes los ha utilizado precisamente para su teoría del concepto en Meditaciones, sobre todo partiendo del prólogo a la Fenomenología. Aún así, hay algo que permanece, tanto en la crítica de Ortega como en su valoración: es la idea de integración. En El tema de nuestro tiempo expresará el problema refiriendo a Hegel... y a toda la filosofía del XIX, y mostrará sus propias intenciones:

521" Prólogo a «Historia de la filosofía» de Karl Vorländer" (1921). OC VI, 298.

522" El «Quijote» en la escuela" (1920). OC II, 299.

523"Hegel ha construido más hondamente que nadie el sistema de la evolución". "Algunas notas" (1908). OC I, 114.

524" Prólogo a «La decadencia de Occidente» de Oswald Spengler" (1923). OC VI, 310. 
"Todo el alto pensamiento germánico, desde Kant hasta 1900, puede reunirse bajo esta rúbrica: Filosofía de la cultura. A poco que en él entrásemos, veríamos su semejanza formal con la teología medieval. Ha habido sólo una suplantación de entidades, y donde el viejo pensador cristiano decía Dios, el contemporáneo alemán dice «Idea» (Hegel), «Primado de la Razón Práctica» (Kant-Fichte) o «Cultura» (Cohen, Windelband, Rickert). Esta divinización ilusoria de ciertas energías vitales a costa del resto, esa desintegración de lo que sólo puede existir junto -ciencia y respiración, moral y sexualidad, justicia y buen régimen endocrino- trae consigo los grandes fracasos orgánicos, los ingent es derrumbamientos. La vida impone a todas sus actividades un imperativo de integridad, y quien diga «sí» a una de ellas tiene que afirmarlas todas. / ¿No es incitante la idea de convertir por completo la actitud y, en vez de buscar fuera de la vida su sentido, mirarla a ella misma? ¿No es tema digno de una generación que asiste a la crisis más radical de la historia moderna hacer un ensayo opuesto a la tradición de ésta y ver qué pasa si en lugar de decir «la vida para la cultura» decimos «la cultura para la vida»?"525.

Todos esas divinizaciones y suplantaciones de realidad (por orden: filosofía de la cultura, teología medieval, idea, primado de la razón práctica, etc.) son lo que Ortega llama "idealismo", y a su superación dirige todos los esfuerzos. La crítica que efectúa ahora contacta con la serie de representaciones integradoras que han venido apareciendo desde el comienzo: esos "idealismos" son divinizaciones de ciertos rasgos parciales, y toda parcialización debe ser asumida en integración. Esa integración se refiere a integración de Europa y España, de ideal y realidad, de hombre del norte y hombre del sur, de concepto y materia, y, ahora en El tema de nuestro tiempo, de cultura y vida. Lo referente a Hegel es fácil de concretar: se aplaude la evolución, la continuidad, el sistema como proceso, pero no la parcialización de sus fines, sea, en la historia, la tendencia progresiva a derechos y libertades idealizados por esa "dialéctica abstracta de los conceptos", sea, en general, la divinización de la idea.

Las causas de la crítica de Ortega, del ataque a ese progresismo idealista que encuentra en la filosofía de la historia de Hegel, entre otros, no responde únicamente a problemas filosóficos o teóricos. Es el momento de crisis, tanto en España como en Europa, tanto en filosofía como política, el que exige las integraciones y la fidelidad a las cosas que reúna en sí misma lo real y su ideal de perfeccionamiento, de mejora. En "Pedagogía y anacronismo", texto del mismo año que El tema de nuestro tiempo, Ortega incide en esto de un modo concreto: "En 1890 regía el alma europea una interpretación política de la historia y del hombre. Se pensaba todavía, con Kant y con Hegel, con Comte y Stuart Mill,

${ }^{525}$ El tema de nuestro tiempo (1923). OC III, 187. 
que la existencia humana, a lo largo de los siglos, había sido como una preparación para la conquista de la libertad política y de un cierto orden jurídico que se denomina Estado. [...] El Estado moderno y aun el ideal del Estado moderno, que parecía a nuestros abuelos una forma definitiva, conclusión del paisaje histórico, aparece hoy como uno de tantos gestos momentáneos destinados a disolverse en el proceso incesante de la vitalidad humana"526. La crítica de Ortega tiene las dos vertientes, la de la parcialización de los talantes, y la de la inutilidad de un progresismo idealista que, bajo la máscara de la realización de un fin, de un ideal, olvida precisamente tanto los caracteres de mejora y perfeccionamiento como el anhelo de felicidad que debe mantenerlos.

Años antes, en Ideas sobre Pío Baroja", y citando a los mismos autores, Ortega había concretado ambos aspectos: "Entre las muchas maneras de falsedad objetiva es una la de lo incompleto. Una cultura contra la cual puede lanzarse el gran argumento ad hominem de que no nos hace felices, es una cultura incompleta. / ¡Ah, no faltaba más! ¡Buen siglo XIX, nuestro padre! ¡Siglo triste, agrio, incómodo! ¡Frígida edad de vidrio que ha divinizado las retortas de la química industrial y las urnas electorales! Kant o Stuart Mill, Hegel o Comte, todos los hombres representantivos de ese clima moral bajo cero, se han olvidado de que la felicidad es una dimensión de la cultura"527. La solución que ofrece Ortega es la de la nueva sensibilidad, la del ideal como perfeccionamiento y tendencia a la mejora, el ideal cercano, como espuela, el ideal de la cultura caballeresca, de la cultura miope que, por ello, por miope, no deviene divinizada, sino asentada en su unión indisoluble con la vida: "Nada malo haríamos ensayando, como reacción, una cultura miope -que exija a los ideales proximidad, evidencia, poder de arrebatarnos y de hacernos felices. $/$ ¡Un ideal que fuera a la vez espuela! La espuela ideal -símbolo de una cultura caballeresca"528.

Contacta así el ideal como espuela, como perfeccionamiento y anhelo de felicidad, con la conexión entre cultura y vida. Es la razón vital mostrada en El tema de nuestro tiempo, que conjuga en su definición la atención a cultura e historia, a perspectivas y limitaciones, a la articulación de las particularidades y, sobre todo, a las posibilidades de transformación que no olviden esa felicidad, real, de perfeccionamiento, nunca utópica o divinizada: "Hasta

526" Pedagogía y anacronismo" (1923). OC III, 132.

527"Ideas sobre Pío Baroja" (1916). OC II, 89. 
ahora, la filosofía ha sido siempre utópica. Por eso pretendía cada sistema valer para todos los tiempos y para todos los hombres. Exenta de la dimensión vital, histórica, perspectivista, hacía una y otra vez vanamente su gesto definitivo. [...] La razón pura tiene que ser sustituida por una razón vital, donde aquélla se localice y adquiera movilidad y fuerza de transformación"529. Esta es la conexión explícita entre historia y perspectiva, entre la dimensión histórica y la dimensión vital, y el sentido debe aumentarse, no refiriendo únicamente a la historia de la filosofía. La fuerza de transformación, el ideal como poder de arrebatarnos y hacernos felices, la crítica al olvido de la felicidad en el progresismo del XIX, todos ellos son caracteres generales que afectan al conjunto de los contextos.

Llama la atención este tema de la felicidad. Si ahora Ortega critica su olvido en el siglo XIX, al perseguir ideales abstractos de Estado y Derecho, Ética y Libertad, más adelante, y también con referencia a Hegel, volverá al tema de la felicidad en un sentido muy diferente. La distinción es sencilla: en este segundo momento la divinización, la totalización de los fines idealizados, ha devenido particularizada, individualizada, esto es, el contexto es el de las épocas de la historia. En 1930 escribe Ortega:

"El problema de la historia es el problema de la felicidad. Porque la historia se propone comprender lo que en su última intimidad fue la vida de esta o la otra época. Ahora bien; toda época se siente, en su postrer fondo, feliz. La vida es siempre feliz en su gran cuenca total. La prueba de ello es que ninguna época ha querido en serio ser otra determinada. [...] Las desdichas son tan sólo meteoritos, que caen sobre la felicidad constitutiva, sustancial, inalterable, de cada astro. Los lamentos sobre los «tiempos que corren» son un factor de placer, el deleite de la quejumbre, la delicia de llorar. En Hegel hay una entrevisión de esto que no he visto subrayada ni explotada por nadie. Cada época tiene $s u$ vida, y la siente como suya, porque en ella, siendo tal y como es, se siente feliz. El error está en creer que la felicidad excluye el dolor y las angustias. Al revés, las incluye, son ingredientes de ella"530.

El texto está incluido en un artículo de 1930, pero su origen es anterior: se encuentra en las notas de lectura de Ortega sobre Hegel. Escribía Ortega: "El problema de la historia es el problema de la felicidad. Toda época es feliz. La vida es siempre feliz en su gran cuenca fatal. No hay época que, en serio, quisiera ser otra determinada (sólo ucronías, utopías). Las

\footnotetext{
528 Ibid. pp. 89-90.

${ }^{529}$ El tema de nuestro tiempo (1923). OC III, 201.

530" Revés de almanaque" (1930). OC II, 736.
} 
desdichas son meteoritos que caen sobre la felicidad constitutiva de cada astro. Los lamentos sobre los "tiempos que corren" son un elemento de voluptuosidad, la delicia de la quejumbre, el placer de llorar, el deleite de la quérula"531. Y, antes de pasar a comentar el tema en su conjunto, falta una referencia. En esas mismas notas de lectura sobre Hegel, en lo que concierne a este tema de la felicidad, hay un apunte de Ortega aparentemente extraño. Escribe: "Felicidad: "Der Lauf der Welt...". Lotze, Mikrokos." 532.

Ortega remite a Mikrokosmus. Ideen zur Naturgeschichte und Geschichte der Menschheit, y, de un modo más concreto, al siguiente texto de Lotze: "Und alle Poesie endlich, wenn sie den rohen Ausschrei des Schmerzes oder den Iubel der Lusst in ein reiches Gedankengebilde ausbreitet und für das eigne Erlebnis Gleichniss in der Ferne sucht, was tut sie anders, als dass sie das empfundene Geschick entweder als ein echtes Glied, oder als einen Widerspruch, dem seine Lösung gewiss sei, in diesem Lauf der Welt einzufügen sucht, der, wie auch die Oberfläche seines Stromes sich zeigen mag, in seinem Grunde immer den Zug zur Verwirklichung eines allgemeinen und organisirten Glückes habe"533.

Para Ortega, el idealismo subjetivista y parcializador del XIX, más que causante de divinizaciones inocuas, es culpable de no haber atendido a la concreción y realidad de los ideales en que se fundaba. Su carácter de incompletud parte de esta tesis: la cultura, o la idea, o el concepto, o cualquier forma de divinización es incompleta porque, sencillamente, no hace nada para aumentar la felicidad. Para poder hacerlo esa cultura debe ser superada en una integración que la contemple junto a historia y vida, realidad e ideal, perfeccionamiento y fuerza de transformación. Sólo así la felicidad puede mostrarse como posible, pues no estará separada de los talantes prácticos de evolución y mejora.

531Archivo de la "Fundación José Ortega y Gasset", Carpetilla "Hegel: filosofía de la historia". Conjunto de notas titulado "Detalles históricos".

532Archivo de la "Fundación José Ortega y Gasset", Carpetilla "Hegel: filosofía de la historia".

533LOTZE, H. Mikrokosmus. Ideen zur Naturgeschichte und Geschichte der Menschheit. II. Bd. Leipzig: Hirze, $1878^{3}$, p. 310. Traducción: "Y finalmente toda poesía, cuando despliega en una rica forma de pensamiento el brutal grito del dolor o el júbilo del placer, y busca para la vivencia propia la alegoría en lo lejano, no lo hace de otro modo más que tratando de introducir el destino sentido (sea un elemento auténtico, sea una contradicción para la cual su solución sea cierta) en esta marcha del mundo, la cual, como también quiere mostrarse la superficie de su corriente, siempre tiene en el fondo el impulso para la realización de una felicidad general y organizada". 
Por ello el problema de la historia es el problema de la felicidad: la evolución debe ser verdaderamente de futuro, de progreso, y no enmascararse en divinizaciones inoperantes. La felicidad es una dimensión de la cultura y, a la vez, el problema de la historia, porque constantemente el objetivo de Ortega es teórico y práctico, un objetivo, con ello, de articulación. De ese texto de Lotze citado la idea que toma Ortega es la que lo concluye: la marcha del mundo aspira a la realización de la felicidad, pero una realización basada en ideales próximos, vitales, que no conviertan esa realización en objetivos imposibles.

La felicidad es vital porque incluye dolores y angustias, porque es intento de adecuación con la circunstancia, sea espacial, sea temporal, histórica. La felicidad incluye el dolor porque, en su carácter de máximo objetivo vital, no olvida aquella expresión de Hegel según la cual el dolor es el privilegio de los seres vivos. Cada época es feliz, aunque incluya sus dolores, porque es la circunstancia disponible, la perspectiva de cada hombre en ese momento: no es una felicidad utópica, idealizada, sino humana, vital en sus caracteres culturales e históricos. La referencia a Hegel en este sentido implica los caracteres de plenitud de cada época determinada, los deseos de ser la única. Pero Ortega no olvida que, en su lectura, la filosofía de la historia de Hegel no deja lugar al futuro, y la felicidad, como rasgo de progreso y evolución, exige ese futuro: la mejora de la época, la conexión con otras épocas, con otras limitaciones.

Si las filosofías de la historia, si los sistemas filosóficos del XIX han olvidado el carácter vital e histórico de la felicidad, primero habrá que superarlos y, segundo, conseguir un nuevo concepto de felicidad que incluya vida, historia y cultura, esto es, concreción, circunstancia y posibilidades de integración, de articulación de la pluralidad. Es este sentido de pluralidad el que Ortega enfrentará a lo que él entiende como el carácter unitarista de los siglos anteriores, concretamente referido a Hegel. 


\section{De la soledad a la solidaridad}

En 'Las Atlántidas", un año después de El tema de nuestro tiempo, Ortega desarrollará el tema del enfrentamiento entre pluralidad y unitarismo como sigue: "Ampútese a la idea todo su superlativo metafísico y déjesela como la intuición de un hecho, del hecho básico donde el historiador tiene hoy que tomar su arrancada. El siglo XIX ha sido, como su padre el XVIII, radicalmente unitarista. En su primera mitad vive bajo la constelación de Hegel, para quien la historia es el desarrollo de la Idea, término que exige ser escrito con mayúscula a fin de recalcar que no tolera pluralidad ninguna. El sujeto de la historia es el Espíritu, un espíritu único, que, en cierto modo, es el heredero de la «Humanidad» dieciochesca (la cual a su vez se perpetúa en la «Humanidad» de Augusto Comte)"534. Esta intolerancia de la pluralidad se opone a todas las teorías de Ortega, y permite ver la conexión en este momento con la serie de temas que han conducido hasta aquí: el paisaje, la limitación, la perspectiva, etc.

En primer lugar, la respuesta explícita de Ortega a ese unitarismo: "El historiador partía caprichosamente de una quimera: la unidad humana, la Humanidad homogénea y luego se daba de bruces con el hecho bruto, irracional, alógico, pero innegable, de la pluralidad de las formas humanas, de la heterogeneidad de los espíritus colectivos" 535 . Y, en segundo lugar, las causas de esa respuesta: la aceptación de lo real, el imperativo de vida múltiple, la pluralidad de limitaciones o paisajes y su necesaria integración, todo ello exige tanto un sentido de la existencia como un sentido de la diferencia. En el carácter epocal, temporal, esa ambivalencia de identidad y diferencia se muestra como sentido histórico, que implica el pluralismo tanto de modos de ver el mundo, como la necesaria comunicación entre las particularidades: "El sentido histórico comienza cuando se sospecha que la vida humana en otros tiempos y pueblos es diferente de lo que es en nuestra edad y en nuestro ámbito cultural. La diferencia es la distancia cualitativa. El sentido histórico percibe esta distancia psicológica que existe entre otros hombres y nosotros" 536.

${ }^{534}$ Las Atlántidas (1924). OC III, 302.

535 Ibid.

536 Ibid. p. 308 
La distancia cualitativa es la que permite la comunicación, pues adquiere los caracteres de distancia-límite: simultáneamente acerca y diferencia, conecta y diversifica. La comunicación es un diálogo con los semejantes, sean pasados, sean presentes. En lo referente al pasado ese diálogo se encuentra en el estudio de la historia, en lo referente al presente es la vida, como convivencia, como pluralidad de paisajes y limitaciones, y en lo referente a la filosofía, a la teoría, es la conexión entre perspectivas, entre los distintos aspectos de lo real, entre las posibilidades que ofrecen las cosas si se las mira con la suficiente honradez. De aquí la conexión de historia, vida y realidad. El diálogo es tanto con los semejantes, como con el entorno, el paisaje, como con las épocas.

Esta es la conjunción de razón histórica yrazón vital, uniéndose ambas en una misión de evolución y futuro: la suma integradora de pluralidades es una tarea histórica, aludiendo con ello tanto a las épocas como a los paisajes, pues la doctrina del paisaje vital es "decisiva para la historia, que, a la postre, no consiste sino en una hermenéutica o interpretación de las vidas ajenas" 537 . Se trata ahora de un imperativo de pulcritud, que no confunde el es y el debe, que obliga a partir "de la pluralidad que es el hecho"538, cuando esa pluralidad refiere a contextos varios: épocas pasadas, vidas ajenas, paisajes extraños, limitaciones diversas, perspectivas diferentes, etc. Se trata constantemente de intentar mirar desde la pupila del otro, con el fin de ampliar la nuestra.

En la historia, ese imperativo de pulcritud, y con él acudirá Ortega al enfrentamiento con las teorías de Hegel (y por eso escribirá, junto el prólogo a la Filosofía de la historia, el "Hegel y América"), supondrá el policentrismo de la historia universal, la necesaria aceptación de los puntos de vista ajenos: "Si hasta el presente la «historia universal» había padecido un exceso de concentración en un punto de gravitación único, hacia el cual se hacían converger todos los procesos de la existencia humana -el punto de vista europeo-, durante una generación, cuando menos, se elaborará una historia universal policéntrica, y el horizonte total se obtendrá por mera yuxtaposición de horizontes parciales, con radios heterogéneos que hacinados formarán un panorama de los destinos humanos bastante

\footnotetext{
537 Ibid. p. 293.

538Ibid. p. 303.
} 
parecido a un cuadro cubista"539. Con estos presupuestos, no es extraño que a Ortega le molestara la Filosofía de la historia de Hegel, pero tampoco lo es la atracción que le produjo: encontrará ahí la pluralidad que busca, pero no será una pluralidad libre, independiente del unitarismo de la idea.

La integración de España y Europa que buscaba Ortega, la integración entre el hombre del sur y el hombre del norte, supone la ampliación de tal integración. Esa integración es de futuro, con vistas a un crecimiento de las limitaciones, y esos aspectos pasan por ir más allá del "punto de vista europeo". El "Hegel y América" se situará en este contexto, y la intención es siempre la misma: yuxtaposición o integración de horizontes parciales, pero siempre sin romper la heterogeneidad o pluralidad, es más, utilizando esas diferencias como medios de crecimiento. La pluralidad que encontrará en Hegel no será para Ortega independiente del estatuto ontológico, de la pluralidad de los distintos modos de mostrarse el espíritu. La propuesta de Ortega será la de la aceptación de las pluralidades, la aceptación de los otros, las limitaciones, precisamente para afirmar la limitación propia, para conseguir el crecimiento y la mejora. En las notas de lectura sobre Hegel escribirá Ortega: "Necesito de los otros para poder estar libre de ellos. En Hegel la pluralidad, supuesto de la libertad, no tiene independencia ontológica"540. La pluralidad independiente es la que buscará Ortega.

En realidad, entonces, el problema de la pluralidad exige el contacto con un tema afín, el de la relación con el otro, la relación con el prójimo. Pero, para Ortega, en Hegel esta relación con el otro está determinada por una categoría fundamental, el ser-para-sí, el Fürsichsein. No es casual la referencia, "como de pasada", al ser-para-sí en un texto determinante de las "Reflexiones de centenario" sobre Kant. Ahí escribe Ortega, criticando el "yo" del idealismo subjetivista:

"¡Extraña naturaleza la de este Yo! Mientras las demás cosas se limitan a ser lo que son -la luz a iluminar, el son a sonar, la blancura a blanquear-, ésta sólo es lo que es en la medida en que se da cuenta de lo que es. Fichte, que fue el enfant terrible del kantismo, que dice a voz en grito lo que Kant musitaba o retenía, define taxativamente el Yo como el ser que se sabe a sí mismo, que se conoce a sí mismo. Su realidad no

539Ibid. p. 307.

${ }^{540}$ Archivo de la "Fundación José Ortega y Gasset", Carpetilla "Hegel: filosofía de la historia". Conjunto de notas titulado "Detalles históricos". 
es otra que esta reflexividad. El yo está siempre consigo, frente a frente de sí mismo; su ser es un Ser-para-

sí. A Hegel debemos la acuñación de esta nueva categoría - Fürsichsein" ${ }^{541}$.

$\mathrm{Si}$ nos centramos en Hegel, puede decirse que esa aparición del Fürsichsein es demasiado pobre, y no porque Ortega no pudiera decir nada más, sino, todo lo contrario, porque no dice todo lo que podría. Las "Reflexiones de centenario" insisten, remitiendo directamente a Kant, en que "la nueva filosofía -y la nueva vida- sólo puede tener un lema cuya fórmula negativa suene así: superación del idealismo"542. La filosofía moderna habría estado asentada en la idea de no errar, esto es, no en la realidad, sino en el conocimiento, en saber si yerro, conociendo el conocimiento. Es una filosofía de la precaución, de la suspicacia, a la defensiva, una filosofía burguesa que conduzca a la seguridad, a la eliminación de toda ingenuidad. La propuesta de Ortega sustituye la suspicacia por la fidelidad a lo real, por la confianza: "mejor que la suspicacia es una confianza vivaz y alerta"543. Y es en este sentido en el que reaparece un tema que viene examinando Ortega desde bastantes años antes: la diferencia entre el alma meridional, vertida sobre la realidad, sobre el exterior, y el alma alemana, vertida sobre el yo, sobre lo interior, la conciencia.

El idealismo quedaría definido por los dos caracteres de suspicacia y subjetivismo, y se trataría de superarlo en sus dos vertientes, el idealismo teórico, basado en entender la realidad como idea, y el práctico, basado en entender la moral como una política de ideales subjetivos. En el fondo se encuentra el mismo talante de integración al que Ortega nos tiene habituados, pero ahora ya con un avance: la superación del subjetivismo supone la creación de la solidaridad, aprovechar la fortaleza del yo que posee el alma del norte para convertirla en contactos con los otros, particularizarla, hacerla solidaria y no solitaria. Así, escribirá Ortega: "La Crítica de la Razón Pura es la historia gloriosa de esta lucha. Un Yo solitario pugna por lograr la compañía de un mundo y de otros Yo - pero no encuentra otro medio de lograrlo que crearlo dentro de sí"544. La superación del idealismo subjetivista que pretende Ortega, desde la teoría de la perspectiva, de la limitación, de la historia, desde todos los

541" Kant. Reflexiones de centenario (1724-1924)" (1924). OC IV, 36-37.

542 Ibid. p. 39.

543 Ibid. p. 32.

${ }^{544}$ Ibid. p. 35. 
marcos pluralizadores e integradores, intenta llevar a cabo la conversión de ese yo solitario en un yo solidario, pero siempre sin crearlo desde dentro, sino desde la fidelidad a las cosas y los contactos con los otros, con las perspectivas ajenas.

Es en este contexto en el que la referencia al Fürsichsein de Hegel aumentaría el carácter de simple alusión que presentaba el texto citado. El Fürsichsein superaría en este sentido la referencia al yo como reflexividad y conectaría con el Fürsichsein como categoría lógica de la determinidad, de la cualidad, en el contexto del primer libro de la Ciencia de la lógica, "La doctrina del ser". El ser-para-sí como reflexividad lo veremos más adelante conectando el concepto hegeliano de espíritu con el orteguiano de vida, pero no en el sentido de la "Lehre von Sein" de la Lógica.

El tema del Fürsichsein como momento de la determinidad no aparece en los textos de Ortega sobre Hegel, pero con un matiz: no aparece en los textos... publicados. En las notas de lectura sobre la Lógica se encuentra la clave que amplía el contexto. Esa clave permite ver que, si en el texto citado el Fürsichsein aparece como representante de la subjetividad idealista, de la reflexividad, del Yo, con mayúsculas, aludiendo a Kant y a Fichte, Ortega, con todo, no pasa por alto uno de los momentos determinantes del discurrir de esa categoría en la lógica de Hegel: la relación con el ser-para-otro, la relación con un otro. Esto no aparece en los textos publicados sobre Hegel, ni en ninguna otra referencia perdida entre la multitud de escritos de Ortega, pero eso no quiere decir que no lo utilizara, sin remitir explícitamente a Hegel. El tema de la solidaridad, del contacto con los otros, con las pupilas ajenas, con las limitaciones, es un hilo conductor de la filosofía de Ortega. Entre las notas de lectura se encuentra una que se titula "Dasein y Fürsichsein", y, citada completa, dice así:

Se ve -caigo en ello en la página 152- que por Dasein -o sea, Sein da-entiende H. ante todo el Anderssein o alteridad, el modo de ser en que se es fuera una cosa de otra. Al estar constituido este ser por la simple determinación, que es simple negación, es ser exclusivo -o ser aparte lo uno de lo otro. Pero la "infinitud verdadera" nos descubre que ese modo de ser aparte, da -limitado o finito- no es un modo de ser definitivo, sino, al revés, in-definitivo. La alteridad que parece ser en el aparte de cada cosa, en verdad, transfiere la responsabilidad de ese ser a lo otro y así sucesivamente hasta el infinito. De lo cual resulta que en verdad nada finito es suficientemente - sino que se transfiere a sí mismo a otro modo de ser más suficiente: o lo que es igual - el "ser aparte" deja de ser propiamente, se hace cuasiser y esto, ser cuasiser, es el ser ideal. Porque el cuasi-ser sólo es propiamente en verdad en su ser reflejado y reflejante. Es el ser aparte o "no ser determinado" reflejado en sí mismo - es decir, siendo en cuanto no siendo o como no 
siendo. Esto es el ser para sí - lo contrario de la alteridad. En suma el "ser exclusivo" se completa a sí mismo en "ser inclusivo", en que lo uno incluye su otro, en vez de excluirlo. Queda el "ser aparte" depotenciado en la nueva potencia del "ser en conjunto o ser uno o infinito" 545.

Esa página 152 que menciona al comienzo remite a la edición que está manejando Ortega, la de Lasson. En esa página, y en las que la rodean, subraya textos significativos como los siguientes: "Das Fürsichsein ist das polemische, negative Verhalten gegen das begrenzende Andere", "Das Vorstellen ist ein Fürsichsein, in welchem die Bestimmtheiten nicht Grenzen und damit nicht ein Dasein, sondern nur Momente sind", "Das Fürsichsein ist die einfache Einheit seiner selbst und seines Moments, des Seins-für-Eines. Es ist nur eine Bestimmung vorhanden, die Beziehung-auf-sich-selbst des Aufhebens"546. Más que la interpretación de los textos de Hegel, interesa la lectura que lleva a cabo Ortega en esa nota citada. Con todo, pueden enunciarse, aunque sean expresados brevemente, los caracteres del ser-para-sí en la Lógica.

El Fürsichsein es la categoría que continúa inmediatamente a la infinitud afirmativa, esto es, la infinitud que, después de haber conseguido el traspaso desde lo finito, no se muestra como un infinito proceso (la mala infinitud, el proceso al infinito o reunión infinita de finitudes), sino como la infinitud verdadera, la que incluye finito e infinito en su interior y se constituye como círculo, sin principio ni final. El Fürsichsein expresa la concreción de estos caracteres de la infinitud verdadera, la conjunción del sí-mismo y el otro, la negación de la negación, la referencia hacia sí mismo habiendo asumido las diferencias con el otro 547 . Dicho de un modo lo más concreto posible, el ser-para-sí de la lógica hegeliana

\footnotetext{
545Archivo de la "Fundación José Ortega y Gasset", Carpetilla "Hegel - Filosofía de la historia". Los subrayados son de Ortega. He corregido la puntuación.
}

546HEGEL, Wissenschaft der Logik, I Hrsg. G. Lasson. Leipzig: Meiner, 1923, pp. 148, 152 y 153. Traducción, respectivamente: "El ser-para-sí es el comportamiento polémico, negativo, contra el otro que limita [limitante, sic]"; "El representar es un ser-para-sí en el que las determinidades no son límites y, por ello, tampoco un estar-ahí [Dasein], sino únicamente momentos"; "El ser-para-sí es la simple unidad de sí mismo y su momento, el ser-para-uno. Se presenta únicamente una determinación, la referencia a sí mismo del asumir".

${ }^{547}$ Acudiendo al parágrafo 96 de la Enciclopedia, y más concretamente al Zusatz correspondiente, puede leerse: "Das Fürsichsein ist die vollendete Qualität und enthält als solche das Sein und das Dasein als seine ideellen Momente in sich. Als Sein ist das Fürsichsein einfache Beziehung auf sich, und als Dasein ist dasselbe bestimmt; diese Bestimmtheit ist dann aber nicht mehr die endliche Bestimmthe it des Etwas in seinem Unterschied vom Anderen, sondern die unendliche, den Unterschied in sich als aufgehoben enthaltende Bestimmtheit". HEGEL, Enzyklopädie der philosophischen Wissenschaften im Grundrisse, 1830. 
significa la referencia a sí mismo a través de todas las mediaciones negativas. Es la síntesis de Sein y Dasein alcanzada mediante la reintegración de las dferencias, teniendo en cuenta que no se trata ya de la simple referencia a sí, como lo era el Sein del comienzo de la Lógica, ni de la determinación de ese Sein, como lo es el Dasein, sino del ser autodeterminado.

La forma en que Ortega entiende la relación entre Dasein y Fürsichsein sobrepasa la alusión de las "Reflexiones de centenario" al ser-para-sí como reflexividad. Lo que interesa a Ortega es la reunión del ser exclusivo (su modo de entender el Dasein, al concebirlo, con Hegel, íntimamente unido a la alteridad) y el ser inclusivo (su modo de entender el Fürsichsein), esto es, la interpretación del infinito hegeliano como "ser en conjunto" ("la nueva potencia del ser en conjunto o ser uno o infinito", escribía en la nota). Puede decirse que en el fondo se encuentra la temática de la limitación y su superación por medio de las relaciones, la superación como crecimiento, el ideal como perfeccionamiento. El cuasi-ser como ser ideal debería entenderse en este sentido. No está refiriendo Ortega ahora a ese sentido negativo del cuasi que mantenía en aquél artículo del $18^{548}$, sino a la necesaria conexión entre las distintas limitaciones o finitudes como medio de progreso y evolución.

El cuasi-ser, como ser ideal, constituyéndose como ser reflejado y reflejante emite a esta serie de caracteres: es el reflejo de los otros, es el reflejo en el otro. Y estos "otros" refieren a cosas y naciones, a individuos y perspectivas, a cualquier modo de limitación. Entender la relación entre la infinitud verdadera hegeliana y el Dasein mediante el concepto de ser "in-definitivo" es de una importancia determinante, en tanto significa, por un lado, la necesaria conexión entre particularidades, y por otro, la exigencia de mostrar esa conexión como medio de evolución, de crecimiento, esto es, la in-definitividad de lo finito $\mathrm{y}$ limitado, que requieren las relaciones con los otros para profundizar en su propia limitación y, con ello, aumentarla. Lo que está haciendo Ortega, entonces, es convertir la dialéctica hegeliana del Dasein en una serie de contactos entre particularidades, que, en su conexión, suponen el aumento y crecimiento de esas mismas particularidades, finitas, limitadas. Son

Erster Teil: Die Wissenschaft der Logik. Hrsg. E. Moldenhauer, K. Michel. Frankfurt/M.: Suhrkamp, $1992^{3}$ Werke, 8- p. 203, §96 Zusatz.

548" Hacia una mejor política" (1918). OC X, 386. Ver el primer apartado, "Política del «cuasi»". 
las posibilidades de determinación de cada algo a través de sus contactos, contactos que refieren tanto hacia fuera de sí como hacia el crecimiento de sí mismo.

El conjunto de la teoría de la limitación que viene apareciendo se basa en esta serie de caracteres, y, si se quiere expresar con los rasgos de la nota citada, la conexión de ser exclusivo y ser inclusivo, en el sentido de Ortega, consiste en la relación entre limitaciones, que tanto justifica y amplía la limitación propia, como exige la presencia de las que le son extrañas. El "siendo en cuanto no siendo o como no siendo" de la nota citada quedaría entendido así como "siendo a partir de lo que no se es", como "siendo lo que se es acogiendo rasgos que no se tienen", aumentar el horizonte de la pupila propia siendo capaces de acercarnos a la del otro.

Ese "ser exclusivo que se completa a sí mismo en ser inclusivo, en que lo uno incluye su otro, en vez de excluirlo", remite a todos los caracteres de solidaridad entre limitaciones que busca Ortega, la pluralidad independiente que permita el aumento y progreso de las particularidades. Si esto es así, puede decirse que Ortega ejerce cierta función de abogado del diablo: por un lado muestra, en los escritos publicados, el Fürsichsein como máxima categoría del idealismo subjetivista, del yo solitario en su forma de reflexividad, y, por otra, en las notas no publicadas, utiliza esa misma categoría del Fürsichsein desde el contexto de la lógica del ser y la infinitud afirmativa, para alcanzar una serie de caracteres solidarios, de ideas en torno a la conexión de particularidades, de todo algo con su otro, que van a ser utilizados constantemente... sin referir a Hegel de modo explícito.

El descontento como "emoción idealista"549, el ideal como espuela, como perfeccionamiento, la conexión de limitaciones partiendo del profundizamiento en la propia, todos ellos son rasgos que pueden encontrarse a partir de ese cuasi-ser como ser ideal, a partir de esa concreción de lo limitado como in-definitivo, o a partir de esa conexión entre ser exclusivo y ser inclusivo apareciendo en un ser en conjunto. Y éstos últimos son caracteres que surgen de su comentario a la relación entre Dasein y Fürsichsein en el contexto de la Lógica de Hegel, con lo que podría decirse que ya, a través del propio Hegel, Ortega encuentra medios que permiten la conversión de la soledad idealista en la solidaridad que busca, solidaridad entre todo tipo de limitaciones.

549" La Gioconda" (1911). OC I, 556. 


\section{La libertad en la historia}

Del mismo modo que con el tema del ser-para-sí Ortega, por un lado, critica el unitarismo y la pluralidad ontológica, y con ello ficticia, de Hegel, pero, por el otro, aprovecha rasgos e ideas del propio Hegel que le permiten superar ese unitarismo, expresando el conjunto una cierta ambigüedad o contradicción en la relación general entre Hegel y Ortega, así, el acercamiento definitivo al tema de la historia en los escritos publicados sobre Hegel parte ya de ese mismo talante ambiguo. $\mathrm{Si}$, en el fondo, el enfrentamiento se produce entre los rasgos de unitarismo, divinización de caracteres o abstraccionismo de libertad o Estado, por un lado, y la pluralidad de las particularidades y los necesarios contactos que supongan la superación de limitaciones, la unión de libertad y fatalidad, o felicidad y dolor, la afirmación de una individualidad que no se disuelva en abstracciones, por el otro, todo ello explica que uno de los polos más importantes del enfrentamiento, tanto positivo como negativo, sea el del espíritu objetivo.

El tratamiento del espíritu objetivo que Ortega lleva a cabo aparecerá de un modo más detallado en los escritos sobre Hegel, pero ya en los textos de años previos se inicia la atracción, ambigua, como habitualmente, que a Ortega le supone el concepto. Si en 1925 lo define a partir de la contradicción que contiene, y escribe: "El Estado es un sistema de moldes intelectuales y morales. Genialmente, Hegel lo llamó «espíritu objetivo», aceptando la contradicción que la fórmula incluye"550, sólo dos años más tarde ese espíritu objetivo aparecerá representando a un alma colectiva en el que el individuo queda automatizado, perdido como tal individualidad: "Para el fraseólogo, pensar y sentir era hacer espontáneamente, preconscientemente, el esfuerzo de ajustarse a un pensar y sentir genéricos que se consideraban como debidos. De esta manera, el individuo tendía automáticamente a instalarse y sumirse en un alma colectiva y como ejemplar -lo que Hegel llama el «espíritu objetivo»"551.

El tema que está en la base es el de la falta de individualidad, sea negada a través del Estado ("entidad abstracta y sobreindividual"552), sea a través del alma colectiva como

550"Egipcios" (1925). OC II, 717.

551" Fraseología y sinceridad" (1927). OC II, 488.

552" Egipcios" (1925). OC II, 717. 
representante de "moldes preexistentes" o convenciones. Es la fraseología del XVIII y el XIX, frente a la sinceridad que debe incluir la nueva sensibilidad. Esa fraseología, en su parte positiva, incluía el anhelo de la vida en común, los deseos de convivencia, y "su máximo fruto fue el cosmopolitismo, la filantropía, el humanitarismo y el parlamentarismo"553, pero, en la negativa, supone la prioridad del debe, de las abstracciones y los unitarismos, imposibles de admitir por la nueva sensibilidad basada en el es, en la aceptación de las limitaciones, en la fidelidad a lo real, en la "nudificación de las cosas"554. Y, con todo, ese espíritu objetivo, como representante de ideas o convicciones situadas por encima de la vida individual, no puede pasarse por alto. En las notas de lectura de la Filosofía de la historia de Hegel escribirá Ortega: "El espíritu objetivo es el hecho más empírico. Vivimos por fuerza -es lo específico del vivir humano- de ciertas ideas, convicciones, normas y anhelos, que tienen independencia de nosotros" 555 .

En el fondo, entonces, el problema del espíritu objetivo, para Ortega, es el problema de la libertad, una libertad que no debe basarse en las abstracciones del liberalismo de siglos anteriores, sino en los síntomas vitales, que, como tales, incluyen libertad y fatalidad, felicidad y dolor, deporte y necesidad. Ya en 1921, en el prólogo a la Historia de la filosofía de Vorländer, escribía Ortega que "la vida no consiste exclusivamente en someterse a la necesidad respondiendo a sus urgencias, sino que la vida es eso precisamente porque aspira, dominada la necesidad, a ejercitar el lujo vital de la libertad'556. En El origen deportivo del Estado concretará estos caracteres: "La actividad original y primera de la vida es siempre espontánea, lujosa, de intención superflua, es libre expansión de una energía preexistente. No consiste en salir al paso de una necesidad, no es un movimiento forzado o tropismo, sino más bien, la liberal ocurrencia, el imprevisible apetito'557. Esa liberal ocurrencia e imprevisible apetito remiten a la libertad como lujo vital, a través de la cual se vitaliza la libertad abstracta idealista.

\footnotetext{
553" Fraseología y sinceridad" (1927). OC II, 489.

${ }^{554}$ Ibid.

555Archivo de la "Fundación José Ortega y Gasset", Carpetilla "Hegel: filosofía de la historia". Conjunto de notas titulado "Detalles históricos".

556" Prólogo a «Historia de la filosofía» de Karl Vorländer" (1925). OC VI, 298.

557" El origen deportivo del Estado" (1925). OC II, 609.
} 
La vitalización de la libertad, al enfrentarse a los caracteres utilitarios, remite a un sentido de los ideales en que estos pierden su carácter subjetivo. La libertad se mostrará como ideal en el sentido de espuela, de cultura caballeresca, del deporte de los ideales, que menciona Ortega en las "Notas de vago estío", el "carácter ficticio de alto juego o sublime deporte que suelen poseer los ideales"558. La libertad, en el contacto entre ideal como incitación y la vida como conjunción de deporte y necesidad, remite al talante de progreso, de evolución, de mejora, que la conduce hasta el tema de la historia, pero, ahora ya, una historia en la que no se tiende a una Libertad y Estado abstractos, sino plenamente vitalizados en su sentido deportivo, en el sentido del ideal como deporte. La libertad adquiere así el sentido de posibilidad, que implica la necesaria conexión de historia y vida: "Lo único que estrictamente quisiera insinuar es que, en todo proceso vital, lo primario, el punto de partida, es una energía de sentido superfluo y libérrimo, lo mismo en la vida corporal que en la vida histórica. Al hacer la historia de toda existencia viviente hallaremos siempre que la vida fue primero una pródiga invención de posibilidades y luego una selección entre ellas que se fijan y como solidifican en hábitos utilitarios"559. Esa energía libre, que remite a la vida y a la historia, presenta a las posibilidades en el contexto de la pluralidad liberada de todo unitarismo ontológico.

Lo importante es tener en cuenta las dos direcciones que adquiere el tema de la libertad. Por un lado, libertad y vida, donde la libertad se expresa como deporte, como juego, frente a la necesidad y el utilitarismo. Por otro lado, la libertad basada en los juegos de pluralidad, de negación de soledades y divinizaciones. En las notas de lectura sobre Hegel, escribirá Ortega, criticando la libertad como soledad que habría caracterizado todo el idealismo subjetivista desde Kant: "Decir que el solitario es libre es una superchería y una superfelación. La libertad es el estatuto del ser en la pluralidad"560. Esa pluralidad se refiere tanto a individuos como a posibilidades, con lo que, insistentemente, conectan historia y vida, pero teniendo muy claro que la libertad de la que parte no es la Libertad abstracta y solitaria, detenida, del idealismo subjetivista, sino que remite a los ideales como

558"Notas del vago estío" (1925). OC II, 434.

559" El origen deportivo del Estado" (1925). OC II, 610.

${ }^{560}$ Archivo de la "Fundación José Ortega y Gasset", Carpetilla "Hegel: filosofía de la historia". Conjunto de notas titulado "Detalles históricos". 
proyecto, como incitación y deporte, en los que la libertad está siendo pensada siempre en caracteres de futuro.

De este modo, no sólo no puede aceptar Ortega que el solitario sea libre, sino tampoco que la libertad sea solitaria, esto es, que sea lo único buscado, la Libertad, de nuevo, con mayúsculas, la Libertad que criticaba al liberalismo por olvidar por ella otros rasgos determinantes, y es que "la libertad solitaria es una forma vacía, un vaso inane"561. La libertad, como la política, hay que hacerla, y eso supone tanto la integración de caracteres vitales, de ideales "reales", como la conexión con la pluralidad de la historia, una historia no ontologizada. Es el lema de "libertad y todo'562, que Ortega presentaba en 1926, sustituyendo al de "libertad ante todo" del siglo anterior: de la misma forma que la vida era invención de posibilidades, también la política es cuestión de ensayos, de "tanteos"563, siempre con caracteres plurales de futuro, de libertad a conseguir, a hacer. Las posibilidades y los tanteos, como en la historia, aseguran la evolución y la mejora a través de la conexión entre ellos, de la relación entre las particularizaciones, siempre de por sí limitadas. La historia es también, precisamente porque afirma las particularidades, una constante superación de las limitaciones 564 .

De todo esto parte la conexión con el análisis anterior del ser-para-sí, así como la relación con el espíritu objetivo... y con la historia, lo que, de nuevo, conduce a Ortega hasta Hegel. Ya en 1927, y puede decirse que es el texto previo que conecta directamente con los artículos sobre Hegel, escribe Ortega:

"No tiene sentido hablar de libertad sino junto a la fatalidad. En un mundo donde no existiese la necesidad, el fatum, no habría de qué libertarse. La libertad es siempre la evasión de una necesidad, el abandono de una cadena. En un mundo fofo, sin férrea consistencia, no hay libertad. Quien vea en la

561" Vaguedades" (1925). OC XI, 53.

562" Dislocación y restauración de España" (1926). OC XI, 97.

563 Ibid. p. 98.

564Veinte años más tarde respecto al contexto en el que nos movemos ahora, escribirá Ortega: "El sentido histórico es, en efecto, un sentido -una función y un órgano de la visión de lo distante como tal. Representa la máxima evasión de sí mismo que es posible al honbre y, a la vez, por retroefecto, la última claridad sobre sí que el hombre individual puede alcanzar. Pues al tener que descubrir, para hacérselo verosímil, los supuestos desde los cuales vivió el antepasado y, por lo tanto, sus límites, descubre por repercusión los supuestos tácitos sobre que él mismo vive y en que mantiene inscrita su existencia. Conoce, pues, mediante el rodeo que es la historia, sus propios límites, y esta es la única manera otorgada al hombre de trascenderlos". "Prólogo a «Historia de la filosofía», de Émile Bréhier (Ideas para una historia de la filosofía)" (1942). OC VI, 388. 
historia, como Hegel, el dramático progreso en la conciencia de libertad, no extrañará que esta liberación se verifique soltando el grillete geográfico que retiene a la historia en cada estadio. Cuando Dios quiere un futuro mejor promete al hombre otra tierra. La historia sería así, en efecto, una evasión, una fuga de tierra en tierra, una emigración hacia la tierra prometida. Y la vida ideal, la última, la que soñamos más perfecta, la alojamos en una tierra tan otra de las demás tierras, que resulta la «tierra ninguna»-utopía" 565 .

Si más arriba criticaba Ortega la interpretación política de la historia y del hombre del XIX, que habría basado todas sus intenciones en la conquista de una Libertad y un Estado ideales, definitivos, ahora defiende esa historia como progreso en la conciencia de la libertad, pero habiéndole añadido ya los rasgos propios de la nueva sensibilidad: la libertad no es nunca definitiva, sino que tiene caracteres de futuro, está siempre en evolución, es conexión de historia y vida. Es precisamente este talante de futuro el que llevará a Ortega a escribir el "Hegel y América", y es, a la vez, uno de los modos de explicar la constante enfatización de la relación entre historia y geografía en los escritos sobre Hegel.

Esa geografía es uno de los modos de entender, en la temática de la historia, el concepto de paisaje, y no hay que olvidar nunca que la teoría del paisaje está basada en la percepturitio, en los paisajes aún no vistos, en los que hay que hacer, cuando esa tarea se inicia en plenificar el paisaje propio. Se trata del paisaje como tarea futura, de la historia hacia adelante, y en este sentido conectarían la teoría de la libertad, la de la historia y la de la vida, basadas en conjunto sobre el anhelo de progreso y mejora. Se trata, de nuevo, de la conexión entre tiempo y espacio, de la conexión de la historia con la estética espacial, que aparecería ahora, precisamente, desde esa "geografía" recogida en Hegel a la que Ortega concede valor especial.

Una página más arriba de esa referencia a Hegel escribe Ortega: "Tal vez exista un progreso en la historia universal. Parece ésta, en efecto, libertarse de esa limitación que cada paisaje impone al no permitir con plenitud más que un solo tipo de vida. Pero ¿cómo se verifica esa liberación, cómo pasa la historia universal de ese tipo de vida a otro superior? Hallamos respuesta en el hecho más misterioso y a la par más evidente que el pretérito humano manifiesta: el hecho de que el eje de la historia universal -el tipo de vida superior en cada época- se desplaza de una región planetaria a otra. De ordinario vemos la historia sólo como un movimiento en el tiempo. ¿No es misterioso ese otro movimiento en

565" Abenjaldún nos revela el secreto (Pensamientos sobre África menor)" (1927). OC II, 682. 
el espacio?"566. La liberación de la limitación que efectúa la historia tiene varios sentidos (el habitual es, en el contexto de la historia como "estudio" de las épocas pasadas, la superación de la limitación propia mediante el conocimiento de las limitaciones de los otros). El que presenta Ortega en ese texto se refiere a la historia como proceso, como evolución de la humanidad. En ese sentido la limitación es superada al saltar no sólo por encima de tiempos, sino también de espacios, desplazamiento de épocas y desplazamiento de paisajes, con intenciones claras de evolución. El talante hegeliano se encuentra ya en la base.

Ese desplazamiento por espacios, por geografías, en busca del más adecuado, puede también entenderse en los términos de la teoría del paisaje que veíamos más arriba. Cada pueblo tiene un paisaje propio, una circunstancia particular y, de la misma forma que el nivel temporal exige que las épocas sean "agotadas", utilizadas, el espacial requiere que cada paisaje, cada espacio, sea plenificado de un modo exclusivo. Esa plenificación exige, primero, el conocimiento de las limitaciones propias, segundo, la conexión con otras limitaciones para ampliar la nuestra, y, tercero, el progreso mutuo en los contactos.

El movimiento del paisaje en este sentido no sería ese movimiento general que expresaba Ortega con el talante hegeliano de la conexión entre geografía e historia, y, sin embargo, expresa una liberación de la limitación que converge directamente en la ampliación y mejora de la limitación popia. La tierra prometida, en este sentido, sería la de la limitación propia, si la asentamos sobre los caracteres de futuro que deben dirigirla. La utopía, como paisaje ideal, perfecto, sería la que parte de la limitación propia, en tanto "hay, pues, una perfección que se conquista a fuerza de limitarse"567.

$566_{\text {Ibid. p. } 681 .}$

567"Leyendo «Le petit Pierre» de Anatole France" (1919). OC II, 230. 


\section{El arte y los límites}

La superación de la limitación, de un modo u otro, continuará apareciendo, y, como veremos, en los artículos sobre Hegel proseguirá aquella "necesidad de leer a Hegel para entender el tema del límite". Puede decirse incluso, de un modo concreto, que la geografía es la aplicación del tema del paisaje a la teoría de la historia. En el fondo, pues, continuará el juego de los límites, de las limitaciones y su superación.

Si nos fijamos en los escritos sobre arte de estos años, partiendo de que el arte, en su sentido de irrealización, de artificio, es el mejor ejemplo de la superación de la limitación, aparecerán, de nuevo e insistentemente, las dialécticas de límites y limitaciones. En 1920 exponía Ortega el arte de los hermanos Zubiaurre del modo siguiente: "Les importa mucho cada cosa, y como el perfil representa la demarcación de fronteras entre unas y otras, se han hecho pintores de perfiles, de siluetas. Puede decirse que la parte de nosotros mismos donde más enérgicamente nos hallamos es nuestro perfil. Viene éste a ser la línea de batalla que constantemente oponemos al resto del mundo, presto siempre a aniquilarnos, a borrar nuestra singularidad" 568

Esa pintura de perfiles tiene un sentido explícito: mostrar la singularidad, la individualidad, y hacerlo en el contacto con los otros, esto es, mostrar diferencias e identidades. El perfil, como límite, expresa el contacto entre individualidad y pluralidad, el contacto entre las limitaciones, y, por ello, deja ver la intimidad de las cosas, sus secretos: los cuadros de los Zubiaurre son "una incesante irradiación de intimidad"569, cuando esa intimidad de las cosas, manifestada a través del límite, del perfil, se presenta desde los caracteres equívocos de todo lo que es por contacto, de todo lo que conjuga el ser inclusivo y el ser exclusivo, como mostraba más arriba la nota sobre el Fürsichsein de Hegel.

Ese equívoco del límite es precisamente el que determinará la relación entre la limitación y las posibilidades de ampliación. Un año después de "Los hermanos Zubiaurre" insistía Ortega en "el equívoco propio de todo lo que es término y extremo; así, el perfil de los cuerpos, que es línea en que terminan, no se sabe bien si les pertenece a ellos o al

\footnotetext{
568" Los hermanos Zubiaurre" (1920). OC II, 270.

569 Ibid. p. 268.
} 
espacio circundante que los limita"570. A partir de estos caracteres se entienden todos los rasgos de la movilidad de las limitaciones. Los perfiles no son únicamente de cuerpos o de objetos, también refieren a épocas, a historias, a naciones, y conjugan en su interior siempre la misma dialéctica: la posibilidad de afirmar y ampliar la particularidad propia a través del contacto con otras limitaciones. La línea equívoca del límite permite esta dialéctica.

En "Azorín: primores de lo vulgar" ya labía mostrado Ortega la conjunción de esta serie de motivos, y lo había hecho decididamente presentando los juegos de contactos como la "realidad" de las cosas: "La realidad es el poder que tienen las cosas de llenar el espacio, de afirmarse unas contra otras, y mutuamente imponerse un puesto determinado. [...] Este compromiso se manifiesta en una delimitación de fronteras, en la línea o perfil de cada objeto que indica dónde la una cosa concluye y la otra comienza. Marca, por tanto, el perfil las pretensiones extremas de un cuerpo; la fuerza respetable y eficaz es justamente lo de dentro del perfil, la masa cúbica, la materia expansiva. / Esta consideración nos lleva a fijarnos en que sólo la materia, la masa cúbica interna justifica el perfil, como la fuerza íntima de una nación hace que sus fronteras no se conviertan en líneas irrisorias"571. La indicación del comienzo y la conclusión, que en Meditaciones refería al concepto, al concepto como límite, aparece aquí directamente configurando la realidad de las cosas.

El límite y lo limitado, las fronteras y lo que delimitan, se muestran ahora fortalecidos mediante la conexión entre ambos polos. Los perfiles o los límites sólo adquieren sentido a través de la individualidad que demarcan, y viceversa; en este sentido, la conexión entre las limitaciones y los límites parte de la fortaleza mutua que se conceden. En general, los caracteres que expresan las referencias de Ortega a límites, a limitaciones o a la superación de éstas, son siempre tres: la identificación, la diferenciación y la relación. Esos caracteres son los que ponen en contacto los distintos marcos donde aparece el tema, pues permiten entender con categorías similares el movimiento de espacios, de naciones, de individuos, de épocas, de cosas, etc., aunque ese movimiento sea distinto dependiendo de los contextos.

Cuando las zonas bifurcadas por el límite son la realidad y la irrealidad nos situamos en el campo del arte. La 'Meditación del marco" expresa el problema de un modo explícito, al entender el marco del cuadro como la expresión del límite entre ambos "espacios". El

\footnotetext{
570"Esquema de Salomé" (1921). OC II, 360.
} 
cuadro, como obra de arte, como irrealidad o des-realización, como "isla imaginaria que flota rodeada de realidad por todas partes" 572 , necesita aislarse del contorno vital, real, y para ello requiere "que la pared real concluya de pronto, radicalmente, y que súbitamente, sin titubeo, nos encontremos en el territorio irreal del cuadro. Hace falta un aislador. Esto es el marco"573. El marco ejerce, entonces, una función de aislante, de separador, en tanto lo que delimita son mundos diferentes, no las particularidades que, de un tipo $u$ otro, aparecían más arriba. Y sin embargo, atendiendo, a los caracteres de todo límite, la separación debe integrar los contactos, las uniones.

Este es el sentido en el que la irrealidad del arte supera la limitación, el territorio real, y lo hace precisamente ampliando, re-creando, haciendo un mundo propio con elementos de ese espacio real y consiguiendo que nuestra atención recaiga sobre ese mundo de idealidad e inverosimilitud. El marco ya no aisla solamente, sino que también ejerce su función de trampolín: "Frontera de ambas regiones, sirve para neutralizar una breve faja de muro y actúa de trampolín que lanza nuestra atención a la dimensión legendaria de la isla estética"574. El marco como límite aglutina, de nuevo, la conexión y la diferenciación de territorios; la relación entre ellos es la que conectará al arte con los demas medios de creación de realidad: ciencia, política, cultura, etc. Ahora bien, si esa relación no es gratuita, sino que parte de una serie de intenciones basadas en la creación y el aumento de realidad, de mundo, entonces exigirá instrumentos que se inicien en la conexión entre los dos territorios, que utilicen los medios que proporciona el mundo real para contactar con la verosimilitud o irrealidad del artístico, que utilicen esos medios, sus objetos, para ampliarlos, re-crearlos. Por ello, uno de los protagonistas de esa conexión de mundos es la metáfora, una metáfora entendida explícitamente en su función intelectiva: en ningún caso se trata de suplantar realidades, sino de aumentarlas.

Mostrar esa función intelectiva de la metáfora, que permite verla tanto en el contexto artístico como en el científico o filosófico, es la intención de Ortega en 'Las dos grandes metáforas": "La metáfora es un procedimiento intelectual por cuyo medio conseguimos

571"Azorín: primores de lo vulgar" (1916). OC II, 183.

572" Meditación del marco" (1921). OC II, 311.

573 Ibid.

574 Ibid. 
aprehender lo que se halla más lejos de nuestra potencia conceptual. Con lo más próximo y lo que mejor dominamos, podemos alcanzar contacto mental con lo remoto y más arisco. Es la metáfora un suplemento a nuestro brazo intelectivo, y representa, en lógica, la caña de pescar o el fusil"575. Que el contacto se establezca tanto con lo más lejano como con lo nuevo o difícil es lo que expresa las dos funciones de la metáfora, la artística y la científica. La primera remite, como ya aparecía en el "Ensayo de estética a manera de prólogo", a la identificación parcial de dos cosas para afirmar su identidad total, con lo que el excedente se constituye como mundo nuevo, creado, poético, que aumenta el habitual, el "real". La función científica de la metáfora, al revés, parte de la identidad total de dos concreciones, sabiendo que esa totalidad es falsa, para quedarse únicamente con lo que incluye de verdad. Es un procedimiento de ayuda, de socorro a las conceptualizaciones que todavía no han alcanzado su seguridad. En el arte, la metáfora permanece como ampliación re-creadora de mundos nuevos, se sostiene sobre la función creadora del arte, sabiendo que "el arte es siempre creación"576.

En La deshumanización del arte, Ortega concretará esa misión de la metáfora, pero refiriéndola únicamente al plano artístico. La función intelectiva de la metáfora se generalizará en el placer estético: la metáfora guarda una función intelectiva, en tanto que el placer estético "tiene que ser inteligente" 577 . Inteligencia para poner límites, para saber mantener las fronteras entre los dos mundos, para ser capaces de alcanzar esa sensibilidad artística constituida como "poder de acomodación a lo virtual y transparente"578. La transparencia, que en el Ensayo de estética remitía a la metáfora como transparencia de sí misma, refiere ahora a la virtualidad e irrealidad del arte en su conjunto, y exige para distinguirla esos caracteres de sensibilidad, de inteligencia, que permitan detenerse en la transparencia misma. Se trata, en el fondo, de la misma exigencia de pulcritud mental que contiene la nueva sensibilidad en general:

"No sé, no sé; pero creo que el poeta joven, cuando poetiza, se propone simplemente ser poeta. Ya veremos cómo todo el arte nuevo, coincidiendo en esto con la nueva ciencia, con la nueva política, con la

575" Las dos grandes metáforas (En el segundo centenario del nacimiento de Kant)" (1924). OC II, 391.

576"Nuevas casas antiguas" (1926). OC II, 550.

${ }^{577}$ La deshumanización del arte (1925). OC III, 369.

578 Ibid. p. 359. 
nueva vida, en fin, repugna ante todo la confusión de fronteras. Es un síntoma de pulcritud mental querer que las fronteras entre las cosas estén bien demarcadas. Vida es una cosa, poesía es otra -piensan, o, al menos sienten. No las mezclemos. El poeta empieza donde el hombre acaba. El destino de éste es vivir su itinerario humano; la misión de aquél es inventar lo que no existe. De esta manera se justifica el oficio poético. El poeta aumenta el mundo, añadiendo a lo real, que ya está ahí por sí mismo, un irreal continente. Autor viene de «auctor», el que aumenta. Los latinos llamaban así al general que ganaba para la patria un nuevo territorio" 579 .

Ortega admira esa pulcritud mental, la que se incrusta entre el es y el debe, entre lo real y lo ideal, la que demarca las fronteras. Y, sin embargo, el ideal debe permanecer como descontento, como perfeccionamiento, el ideal debe permanecer objetivizado, y el arte asumir aquella función que mencionaba en "Para un museo romántico": el arte nuevo en tanto "vida como arte"580. Demarcación de fronteras, pero sin que esas fronteras sean únicamente negativas: la ampliación de horizontes debe permanecer en la base, las fronteras, como la metáfora, deben ejercitar su función de trampolines. El poeta aumenta el mundo, y eso debe entenderse de un modo literal, en el sentido transitivo del verbo: es el final del texto citado, esto es, ganar un nuevo territorio, sí, pero para la patria. Este es el marco en el que se presenta el ambiguo acercamiento de Ortega al arte nuevo, el que queda expresado de un modo concreto en el final de La deshumanización del arte y que muestra la imposibilidad de regresar a formas románticas o realistas, no artes "artistas", pero también los inconvenientes de la deshumanización, del asentamiento de fronteras únicamente negativas: "La insinuación de otro camino para el arte que no sea este deshumanizador ni reitere las vías usadas y abusadas" 581 .

Pero, si se parte de que el fondo común es la afirmación de una nueva sensibilidad en la que, de un modo u otro, la superación de limitaciones y ampliación de fronteras dirigen las intenciones, entonces no hay que pasar por alto que quizá la mejor definición de ese talante se halla también precisamente en La deshumanización del arte. Ortega no elude su crítica a unas fronteras demasiado agresivas: "Poca es la vida si no piafa en ella un afán formidable de ampliar sus fronteras. Se vive en la proporción en que se ansía vivir más. Toda obstinación en mantenernos dentro de nuestro horizonte habitual significa debilidad,

579 Ibid. p. 371.

580" Para un museo romántico" (1921). OC II, 519. 
decadencia de las energías vitales. El horizonte es una línea biológica, un órgano viviente de nuestro ser; mientras gozamos de plenitud, el horizonte emigra, se dilata, ondula elástico casi al compás de nuestra respiración. En cambio, cuando el horizonte se fija es que se ha anquilosado y que nosotros ingresamos en la vejez" 582 .

La metáfora basada en "el afán de evitar la realidad"583, el cuadro como "lo que auténticamente es: un cuadro - una irrealidad"584, en general, la misión del arte como "suscitar un irreal horizonte"585 o la complacencia en "el delicioso fraude del arte, tanto más exquisito cuanto mejor manifieste su textura fraudulenta"586, no deben olvidar la función intelectiva, de pulcritud mental, en la que se basan, en tanto esa función, primero, exige delimitar las fronteras $\mathrm{y}$, segundo, utilizarlas, permitir el contacto que suponga el aumento y la creación de realidad. No se trata en ningún caso de volver a formas pasadas, de copias de lo real, de simulacros, de realismos, pero tampoco de idealizaciones subjetivas que olviden la fidelidad a las cosas. En realidad, entonces, la relación de Ortega con el arte nuevo es muy similar a la que mantiene en general con el tema del idealismo y el realismo: superación hegeliana de ambos, para conseguir una nueva sensibilidad que contenga los ideales objetivos en la propia fidelidad a lo real.

No hay que olvidar que "el objeto es siempre más y de otra manera que lo pensado en su idea"587, que ésta lo esquematiza, lo limita precisamente al idealizarlo; no hay que olvidar, sobre todo, que junto al "suprarrealismo" de la metáfora como medio de evasión de lo real, también se encuentra el "infrarrealismo" de la "inmersión bajo el nivel de la perspectiva natural. Los mejores ejemplos de cómo por extremar el realismo se le supera -no más que con atender lupa en mano a lo microscópico de la vida- son Proust, Ramón Gómez de la Serna, Joyce"588. En el fondo se halla siempre el mismo talante: la fidelidad a lo real, el

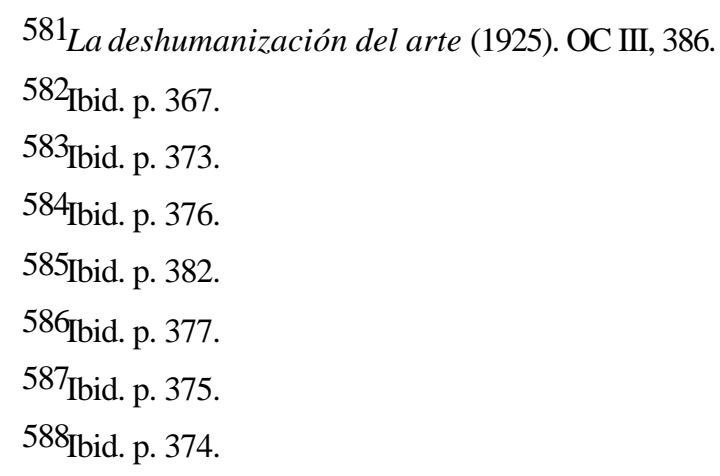


saber mirar las cosas, encontrar los secretos que se hallan escondidos en ellas, incluidos los ideales objetivos, supera asumiendo tanto el realismo, de la copia, del simulacro, como el idealismo subjetivista e idealizador. Tanto el objeto que es siempre más que su idea, como el infrarrealismo y su mirada microscópica, micrológica, escribiría Benjamin, son pistas en esta conjugación de los contextos, que permiten entender tanto la valoración como la crítica de Ortega al arte deshumanizado.

La dialéctica entre la ampliación de horizontes y la demarcación de fronteras explica las relaciones de Ortega con el arte. Por un lado la creación de mundo, de aventuras, por el otro la conciencia constante de que la mayor aventura es la de la propia vida, la que se encuentra en los secretos de las cosas. Es esto lo que explica el hermetismo que Ortega entiende como el rasgo más propio de la novela: ésta, "en vez de querer agrandar su horizonte - ¿qué horizonte o mundo de novela puede ser más vasto y rico que el más modesto de los efectivos?- ha de tender a contraerlo, a confinarlo'589. El poder multiplicador y liberador de la novela, "isublime, benigno poder que multiplica nuestra existencia, que nos liberta y pluraliza, que nos enriquece con generosas transmigraciones!"590, supone el hermetismo del mundo ficticio, novelado, y la ampliación que produce parte ya de la demarcación de fronteras. Es la misma dialéctica: la ampliación de horizontes exige la demarcación de fronteras. La negación de la realidad efectiva para afirmar la novelada, el abandono, "sin nostalgia"591, del mundo real, todos los caracteres de hermetismo, son precisamente los que permiten a la novela la construcción de mundo: el novelista "lleva a cuestas todo el atrezzo de un mundo'592. Ese mundo novelado no debe ser confundido con el real, superior en sus aventuras, pero las ampliaciones que supone, la multiplicación de perspectivas, permite utilizarlas en la propia vida. Se trata del mismo carácter de intelectualidad que posee la metáfora. No se confunden los mundos, es más, se hermetizan, y es precisamente esa limitación la que permite el aumento, la ampliación de horizontes.

Pero no hay que olvidar que en Ortega se ha producido un cambio, el cambio que supone la introducción del tema de la historia: la sensibilidad histórica, el sentido histórico. No es

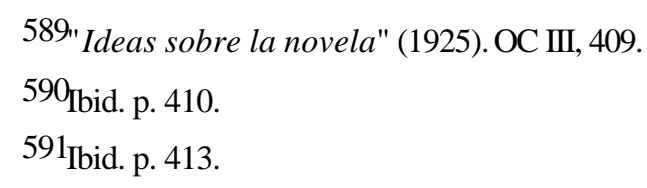


posible entender el tratamiento del arte en estos años sin tener en cuenta el tema de la historia. La ampliación de horizontes que supone el arte, en otro sentido también se encuentra en la historia, la sensibilidad histórica "comienza verdaderamente cuando el plano único se quiebra y se buscan con fruición las lejanías, las profundidades. La historia es una voluptuosidad de horizontes"593. La ampliación de mundo, la creación de mundo, supone por necesidad la ruptura del unitarismo. Tanto el unitarismo como la pluralidad los encontrará Ortega en Hegel, con lo que no es de extrañar el carácter ambiguo de su contacto. La unión del arte y la historia es la que determina todos esos caracteres de ruptura con el pasado en los que insiste Ortega, y es también la que "detalla" aquel carácter de eternidad que aparecía en los artículos de 1910594: "se habla, a menudo, de la eternidad de la obra de arte. Si con ello se quisiera decir que crearla y gozarla incluye la aspiración a que su valor sea eterno, no habría reparo que poner. Pero el hecho es que la obra de arte envejece y se pudre antes como valor estético que como realidad material"595, o, en general, "la monserga de que el arte es eterno no puede satisfacer ni aclarar nada"596.

En el fondo de esa negación de la eternidad del arte, y, con ello, afirmación del sentido histórico, se encuentra también su carácter de ser puro juego, deporte. Este rasgo remite a exigencias del arte nuevo: "el nuevo estilo, por el contrario, solicita, desde luego, ser aproximado al triunfo de los deportes y juegos. Son dos hechos hermanos, de la misma oriundez"597; pero también remite a todo el sentido de los ideales como deporte, de la cult ura caballeresca que permite encontrar en la pluralidad de mundos y talantes los medios de progreso, de perfeccionamiento, de mejora. Con todo, la misma demarcación de fronteras entre el mundo real y el ficticio, requerida precisamente para la ampliación de horizontes, viene exigida por la conexión del arte con la historia: no mezclar pasado y presente, no mezclar sensibilidades, mantener la misma pulcritud intelectual. La pluralidad

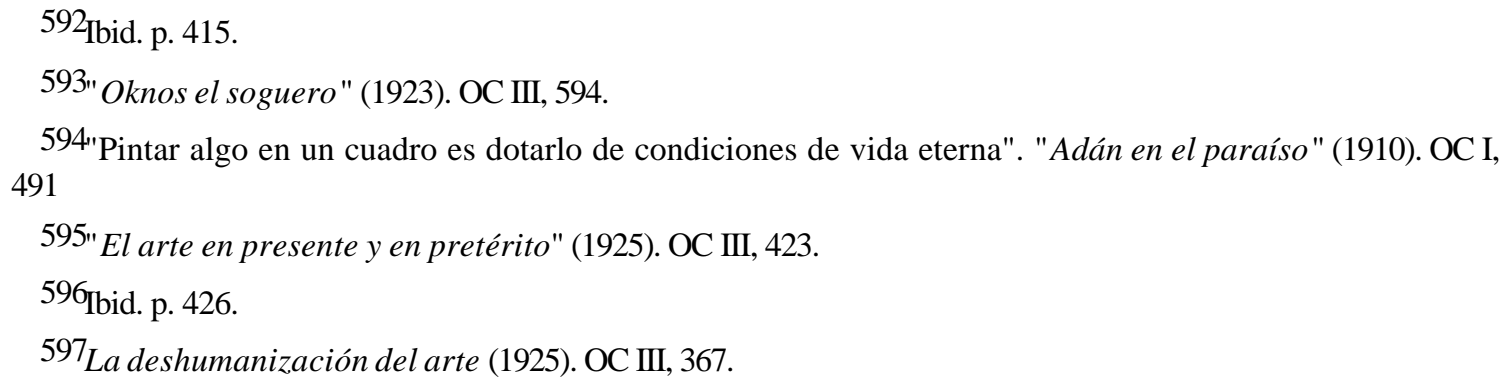


de aventuras, sean las halladas en los secretos de las cosas, a partir de la fidelidad a lo real, sean las de los mundos herméticos de la novela, sean las del supra e infrarrealismo del arte en general, ese mismo carácter aventurero, de ampliación, es precisamente el que conecta con la historia:

"El mismo gesto con que alejamos de nuestro trato actual el pasado hace a éste renacer justamente como pasado. En vez de una sola dimensión donde hacer resbalar la vida -el presente-, tenemos ahora, dos, pulcramente diferencias, no sólo en la idea, sino en el sentir. El placer humano se amplía gigantescamente al llegar a madurez la sensibilidad histórica. Mientras se creyó que antiguos y actuales somos todos unos, el paisaje era de gran monotonía. Ahora la existencia cobra una inmensa variedad de planos, se hace profunda, de hondas perspectivas, y cada tiempo sido es una aventura nueva. La condición de ello será que sepamos mirar a lo lejos lo lejano sin miopía, sin contaminar el presente con el pretérito"598.

Puede decirse, en general, que este es el contexto desde el que Ortega llega hasta Hegel, o, más en concreto, hasta los artículos publicados sobre Hegel en 1928. Este contexto, tanto en lo que refiere a las apariciones de Hegel en Ortega en estos años, desde 1915, como en las temáticas que las rodean, determinará los tres artículos publicados, el prólogo a la Filosofía de la historia, el "Hegel y América" y "En el centenario de Hegel". Si es cierto que el marco de la historia ocupará el lugar prioritario, tanto en los intereses de Ortega como en las temáticas de Hegel analizadas por él, no lo es menos que alrededor de ese marco se situarán conceptos y categorías que lo complicarán. Esta complicación se produce en la filosofía de Ortega en general y en su acercamiento a Hegel en concreto, y es por ello por lo que no hay que pasar por alto en ningún momento el contexto que dirige a Ortega hasta Hegel, sea en las temáticas propias de Ortega, sea en las apariciones explícitas de Hegel en su filosofía.

El tema de la superación del idealismo, entendida esa superación como Aufhebung, ya acerca a Hegel y Ortega, y, sin embargo, las intenciones concretas de Ortega, la fidelidad a lo real, la nueva sensibilidad, la teoría de la perspectiva, la superación de la limitación trágica, etc., muestran cómo Ortega utiliza caracteres muy determinados, en un entido muy determinado y para seguir por un camino muy determinado. Las críticas a las filosofías restauradoras, el ataque a todo tipo de abstraccionismo, la negación del ideal subjetivo o la ofensiva frontal contra la prioridad del debe, han mostrado que la relación Ortega-Hegel 
presenta la serie de acercamientos y distanciamientos que, en general, caracteriza la conexión entre Ortega y las filosofías que recibe. Esa especie de ambigüedad en la relación viene explicada por un talante general: tomar determinadas cosas y utilizarlas en sentidos muy propios, re-crearlas, recibirlas. En el tema de la historia se mantiene el mismo carácter: por un lado la crítica a los unitarismos, por otro la afirmación de la geografía o del espíritu objetivo, en varios contextos, por un lado la crítica al Fürsichsein, por otro el acercamiento al mismo concepto a partir de un examen propio, por un lado la crítica a la ausencia de libertad y de futuro en la filosofía de Hegel, por el otro el ataque común al liberalismo abstracto, etc.

Los capítulos siguientes intentan penetrar en la recepción de Hegel por Ortega en los escritos publicados. Para ello, no se atenderá únicamente a Hegel, sino también a los temas concretos que aparecen, aunque vayan más allá de la relación explícita Hegel-Ortega, así como a las referencias a otros autores que Ortega coloca expresamente al lado de Hegel en su tratamiento. La intención es llevar a cabo un análisis pormenorizado de los tres artículos de Ortega sobre Hegel, que permitirá situar en un marco adecuado tanto al Hegel que ha aparecido hasta ahora, como al que aparecerá más adelante, en el tema de la dialéctica y en el tema de la nación, o de Europa, y que superarán el contenido explícito de los tres textos a examinar en este momento.

598" El arte en presente y en pretérito" (1925). OC III, 427. 


\section{LOS ESCRITOS DE ORTEGA SOBRE HEGEL (1928-1931)}

\section{Introducción}

Esta sección se dedicará a analizar explícitamente los tres escritos de Ortega sobre Hegel: 'La «Filosofía de la historia» de Hegel y la historiología", "Hegel y América" y "En el centenario de Hegel". Los dos primeros son de 1928, el tercero de 1931. Las diferencias existentes entre ellos no responden únicamente a caracteres de contenido, sino también de método, de intención y de recepción. Con todo, los tres mantienen una identidad en el talante general de Ortega: se trata de conjugar dos ámbitos, por un lado ciertos temas de la filosofía de Hegel, y, por el otro, ciertos intereses propios de Ortega que encontrarían un punto de apoyo, un inicio, en sentido débil (porque habrá muchos otros "inicios" refiriéndose a los mismos temas), en el marco de la teoría de Hegel.

En ningún momento se tratará únicamente de una exposición de la teoría de Hegel por parte de Ortega, sino, sobre todo, de una utilización o recepción de textos e ideas de Hegel, unas veces ampliando o concretando su sentido, otras sacándolos de contexto, algunas incluso partiendo de malentendidos en la interpretación. En general, todo lo que Ortega toma de Hegel tendrá un fin propio y muy concreto, y no sólo un fin, sino también, y exigido por ese fin, un modo definido de lectura y comentario.

Si el acercamiento a los tres artículos se realiza con la intención única de mostrar la relación entre Hegel y Ortega a partir de esos textos, esto es, si se pretende llevar a cabo un examen de la conexión Hegel-Ortega basada exclusivamente en esas páginas, entonces surge una conclusión sencilla: el único interés de Hegel para Ortega se situaba en el contexto de las Lecciones sobre la filosofía de la historia. Pero este método de acercami ento no es el adecuado. Y no lo es por dos razones. Primero, porque pasa por alto referencias de ideas y temas presentes en esos artículos que sólo pueden ser entendidas desde el marco general de la filosofía de Ortega. Y, segundo, porque omite un material de trabajo ineludible para entender la conexión entre Hegel y Ortega: las notas de trabajo que tomó éste en su lectura de aquél, así como la investigación en la biblioteca propia de Ortega, que, gracias a los subrayados y anotaciones que efectuaba el Ortega lector en los 
textos, permite conocer de un modo lo suficientemente riguroso cómo leyó tanto las obras de Hegel, como los estudios sobre éste y los autores que explícitamente estaba manteniendo al lado de Hegel.

Teniendo en cuenta estos dos momentos, la referencia constante al resto de escritos de Ortega y el margen de rigurosidad que permiten tanto las notas de lectura como el manejo de las propias obras utilizadas por Ortega, el análisis de los escritos sobre Hegel adquirirá un sentido especial. Ese análisis, partiendo del método de recepción explicitado desde el inicio, se regirá por un movimiento constante de entrada y salida en los textos sobre Hegel. Tal salida, por un lado se dirigirá a analizar temas o ideas, que aparecen en esos textos, a partir de otros escritos de Ortega, a partir del análisis de los textos superando la referencia a Hegel; y, por otro, remitirá a los orígenes de esos mismos temas en el contexto de la lectura de Hegel por parte de Ortega, basándose para ello en las notas de trabajo y en los textos que al respecto manejaba. Con estos presupuestos, decir que el único interés de Ortega, aunque pueda parecerlo, estaba en la Filosofía de la historia, se mostrará, como poco, insuficiente, sobre todo porque el objetivo del análisis estará centrado en Ortega mucho más que en el propio Hegel.

La sección estará dividida en tres apartados, excluyendo esta introducción, uno para cada uno de los artículos sobre Hegel. El primero, dedicado a "La «Filosofía de la historia» de Hegel y la historiología", intenta determinar los tres objetivos que llevaron a Ortega a escribir ese texto, el cual serviría de prólogo a la traducción española de la obra de Hegel: situar el marco a que habían sido conducidas los estudios sobre la historia, situar la posición de Hegel en ese marco, situar del mismo modo la posición del propio Ortega. Sobre este primer artículo sí que puede decirse que el interés de Ortega se centra en la Filosofía de la historia, pero, más que en la teoría general de Hegel, en lo que ésta permite. No es casual que Ortega haya titulado el artículo como lo ha hecho, introduciendo esa "y" copulativa que, en realidad, tanto une como separa los dos polos: por un lado Hegel y su filosofía de la historia, por el otro Ortega y su historiología. Habrá una relación entre ambos, y esa relación incluirá coincidencias y divergencias.

La misma "y" aparecerá en el título del segundo de los artículos, el "Hegel y América", manteniendo una intención semejante: esa "y" no significa únicamente "sobre", esto es, "Hegel sobre América", sino que reúne a Hegel con un tema, el de América, que deberá ser 
atendido tanto desde lo que dice Hegel, como desde lo que piensa Ortega. El problema es que las opiniones de Ortega sobre América no se encuentran en el artículo sobre Hegel, sino que habrá que acudir a otros textos para encontrarlas, y, con ellas, la situación de la recepción de Hegel en torno al tema. Pero el 'Hegel y América" en concreto, además de la referencia a América, contiene una problemática clave en Ortega: d tema del futuro. Este tema, de nuevo, debe ser analizado en el marco general de la filosofía de Ortega, porque no remite únicamente a la historia, a la conexión de futuro e historia, sino también a la vida, a la vida como proyecto y tarea futura. La conexión de ambos aspectos, América y futuro, significando por un lado la situación de América como futuro, pero por otro el tema del futuro en general, determinará el artículo.

"En el centenario de Hegel", el tercero y último de los textos de Ortega sobre Hegel, es posterior en tres años a los dos anteriores. Para los propósitos de mi trabajo es el más interesante de los tres, debido tanto al método que utiliza Ortega, como a los contenidos examinados. Si los dos primeros exigen para ser entendidos un acercamiento receptivo, que examine las razones y objetivos que han llevado a Ortega hasta Hegel y que, una vez ahí, han causado el tipo de lectura que realiza, "En el centenario de Hegel" es una recepción explícita por parte del propio Ortega. Si los dos primeros artículos implican una recepción implícita, este tercero la muestra de un modo explícito: Ortega analizará el concepto hegeliano de espíritu a partir de sus teorías de la vida y mostrará su tema del paisaje en relación concreta con Hegel.

Además, en "En el centenario de Hegel" aparecerá la conexión entre el paisaje y la limitación, conexión que determinaba la primera sección de este trabajo, en el contexto de la filosofía de Hegel. Con ello, se mostrará un hilo conductor que ha recorrido el conjunto del trabajo hasta el momento, aquel hilo ya iniciado en el no escrito Ensayo sobre la limitación, cuando aparecía que las dos pistas que deberían haber determinado ese ensayo no escrito eran el tema del paisaje y la referencia a Hegel. En este momento se mostrará en cierto modo la culminación del esquema, al situar la conexión entre el paisaje y la limitación en el contexto propio de la recepción por Ortega de unos temas muy concretos de la filosofía de Hegel.

En general, entonces, los temas que examinará Ortega en los escritos sobre Hegel son todos ellos fundamentales en la filosofía propia de Ortega: la historia, América, el futuro, el 
paisaje, etc. Esto implica que su análisis sea llevado a cabo a tres bandas: en el contexto de los escritos sobre Hegel, en el contexto general de la filosofía de Ortega y en el contexto de la recepción (tanto en el método como en el contenido) que aquí se está efectuando. La conjunción de las tres direcciones debe mostrar no sólo cómo recibe Ortega a Hegel, sino también cómo recibimos nosotros esa recepción. 


\section{2. "La «Filosofía de la historia» de Hegel y la historiología"}

En febrero de 1928 publica Ortega lo que él mismo llama "algunos apuntes para un prólogo a la traducción española del famoso curso de Hegel"1. El "famoso curso" son las lecciones de Hegel sobre filosofía de la historia, y esos "apuntes" llevan por título "La «Filosofía de la historia» de Hegel y la historiología", el primero de los tres artículos que Ortega publicó sobre Hegel. Este escrito, dicho de un modo general, se caracteriza por dos rasgos: por no hablar demasiado de Hegel en concreto, y por basar en un extraño error de traducción lo poco que dice sobre él. Hay que acudir a las notas de trabajo para ver lo que es quizá lo más interesante de ese artículo: lo que Ortega no dice sobre Hegel, lo que se encuentra sosteniendo aquello que sí fue publicado. La intención de Ortega consistía en situar la traducción de la Filosofía de la historia en el primer lugar de toda una "biblioteca de historiología", con lo que no es de extrañar que, en el prólogo de Ortega, Hegel, más que recibir una atención concreta, fuera utilizado, primero, para mostrar la definición de historiología, y, segundo, para presentar la situación general de los estudios sobre historia.

Con el prólogo a la Filosofía de la historia Ortega persigue tres objetivos. El primero, situar el marco al que habían sido conducidas las ciencias históricas, con los distintos contextos de historicismo, escuela histórica, filosofía de la historia, etc., así como la serie de nombres que los llenan: Ranke, Niebuhr, Savigny, el propio Hegel... Las referencias de Ortega a esos autores no son tomadas de primera mano, por lo menos habitualmente y exceptuando a Hegel, pero es fácil, y muy importante, encontrar las obras concretas de las que Ortega recibe la mayor parte de las ideas para realizar esa contextualización. Son sobre todo tres estudios, clásicos en el tema, que Ortega conocía muy bien (los ejemplares presentes en la "Fundación José Ortega y Gasset" manejados por Ortega están subrayadísimos y, por las constantes anotaciones al margen, leídos de un modo exhaustivo y detenido) y a los que les sacará un partido espléndido. En primer lugar está la obra de Ottokar Lorenz Geschichtswissenschaft in Hauptrichtungen und Aufgaben, publicado en 1886 el primer tomo y en 1891 el segundo 2 .

\footnotetext{
1"La «Filosofía de la historia» de Hegel y la historiología" (1928). OC IV, 521.

${ }^{2}$ La referencia completa es: LORENZ, O. Geschichtswissenschaft in Hauptrichtungen und Aufgaben. Berlin: Hirze, 1886 (I. Band), 1891 (II. Band).
} 
Casi todo lo que Ortega dice de Ranke en 'La «Filosofía de la historia» de Hegel y la historiología" está tomado de este texto, en concreto del segundo volumen, titulado directamente "Leopold von Ranke. Die Generationenlehre und der Geschichtsunterricht". La importancia del escrito de Lorenz en la obra de Ortega no remite únicamente al tema de la historia, o, en general, a su utilización como manual para conocer toda la polémica al respecto, sino también a un aspecto, que no aparece en los textos sobre Hegel, pero que es determinante en Ortega, como es el tema de las generaciones: la segunda parte del segundo volumen de la obra de Lorenz se titula, explícitamente, "Zur Generationenlehre"3.

Los otros dos volúmenes indispensables refieren al segundo objetivo en el texto de Ortega sobre Hegel: determinar la posición de Hegel en el contexto de toda la polémica alrededor del estudio de la historia. Esas dos obras son la de Rothacker, Einleitung in die Geisteswissenschaften, de 19204, y la de Troeltsch, Der Historismus und seine Probleme, de 1922. En la obra de Rothacker, Ortega aprovechará sobre todo la segunda sección, dedicada explícitamente a la escuela histórica (con ese mismo título, "Die historische Schule"), y en concreto capítulos importantes para él como el dedicado a Savigny, el que se

\footnotetext{
${ }^{3}$ Ortega encontró en su lectura textos como éstos: "Einzel und in der Vielheit ist und bleibt der historische Mensch ein Produkt seiner Genealogie, beziehungsweise seiner Generation", o "Dass auf dem Wechsel der Generationen alles das ruht, was man den Fortgang der Dinge nennt, ist ein anerkanntes Axiom". LORENZ, O. Geschichtswissenschaft... Op. cit. p. 275 y 278 (II. Band). Cuando Ortega en Argentina, también en 1928, muestre su prioridad en la teoría y afirme: "Los cambios históricos suponen el nacimiento de un tipo de hombre distinto en más o en menos del que ya había, es decir, suponen el cambio de generaciones. Desde hace años yo predico a los historiadores que el concepto de generación es el más importante en historia y debe haber llegado al mundo una nueva generación de historiadores porque veo que esta idea ha prendido sobre todo en Alemania" (Meditación de nuestro tiempo. Las conferencias de Buenos Aires, 1916 y 1928. Ed. J.L. Molinuevo. Madrid: F.C.E., 1996, p. 211), parece, sólo lo parece, no tener en cuenta que el texto de Lorenz es de 1891, y que en el mismo Lorenz se encuentran referencias a escritos, por lo tanto anteriores a esa fecha, como el de Rumelin, "Über den Begriff und die Dauer einer Generation". Esa "nueva generación de historiadores" que menciona Ortega es posterior a Lorenz, y también a Troeltsch, que no olvida la teoría de Lorenz sobre las generaciones (cfr. TROELTSCH, E. Gesammelte Schriften. Dritter Band: Der Historismus und seine Probleme. Tübingen: Mohr, 1922, p. 737), ni tampoco que ya Harnack había defendido el principio de las generaciones en Aus Wissenschaft und Leben. Cuando Ortega, en ¿Qué es filosofía?, utilice esos mismos textos ya presentes en las lecciones de Argentina (y que volverán a aparecer en la reproducción de las primeras lecciones de ¿Qué es filosofía? para La Nación: cfr. "¿Por qué se vuelve a la filosofía?" (1930). OC IV, 89 ss.), concretará que la referencia es a Pinder, y que no ha olvidado a Lorenz o Harnack, aunque a Troeltsch no lo menciona: "Lorenz, Harnack, Dilthey insinuaron en su hora algo sobre la idea de las generaciones; pero la manera más radical de tomar el asunto, que va apuntada en alguno de mis libros, es reconocida, por ejemplo, en el libro de Pinder, Das Problem der Generationen, segunda edición, 1928". ¿Qué es filosofía? (1929). OC VII, $290 \mathrm{n}$.

${ }^{4}$ La referencia completa es: ROTHACKER, E. Einleitung in die Geisteswissenschaften. Tübingen: Mohr, 1920.
} 
centra en el concepto de vida en la escuela histórica, y, sobre todo, la sección titulada "Hegel und die historische Schule".

En la obra de Troeltsch, de nuevo, Ortega se centrará en temas muy similares, aunque de un modo más detallado. Aparte de estos temas, que conectan directamente con su tratamiento en "La «Filosofía de la historia» de Hegel y la historiología", la obra de Troeltsch contiene aspectos que superan en cierto sentido el marco en el que se mueve esta sección, pero que interesan a Ortega de un modo determinante. Para encontrar la opinión de Ortega al respecto, en conexión con Hegel, hay que esperar hasta años posteriores, y, en mi trabajo, a la cuarta sección. Esos aspectos cruciales estarían formados por temas (enunciando, por ahora, únicamente títulos de capítulos de la obra de Troeltsch) como los expuestos en el último capítulo, 'Ueber den Aufbau der europäischen Kulturgeschichte", o, más en concreto, la segunda sección de ese capítulo, "Der Europäismus".

Las temáticas de esos contextos conducen en Ortega, directamente, a la 'Meditación de Europa", del 49, desde donde puede encontrarse otro Hegel, relacionado explícitamente con Meinecke. Es el tema de la nación el que estará en la base, así como el de Europa, aunque por ahora, en estos escritos del 28, Ortega no mantenga su objetivo en esa dirección. Incluso, y valga como curiosidad, los subrayados de Ortega en el libro de Troeltsch han sido realizados con lápices distintos, uno para todo lo que remite a la escuela histórica y a la problemática de la historia, otro para esos capítulos finales sobre Europa y sobre la relación entre el europeísmo y los estudios sobre historia. Esto parece indicar que las lecturas de Ortega han sido llevadas a cabo en épocas diferentes. Lo importante es tener en cuenta que, en lo que concierne a Hegel, las mismas obras que Ortega ha utilizado para el tema de la historia le conducirán a otros aspectos determinantes que en su recepción de Hegel no pueden ser pasados por alto. De un modo concreto: no es, ni mucho menos, el tema de la historia lo único que a Ortega interesaba de Hegel 5 . Tanto lo que hemos venido viendo, como lo que podrá llamarse "la última parte de la recepción de Hegel por Ortega" permitirá encontrar a un Hegel, como se verá, que conduce a otros contextos.

Resta un tercer objetivo. Si el primero era explicar el marco de los estudios sobre historia, y el segundo situar a Hegel en él, el tercero, y más importante, es el que dirige el 
desarrollo: mostrar la situación del propio Ortega en esa temática. Siendo esto así, si uno de los objetivos es sobre el contexto, y otro sobre las propias intenciones de Ortega, no es de extrañar que sobre Hegel en concreto no diga demasiado, y que habrá que esperar a los dos siguientes artículos, sobre todo a "En el centenario de Hegel" para ver cómo ha leído Ortega la Filosofía de la historia. No es "muy acertado" (por decir algo) afirmar que sobre la Filosofía de la historia "hablo largamente en el prólogo a la versión española"6, pero, y éste debe ser el objetivo del capítulo, es imprescindible examinar qué es exactamente lo que sí dice Ortega, qué es lo que rodea a Hegel en los intereses de Ortega, o en concreto, comenzar a contestar a la cuestión de por qué y para qué escribe Ortega los tres artículos sobre Hegel.

5INSAUSTI, F.-J. Miguel de Unamunos und José Ortega y Gassets Philosophie im Zusammenhang mit ihrer Hegel-Rezeption. San Sebastián: Zorroaga, 1993, p. 84: "[...] Ortega sich nur für einen Aspekt der Philosophie Hegels interessierte, nämlich für seine Philosophie der Geschichte".

6" Hegel y América" (1928). OC II, 564. 


\subsection{Contra la historia diplomática}

Según Ortega, la "biblioteca de Historiología" que debía iniciarse con la traducción de la Filosofía de la historia de Hegel "ha sido inspirada por la insatisfacción sentida al leer los libros de historia, ante todo los libros de Historia. Conforme volvemos sus páginas, siempre abundantes, nos gana irremediablemente, contra nuestra favorable voluntad, la impresión de que la Historia tiene que ser cosa muy diferente de lo que ha sido y es"7. A esa insatisfacción por los libros de historia acompañan unos párrafos importantes de Ortega sobre la capacidad de insatisfacción en el hombre, que van más allá de la referencia al tema de la historia. La conexión se establecerá con la teoría del descontento, precisamente como emoción idealista, que ya ha aparecido en más de una ocasión. Más adelante examinaré esa teoría del descontento en relación con aspectos importantes del artículo de Ortega; por ahora, basta con lo siguiente: la insatisfacción producida por los "libros de Historia" viene causada por el remordimiento de saber que los males de esos libros tienen arreglo, permiten vislumbrar la posibilidad de su perfección o, por lo menos, de su mejora. Ahora bien, ¿cuáles son esos males?

En primer lugar, "que la Historia parece no haber adquirido aún figura completa de ciencia"8. En realidad, será la conexión de historia y ciencia la que dirija todo el artículo de Ortega, así como, en concreto, el concepto de historiología. Para iniciar el desarrollo de esa conexión, Ortega parte del enfrentamiento con el que "los alemanes nos presentan una y otra vez como prototipo de historiador, como gran historiador ante el Altísimo, a Leopoldo de Ranke. Tiene fama de ser el más rico en «ideas»"9. Para Ortega, Ranke no sólo no es rico en ideas sino que se caracterizaría por la ausencia de ellas y la vaguedad de sus teorías. Esta ausencia de ideas es, precisamente, la que conduce hasta Hegel: "Pero a esta sincera impresión del lector responden los historiadores diciendo: «Esa falta de «ideas» que se advierte en Ranke no es su defecto, sino su específica virtud. Tener «ideas» es cosa para los filósofos. El historiador debe huir de ellas. La idea histórica es la certificación de un hecho o la comprensión de su influjo sobre otros hechos». Nada más, nada menos. Por eso, según

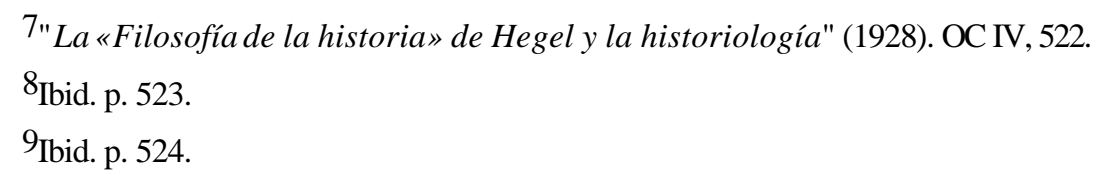


Ranke, la misión de la Historia es «tan sólo decir cómo, efectivamente, han pasado las cosas»"10. La afirmación de Ranke sólo puede entenderse si se toma en la intención que la sostiene: la del enfrentamiento con la filosofía de la historia de Hegel. Ese enfrentamiento conduce a un contexto más general, el de la rivalidad entre la escuela histórica y la escuela filosófica.

El concepto de escuela histórica que manejará Ortega, recibido de Troeltsch y Rothacker, está concretado en una nota a pie de página: "El término «escuela histórica» se usa con diferente radio. Troeltsch lo reduce a la escuela de Savigny, Eichhorn, etc. (Der Historismus und seine Probleme, 277 y sigs., 1923); Rothacker incluye a casi todos los postrománticos (Einleitung in die Geisteswissenschaften, 40 y ss., 1920). Puede ampliarse aún más y comprender en él todos los historiadores enemigos de la filosofía de la historia"11. De Troeltsch tomará Ortega los caracteres de "escuela histórica" que está utilizando, de Rothacker, la diferencia entre Hegel y la escuela histórica. De un modo demasiado amplio, Ortega entiende por escuela histórica la teoría enfrentada a la filosofía de la historia, la teoría que se basaría exclusivamente en el carácter de documentación, de acudir a los datos y a las fuentes para mostrar cómo "efectivamente han sucedido las cosas", frente a esa filosofía de la historia que buscaría ideas, constantes, conceptos, que permitieran entender y dar un sentido a esos datos.

Es un modo demasiado amplio porque Ortega parece olvidar la dificultad del propio Troeltsch para determinar el concepto. Escribía Troeltsch, y esa "circunscripción más estrecha del concepto" la subraya Ortega en su edición de la obra: "[...] Bedarf es einer strengeren Umschreibung des Begriffs der "historischen Schule" als gemeinhin üblich ist. Viele denken dabei an die Romantik und ihre Nachwirkungen in der Historie im allgemeinen, andere vor allem an die beiden grössten Bahnbrecher modernen historischen Denkens, an Niebuhr und Ranke. Andere wieder werfen sie [...] mit der Hegelschen Schule zusammen, indem sie die seinerzeit so leidenschaftlich empfundenen und ausgesprochenen Gegensätze für nebensächlich halten, und fassen die ganze antirevolutionäre, kontemplativ an den Fluss der Dinge sich hingebende und die Gegenwart aus der Vergangenheit

\footnotetext{
${ }^{10}$ Ibid.

${ }^{11}$ Ibid. p. 525 n.
} 
verstehende und meisternde Denkweise als das Wesen der "historischen Schule" zusammen"12.

El contexto general al que remite la disputa entre escuela histórica y escuela filosófica, utilizando los términos de Ortega, es el de la superación del idealismo. Por eso era tan importante mostrar cómo llegaba Ortega hasta los artículos sobre Hegel, y, en general, cómo llevará a cabo él mismo esa superación. Ortega tomará los caracteres que más le convengan de ambas posturas. El enfrentamiento se produjo cuando la conciencia del siglo XIX intenta superar el idealismo acudiendo a los conceptos de ciencia e historia, cambiando el significado hegeliano de ambos términos. Con palabras de Schnädelbach, "el cambio se podría expresar a través de estos lemas «ciencia, en lugar de sistema filosófico» y «ciencia histórica, en lugar de filosofía de la historia»"13. La nueva ciencia histórica posterior a Hegel dominó la oposición científica al idealismo, y además se constituyó como primera fuerza cultural, al ocupar el puesto que hasta entonces había ocupado la filosofía. Humboldt, Ranke, Droysen, etc. mantenían la fuerza de la conciencia histórica en la aproximación científica a los hechos y, con ello, en el lema de Ranke de "decir cómo efectivamente han pasado las cosas".

Ortega, que mantiene como tema de su tiempo la superación del idealismo, comienza precisamente el artículo sobre Hegel atacando esas pretensiones de cientificidad de la Historia, atacando, entonces, el pilar sobre el que se había sostenido todo ese historicismo del XIX. Si con Niebuhr y Ranke se había datado la ascensión de la Historia a auténtica ciencia, las críticas de Ortega se dirigirán frontalmente contra los supuestos que mantenían ese carácter científico: la atención única a los datos, a los documentos, a las fuentes, que suponen una Historia como agregado, que no construye, que no da sentido, sino que se

12TROELTSCH, E. Der Historismus und seine Probleme. Op. cit. p. 278. Traducción: "Se necesita una circunscripción del concepto de "escuela histórica" más estrecha que la que se usa habitualmente. Con ese concepto muchos piensan en los románticos y sus efectos en la Historia en general, otros sobre todo en los dos más grandes precursores del pensamiento histórico moderno, Niebuhr y Ranke. Ot ros en cambio la confunden [...] con la escuela hegeliana, en tanto colocan en un lugar secundario las oposiciones sentidas y manifestadas tan fervorosamente en su día, y sintetizan como la esencia de la "escuela histórica" el modo de pensar totalmente antirevolucionario, que se abandona a la contemplación del fluir de las cosas, y que entiende y dirige el presente desde el pasado".

${ }^{13}$ SCHNÄDELBACH, H. Filosofía en Alemania, 1831-1933. Madrid: Cátedra, 1991, p. 47. 
mantiene en una simple labor filológica. Es por ello por lo que, para Ortega, Ranke representa la "historia diplomática o documental"14.

Ortega insiste, tanto en el prólogo a la Filosofía de la historia, como en las notas de lectura de la obra de Hegel, en este carácter de "historia diplomática" para definir el talante de la escuela histórica, de la pretendida historia científica. La expresión no es suya, sino que la toma de Lorenz. Escribía éste:

"Den Ausdruck «diplomatische Geschichtschreibung» gebrauche ich nur der Kürze wegen [...]. Was über diesen Gegenstand im allgemeinen zu sagen ist, hat Gervinus in der Vorrede zur Geschichte des 19. Jahrhunderts musterhaft geäussert, wobei es ihm auch gewiss nicht darauf ankam, die Nachforschung in den Archiven der handehden Menschen irgend zu verkleinern. Bei aller Hochschätzung der Ausdauer und des Fleisses, welche in der letzteren Richtung herrschen, seit Ranke den kanonischen Satz der modernen Geschichtschreibung ausgesprochen, dass Memoiren, Tagebücher, Briefe, Gesandtschaftberichte die Grundlage der Geschichtkenntnis bilden, und gezeigt hat, dass alle Überlieferungen von Geschichtschreibern [...] dem kritischen Messer unbarmherzig anheimfallen, darf man zweierlei nicht vergessen: 1. dass Ranke selbst eines seiner herzlichsten Bücher geschrieben, ohne auch nur in Besitze eines einzigen geheimen diplomatischen Aktenstückes über den Gegenstand zu sein, und 2. dass man über die Methode der Benutzung und Verwertung des amtlichen Aktensctückes in dem ganzen halben Jahrhundert erstaunlicher Regsamkeit und grossartiger Publikationen auch nicht zu den geringsten feststehenden und anerkannten Grundsätzen der Kritik gelang ist, ja dass Meiste in dieses Beziehung unter der Herrschaft der Zufalls der Auffindung oder Entdeckung steht. Weil nun der Zufall freilich nichts "Subjektives" ist, scheint man sich einzubilden, dass die sogenannte diplomatische Geschichtschreibung "objektiv" ware" 15 .

14"La «Filosofía de la historia» de Hegel y la historiología" (1928). OC IV, 525.

15LORENZ, O. Geschichtswissenschaft in Hauptrichtungen und Aufgaben, I. Op. cit. p. 51. Traducción: "Utilizo la expresión «historiografía diplomática» únicamente por razones de concisión [...]. Lo que se puede decir sobre este asunto, en general, ya lo ha mostrado Gervinus de un modo ejemplar en el prólogo a la Historia del siglo XIX. Ciertamente Gervinus no se plantea que la investigación en los archivos de los hombres de acción se produzca en detrimento de nada. Sin embargo, con todo respeto a la tenacidad y diligencia que dominan en la más reciente dirección, desde que Ranke promulgó el principio canónico de la historiografía moderna, según la cual el fundamento del conocimiento histórico lo constituyen memorias, diarios, cartas, informes de legación, etc., y se indicase que todas las fuentes de los historiadores [...] están despiadadamente sometidas al cuchillo crítico, cabe decir que no deben olvidarse dos cosas: 1. que Ranke mismo ha escrito uno de sus libros más entrañables sin poseer un único documento diplomático secreto sobre el tema, y 2. que tampoco se han alcanzado, en todo un medio siglo de sorprendente actividad y monumentales publicaciones, unos mínimos principios de crítica establecidos y reconocidos sobre el método de utilización y valoración de documentos oficiales. Por el contrario, la mayor parte del trabajo historiográfico en este sentido está bajo el imperio de la casualidad del hallazgo o del descubrimiento. Por el hecho de que la casualidad no es algo subjetivo, parece imaginarse que la llamada «historiografía diplomática» sea objetiva". 
Para Ortega, el carácter diplomático de la historia consiste en su dedicación exclusiva a los documentos, a las fuentes, a los datos. Es ese carácter que en la ciencia consiste en entender ésta como la atención exclusiva al experimento, en creer que la física es la ciencia nueva porque descubrió el experimento. Pero tanto los historiadores anteriores al XIX habían criticado fuentes e investigado documentos, como los científicos griegos $\mathrm{o}$ medievales habían experimentado e intentado justificar sus teorías. Ortega tiene clara la conclusión: "ni la física es el experimento -así, sin más ni más- ni la Historia el documento"16.

La innovación de Galileo no consistió en la permanencia en el experimento, en la simple observación del hecho, sino en la unión de ese empirismo, que se detiene en la observación, con una disciplina como es el análisis, que supera el carácter empírico: "El análisis no observa lo que ve, no busca el dato, sino precisamente lo contrario: construye una figura conceptual (mente concipio) con la cual compara el fenómeno sensible. Pareja articulación del análisis puro con la observación impura es la física. / Ahora bien: ésta es la anatomía de toda ciencia de realidades, de toda ciencia empírica. Cuando se usa esta última denominación se suele malentender, y la mente atiende sólo al adjetivo «empírica», olvidando el susbstantivo «ciencia». Ciencia no significa jamás «empiria», observación, dato a posteriori, sino todo lo contrario: construcción a priori"17. La articulación entre el a priori y el a posteriori, entre la idea y la materia, entre la forma y la intuición, si se quiere, va a ser el objetivo de Ortega. En la historia supone la unión de datos, o fuentes, o documentos, e ideas, pero, como se ha venido viendo, el tema remite al conjunto de los caracteres que definen la filosofía de Ortega, desde la superación del idealismo hasta la integración del hombre del norte y el hombre del sur. Los caracteres de articulación de ambos talantes permanecen en la base del conjunto.

La articulación muestra la necesidad de que sea un a priori, una idea, la que confiera sentido a la materia, lo observado, el documento. La historia no puede basarse únicamente en el documento, como pretendía la escuela histórica en sus intenciones de cientificidad. Si de lo que se trataba, en el fondo, era de una superación del idealismo partiendo de la aseguración de los datos, de lo observable, esto no significa, con todo, que la historia deba

16"La «Filosofía de la historia» de Hegel y la historiología" (1928). OC IV, 526. 
permanecer y reducirse a esos datos, a eso observable. "Todo un sistema de técnicas complicadas va a surgir en la pasada centuria con el propósito exclusivo de asegurar los «datos históricos». Pero los datos son lo que es dado a la ciencia -ésta empieza más allá de ellos. Ciencia es la obra de Newton e Einstein, que no han encontrado datos, sino que los han recibido o demandado. Parejamente, la Historia es cosa muy distinta de la documentación y de la filología"18.

Esta crítica a la historia como filología, a la historia diplomática que se reduce a recopilación de datos y permanece en el estudio de las fuentes, la encuentra Ortega ya en el propio Hegel, cuando éste muestra que incluso los historiadores que se basan en las fuentes ya incluyen lo a priori: "Die Geschichte aber haben wir zu nehmen, wie sie ist; wir haben historisch, empirisch zu verfahren. Unter anderem auch müssen wir uns nicht durch Historiker vom Fache verfuihren lassen; denn wenigstens unter den deutschen Historikern, sogar solchen, die eine grosse Autorität besitzen, auf das sogennante Quellenstudium sich alles zugute tun, gibt es solche, die das tun, was sie den Philosophen vorwerfen, nämlich apriorische Erdichtungen in der Geschichte zu machen"19.

La crítica de Ortega se dirige fundamentalmente contra la parcialización de la tarea, esto es, la precisión en la recolección de datos o en la investigación de fuentes queda situada por encima de lo que, para él, debe mantenerse como verdaderamente científico de la historia: las ideas constructivas, el hallazgo de sentidos y constantes a priori, razones, que dirijan esos datos 20 . Es precisamente para compensar este desnivel entre la historia como filología y la historia como ciencia por lo que Ortega acude a Hegel. La historiología, como tal, se

\footnotetext{
17"La «Filosofía de la historia» de Hegel y la historiología" (1928). OC IV, 527.

18 Ibid. p. 529.
}

${ }^{19}$ HEGEL, Vorlesungen über die Philosophie der Weltgeschichte. Werke, VIII. Hrsg. G. Lasson. Hamburg: Meiner, 1920, p. 7. Gaos traduce: "Pero hemos de tomar la historia tal como es; hemos de proceder histórica, empíricamente. Entre otras cosas, no debemos dejarnos seducir por los historiadores de oficio. Pues, por lo menos entre los historiadores alemanes, incluso aquellos que poseen una gran autoridad y se enorgullecen del llamado estudio de las fuentes, los hay que hacen lo que reprochan a los filósofos, esto es, llevar a la historia invenciones a priori". HEGEL, Lecciones sobre la filosofía de la historia universal. Ed. J. Gaos. Madrid: Alianza, 1994 (5a reimp.), p. 45.

\footnotetext{
${ }^{20}$ Años más tarde, cuando vuelva a examinar el tema de la escuela histórica para el "Guillermo Dilthey y la idea de la vida", insistirá Ortega en los mismos caracteres: "No basta con preparar cuidadosamente el hecho del pasado para que en toda su pureza se le pueda ver. La historia no es sólo ver: es pensar lo visto. Y pensar es siempre, en uno u otro sentido, construcción. La «escuela histórica», en última instancia, no añade ningún
} 
dirige contra ese desnivel: "Contra este estado de las cosas en el reino de la Historia se levanta la historiología. Va movida por el convencimiento de que la Historia, como toda ciencia empírica, tiene que ser, ante todo, una construcción y no un «agregado» - para usar el vocablo que Hegel lanza una vez y otra contra los historiadores de su tiempo"21.

Ese carácter de "agregado" que supone la historia diplomática, filológica, y que Ortega remite a Hegel, lo encuentra en su lectura de Rothacker 22 : "[...] die historische Schule, die historisch-kritische Methode und das «Aggregat» der Philologie"23. Es éste carácter de "agregado" el que no puede aceptar Ortega, no puede aceptar que el historiador se limite a coleccionar datos, sin intentar construir su sentido, sin concederles una estructura, una serie de constantes que los plenifiquen, una razón: "Es preciso, ante todo, por alta exigencia de la disciplina intelectual, negarse a reconocer el título de científico a un hombre que simplemente es laborioso y se afana en los archivos sobre los códices"24. Y no sólo se le niega el título de científico, sino que, además, como afirmaba Hegel, Ortega insiste en la imposibilidad de pasar por encima de ciertos a prioris o ideas que determinen esos datos, $\mathrm{o}$, con palabras de Hegel, la imposibilidad de dormir de la razón.

Para Ortega, "el mero acto de llamar «histórico» a cierto hecho y a tal dato introduce ya, dése o no cuenta el historiador, todo el a priori historiológico en la masa de lo puramente facticio y fenoménico. «Todo hecho es ya teoría», dijo Goethe"25; para Hegel, "auch der gewöhnliche und mittelmässige Geschichtschreiber, der etwa meint und vorgibt, er verhalte sich nur aufnehmend, nur dem Gegebenen sich hingebend, ist nicht passiv mit seinem Denken; er bringt seine Kategorien mit und sieht durch sie das Vorhandene. Das Wahrhafte

principio al siglo XVIII, y surge, más bien, por una operación de resta: desentenderse de la raison". "Guillermo Dilthey y la idea de la vida" (1933-1934). OC VI, 182.

$21 " L a \ll$ Filosofía de la historia» de Hegel y la historiología" (1928). OC IV, 530.

22"La filología como un aggregat. Según Hegel. No sé donde lo dice. Lo tomo de Rothacker". Archivo de la "Fundación José Ortega y Gasset", Carpetilla "Hegel: filosofía de la historia". Conjunto de notas titulado "Filología. Historiología".

${ }^{23}$ ROTHACKER, E. Einleitung in die Geisteswissenschaften. Op. cit. p. 62. Traducción: "La escuela histórica, el método histórico-crítico y el «agregado» de la filología".

24"La «Filosofía de la historia» de Hegel y la historiología" (1928). OC IV, 529.

25 Ibid. p. 531. 
liegt nicht auf der sinnlichen Oberfläche; bei allem insbesondere, was wissenschaftlich sein soll, darf die Vernunft nicht schlafen und muss Nachdenken angewendet werden"26.

En las notas de lectura, Ortega expresará el contexto de un modo lo suficientemente explícito: "El historiador que asegura necesitar sólo documentos y haber hallado ninguna ley histórica es como el arriero que al contar los burros no hallaba uno, aquel en que iba montado"27. Pero la intención personal de Ortega va más allá de la conjunción entre los datos y lo a priori. Toma de Hegel este momento de introducción de la idea, de las constantes a priori que confieran sentido a los datos, pero la fidelidad a lo real, la superación del idealismo o el carácter de ideal objetivado, que habite en lo real mismo ${ }^{28}$, obligan a que sea el hecho, las cosas sucedidas, las que dirijan su propia construcción. De la misma forma que se ataca el empirismo de la recaída en el documento, también se rehuye el idealismo de la idea única, del absoluto como tirano.

Esta es la relación, bidireccional, como siempre, entre Hegel y Ortega en este momento. Utilizando la expresión de Goethe que citaba más arriba, en las notas de lectura escribirá: "Los hechos como leyes o desviación de leyes a priori. Alles faktische ist schon Theorie. Aparte la influencia de la observación como guión e incitación de la creación científica"29. La fidelidad a lo real, una fidelidad que exige su idealización y plenitud, se separa de, y al mismo tiempo reúne, la historia diplomática y la filosofía de la historia de Hegel: los hechos son ya leyes a priori, en ningún momento hay que olvidar aquello de que "si sabemos mirarla, toda realidad nos enseñará su defecto y su norma, su pecado y su deber"30.

\footnotetext{
26HEGEL, Vorlesungen über die Philosophie der Weltgeschichte. Op. cit. p. 7. Gaos traduce: "El historiógrafo corriente, medio, que cree y pretende conducirse receptivamente, entregándose a los meros datos, no es en realidad pasivo en su pensar. Trae consigo sus categorías y ve a través de ellas lo existente. Lo verdadero no se halla en la superficie visible. Singularmente en lo que debe ser científico, la razón no puede dormir y es menester emplear la reflexión". HEGEL, Lecciones sobre la filosofía de la historia universal. Op. cit. p. 45 .

${ }^{27}$ Archivo de la "Fundación José Ortega y Gasset", Carpetilla "Hegel: filosofía de la historia".

${ }^{28}$ En Rothacker precisamente, y en referencia a la vida, leerá Ortega la afirmación de Ranke: "Das Leben trägt sein Ideal in sich". ROTHACKER, E. Einleitung in die Geisteswissenschaften. Op. cit. p. 159. Traducción: "La vida lleva su ideal en sí misma".

${ }^{29}$ Archivo de la "Fundación José Ortega y Gasset", Carpetilla "Hegel: filosofía de la historia".

${ }^{30}$ España invertebrada. Bosquejo de algunos pensamientos históricos(1921). OC III, 102.
} 
Por todo esto, Ortega insiste en su crítica a la historia diplomática, la historia como filología, como agregado, y se sitúa del lado de la filosofía de la historia de Hegel en su introducción de una idea, un sentido que rija los datos y documentos. Pero, con todo, no olvida el carácter que le interesa mantener de la escuela histórica: "Es preciso reconocer que la escuela histórica comienza por tener razón frente a la «escuela filosófica», frente a Hegel. Su filosofía es, en uno u otro riguroso sentido, lógica, y opera mediante un movimiento de puros conceptos lógicos, y pretende deducir lógicamente los hechos alógicos, no hay duda que la Historia debe rebelarse contra su intolerable imperialismo. Ahora bien, la filosofía de la Historia de Hegel pretende, por lo tanto, y muy formalmente, ser eso"31. La pretensión de Ortega es la de la integración, la que concluya en una filosofía de la experiencia, no de los conceptos, pero una experiencia a priori. La integración del carácter científico y el filosófico, que incluya la fidelidad a lo real, y con ella a su plenitud, a su idealización, implica la necesidad de reunir el marco empírico y el marco de lo a priori, integrar la escuela histórica y la filosofía de la historia de Hegel, eliminando de ambas los aspectos restrictivos.

31"La «Filosofía de la historia» de Hegel y la historiología" (1928). OC IV, 529. 


\subsection{Historiología y humanidades}

El carácter cientificista que mantenía la escuela histórica, basado únicamente en la observación, ni es científico ni puede aceptarse como directriz. La filosofía debe estar integrada en ese marco empírico. En las notas inéditas sobre Hegel escribe Ortega: "Hay que volver a regimentar las ciencias -bajo la filosofía-. Sólo que esta filosofía es una filosofía de experiencia - no de formas conceptuales - Experiencia a priori - término a que se ha llegado ¡desde el 18! ¡Suma integración! ¡Inglaterra y Alemania!"32. La integración refiere a los dos polos, experiencia y concepto; la conclusión debe constituir una experiencia a priori que permita su constante interrelación. El carácter cientificista de la historia diplomática, que para Ortega es todo menos científico, mantiene el deseo de acabar con la filosofía, con las ideas, con el a priori, pero eso supondría su propia aniquilación.

A continuación de ese texto citado escribe Ortega: "Sobre filología y filosofía vease la admirable frase de Boeckh citada en Rothacker". Esa frase de Boeck no puede ser otra que la siguiente, subrayada al margen por Ortega con tres gruesas líneas: "Heutzutage freuen sich viele daran, dass, wie sie glauben, die Philosophie immer mehr abnehme, und jubeln darüber, dass die Philosophie bald werde zu Grabe getragen sein: das heisst für mich nichts anderes als sich darüber freuen, dass das Licht der Welt bald werde ausgelöscht sein"33. La relación, entonces, entre la materia y la idea, entre la experiencia y el a priori, no se refiere únicamente a la historia, sino también a la filosofía en general como forja de sentidos, de ideas, de razones.

El marco supera incluyéndolas tanto la relación con el tema de la historia como con Hegel en concreto. La integración entre forma y materia, entre forma e intuición, si se quiere, es una pretensión general de Ortega sobre la que descansan los dos momentos, en el fondo el mismo, que dirigen sus intenciones: la superación del idealismo y la fidelidad a lo real. Por ello no puede pasar por alto que la forma, o la idea, o el concepto, en Hegel tienen únicamente figura lógica. La rebelión de la historia contra el imperialismo de la Lógica, que

\footnotetext{
32 Archivo de la "Fundación José Ortega y Gasset", Carpetilla "Hegel: filosofía de la historia". Conjunto de notas titulado "Filología. Historiología".

${ }^{33}$ ROTHACKER, E. Einleitung in die Geisteswissenschaften. Op. cit. p. 131. Traducción: "Muchos se alegran hoy día de que, según creen ellos, la filosofía disminuya más y más, y se regocijan por el hecho de
} 
citaba más arriba, caminaría en esta dirección, y, sin embargo, Ortega insiste en colocarse en un lugar propio. Se trata, en el fondo, de la relación que mantiene con Hegel, o incluso con Kant. En las notas de lectura sobre Hegel escribe: 'Para Hegel como para toda su época y toda la siguiente y aun los retardados - (salvo acaso Schelling) - forma sólo tiene pensamiento de la lógica - fenómenos son lo informe. [...]. Kant amplía el racionalismo con su lógica trascendental - Hegel aún más on su lógica contradictoria o dialéctica - Pero hay que decir que somos un tercero en discordia: las formas: los form-anschauer - no distinguimos entre intuición y pensar"34.

En el mismo contexto, Ortega había leído en Troeltsch: "Es ist der Streit der LebensAnschauer und der Form-Denker"35. Al lado de esa frase de Troeltsch, en el ejemplar que manejó Ortega está escrito a mano por éste en el margen: "Pero hay hoy un tercero en discordia: el Form-Anschauer". Esa unión de forma e intuición, esa no distinción entre intuición y pensamiento, conecta con la experiencia a priori de más arriba y reaparecerá en los años cuarenta, como veremos, en el modo de pensamiento intuitivo, sobre todo en las notas para Epílogo... Es la integración que pretende llevar a cabo Ortega, y para ello acude a la historia, una historia que, desde el comienzo, debe incluir su materia y su forma, sus datos y la razón que los estructure. Ortega como Form-anschauer exige el acercamiento a contextos que no sólo imposibiliten la parcialización, sino que, además, muestren en la integración su carácter principal: uno de esos contextos es la historia, que, como unión de individualidades y generalidades, como realidad histórica, conlleva la cohesión de forma y materia, idea y experiencia. El otro contexto integrador, que determina la filosofía de Ortega en su conjunto, será el de la vida, donde la relación, amistosa unas veces, enfrentada otras, entre individualidad y generalidad será la clave del desarrollo.

Este es el marco que define la relación con la filosofía de la historia de Hegel, tanto en su parte positiva como en la negativa, y es también el que explica el concepto de historiología. En primer lugar hay que determinar qué es lo que conduce a Ortega hasta Hegel, y una vez concretado eso mostrar las diferencias, esto es, qué toma y qué deja Ortega de la filosofía de la historia de Hegel, o, una vez más, cómo lo recibe. La primera que la filosofía pronto será llevada a la tumba: para mí, esto no significa otra cosa que se alegran de que pronto la luz del mundo será extinguida".

${ }^{34}$ Archivo de la "Fundación José Ortega y Gasset", Carpetilla "Hegel - Filosofía de la historia". 
cuestión se puede delimitar aún más: ¿por qué la biblioteca de historiología que Ortega pretendía comenzar con la traducción de las lecciones de Hegel se inicia precisamente con esa obra? ¿por qué, junto al contexto de las críticas al idealismo, de la fidelidad a lo real y de la necesidad de la objetivización del ideal acude Ortega precisamente a Hegel? La respuesta es la siguiente: porque en la filosofía de la historia de Hegel, Ortega encuentra tanto lo que necesita para iniciar el desarrollo de su historiología, como, por defecto, la vislumbre de lo que puede ser su personal innovación, es decir, encuentra tanto lo que es historiología como lo que todavía no es.

Esto se percibe mucho mejor en las notas de lectura que en los textos publicados. Una de esas notas es clara al respecto: "Una biblioteca de historiología debe partir de este libro de Hegel. No porque su doctrina parezca la mejor, sino porque es el ensayo más radical, total y enérgico que se ha hecho hasta ahora sobre la materia que en debida depuración constituye el tema historiológico: la realidad histórica. Los demás libros o son metodología histórica, o son ya simplemente historias. Hacerse cuestión radicalmente de la realidad histórica como tal, con decisión sólo este. Y sin embargo, no es aún historiología"36.

La filosofía de la historia de Hegel es necesaria para la historiología porque en ella encuentra Ortega cómo lo histórico emana de una razón que le confiere un sentido, una estructura. Pero no es aún historiología porque Hegel identifica lo racional con lo general, con lo lógico, con el concepto. La historiología no es "una reflexión metodológica sobre la historia rerum gestarum o historiografía, sino un análisis inmediato de la res gesta, de la realidad histórica"37, no es una lógica de la historia, del pensamiento de lo histórico, sino que remite a eso histórico mismo, a la realidad vivida previa a su pensamiento. La escuela histórica vio únicamente una dimensión del problema histórico, la que acudía a los datos y fuentes, a los hechos, pero olvidó la necesaria introducción del sentido, de la construcción y estructuración de esos hechos. La historiología trata de descomponer, analizar y reconstruir la vida o realidad histórica con el concepto, con la razón, y en esta exigencia del concepto

\footnotetext{
35TROELTSCH, E. Der Historismus und seine Probleme. Op. cit. p. 673.

36 Archivo de la "Fundación José Ortega y Gasset", Carpetilla "Hegel: Dialéctica".

37"La «Filosofía de la historia» de Hegel y la historiología" (1928). OC IV, 539.
} 
estaría la conexión con Hegel ${ }^{38}$. El problema es que en Hegel ese concepto no está tomado en lo histórico como tal, sino en el absolutismo de lo lógico. La pretensión, y la innovación de Ortega, es conseguir el puro concepto histórico: "Hace falta el puro concepto histórico que sea histórico y a la vez puro es nuestra paradoja y nuestra innovación"39. En este sentido coincidirían las diferencias entre Ortega y la escuela histórica, por un lado, y la filosofía de la historia de Hegel, por el otro.

En Rothacker ha leído Ortega la clave de esa diferencia basada en el concepto: "Will man den Unterschied Hegels und der Historischen Schule auf eine knappe Formel bringen, so sagt man richtig: es ist die Stellung zum Begriff, welche beide scheidet. Denn Hegel war auch gegenüber der geschichtlichen Welt Philosoph und sah als solcher gerade im Deduzieren und Begründen sein eigentliches Recht"40. Si el talante de la escuela histórica es contemplativo y no constructivo, el de Hegel es constructivo, conceptual, pero con una base únicamente lógica, que refiere al pensamiento de lo histórico y no a lo histórico mismo. La historiología pretende que esa construcción, esa búsqueda de la razón y el sentido de lo histórico proceda de la experiencia a priori que, sí, mantiene su situación por encima de los hechos, pero, al ser experiencia, parte de esos mismos hechos, de la realidad histórica. Ortega, como Hegel, busca un sentido para lo histórico, pero, contra Hegel, pretende que ese sentido sea humano: el puro concepto histórico es un concepto real, vivo, humano.

Esta es la gran diferencia con Hegel, y la que conduce a Ortega hasta un tema que no se encuentra en los textos publicados sobre Hegel y que, sin embargo, es una clave determinante: la equiparación de la historiología con una depuración muy explícita del concepto de "humanidades". Tal equiparación no se encuentra en lo publicado, pero sí en las notas de trabajo: "La historiología no sería a la postre sino la seria realización de lo que

\footnotetext{
${ }^{38}$ Definiendo la escuela histórica en el "Guillermo Dilthey y la idea de la vida" escribirá Ortega: "Significa la obra de ésta [la escuela histórica] el primer enfronte de la conciencia científica con una extraña forma o región de realidad hasta entonces inadvertida: la realidad que es la vida humana". "Guillermo Dilthey y la idea de la vida" (1933-1934). OC VI, 182.

${ }^{39}$ Archivo de la "Fundación José Ortega y Gasset", Carpetilla "Hegel: Filosofía de la historia". Conjunto de notas titulado "Naturaleza e historia. Pasado y futuro".

${ }^{40}$ ROTHACKER, E. Einleitung in die Geisteswissenschaften. Op. cit. p. 89. Traducción: "Si se quiere reducir a una fórmula condensada la diferencia entre Hegel y la escuela histórica, puede decirse de un modo correcto lo siguiente: es la posición ante el concepto la que separa a ambos. Pues Hegel era frente al mundo histórico también filósofo, y, como tal, veía justamente en el deducir y el fundamentar su propio derecho".
} 
vagamente se llamó humanidades", escribe Ortega, sin dar más explicaciones ${ }^{41}$. Esas explicaciones se encuentran en obras de Ortega posteriores a estos escritos sobre Hegel y que superan el marco de la relación entre ambos filósofos. Con todo, en las notas de trabajo se halla la pista que une los contextos: "Contraposición extrema de la historia como hoy se hace, la filosofía de la historia de Hegel convierte la historia toda en historia sagrada. Esto nos desilusiona por exceso: quisiéramos una historia que no fuese movimiento de cosas, de hechos y actos sueltos - con "sentido" pero con sentido humano. Si es sobrehumano la historia es sólo espectáculo trágico - no suceso trágico real"42.

La filosofía de la historia de Hegel es, para Ortega, construcción y estructuración de los hechos históricos, pero esa construcción está regida por el carácter sobrehumano del concepto y el espíritu. La historiología de Ortega también busca un sentido, una razón histórica que sea capaz de explicar la marabunta de los sucesos del pasado, pero su sentido es humano, con unas intenciones de futuro, de historia hacia adelante, que faltan en la teoría de Hegel. Este sentido humano, que se constituye en la historia al entenderla como realidad histórica, como vida histórica, es el carácter que reúne la historiología y las humanidades.

Cuando en los años cuarenta Ortega retome el estudio del concepto de "humanidades", con el fin de mostrar de un modo lo suficientemente claro las intenciones de su Instituto de Humanidades, volverá a insistir en la cercanía de ambos conceptos: al mismo tiempo que en el Toynbee define la historiología como "una teoría general de las realidades humanas"43, en el "Prospecto del Instituto de Humanidades" utiliza el concepto de "humanidades" para "designar las disciplinas todas que se ocupan de los hechos exclusivamente humanos [...]. Lo que ahora queremos nombrar: el conjunto de los hechos propiamente humanos"44. No es ni mucho menos casual que en el mismo prospecto Ortega remita a la historiología, con palabras tomadas casi literalmente del artículo sobre Hegel:

"La base de todo ello es la Historiología, disciplina que nunca ha sido acometida en serio, dando lugara que los libros de historia, cualesquiera sean sus virtudes y méritos singulares, contengan materia tan vagarosa y sin compromiso y hablen del pasado como de algo ajeno a nosotros, siendo así que constituye

\footnotetext{
${ }^{41}$ Archivo de la "Fundación José Ortega y Gasset", Carpetilla "Hegel - Filosofía de la historia".

${ }^{42}$ Archivo de la "Fundación José Ortega y Gasset", Carpetilla "Hegel: filosofía de la historia". Conjunto de notas titulado "Detalles históricos".

${ }^{43}$ Una interpretación de la historia universal. En torno a Toynbee (1948-1949, curso). OC IX, 148.
} 
nuestros propios entresijos. La historia tiene que tener razón, es razón narrativa, una narración que explica o una explicación que consiste en narrar. Es inadmisible la conducta habitual de la historia, que se fatiga en probar, a veces con una superflua ostentación de rigor, los datos que maneja, pero no prueba lo que ella dice sobre esos datos y aun rehuye plantearse las cuestiones de realidad humana que anuncian, con lo cual resulta que siendo los libros de historia los más fáciles de leer son los menos inteligibles 45 . No se hace nada con decir que pasó esto y aquello, porque entonces nos quedamos sin saber qué es esto y qué es aquello y nos encontramos simplemente ante palabras sin sentido propio" 46 .

En el prólogo a la Filosofía de la historia de Hegel todavía no ha llegado Ortega a la exposición de ese carácter narrativo de la razón histórica, pero sí a la necesidad de esa misma razón en el constructo o estructuración de los hechos históricos, y es de Hegel, con todas las cautelas expuestas, de donde proceden los inicios de esa necesidad. Si el carácter lógico de la historio-logía remite a Hegel, el carácter humanista, por decirlo así, es el que lo supera. El sentido sagrado, absoluto, de la filosofía de la historia hegeliana ("absoluto o teológico", escribe Ortega en su artículo ${ }^{47}$ ) vislumbra el sentido trágico del hombre, de su carácter finito, limitado, pero lo hace únicamente como espectáculo, sobrevolando los caracteres más cercanos. Ortega pretende que esa tragedia sea real, que la tragedia de la limitación encuentre en el propio carácter humano la posibilidad de su superación.

Ese sentido humano es el que conecta historia y humanidades, al colocarlas a ambas en el contexto de lo real mismo, la vida, la realidad histórica. Del mismo modo que Ortega con el Instituto de Humanidades pretendía la integración del estudio del pasado humano con la atención a la actualidad y el futuro 48 , y, con ello, la atención a "los hechos propiamente

\footnotetext{
44" Prospecto del Instituto de Humanidades" (1948). OC VII, 15.

${ }^{45}$ Que Ortega al escribir esas líneas tiene en mente su prólogo a la Filosofía de la historia de Hegel es evidente: "Por no hacer esto y contentarse con una presunta constatación de lo «singular», de lo azaroso, acontece lo que menos podía esperarse de los libros históricos, a saber: que son casi siempre incomprensibles [...] No sabemos nunca de qué se nos habla en el libro histórico; está escrito en un lenguaje compuesto sólo de adjetivos y adverbios, con ausencia grave de los substantivos". "La «Filosofía de la historia» de Hegel y la historiología" (1928). OC IV, 536-537.

46" Prospecto del Instituto de Humanidades" (1948). OC VII, 18.

47"La «Filosofía de la historia» de Hegel y la historiología" (1928). OC IV, 532.

48"Prospecto del Instituto de Humanidades" (1948). OC VII, 18: "Tenemos un programa ideal de lo que pudiera ser el Instituto de Humanidades. En él, junto a las ciencias fundamentales, que no queremos especificar aquí porque sus nombres parecerían abstrusos o desviadores y al lado de los grandes estudios sobre el pasado, habría la sección de investigaciones metódicas sobre el presente hasta el día, la información sobre el mundo humano en la actualidad, «observación masiva» sobre las gentes de nuestro país, donde podrían hallar sugestiva tarea numerosos equipos de jóvenes, etc., etc.".
} 
humanos", la historiología, al humanizar y concederle carácter real, vital, al estudio de lo histórico, deberá incluir esa referencia al futuro. En este contexto se sitúa la explicación de por qué Ortega escribirá el 'Hegel y América": la realidad histórica incluye, junto al estudio del pasado, la necesidad de ponerlo en contacto con el presente y con el futuro. Ortega intentará aprovechar las dificultades de Hegel con respecto al tema del futuro para, precisamente, mostrar lo que él entiende como la innovación de su propuesta: el sentido humano, vital, real, de la historiología. 


\subsection{Las leyes intrahistóricas}

La conexión entre historiología y humanidades se inicia entonces en este momento del enfrentamiento con Hegel. La pretensión de Ortega es dirigir el estudio de la historia hasta su carácter vital, humano, mostrando la necesidad de acudir a la realidad histórica con intenciones de presente y de futuro, frente al sentido sobrehumano, de espectáculo y no de suceso real, que suponía la filosofía de la historia de Hegel.

Cuando unos años más tarde, en 1937, Ortega insista en la exigencia de renacimiento para las humanidades, lo hará de nuevo junto a estos caracteres de la realidad histórica: "Frente a las ciencias naturales tienen hoy que renacer las «humanidades», si bien con signo diverso del que siempre tuvieron. Necesitamos acercarnos de nuevo al griego y al romano, no en aunto modelos, sino, al contrario, en cuanto ejemplares errores. Porque el hombre es una entidad histórica y toda realidad histórica -por tanto, no definitiva- es, por lo pronto, un error. Adquirir conciencia histórica de sí mismo y aprender a verse como un error, son una misma cosa. Y como eso -ser siempre, por lo pronto y relativamente, un error- es la verdad del hombre, sólo la conciencia histórica puede ponerle en su verdad y salvarle"49. El sentido humano que pretende la historiología conecta historia y vida al ser capaz de utilizar esa experiencia a priori, ese carácter de Form-anschauer que debe conferir un sentido a los hechos sin desvirtuar su rango de realidad, en un provecho propio, humano, vivo, y no en el de la idea o el absoluto.

En realidad, lo que critica Ortega a Hegel es que la fuerza que presenta el movimiento en la lógica, en la idea, no haya sido verdaderamente hallada en la historia. Esto es: Hegel no habría conseguido con la incursión de la razón en la historia la misma dinámica explicativa del movimiento que en los momentos lógicos. El movimiento del concepto que lleva hasta la historia no es histórico, sino lógico, con lo que no es capaz de mostrar la relación entre las determinaciones históricas. Hegel no habría sabido presentar esa razón histórica, humana, que permita utilizar el pasado, como error, como limitación, con pretensiones de futuro. La crítica de Ortega a Hegel no es, aunque pueda parecerlo, por exceso (el imperialismo de la idea), sino por defecto (no haber conseguido realmente el imperialismo de lo histórico, de lo real y humano). En el final de un apéndice, interrumpido, 
correspondiente al manuscrito con el que se inició el prólogo a la Filosofía de la historia de Hegel, y que luego fue omitido y sustituido por el publicado, escribe Ortega:

"Nos urge conocer, siquiera en vaga proximidad, la estructura real de lo histórico. Como toda estructura real tendrá su substancia: quien subsiste en lo histórico. Sin embargo, no es esto -la substancia- lo más urgente. Lo histórico comienza por presentársenos en forma de variación en el tiempo, de modificación, de cambio. Lo histórico es primero cambio histórico. Por tanto, su aspecto primero es movimiento. De aquí que nuestra curiosidad más urgente vaya a esta pregunta: ¿qué hay de real en ese movimiento aparente, por tanto, en qué consiste el movimiento real? Hasta pudiera ocurrir que la substancia histórica fuese en sí misma movilidad, es decir, movimiento. / De tal modo siente Hegel este carácter móvil de la historia, de tal modo ve a ésta como esencial inquietud que su metafísica (lógica) queda informada por esa visión. No ya lo histórico sino lo absoluto es movimiento. Pero como a la vez para él lo absoluto es Idea se trata de un puro movimiento lógico. / Ahora bien, su filosofía de la historia se reduce a mostrar que cada punto de tránsito de ese movimiento lógico -y en el orden racional que a éste preside y le mueve- encuentra un representante en la historia (un pueblo) en un orden temporal que es conforme con el racional. / El aspecto del movimiento histórico coincide con el movimiento absoluto de la Idea. / Pero aquí se ve cómo se trata sólo de un pararelismo espectral, contingente, una resonancia casual del puro proceso lógico en el histórico. La realidad del movimiento histórico no está así ni de lejos definida y construida. Para ello sería preciso lo siguiente: así como en el proceso lógico intemporal cada determinación nace de la antecedente por necesidad de la fuerza lógica, sería menester mostrar qué fuerza y mecanismo no lógicos sino precisamente históricos, temporales, hacen que el momento griego salga del momento egipcio. / La dinámica del movimiento, que es precisamente la gran preocupación de Hegel en lógica-metafísica -fue por otra parte su intuición de lo histórico-, no está ni siquiera intentada. Lo que hace es clasificar los pueblos descriptivamente (no dinámicamente) bajo rúbricas -generalmente muy finas y certeras - y luego encontrar que, así rubricados, su orden temporal coincide con el racional" 50 .

La "estructura real de lo histórico" no son los hechos o datos que busca el filólogo, éstos son únicamente manifestaciones o síntomas de lo real ${ }^{51}$. Esos datos son ofrecidos a alguien para algo: el alguien es el historiador, el algo la realidad histórica. La realidad histórica está formada por un número de ingredientes variables y una serie de constantes invariables o a priori que los estructuran. La historiología trata de determinar esas constantes invariables,

\section{9"Miseria y esplendor de la traducción" (1937). OC V, 450.}

50"Apéndice: La historiología", en: Kant - Hegel - Scheler. Madrid: Revista de Occidente en Alianza Obras de José Ortega y Gasset, 23-, 1983, pp. 94-95.

${ }^{51}$ Desde varios años antes de la publicación del prólogo a la obra de Hegel (y utilizando casi siempre el mismo ejemplo de la muerte de César) venía Ortega insistiendo en el carácter "sintomático" de los hechos: "Los «hechos» son sólo datos, indicios, síntomas en que aparece la realidad histórica". "Prólogo a «La decadencia de Occidente», de Oswald Spengler" (1923). OC VI, 310. 
en tanto lo histórico, que, en definitiva, no es más que la vida humana en sus variaciones, determina la propia variación de sus hechos mediante esas constantes a priori que les dan sentido. Lo histórico es cambio, movimiento, y esos caracteres móviles remiten a lo histórico mismo, no a un absoluto sobrehistórico que transfiera a la historia la razón de su movilidad.

Para Hegel, el movimiento histórico es movimiento lógico: se produce una anticipación de la historia en el pensamiento, en el concepto, en la idea. Ortega no puede aceptar esta anticipación, no puede aceptar que la dialéctica del concepto mueva mágicamente la historia, que la necesidad histórica, el por qué de los hechos, proceda de causas mágicas, sobrehistóricas, lógicas. Es la crítica de Ortega al idealismo del debe-ser, en su pretensión de "operar mágicamente sobre la historia"52.

Si para Hegel cada determinación lógica encuentra un representante en la historia, esto es, cada determinación racional encuentra un representante temporal, esto significa que el movimiento histórico no está explicado, estructurado. Hegel, al convertir el movimiento histórico en representante del movimiento lógico, habría dejado sin explicar los engranajes puramente históricos, humanos y no sobrehumanos, de la realidad histórica. Esta sería la falta por defecto de Hegel, que procede del exceso efectuado al absolutizar la historia, al eternizarla.

Ortega siempre se situará contra toda eternización de la historia, porque ello significa desvitalizarla, deshumanizarla. En este sentido, Ortega lleva hasta el máximo extremo sus exigencias respecto a Hegel: la dinámica del movimiento lógico, objetivo de Hegel en su metafísica, ni siquiera la ha intentado en la historia. Hegel ha trasladado el movimiento lógico a la historia, cuando lo que se trataría de hacer es trasladar el afán de búsqueda de ese movimiento en la historia misma. Esto es lo que pretende Ortega: la realidad del movimiento histórico, la dinámica de la historia, con constantes y a prioris históricos y no lógicos. Hegel, al llevar la lógica hasta la historia, habría en cierto sentido olvidado la historia misma. Para Ortega, olvidar la historia, la vida o realidad histórica, significa olvidar los caracteres más humanos. Por ello, si el talante de Hegel es sobrehumano, sobrehistórico, el de Ortega será humano, intrahistórico.

${ }^{52}$ España invertebrada. Bosquejo de algunos pensamientos históricos (1921). OC III, 101. 
Este carácter intrahistórico remite a la serie de rasgos que muestran la necesidad de detenerse en la realidad histórica misma. En los textos publicados, quizá para que no hubiera confusiones al respecto con otros usos del concepto, Ortega no utiliza el término "intrahistórico", pero en las notas de lectura sobre Hegel es sin duda el protagonista de la relación entre ambos filósofos: Hegel, historia sobre-histórica, sobrehumana; Ortega, historia intra-histórica, vital, humana, historia en conexión con las humanidades. Ortega es tajante al respecto: "Lo importante para el historiador es el proceso intrahistórico. No es lo importante la historia universal"53, y "para Hegel no hay una causalidad intrahistórica, sino sólo la necesidad lógica trascendente" 54.

La historia tiene en común con la ciencia el carácter de construcción, de conferirle un núcleo a priori, el análisis, a la periferia empírica, los datos, pero ese a priori debe ser intrahistórico y no lógico, el puro concepto histórico como paradoja e innovación de Ortega. Aparece así la diferencia con la ciencia: la historia es descubrimiento de realidades, con lo que no puede alejarse lo más mínimo de la realidad histórica misma. Así, "una vez que la historiología reconoce lo que la Historia tiene de común con la física y con toda otra ciencia empírica -a saber, ser construcción y no mera descripción de datos-, pasa a acentuar su radical diferencia. La Historia no es manipulación, sino descubrimiento de realidades: alétheia. Por eso tiene que partir de la realidad misma y mantenerse en contacto ininterrumpido con ella, en actos de comprensión y no simplemente en operaciones mecánicas que sustituyen a aquélla"55.

Para Ortega la historia como racionalidad lógica no es racional, sino irracional. La historia es racionalidad vital, no lógica, y exige caracteres humanos e intrahistóricos que la sitúen en un marco cercano y útil, no en la posición sobrehistórica que observa la vida como espectáculo. El espectáculo debe ser real, estar vivo, y la vida es histórica, no espiritual. En las notas de trabajo ofrece Ortega una curiosa definición del espíritu hegeliano: "Biografía del Espíritu: El Espíritu es el personaje a quien le pasan las cosas que

\footnotetext{
${ }^{53}$ Archivo de la "Fundación José Ortega y Gasset", Carpetilla "Hegel - Filosofía de la historia".

54Archivo de la "Fundación José Ortega y Gasset", Carpetilla "Hegel: filosofía de la historia". Conjunto de notas titulado "Lo histórico".

55"La «Filosofía de la historia» de Hegel y la historiología" (1928). OC IV, 532-533.
} 
pasan"56. Lo importante de esa definición es que el espíritu queda presentado en una biografía, y, como tal, en una historia, con vida. La relación entre vida y espíritu aparecerá más adelante, cuando Ortega muestre en "En el centenario de Hegel" las conexiones y diferencias entre ambos ("Hegel mismo vaciló mucho antes de decidirse por esta terminología. En su juventud prefería hablar de «vida». Hoy le acompañaríamos en esta preferencia. ¿Por qué?" ${ }^{57}$ ). Es a la vida, a la vida histórica, a quien le pasan las cosas que pasan; al espíritu no le pasan, sino que le sobrepasan. Sólo situado en una biografía, adquiriendo con ello caracteres históricos y vitales, le pasan realmente las cosas.

Pero, de nuevo, con el carácter intrahistórico de la historiología, Ortega presenta la bidireccionalidad de su acercamiento a Hegel, aquella que obligaba a comenzar la biblioteca de historiología con la traducción de las Lecciones sobre filosofía de la historia y que, sin embargo, mostraba la obra de Hegel como no siendo todavía historiología. Junto al "para Hegel no hay una causalidad intrahistórica" o, más claro, "lo radical es cuál será la estructura real. Para Hegel esta estructura es trans-histórica: una realidad de carácter absoluto mueve a la historia - como el Dios bíblico el mundo desde fuera del mundo. Nada intrahistórico es causa y principio de la variación"58, junto a estas afirmaciones lo suficientemente fuertes, Ortega duda, al encontrar en el propio Hegel caracteres intrahistóricos: "la «corrupción» como movimiento intrahistórico de la dialéctica"59, o "vease la ley de pueblo y monarquía. ¿No es eso una ley? ¿De qué ciencia? ¿Con qué método obtenida? No es filosófica - sino intrahistórica. Otra ley: 699. Otra: 885'60, o, en general, "el mismo Hegel reconoce la necesidad de determinar una dinámica

\footnotetext{
56 Archivo de la "Fundación José Ortega y Gasset", Carpetilla "Hegel: filosofía de la historia". Conjunto de notas titulado "Detalles históricos".

57"Enel centenario de Hegel" (1931). OC V, 420.

58 Archivo de la "Fundación José Ortega y Gasset", Carpetilla "Hegel: filosofía de la historia". Conjunto de notas titulado "Detalles históricos".

${ }^{59}$ Archivo de la "Fundación José Ortega y Gasset", Carpetilla "Hegel: Filosofía de la historia". Conjunto de notas titulado "Teoría general de Hegel".

${ }^{60}$ Archivo de la "Fundación José Ortega y Gasset", Carpetilla "Hegel: Filosofía de la historia". Conjunto de notas titulado "Mi teoría general, con puntos críticos".
} 
intrahistórica"61. Ahora bien, ¿cuáles son exactamente estos caracteres intrahistóricos que Ortega encuentra en Hegel?

Es posible llevar a cabo un procedimiento de rastreo, mostrando por partes los textos de Hegel a los que refiere Ortega:

- La corrupción, el principio de la corrupción como movimiento intrahistórico lo encuentra Ortega en el capítulo de la Filosofía de la historia titulado "La decadencia de la eticidad griega". Escribía Hegel "Man findet in neuerer Zeit grosse, tiefe Männer wie z. B. Rousseau, die das Bessere rückwärts suchen. Das ist aber ein Irrtum. Wir werden uns zwar ewig von Griechenland angezogen fühlen; aber die höchste Befriedigung finden wir da nicht, denn es fehlt dieser Schönheit die Wahrheit. Das höhere Prinzip erscheint für das frühere, niedere, immer als Verderben, als solches, wodurch die Gesetze der bestehenden Welt verneint, nicht anerkannt werden"62.

- La ley "de pueblo y monarquía" la encuentra Ortega ya no en el tratamiento del mundo griego, sino del romano. El texto concreto sería: "Die Plebejer haben durch die Vertreibung der Könige nichts gewonnen. Diese hatten wenigstens in der bürgerlichen Gesellschaft die Plebs vor den Patrizier hervorgehoben und die Patrizier verhindert, sie zu drücken. So verdankt das Volk überall, auch in neueren Zeiten, dem Könige die Befreiung von der Unterdrückung der Aristokraten"63.

- La "otra ley" de la página 699 también refiere al mundo romano: "Je heftiger die Zwietracht in Innern getobt hatte, desto energischer wirkten die Römer dann wieder zusammen nach aussen. Wenn die Völker nach bürgerlichen Unruhen sich nach aussen wenden, so erscheinen sie am stärksten; denn es bleibt die vorhergehende Erregung, welche

\footnotetext{
61 Archivo de la "Fundación José Ortega y Gasset", Carpetilla "Hegel: Filosofía de la historia". Conjunto de notas titulado "Teoría general de Hegel".

62 HEGEL, Vorlesungen über die Philosophie der Weltgeschichte. Op. cit. p. 640. Gaos traduce: "Se encuentran en la Edad moderna hombres grandes y profundos, como, por ejemplo, Rousseau, que buscan lo mejor en el pasado. Pero esto es un error. Nos sentiremos, sin duda, atraídos eternamente por Grecia; pero no encontramos en ella la suprema satisfacción, porque a esta belleza le falta la verdad. El principio superior aparece, para el anterior e inferior, siempre como corrupción, como aquello por lo cual las leyes del mundo existente son negadas, desconocidas". HEGEL, Lecciones sobre la filosofía de la historia universal. Op. cit. pp. 481-482.

63HEGEL, Vorlesungen über die Philosophie der Weltgeschichte. Op. cit. p. 693. Gaos traduce: "Los plebeyos no ganaron nada con la expulsión de los reyes. Estos habían preferido -al menos en la sociedad civila la plebe antes que a los patricios; habían impedido que los patricios oprimieran a la plebe. El pueblo debe al
} 
nun kein Objekt mehr im Innern hat, und dasselbe nach aussen hin sucht. So war es auch in der Französischen Revolution"64.

- La última ley mencionada la encuentra Ortega en la exposición que lleva a cabo Hegel del tema de la Reforma, por tanto ya en los capítulos dedicados a la Edad Moderna. Se trata de la explicación de Hegel de por qué no ha penetrado la reforma en las naciones eslavas: "Die Slawischen Nationen waren ackerbauende. Dieses Verhältnis führt aber das von Herren und Knechten mit sich. Beim Ackerbau ist das Treiben der Natur überwiegend; menschliche Betriebsamkeit und subjektive Aktivität findet im ganzen bei dieser Arbeit weniger statt. Die Slawen sind daher langsamer und schwerer zum Grundgefühl des subjektiven Selbsts, zum Bewusstsein des Allgemeinen, zu dem, was wir früher Staatsmacht genannt haben, gekommen, und sie haben nicht an der aufgehenden Freiheit teilnehmen können"65.

- Por último, el contexto temático que rodea en las notas de trabajo la afirmación de que el mismo Hegel reconoce la necesidad de determinar una dinámica intrahistórica, permite ver que Ortega está pensando sobre todo en el capítulo en el que Hegel muestra el traspaso de Oriente a Occidente, esto es, en concreto, de Persia a Grecia. Al final de ese capítulo, "El tránsito al espíritu griego", Ortega subraya en su edición de la obra de Hegel el párrafo en el que éste explica las causas de la caída de Persia. Ese párrafo dice: "Man spricht von der Verweichlichung der Perser. Aber nicht diese, obgleich Babylon sie schwächte, hat sie zum Sinken gebracht. Freilich waren dir Resindenzbewohner verweichlicht; aber die andern Perser haben sich auch noch zur Zeit der medischen Kriege tapfer und edel gezeigt. [...] Vielmehr ist das Massenhafte, Unorganisierte ihres Heeres gegen die griechische rey en todas partes (también en los tiempos modernos) el verse libre de la opresión por los aristócratas". HEGEL, Lecciones sobre la filosofía de la historia universal. Op. cit. p. 524.

${ }^{64}$ HEGEL, Vorlesungen über die Philosophie der Weltgeschichte. Op. cit. p. 699. Gaos traduce: "Cuanto más vivamente se hubo agitado la discordia en el interior, tanto más enérgicamente obraron juntos los romanos en el exterior. Cuando los pueblos se orientan hacia el exterior, después de un periodo de agitaciones civiles, aparecen más fuertes que nunca; pues la excitación anterior, que subsiste todavía, no teniendo ya su objeto dentro, lo busca fuera. Así sucedió también en la Revolución Francesa". HEGEL, Lecciones sobre la filosofía de la historia universal. Op. cit. p. 528.

65 HEGEL, Vorlesungen über die Philosophie der Weltgeschichte. Op. cit. pp. 885. Gaos traduce: "Las naciones eslavas eran agricultoras. Esta situación trae consigo la organización en señores y siervos. En la agricultura prepondera el impulso de la naturaleza; la laboriosidad humana y la actividad son en suma escasas en este trabajo. Los eslavos, por consiguiente, han llegado con más lentitud y dificultad al sentimiento básico del yo subjetivo, a la conciencia de lo universal, a lo que hemos llamado anteriormente poder del Estado, y no 
Organisation unterlegen, d. h. das höhere Prinzip hat das untergeordnete überwunden. Die Griechen hatten sich gegenüber Heere von ungeheurer Anzahl, aber ohne Organisation, disparate Mengen ohne Zusammenhang. Gesiegt hat die griechische Tapferkeit, Disziplin mit der geistigen Freiheit der Griechen. Das Zutrauen der Disziplin, dass jeder an seiner Stelle das tun würde, was sich gehörte, konnte bei der persischen Masse nicht sein"66.

Todos éstos son ejemplos de leyes históricas, de constantes que confieren sentido a los hechos, pero con carácter intrahistórico, no lógico, sobrehumano, y Ortega las encuentra en Hegel. Ahora bien, ¿por qué son leyes intrahistóricas? ¿Qué tienen en común todas esas ideas expuestas por Hegel y que Ortega entiende como intrahistóricas? En primer lugar hay que concretar el significado de ley histórica: las leyes históricas suponen el momento analítico, de construcción, científico, por el cual los hechos singulares son organizados en una estructura, en un sistema; son leyes pero, a la vez, históricas, esto es, remiten a la "experiencia a priori" y al "puro concepto histórico" que aparecían más arriba como la innovación de Ortega.

Al ser históricas habrá innumerables leyes (tantas, que Ortega no comprende "cómo Meyer puede asegurar que, por su parte, no ha tropezado jamás con una ley histórica"67. A Meyer se refería Ortega, entonces, cuando escribía que el historiador que asegura no haber hallado ninguna ley es como el arriero que olvida, al contar sus asnos, aquél sobre el que montaba), pero todas ellas organizarán una pluralidad de hechos, y, con ello, podrán formar una estructura, un sistema. Cuatro años antes del texto sobre Hegel, en 1924, escribía Ortega, concretando toda esta serie de caracteres (y todavía faltan algunos años hasta Historia como sistema, de 1935): "Si algún día deja de ser la Historia el cuento de viejas que todavía es, se deberá al descubrimiento de leyes específicas que rigen los movimientos

han podido participar en la libertad naciente". HEGEL, Lecciones sobre la filosofía de la historia universal. Op. cit. p. 663.

66 HEGEL, Vorlesungen über die Philosophie der Weltgeschichte. Op. cit. p. 513. Gaos traduce: "Se habla de la relajación de los persas. Pero no es ésta -aunque Babilonia debilitó a los persas- la que los condujo a la ruina. Los habitantes de la corte estaban relajados sin duda; pero los demás persas se mostraron valientes y nobles en el tiempo de las guerras médicas. [...] Más bien puede decirse que la masa inorgánica de su ejército sucumbió frente a la organización griega, esto es, que el principio superior venció al inferior. Los griegos se encontraron frente a ejércitos de un enorme número de hombres, pero sin organización; frente a multitudes dispares y sin cohesión. Y vencieron la valentía y la disciplina, con la libertad espiritual de los griegos. La confianza que la disciplina da en que cada cual hará en su puesto lo que más conviene, no podía existir en la masa persa". HEGEL, Lecciones sobre la filosofía de la historia universal. Op. cit. p. 395.

67"La «Filosofía de la historia» de Hegel y la historiología" (1928). OC IV, 536. 
colectivos como las mecánicas imperan la inquietud de los astros. [...] Esperamos un Galileo de la historia y nos resistimos a aceptar que la hipótesis del libre albedrío, aunque sea bien fundada e inexcusable en Ética, obture el paso hacia un sistema de la Historia, construcción que, como ninguna otra, es postulada por los nervios de nuestra época"68.

Si se acude ahora a los textos de Hegel podrá entenderse por qué encontraba Ortega en ellos ejemplos de leyes intrahistóricas, leyes historiológicas. En este momento a Ortega no le interesan demasiado los contenidos de esas leyes, sino el hecho de que se comporten como leyes en su carácter intrahistórico e historiológico. Los cinco ejemplos utilizados se muestran con un carácter general, a priori, que va más allá de referirse a un único hecho, y, sobre todo, lo hacen desde un marco puramente histórico, no lógico:

- El principio más alto aparece para el más bajo siempre (immer) como corrupción (el tema es importante para Ortega, y por ello lo sitúa como principio intrahistórico de la dialéctica en general: se trata del contexto, ya comentado, de no tomar el pasado como presente, sino de aceptarlo como eso que ha sido, pasado, limitación, error, si se quiere, y, al hacerlo, utilizarlo como instrumento de futuro).

- El pueblo debe al rey en todas partes (überall) la liberación frente a la opresión de la aristocracia.

- Cuando los pueblos, después de agitaciones interiores, giran hacia el exterior, muestran su mayor fuerza, y esto ocurre siempre que se reúnen esas coordenadas, sea en el mundo romano o en la Revolución Francesa.

- En las naciones eslavas no penetra la Reforma porque eran pueblos agricultores, y en la agricultura, siempre, domina la naturaleza, impidiendo el sentimiento de subjetividad y la conciencia de universalidad.

- Por último, la organización y la disciplina, como principios superiores, vencen siempre a la desorganización, como principio inferior.

Se trata, entonces, de principios generales, leyes, que dan sentido, estructuran, los hechos que se presentan bajo sus coordenadas. Su carácter intrahistórico, y por eso interesan a Ortega, y por eso también muestran la bidireccionalidad de su recepción de Hegel, consiste en que la explicación no es lógica, no corresponde a categorías sobrehumanas o espirituales, sino que están formados por aspectos vitales, humanos, de

68"Abejas milenarias" (1924). OC IV, 520. 
experiencia, aunque Ortega no entre a comentar si esas leyes que ofrece Hegel a él le parecen correctas o incorrectas. Son conceptos históricos, o experiencias a priori, que, tomados de la realidad histórica misma, ofrecen la misma función que la razón lógica y sobrehumana que determina en general la Filosofía de la historia de Hegel, pero sin perder su carácter real, histórico, vital. Es por esto por lo que más arriba aparecía que, en el fondo, la exigencia de Ortega a Hegel estriba en pedirle cuentas por no haber conseguido para la historia las pretensiones que tenía para la lógica.

Que Ortega encuentre en la obra de Hegel esos ejemplos de leyes históricas intrahistóricas no significa por tanto, ni mucho menos, que Hegel haya superado los ragos de sobrehumanidad, de espiritualidad que caracterizan su teoría. Ortega ve cómo Hegel, a pesar de todo, no puede pasar por alto el talante intrahistórico de la historiología, y, sin embargo, su intención no era esa, sino la de mantener el tono sobrehistórico, el de la razón lógica en la historia. ¿Cuál va a ser la propuesta de Ortega? Intentar completar las pistas que ya encuentra en el propio Hegel, hacer intencionadamente lo que éste parecía llevar a cabo sin premeditación. Hegel debe iniciar la biblioteca de historiología, pero su obra todavía no es totalmente historiológica: en ella hay leyes intrahistóricas, pero la intención de Hegel, para Ortega, consistía en que esas leyes fueran únicamente lógicas. En las notas de trabajo, Ortega concreta la idea: "Hegel tiene constantemente y sin premeditación que hacer historiología: por ej. todo el importantísimo capítulo: la dependencia de lo natural o base geográfica de la historia - ¿Por qué no hacerlo con premeditación?'69. Precisamente ese capítulo será la clave de "En el centenario de Hegel" y precisamente ese llevar a cabo con premeditación lo que Hegel hacía sin ella será la propuesta de Ortega.

${ }^{69}$ Archivo de la "Fundación José Ortega y Gasset", Carpetilla "Hegel - Filosofía de la historia". 


\subsection{La realidad histórica}

Toda ciencia de realidad, y la historia es una de ellas, comprende para Ortega cuatro elementos: un núcleo a priori, analítico; un sistema de hipótesis que une el núcleo a priori con los hechos observables; una zona de inducciones que conecta las hipótesis con los hechos; $\mathrm{y}$, por último, la superficie empírica, observable, de los hechos o datos. Dependiendo de las ciencias, la zona de influencia de cada uno de esos elementos variará: "Es posible que en la Historia no llegue nunca el núcleo a priori, la pura analítica, a dominar el resto de su anatomía como ciencia, según acontece en física; pero lo que parece evidente es que sin él no cabe la posibilidad de una ciencia histórica"70. El estudio de la historia no puede permanecer ni en la simple recolección de datos ni en el imperialismo de la razón lógica, sobrehumana. Cuando el historicismo del siglo XIX decide basar su carácter científico en la atención exclusiva a los datos y fuentes, olvidando el núcleo a priori que debería estructurarlos, lo hace por una causa determinada: intentar huir así del subjetivismo e idealismo filosóficos que le habían precedido.

Pero para Ortega la situación ha cambiado. Ya no es el sujeto el que concede una forma al mundo, el que estructura, con términos de Kant, el "caos de sensaciones", ya no es el "debe-ser" el que rige las intenciones, sino que la fidelidad a lo real, el ideal objetivo y la atención a la vida y a la propia historia, exigen que "la primera «condición de la posibilidad de la experiencia» o conocimiento de algo es que ese algo sea, y que sea algo; por tanto, que tenga forma, figura, estructura, carácter"71. Es por ello por lo que la historia tiene que partir de la realidad misma, de lo que es, y no de la construcción simbólica de la realidad que lleva a cabo, por ejemplo, la física. Los inicios son comunes, el aparato analítico o a priori para estructurar los datos, pero no la continuación: de ningún modo se trata de sustituir la realidad, sino de comprenderla, permanecer en ella, encontrarla como realidad histórica. La realidad histórica, al incluir lo a priori y lo observable, y al mantener a la historiología como la ciencia histórica que busca determinar eso a priori, es la propuesta de Ortega tanto frente a Hegel como frente a la escuela histórica:

\footnotetext{
70"La «Filosofía de la historia» de Hegel y la historiología" (1928). OC IV, 530.

${ }^{71}$ Ibid. p. 531.
} 
"Esta realidad histórica se halla en cada momento constituida por un número de ingredientes variables y un núcleo de ingredientes invariables -relativa o absolutamente constantes. Estas constantes del hecho o realidad históricos son su estructura radical, categórica, a priori. Y como es a priori, no depende, en principio, de la variación de los datos históricos. Al revés, es ella quien encarga al filólogo y al archivero que busque tales o cuales determinados datos que son necesarios para la reconstrucción histórica de tal o cual época concreta. La determinación de ese núcleo categórico, de lo esencial histórico, es el tema primario de la historiología"72.

Ahora bien, el hecho de que la realidad histórica mantenga junto a lo variable y empírico una serie de ingredientes a priori o leyes históricas, no debe ocultar en ningún momento que eso a priori, esas leyes, son precisamente históricos, y, como tales, humanos, vitales. En este carácter vital de la realidad histórica viene insistiendo Ortega desde años antes, y continuará haciéndolo en los posteriores. Aparece en El tema de nuestro tiempo, junto al tema de las generaciones 73 : "El cuerpo de la realidad histórica posee una anatomía perfectamente jerarquizada, un orden de subordinación, de dependencia entre las diversas clases de hechos. Así, las transformaciones de orden industrial o político son poco profundas; dependen de las ideas, de las preferencias morales y estéticas que tengan los contemporáneos. Pero, a su vez, ideología, gusto y moralidad no son más que consecuencias o especificaciones de la sensación radical ante la vida, de cómo se sienta la existencia en su integridad indiferenciada. Esta que llamaremos «sensibilidad vital» es el fenómeno primario en historia"74. También en La rebelión de las masas concretará Ortega la realidad histórica como afán de vida: "La realidad es [...] un puro afán de vivir"75, y este texto interesa especialmente porque es uno de los que Ortega ya había utilizado en las

${ }^{73}$ La relación entre la realidad histórica y el tema de las generaciones aparece ya en 1909, en la conferencia "Los problemas nacionales y la juventud". Allí escribía Ortega, iniciando ideas que sólo años más tarde alcanzarán un formato definitivo: "La realidad his tórica, señores, no es el montón de los hechos: la muerte de César aislada, en sí misma, es un hecho biológico, un problema que sólo puede interesar a la medicina legal. Lo histórico en la muerte de César es su sentido, su valor, el porqué fue asesinado y el cambio de la constitución romana que motivó. Del mismo modo, la realidad histórica de una generación consiste en ser el punto de intersección de una generación anterior que la ha preparado y de otra subsecuente que mana y deriva de ella: cada generación es discípula de una más vieja y maestra de otra más joven. Esta doble función de maestro y discípulo es lo importante, lo serio en la historia. [...] Cada cual hace lo que es capaz de hacer, mas su capacidad depende completamente de su preparación: esto nos obliga a mantener despierta la conciencia de nuestra solidaridad con las fuerzas y hasta con los vicios del pasado". "Los problemas nacionales y la juventud" (1909). OC X, 109.

${ }^{74}$ El tema de nuestro tiempo (1923). OC III, 146.
} 
conferencias de Buenos Aires de 1928, el mismo ão que se publica "La «Filosofía de la historia» de Hegel y la historiología": "la realidad histórica es [...] una potencia biológica, la pura vitalidad, lo que en el hombre hay de energía cósmica"76.

Al no poder pasar por alto en ningún momento el carácter vital, humano, de la realidad histórica, que de hecho puede entenderse en general como la vida en sus variaciones, lo a priori que debe estructurar los hechos exige para su estudio historiológico una ontología, pero una ontología de la realidad histórica: "A las técnicas inferiores con que rebusca los datos es preciso añadir y anteponer otra técnica de rango incomparablemente más elevado: la ontología de la realidad histórica, el estudio a priori de su estructura esencial. Sólo esto puede transformar a la Historia en ciencia, es decir, en reconstrucción de lo real mediante una construcción a priori de lo que en esa realidad -en este caso la vida histórica- haya de invariante"77. Al grupo de carácteres jánicos, bifrontes, que han venido apareciendo (la experiencia a priori, el puro concepto histórico, la historiología misma) se une ahora este otro, ontología de lo histórico, ontología dedicada a determinar los núcleos a priori de la realidad o vida histórica. El objetivo que los mantiene unidos es el de la construcción a priori de lo invariable en lo histórico, las leyes; una construcción, por tanto, que es una reconstrucción, pues parte de lo real mismo para permanecer en ello, el a priori consiste únicamente en dotar de un sentido, de una razón, a los hechos variables o azarosos.

Es más, esos hechos variables o azarosos, que muestran el carácter individual e innovador de lo histórico y que habían sido habitualmente movilizados contra el a priori histórico (por Rickert, al insistir en la distinción entre historia y ciencia de leyes, de hechos generales, en su Die Grenzen der naturwissenschaftlichen Begriffsbildung, o por Meyer, al mantener como una de sus tesis principales en la Geschichte des Altertums la afirmación de que en el mundo histórico rigen el azar y el albedrío), sólo adquieren precisamente su rasgo diferencial sobre la base de las leyes o invariables históricas. Utilizando el ejemplo que ofrece Ortega, César y Pompeyo mostrarían su individualidad más propia al diferenciarse en su "modo de ser romanos - una constante- y de ser romanos del siglo I a. de C. -otra

\footnotetext{
${ }^{75}$ La rebelión de las masas (1930). OC IV, 160.

76 Meditación de nuestro tiempo. Las conferencias de Buenos Aires, 1916 y 1928. Ed. J.L. Molinuevo. Madrid: F.C.E., 1996, p. 265.

77"La «Filosofía de la historia» de Hegel y la historiología" (1928). OC IV, 536.
} 
constante. Estas constantes son relativas, pero en César y Pompeyo hay, cuando menos, un sistema común de constantes absolutas -su condición de hombres, de entes históricos. Sólo sobre el fondo de esas invariantes es posible su diferencialidad"78.

Esta indisolubilidad de la identidad y la diferencia, o, mejor, de la generalidad y la particularidad, es determinante. También en Hegel había visto Ortega la relación entre lo general y lo singular, pero en él esa misma relación expresaba lo que Ortega llama la limitación de Hegel: "Limitación de Hegel: identifica racional con general. Equívoco: pensar como generalidad"79. Hegel es "aceptable" para Ortega en tanto afirma que hay que partir de una generalidad para determinar cada tema o hecho histórico, y que hay que poseer un sistema concreto de referencia conceptual para definir esa generalidad. El problema surge en el modo de llevar a cabo ese proyecto: para Hegel tal referencia viene marcada por la evaluación pura de la idea, para Ortega por el punto de vista de la vida, para Hegel la historia es representación de la idea, para Ortega es realidad, vida histórica. Lo general que encuentra Hegel en la historia (aunque muchas veces, como vimos, no pueda eludir las leyes historiológicas) procede de la generalidad de la idea, lo general que busca Ortega está siempre unido con la individualidad de vida y realidad histórica. Se trata de comprender, de mostrar el cómo es, el sentido o razón, pero en términos vitales e históricos, objetivos, humanos. De un modo más concreto: la relación histórica entre individualidad y generalidad en Hegel es una relación lógica, y en Ortega una relación vital.

Cuando Ortega concentra la misión de la historiología en "determinar en cada caso lo que hay de constante y lo que hay de azaroso, si es que lo hay" 80 , no está pensando únicamente en las diferencias con el historicismo del siglo anterior o en mostrar su modo de adecuar lo que ha tomado de Hegel y lo que ha tomado de ese historicismo, sino también, y sobre todo, en utilizar la recepción de ambos para construir su ontología de lo histórico como "un sistema de definiciones sobre la estructura genérica de la vida humana"81. El tema de lo azaroso y lo general en la historia conecta decididamente con esa estructura de la vida. Del mismo modo que, al establecer las constantes históricas, el a priori, se puede

\footnotetext{
${ }^{78}$ Ibid. p. 534.

${ }^{79}$ Archivo de la "Fundación José Ortega y Gasset", Carpetilla "Hegel - Filosofía de la historia".

80"La «Filosofía de la historia» de Hegel y la historiología" (1928). OC IV, 536.
} 
definir la posibilidad o imposibilidad de los hechos mediante su adecuación o inadecuación con las leyes, y sabiendo que esas mismas leyes parten de la realidad histórica misma, así es en general el contacto que busca Ortega entre historia y vida: la historia mostrando posibilidades e imposibilidades, educando la actuación en un futuro 82 , permitiendo que la vida, tanto la individual como la colectiva, pueda utilizar sus variaciones como medios de progreso y desarrollo.

Del mismo modo que la realidad histórica puede explicar lo que fue y lo que no fue, con lo que "rebosa la realidad histórica el área superficial de los hechos"83 y la razón histórica muestra su extensión ("el lógos histórico es más extenso de lo que se presume"84), así la vida encuentra en su carácter histórico el medio para ver los límites de sus posibilidades en cada momento, lo que ha podido o no ha podido hacer, lo que todavía o ya no puede llevar a cabo. La unión entre historia y vida muestra un pasado hacia adelante, un presente y un futuro tanto limitados como posibilitados y abiertos por su pasado.

Pero para llevar a cabo ese proyecto hay que superar tanto la metafísica histórica de Hegel, basada en una razón lógica y no histórica, como los dogmas que regían la reflexión sobre la historia del neokantismo (Ortega piensa sobre todo en Rickert): "Los neokantianos conservan del gran chino de Königsberga el dogma fundamental que niega a todo ser o realidad la posesión de una forma o estructura propia. Sólo el pensar tiene y da forma a lo que carece de ella. De aquí que tampoco lo histórico tenga por sí una figura y un verdadero ser. El pensamiento encuentra un caos de datos humanos, puro material informe, al cual, mediante la historiografía, proporciona modelado y perfil"85. Lo importante del tema consiste en que para mostrar cómo la historiología supera este talante subjetivista de la historiografía neokantiana, Ortega utiliza a Hegel. Esto es tan curioso como importante:

\footnotetext{
81 Ibid.

82De nuevo, ya en 1909 aparece, junto a Lessing, el nivel pedagógico de la historia, en conexión con el tema de la pedagogía social examinado más arriba: "Lessing interpretaba ésta [la historia] como el proceso de educación del humano linaje, y, en tal sentido, nada más cierto que ver en la pedagogía la méduda de la historia". "Los problemas nacionales y la juventud" (1909). OC X, 109.

83"Prólogo a «La decadencia de Occidente» de Oswald Spengler" (1923). OC VI, 310.

84"Apéndice: La historiología", en: Kant - Hegel - Scheler. Madrid: Revista de Occidente en Alianza Obras de José Ortega y Gasset, 23-, 1983, pp. 94.

85"La «Filosofía de la historia» de Hegel y la historiología" (1928). OC IV, 537-538.
} 
curioso porque se basa en un error de traducción, e importante porque se amplía la recepción de Hegel en un sentido que no había aparecido, un sentido determinante. 


\subsection{Problemas de traducción: historia y razón}

El contexto, de nuevo, es el de la superación del idealismo, en este caso el del subjetivismo neokantiano. La fidelidad a lo real es, ahora, la fidelidad a la realidad histórica, pero para fundamentar esta segunda fidelidad es necesario justificar la primera. En este sentido, el enfrentamiento entre la historiología de Ortega y la historiografía subjetivista se expresaría del modo siguiente: "La historiología parte de una convicción inversa. Según ella, todo ser tiene su forma original antes de que el pensar lo piense. Claro es que el pensamiento, a fuer de realidad entre las realidades, tiene también la suya. Pero la misión del intelecto no es proyectar su forma sobre el caos de datos recibidos, sino precisamente lo contrario. La característica del pensar, su forma constitutiva, consiste en adoptar la forma de los objetos, hacer de éstos su principio y norma"86. La idea de Ortega se sitúa en lo más propio de su filosofía: la fidelidad a las cosas, la superación del subjetivismo, la prioridad del es ante el debe, o cualquier otro de los caracteres de la nueva sensibilidad.

Aplicados al tema de la historia, esos caracteres adquieren el significado de no tolerar un principio subjetivo que confiera la forma a lo histórico, sino que el sentido que concede el $a$ priori de las constantes o leyes procede de la realidad histórica misma en su carácter más humano y vital, en tanto la historiología es un análisis inmediato de la realidad histórica. Pero, si esto es así, y por todas las causas ya examinadas, las mismas ideas se enfrentan con el imperialismo hegeliano de la razón lógica. Sin embargo, la continuación del tema es la siguiente:

"Es la materia o tema del pensamiento quien, a la par, se constituye en su norma o principio. En suma, pensamos con las cosas. / A mi juicio, ésta fue la gran averiguación de Hegel. ¿Cómo no se ha entrevisto nunca, por debajo de la realización que el sistema de Hegel proporciona a ese descubrimiento -y que es, sin duda, manca-, el brillo de esta magnífica verdad? «La razón, de la cual se ha dicho que rige el mundo, es una palabra tan indeterminada como la de Providencia. Se habla siempre de la razón (logos), sin saber indicar cuál sea su determinación, cuál sea el criterio según el cual podemos juzgar si algo es racional o irracional. La razón determinada es la cosa». / Se trata, pues, nada menos que de la des-subjetivación de la

86 Ibid. p. 538. 
razón. No es esto volver al punto de vista griego, pero sí integrarlo con la modernidad, juntar en una síntesis a Aristóteles y a Descartes, y al juntarlos evadirse de ambos" 87.

Después de haber atacado por activa y por pasiva la razón lógica hegeliana como motor de la historia (su carácter de logicidad, no la razón en la historia), y hacerlo por causas internas completamente coherentes, pues esa razón lógica se opone a todas las connotaciones de razón histórica y razón vital que defiende Ortega, ahora resulta que una de las bases ineludibles de esa crítica, la fidelidad a lo real o este "pensamos con las cosas", se constituye nada más y nada menos que como la máxima averiguación de Hegel. De otro modo: centrándonos en Hegel y olvidando por un momento la que en realidad es la intención de Ortega con este "pensamos con las cosas", esto es, la crítica al subjetivismo, lo que viene a decir es que la razón hegeliana, antes considerada como imperialista y teológica, ahora es, sin más, la cosa, que la razón determinada es la cosa. De ahí el pensamos con las cosas como máxima averiguación de Hegel. La clave que explica todo esto se encuentra en el texto de Hegel que cita Ortega, pues éste "confunde" la traducción de la última frase del párrafo.

Hegel escribe: "Die Vernunft, von der gesagt worden, dass sie die Welt regiere, ist ein ebenso unbestimmtes Wort als die Vorsehung, - man spricht immer von der Vernunft, ohne eben angeben zu können, was denn ihre Bestimmung, ihr Inhalt ist, was das Kriterium sei, wonach wir beurteilen können, ob etwas vernünftig ist oder unvernünftig. Die Vernunft in ihrer Bestimmung gefasst, dies ist erst die Sache"88. El texto está subrayado por Ortega en su edición de la obra, y de un modo más fuerte la frase clave, "die Vernunft in ihrer Bestimmung gefasst, dies ist erst die Sache". La traducción de esa afirmación de Hegel vendría a decir: "La razón tomada en su determinación, éste es únicamente el asunto". Ahora bien, el error es demasiado grave como para que Ortega lo hubiera pasado por alto, más sabiendo que lo había leído en el original alemán, no en la equívoca traducción de Gaos ("La razón aprehendida en su determinación, es la cosa"), traducción que, con todo,

\footnotetext{
87Ibid. pp. 538-539.

88 HEGEL, Vorlesungen über die Philosophie der Weltgeschichte. Op. cit. p. 26. La traducción de Gaos, que difiere de la que utiliza Ortega en la parte final, aunque mantiene el mismo error que éste, es la siguiente: "La razón, de la cual se ha dicho que rige el mundo, es una palabra tan indeterminada como la de Providencia. Se habla siempre de la razón, sin saber indicar cuál sea su determinación, su contenido; cuál sea el criterio según el cual podemos juzgar si algo es racional o irracional. La razón aprehendida en su determinación, es la cosa". HEGEL, Lecciones sobre la filosofía de la historia universal. Op. cit. p. 57.
} 
es mejor que la de Ortega. La respuesta parece obvia: el error es intencionado. A Ortega le venía muy bien ese "la razón determinada es la cosa" para unirlo con su "adoptar la forma de los objetos" o el "pensamos con las cosas". Pero esto es lo que no se entiende, el hecho de que quisiera encontrar en Hegel un justificante de esa parte de su teoría, cuando ya había concretado tanto sus conexiones como sus diferencias respecto al tema de la historia.

$\mathrm{Y}$ el tema se entiende aún menos si se tiene en cuenta que esa afirmación concreta de Hegel, en su traducción correcta, sí que era admitida por Ortega: se trata de la necesidad de una razón en la historia, de un sentido que estructure los hechos. Los problemas vendrían después, cuando Ortega niega el carácter lógico de esa razón y defiende su razón vital e histórica, su concepto puro histórico. Pero el hecho de entender la cosa como razón determinada va más allá del tema de la historia. De lo que no hay duda es de que lo que está afirmando Ortega es el sentido objetivo de "Sache": el anterior "pensamos con las cosas" y la posterior "des-subjetivación de la razón" así lo prueban. Es evidente que el error es intencionado, que le interesa para sus propósitos de superación del subjetivismo, pero es que, de todos modos, ya en Meditaciones había afirmado aquello de "muy lejos nos sentimos hoy del dogma hegeliano, que hace del pensamiento sustancia última de toda realidad'89.

Si está más o menos claro que Ortega hace decir a Hegel algo que éste no dice, algo que le convenía para sus caracteres de la nueva sensibilidad, la pregunta, entonces, no es por qué forzó la traducción del texto de Hegel, sino para qué necesitaba hacerlo, para qué necesitaba Ortega a su lado a Hegel en este momento. O, de otro modo: ¿para qué saca Ortega del marco de la historia el párrafo de Hegel (que se refiere al tema de la idea de la historia y su realización en el mundo, es decir, la razón en la historia, en el sentido hegeliano), lo conduce hasta un tema más general como es el de la relación entre pensamiento y realidad, y lo fuerza para que se muestre coherente con sus teorías en ese contexto de la des-subjetivación de la razón?

A esas cuestiones es necesario contestar desde dos perspectivas. Según la primera, Ortega fuerza la traducción de Hegel por una razón sencilla: porque desea utilizar las críticas de Hegel a Kant para lanzarlas de nuevo contra ese neokantismo que ahora le

${ }^{89} \mathrm{MQ}, 153$. 
molesta en el tema de la historia90. Como no encuentra un texto adecuado en la Filosofía de la historia para probarlo, fuerza la traducción del que tiene. La segunda perspectiva es más complicada, en tanto remite al tema del espíritu objetivo y a la conexión entre espíritu y vida, que Ortega no trata en este artículo sino en "En el centenario de Hegel". Ambas perspectivas se concretarían del modo siguiente:

1. Ortega ha encontrado en la Lógica de Hegel (los textos están subrayados en la edición que maneja, y las notas de trabajo remiten a esos temas de un modo explícito) las ideas que le permiten tanto la crítica al subjetivismo neokantiano como la afirmación del "pensamos con las cosas" como gran averiguación de Hegel. Al inicio de la "Doctrina del concepto" lee Ortega: "Es wird immer als etwas Verwundernswürdiges ausgezeichnet werden, wie die Kantische Philosophie [zwar] dasjenige Verhältnis des Denkens zum sinnlichen Dasein, bei dem sie stehenblieb, für ein nur relatives Verhältnis der blossen Erscheinung erkannte und eine höhere Einheit beider in der Idee überhaupt und z. B. in der Idee eines anschauenden Verstandes sehr wohl anerkannte und aussprach, doch bei jenem relativen Verhältnisse und bei der Behauptung stehengeblieben ist, dass der Begriff schlechthin von der Realität getrennt sei und bleibe - somit als die Wahrheit dasjenige behauptete, was sie als endliche Erkenntnis aussprach, und das für überschwenglich, unerlaubt und für Gedankendinge erklärt, was sie als Wahrheit erkannte und wovon sie den bestimmten Begriff aufstellte"91, y, sobre todo, el siguiente texto sobre la cosa en sí: "Kant, indem er in der Kritik der reinen Vernunft, B, S. 83 in Beziehung auf die Logik auf die alte und berühmte Frage, was die Wahrheit sei, zu reden kommt, schenkt fürs erste als etwas Triviales die Namenerklärung,

\footnotetext{
${ }^{90}$ Esta es la explicación que ofrece Insausti: "Jedes Sein hat bereits für sich seine Form, schon bevor das Subjekt es denkend erfasst. Denken ist demzufolge nur die Tätigkeit, die Gestalt der Sache aufzunehmen, sich von den Dingen eine Gestalt geben zu lassen. Ortega folgt hier also Hegels Kritik am Formalismus der Philosophie Kants, insoweit dieser von der prinzipiellen Nichterkennbarkeit des Dings an sich ausgeht; diese Kritik wird von Ortega so formuliert: «Kurz, wir denken mit den Sachen»". INSAUSTI, F.-J. Miguel de Unamunos und José Ortega y Gassets Philosophie im Zusammenhang mit ihrer Hegel-Rezeption. San Sebastián: Zorroaga, 1993, p. 92.

${ }^{91}$ Cito por la edición que maneja Ortega: HEGEL, Wissenschaft der Logik, II. Hrsg. Lasson. Leipzig: Meiner, 1923, p. 230. Traducción: "Siempre se resaltará como algo digno de asombro que la filosofía kantiana, que reconocía aquella relación del pensar con el estar-ahí sensible, en la que se detuvo, como una relación únicamente relativa, de simple apariencia, y reconocía y expresaba una unidad más alta de ambos en la Idea en general, por ejemplo en la idea de un entendimiento intuitivo, sin embargo se haya detenido en aquella relación relativa, y en la afirmación de que el concepto es y permanece separado totalmente de la realidad. Con ello afirmaba como verdad aquello que había expresado como conocimiento finito, y declara como delirante, ilícito y objeto mental lo que había reconocido como verdad y de lo cual había erigido el concepto determinado".
} 
dass sie die Übereinstimmung der Erkenntnis mit ihrem Gegenstande sei, - eine Definition, die von grossen, ja von dem höchsten Werte ist. Wenn man sich derselben bei der Grundbehauptung des transzendentalen Idealismus erinnert, dass die Vernunfterkenntnis die Dinge an sich zu erfassen nicht vermögend sei, dass die Realität schlechthin ausser dem Begriffe liege, so zeigt sich sogleich, dass eine solche Vernunft, die sich mit ihrem Gegenstande, den Dingen an sich, nicht in Übereinstimmung zu setzen vermag, und die Dinge an sich, die nicht mit dem Vernunfbegriffe, der Begriff, der nicht mit der Realität, eine Realität, die nicht mit dem Begriffe un Übereinstimmung ist, unwahre Vorstellungen sind"92.

Del mismo modo, en el tratamiento hegeliano de la idea, Ortega incide en los caracteres de unidad, de coincidencia entre concepto y realidad. Se centra, por ello, en los rasgos generales de la idea: "Der Gegenstand, die objektive und subjektive Welt überhaupt sollen mit der Idee nicht bloss kongruiere, sondern sie sind selbst die Kongruenz des Begriffs und der Realität; diejenige Realität, welche dem Begriffe nicht entspricht, ist blosse Erscheinung, das Subjektive, Zufällige, Willkürliche, das nicht die Wahrheit ist'93, o: "Sein hat die Bedeutung der Wahrheit erreicht, indem die Idee die Einheit des Begriffs und der Realität ist"94, o: "Die Idee hat aber nicht nur den allgemeineren Sinn des wahrhaften Seins, der Einheit von Begriff und Realität, sondern den bestimmteren von subjektivem Begriffe und der Objektivität. Der Begriff als solcher ist nämlich selbst schon die Hentität

\footnotetext{
92Ibid. p. 231-232. Traducción: "Cuando Kant en la Crítica de la razón pura, B, p. 83, llega en relación a la lógica a la vieja y conocida cuestión de qué es la verdad, presenta por lo pronto como algo trivial la definición nominal de que la verdad sea la coincidencia del conocimiento con su objeto, - una definición que es de gran valor, del más alto valor. Si se la recuerda junto a la afirmación fundamental del idealismo trascendental, esto es, que el conocimiento racional no es capaz de aprehender la cosa en sí, que la Realidad yace en absoluto fuera del concepto, entonces se muestra que una razón semejante, la cual no es capaz de ponerse en coincidencia con su objeto, las cosas en sí, así como las cosas en sí, que tampoco pueden ponerse en coincidencia con el concepto racional, son representaciones carentes de verdad. Lo son tanto el concepto, que no coincide con la realidad, como esta realidad, que no coincide con el concepto".

93Ibid. p. 409. Traducción: "El objeto, en general el mundo objetivo y subjetivo, no sólo deben ser congruentes con la idea, sino que ellos mismos son la congruencia de concepto y realidad; aquella realidad que no corresponda al concepto es pura apariencia, lo subjetivo, accidental, arbitrario, lo que no es la verdad".

${ }^{94}$ Ibid. p. 409. Traducción: "Ser ha alcanzado el significado de verdad, en tanto la idea es la unidad del concepto y la realidad".
} 
seiner und der Realität; denn der unbestimmte Ausdruck Realität heisst überhaupt nichts anderes als das bestimmte sein" 95 .

De esta serie de textos e ideas surge en Ortega el "pensamos con las cosas" como máxima averiguación de Hegel. De las críticas a Kant por el hecho de que el concepto permanezca totalmente separado de la realidad, del ataque tanto a la razón kantiana como a las cosas en sí, por no alcanzar la coincidencia entre razón y objeto, de la correspondencia en el concepto entre él mismo y la realidad, de la unidad en la idea de concepto y realidad o de, en general, la definición del ser verdadero como unidad en la idea entre concepto y realidad. Ortega toma de esos caracteres únicamente el talante de congruencia, de unidad, de coincidencia, esto es, el "pensamos con las cosas", sin añadirle la preponderancia hegeliana del concepto o la idea (de aquí que la realización del sistema de Hegel sea "sin duda, manca"96). Con esos caracteres puede utilizar a Hegel para atacar el subjetivismo neokantiano, una vez que los ha despojado del carácter lógico y subjetivo que encuentra en Hegel. En las "Reflexiones de centenario (1724-1924)" ha incidido en la crítica: "Kant no se pregunta qué es o cuál es la realidad, qué son las cosas, qué es el mundo. [...] Es una mente que se vuelve de espaldas a lo real y se preocupa de sí misma"97, o, en general, la ontofobia kantiana: "El espíritu de Kant se estremece con vago terror ante lo inmediato, ante todo lo que es simple y clara presencia, ante el ser en sí. Padece ontofobia'98.

El "pensamos con las cosas" que Ortega encuentra en Hegel iniciaría la superación de esa ontofobia. La unidad de concepto y realidad sería una primera clave de integración entre sujeto y objeto. Ahora bien, y a pesar de ello, Ortega no puede admitir la razón lógica e imperialista hegeliana, no puede admitir que la unidad de concepto y realidad se dé únicamente en la idea. Su propuesta de integración se basará en el concepto de vida, en la razón vital e histórica, que no admiten el carácter sobrehumano de la razón hegeliana. En el anejo que añade Ortega a las reflexiones sobre Kant, en 1929, ofrecerá la superación del

\footnotetext{
95 Ibid. p. 410. Traducción. "La idea no tiene únicamente el sentido más general de serverdadero, la unidad entre concepto y realidad, sino también el más determinado de unidad entre concepto subjetivo y la objetividad. El concepto como tal es ya él mismo justamente la identidad de sí mismo y su Realidad; pues la expresión indeterminada Realidad no significa otra cosa que el ser determinado".

96"La «Filosofía de la historia» de Hegel y la historiología" (1928). OC IV, 539.

97"Kant. Reflexiones de centenario (1724-1924)" (1924). OC IV, 27.

98 Ibid. p. 42.
} 
subjetivismo idealista en este sentido: "el ser, lo objetivo, etc., sólo tienen sentido si hay alguien que los busca, que consiste esencialmente en un ir hacia ellos. Ahora bien; este sujeto es la vida humana o el hombre como razón vital. La vida del hombre es en su raíz ocuparse con las cosas del mundo, no consigo mismo"99. El "pensamos con las cosas" de Hegel, y este ocuparse con las cosas, del hombre en la vida, encontrarían así su relación en el enfrentamiento con Kant, siendo el primero un necesario momento previo que sólo será concretado y desalojado de sus caracteres lógicos en la teoría de la vida.

En este sentido de la relación con Kant y de la crítica al subjetivismo neokantiano, la forzada traducción del texto de Hegel tendría la explicación siguiente: Ortega ha visto en esos temas de la Lógica la crítica de Hegel a Kant basada en la separación que efectúa éste entre la razón y su objeto, la crítica a la cosa en sí al no ser capaz de alcanzar la coincidencia con el concepto, al ser inaprehensible. Ortega quiere servirse de la identidad hegeliana de concepto y realidad en la idea, pero sin el talante lógico, sin la idea, con lo que nada mejor que utilizar un texto de la Filosofía de la historia, que es el contexto a tratar en el artículo sobre Hegel. Como no encuentra el texto adecuado, Ortega fuerza la traducción.

2. A Ortega le interesa muchísimo un tema que todavía no ha tratado (y en este artículo no hará más que mencionarlo), pero que tratará, como es el del espíritu objetivo. Además, comienza a ver algo que, aunque para su concreción habrá que esperar hasta "En el centenario de Hegel", supera el marco de la historia: la relación entre su concepto de vida y el hegeliano de espíritu. Al ser esto así, la intención del "pensamos con las cosas" como máxima averiguación de Hegel, basado en esa "traducción" de "la razón determinada es la cosa", iría más allá de utilizar a Hegel tanto para que coincidiera con las teorías propias de Ortega, como para que le sirviera en su lucha contra la superación del subjetivismo neokantiano (utilizando las críticas de Hegel a Kant). Dicho de un modo concreto: el lugar en el que Ortega coloca a Hegel en la tarea de la "des-subjetivación de la razón" remite al tema del espíritu objetivo y a la conexión entre espíritu y vida. Por ello, en primer lugar, esa máxima averiguación de Hegel aparece en el artículo sobre la historiología (el espíritu objetivo que interesa a Ortega es el que circula por las Lecciones sobre filosofía de la historia) y, en segundo lugar, se encuentra a la vez superando el marco de la historia.

99"Filosofía pura. Anejo a mi folleto «Kant»" (1929). OC IV, 57. 
De este modo, el problema estriba, antes que en intentar encontrar una explicación a la mala traducción de Ortega, en tener en cuenta que el contexto de esa traducción, más que en el artículo donde se halla, se encuentra en "En el centenario de Hegel". Una de las pruebas de esta idea es que el final de "La «Filosofía de la historia» de Hegel y la historiología" conecta directamente con el comienzo de "En el centenario de Hegel". Ese final y ese principio son el mismo, la relación entre vida individual, vida social y vida o realidad histórica, y la unión de esos aspectos se sitúa alrededor del concepto hegeliano de espíritu objetivo.

Aunque más adelante concretaré estos temas, puede acudirse en este momento a las notas de trabajo para probar mi idea. Escribe allí Ortega: "Perfecto lo de espíritu objetivo: historia si espíritu - vida - no entender objetivo como objetivado. Así estaría perfecto"100. La des-subjetivación de la razón, intención primordial del "pensamos con las cosas", coincidiría con esta negación del "objetivo" como "objetivado", en tanto algo objetivado tendría su base en un sujeto que objetiva. En las notas insiste Ortega en la estrechez de la razón en Hegel, estrechez basada en su carácter subjetivo. Ortega está pensando en la definición de Vernunft que da Hegel en la introducción a las lecciones: "Die Vernunft ist das ganz frei sich selbst bestimmenden Denke, Nus"101. Comentando ese texto escribe: "Estrechez de la razón en Hegel [...] Así se llega [...] a una razón subjetiva - puesto que no coincide con el objeto"102. Por un lado, la razón de Hegel no coincide con el objeto, por el otro el "la razón determinada es la cosa".

De este modo, no se entiende que en el final del prólogo a la Filosofía de la historia insista en colocar a Hegel, forzando la traducción, al lado de esa des-subjetivación de la razón... a no ser que, primero, hubiera otra razón que no sólo no fuera estrecha, sino que se caracterizara por aumentar los marcos, $\mathrm{y}$, segundo, hubiera encontrado Ortega algún tema en la filosofía de la historia de Hegel que le condujera a esa des-subjetivación (dejando aparte la identidad de concepto y realidad en la idea). Este tema conductor será el del espíritu objetivo, en este artículo únicamente presentado, y por ello es difícil entender la

\footnotetext{
100Archivo de la "Fundación José Ortega y Ga sset", Carpetilla "Hegel - Filosofía de la historia".

${ }^{101}$ HEGEL, Vorlesungen über die Philosophie der Weltgeschichte. Op. cit. p. 15. Traducción: "La razón es el pensamiento, el nous, que se determina a sí mismo con entera libertad". HEGEL, Lecciones sobre la filosofía de la historia universal. Op. cit. p. 50.
} 
causa de la malinterpretación de Hegel; esa razón más amplia será la razón vital de la historiología, y, de nuevo, ésta es la causa de que, a pesar de dejar en una situación comprometida esa "máxima averiguación de Hegel", se encuentre ésta al final de "La «Filosofía de la historia» de Hegel y la historiología". En las notas de trabajo aparece la explicación: "Historio-logía - la razón no es sólo la lógica o razón pura. [...] Razón es todo lo que se puede comprender -es decir- la razón no hay que definirla por la facultad de un sujeto sino por la cosa - donde hay algo, donde hay ser hay razón - porque hay posibilidad de comprenderlo - la razón subjetiva no es sino el regreso del ser en la mente. Tanto ser, tanta razón. La historio-logía como razón vital es una integración de la razón, un aumento de ésta"103.

La historiología exige un concepto de razón que supera el marco lógico. La realidad histórica incluye lo racional y lo irracional, lo general y lo individual, y no únicamente lo vernünftiges. En este sentido, uno de los mayores enfrentamientos entre Hegel y Ortega gira en torno a esa afirmación del primero de que "der philosophischen Betrachtung ist es nur angemessen und würdig, die Geschichte da aufzunehmen, wo die Vernünftigkeit in weltliche Existenz zu treten beginnt"104. Para Ortega, la razón lógica hegeliana no puede explicar lo individual, no puede explicar los pueblos primitivos, no puede explicar todo lo que no se adecúa a su lógica (África, China, Oceanía...). Esa es su estrechez, que proviene de definir la razón por el sujeto y no por la cosa. La razón histórica y vital aumentan su marco al partir precisamente de la fidelidad a lo real, al partir de la cosa. De aquí la traducción forzada de Hegel que ofrece Ortega: no se refiere a la razón lógica, sino a la vital e histórica, a la que puede incluir irracionalidades y leyes, individualidades y a prioris en su integración.

\footnotetext{
102 Archivo de la "Fundación José Ortega y Gasset", Carpetilla "Hegel - Filosofía de la historia".

${ }^{103}$ Archivo de la "Fundación José Ortega y Gasset", Carpetilla "Hegel: filosofía de la historia". Conjunto de notas titulado "Detalles históricos".

${ }^{104}$ HEGEL, Vorlesungen über die Philosophie der Weltgeschichte. Op. cit. p. 142. Traducción: "Lo único propio y digno de la consideración filosófica es recoger la historia allí donde la racionalidad empieza a aparecer en la existencia terrestre". HEGEL, Lecciones sobre la filosofía de la historia universal. Op. cit. p. 136.
} 
La razón hegeliana es demasiado estrecha para Ortega, tanto que "no es suficientemente ancha para poder afirmar que todo lo real es racional"105, e intentará dar un paso más: ofrecer una razón de todo lo histórico, individual o general, y para ello acudirá a la razón vital e histórica, que consigan el aumento por integración: "Gran idea de Hegel: histórico emana de la razón. Aunque para él no todo lo histórico es racional. Este es el paso que hay que dar"106.

105Archivo de la "Fundación José Ortega y Gasset", Carpetilla "Hegel: filosofía de la historia". Conjunto de notas titulado "Detalles históricos".

106Archivo de la "Fundación José Ortega y Gasset", Carpetilla "Hegel - Filosofía de la historia". 


\subsection{El descontento en la historia}

Conjuntando las dos vertientes de la explicación de ese "error" de traducción puede verse tanto la relación entre Hegel y Kant (y neokantismo), como el inicio del tema de la presencia de Hegel en la teoría de la vida (la relación entre espíritu y vida), que expondrá Ortega en "En el centenario de Hegel". El "pensamos con las cosas" como gran averiguación de Hegel es determinante por dos sentidos, porque muestra a Hegel en Ortega iniciando, desde caracteres de la Lógica, la superación del subjetivismo kantiano y neokantiano, y porque muestra la forma de darse esa superación en la historia. La conjunción de concepto y realidad, una vez liberada del marco impuesto por Hegel, la idea, tendrá su concreción en esa vida como realidad histórica que exige el paso de la razón lógica a la razón vital e histórica. La unión de sujeto y objeto se producirá en el concepto de vida, con lo que se sintetizará el realismo aristotélico y el idealismo cartesiano, "y al juntarlos evadirse de ambos".

La unidad de oncepto y realidad, que para Hegel se daba en la idea, en Ortega tendrá lugar en la vida, en la realidad histórica. Por esto, la "gran averiguación de Hegel" procede de la Lógica, y no de la filosofía de la historia (de ahí la traducción forzada), pero se sitúa en el marco de la historiología al conectar directamente con la razón histórica y vital, que superan por aumento la estrecha razón lógica hegeliana. Además, ese "pensamos con las cosas" como síntoma de des-subjetivación conectará directamente con el tema del espíritu objetivo y la relación entre espíritu y vida, guiados ambos por el carácter de aumento de la razón histórica frente a la estrechez de la hegeliana.

En este sentido, el descontento con el que Ortega inicia La «Filosofía de la historia» de Hegel y la historiología", referido únicamente a la insatisfacción surgida al leer "los libros de Historia", y dedicado a los autores de la escuela histórica y no a Hegel, ampliaría su contexto. La parte positiva de ese descontento, expresada por Ortega ømo "lo que más vale en el hombre es su incapacidad de insatisfacción. $\mathrm{Si}$ algo de divino posee es, precisamente, su divino descontento"107, remitiría también a la estrechez de la razón lógica hegeliana. Ésta, en su estrechez, en su incapacidad para atender a lo humano, a lo vital, a lo individual, impide la función capital del descontento: el afán de progreso, de futuro, de 
mejora. Es, precisamente, "el divino descontento"108 como afán de vida, el descontento como "la emoción idealista"109 el que remite a la posibilidad de la completación, del progreso. El hombre ve en él "con toda claridad que podría aquélla [la cosa, la obra humana defectuosa] hacerse mejor; encuentra ante sus ojos, junto a la obra monstruosa, el perfil ideal que la depura o completa"110.

Ese perfil ideal no surge de deseos utópicos o de razones lógicas, sino de la realidad histórica misma, de lo vital y circunstancial. Es la "higiene de los ideales" en el sentido del "Mirabeau o el político"111, higiene que lleva a "considerar como ideal la realidad misma en lo que tiene de profunda y esencial", a definir el idealismo como "falta de imaginación. Todo el que sea capaz de imaginarse con exactitud realizado su abstracto ideal sufre una desilusión, porque ve entonces cuán sórdido y mísero era si se compara con la fabulosa cuantía de cosas deseables que la realidad, sin nuestra colaboración, ha inventado. [...] El «ideal» al uso es menos, y no más, que la realidad"112.

El carácter de descontento, basado en la atención a lo real y en la crítica al ideal abstracto, no permite ninguna forma de conclusión, de perfección. $\mathrm{O}$, de otro modo: la realidad histórica no permite la eternidad de la historia, y no lo permite porque "la vida de la persona o del universo no conoce situaciones definitivas, sino que consiste en una serie inacabable de circunstancias que se van sucediendo y negando la una a la otra. Ninguna de ellas puede alzarse frente al resto como la única perfecta"113. Es el carácter vital y circunstancial de la realidad histórica, es el carácter histórico de la vida, el que mantiene al ideal únicamente como afán de perfeccionamiento. Ninguna circunstancia, ninguna particularidad o época, en el contexto de la historia, puede considerarse como definitiva, sino que cada una incluye en sí la perfección en su propia individualidad: "Cada complejo

107" La «Filosofía de la historia» de Hegel y la historiología" (1928). OC IV, 521.

108 ORTEGA Y GASSET, J. "La verdad no es sencilla" (1926), en: La deshumanización del arte y otros ensayos de estética. Madrid: Revista de Occidente en Alianza -Obras de José Ortega y Gasset, 10 -, 19886, p. 230.

109" La Gioconda" (1911). OC I, 556.

110" La «Filosofía de la historia» de Hegel y la historiología" (1928). OC IV, 522.

111"Mirabeau o el político" (1927). OC III, 603.

112Ibid. p. 604. 
histórico encierra dentro de sí el esquema de una posible estructura, la mejor imaginable en aquel caso"114. O, invirtiendo los términos, definitivas lo son todas, no hay épocas clásicas porque clásicas lo son todas: "Todas las épocas son clásicas", escribe Ortega lacónicamente en sus notas de lectura 115 .

Del mismo modo que el tema del descontento aparece al comienzo del artículo, a primera vista como un momento secundario que no es (la realidad histórica, por ser vital y humana, consiste en general en caracteres de descontento), también lo hace el tema de los clásicos. De nuevo, a primera vista, parece detenerse en la intención expuesta por Ortega: en los estudios sobre historia no hay clásicos, y no los hay porque se han errado los objetivos, atender únicamente a datos y fuentes, la historia diplomática, etc. En las notas de trabajo aparece el tema de los clásicos constantemente, tanto referido a autores o personajes como a las épocas clásicas.

El contexto es siempre el mismo: lo clásico no remite a lo eterno, a lo acabado, sino a lo actual, a los problemas. "Ni nuestra caritativa admiración ni una perfección ilusoria y «eterna» hacen al clásico, sino precisamente su aptitud para combatir con nosotros. [...] Clásico es cualquier pretérito tan bravo que, como el Cid, después de muerto nos presente batalla, nos plantee problemas. [...] Actualidad es lo mismo que problematismo"116. Todas las épocas son clásicas porque incluyen en sí mismas su particular ideal, su particular posibilidad de perfeccionamiento; los clásicos son clásicos porque son actuales, porque plantean problemas. Ambos están unidos por el mismo carácter: la ausencia de finalización, de eternidad, el descontento propio como rasgo de su actualidad, la plenitud no como final sino como comienzo, como afán de perfeccionamiento.

La crítica a la historia eterna es la misma que la crítica al clásico como concluido. Es el carácter histórico y vital el que produce esa "melancolía de lo eterno" que mencionaba Ortega en Argentina en 1928117, que volverá a aparecer en La rebelión de las masas 118 y

113" Reforma de la inteligencia" (1926). OC IV, 493.

114Ibid. p. 494.

115 Archivo de la "Fundación José Ortega y Gasset", Carpetilla "Hegel - Filosofía de la historia".

116" La «Filosofía de la historia» de Hegel y la historiología" (1928). OC IV, 523.

117Meditación de nuestro tiempo. Las conferencias de Buenos Aires, 1916 y 1928. Ed. J.L. Molinuevo. Madrid: F.C.E., 1996, p. 265. 
que Ortega utilizaba por primera vez algunos años antes, en 1926, mostrando el origen nietzscheano de su idea: "Lo demasiado seguro y estable que se alza con un gesto de invulnerable eternidad produce en nosotros una específica angustia. Si hay la melancolía de las ruinas, existe también lo que Nietzsche llamaba la melancolía de las construcciones eternas que se apoderaba del provincial cuando iba a Roma y contemplaba los edificios imperiales. Un mundo en que nada puede cambiar ni nada cabe emprender sería un sepulcro"119. Hegel insistía en la melancolía de las ruinas ${ }^{120}$, en que el primer aspecto ofrecido por la realidad histórica es un montón de ruinas, pero olvidaba el segundo punto, que Ortega recoge en Nietzsche, la melancolía de lo eterno.

Esa melancolía de lo eterno viene causada por la imposibilidad real (y no lógica) de progreso, de futuro, de vida. De este modo se entiende una de las críticas más importantes de Ortega a Hegel: la ausencia de futuro, de posibilidad real de progreso, en su filosofía de la historia. Esa misma crítica es la que explica que Ortega escribiera el "Hegel y América", y no únicamente su interés por los pueblos americanos: el tema de América es el tema del futuro, y éste abarca multitud de referentes, entre ellos dos determinantes, la conexión con la historia (historia hacia adelante) y con la vida (la vida como proyecto, como futuro).

118 La rebelión de las masas (1930). OC IV, 160.

119" Sobre la muerte de Roma" (1926). OC II, 538.

120HEGEL, Vorlesungen über die Philosophie der Weltgeschichte. Op. cit. p. 11: "Was uns niederdrücken kann, ist dies, dass die reichste Gestaltung, das schönste Leben in der Geschichte den Untergang finden, dass wir da unter Trümmern des Vortrefflichen wandeln. Von dem Edelsten, Schönsten, für das wir uns interessieren, reisst uns die Geschichte los: die Leidenschaften haben es zugrunde gerichtet; es ist vergänglich. Alles scheint zu vergehen, nichts zu bleiben. Jeder Reisende hat diese Melancholie empfunden". Traducción: "Lo que nos oprime es que la más rica figura, la vida más bella encuentra su ocaso en la historia. En la historia caminamos entre las ruinas de lo egregio. La historia nos arranca a lo más noble y más hermoso, por que nos interesamos. Las pasiones lo han hecho sucumbir. Es perecedero. Todo parece pasar y nada permanecer. Todo viajero ha sentido esta melancolía". HEGEL, Lecciones sobre la filosofía de la historia universal. Op. cit. p. 47. Ortega repite insistentemente esta idea de Hegel: cfr. Idea del teatro. Una abreviatura (1946). OC VII, 449; Origen y epílogo de la filosofía (1946). OC IX, 353; Una interpretación de la historia universal. En torno a Toynbee (1948-1949, curso). OC IX, 85; Meditación de Europa (1949). OC IX, 252. Como se mostrará, no es casual que todas esas referencias a la misma idea se encuentren en escritos de los años cuarenta: detrás se halla el contexto de la situación europea. 


\subsection{Historia y convivencia}

Con todos estos caracteres en la base, la razón histórica como aumento en su integración, incluyendo los talantes vitales de insatisfacción y descontento, el perfil ideal en la realidad y no en el ámbito subjetivo, la negación de eternidad, la ausencia de épocas clásicas, por el hecho de que lo son todas, los clásicos como actualidad y problematismo, o, en general, la melancolía de lo eterno, Ortega acude al concepto hegeliano de Volksgeist. De él tomará el carácter de plenitud particularizado, esto es, de plenitud de cada pueblo, de cada tiempo: "Dentro de cada evolución particular hay una norma de perfección: que cada Volksgeist llegue a elaborar su mundo - conforme a él. Cada pueblo tiene su fin propio y aparte. Por esto son naturaleza. Plenitud de los tiempos"121.

La norma de perfección particularizada remite a la idea expuesta en "Reforma de la inteligencia", el hecho de que cada complejo histórico "encierra dentro de sí el esquema de una posible estructura, la mejor imaginable en cada caso"122. Ortega le añadirá su esquema propio: la norma de perfección no remite al carácter cerrado de la razón lógica, sino al horizonte abierto de la verdadera plenitud de vida, "ser un horizonte siempre abierto a toda posibilidad, es la vida auténtica, la verdadera plenitud de vida", escribe para las conferencias del 28 en Argentina 123 .

No es casual que Ortega, en esa nota de trabajo, hable de "plenitud de los tiempos", en plural. Para él, Hegel no plenifica las particularidades, no ofrece el carácter de "todas las épocas son clásicas", sino que lo idealiza en la generalidad del tiempo, sin concederle carácter histórico: "Idealización de Hegel: sólo conoce plenitud de tiempo: plenitud: saca la cabeza fuera del tiempo"124. Este sacar la cabeza fuera del tiempo es el que impide la conexión entre la razón lógica hegeliana y la realidad histórica: en Ortega están plenificadas las particularidades, en Hegel las generalidades; la razón lógica sitúa al tiempo fuera de sí, la realidad histórica es vital, y, como tal, temporal. Y es, además, el que explica

\footnotetext{
${ }^{121}$ Archivo de la "Fundación José Ortega y Gasset", Carpetilla "Hegel - Filosofía de la historia".

122" Reforma de la inteligencia" (1926). OC IV, 493.

123Meditación de nuestro tiempo. Las conferencias de Buenos Aires, 1916 y 1928. Op. cit. p. 265. El mismo texto será incluido en La rebelión de las masas. cfr. La rebelión de las masas (1930). OC IV, 160.

${ }^{124}$ Archivo de la "Fundación José Ortega y Gasset", Carpetilla "Hegel - Filosofía de la historia".
} 
el interés de Ortega por el concepto de Volksgeist, pues encontrará en él una base para la plenificación de las particularidades, pero eludiendo el carácter generalizador y lógico de la filosofía de la historia de Hegel.

Sin embargo, previamente al concepto de Volksgeist, que Ortega no trata en "La «Filosofía de la historia» de Hegel y la historiología", necesita examinar el de "espíritu objetivo". El concepto de espíritu objetivo aparecerá únicamente en una nota al final del artículo, pero con ello deja enunciado Ortega por dónde va a continuar su relación con Hegel, una vez que ya ha aprovechado lo que le interesa del tema de la historia. Esta fugaz aparición del concepto de espíritu objetivo es más importante de lo que parece, pues con él se inicia un contexto que irá más allá del propio Hegel y remitirá a aspectos cruciales de la filosofía de Ortega en general. Ese contexto, que en el fondo se encuentra determinado por otra de las claves del enfrentamiento con Hegel, la de la relación entre lo individual y lo general, remite a la unión de tres caracteres, la vida individual, la vida social y vida histórica, siendo el conjunto de los tres el que da sentido y confiere contenido a la realidad histórica.

La vida individual encuentra frente a ella otras vidas individuales que "tangentean, hieren o traspasan por diferentes puntos la mía; así como la mía, aquéllas"125. Se trata de una relación de convivencia, "en el convivir se completa el vivir"126, y, como tal, trasciende la vida individual: en la convivencia aparece la vida interindividual. Ambas vidas, la individual y la interindividual, se encuentran envueltas por un tercer elemento, la vida social, anónima, que ejerce presiones de todo tipo sobre las otras dos y que supone una segunda trascendencia. La vida social rompe con el carácter presuntamente independiente de la vida individual, el individuo "no puede decir dónde empieza en él lo suyo propio y dónde termina lo que de él es materia social. Ideas, emociones, normas que en nosotros ni pueden ser dichos de nuestra propiedad. Así notamos toda la amplitud ingenua de la abstracción cometida cuando creíamos plenamente recogida nuestra realidad por la psicología. Antes que sujetos psíquicos somos sujetos sociológicos"127. A ese texto Ortega añade una escueta nota: "Esto es lo que Hegel llamó espíritu objetivo". Nada más: ni la

125" La «Filosofía de la historia» de Hegel y la historiología" (1928). OC IV, 539.

$126_{\text {Ibid. }}$ 
conexión con el Estado que aparecía más arriba, ni con la libertad, ni con el propio Volksgeist. Y, sin embargo, Ortega deja iniciado su tratamiento.

En "La «Filosofía de la historia» de Hegel y la historiología" Ortega se limita a conectar la vida individual con la vida social y ésta con la vida o la realidad histórica. La vida social procede siempre de un pasado, se ha formado como tal debido a determinados caracteres que han permanecido, o que se han diluido y han permitido la aparición de otros, y, a la vez, mantiene siempre una dirección de futuro, un camino y unas expectativas concretas: "La vida social presente es sólo una sección de un todo vital amplísimo, de confines indefinidos hacia pasado y futuro, que se hunde y esfuma en ambas direcciones. Ésta es sensu stricto la vida o realidad histórica"128. Ortega no dice más y concluye así el artículo, aunque deja presentados los temas que deberían continuarlo: la determinación de cada círculo en particular, individuo, sociedad e hist oria, y el modo de relación entre ellos.

La conexión con el espíritu objetivo, con esa vida social que rompe la independencia del individuo, debe ser entendida en un sentido importante: en esa conexión el individuo hace suyos aspectos puramente objetivos, tan objetivos que son anónimos, el individuo actualiza lo objetivo y vive de ello. Por ello la conclusión de 'La «Filosofía de la historia» de Hegel y la historiología" en dos pasos: primero el pensamos con las cosas, y segundo la realidad histórica como unidad de aspectos individuales, objetivos e históricos. Se trata de la integración de sujeto y objeto en los contextos vital e histórico, que Ortega encontrará como única posibilidad de concordancia.

Así finaliza Ortega el artículo, y, sin embargo, es posible decir más cosas. En primer lugar, que en los estudios que ha manejado para llevar a cabo el estudio sobre Hegel ha encontrado ya temas muy similares a los expuestos en estas páginas finales. En Lorenz ha leído Ortega: "Nicht der Mensch als Individuum betrachtet, sondern der Mensch in seinen Beziehungen $\mathrm{zu}$ andern Menschen, seine Handlungen als das gesselschaftliche Thier des Aristoteles; Lebensäusserungen in Rücksicht auf die politische Form des Zusammenseins der Vielen sind das Objekt der historischen Forschung. Und indem der gesellschaftliche Zustand einer bestimmten Zahl von Menschen seinen Ausdruck durch den Staat erhält, so beschäftigt sich die Geschichte in erster Linie nur mit denjenigen Geschehnissen, welche

\footnotetext{
${ }^{127}$ Ibid. p. 540.

128 Ibid. p. 541.
} 
sich auf die staatlichgesellschaftlichen Verhältnisse gewisser Menschen beziehen"129. Y en Rothacker, en el capítulo dedicado a Savigny: "Das individuelle Subjekt erkennt sich als Repräsentanten seiner Familie, seines Standes, seines Volkes und Staates, seiner Epoche, als Forsetzung und Entwicklung aller vergangener Zeiten. Es nimmt diese Mächte in sein Selbstbewusstsein auf, fühlt sich als ihr Glied, und so gelangt sein ganzes Tun in Einklang und unauflösliche Gemeinschaft mit der Vergangenheit seiner Körperschaften"130. Incluso en el propio Lasson, en la introducción que acompaña a las primeras ediciones de la Filosofía de la historia de Hegel, y que luego fue editada como texto propio131, encuentra Ortega: "Der Staat also ist früher als das Individuum, und das Volk ist niemals die Summe der im Augenblick lebendigen, dem Gemeinwesen zugehörenden Einzelnen, sondern der von einem Geiste beseelte Organismus, der wie sich der körperliche Organismus durch den Stoffwechsel, so durch den Wechsel der Individuen sich beständig erhält"132.

Sobre este último texto citado de Lasson, escribirá Ortega en las notas de trabajo, y, por tanto, remitiendo al concepto hegeliano de Estado: "Hay los individuos y el estado o civilización frente, sobre y bajo aquéllos"133. De nuevo la problemática de la relación entre el Estado y los individuos. La superposición del Estado sobre los individuos, que aparece

129LORENZ, O. Geschichtswissenschaft in Hauptrichtungen und Aufgaben, II. Op. cit. p. 188. Traducción: "El objeto de la investigación histórica no es el hombre tomado como individuo, sino el hombre en sus relaciones con otros hombres, sus actos como el animal social de Aristóteles, las manifestaciones vitales en vista de la forma política de la convivencia de los muchos. Y, debido a que la condición social de un determinado número de hombres encuentra su expresión a través del Estado, es por ello que la historia se ocupa en primera línea únicamente de aquellos acontecimientos que se refieren a las relaciones socioestatales de ciertos hombres".

130 ROTHACKER, E. Einleitung in die Geisteswissenschaften. Op. cit. p. 47. Traducción: "El sujeto individual se reconoce como representante de su familia, de su posición, de su pueblo y Estado, de su época, como continuación y desarrollo de todos los tiempos pasados. Recibe estos poderes en su autoconciencia, se siente como su miembro, y todas sus acciones, así, alcanzan la concordancia y comunidad indisoluble con el pas ado de sus corporaciones".

${ }^{131}$ En la Biblioteca de la "Fundación José Ortega y Gasset" hay, además del texto presente en el volumen de la obra de Hegel, otros dos ejemplares de libro de Lasson, y ambos están subrayados y anotados por Ortega.

132LASSON, G. Hegels als Geschichtsphilosoph. Leipzig: Meiner, 1920, p. 95. Traducción: "El Estado está antes que el individuo, y el pueblo no es nunca la suma de los particulares vivos y pertenecientes a la comunidad en el momento, sino el organismo vivificado por un espíritu, que se mantiene estable a través del cambio de individuos, del mismo modo que el organismo corporal lo hace a través del cambio de materia [metabolismo]".

133 Archivo de la "Fundación José Ortega y Gasset", Carpetilla "Hegel: filosofía de la historia". Conjunto de notas titulado "Detalles históricos". 
en el texto de Lasson y que Ortega ha visto en Hegel, no podrá ser aceptada por Ortega. El problema no es únicamente social o político, sino también histórico. En una de las notas de trabajo puede leerse: "A la distancia - monumental - a que H. quiere mirar la historia desparece la granulosidad de todo lo individual [...]. Queda sólo la gran pasta humana, la nebulosa de un pueblo. Por eso también - ciencias, artes, etc. desaparecen - Y sólo se atiende a las dos grandes fuerzas de la nebulosa popular como tal: Estado y Religión - lo demás, en efecto, no existe para el pueblo"134. El carácter vital de la realidad histórica no soporta esa mirada sobrehumana que pasa por lo individual sin verlo. Únicamente Estado y Religión, las concreciones del Volksgeist, aparecerían con una determinación propia.

Para Ortega esto es, sobre todo, insuficiente. Por ello la compenetración indisoluble de los tres componentes, vida individual, social e histórica, en el desarrollo de la vida o realidad histórica. Ortega admite de la idea de Lorenz el carácter determinante de las relaciones entre individuos, la forma política de convivencia; de Rothacker la relación con el pasado; del propio Hegel, en general y aglutinando esas ideas, el carácter social del espíritu objetivo, pero a todo ello le añade las determinaciones históricas y humanas de la razón vital.

$\mathrm{Si}$, tanto en los textos citados, como en el propio Hegel, Ortega ha visto la conexión entre Estado y convivencia, no por ello deja de afirmar el talante secundario, en el sentido de posterioridad, de medio y no fin, del Estado respecto a la vida. La relación se establecerá, entonces, aunque todavía no en "La «Filosofía de la historia» de Hegel y la historiología", entre el espíritu objetivo y el Volksgeist, o, dicho de un modo más concreto, entre la vida social y el Estado. En este momento, al final del artículo, Ortega presenta únicamente la imposibilidad de sacar fuera de esa relación, como haría Hegel, los caracteres vitales e históricos.

Si el contexto se coloca en conexión con los escritos políticos de los mismo años, 19271928, se encuentra una ayuda en la explicación. Esos escritos forman un volumen propio, La redención de las provincias. El segundo artículo de esa serie se titula "¿Reforma del Estado o reforma de la sociedad?", y muestra la ambivalencia en los defectos españoles: por un lado los defectos del Estado, de las instituciones y su funcionamiento, por el otro,

\footnotetext{
${ }^{134}$ Archivo de la "Fundación José Ortega y Gasset", Carpetilla "Hegel: filosofía de la historia". Conjunto de notas titulado "Detalles históricos".
} 
los de la sociedad española, los de la vida individual y sus formas de convivencia. Son éstos los que determinan a los primeros, una sociedad fuerte siempre mantendrá a flote a un Estado débil, pero no viceversa, y ésa es la crítica principal a la situación española. Este es uno de los sentidos en los que deben entenderse los ataques de Ortega a la preponderancia hegeliana del Estado. En su carácter general: "En la realidad histórica, el Estado y cuanto a él se refiere representa un estrato superficial en comparación con lo que pasa en los senos de la sociedad"135, y en el concreto, "la gran reforma española, la única eficiente será la que, al reformar el Estado, se proponga no tanto acicalar a éste como reformar, merced a él, los usos y el carácter de la vida española" 136 .

El carácter vital e histórico que Ortega enfrenta tanto a la razón lógica como a la preponderancia de un Volksgeist insuficiente, que caracterizarían la teoría de Hegel, no responde únicamente a caracteres filosóficos. El interés de Ortega por el concepto de espíritu objetivo, la vida social, los estratos que mueven el Estado, no remite únicamente a la conexión de individuo, sociedad e historia, o a la superación del subjetivismo a través de esta integración de subjetividades y objetividades, sino también a la aplicación de esos rasgos en la necesidad de reforma para la vida social española, reforma siempre previa a la del Estado. La exigencia de vitalidad en la teoría de la historia y en las connotaciones de convivencia es, también, exigencia de vitalidad en España, en la historia y en la convivencia españolas.

La idea de Ortega de que "la política nacional ha de ser, primero que todo, política para las provincias y desde las provincias"137 remite a estos caracteres de exigencia de actividad, de vitalidad para el individuo medio, que es el que debe mover la maquinaria política, el que debe llevar a cabo la realización de los proyectos y convertir la vieja política en política efectiva. Si se tiene en cuenta que esta misión consiste en dotar a la política de una perspectiva histórica, se entenderá la conexión entre esa preponderancia de lo social y la realidad histórica:

"Se trata de armar una política cuyo contenido sea una perspectiva histórica; fletar nuevamente para alta
mar la nao hispana. Es preciso que nuestro pueblo vuelva a hacer historia. Pero hacer historia no ha de

135" ¿Reforma del Estado o reforma de la sociedad?" (1927). OC XI, 185.

136 Ibid. p. 187.

137" Primero las provincias" (1928). OC XI, 200. 
entenderse, folletinescamente, como un hacer escenas fuera de sí mismo -guerras, exploraciones, colonizaciones-. Todo esto es, o consecuencia, o síntoma o mise en scéne del verdadero hacer historia, que consiste, simplemente, en que un pueblo se haga y construya a sí mismo, se incorpore y organice. Con eso basta; con ser y estar ahí firme sobre el mundo, ya está haciendo magníficamente historia. Los demás no tienen más remedio que contar con él"138.

La pretensión de Ortega con estos artículos era mostrar la necesidad de encontrar una unidad política que integrara la localidad y la vida pública, llegando a afirmar la concreción de esa unidad política en "la gran comarca", esto es, en la división de España en regiones autonomías-. La intención que sustentaba esa pretensión era la de concederle carácter real, vital, poniendo los aspiraciones y proyectos de cada región en manos de sus habitantes, a la política y vida españolas del momento. La idea sobre la que se apoyaba Ortega sobrepasa el tema de España y remite a caracteres generales de su filosofía: "Una nación no esta en pie por obra mágica [...], sino que está sostenida por fuerzas sociales de carácter político. [...] Las instituciones -el orden- sólo son fuertes cuando hay fuerzas sociales que las nutran con su dinamismo. Para que un Estado se derrumbe no hace falta que se produzcan revoluciones contra él; basta con que aflojen su asistencia de fervor las masas pacíficas de ciudadanos"139. Es en este contexto en el que adquiere un sentido y un objetivo la unión de los tres componentes de la vida o realidad histórica, la vida individual, la social y la histórica.

Los caracteres de convivencia no remiten únicamente a su situación en esa realidad histórica, sino también y sobre todo a su función, a su poder dinamizador. La acusación al intervencionismo del Estado, que Ortega expone en ese peligro de La rebelión de las masas titulado "El mayor peligro, el Estado", se explicaría en este sentido: "Éste es el mayor peligro que hoy amenaza a la civilización: la estatificación de la vida, el intervencionismo del Estado, la absorción de toda espontaneidad social por el Estado; es decir, la anulación de la espontaneidad histórica, que en definitiva sostiene, nutre y empuja los destinos humanos"140. Con esto, las críticas tanto al Estado hegeliano como a su razón lógica se sitúan en un mismo contexto, el de la imposibilidad de fundamentar con ellos un proyecto

\footnotetext{
138" Respiro, reiteración y tránsito" (1928). OC XI, 229.

139" La unidad política es la gran comarca" (1928). OC XI, 252.

${ }^{140}$ La rebelión de las masas (1930). OC IV, 225.
} 
fuerte de realidad vital e histórica que aglutine tanto la atención a lo individual y particularizado, como la estructuración de un esquema de futuro que permita los caracteres reales de progreso.

Esa idea de futuro queda impedida por la filosofía de la historia hegeliana tal como la entiende Ortega, una filosofía de la historia detenida y eterna que no permite el movimiento real de progreso, sino únicamente los caracteres dinámicos de la idea y el concepto. Este tema del futuro es el que Ortega examinará en el "Hegel y América". 


\section{3. "Hegel y América"}

Ortega comienza el "Hegel y América" describiendo a Hegel como "un emperador del pensamiento"141, aunque la expresión no es suya, sino que la ha encontrado en Dilthey ("Er durfte sich als der Imperator fühlen"142). El contexto remite a aquella idea presentada en "Temas del Escorial", y que he examinado más arriba, de la perniciosa "aproximación a Hegel"143. La explicación de ese talante de emperador, trece años después de Temas del Escorial", la ofrece ahora Ortega del modo siguiente:

"Hegel es un caso curioso de archiintelectual, que tiene, no obstante, psicología de hombre de Estado. Autoritario, imponente, duro y constructor. Su alma no se parece nada ni a la de Platón ni a la de Descartes, ni a la de Spinoza, ni a la de Kant. La casta de su carácter le sitúa más bien en la línea de César, Diocleciano, Gengis-Khan y Barbarroja. Y no es que fuese uno de estos personajes aparte de ser un pensador, sino que lo fue precisamente como pensador. Su filosofía es imperial, cesárea, gengiskhanesca. Y así ocurrió que, a la postre, dominó políticamente el Estado prusiano, dictatorialmente, desde su cátedra universitaria"144.

Si en aquel texto de Temas del Escorial" aparecía esa "dominación", que llevaría a cabo Hegel, únicamente en el contexto de la situación política de la Alemania del momento, ahora adquiere un segundo sentido: el carácter imperial de Hegel se encuentra en su pensamiento, en su filosofía, y se expone en el unitarismo del espíritu que domina el conjunto del sistema. Ese es el imperio que ahora interesa a Ortega, el imperio b́gico que dirige el conjunto de las determinaciones, sean del tipo que sean. "Hegel y América" es un enfrentamiento con ese imperio, enfrentamiento llevado a cabo no desde los entresijos del sistema hegeliano, sino desde aquella sección que, en su modo de entender a Hegel, Ortega no puede aceptar: la imposibilidad de un futuro.

Es un enfrentamiento, y por ello precisamente es por lo que resulta útil, en el que Ortega elige las armas y el campo de batalla. Ortega huye del cuerpo a cuerpo con Hegel, incluso ni siquiera comentará los textos que cita de éste, sino que, de nuevo, únicamente muestra

141" Hegel y América" (1928). OC II, 563.

${ }^{142}$ DILTHEY, W. Die Jugendgeschichte Hegels und andere Abhandlungen zur Geschichte des deutschen Idealismus. Gesammelte Schriften. IV Band. Leipzig und Berlin: Teubner, 1925², p. 217.

143"Temas del Escorial" (1915), en: Notas de andar y ver. Viajes, gentes y países. Madrid: Revista de Occidente en Alianza -Obras de José Ortega y Gasset, 32-, 1988, p. 45. 
cuál es la situación de la batalla (la relación entre historia y futuro) y nos remite a que busquemos en otros textos su comportamiento en ella. Dicho de un modo más sencillo: en el "Hegel y América" Ortega expone el contexto de un tema en el que nunca podrá estar de acuerdo con Hegel, pero la propia exposición de ese tema por parte de Ortega no se encuentra en el texto sobre Hegel.

De este modo se presenta la diferencia entre los tres artículos que Ortega dedica a Hegel: "La «Filosofía de la historia» de Hegel y la historiología" era la exposición de la situación en torno a los estudios sobre historia, con la inclusión del concepto propio de historiología. Hegel era utilizado para mostrar una de las partes que deben definir esa historiología, la de la presencia ineludible de la razón en la historia, aunque los conceptos de razón de Hegel y Ortega sean diferentes. "Hegel y América", por el contrario, es la exposición de un enfrentamiento, en el que únicamente se mostrarán las diferencias, pero no la exposición de los contenidos. Hegel será utilizado para defender, por contraposición, una idea propia, la de la presencia del futuro en la historia, pero únicamente enunciando esa idea, sin presentar su modo de funcionamiento. "En el centenario de Hegel", sin duda el más interesante, Ortega expondrá directamente una recepción, la de la conexión entre espíritu y vida, y la del tema de la geografía en la historia, con una tematización explícita del tema del paisaje y del límite, tematización que, al remitir a todo lo expuesto en la primera parte de este trabajo, reúne ambas secciones.

De un modo concreto, y con todas las salvedades necesarias: "La «Filosofía de la historia» de Hegel y la historiología" es una utilización, "Hegel y América" un enfrentamiento, y "En el centenario de Hegel" una recepción, cuando "utilización" significa la admisión de partes coincidentes, "enfrentamiento" la distinción de intenciones y "recepción" la traducción de ciertos caracteres de conceptos hegelianos al idioma filosófico de Ortega.

Respecto al contenido concreto del "Hegel y América" es necesario hablar, evidentemente, de aquello que Hegel no trata: su exposición del tema de América, esto es, no un "Hegel y América", sino un "Ortega y América". En este caso, entender lo primero sólo es posible conociendo lo segundo. El artículo, entonces, tiene tres direcciones: Ortega y Hegel, Hegel y América, Ortega y América, direcciones que no pueden ser separadas,

\footnotetext{
144" Hegel y América" (1928). OC II, 563.
} 
esto es, no discurren paralelamente, sino que se entrecruzan desde el inicio. El vínculo que une esas direcciones es el tema de la historia, y dentro de éste una sección concreta, el tema del futuro.

Si por un lado es necesario comentar cuál es la relación entre Hegel y Ortega en este momento, por el otro es ineludible la conexión de Ortega con el tema de América. No hay que olvidar que en 1928 Ortega ha estado en Argentina, que durante esos años ha publicado varios artículos sobre el tema de América, y que el conjunto muestra su interés concreto por el tema no sólo en relación con la historia (América como futuro), sino con la situación especial de la conexión entre España y América.

En este contexto hay que examinar el articulito sobre Hegel, por un lado el binomio Ortega-Hegel, por el otro el binomio Ortega-América. Puede afirmarse que Ortega escribió el "Hegel y América" porque le interesaba, más que Hegel, el tema concreto de América, pero también puede afirmarse que su interés por este último se explica desde una forma determinada de entender la Historia, y en ésta, de nuevo, aparece Hegel. Únicamente de este modo, entrecruzando las temáticas, podrá entenderse el artículo de Ortega. 


\subsection{Heidegger y el tema de la muerte}

El "Hegel y América" tiene un tema principal que incluye, y supera por amplitud, la relación tanto con Hegel como, en general, con la filosofía de la historia: es el tema del futuro. La intención de Ortega es muy clara: mostrar los problemas de una filosofía que, según él, no permite las posibilidades de futuro ${ }^{145}$. En este sentido, hay un texto que determina el artículo y que debe guiar todo lo que se diga al respecto. Escribe Ortega: "El caso de Hegel patentiza sonoramente el error que hay en definir lo histórico como el pasado. Uha concepción cautelosa de lo real histórico tiene que contar con el futuro, con nuestro futuro, no sólo con nosotros, en cuanto futuro de lo pretérito. Así acaece que esta filosofía de la historia no tiene futuro, no tiene escape. Por eso es de un peculiarísimo interés averiguar cómo se las arregla Hegel con América, que si es algo es futuro"146. Partiendo de esta idea puede comenzarse el análisis.

Al final de La «Filosofía de la historia» de Hegel y la historiología", Ortega explicaba cómo toda vida social se inicia en un pasado, en una vida social pasada, y se dirige a un futuro, a una vida social futura. El "hoy" no puede separarse del "ayer" ni del "mañana", la vida social presente es sólo un trozo de algo mucho más amplio "de confines indefinidos hacia pasado y futuro, que se hunde y esfuma en ambas direcciones"147. Ese todo

\footnotetext{
${ }^{145}$ Edgardo Albizu, en "Ortega, Hegel y el pensamiento latinoamericano actual", ha mostrado lo que él mismo considera errores en la interpretación de Hegel por parte de Ortega, tanto en lo que se refiere al tema del futuro, como a las ideas generales de Ortega sobre el sistema de Hegel. Albizu, basándose en la propia filosofía de Hegel y con razones hermenéuticas fundadas, culmina su artículo de este modo: "Lo que Ortega hace resaltar en el sistema del saber absoluto -su crueldad, su ingenuidad, su optimismo de estrechas miras, su ceguera para el futuro - no es sino resultado de uno de los grandes malentendidos que suelen hallarse en el origen de las tradiciones filosóficas y que hacen tan díficil toda hermenéutica. En ese malentendido Ortega cayó como casi toda su generación. La filosofía que quiere hablar español, que se gesta con inconcebibles dificultades en territorio de América, no debiera, pues, imputar a la presunta ceguera para el futuro de uno de los máximos fecundadores del pensar, lo que puede no ser sino ceguera de ella misma para sus tareas presentes en la historia del mundo". ALBIZU, E. "Ortega, Hegel y el pensamiento latinoamericano actual", en: Sur, $\mathrm{n}^{\circ}$ 2, Buenos Aires, 1983, p. 15. El artículo de Albizu es un buen ejemplo para mostrar, por contraposición, el método de recepción que estoy llevando a cabo durante todo el trabajo. Albizu se centra en demostrar dónde se sitúan los errores en la lectura que hizo Ortega de Hegel. Sin embargo, antes que en buscar errores en la interpretación de Ortega, el interés está en saber por qué lo interpretó como lo hizo, es decir, no si Ortega se equivocó en la lectura, sino con qué intenciones determinadas llevó a cabo esa lectura. En el tema concreto del futuro, por ejemplo, el centro del análisis no está en saber si Hegel deja o no lugar para el futuro, sino por qué y para qué Ortega necesitaba enfrentarse a una idea que él entiende como "ausencia de futuro".
}

146" Hegel y América" (1928). OC II, 566.

147" La «Filosofía de la historia» de Hegel y la historiología" (1928). OC IV, 541. 
amplísimo y de márgenes indefinidos es lo que Ortega llama vida o realidad histórica. A la línea citada Ortega añadía la nota siguiente: "Es esencial a la vida del individuo datarse a sí misma de un cierto instante -el nacimiento- y extenderse desde cualquier presente hasta un tiempo aproximado en que la muerte ha de venir. Esta conclusión cierta actúa por anticipado en «nuestros días»; es el gran mañana, que modela nuestro hoy. Sobre esto, finas verdades y finos errores en el estudio reciente de Heidegger: Sein und Zeit, 1927. Puede descubrirse aquí, desde luego, una diferencia a priori entre la estructura de lo histórico y la del vivir individual. La historia no muere nunca, y sus movimientos no van gobernados por la idea de un término y consumación"148.

El tema es el de la relación entre vida histórica y vida individual, pero está articulado en torno a un problema, el problema del tiempo, y éste es el centro de la controversia con Hegel en el "Hegel y América": "Para Hegel la última realidad del universo es por sí evolución y progreso; consecuentemente, que lo cósmico es, desde luego histórico. Sólo que la expresión propia de aquella evolución absoluta es la cadena de la Lógica, la cual es una historia sin tiempo"149. La diferencia se expresa, entonces, en términos de finales, de conclusiones. La historia que no muere nunca, que no se dirige hacia un final determinado o consumación que rija todo lo anterior, tiene su contrapuesto en la historia lógica de Hegel, la historia sin tiempo en la que todo obedece las normas impuestas por el despliegue del espíritu.

Si éste es el problema con Hegel, con Heidegger la aventura es en cierta medida diferente, pero, de nuevo, va a recaer en aspectos que ya se encuentran en el enfrentamiento con Hegel. En las notas de trabajo aparece (incompleto) el final de "La «Filosofía de la historia» de Hegel y la historiología" y puede verse que Ortega, en la publicación, ha colocado en nota esa diferenciación entre vida individual y vida histórica, que se encontraba en el texto, y ha añadido la referencia a Heidegger, que en principio no hacía: "Que la vida social actual es influida no sólo por el pasado sino por el futuro es evidente. Así como en mi vida individual influye la idea que tengo del tiempo verosímil de existencia que al hombre es concedido y por tanto, el saber que moriré modela e informa mis actos, así la sociedad "piensa" que no va a morir, que tiene un futuro ilimitado y se comporta en

\footnotetext{
${ }^{148}$ Ibid. p. 541 n.
} 
consecuencia. Esta diferencia confirma la realidad de la diferenciación entre las dos vidas" 150 .

Esa diferenciación aparece en primer lugar como un problema de limitaciones, las de la vida individual frente a la ausencia de ellas en la vida social o histórica. Si esto es sí, la controversia con Hegel parece clara: el futuro ilimitado que presenta Ortega, frente a la ausencia de futuro en la historia que Ortega encuentra en Hegel. Pero si la diferencia entre Hegel y Ortega en el tema de la historia refiere a la ausencia o pesencia de futuro, esa distinción no es la misma entre la vida individual y la histórica. Aquí la diferencia no se encuentra en la ausencia o presencia de futuro, sino en los caracteres de ese futuro, esto es, el futuro limitado de la vida individual frente al ilimitado de la vida histórica.

En este tema, el del futuro limitado de la vida individual, o, más en concreto, el tema de la muerte, la relación con Heidegger es fundamental, y de ningún modo es gratuita esa presencia de Heidegger al final del texto sobre Hegel. Esa nota no indica únicamente que Ortega comenzara a leer Ser y tiempo casi a la vez que su publicación, sino, además, que Heidegger va a introducirse inmediatamente en la relación con Hegel, y, en general, en el tema de la historia. La conexión Ortega-Heidegger en torno al tema de la muerte presenta un itinerario particular ${ }^{151}$, el que conduce desde la nota citada hasta las lecciones sobre ¿Qué es conocimiento?, para culminar en la Idea del teatro y La idea de principio en Leibniz. Si estos dos últimos puntos del recorrido remiten explícitamente a la relación con Heidegger, y a la explicación del "finas verdades y finos errores", ¿Qué es conocimiento?, concretamente la primera lección, conecta de un modo especial con el comienzo del "Hegel y América". No es casual: el artículo sobre Hegel es de 1928, las lecciones sobre el conocimiento de 1929.

En el texto sobre el teatro, Ortega aclara su relación con Heidegger en este tema: "Mi nacimiento es un cuento, un mito que otros me cuentan pero a que yo no he podido asistir y que es previo a la realidad que llamo vida. En cuanto a mi muerte es un cuento que ni siquiera pueden contarme. De donde resulta que esa extrañísima realidad que es mi vida se

149" Hegel y América" (1928). OC II, 565.

${ }^{150}$ Archivo de la "Fundación José Ortega y Gasset", Carpetilla "Hegel: filosofía de la historia". Conjunto de notas titulado "Lo histórico". 
caracteriza por ser limitada, finita y, sin embargo, por no tener ni principio ni fin. Así es, a mi juicio, como hay que plantear el problema de mi propia muerte, y no como lo plantea el melodramático señor Heidegger"152. En el Leibniz Ortega concretará aún más la relación: "Heidegger ha desapercibido siempre que la realidad Vida tiene desde luego el sorprendente carácter de que no sólo es en todo instante «Muerte posible»y, por tanto, absoluto peligro, sino que esa muerte está en la mano de la Vida, es decir, que la Vida puede darse la Muerte153. Pero si fuese sólo Muerte eso no sería posible sino inevitable esto es, que la Vida, el hombre, no viviría más que el instante preciso para suicidarse. Aun admitiendo -con reservas, cuya enunciación es aquí inoportuna- que la Vida es el fenómeno del ente mortal y, por tanto, peligro viviente y Nada existiendo, resulta que sólo puede ser esto si es además aceptación del peligro, consagración jovial y fecunda de la muerte. La vida es precisamente la unidad radical y antagónica de esas dos dimensiones entitativas: muerte y constante resurrección o voluntad de existir malgré tout, peligro y jocundo desafío al peligro, «desesperación» y fiesta, en suma, «angustia» $\mathrm{y}$ «deporte»"154.

Estas dos referencias, entre otras cosas porque están escritas más de quince años después de los artículos sobre Hegel y las lecciones sobre el conocimiento, superan tanto el marco de la historia como el de la relación con Hegel, pero deben ser tenidas en cuenta para entender la aparición de Heidegger al final del texto sobre la historiología. En ambas aclara Ortega su relación con Heidegger ante el tema de la muerte. No se trata únicamente de su apuesta por la vida, por la razón vital e histórica y el sentido deportivo de la existencia, sino también por la conexión de limitaciones e ilimitación en el propio contexto de la vida. La vida es limitada, pero permite opciones ilimitadas: es la limitación de una ilimitación. La muerte, mi final, no me puede ser narrado, no forma parte de mi biografía, y, sin embargo,

\footnotetext{
${ }^{151}$ Itinerario que ha visto bien Regalado, aunque sin tocar la relación con Hegel: cfr. REGALADO, A. El laberinto de la razón: Ortega y Heidegger. Madrid: Alianza, 1990, p. 227 ss.

152"Máscaras", en: Idea del teatro. Una abreviatura (1946). OC VII, 496. "Máscaras" es un añadido a Idea del teatro, conferencia pronunciada por Ortega en abril del 46 en Lisboa, repetida en mayo en Madrid, y que pensaba publicar agregándole unos anejos que comenzó a escribir inmediatamente. "Máscaras" es el primero de esos anejos.
}

153 No hay que olvidar que también en la Filosofía del derecho de Hegel leerá Ortega (el texto se encuentra subrayado en la edición que maneja): "Ich habe diese Glieder, das Leben nur, insofern ich will; das Tier kann sich nicht selbst verstümmeln oder umbringen, aber der Mensch". HEGEL, Grundlinien der Philosophie des Rechts. Hrsg. G. Lasson. Leipzig: Meiner, 1928, § 47, p. 56.

${ }^{154}$ La idea de principio en Leibniz y la evolución de la teoría deductiva (1947). OC VIII, 297. 
supone mi limitación. Cuento con ella, pero no me la cuentan, cuento y no cuento con la muerte: la vida es constante muerte y constante resurrección, constante limitación e ilimitación. En la crítica a Heidegger, por tanto, la vida individual no se detiene en su futuro limitado, mortal, sino que, consciente de las propias limitaciones, en cierto modo juega con ellas, las "consagra jovial y fecundamente", y, también en cierto modo, las supera.

La aceptación del peligro, esto es, la conjunción del sentido trágico y el sentido jovial, uniendo la crítica a Unamuno con la afirmación de una nietzscheana voluntad de vida, presenta la expresión de esa paradoja de limitación en la ilimitación o ilimitación en la limitación. Su contenido, en cambio, es previo, en tanto remite a la caracterización histórica de la vida y al talante que supera la cerrazón del espíritu en sí mismo. Es un talante que debe ser entendido en los rasgos del ¿Qué es conocimiento?: la vida como ejecutividad. A partir de aquí se forma el esquema que une las críticas a Hegel y a Heidegger, así como los temas de la historia, la vida y el futuro. Frente al espíritu hegeliano, que "no es otra cosa que aquello que se conoce a sí mismo"155, el ser de la vida es "un hacer, mejor aún, un hacerse. La reflexión sobre sí de todo lo vital no es intelectual, o reflexión objetivadora, sino eficiente, operante; un hacerse a sí misma, un efectuarse o ejecutarse"156. De aquí las connotaciones de futuro, la conjunción de limitación e ilimitación en la vida y las críticas tanto a Hegel como a Heidegger. El modo completo de exposición es el siguiente:

\footnotetext{
"Nuestra vida halla siempre que no es aún, que es preciso hacerla, darle el ser o llegar a serla. En otra fórmula más adecuada diríamos que lo que halla es que tiene necesariamente que ser hecha. Halla, pues, una existencia que consiste en «necesaria existencia». Dicho de otra forma: el viviente no puede no ser. / Por eso el viviente no puede dejar de ser. Puede querer o pensar no ser, pero no puede ser no-ser. / Consecuencia de esto es que la vida no tiene principio ni fin. Esto califica muy bien el sentido que tiene la categoría raciovital de «existir». Yo no puedo vivir el comienzo ni el término de mi vida. (De aquí cabe (?) derivar una crítica de la idea de muerte en Heidegger). Comenzar a vivir o terminar de vivir no pertenecen a la vida, no son conceptos que parezcan posibles bajo la óptica de la vida. Precisamente porque son las dos cosas que no toleran reflexividad activa (ni, en este caso, tampoco de reflexividad
}

155" Hegel y América" (1928). OC II, 565.

156. ¿Qué es conocimiento? Madrid: Revista de Occidente en Alianza -Obras de José Ortega y Gasset, 25-, 1984, p. 16. 
intelectual), que no puede uno hacer o hacerse. / El carácter más obvio con que nos aparece esta nueva realidad -la vida- es la ejecutividad" 157 .

Los finos errores y finas verdades del artículo sobre Hegel aparecen ahora como la posibilidad de una crítica de la idea de la muerte en Heidegger. Esa crítica es la que expresará Ortega años más tarde, en el Leibniz y en el texto sobre el teatro: la unión en la vida del sentido de muerte y del sentido deportivo de la existencia, y la unión de limitación e ilimitación en la propia vida. En la base de esa crítica se encuentra la teoría de la vocación, de las posibilidades, del destino, etc. que están siendo presentadas tanto en ¿Qué es conocimiento? como en ¿Qué es filosofía?, por tanto en escritos muy cercanos, en todos los sentidos, a los artículos sobre Hegel. La vida como ejecutividad, contexto en el que se muestra esa referencia a Heidegger en ¿Qué es conocimiento?, debe acompañar de un modo íntimo la aparición de la misma referencia al final del escrito sobre Hegel y la historiología.

Del mismo modo que la vida se basa en su carácter de tener que ser hecha, y, por lo tanto, en la remisión a un futuro, a algo siempre inacabado, incompleto, y por ello tanto limitado como ilimitado en sus posibilidades, también la historia hay que hacerla. Y no únicamente en el sentido de conferirle una razón o encontrar sus leyes, sino en relación a sus posibilidades de futuro o, dicho de un modo más concreto, su conexión con la vida y su situación como realidad histórica. Ahora bien, el espíritu hegeliano que determina la historia presenta caracteres cerrados, autónomos: "Ese Espíritu, que, consistiendo en un conocerse, consiste en una actividad, en un movimiento y esencial agilidad que le lleva del ignorarse hasta el saberse. Va, pues, pasando de idea en idea hasta arribar a la idea completa de sí, hasta volver en sí, como un jerifalte que vuelve al puño, si el puño fuera un jerifalte"158; la vida, por su parte, y coincidiendo en algunos de esos caracteres, los modifica al introducir el talante de ejecutividad, de futurición, de estar constantemente haciéndose y depender de un futuro, de un proyecto elegido que determina el presente: "Mi vida de ahora, presente o actual y, por tanto, mi "yo" ahora, actual y presente es lo que es merced a un mi yo futuro, a mi vida futura y no al revés"159.

\footnotetext{
157 Ibid. p. 17.

158" Hegel y América" (1928). OC II, 564.

159 ¿Qué es conocimiento? Op. cit. p. 129.
} 
Son estos caracteres de futuro, que Ortega presentará de un modo detallado tanto en ¿Qué es conocimiento? como, sobre todo, en ¿Qué es filosofía?, los que exigen el enfrentamiento con Hegel en torno al tema de América. Si se tiene en cuenta que esos dos textos se están haciendo casi a la vez que los escritos sobre Hegel, entre 1928 y 1930, podrá entenderse la necesidad de Ortega por atender al tema del futuro en la filosofía de la historia de Hegel. Más adelante, al analizar la conexión de espíritu y vida en "En el centenario de Hegel", y cuando ya Ortega explícitamente utilice los caracteres de la vida que ha expuesto en ¿Qué es conocimiento? y ¿Qué es filosofía?, será necesario volver sobre este tema. Ahora baste con esto: Ortega necesita enfrentarse con el tema del futuro en la filosofía de la historia porque ese rasgo, el de la vida como futuro, el del talante de futuro de la realidad histórica, es imprescindible en su proyecto. Al hacerlo ahora, en relación con Hegel, cumple con ello otros dos objetivos: centrar el contexto en el tema de América y el de la historia. Si esto es así, la importancia del "Hegel y América" asciende hasta caracteres a primera vista insospechados, en tanto refiere a un marco de temas que superan ampliamente el artículo como tal. 


\subsection{El futuro en la historia: las profecías}

Ya en la definición del espíritu hegeliano como actividad, movimiento y esencial agilidad se perciben las conexiones y las diferencias entre Hegel y Ortega: se admite, para la vida, el movimiento y la agilidad, pero no la vuelta a sí. Esa esencial agilidad, más que a Hegel, remite Fichte. Ortega únicamente lo dejará claro años más tarde, en la Meditación de Europa, cuando escriba: "el hombre, como persona o como colectividad, es siempre una ecuación entre su ser inercial -receptivo, tradicional- y su ser ágil-emprendedor, afrontador de problemas"160. A ese texto añadirá una nota determinante, que puede ya entenderse desde el contacto con Hegel que está manteniendo veinte años antes y que permite ver qué es exactamente lo que buscaba Ortega en Fichte, Leibniz o el propio Hegel, a pesar de toda la temática de la superación del idealismo, o, mejor, permite ver qué es aquello con lo que quería quedarse Ortega después de la superación del idealismo como subjetivismo:

"Empleo el término de «ser-ágil» en homenaje al genio enorme de Fichte, el primer pensador que define al hombre como siendo primaria y fundamentalmente reine Agilität. Sería, de todo el pasado, el filósofo más actual si no le estorbase su patetismo constante, ingenuo y predicante. En Fichte llega a madurez la grande idea de Leibniz, por tanto, la gran idea alemana de que la realidad, la sustancia no es forma, como creían los griegos -aun los que intentan superarse como Aristóteles, o como tras ellos creyeron los escolásticos- y han creído siempre los mediterráneos, sino que es vis activa. Ahora bien, qué sea una realidad consistente en actividad, dice Leibniz, arcus tensi illustrari potest, puede representarse por un arco tenso hacia algo. Por eso, desde mi s veinte años la portada de mis libros españoles lleva un arquerito salvaje lanzando su flecha. Pertenezco a la tribu de los flecheros" 161.

No hay mejor explicación que esta metáfora: Ortega no puede admitir una historia sin futuro porque él pertenece a la tribu de los flecheros. Pero la relación no es únicamente con Fichte y con Leibniz, y en esos textos de los años cuarenta, sino también con Hegel y en la situación de finales de los veinte y comienzos de los treinta. La conexión no es gratuita, sino que se apoya, además de en el texto del "Hegel y América" citado, en las notas de trabajo sobre Hegel, donde el propio Ortega remite al binomio ser inerte - ser ágil en relación explícita con la conciencia hegeliana: "La conciencia es agilidad, por tanto, 
inquietud. [...] El ser ágil - frente al ser inerte"162. Si en Fichte y Leibniz aparece esa realidad como actividad, como agilidad, por su parte "Hegel ha sido uno de los últimos filósofos para quienes el universo es algo real. Después de él vino el diluvio del fenomenalismo en todas las formas, formatos y variantes posibles. Como ahora sentimos -y no sólo sentimos- la urgencia de redescubrir la realidad tras de los meros fenómenos, más allá de todo relativismo, el contacto con Hegel, ya que no nos conquista, nos corrobora"163. Si se tiene en cuenta que esa realidad que Hegel descubrió fue el Espíritu, y que éste se constituye como actividad y agilidad, como evolución y movimiento, los caracteres se presentan idénticos. El problema de Hegel, y por eso "no nos conquista", es que su realidad no es humana, no es vital: para Ortega, la actividad y agilidad del espíritu se desperdicia en un marco lógico.

El hombre como ecuación del ser inercial y el ser ágil, o, de otra manera, de ser desde el pasado y ser hacia el futuro, muestra el punto culminante que ocupa toda categoría de actividad, de movilidad, pero en el sentido de Ortega, y que explica tanto su atracción como su repulsa por el concepto hegeliano de espíritu. Es en estos caracteres móviles donde se asienta la reunión de vida e historia, donde se muestra el significado del arquero en sus dos referencias, la de la tensión, la del esfuerzo, y la de la dirección, la del proyecto, desde donde se explica la insistencia de Ortega en los talantes de acción, de aventura, de héroe. El conjunto exige la inseparabilidad de pasado y futuro, la presencia de la historia entendida en los caracteres vitales que la muestran determinando un futuro, presentando cómo se ha llegado a cierto punto, cómo ha tenido lugar el proceso, cuáles son las potencialidades, cuáles las posibilidades que tenemos y que deberemos amoldar a ese futuro como proyecto que rige nuestra actuación. No hay que olvidar nunca que el carácter de la vida como futurición no es un rasgo cualquiera de la filosofía de Ortega: "La estructura de la vida como futurición es el más insistente leit motiv de mis escritos"164.

A Ortega, en 1916, años antes por tanto de la aparición de los artículos sobre Hegel, no le importaba que eso activo, potencial, vital, histórico, recibiera un nombre u otro:

\footnotetext{
162Archivo de la "Fundación José Ortega y Gasset", Carpetilla "Hegel: filosofía de la historia". Conjunto de notas titulado "Detalles históricos".

163" Hegel y América" (1928). OC II, 564.

164" Pidiendo un Goethe desde dentro" (1932). OC IV, 403 n.
} 
"Llámesele alma, conciencia, espíritu o como se quiera, eso que somos consiste en un haz de actividades, de las cuales unas se ejecutan y otras aspiran a ejercerse. Consistimos, pues, en un potencial de actos: vivir, es ir dando salida a ese potencial, es ir convirtiéndolo en actuación"165, y, al hacerlo, gastándolo, consumiéndolo: "La vida, señores, es un fluido indócil que no se deja retener, apresar, salvar. Mientras va siendo, va dejando de ser irremediablemente"166. Ese es el talante histónico, la conexión de pasado y futuro, el carácter activo de la vida.

La diferenciación entre vida individual y vida social e histórica, que se expresaba por la remisión de aquélla a un principio y un final, nacimiento y muerte, mientras que éstas no admitían su consumación, y que permitía la referencia de Ortega a Heidegger, adquiere con todo esto un sentido más detallado. Pasados ambos por el tamiz de Ortega, el enfrentamiento se produce entre Hegel y Heidegger, y no sólo en referencia al tema de la muerte. En las notas de trabajo remite Ortega a otro contexto que no aparece en los escritos publicados. Escribe: "Algo sobre "Fortschrit" y "Entwicklung" en Hegel ver Heidegger"167. Ortega está pensando en las páginas finales de Ser y tiempo, concretamente en el capítulo titulado "Exégesis hegeliana de la conexión entre el tiempo y el espíritu"168. Si en el tema de la muerte difiere de la interpretación de Heidegger, no ocurre igual en este contexto del Fortschritt y la Entwicklung hegelianos, el progreso y el desarrollo. En este sentido Ortega y Heidegger coinciden: el progreso en Hegel no es cuantitativo, el desarrollo del espíritu consiste en llegar a sí. El enfrentamiento se produce en los caracteres temporales, el tiempo lógico de Hegel, frente al vital e histórico de Ortega. De otro modo:

\footnotetext{
165" Ideas sobre Pío Baroja" (1916). OC II, 80.

166" Para un museo romántico" (1921). OC II, 519.

${ }^{167}$ Archivo de la "Fundación José Ortega y Gasset", Carpetilla "Hegel: filosofía de la historia". Conjunto de notas titulado "Detalles históricos".

168Y más en concreto todavía, pensando únicamente en los conceptos de Fortschritt y Entwicklung, en el siguiente texto: "Das «Fortschreiten» des in der Geschichte sich verwirklichenden Geistes trägt ein «Prinzip der Ausschliessung» in sich. Diese wird jedoch nizht zu einer Ablösung vom Ausgeschlossenen, sondern zu seiner Überwindung. Das überwindende und zugleich ertragende Sichfreimachen charakterisiert die Freiheit des Geistes. Der «Fortschritt» bedeutet daher nie ein nur quantitatives Mehr, sondern ist wesentlich qualitativ und zwar von der Qualität des Geistes. Das «Fortschreiten» ist gewusstes und in seinem Ziel sich wissendes. In jedem Schritt seines «Fortschritts» hat der Geist «sich selbst als das wahrhafte feindselige Hindernis seines Zweckes zu überwinden». Das Ziel der Entwicklung des Geistes ist, «seinen eignen Begriff zu erreichen». Die Entwiclung selbst ist «ein harter, unendlicher Kampf gegen sich selbst»". HEIDEGGER, M. Sein und Zeit. Tübingen: Niemeyer, $1993^{17}$, p. 434.
} 
el progreso y el desarrollo en Ortega deben ser históricos y vitales, y, con ambos caracteres, tanto cualitativos como cuantitativos.

El objetivo es superar el espíritu, con lo que Ortega se acerca, en un sentido muy determinado, a las críticas de Heidegger al propio Hegel: "Die vorstehende existenziale Analytik des Daseins setzt dagegen in der «Konkretion» der faktisch geworfenen Existenz selbst ein, um die Zeitlichkeit als deren ursprüngliche Ermöglichung zu enthüllen"169. La vida y la historia, con sus inseparables connotaciones de futuro, serán en Ortega la expresión de esas "concreción de la existencia fáctica" y "temporalidad" heideggerianas, pero el contacto con Hegel tanto de Heidegger como de Ortega es similar en este punto: la crítica a la abstracción del espíritu y la defensa de la concreción, sea de la "existencia fáctica", sea de la vida y la historia.

A partir de estos contextos se entiende el sentido de la historia que no se consuma nunca, frente a la historia sin futuro de Hegel. La vida individual, por su parte, si al final del artículo sobre Hegel y la historiología incluía la presencia de un principio y un final, ahora, visto tanto desde la crítica a Heidegger en el tema de la muerte, como desde los rasgos de futurición expuestos en ¿Qué es filosofía? y ¿Qué es conocimiento?, adquiere la conexión de ilimitaciones y limitación en un sentido propio, el de la conjunción de las potencialidades y el sentido restrictivo en su ejecución, sentido restrictivo al tener que elegir, al no poder efectualizarlas todas. Por esto el enfrentamiento entre vida y espíritu: la vida es futuro, el espíritu consiste en su regreso a sí. Y, sin embargo, ese mismo espíritu es el que Ortega entiende como la realidad universal que Hegel descubre, y, en este sentido, conecta en su crítica a fenomenalismos y relativismos y en la urgencia de "redescubrir la realidad".

El contacto se produce con el tema que cerraba el artículo anterior, el "pensamos con las cosas", y la acusación general a la modernidad de pérdida de la sensación de realidad. Hegel habría reencontrado esa sensación; el problema estaría en que la realidad que siente no es la misma que la de Ortega: la de Hegel es espíritu, la de Ortega es vida, realidad histórica. En las notas de trabajo Ortega reconoce en este sentido el valor de Hegel: "Es

\footnotetext{
169HEIDEGGER, M. Sein und Zeit. Op. cit. p. 435. Traducción: "La precedente analítica del "ser ahí" entra, por lo contrario, en la "concreción" misma de la existencia fácticamente yecta, para desembozar la temporalidad como aquello que la hace originalmente posible". HEIDEGGER, M. El ser y el tiempo. Trad. J. Gaos. Madrid: F.C.E., 198977, p. 469.
} 
bueno refrescar en la mente moderna esta forma de historia en que el hecho cismundano tiene siempre una magnífica resonancia en el seno mismo del universo, desde el cual nos es repercutido como bueno divino que de lo alto llega - el hecho adquiere el rango de destino. El horizonte escurril del fenómenalismo requiere esta compensación"170. El problema es siempre el mismo: se admite el carácter real, histórico, pero sin Espíritu, se admiten ciertos caracteres de éste, pero aplicados a la vida y a la traducción que ejerce ésta sobre ellos. Hegel es "bueno" como compensación, pero no hay que detenerse en él.

Por fenomenalismo está entendiendo ahora Ortega un sentido general, con caracteres únicamente negativos, de desatención por la vida como realidad radical y atención única hacia aspectos que olvidan el marco esencial y se centran en relativismos y positivismos futiles. Hegel habría descubierno la realidad absoluta que éstos pasaban por alto; la diferencia con Ortega será de contenido, el contenido de esa realidad, el espíritu frente a la vida como realidad histórica. Por esto el problema de la relación entre tiempo e historia. Si para Hegel el carácter lógico de la idea exige la proyección en el tiempo de los estadios lógicos, representados siempre por algún pueblo, si para Hegel la historia es la proyección lógica de los estadios en el tiempo, para Ortega ese tiempo, en primer lugar, no tiene nada que ver con estadios lógicos, $\mathrm{y}$, en segundo, se trata de constituirlo como nuestro tiempo, esto es, con los caracteres de realidad histórica y vital. El marco temporal de la historia no remite para Ortega únicamente a su continuidad, sino también a su contemporaneidad: el tiempo histórico siempre tiene que posibilitar su conversión en nuestro tiempo, y, por ello, exige los caracteres de futuro. Esto sólo es posible si la historia abandona su marco lógico y adquiere el talante vital, si es capaz de adquirir un modo de expresión biográfico, en el que el pasado siempre sea visto en términos de futuro.

Cuando Ortega culmina el artículo sobre América citando el párrafo con el que Hegel cierra su exposición de "El Nuevo mundo", párrafo del que, en realidad, ha partido Ortega, y lo deja sin comentar, ya está mostrando cuál ha sido en concreto el enfrentamiento. Ese enfrentamiento estaba expuesto en el Tema de nuestro tiempo: es el enfrentamiento entre Hegel y Schlegel, y es a éste a quien sigue Ortega. El texto de Hegel que culmina el 'Hegel y América" es el siguiente: "Und als ein Land der Zukunft [América] geht es uns überhaupt

\footnotetext{
170Archivo de la "Fundación José Ortega y Gasset", Carpetilla "Hegel: filosofía de la historia". Conjunto de notas titulado "Detalles históricos".
} 
hier nichts an. Der Philosoph hat es nicht mit dem Prophezeien zu tun. Wir haben es nach der Seite der Geschichte vielmehr mit dem zu tun, was gewesen ist, noch erst nur sein wird, sondern mit dem, was ist und ewig ist, - mit der Vernunft, und damit haben wir zur Genüge zu tun"171. Ortega escribe en cursiva las primeras líneas del párrafo, cursivas suyas, no de Hegel.

Aunque no comente el texto, el simple hecho de presentar subrayado ese "como país del porvenir, América no nos interesa; pues el filósofo no hace profecías"172, es toda una declaración de intenciones. Hay que salir del artículo sobre Hegel para entenderla, y hacerlo intentando encontrar una contraposición a esa hegeliana ausencia de profecías. En El tema de nuestro tiempo ha concretado Ortega el contexto del modo siguiente:

\footnotetext{
"Acaecen en una época mil azares imprevisibles; pero ella misma no es un azar, posee una contextura fija e inequívoca. Pasa lo propio que con los destinos individuales: nadie sabe lo que le va a acontecer mañana, pero sí sabe cuál es su carácter, sus apetitos, sus energías y, por tanto cuál será el estilo de sus reacciones ante aquellos accidentes. Toda vida tiene una órbita normal preestablecida, en cuya línea pone el azar, sin desvirtuarla esencialmente, sus sinuosidades e indentaciones. / Cabe en historia la profecía. Más aún: la historia es sólo una labor científica en la medida en que sea posible la profecía. Cuando Schlegel dijo que el historiador es un profeta, del revés, expresó una idea tan profunda como exacta"173.
}

La idea de la profecía en la historia aparecerá constantemente en Ortega, pero la referencia (explícita) a Schlegel en este tema concreto únicamente la repetirá una vez más, en En torno a Galileo. Será ahí donde Ortega enfrente a Hegel y a Schlegel, pero la referencia a éste último no la muestra en el "Hegel y América". Aquí únicamente aparece, en cursiva, ese "el filósofo no hace profecías" de Hegel.

En ninguna de las dos apariciones de la idea de Schlegel muestra Ortega de dónde la tomó: es uno de los fragmentos del primer Athenaeum, de 1798, "der Historiker ist ein rückwärts gekehrter Prophet"174, el historiador es un profeta vuelto hacia atrás, de

171 HEGEL, Vorlesungen über die Philosophie der Weltgeschichte. Op. cit. p. 200. Gaos traduce: "Como país del porvenir, América no nos interesa, pues el filósofo no hace profecías. En el aspecto de la historia tenemos que habérnoslas con lo que ha sido y con lo que es. En la filosofía, empero, con aquello que no sólo ha sido y no sólo será, sino que es y es eterno: la razón. Y ello basta". HEGEL, Lecciones sobre la filosofía de la historia universal. Op. cit. p. 177.

172" Hegel y América" (1928). OC II, 576.

173 El tema de nuestro tiempo (1923). OC III, 153.

${ }^{174}$ SCHLEGEL, F. und SCHLEGEL, A.W. Athenaeum: eine Zeitschrift. Band I Nachdruck. Darmstadt: W.B., 1980, p. 196. 
espaldas, o, como escribe Ortega, puesto del revés. La interpretación habitual de la idea de Schlegel remite al carácter religioso de su filosofía de la historia, a la "palabra creadora de Dios como llave para el correcto entendimiento" del conjunto de acontecimientos históricos 175 . Ortega, por su parte, utilizará al historiador como profeta del revés en un sentido muy determinado.

El enfrentamiento se produce entre el filósofo que no hace profecías de Hegel y el historiador como profeta del revés de Schlegel. Y, sin embargo, ese mismo enfrentamiento explicitará la relación entre Ortega y Hegel: en Hegel, el filósofo no hace profecías porque sigue los mandatos de una razón lógica, eterna, que se lo impide, al mostrarle que la historia únicamente tiene que ver con lo que ha sido y lo que es, no con lo que será; en Ortega, después de la crítica al carácter lógico y eterno de esa razón (aunque, y en esto hay que insistir, no a la razón en la historia), las profecías vienen exigidas por la propia razón vital e histórica. O, de otro modo, al sustituir en la historia la razón lógica por la razón vital e histórica Ortega puede quedarse con el historiador como profeta de Schlegel frente al filósofo hegeliano carente de ese poder.

Para Ortega, la idea del historiador como profeta del revés, nada más y nada menos, resume toda la filosofía de la historia. Sin citar a Schlegel, escribirá en La rebelión de las masas: "Es falso decir que la historia no es previsible. Innumerables veces ha sido profetizada. Si el porvenir no ofreciese un flanco a la profecía, no podría tampoco comprendérsele cuando luego se cumple y se hace pasado. La idea de que el historiador es un profeta del revés resume toda la filosofía de la historia. Ciertamente que sólo cabe anticipar la estructura general del futuro; pero eso mismo es lo único que, en verdad, comprendemos del pretérito o del presente"176, y años antes, en El tema de nuestro tiempo, "creo, pues, que no parecerá aventurada la expresión antecedente, según la cual la ciencia

\footnotetext{
175 Jean -Jacques Anstett, en la introducción a su edición de las lecciones de Schlegel sobre filosofía de la historia, explica el fragmento de este modo: "Da der christliche Geschichtsphilosoph immer wieder an das uranfängliche Wort Gottes anknüpft und gemahnt, ist er wahrhaft «ein rückwärts gekehrter Prophet», nicht aber, weil für ihn die Erkenntnis der Wirkungen gewisser Ursachen in der Vergangenheit deterministisch auf die Wiederkehr derselben Wirkungen bei den gleichen Ursachen für die Zukunft schliessen liesse, sondern weil das schöpferische Wort Gottes der Schlüsel zum richtigen Verständnis vom Seienden und Werdenden, vom Alten und Neuen ist; insofern gehören Geschichte und Prophetie zusammen". ANSTETT, J.-J. Einleitung, en: SCHLEGEL, F. Philosophie der Geschichte. In achtzehn Vorlesungen gehalten zu Wien im Jahre 1828. Kritische Friedrich-Schlegel-Ausgabe, IX. München, Paderborn, Wien: Ferdinand Schöningh, 1971, p. XLIX.
} 
histórica sólo es posible en la medida en que es posible la profecía"177. Ahora bien, ¿cuál es exactamente el sentido que Ortega concede a la profecía?

El contexto remite a los caracteres de la vida como ejecutividad. La vida no es una realidad cuyo ser le es dado al hombre, "como le es dado a la piedra"178, que recibe su ser de un modo inmediato, está terminada ya en su comienzo, sino que la vida humana hay que hacerla, y, por ello, está dirigida por las connotaciones de futuro que determinen ese hacer. En este sentido la vida es profecía constante, continua anticipación de futuro, en tanto solicita la anticipación de una dirección antes de dar cualquier paso, un proyecto previo a cualquier efectivización, cualquier elección. Este es el carácter profético de la vida como futurición.

En la historia el marco se amplía: no se trata ya de individualidades, de vidas individuales, sino de épocas, de hacia dónde va una época, de dónde viene, por qué es como es. Es aquí donde se encuentran Hegel y Schlegel (el enfrentamiento deviene encuentro), en tanto el tiempo de la historia únicamente revierte en nuestro tiempo si es posible encontrarle un sentido en el proceso que lo ha formado, un pasado que ya era futuro. Pero marcar ese proceso sólo es posible si pueden determinarse las leyes, las razones de la historia, la profecía sólo es posible si hay leyes históricas: la profecía de Schlegel sólo es posible con el carácter racional de la historia, de Hegel. En la unión entre ambos se sitúa Ortega: el resultado de ese enfrentamiento exige el carácter vital de la razón histórica.

Estos dos caracteres, la historia de Hegel y la de Schlegel, Ortega sólo los presenta unidos al comienzo de la lección XI del curso En torno a Galileo:

"La realidad histórica, el destino humano avanza dialécticamente, si bien esa esencial dialéctica de la vida no es, como creía Hegel, una dialéctica conceptual, de razón pura, sino precisamente la dialéctica de una razón mucho más amplia, honda y rica que la pura -a saber, la de la vida, la de la razón viviente. / Pero claro es que si al reconstruir nosotros el pasado mediante la historia, hallamos que cada nueva época o estadio emerge del anterior con una cierta lógica o, dicho de otro modo, que a cada forma de vida sucede

176La rebelión de las masas (1930). OC IV, 175.

177 El tema de nuestro tiempo (1923). OC III, 154.

${ }^{178}$ En torno a Galileo (1933). OC V, 137. Este ejemplo de h piedra, que Ortega utiliza constantemente para contraponer el carácter ejecutivo de la vida, el ser que tiene que ser hecho, frente al ser dado, ya hecho, "preparado" para actuar, se encuentra también en Hegel. Es un texto de las lecciones sobre la filosofía de la religión, que Ortega subraya explícitamente en la edición que ha manejado: "Der Stein ist unmittelbar, ist 
otra que no es cualquiera, sino precisamente una que la anterior predetermina, quiere decirse que también será posible en alguna medida lo contrario, a saber, viviendo en una época vaticinar cómo sera en sus líneas generales la inmediata futura, en suma, que es en serio posible la profecía. Schlegel solía decir que un historiador es un profeta del revés, pero yo sostengo que eso implica también que el profeta es un historiador a la inversa, un hombre que narra por anticipado el porvenir" 179.

En la vida individual, ese carácter profético conduce a la vida como obra de imaginación, a la construcción del hombre por sí mismo, a su propio novelarse, al hombre como novelista de sí mismo. En la historia, al marco que acompañará a la razón histórica y vital, la razón narrativa. Las conexiones entre vida individual y vida histórica, al sustituir la razón histórica y vital a la razón lógica, se unen en este sentido a aquella diferenciación que, con la aparición de Heidegger, distinguía el futuro limitado de la individual del ilimitado de la histórica. Ahora se amplía la relación: limitado o ilimitado, es necesario contar con él, es necesario vivir para el futuro, y con la historia como ciencia profética que, por lo menos, permita intuirlo, verlo a grandes rasgos. Para ello, la historia, la vida, no pueden permanecer entendidas como una mera sucesión de azares, de hechos, sino que tiene que haber algo que los estructure, que les remita una razón, un sentido.

Este es el carácter de ciencia histórica, que pone en contacto historia y vida, y que se inicia en la razón lógica de Hegel, pero que la supera al conferirle carácter vital, histórico; es el carácter de historiología, de la historia como ciencia que exige una razón, una ley: si se entiende el proceso histórico como una serie de peripecias sin ley, entonces "no es posible, por tanto, ciencia histórica, ya que ciencia sólo es posible donde existe alguna ley que pueda descubrirse, algo que tenga sentido y que, por tenerlo, pueda ser entendido. I Pero la vida no es un proceso extrínseco donde simplemente se adicionan contingencias. La vida es una serie de hechos regida por una ley"180. Por ello, por el hecho de que los acontecimientos tienen un sentido, remiten a leyes históricas, profetizar el futuro sigue la misma operación intelectual que conocer el pasado: completar un línea, una ley, una estructura, continuar los pasos marcados. No se profetizarán hechos particulares, concreciones, pero sí talantes, tonos, estilos. Es el carácter futuro del pasado, el carácter

fertig. Aber schon das Lebendige ist diese Tätigkeit der Vermittlung mit sich". HEGEL, Vorlesungen über die Philosophie der Religion, I. Hamburg: Meiner, 1925, p. 70.

${ }^{179}$ En torno a Galileo (1933). OC V, 137.

${ }^{180}$ El tema de nuestro tiempo (1923). OC III, 153. 
contemporáneo de toda historia, la conversión de el tiempo en nuestro tiempo, y es el carácter que permite utilizar la historia como previsión: "Cuando el sentido histórico se perfecciona, aumenta también la capacidad de previsión"181. Ahora bien, en Ortega las intenciones son muy claras: la capacidad de profecía vale para todo tiempo, pero a él el que le interesa es el suyo, su época, y su país, y su historia... pero no como finales, sino como inicios.

${ }^{181}$ Ibid. p. 154 


\subsection{Futuro y presente: nuestro tiempo}

Hegel justificaba toda la historia, todo el pasado, desde el presente, desde su presente: "Sólo desde el presente, y en función de lo que es para nosotros nuestra vida, cabe, según Hegel, justificar las edades pretéritas"182. Ortega ve siempre su presente, su tiempo, en conexión con un futuro, no únicamente con un pasado, y de ahí la necesidad de defenderlo en la historia: la historia es la ocupación con un pasado por la preocupación por un futuro. Para Hegel, "Der Geist der gegenwärtigen Welt ist der Begriff, den der Geist sich von sich selbst macht; er ist es, der die Welt hält und regiert, und er ist das Resultat der Bemühungen von 6000 Jahren, das, was der Geist durch die Arbeit der Weltgeschichte vor sich gebracht hat und was durch diese Arbeit hat herauskommen sollen"183. La diferencia entre Hegel y Ortega se encuentra en los caracteres de futuro del presente: para Hegel, en el presente el concepto ha vuelto a sí, es un final, un presente que incluye todo el pasado y no deja paso a su futuro; para Ortega, el presente viene de un pasado y camina hacia un futuro, es siempre transición, nunca final. Y esto no sólo en el sentido de la vida como futurición o de la historia hacia adelante, sino también en referencia al carácter actual concreto de la nueva época, a los caracteres de nueva sensibilidad.

$\mathrm{Si}$ en Hegel el pasado es únicamente para el presente, en Ortega la historia es la combinación, la articulación de presente y pasado. Es esa articulación la que permite las posibilidades de futuro, al no dominar el presente el pasado que ha conducido hasta él. En las notas de trabajo, Ortega concreta esta idea: "Mirar la historia desde el espíritu es mirarla desde hoy, pero historia es verlo desde ayer, desde cada vez. Perpetuo presente que cada vez es distinto. Hoy articulado con hoy pasado: combinación de esto es la historia"184, la combinación, por tanto, de un hoy que es actual con un hoy que fie pasado, la combinación de un pasado con un presente que posibilita entenderlos en caracteres de futuro al ser

182" Hegel y América" (1928). OC II, 565.

183HEGEL, Vorlesungen über die Philosophie der Weltgeschichte. Op. cit. p. 165. Gaos traduce: "El espíritu del mundo actual es el concepto que el espíritu tiene de sí mismo. Él es quien sustenta y rige el mundo. Él es el resultado de los esfuerzos de seis mil años. Es lo que el espíritu ha producido mediante el trabajo de la historia universal, lo que ha debido nacer de este trabajo". HEGEL, Lecciones sobre la filosofía de la historia universal. Op. cit. pp. 149-150.

${ }^{184}$ Archivo de la "Fundación José Ortega y Gasset", Carpetilla "Hegel - Filosofía de la historia". 
ambos actuales, contemporáneos. El historiador es un profeta hacia atrás porque conjunta las dos direcciones, mira hacia atrás, pero camina hacia adelante.

La expresión de Ortega es general, con caracteres de filosofía de la historia, pero la intención es concreta. El interés por la historia era indispensable en su proyecto de regeneración de España, de revisión de mitos, de encontrar un esquema de futuro, pero el contexto remite al conjunto de la situación actual: no sólo España, también Europa, "Europa tiene que aprender en la Historia, no hallando en ella una norma de lo que puede hacer [...] sino que tiene que aprender a evitar lo que no hay que hacer; por tanto, a renacer siempre de sí misma evitando el pasado"185. La situación es la de entreguerras. Ortega refiere al poder del sentido histórico como previsión, y, aunque ésta le falle, nunca dejará de mantener el poder de Europa para renacer de sí misma, su poder de futuro.

Hasta las conferencias de Munich del 53 (después, por tanto, de guerras, exilios, regresos a España...), donde Ortega intenta defender la presencia de una conciencia cultural unitaria en Europa frente a los talantes nacionalistas, llegará la serie de connotaciones de futuro que no permiten un carácter cerrado: "[La cultura europea] no es, como las otras, una cultura cerrada, cristalizada una vez para siempre. [...] Su gloria y su fuerza reside en que está siempre dispuesta a ir más allá de lo que era, más allá de sí misma. La cultura europea es creación perpetua"186. Y al ser creación perpetua ni se admite el progresismo que olvida el pasado, ni el optimismo que centraliza todo en un presente.

Es cierto que Hegel, mediante la articulación de razón e historia, tiene "la ambición de justificar cada época, cada etapa humana, evitando la indiscreción del vulgar progresismo que considera todo lo pasado como esencial barbarie"187, pero la justificación de Hegel remite a las exigencias del concepto, al poder del presente, que utiliza todo pretérito como medio para llegar hasta él. La historia en la interpretación progresista carecía de interés porque "consistía simplemente en seguir todo derecho en una dirección preestablecida, por

185" Para el «Archivo de la palabra»" (1932). OC IV, 368.

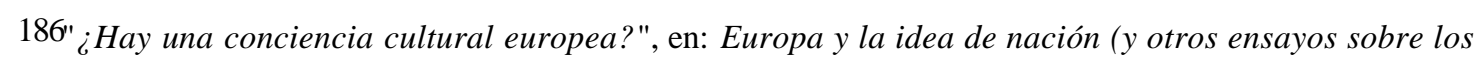
problemas del hombre contemporáneo). Madrid: Revista de Occidente en Alianza -Obras de José Ortega y Gasset, 26-, 1985, p. 28. El texto es el manuscrito, interrumpido, de la conferencia dada en Münich en el 53, Gibt es ein europäisches Kulturbewusstsein?

187" Hegel y América" (1928). OC II, 565. 
tanto, sin peripecia ni innovación"188. Pero el hombre es un animal de novedades, añade Ortega en nota a ese texto de las lecciones del 28 en Argentina. No quiere restricciones, sino inseguridades, inquietudes, posibilidades, es decir, futuro. $\mathrm{Ni}$ el optimismo de Hegel, que muestra cómo todo pasado ha existido para que nuestro presente sea tal como es, ni el talante de seguridad, de quietud del progresismo son caracteres del tiempo nuevo. Hegel se enfrenta a la negación del pasado por parte del vulgar progresismo, Ortega no soporta el optimismo de Hegel: "El optimismo sin reticencia que esta actitud de Hegel revela es un punto de contraste para definir el cambio de sensibilidad que en los últimos años ha experimentado el alma «moderna», sobre todo la europea. El «moderno» no se cree ya tan ingenuamente la edad definitiva"189, y no se la cree, entre otras cosas, porque uno de los caracteres de la nueva sensibilidad es la ausencia de tiempos definitivos.

Es la crítica a Hegel y a su presente definitivo desde las lecciones de Argentina en el 28, en textos que luego utilizará Ortega en La rebelión de las masas, es la crítica a Hegel desde los caracteres de nuestro tiempo, de la nueva sensibilidad: "Nuestro tiempo, en efecto, no se siente ya definitivo, al contrario, en su raíz misma encuentra oscuramente la intuición de que no hay tiempos definitivos, seguros, para siempre cristalizados, sino que, al revés, esa pretensión de que un tipo de vida, -el llamado de «cultura moderna», fuese definitivo, nos parece una obcecación, y es estrechez inverosímil del campo visual. Y al sentir así sentimos una deliciosa impresión de habernos evadido de un recinto angosto y hermético, de haber escapado y salir de nuevo bajo las estrellas al mundo enorme, profundo, imprevisible e inagotable, donde todo, todo es posible!"190, todo, tanto lo bueno como lo malo. Si hay algo que le impide a Ortega la aceptación de ese optimismo hegeliano es la inseguridad que se desprende del momento en que está escribiendo.

Así, viendo las referencias del escrito sobre Hegel en otros textos de la época, puede afirmarse que la intención de Ortega no era únicamente criticar la interpretación hegeliana de América sino, al hacerlo, mostrar la diferencia de sensibilidades. No sólo enfrentar la historia hacia adelante con la historia definitiva de Hegel, sino, sobre todo, dos talantes, el

188ORTEGA Y GASSET, J. Meditación de nuestro tiempo. Las conferencias de Buenos Aires, 1916 y 1928. Ed. J.L. Molinuevo. Madrid: F.C.E., 1996, p. 273.

189" Hegel y América" (1928). OC II, 565-566.

190Meditación de nuestro tiempo. Las conferencias de Buenos Aires, 1916 y 1928. Op. cit. p. 264. 
de los tiempos detenidos frente al de los tiempos móviles, el del optimismo frente al de la inseguridad, el de la sensibilidad de la razón pura frente al de la nueva sensibilidad de la razón vital e histórica. La crítica de Ortega a la situación hegeliana del tiempo en la historia responde a las necesidades de conformar ese tiempo como nuestro tiempo.

La crítica desde la nueva sensibilidad es la que explica el ataque en este momento al sistema cerrado de Hegel. Este sistema cerrado es el de la historia, con un presente definitivo, y su crítica la que procede también de la historia, pero la de la razón vital e histórica, la de nuestro tiempo:

\begin{abstract}
"A mí me abruma la cantidad de gratitud que esta idea me impone para esos seis mil años y esos miles de millones de hombres que se han fatigado en producirme. Pero ésta es la dimensión de ingenuidad que reside en el hegelianismo -de ingenuidad y de crueldad imperial. Es un pensamiento de faraón que mira el hormiguero de trabajadores afanados en construir su pirámide. A él debe el sistema de Hegel su carácter de sistema cerrado, sin evolución más allá de sí mismo, sin mañana. El presente, para Hegel, no es un tiempo cualquiera; es éste y sólo éste. Y poreso nuestro presente no cambiará en nada esencial, perdurará idéntico, sin preterir jamás. (El estado de espíritu de un Trajano cuando edifica sus edificios eternos). [...] Prisionero de su propia perfección, hieratizado en ella, se condena el presente a una perdurabilidad que a mí me parecería desesperante. La etapa actual de la historia sería, por fin, la meta lograda, el lugar apetecido, en busca del cual todo el pretérito se afanó, se movió y, por lo mismo, pasó. Si yo estuviera convencido de esta idea hegeliana y me sintiese adscrito a este eterno presente, se me iría con nostalgia el alma hacia el pasado, que era un camino y un andar -no, como el presente, un haber llegado y reposar.
\end{abstract} Como Cervantes decía, es preferible el camino a la posada" 191 .

Ortega no admite el trabajo del espíritu, "die Arbeit des Geistes"192, pretende salir de la reclusión a que Hegel ha sometido a la historia, "hay que volver a encontrar la gran salida al mundo: perforar la reclusión que es el Espíritu"193, escribirá en las notas. Esa salida no remite únicamente al futuro de la historia, sino también al futuro de las cosas, de lo real, hasta ahora recluidas en el Espíritu. Es la fidelidad a lo real de la nueva sensibilidad. También las cosas tienen una historia, y ésta enseña a verlas desnudas, a verlas desde su status nascens: "Esto es la Historia: el mañana nos revela inexorablemente la placa que fue ayer impresionada. Lo que había en el hoy secreto y latente, se hace en el futuro paladino.

191" Hegel y América" (1928). OC II, 566-567.

192HEGEL, Vorlesungen über die Philosophie der Weltgeschichte. Op. cit. p. 165.

${ }^{193}$ Archivo de la "Fundación José Ortega y Gasset", Carpetilla "Hegel: filosofía de la historia". Conjunto de notas titulado "Detalles históricos". 
La Historia es la marcha gigante hacia un prodigioso nudismo de lo real"194, escribirá Ortega en el Leibniz, y es el propio Leibniz el que le ha enseñado a buscar las cosas en su status nascens, en la biografía histórica de la conjunción de razón vital e histórica. El arte, al acceder a ese status, permite "asistir a su generación"195, verlas "en perpetuo status nascens"196; el arte narra la historia de las cosas, desde su generación, y narra también su futuro, las posibilidades de futuro.

$\mathrm{El}$ arte muestra el origen, el pasado de las cosas, al presentarlas naciendo en un mundo particular y propio, el mundo artístico, el contexto simbólico y metafórico. Muestra cómo nacen en él y cómo se movilizan dinámicamente en ese mundo propio. Con ello aparece también su futuro, las posibilidades causadas por su inconclusión, por la potencialidad de crear realidad a partir de su situación especial en un mundo particular. El arte, al narrar la intimidad de las cosas narra su status nascens, pero también su futuro: la posibilidad constante de superar limitaciones, de ampliar mediante la esencia simbólica y metafórica su propia realidad. El arte presenta la historia de las cosas al mostrar simultáneamente su origen íntimo y su futuro siempre abierto.

Pero no sólo el arte encuentra ese status nascens: también la historia insiste en narrar la conexión de pasado y futuro, y es así precisamente como Ortega veía a Argentina en su primer viaje, "pueblo de vida germinal, como Leibniz diría, un pueblo en status nascens, absorbido por la organización económica, lleno de optimismo aspirante"197. Este optimismo no es el mismo que el de Hegel, éste es un optimismo de futuro, el de Hegel lo era de presente. El optimismo de Hegel era el de lo eterno, el de la perpetua perdurabilidad; el de Ortega es el de las múltiples posibilidades, el que comienza en la salida al mundo, el que se asienta en "preferir el camino a la posada" al negar el presente eterno de Hegel. Y es importante la referencia a la frase de Cervantes. Incluso puede explicarse la crítica al presente eterno de Hegel mostrando únicamente los contextos de las distintas utilizaciones por parte de Ortega de esa preferencia del camino por la posada.

\footnotetext{
${ }^{194}$ La idea de principio en Leibniz y la evolución de la teoría deductiva (1947). OC VIII, 248.

195" Azorín: primores de lo vulgar" (1916). OC II, 175.

196" Ideas sobre la novela" (1925). OC III, 392.

197"El novecentismo" (1916), en: Meditación del pueblo joven y otros ensayos sobre América. Madrid: Revista de Occidente en Alianza -Obras de José Ortega y Gasset, 11-, 1981, p. 14.
} 
La primera vez que aparece en los escritos publicados de Ortega es en 1915, en "La nación frente al Estado", para definir la vida noble: "Una vida noble no es una vida con buen éxito, sino una vida poblada de honrados intentos. Cervantes, nuestro divino y dolorido Cervantes, nos lo dice como en un supremo consejo: «Vale más el camino que la posada»"198. Vuelve a ser utilizada en 1922, para ilustrar la misión del intelecual como inteligencia creadora, como forjador de empresas y de influencias: "La escena triunfal hace bostezar al verdadero triunfador. Lo importante en la vida es tener quehacer, una misión, una empresa, una tarea. Como Cervantes sugiere, es más sabroso el camino que la posada"199. Reaparece en 1928, criticando el presente eterno de Hegel, y en el mismo año la utiliza Ortega en las lecciones de Argentina, mostrando la conexión de la crítica a Hegel con la sensibilidad del tiempo nuevo: "La auténtica plenitud vital no consiste en la satisfacción, en el logro, en la arribada. Ya decía Cervantes que «el camino es siempre más divertido que la posadas"200. Este mismo texto lo utilizará Ortega, de nuevo, en 1930, en La rebelión de las masas, criticando los tiempos satisfechos, pero le añadirá una nota que nos interesa: "No dejen de leerse las maravillosas páginas de Hegel sobre los tiempos satisfechos en su Filosofía de la historia"201.

En 1939, en la Meditación de la criolla, comentando el "estilo" de la criolla como nuevo modo de ser mujer, y remitiendo a la necesidad de la presencia de la mujer en la nueva historiografía, vuelve a aparecer la frase de Cervantes: "Piensen que acaso tiene razón Cervantes -que tanto sabía del vivir- cuando asegura que después de todo es más divertido el camino que la posada. En la vida, amigos, lo importante no es llegar, sino ir, estar yendo"202. Por último, en 1953, en la conferencia de Munich "Gibt es ein europäisches Kulturbewusstsein?", continuando a la cita transcrita más arriba y en el contexto de que Europa debe superar las distancias y distinciones entre sus naciones para afirmar la conciencia cultural europea: "La cultura europea es creación perpetua. No es posada, sino

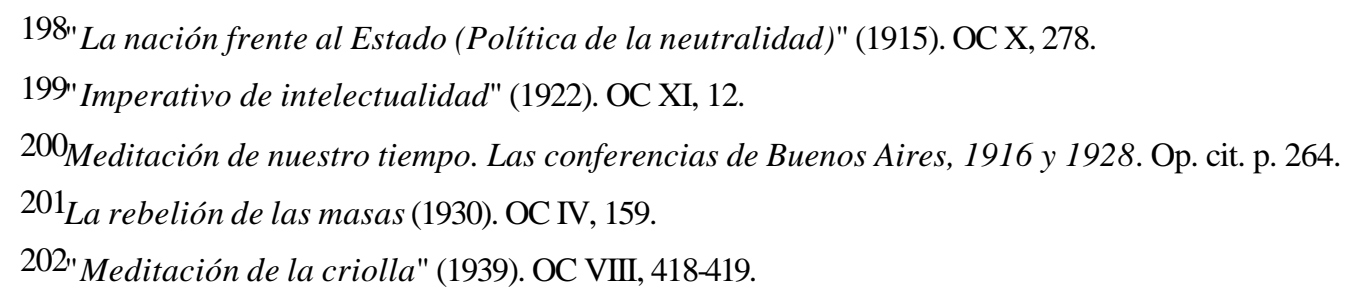


un marchar. Ahora bien, Cervantes, que había vivido mucho, nos dice, ya viejo, que el camino es mejor que la posada"203.

La nota que incluye Ortega en La rebelión de las masas es importante, y lo es porque, de nuevo, muestra la ambigüedad de la relación con Hegel. En primer lugar, la descripión de Hegel de los tiempos satisfechos es muy similar a los caracteres que Ortega presenta tanto en las conferencias de Argentina como en la propia Rebelión de las masas para definir el tiempo de plenitud, la modernidad, que precede al tiempo nuevo: los deseos agotados, el sentirse definitivo, no sentir necesidades, la tristeza y el aburrimiento, etc. Pero, además, es importante porque la crítica que Ortega hace al eterno presente de Hegel estará basada en esos caracteres. Esto es: se criticará el eterno presente de Hegel con los materiales concedidos por el propio Hegel al definir los tiempos satisfechos. Merece la pena citar los textos de Hegel a que refiere Ortega:

"Das Nächste ist nun, was eintritt, wenn der Geist hat, was er will. Seine Tätigkeit ist nicht mehr erregt, seine substanzielle Seele nicht mehr in Tätigkeit. Sein Tun steht nur mehr in entfernterem Zusammenhange mit seinen höchsten Interessen. Ich habe Interesse für etwas nur, insofern es mir noch verborgen oder für meinen Zweck notwendig, dieser aber noch nicht erfüllt ist. [...] In die Periode, wo der Geist noch tätig ist, fällt die schönste Zeit, die Jugend eines Volkes; da haben die Individuen den Drang, ihr Vaterland zu erhalten, den Zweck ihres Volkes geltend $\mathrm{zu}$ machen. Ist das vollbracht, titt die Gewohnheit des Lebens ein; und wie der Mensch an der Gewohnheit des Lebens erstirbt, so auch der Volksgeist an dem Genusse seiner selbst. Wenn der Geist des Volkes seine Tätigkeit durchgesetzt hat, dann hört die Regsamkeit und das Interesse auf; das Volk lebt in dem Übergange vom Mannesalter ins Greisenalter, im Genusse des Erreichten. Vorher war ein Bedürfnis, eine Not, hervorgetreten; sie ist durch irgend eine Einrichtung befriedigt worden und nicht mehr vorhanden. Dann ist auch die Einrichtung aufzuheben, und es tritt bedürfnislose Gegenwart ein. [...] Es lebt nun in der Befriedigung des erreichten Zwecks, verfällt in die Gewöhnheit, in der keine Lebendigkeit mehr ist, und geht so seinem natürlichen Tode entgegen. Es kann noch viel tun in Krieg und Frieden, im Innern und Äussern; es kann noch lange fortvegetieren. Es regt sich; aber diese Regsamkeit ist bloss die der besondern Interessen der Individuen, nicht mehr das Interesse des Volkes selbst. Das grösste, höchste Interesse hat sich aus dem Leben verloren; denn Interesse ist nur vorhanden, wo Gegensatz ist"204.

203" ¿Hay una conciencia cultural europea?", en: Europa y la idea de nación (y otros ensayos sobre los problemas del hombre contemporáneo). Op. cit. p. 28.

${ }^{204}$ HEGEL, Vorlesungen über die Philosophie der Weltgeschichte. Op. cit. p. 45-46. Gaos traduce: "Ahora bien, ¿qué sucede cuando el espíritu tiene lo que quiere? Su actividad ya no es excitada; su alma sustancial ya no entra en actividad. Su actividad sólo está ya en una lejana relación con sus intereses supremos. Sólo tengo interés por algo, mientras este algo permanece oculto para mí, o es necesario para un fin mío, que no se halla 
Ortega ha dejado claro que el tiempo nuevo, nuestro tiempo, "es un tiempo que viene después de un tiempo de plenitud"205. El tiempo nuevo no admite los finales, las conclusiones, los presentes definitivos. Para Ortega, la plenitud de vida es el horizonte abierto a toda posibilidad, y la plenitud satisfecha de la modernidad no era una apertura, sino una conclusión. El mismo carácter de conclusión es el que define al eterno presente de Hegel. Ortega identifica el tiempo satisfecho con el eterno presente, la tristeza del tiempo satisfecho con la perenne perdurabilidad del presente a la cual conduce el espíritu después de haber vuelto a sí. No es casual que Ortega coloque como más "divertido" el camino que la posada, la transición y el avance que la conclusión. En el propio Hegel ha encontrado los caracteres de ese aburrimiento: el tiempo satisfecho es aburrido 206 , la naturaleza (en la que no pasa nada, todo se repite siempre igual, en contraposición a la historia, que "es lo divertido"207) es aburrida 208 , pero para Ortega también es aburrido el espíritu hegeliano, el espíritu optimista del perpetuo presente: "Con frecuencia repite esto del aburrimiento y siempre cuando no hay evolución - es decir, variación innovante. Para él Naturaleza =

cumplido todavía. [...] La edad florida, la juventud de un pueblo es el periodo en que el espíritu es todavía activo. Los individuos tienen entonces el afán de conservar su patria, de realizar el fin de su pueblo. Conseguido esto, comienza el hábito de vivir. Y así como el hombre perece por el hábito de vivir, así también el espíritu del pueblo perece en el goce de sí mismo. Cuando el espíritu del pueblo ha llevado a cabo toda su actividad, cesan la agitación y el interés; el pueblo vive en el tránsito de la virilidad a la vejez, en el goce de lo adquirido. La necesidad que había surgido ha sido ya satisfecha mediante una institución; y ya no existe. Luego también la institución debe suprimirse. Y se inicia un presente sin necesidades. [...] Vive, pues, ahora en la satisfacción del fin alcanzado, cae en la costumbre, donde ya no hay vida alguna, y camina así hacia su muerte natural. Todavía puede hacer mucho en la guerra y en la paz, en el interior y en el exterior. Todavía puede seguir vegetando largo tiempo. Se agita, sí. Pero esta agitación es meramente la de los intereses particulares de los individuos, no el interés del pueblo mismo. La vida ha perdido su máximo y supremo interés; pues el interés sólo existe donde hay oposición, antítesis". HEGEL, Lecciones sobre la filosofía de la historia universal. Op. cit. p. 71-72.

205 Meditación de nuestro tiempo. Las conferencias de Buenos Aires, 1916 y 1928. Op. cit. p. 263.

206HEGEL, Vorlesungen über die Philosophie der Weltgeschichte. Op. cit. p. 46: "So sterben Individuen, so sterben Völker eines natürlichen Todes; wenn letztere auch fortdauern, so ist es eine interesselose, unlebendige Existenz, die ohne das Bedürfins ihrer Institutionen ist, eben weil das Bedürfnis befriedigt ist, eine politische Nullität und Langeweile".

207" Hegel y América" (1928). OC II, 568.

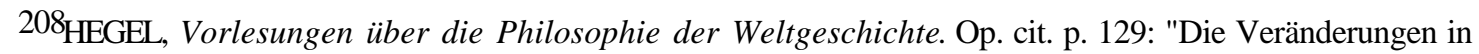
der Natur, so unendlich mannigfaltig sie sind, zeigen nur einen Kreislauf, der sich immer wiederholt; in der Natur geschieht nichts Neues unter der Sonne, und insofern führt das so vielformige Spiel ihrer Gestaltungen eine Langeweile mit sich". 
aburrimiento - Geist: diversión. Yo digo que su espíritu es también aburrido. [...] El saberse es aburrido. Lo divertido es trascender - salir de sí a un puro e imprevisto otro"209.

El espíritu es aburrido porque permanece en sí mismo, el presente eterno es aburrido porque no permite la salida hacia un futuro. La trascendencia como lo divertido remite tanto a la apertura hacia un tiempo nuevo, como hacia un paisaje nuevo: la nueva sensibilidad, la conexión de España y América, la conexión de España y Europa. El camino más divertido que la posada no es únicamente una muestra de los deseos de evolución, de progreso, sino también una definición del carácter más propio del tiempo nuevo: el carácter de posibilidad, de poder pasar cualquier cosa. La imagen de Cervantes ha tenido diversos momentos, desde la descripción de la vida noble como vida poblada de intentos en 1915, pasando por el carácter ejecutivo de la vida, de tener un quehacer, una tarea, en 1922, hasta llegar a iluminar los rasgos de plenitud vital en estos textos del 28. El contexto siempre es el mismo: negar las detenciones, negar los estancamientos, negar el desfallecimiento en los intentos. De nuevo, entonces, las exigencias de futuro.

Si en el tiempo actual, si en nuestro tiempo "la inseguridad del porvenir -de qué es posible y qué es imposible- afecta a los estratos últimos de la vida actual, como «no se está seguro de nada», será preciso sumergirse en la historia hasta honduras abisales"210. Ortega no acude a la historia de un modo gratuito, sino que le viene exigido por su propio tiempo, y Ortega era un especialista en su tiempo, como lo definió Curtius. Ese tiempo es un tiempo de futuro, y acudir a la historia significa, sin más, recurrir al pasado para intentar entender el futuro, tanto cómo se ha llegado hasta él, como por dónde continuará la evolución.

\footnotetext{
${ }^{209}$ Archivo de la "Fundación José Ortega y Gasset", Carpetilla "Hegel: Filosofía de la historia". Conjunto de notas titulado "Teoría general de Hegel".

210"Libros del siglo XIX. Guizot y la «Historia de la civilización en Europa»" (1935). OC V, 251.
} 


\subsection{Lo temporal y lo eterno}

Las críticas al eterno presente de Hegel responden a las urgencias de futuro, de futuro que es un presente y de presente que es un futuro, que tiene sobre todo talante de futuro, de posibilidad. Estos caracteres de futuro, permitidos y exigidos en la historia por la razón vital e histórica, son las únicas exposiciones de "eternidad" que muestra Ortega en la historia, no las de un presente definitivo. Cuando afirme decididamente que "el tema de nuestro tiempo -la unión de lo temporal y lo eterno- no está resuelto en Hegel"211 el objetivo es éste: con el presente eterno, con el espíritu que únicamente pretende volver sobre sí, Hegel no habría sabido reconciliarse con el tiempo, y mucho menos con su carácter de futuro.

Si el talante del tiempo de Ortega es precisamente de futuro, el enfrentamiento está servido. Superar a Hegel significa superar el espíritu, aunque, como ya he citado, superar a Hegel significa llegar hasta él, y eso es lo que está haciendo Ortega (de ahí la ambigüedad de la superación, o, mejor, el carácter hegeliano de la superación, o, mejor, su recepción de Hegel): "El destino de nuestro tiempo es precisamente superar a Hegel, lo que implica llegar hasta él. Hay que superar la idea del Espíritu"212.

El tema de nuestro tiempo como la unión de lo temporal y lo eterno, que aparece ahora en el escrito sobre Hegel de 1928, debe ser leído junto a la primera lección de ¿Qué es filosofía?, de 1929, y junto al penúltimo texto de El Espectador, "Revés de almanaque", de 1930:

- En el "Hegel y América" Ortega expone el problema del modo siguiente: "El historiador que con su persona cierra, tapona el curso futuro de la historia es arrastrado por él -no lo domina, hace de sí un pretérito perfecto. Y la defensa que de la filosofía hegeliana se ha hecho, diciendo que en ella misma está previsto el lugar que ella ocupa -ser la verdad de $s u$ época (como el rey que deja en el monumento preparada su tumba) ${ }^{213}$ - revela una

\section{1" Hegel y América" (1928). OC II, 566.}

212Archivo de la "Fundación José Ortega y Gasset", Carpetilla "Hegel: filosofía de la historia". Conjunto de notas titulado "Detalles históric os".

${ }^{213}$ Con esa "defensa que de la filosofía hegeliana se ha hecho" no refiere Ortega a una serie de autores o de ideas, sino directamente a Kroner. En una de las notas de trabajo escribe: "En qué sentido es para Hegel su filosofía la definitiva. Contra Kroner. No como lo es para casi todo filósofo sino porque su contenido excluye, 
aceptación de relativismo que pondría fuera de sí al imperial, al «absoluto» Hegel. Tal relativismo sería escepticismo. Esa verdad para un tiempo no es la verdad. De todos modos, el tema de nuestro tiempo -la unión de lo temporal y b eterno- no está resuelto en Hegel" 214 .

- En ¿Qué es filosofía? escribirá Ortega: "La historia es precisamente la segunda vista que logra encontrar la razón de la aparente sinrazón. / Según esto, la historia no es propiamente tal, no cumple con su misión constitutiva si no llega a entender el hombre de una época, sea ésta la que sea, incluso la más primitiva. Pero no puede entenderlo si el hombre mismo de esa época no lleva una vida con sentido, por tanto, si lo que piensa y hace no tiene una estructura racional. De este modo queda comprometida la historia a justificar todos los tiempos y es lo contrario de lo que al pronto amenazaba con ser: al mostrarnos la variabilidad de las opiniones humanas parece condenarnos al relativismo, pero como da un sentido plenario a cada posición relativa del hombre y nos descubre la verdad eterna que cada tiempo ha vivido, supera radicalmente cuanto en el relativismo hay de incompatible con la fe en un destino trasrelativo y como eterno en el hombre. Yo espero, por razones muy concretas, que en nuestra edad la curiosidad por lo eterno e invariable que es la filosofía y la curiosidad por lo voluble y cambiante que es la historia, por vez primera, se articulen y abracen. [...] Es inútil que intentemos violentar nuestra sensibilidad actual, que se resiste a prescindir de ambas dimensiones: la temporal y la eterna. Unir ambas tiene que ser la gran tarea filosófica de la actual generación"215.

anula el futuro y no deja posible cambio". Archivo de la "Fundación José Ortega y Gasset", Carpetilla "Hegel: Filosofía de la historia". Conjunto de notas titulado "Naturaleza e historia. Pasado y futuro". En el contexto del ataque a Kroner, Ortega no está pensando tampoco en las ideas generales del Von Kant bis Hegel, obra sobre la que tiene una opinión explícita ("El libro tan celebrado de Kroner, Von Kant zu Hegel [sic], me parece un gran error, porque adopta la actitud menos aceptable, cual es explicar a Kant desde Hegel, como si Hegel fuese la actualidad". "Filosofía pura. Anejo a mi folleto «Kant»" (1929). OC IV, 52 n.), sino en una referencia concreta, la que se encuentra en una nota del segundo volumen. Allí ha leído Ortega: "Hegel behauptet nicht, dass seine Philosophie im empirischen Sinne die Geschichte abschliesse. [...] Hegel behauptet daher lediglich, dass seine Philosophie die bisher erreichte höchste Gestalt ist, - welcher Philosoph, der von der Wahrheit seiner Lehre überzeugt ist, wird nicht dasselbe behaupten müssen? Eben das heisst ja Überzeugtsein. Hegel spricht nur den Sinn dieses Überzeugtseins, der allen Philosophien gemeinsam ist, explizite aus. Der Philosoph stellt sich als Philosoph aus seiner Zeit heraus, weil er sich aus aller Zeit herausstellt, er stellt sich ins Absolute hinein". KRONER, R. Von Kant bis Hegel. Bd. II: Von der Naturphilosophie zur Philosophie des Geistes. Tübingen: Mohr, 1921, pp. 505-506 n.

214" Hegel y América" (1928). OC II, 566.

215 ¿Qué es filosofía? (1929). OC VII, 285-286. 
- Por último, en "Revés de almanaque" puede leerse: "La insistencia con que me he ocupado en filiar los rasgos de «nuestro tiempo» no es una manía, ni siquiera me es peculiar, sino que, a su vez, constituye uno de los rasgos esenciales de «nuestro tiempo». Porque vivimos en una coyuntura tal vez sin ejemplo hasta ahora. [...] Por vez primera el hombre asiste a su propia mutación; cambia y sabe que cambia. Antes, en cada cambio efectivo se creía eterno y no se veía a sí mismo -sus creencias y modos de vida- como algo transitorio, sino como algo definitivo. Por tanto, el cambio no era tal para el cambiante. / El río de Heráclito ha cobrado conciencia de su fluidez. La gota que rueda valle ayuso se ve a sí misma correr y, por tanto, está también fuera del río, quieta. / El hombre no tiene más remedio que aprender a vivir en esta forma dual y sentirse a la par mudable y eterno. [...] Necesitamos aprender que sólo somos definitivos cuando henchimos bien el perfil transitorio que nos corresponde, es decir, cuando aceptamos «nuestro tiempo» como nuestro destino, sin nostalgia ni utopismos"216.

Hegel, al cerrar en el presente el curso de la historia e imposibilitar el futuro, queda determinado por ese futuro. Su situación deviene relativa al convertirse su presente en pasado. Pero ese relativismo no podría ser aceptado por Hegel: la verdad para un tiempo no es la verdad. La verdad es acrónica, no tiene que ver con el tiempo, aunque se le apliquen caracteres de eternidad para intentar diferenciarla de la historia y vida humanas, temporales. Esa conexión, la de la verdad y la historia, es el tema de nuestro tiempo: las verdades no cambian, los que cambian son los individuos que las piensan. Hegel no habría sido capaz de articular verdad e historia, eternidad y tiempo, al no conseguir que la intemporalidad del espíritu fuera más allá de su propia razón lógica. Únicamente cuando la razón vital e histórica sustituyan a esa razón lógica, pura, podrá comenzarse a articular los dos polos del enfrentamiento.

Pero la razón que la historia exige para poder ser entendida, para poder darle un sentido, Ortega sí la ha encontrado en Hegel, aunque no coincida en sus caracteres lógicos. Incluso la justificación de todos los tiempos, que invalida el relativismo al conferir un sentido pleno a cada momento, también la ha encontrado Ortega en Hegel, aunque, y este será el problema, Hegel se detenga en el presente. Para Hegel cada pueblo o época es una nueva idea, una nueva representación del espíritu, o, en términos de Ortega, una nueva 
sensibilidad de vida. Es la traducción que efectúa Ortega de los términos hegelianos: "Cada pueblo es la idea que tiene del espíritu - Cada pueblo es la interpretación de la vida y su justificación"217. Ortega se lo reconoce: para Hegel "todas las épocas han tenido razón, precisamente porque fueron diferentes y aún contradictorias"218. El problema es que la evolución de las épocas camina, dirigida por la razón lógica y el desarrollo del espíritu, únicamente en dirección a un presente eterno. Ortega niega ese final, pero no la justificación de cada momento: es la eternidad particular, la verdad eterna que cada tiempo ha vivido. Cambia el hombre, pero no las verdades, y ese es el "a priori fundamental de la historia"219. De este modo, verdad e historia se constituyen en su articulación como tema de nuestro tiempo.

Ese tema, que exige la conjunción de eternidad y temporalidad, se instala en una expresión precisa: conciencia del cambio, adquirir razón del cambio. Esa razón es razón histórica, no lógica, y su eternidad es únicamente la de lo transitorio: eternidad de lo transitorio, la constante y perpetua transición. Nada hay definitivo, y menos el presente, como afirmaba Hegel, excepto la aceptación del propio tiempo, la aceptación de su perfil transitorio. El tema de nuestro tiempo, de este modo, no es únicamente el examen de un momento particular, el actual, sino que su aceptación es una ley historiológica general. Se puede afirmar de un modo paradójico: Ortega acepta su propio tiempo como destino porque el tema de su tiempo, la integración de lo temporal y lo eterno, así se lo pide. Y también viceversa: el carácter confuso, inquieto, inseguro de ese tiempo exige la razón histórica que pueda explicarlo, que pueda, por lo menos, liberarlo de errores pasados.

Cuando Hegel afirmaba que la historia tiene que ver con lo pasado y la filosofía con lo eterno, la razón (en el texto que utiliza Hegel para concluir su exposición de "El nuevo mundo" y Ortega su "Hegel y América"), ya mostraba la conexión y la distinción con Ortega: para éste, primero, la historia no tiene únicamente que ver con el pasado, sino también, y sobre todo, con el futuro. Y, segundo, la filosofía, la verdad, sí tiene que ver con lo eterno, pero con un eterno particularizado, un eterno que no es la razón lógica, sino la reunión de historia y verdad en torno a la eternización de lo transitorio. El tema de nuestro

\footnotetext{
${ }^{217}$ Archivo de la "Fundación José Ortega y Gasset", Carpetilla "Hegel - Filosofía de la historia".

218" Hegel y América" (1928). OC II, 566.
} 
tiempo es la integración de la historia como futuro con la verdad como eternidad particularizada, en su unión con vida e historia, razón vital y razón histórica.

Es así como se reúnen en torno al tema de nuestro tiempo todos los caracteres. La conjunción de Schlegel y Hegel, de la historia como profecía al revés de Schlegel y la ausencia de profecía de Hegel, es posible porque hay unas razones o leyes históricas (la razón en la historia iniciada Hegel) que permiten unir tiempos, permiten ver el carácter eterno de lo transitorio (el historiador como profeta del revés de Schlegel). La intranquilidad del tiempo actual solicita la historia para saber a qué atenerse, solicita tener un proyecto de futuro, saber hacia dónde se dirige, y aceptarlo: aceptar el destino propio aceptando su provisionalidad, aceptar el destino propio aceptando su limitación. Estos son los caracteres de futuro que mantiene la teoría de la historia de Ortega. No son únicamente talantes generales, sino que a la vez remiten a exigencias del propio tiempo. Es por ello por lo que el tema de América, y las dificultades planteadas por la interpretación hegeliana, adquieren una importancia mayor de la que a primera vista puede parecer.

${ }^{219}$ ¿Qué es filosofía? (1929). OC VII, 284. 


\subsection{El Estado en la historia}

Ortega apenas comenta los textos que cita de Hegel sobre el tema de América. Únicamente los transcribe, y les añade lo que él llama una "ley fundamental de la historia" que, como ley, tiene un marco general y no afecta únicamente a América. Para entender de un modo adecuado el artículo hay que salir de él e ir a otros textos de Ortega sobre América. Es necesario incidir, además, en que a Ortega le es muy útil la colocación del tema de América, por parte de Hegel, en el capítulo sobre el fundamento geográfico de la historia universal. No por la relación misma con América, sino sobre todo por la conexión entre pre-historia, o geografía, e historia. Puede decirse que la intención de Ortega es doble, por un lado América, por el otro la relación entre prehistoria e historia. Para entender ambos aspectos hay que salir del artículo sobre Hegel e ir hasta otros textos de Ortega sobre el tema, así como a las notas de trabajo en su lectura de Hegel. De todas formas, el tema de la geografía, aunque iniciado aquí, encontrará su análisis explícito, con las intenciones propias de Ortega, en 'En el centenario de Hegel", y será en el comentario de éste donde será examinado.

Ortega no comenta demasiado las tesis hegelianas sobre América. No lo hace porque su pretensión es muy concreta, y por ello incluye el artículo en El Espectador: se trata de mostrar una contraposición, de mostrar los cambios de sensibilidad, tanto en la interpretación de América como de la historia en general, y se trata precisamente de que eso lo lean no sólo en España, sino también en América. Mostrar una contraposición, pero, a la vez, dejar claro que ciertos rasgos en el modo de entender el tema por parte de Ortega se inician en Hegel. Por todo ello, el examen que Ortega lleva a cabo del tema de América en Hegel comienza con una paradoja, "la paradoja no radica en que Hegel elimine a América repito, a un futuro- del cuerpo propiamente histórico, sino que, no pudiendo colocarla ni en el presente ni el pasado propiamente tal, tiene que alojarla... ¿Dónde dirán ustedes? Pues en la prehistoria"220.

La prehistoria en el pensamiento hegeliano es no-historia, ante-historia. La historia comienza cuando entra en escena el espíritu, la conciencia de sí, y para Hegel el síntoma de esto es la aparición de un Estado. El conocerse a sí mismo del espíritu es tener conciencia 
de su libertad, de su autonomía: "Libre es el que se determina a sí mismo, el que se da a sí propio leyes. Ahora bien: la existencia en el universo de algo que merezca el nombre de Estado es la existencia de algo que da eyes y que no las recibe; por tanto, que se da a sí mismo leyes. [...] La aparición del Estado es la iniciación de una realidad nueva, sobrenatural; es el anuncio de que nace un orbe cuya sustancia es Libertad. Es el orbe histórico o sobrenatural, cuya vida y evolución no consiste en más que en un «progreso de la conciencia de libertad»"221.

Son las ideas clásicas de Hegel, que Ortega no comenta y se limita, sin más, a repetir textos del propio Hegel: "Das Bewusstsein allein ist ja das Offene und das, für welches Gott und irgend etwas sich offenbaren kann, und in seiner Wahrheit, in seiner an und für sich seienden Allgemeinheit, kann es sich nur dem nachdenkend gewordenen Bewusstsein offenbaren. Die Freiheit ist nur, solche allgemeine substanzielle Gegenstände wie das Gesetz und das Recht zu wissen und zu wollen und eine Wirklichkeit hervorzubringen, die ihnen gemäss ist, - den Staat. / Völker können ohne Staat ein langes Leben fortgeführt haben, ehe sie dazu kommen, diese ihre Bestimmung zu erreichen, - und darin selbst eine bedeutende Ausbildung nach gewissen Richtungen hin erlangt haben. Diese Vorgeschichte liegt nach dem angegebenen ohnehin ausser unserem Zwecke; es mag darauf eine wirkliche Geschichte gefolgt oder die Völker gar nicht zu einer Staatsbildung gekommen sein"222.

Si Ortega se limita a transcribir textos del propio Hegel, la cuestión no está en saber si Ortega entendió o dejó de entender a Hegel, ni siquiera en localizar las ideas de Hegel en sus propios textos 223 , sino en saber por qué Ortega no se enfrentó a él, o, de otro modo, en

\section{0" Hegel y América" (1928). OC II, 567-568. \\ 221 Ibid. p. 568}

222HEGEL, Vorlesungen über die Philosophie der Weltgeschichte. Op. cit. p. 143. Gaos traduce: "Nada puede revelarse en su verdad, en su universalidad, en sí y por sí, sino a la conciencia reflexiva. La libertad consiste exclusivamente en conocer y querer los objetivos sustanciales y universales, como la ley y el derecho; y en producir una realidad que sea conforme a ellos - el Estado. / Los pueblos pueden llevar una larga vida sin Estado, antes de alcanzar esta determinación. Y pueden lograr sin Estado un importante desarrollo, en ciertas direcciones. Esta prehistoria cae empero fuera de nuestro fin, según lo ya indicado; aunque la haya seguido una historia real, o los pueblos no hayan conseguido formar un Estado". HEGEL, Lecciones sobre la filosofía de la historia universal. Op. cit. p. 136.

${ }^{223}$ Cosa no demasiado difícil: "Die Materie hat ihre Substanz ausser ihr; der Geist dagegen ist das Beisichselbstsein, und dies eben ist die Freiheit. Denn wenn ich abhängig bin, so beziehe ich mich auf ein anderes, das ich nicht bin, und kann nicht ohne solch ein Äusseres sein. Frei bin ich, wenn ich bei mir selbst bin". HEGEL, Vorlesungen über die Philosophie der Weltgeschichte. Op. cit. p. 33; ó: "Wir haben die zwei 
saber por qué y para qué Ortega se limita a exponer a Hegel, tanto en el tema de América como en las ideas de Hegel que conducen hasta dicho tema. Para empezar, ya hemos visto más arriba que para Ortega la libertad como saberse a sí mismo, como reflexividad, es una superfelación, en tanto "la libertad es el estatuto del ser en pluralidad"224. Si ahora, en un artículo explícito sobre Hegel, no aparece esa crítica, debe haber alguna causa que le impida a Ortega hacerlo.

La respuesta puede ser la siguiente: en el artículo sobre América a Ortega no le interesa criticar las ideas hegelianas, por la razón de que quiere hacerlo con sus propias ideas, basadas sobre todo en atacar el carácter de reflexividad. Esto lo hará únicamente dos años más tarde, en "En el centenario de Hegel", utilizando teorías que expondrá directamente en ¿Qué es filosofía? y en los textos que rodean a esta obra. Pero, si esto es así, ¿para qué escribió realmente Ortega el "Hegel y América"? No lo hizo para "educar filosóficamente" con respecto a un autor y un tema concreto, ni tampoco para ofrecer "otra visión del tema América" necesaria para entender el conjunto, sino únicamente para utilizar las ideas de Hegel como preparación, como el inicio desde donde partirán las propias ideas de Ortega al respecto, ideas que en parte se enfrentarán a Hegel y en parte utilizarán conceptos claramente hegelianos, pero ampliados de contexto. En cierto sentido, la exposición de la lectura hegeliana del tema de América le servirá a Ortega de colchón. El 'Hegel y América" no es una exposición, o, en todo caso, una exposición muy determinada, en tanto está dirigida completamente por las ideas de Ortega en el mismo tema de América, ideas con otros intereses y desde otra situación.

Si para Hegel, según Ortega, libre es el que se determina a sí mismo y que se da a sí mismo leyes, para el propio Ortega libertad es la salida a un otro, sea un mundo nuevo, sea un tiempo nuevo, sea un individuo, una salida que acoja en su dialéctica la referencia a sí. Para Ortega la libertad es trascendencia, posibilidad, pluralidad, no únicamente encierro

Momente aufgestellt, das eine: die Idee der Freiheit als der absolute Endzweck, das andre: das Mittel derselben, die subjektive Seite des Wissens und des Wollens mit ihrer Lebendigkeit, Bewegung und Tätigkeit. Wir haben den Staat als das sittliche Ganze und die Realität der Freiheit und damit als die objektive Einheit dieser beiden Momente erkannt". Ibid. p. 103; ó: "Der Staat ist die geistige Idee in der Äusserlichkeit des menschlichen Willens und seiner Freiheit. In denselben fällt daher überhaupt wesentlich die Veränderung der Geschichte, und die Momente der Idee sind an demselben als verschiedene Prinzipien". Ibid. p. 123; ó, directamente: "Die Weltgeschichte stellt nun den Stufengang der Entwicklung der Prinzips dar, dessen Gehalt das Bewusstsein der Freiheit ist". Ibid. p. 135. 
dentro de sí. Remite al tema del Fürsichsein que veíamos más arriba: la contraposición de la soledad en Hegel a la solidaridad en Ortega, la contraposición dialéctica del ser para sí a la alteridad (aunque Ortega utilice caracteres hegelianos para afianzarse en su posición: aquél cuasi-ser que veíamos más arriba), de la referencia a sí frente a la referencia a un otro.

En Ortega, la libertad del espíritu no consiste únicamente en una entrada a sí o en una salida de sí, sino en la conjunción de ambas. En las notas de trabajo lo explicita de un modo determinante, comentando esta serie de ideas hegelianas sobre la conexión de espíritu y libertad: "El espíritu como substancialmente libertad. Canto a la libertad. Muy bien pero no nos dejemos llevar. "Soy libre cuando estoy en mí mismo" - no - El solitario no es libre porque no puede salir de sí. No sólo es cárcel la reclusión en otro sino la soledad sin otro. Hay que entrar y salir. [...] Es preferible dotar al espíritu de libertad pero no definirlo por ella, no hacer de ella su substancia"225. La conjunción que establecerá Ortega es la de vida y mundo, la de soledad y sociedad, la de vida y convivencia, la de ensimismamiento y alteración, si se quiere, la de la vida como soledad radical y la convivencia como afán de trascendencia, en tanto "cada hombre quisiera ser los otros y que los otros fueran él"226. En general, y conjuntando todos los contextos, la vuelta a sí es sólo una parte, ni más ni menos importante que la salida hacia fuera.

Dotar al espíritu de libertad pero no definirlo por ella refiere a este problema. Si se sustituye "Espíritu" por "Vida", que es en el fondo la intención de Ortega, aprovechar ciertos caracteres del "espíritu" hegeliano para el suyo de "vida", se entenderá el problema: vida es siempre conjunción de fatalidad y libertad, por un lado, y de soledad y trascendencia, por el otro. Incluye la fatal libertad de elección, de posibilidad, e incluye la relación con un mundo, con un otro, desde la soledad de un sujeto. "La vida no es el sujeto solo, sino su enfronte con lo demás, con el terrible y absoluto «otro» que es el mundo donde al vivir nos encontramos náufragos", escribirá Ortega precisamente comentando las

\footnotetext{
${ }^{224}$ Archivo de la "Fundación José Ortega y Gasset", Carpetilla "Hegel: filosofía de la historia". Conjunto de notas titulado "Detalles históricos".

$225_{\text {Ibid. }}$

${ }^{226}$ En torno a Galileo (1933). OC V, 162.
} 
relaciones entre espíritu y vida 227 . Dotar al espíritu de libertad pero no definirlo por ella significa que la libertad es sólo una parte, no el conjunto. Esto en lo que refiere al tema de la libertad, conectando con lo ya examinado más arriba a partir del Fürsichsein. Con el tema del Estado ocurre algo similar.

Si para Hegel, según Ortega, el Estado es el orbe histórico o sobrenatural cuya vida y evolución consiste únicamente en progreso de la conciencia de libertad, para Ortega "cabría decir que un Estado es perfecto cuando, concediéndose a sí mismo el mínimum de ventajas imprescindibles, contribuye a aumentar la vitalidad de los ciudadanos"228. El Estado no es más que una máquina situada dentro de la nación con el único fin de servir a ésta, a la vida, a los individuos. La prioridad de la nación sobre el Estado, que Ortega mantendrá constantemente, no refiere únicamente al tema de España, a la necesaria introducción de vitalidad en las instituciones o demás instrumentos del Estado, sino a la prioridad general de la vida. Este es el problema con Hegel. Para Ortega, Hegel, con su teoría de la historia basada en el despliegue del espíritu y en los caracteres lógicos de la idea, no es capaz de retroceder a la "realidad vida", que es precisamente la que determina los supuestos fundamentales de todo Estado, religión, arte, etc.

Hegel da prioridad al Estado como concreción del espíritu, Ortega antepone la sensibilidad vital. Llega a decir incluso que para Hegel, el Estado es una iglesia profana, olvidando con ello la individualidad y pluralidad de la sensibilidad vital, que es precisamente la que debe dirigir al Estado: "Lo que Hegel dice del Estado como topos en que se realiza la idea - lo había dicho San Agustín y Bossuet de la Iglesia. Si en fecto, como en tantos puntos el idealismo alemán es un catolicismo enclaustrado - como lo fue la Reforma misma - un catolicismo profano - así el estado de Hegel es una iglesia profana"229. No hay que olvidar que Ortega, desde La pedagogía social como programa político", ha insistido en el carácter antisocial de la iglesia ("lo que ciertamente es antisocial

${ }^{227}$ En el centenario de Hegel" (1931). OC V, 420.

228" Mirabeau o el político" (1927). OC III, 631. El mismo texto lo utiliza Ortega en: "La política por excelencia" (1927). OC III, 457.

${ }^{229}$ Archivo de la "Fundación José Ortega y Gasset", Carpetilla "Hegel: filosofía de la historia". Conjunto de notas titulado "Detalles históricos". 
es la iglesia"230), así como en el necesario laicismo del Estado y la separación de la Iglesia 231. En este sentido, Ortega remite a Troeltsch. Allí ha leído: "[...] der Zwang der Identitätsphilosophie den Statt geradezu vergöttlicht hat, während im Westen der Staat immer etwas sehr Relatives und menschlich Bedingtes blieb, auch wenn er im Mittelpunkt stand. Man kannte seine Abhängigkeit von der Gesellschaft aus der Erfahrung"232. El carácter humano, vital, social, si se quiere, es previo a la concreción del Estado: Ortega nunca admitirá esos rasgos espirituales, divinos del Estado.

Si Hegel diviniza el Estado, Ortega insiste en que éste no es el punto de gravitación sobre el que la vida se asienta. En el artículo sobre América, Ortega no expone estas críticas, pero comentando los mismos textos de Hegel en las notas de trabajo, escribe: "No es cierto que el Estado sea nunca la absoluta seriedad de la vida, su punto de gravitación"233. Ortega ya ha presentado en "El origen deportivo del Estado" un ejemplo, al mostrar el nacimiento del Estado, de la "fecundidad creadora residente en la potencia deportiva"234, ya ha antepuesto el carácter vital, teórico, deportivo, a la utilidad práctica, a la aparente seriedad política. La prioridad de la sensibilidad vital siempre estará en Ortega por delante de la maquinaria del Estado. La Libertad, con mayúscula, que Hegel sitúa junto al Estado, siempre será criticada por Ortega, y le antepondrá, como vimos más arriba, la libertad plural y vital que huye de todo tipo de divinizaciones.

230" La pedagogía social como programa político" (1910). OC I, 519.

231"El Estado es laico. La Iglesia católica debe vivir separada del Estado". "Puntos esenciales" (1931). OC XI, 141; "La separación de la Iglesia y el Estado es un fruto que el tiempo ha hecho madurar y se cae solo del árbol". Rectificación de la República (1931). OC XI, 382; "El Estado tiene que ser perfectamente y rigurosamente laico". Ibid. p. 409, etc.

${ }^{232}$ TROELTSCH, E. Der Historismus und seine Probleme. I. Buch: Das logische Problem der Geschichtsphilosophie. Tübingen: Mohr, 1922, p. 376 n. Traducción: "La coacción de la filosofía de la identidad ha divinizado al Estado sin rodeos, mientras que en occidente el Estado siempre permaneció como algo muy relativo y humanamente condicionado, también cuando estaba en el punto central. Se conocía por la experiencia su dependencia de la sociedad".

233Archivo de la "Fundación José Ortega y Gasset", Carpetilla "Hegel: filosofía de la historia". Conjunto de notas titulado "Detalles históricos".

234" El origen deportivo del Estado" (1925). OC II, 619. 


\subsection{La prehistoria y los pueblos primitivos}

En el "Hegel y América", Ortega se limita a exponer los caracteres del Estado y de la libertad hegelianos, sin hacer el más mínimo comentario explícito. Los utiliza únicamente para mostrar su relación con la historia: la historia aparece cuando surge un Estado, la sustancia de éste es la libertad, libertad en progreso, en evolución. Si la historia, en su conexión con el espíritu, con el Estado, con la libertad, es evolución y progreso, la naturaleza, por contra, es constante repetición, "en la naturaleza propiamente no pasa nada, por la sencilla razón de que siempre pasa lo mismo"235. La naturaleza es aburrida, no pasa nunca nada; sólo en la historia pasan cosas, sólo la historia es divertida, "en cambio, la prehistoria nos habla del hombre natural (los alemanes llaman al salvaje o primitivo Naturmensch), del hombre que aún no sospecha su latente potencia espiritual y pervive sonámbulo como el animal o la planta"236. En la naturaleza, en la prehistoria, en la geografía, es donde Hegel colocará al mundo nuevo, a América.

Ortega incide en que además de Hegel, Schelling había sugerido la idea de la esencial prehistoria. Remite a la Introducción a la filosofía de la mitología; concretamente, centrándonos en las lecciones de Schelling, a la octava, donde éste examina la contraposición entre el tiempo prehistórico y el tiempo histórico, con la intención de tratar el inicio histórico del politeísmo. El contexto es el mismo que el que vimos más arriba en referencia a los dioses particulares. Ahora, Ortega utiliza a Schelling para mostrar los caracteres que, como en Hegel, mantendría el tiempo prehistórico:

"Mit dem blossen Begriff der schlechthin vorgeschichtlichen Zeit ist jedes Vor und Nach, das man in ihre selbst denken möchte, aufgehoben. Denn könnte auch in ihr noch etwas sich ereignen [...], so wäre sie eben nicht die schlechthin vorgeschichtliche, sondern gehörte selbst zur geschichtlichen Zeit. Wäre in ihr nicht Ein Princip, sondern eine Folge von Principien, so wäre sie eine Folge wirklich unterschiedener Zeiten, und damit sie selbst ein Theil oder Abschnitt der geschichtlichen Zeit. Die schlechthin vorgeschichtliche Zeit ist die ihrer Natur nach untheilbare, absolut identische Zeit, und daher, welche Dauer man ihr zuschreibe, doch nur als Moment zu betrachten, d. h. als Zeit, in der das Ende wie der

235" Hegel y América" (1928). OC II, 568.

236 Ibid. pp. 568-569. 
Anfang und der Anfang wie das Ende ist, eine Art von Ewigkeit, weil sie selbst nicht eine Folge von

Zeiten, sondern nur Eine Zeit ist, die nicht in sich eine wirkliche Zeit, d. h. eine Folge von Zeiten ist"237.

Aunque Ortega tampoco comenta la referencia a Schelling, la pretensión es clara: dejar constancia de que Hegel, al situar a América en la pre-historia, en la naturaleza, le elimina las connotaciones de tiempo histórico. Para Ortega, y aunque Hegel entienda a América como país del futuro, en primer lugar, al situarla en el tiempo pre-histórico le anula los caracteres temporales, $\mathrm{y}$, en segundo, ese futuro que le refiere no tiene lugar en su filosofía de la historia: el "aún no" que determina cada momento tiene como finalidad el presente, el hoy.

Para Ortega, el futuro en la filosofía de la historia de Hegel es el presente, y ahí la historia se detiene. Por ello utiliza Ortega el tiempo pre-histórico en los caracteres de Schelling, para mostrar que ese tiempo que Hegel remite a América es un no tiempo: "Un tiempo es prehistórico no porque ignoremos lo que él pasó, sino, al revés, porque en él no pasó nunca nada, sino que pasó siempre lo mismo, y el pasado, en vez de pasar, se repitió pertinazmente"238. Este no tiempo, esta constancia de la repetición que remitiría a la naturaleza, perdura hasta nuestros días en los pueblos salvajes, primitivos: "los pueblos salvajes no tienen historia"239, viven prisioneros de la naturaleza, su tiempo no es tiempo, sino repetición, pre-historia. Aunque, de nuevo, Ortega únicamente enuncia el tema en Hegel, éste es otro de los puntos de confrontación, y, para mostrarlo, también de nuevo, hay que salir del texto sobre América.

Para Hegel son históricos aquellos pueblos que formaron claramente un Estado; la vida preestatal es irracional, con lo que los pueblos salvajes no entran en la historia, no tienen conciencia de sí: tras ellos comienza la historia, lo racional. Los pueblos primitivos, como

${ }^{237}$ SCHELLING, F.W.J. Philosophie der Mythologie. I. Einleitung in die Philosophie der Mythologie. Darmstadt: W.B., 1976, p. 182. Traducción: "Con el simple concepto de tiempo absolutamente prehistórico se supera todo Antes y Después que en él se quiera pensar. Porque si en el tiempo prehistórico pudiera suceder todavía algo [...], entonces no sería absolutamente prehistórico, sino que pertenecería ya al tiempo histórico. Si no hubiera en él un único principio, sino una sucesión de principios, entonces sería una sucesión de tiempos efectivamente diferentes, y, con ello, él mismo una parte o sección del tiempo histórico. El tiempo absolutamente prehistórico es, por naturaleza, el tiempo indivisible, absolutamente idéntico, y, por ello, toda duración que se le suscriba hay que considerarla como momento, como tiempo en el que el final es como el comienzo y el comienzo como el final, una especie de eternidad, porque él mismo no es una sucesión de tiempos, sino solamente un único tiempo que no es un tiempo real en sí, es decir, una sucesión de tiempos".

238" Hegel y América" (1928). OC II, 569.

239 Ibid. 
se encarga de recalcar Ortega, son "Völker von trübem Bewusstsein [...], und diese sind von der Weltgeschichte ausgeschlossen"240. Hegel es para Ortega demasiado racionalista, no salva eso irracional, lo que todavía no ha forjado un Estado (que sí será atendido por la razón histórica), no es capaz de justificar toda la historia.

En lo que concierne a los pueblos primitivos, el enfrentamiento Ortega-Hegel es concreto: si para Hegel no entran a formar parte de lo histórico, sino que son naturaleza, notiempo, para Ortega esto es muestra nada más y nada menos que del provincianismo de Hegel, de que su universal histórico es todo menos universal: "El punto es grave porque, en resolución, es la prehistoria la historia que no conocemos. Cada día sabemos más tiempo de atrás: civilizaciones insospechadas, con sus leyes y su historia subjetiva (tartesios, hititas, pueblos americanos, cultura egea) sale de so la tierra. Pero su inesperada aparición desarticularía la armazón de Hegel. En su Weltgeschichte no hay lugar para ellos. Es, justamente, un mundo confinado, provinciano, que es lo que no puede ser un mundo" 241. No hay que olvidar que para Ortega en su lectura de Hegel el mismo carácter de no-tiempo, de prehistoria, coincide en América y los pueblos primitivos.

Si la crítica de Ortega a Hegel en este sentido se dirige a su eliminación de lo irracional, a su sacar fuera de la historia los pueblos primitivos, salvajes, y a entender esa exclusión como causa suficiente para la desarticulación de la filosofía de la historia de Hegel en general, las razones de Ortega son muy concretas, en tanto la exclusión de Hegel se enfrenta a un aspecto central de la filosofía de Ortega: la ampliación de mundo, la "voluptuosidad de horizontes"242, que ya aparecía más arriba en conexión con el tema del arte. Ortega ha insistido a lo largo de su trayectoria filosófica en la necesidad de atender a los pueblos primitivos, salvajes, a la conexión entre esos pueblos y la cultura o la civilización, a mostrar que éstas no surgen de la nada, que no se puede eliminar la continuidad entre el hombre primitivo y el civilizado, o, en general, mediante una expresión

\footnotetext{
240HEGEL, Vorlesungen über die Philosophie der Weltgeschichte. Op. cit. p. 167. Gaos traduce: "Pueblos de conciencia turbia; y estos pueblos quedan excluidos de la historia universal". HEGEL, Lecciones sobre la filosofía de la historia universal. Op. cit. p. 153.

241Archivo de la "Fundación José Ortega y Gasset", Carpetilla "Hegel: Filosofía de la historia". Conjunto de notas titulado "Naturaleza e historia. Pasado y futuro".

242" Oknos el soguero" (1923). OC III, 594.
} 
tajante, que "la civilización es hija de la barbarie y nieta del salvajismo"243 (la misma crítica que años más tarde le hará a Toynbee ${ }^{244}$ ).

La causa de la atención a esos contextos no es únicamente histórico-evolutiva, de mostrar cómo los pueblos salvajes o primitivos son estadios ineludibles del desarrollo histórico, sino también de ampliación de mundo, de presentar esa voluptuosidad de horizontes que no sólo conduce a lejanías espaciales, sino también a las temporales. Se trata del cambio en el modo de hacer historia: el sentido o la razón histórica de Hgel, traducidos a las intenciones de Ortega y convertidos en razón histórica y razón, inicia su trabajo en el juego entre la distancia, la lejanía con lo desconocido, con lo extraño, con todo eso que Hegel retira de la historia, y la cercanía necesaria para conferirles ese sentido que permita entenderlos.

La crítica a Hegel en este sentido es fuerte. No sólo por acusarlo de provincianismo, sino también por ver en ello un centralismo europeo que Ortega siempre se cuidó de mantener. Para entender la acusación de provincianismo en la filosofía de la historia de Hegel lo más conveniente es acudir a Las Atlántidas, texto de 1924 que determinará la relación con Hegel en este sentido y que ya examiné más arriba en relación a la crítica del unitarismo de Hegel frente a la pluralidad de horizontes. Ahora el tema se amplía: "Esto es, en efecto, lo que ha acontecido con la ciencia histórica europea durante tres siglos: ha pretendido deliberadamente tomar un punto de vista universal, pero, en rigor, no ha fabricado sino historia europea"245.

Lo no europeo, lo marginal, incluida América, los pueblos salvajes y primitivos eran tratados como formas secundarias de lo humano; todo se enfocaba en torno a la idea de progreso, pero ese progreso era únicamente el europeo. Esta es la acusación de provincianismo: "Hoy empezamos a advertir cuánto hay de limitación provinciana en este punto de vista. Tal vez uno de los hechos más característicos de la época que ahora vivimos es el despertar de la sensibilidad europea, hasta ahora reclusa en su sueño «provincial», a

243" Notas del vago estío" (1925). OC II, 427.

244 "Esta idea de querer cortar la continuidad entre sociedades primitivas y civilizaciones no puede llevar a nada nuevo a Toynbee". Una interpretación de la historia universal. En torno a Toynbee (1948-1949, curso). OC IX, 170

245Las Atlántidas (1924). OC III, 305. 
un horizonte de radio mucho más vasto y más «universal»"246. Se trata de una ampliación del horizonte de la historia: ya no se ve a ésta como "historia universal europea", sino "universal policéntrica", cuyo horizonte total se obtiene yuxtaponiendo los parciales, tanto temporales como espaciales. La historia, "en cuanto intención, es siempre universal"247, pero esa universalidad debe ser real, no provinciana, y la superación de ese provincianismo sólo puede llevarse a cabo mediante la superación, hegeliana, de las limitaciones.

El provincianismo de España es no salir a Europa o a América, el de la historia centrarse en un único punto de gravitación, Europa, el de la filosofía de la historia de Hegel eliminar lo que el considera lo irracional de la historia, los pueblos salvajes, primitivos. Incluso cuando Ortega incluya en el "Hegel y América", en su sucesión de citas de textos de Hegel, sin comentario, los párrafos en que éste remite explícitamente a la intromisión de Europa en América 248 , ya estará pensando en estos caracteres de imperialismo de Europa en América. Hegel entiende América desde Europa, no desde ella misma, y de ahí su provincianismo en este sentido: su universalismo era universalismo europeo 249 , por un lado, y ese mismo universalismo parcial saca fuera de la historia los pueblos primitivos, lo que él considera irracional, donde incluye a la propia América, por el otro.

El contexto es amplio y no remite únicamente al tema de la historia. En el fondo se encuentra el objetivo orteguiano de la ampliación de vida, la ampliación de mundo, la ampliación de tiempos y espacios. Es el juego entre límites y limitaciones: mantener lejanías a través de cercanías, dar sentido a lo lejano mediante la superación de la limitación

248"Physisch und geistig ohmächtig hat sich Amerika immer gezeigt und zeigt sich noch jetzt so. Denn die Eingeborenen sind, nachdem die Europäer in Amerika landeten, allmählich an dem Hauche der europäischen Tätigkeit untergegangen". HEGEL, Vorlesungen über die Philosophie der Weltgeschichte. Op. cit. p. 191; "...denn die Auswandernden haben vieles abgestreift, was ihnen in der Heimat beengend sein konnte, und bringen den Schatz des europäisches Selbstgefühles und der europäischen Kultur mit ohne die Lasten desselben; und für die, welche anstrengend arbeiten wollen und in Europa die Quellen dazu nicht finden, ist in Amerika allerdings ein Schauplatz eröffnet". Ibid. p. 195; "Eine Vergleichung der nordamerikanischen Freistaaten mit europäischen Ländern ist daher unmöglich; denn in Europa ist ein solcher natürlicher Abfluss der Bewölkerung, troz aller Auswanderungen, nicht vorhanden: hätten die Wälder Germaniens noch existiert, so wäre freilich die französische Revolution nicht ins Leben gretreten. Mit Europa könnte Nordamerika erst verglichen werden, wenn der unermessliche Raum, den dieser Staat darbietet, ausgefüllt und die bürgerliche Gesellschaft in sich zurückgedrängt wäre". Ibid. p. 199.
} 
propia y, a la vez, ser conscientes de esa limitación propia, esto es, mantener la limitación como límite. En este sentido de la ampliación de mundo histórico, de voluptuosidad de horizontes, la intención de Ortega es la misma que con el tema del arte: la conjunción es siempre la de la superación de las limitaciones, pero sin eliminarlas a éstas. Para ello esas limitaciones deben devenir límites. La eliminación de lo irracional, lo salvaje o primitivo, por parte de Hegel en su filosofía de la historia, es una postulación de limitaciones que no permite su superación, que no permite la ampliación de mundo que busca Ortega. Esa ampliación es una ampliación de miradas, de perspectivas, de sentido histórico, de transposición de horizontes, y afecta a todos los contextos.

En este sentido, Ortega, aunque no lo hace en los textos publicados, enfrenta constantemente a Hegel y a Breysig. En Las Atlántidas se puede ver la razón: "El ensayo de Kurt Breysig en su Historia de la Cultura moderna, donde hallamos un primer capítulo «Sobre los pueblos eternamente primitivos», es decir, sobre los salvajes. La ejecución es pobre, pero siempre recaerá sobre Breysig el honor de haber sido el primero que introduce el llamado «salvajismo» como personaje esencial en el gran drama humano"250; y en las notas de trabajo la concreción: "Un aprovechamiento más directo en historiología tendría la idea de Hegel si en vez de verla tendida horizontalmente en el tiempo la ponemos vertical y la convertimos en escala. Las épocas se convierten en grados de evolución. Stufenbau Breysig"251. En su ejemplar de la Filosofía de la historia de Hegel, al lado del siguiente texto, "ein Individuum durchläuft als eines verschiedene Bildungsstufen und bleibt dasselbe Individuum; ebenso auch ein Volk, bis $\mathrm{zu}$ der Stufe, welche die allgemeine Stufe seines Geistes ist. In diesem Punkte liegt die innere, die Begriffsnotwendigkeit der Veränderung."252, escribe Ortega con letras mayúsculas: BREYSIG.

\footnotetext{
249 Reyes Mate ha visto bien esto: "Hay que agradecer a Ortega y Gasset la claridad con que vio y denunció la particularidad del universalismo occidental". MATE, R. "El «Hegel y América» de Ortega o la imposible universalidad occidental", en: Revista de Occidente, $\mathrm{n}^{\circ}$ 160, 1994, p. 114.

250Las Atlántidas (1924). OC III, 306.

251Archivo de la "Fundación José Ortega y Gasset", Carpetilla "Hegel - Filosofía de la historia".

252HEGEL, Vorlesungen über die Philosophie der Weltgeschichte. Op. cit. p. 45. Traducción: "Un individuo recorre distintas fases en la educación y permanece el mismo individuo; e igualmente un pueblo, hasta la fase que sea la fase uinversal de su espíritu. En este punto se halla la necesidad interna, la necesidad conceptual de la variación". HEGEL, Lecciones sobre la filosofía de la historia universal. Op. cit. p. 74.
} 
El tema que rige esa conexión entre Breysig y Hegel es el de la evolución. La idea de Breysig consiste en que la realidad histórica discurre en ciclos, cada uno de los cuales recorre una serie idéntica de estadios: "así, hay en Grecia una época primitiva, una antigüedad, una edad media, una edad moderna, una época reciente. Mas no todos los pueblos avanzan de un estadio a otro; los hay que se quedan perennemente en una determinada altura de su desarrollo histórico esperando la hora de desaparecer. Habría, pues, como razas «eternamente primitivas», naciones irremediablemente medievales $\mathrm{o}$ antiguas"253. Si para Hegel únicamente hay evolución histórica cuando el espíritu inicia su manifestación, cuando comienzan a forjarse Estados, las conciencias de sí, y por ello desaparecen de la historia, de lo racional, los pueblos primitivos, la teoría de Breysig permite a Ortega hablar directamente de grados de evolución no en el sentido del progreso en la conciencia de libertad, con un contexto único, como Hegel, sino en el sentido determinado de la universalidad policéntrica.

Es ese policentrismo, que no admite el carácter unitarista y centralista del europeo, el que, primero, permite hablar de las épocas como grados de evolución, historia vertical, con pasado, presente y futuro, en la que lo irracional, los pueblos primitivos se muestren como niveles iniciales de la escala, y, segundo, permita explicar la presencia de pueblos salvajes en el presente, al no haber sabido circular éstos de un estadio, de un nivel a otro. La conexión entre la prehistoria y los pueblos "salvajes" del presente será, de todos modos, para Ortega siempre problemática, pero lo que no negará nunca es la posibilidad de introducir la conexión entre ambos aspectos 254.

Hegel no habría sabido explicar los caracteres de evolución. Para Ortega, aunque a primera vista el espíritu, al ser movimiento y evolución, parece por sí histórico, esa primera vista es falsa, en tanto la evolución del espíritu, en cuanto del espíritu, no es temporal. De aquí el problema con los pueblos salvajes, la evolución en la historia, que Ortega conecta con la evolución de las especies. En nota, sin más comentario, ya había incidido en ello en

\section{${ }^{253}$ Las Atlántidas (1924). OC III, 306.}

254"Abejas milenarias" (1924). OC IV, 518: "La relación en que se hallen las maneras primigenias de humanidad, perescrutadas por la prehistoria, y las de los pueblos "salvajes" del presente será siempre problemática. No falta quien con graves razones considera las razas primitivas actuales como casos de degeneración, en tanto que el prehistoriador suele encontrarse con restos maravillosos que arguyen una genialidad matinal de la especie humana. Esto invita a mantener diferenciadas la prehistoria y la etnología, a modo de dos idiomas distintos, pero dispuestos en todo instante a traducirse mutuamente". 
el "Hegel y América": "Es sorprendente que Hegel, gran inventor de la idea de evolución, no acierte a descubrirla en las especies vivientes"255. El problema en Hegel sería que a la naturaleza, a lo pre-histórico, le niega los caracteres temporales, y a la historia, a lo puramente racional e histórico, la somete al poder del espíritu. Con ello efectuaría un doble error: no ve la evolución, la continuidad donde se encuentra, y cuando la encuentra, en el progreso del espíritu, no admite diferencias o discontinuidades, no es capaz de mirar con la pupila del prójimo. Es el doble sentido de continuidad y discontinuidad que afirmará constantemente Ortega: buscar la continuidad, la unidad, pero respectar la pluralidad, la diferencia, la discontinuidad 256 .

En las notas de trabajo se ve más claro el pensamiento de Ortega: Hegel "hace demasiado no histórica la naturaleza - demasiado no naturaleza la historia. Ejemplo de lo primero: - Las especies no mueren - como no mueren las órbitas planetarias ${ }^{257}$. En general, la evolución positiva de las especies. Ejemplo de lo segundo: los pueblos salvajes, los pueblos "no universalhistóricos" que, sin embargo, han sido nexo importante y posibilidad de aquéllos, las cesuras, los continentes no weltgeschichtlich, etc., etc. ${ }^{258}$. Ortega llega incluso a interpretar la impotencia de la naturaleza, "die Ohnmacht der Natur"259, como

\section{5" Hegel y América" (1928). OC II, $568 \mathrm{n}$.}

256 Ver, por ejemplo, "Prólogo a «Historia de la filosofía» de Karl Vorländer" (1921). OC VI, 298; ó: Las Atlántidas (1924). OC III, 309.

${ }^{257}$ Es fácil ver que, en ese momento exacto, Ortega está pensando en el siguiente texto de Hegel: "Vergleichen wir die Veränderungen des Geistes und der Natur, so sehen wir, dass hier das Einzelne dem Wechsel unterworfen ist, in dem aber die Gattungen beharren. So verlässt der Planet diesen und diesen Ort; aber die ganze Bahn ist beharrend. Ebenso ist es mit den Gattungen der Tiere. Die Veränderung ist ein Kreislauf, Wiederholung des Gleichen. Alles steht so in Kreisen, und nur innerhalb dieser, unter dem Einzelnen ist Veränderung. In der natur ist das Leben, das aus dem Tode hervorgeht, selbst nur wieder einzelnes Leben; und wenn die Gattung in diesem Wechsel als das Substanzielle angesehen wird, so ist der Untergang des Einzelnen ein Wiederabfallen der Gattung in die Einzelheit. Die Erhaltung der Gattung ist so nur als die gleichförmige Wiederholung derselben Weise der Existenz. Mit der geistigen Gestalt ist es anders; hier geht die Veränderung nicht bloss an der Oberfläche, sondern im Begriffe vor. Der Begriff selber ist es, der berichtigt wird. In der Natur macht die Gattung keine Fortschritte, im Geist aber ist jede Veränderung Fortschritt". HEGEL, Vorlesungen über die Philosophie der Weltgeschichte. Op. cit. p. 133.

258Archivo de la "Fundación José Ortega y Gasset", Carpetilla "Hegel: Filosofía de la historia". Conjunto de notas titulado "Más teoría general, con puntos críticos".

259Ortega está pensando tanto en el parágrafo 250 de la Enciclopedia como en la Filosofía de la historia: "Es ist die Ohnmacht der Natur, die Begriffsbestimmungen nur abstrakt zu erhalten und die Ausführung des Besonderen äusserer Bestimmbarkeit auszusetzen. [...] - Jene Ohnmacht der Natur setzt der Philosohie Grenzen, und das Ungehörigste ist, von dem Begriffe zu verlangen, er solle dergleichen Zufälligkeiten begreifen. [...] In der Ohnmacht der Natur, den Begriff in seiner Ausführung festzuhalten". HEGEL, 
causa de la incapacidad de Hegel para explicar la metamorfosis de las especies: "Véase lo que dice de "la impotencia de la naturaleza", y que le lleva a negar dialéctica intranatural, metamorfosis de las especies - ¡! a él, el gran evolucionista ante el altísimo"260.

En general, las críticas de Ortega a Hegel en este sentido son amplias y, aunque no aparecen en el texto publicado del 'Hegel y América", las causas están ahí: Hegel no admite lo irracional de la historia, los pueblos salvajes, porque se lo impide la estrechez tanto de su razón lógica como de la supuesta universalidad de su historia. En realidad, no permite ni una evolución realmente histórica, porque la suya responde a exigencias del espíritu, ni una evolución natural, de las especies, en tanto ha negado los caracteres temporales a lo natural, a lo pre-histórico (de aquí el interés de Ortega en mostrar los caracteres de no-tiempo que presentaba Schelling en su comentario del tiempo prehistórico). Incluso en el momento en que determina esa evolución, al referirla tanto al espíritu como a la formación de un Estado, centraliza sus intereses en una historia universal-europea, de Libertad y Progreso con mayúscula, como abstracciones, aunque particularizadas en un contexto determinado, que Ortega no está dispuesto a aceptar. La ampliación de mundos, la voluptuosidad de horizontes, el sentido histórico, la pluralidad de perspectivas, la historia policéntrica, etc., no pueden admitir esos caracteres hegelianos.

Enzyklopädie der philosophischen Wissenschaften. Hrsg. G. Lasson. Leipzig: Verlag der Dürr'eschen Buchhandlung, 1905, § 250, pp. 210-211; y: "Die Ohnmacht der Natur vermag ihre allgemeinen Klassen und Gattungen nicht gegen andere elementarische Momente und Wirksamkeiten festzuhalten". HEGEL, Vorlesungen über die Philosophie der Weltgeschichte. Op. cit. p. 151.

${ }^{260}$ Archivo de la "Fundación José Ortega y Gasset", Carpetilla "Hegel: filosofía de la historia". Conjunto de notas titulado "Detalles históricos". 


\subsection{América}

Cuando Hegel versus Ortega presentan la introducción del tema de América, en realidad Ortega ya ha realizado todos los movimientos claves del enfrentamiento, aunque no se presenten de un modo detallado en el "Hegel y América": ha mostrado la ausencia de evolución en Hegel, ha mostrado la necesidad de admitir los pueblos salvajes y primitivos en el desarrollo histórico, ha mostrado la presencia del futuro en la historia, ha mostrado la necesaria sustitución de una historia universal-europea por una historia universalpolicéntrica, ha mostrado la conjunción de continuidades y discontinuidades, identidades y diferencias, etc. Ortega presenta esa serie de textos de Hegel incidiendo en el carácter geográfico y natural de la situación de América:

"Prisionero aún de la Naturaleza vive el hombre ignaro de sí mismo, enajenado y fuera de su propio ser.

Vive, pues, incubando un futuro ser. Esto es, en general, para Hegel la Naturaleza: aquella realidad que precede y prepara al Espíritu. En ella, mezclado con los animales y con el paisaje, fermenta lo humano. Allí debemos buscarlo; por tanto, la Prehistoria es Geografía. En el capítulo geográfico de sus Lecciones sobre la filosofía de la Historia Universal es donde paradójicamente hallamos instalada a América. Después de todo, no es sorprendente. Si decimos de ella que es un futuro, decimos que aún no es lo que va a ser y puede ser. Ahora bien: esto es precisamente la Naturaleza. Como para Hegel sólo es verdaderamente el Espíritu, la realidad de la Naturaleza consiste en algo que va a ser Espíritu, pero que aún no lo es. Así se explica que hallemos alojado el futuro en el absoluto pretérito que es la Prehistoria natural, la geografía"261.

Es la conexión entre historia y geografía la que dirige el contexto. Como en "En el centenario de Hegel" Ortega volverá a examinar el tema de un modo mucho más amplio, con un título preciso, "Historia y geografía", el mismo título de uno de los capítulos de los Temas de viaje, escrito diez años antes (y remitiendo en la conjunción de ambos al Toynbee), ahora me limitaré a comentarlo en relación a América. La crítica de Ortega a Hegel, enmascarada bajo ese "después de todo, no es sorprendente", es sencilla: Hegel dota a América de caracteres de futuro, pero sitúa a este futuro en la prehistoria, es decir, en el no-tiempo. El futuro de Hegel queda situado en el absoluto pasado. Ortega, en las lecciones del 28 en Argentina, con textos e ideas que volverán a aparecer en La rebelión de las masas, ha mostrado que esa prehistoria es todo lo contrario del no-tiempo, en tanto remite

261" Hegel y América" (1928). OC II, 569. 
precisamente al crecimiento de los tiempos, al ascenso en la altitud del tiempo, al crecimiento del mundo: "La prehistoria y la arqueología en veinte años han descubierto espacios históricos de longitud fabulosa"262.

Si Hegel colocaba el futuro en el pasado, Ortega insistirá en el "crecimiento de las potencias vitales que todo eso supone" 263 . Se siente más vida, se siente el aumento de las posibilidades, la potencia del futuro, y esto supone algo que se enfrenta directamente con Hegel: se ha perdido todo respeto por el pasado. El hecho tiene dos lecturas, la positiva y la negativa: la primera muestra todas las posibilidades de futuro, la segunda insiste en la pérdida de modelos, de normas, de historia, "el europeo está sólo, sin muertos vivientes a su vera; como Pedro Schlehmil, ha perdido su sombra. Es lo que acontece siempre que llega el mediodía"264.

Esa llegada del mediodía, de la amplitud de posibilidades, aunque incluya la parte negativa de azoramiento, de no saber por dónde dirigir el caudal de posibilidades, es la situación de la nueva sensibilidad, del mundo nuevo, ampliado, voluptuoso de horizontes en su lectura histórica. Pero es también, de un modo muy concreto, la situación de América, aunque en otra dirección: ésta no ha perdido su pasado, no ha perdido su respeto por los modelos pretéritos, sencillamente porque no los ha tenido, pero se mantiene en la misma llegada del mediodía, en el mismo caudal de posibilidades, de futuro. En este sentido, el interés de Ortega por el tema de América adquiere otra connotación, la de la relación con el carácter general de la nueva sensibilidad. Si Hegel coloca el futuro de América en el pasado, o, mejor, en el no-tiempo, Ortega lo sitúa en el presente, en el presente azorado y con todas las posibilidades de futuro de la nueva sensibilidad.

El carácter que mejor expresa esa conexión entre la nueva sensibilidad y el tema de América es el de juventud. Ya en 1918, comentando la necesidad de modernización para España, basando tal exigencia en la labor que debería cumplir la juventud ("¡Modernizad España: es hoy la jornada de la Juventud"265), y dejando claro que la vida nueva, el mundo nuevo es constantemente estreno, novedad, como lo es de por sí la juventud, había escrito

\footnotetext{
262ORTEGA Y GASSET, J. Meditación de nuestro tiempo. Op. cit. p. 268.

263 Ibid.

264 Ibid. p. 269.
} 
Ortega: "América, exenta de pasados, no arrastra obra muerta: sus órganos están en plena vigencia. No pesa sobre ella la Iglesia, no pesa la aristocracia genealógica, no pesa el arcaico espíritu militar, no sufre la tradición de las añejas burocracias. América es toda de hoy, es pura modernidad"266. Esa modernidad es la de la nueva sensibilidad, la que sintetiza materia y forma, la que se rige por el policentrismo en historia y el universalismo integrador enfrentado a la estrecha y particular "historia universal" de Hegel, la modernidad de la cervantina fidelidad a las cosas en su multiplicidad de perspectivas, de posibilidades. Es por esto por lo que, en realidad, el enfrentamiento con Hegel es el enfrentamiento de la nueva sensibilidad con una sensibilidad de vida caduca. La pura modernidad de América, la América toda de hoy, es la que incluye todos los rasgos de juventud del tiempo nuevo, en su parte positiva y en la negativa. América, para Ortega, también es espera constante del mediodía, pero no ha perdido su sombra, sencillamente porque no la ha tenido.

Cuando Ortega cite el texto de Hegel: "el nuevo mundo no es sólo relativamente nuevo, sino en absoluto"267, en el fondo estará de acuerdo con él, pero en contextos muy diferentes. La novedad del mundo que mantiene Ortega no es sólo la de América, sino también y sobre todo la general de la nueva sensibilidad. El mundo nuevo es mundo joven, pero en a sentido de Ortega, la juventud de las posibilidades ilimitadas, pero también de las potenciales equivocaciones: "nuestro tiempo se caracteriza por el extremo predominio de los jóvenes"268, y América es la juventud misma. En esta serie de contextos Ortega tomará caracteres de Hegel, y ésta es otra de las razones por las que cite los textos sin comentario, pero les aplicará su propia interpretación. Incluso es posible ir texto por texto mostrando el comentario del tema en cuestión, lo que toma y deja de Hegel, que Ortega efectuará fuera del "Hegel y América".

Los puntos concretos que examinaré podrían concretarse todos en uno sólo, el de la relación entre Europa y América, tema que de un modo u otro aparecerá en cada uno de ellos y que causará su entrecruzamiento. Esos puntos, que remiten insistentemente unos a

265" Los momentos supremos" (1918). OC X, 465.

266 Ibid. p. 464.

267"Hegel y América" (1928). OC II, 569. El original de Hegel dice: "Diese Welt ist nicht nur relativ, sondern überhaupt neu". HEGEL, Vorlesungen über die Philosophie der Weltgeschichte. Op. cit. p. 190. 
otros, y centrándome en aquellos temas que se inician en el artículo sobre Hegel, serían cuatro: el futuro y la juventud, el primitivismo, el colonialismo y la emigración.

\subsubsection{El futuro y la juventud}

"Por consiguiente, América es el país del porvenir", escribe Hegel y cita Ortega ${ }^{269}$. En las notas de lectura Ortega es lo suficientemente claro respecto a ese texto: "Sobre el futuro habla para espantárselo como un moscardón molesto - a propósito de América"270. Ortega no olvida que en la filosofía de la historia de Hegel toda época, toda determinación, está guiada por un noch nicht, por un "todavía no", que la refiere a un futuro. El problema es que ese futuro no es tal, sino únicamente la "epifanía del espíritu", el momento último, el presente como final de la serie. Por muy noch nicht que sea cada momento, para Ortega todos ellos quedarían descalificados al ser encaminados por Hegel únicamente hacia el beneficio del último. El noch nicht de Hegel produce a Ortega un efecto angustioso, el efecto de que el sistema esté dirigido por un futuro que no es realmente futuro: "produce un efecto angustioso el perpetuo noch nicht"271. Por ello, al situarse en la relación con América, Hegel tiene que admitir que el filósofo no hace profecías, que la historia se ocupa de lo pasado y la filosofía de la razón eterna.

De todos modos, tanto para Hegel como para Ortega, América es lo esencialmente joven, lo esencialmente futuro. La distinción se halla en las consecuencias, en la lectura de ese futuro: para Hegel está inscrito en un no-tiempo, en la pre-historia, para Ortega, aunque admita los caracteres de primitivismo, ese futuro debe consistir en la apertura hacia una pluralidad de posibilidades que superen todo tipo de enclaustramiento, incluido el del pasado. Pero no hay que confundir los términos: para Ortega, América será constantemente

\footnotetext{
268 Meditación de nuestro tiempo. Op. cit. p. 216. Los mismos textos habían sido ya publicados por Ortega en "Dinámica del tiempo" (1927). OC III, 463 ss.

269" Hegel y América" (1928). OC II, 576. El original de Hegel se encuentra en: HEGEL, Vorlesungen über die Philosophie der Weltgeschichte. Op. cit. p. 200.

270Archivo de la "Fundación José Ortega y Gasset", Carpetilla "Hegel: Filosofía de la historia". Conjunto de notas titulado "Teoría general de Hegel".

${ }^{271}$ Ibid.
} 
el pueblo joven, y, por joven, de futuro, de posibilidades, pero no la tierra del porvenir, no admitirá la mirada de paletos "con la boca abierta ante los Estados Unidos"272. Con los años, y determinado por los acontecimientos, Ortega irá concretando su postura. En el 16, en plena primera guerra y en su primer viaje a Argentina, afirmaba: "yo no sé qué tiene esta América, esta tierra joven que nos induce a adoptar usos nuevos"273. Ortega sí lo sabía: América tenía los caracteres de toda juventud, el afán de novedades, pero también el riesgo de equivocarse.

En 1919, el año del tratado de Versalles, escribía: "El régimen antiguo, que responde a principios borrados ya de las nuevas tablas de la ley, se alza contra la oleada de juventud y de libertad humana representadas por el pueblo americano"274. Ese carácter de juventud de América no dejará nunca de ser afirmado por Ortega. Es el enfrentamiento con la sensibilidad caduca de la vieja Europa, el enfrentamiento con todos esos restos de historia que trata constantemente de superar Ortega. Es esa juventud, esos aires de juventud, los que en este momento buscará Ortega, una nueva modernidad, y no dudará en afirmarlo: "el americano es el europeo moderno que renace en plena modernidad exento de pasado"275. La modernidad europea era fervor hacia el futuro, pero viene arrastrada por su pasado, por su historia; no puede darse a sí misma su juventud, su futurismo es más bien deseo de futuro. Ese mundo de 1924, fecha en la que realiza esa afirmación, era para Ortega el precipitado de ayer, la actualidad regida por el pasado, que remitía ya a otro universo, un "universo futuro, del cual América será el centro"276.

Pero ese universo futuro del cual América será el centro no se basa en lo que el europeo parece encontrar en ella, concretamente en Estados Unidos: la técnica, el mejor nivel de vida, el mayor desarrollo... Todo eso responde a la subida general del nivel de los tiempos. Ortega criticará, antes de la crisis del 29, esa "mirada paleta" del europeo hacia América. En las lecciones del 28 en Buenos Aires insistirá en ello: se trata de una nivelación, la idea

272" Sobre los Estados Unidos" (1932). OC IV, 370.

273" Discurso de despedida en la Institución Cultural Española de Buenos Aires" (1916), en: Meditación del pueblo joven y otros ensayos sobre América. Madrid: Revista de Occidente en Alianza -Obras de José Ortega y Gasset, 11-, 1981, p. 41.

274" España y la Liga de Naciones" (1919). OC X, 502.

275Las Atlántidas (1924). OC III, 295. 
de América como el porvenir provenía de entender como más elevado el nivel de vida media del americano 277 . Después de la crisis del 29 en Estados Unidos Ortega concretará su postura: América es fuerte por su juventud, pero no tiene historia, es un pueblo primitivo disimulado por la técnica proveniente de Europa, nunca le ha pasado nada, no ha tenido pasado, no ha sufrido crisis. Sólo ahora comenzará su historia.

En general, entonces, Ortega insistirá en el carácter de pueblo joven de América, pero sin olvidar ninguna de los dos direcciones, la positiva, de posibilidades, y la negativa, de ausencia de pasado, de historia. En ese sentido es futuro, pero incluyendo los caracteres de primitivismo que el propio Hegel mostraba para América en su filosofía de la historia. La relación con el europeo viejo, lleno de pasado, se produce mediante este doble carácter: atraen los rasgos de novedad, de futuro, de juventud, pero preocupa la ausencia de historia, de pasado, esto es, el primitivismo de América. El ideal sería la unión de ambos momentos.

\subsubsection{El primitivismo}

"Hegel persiste frente a los nuevos Estados americanos en su interpretación del Nuevo Mundo como un mundo esencialmente primitivo"278. Ortega aprovechará los caracteres de primitivismo que Hegel refería a América, pero los centrará en sus ideas sobre Estados Unidos, en concreto sobre el tema de la técnica. En este contexto se producirá tanto el avance respecto al 'Hegel y América", como la utilización de parte de las ideas que ahí se encuentran. Aunque lo detallará en otros escritos, el inicio se halla en el propio "Hegel y América":

"Si hoy reviviera [Hegel] y asistiese a la magnífica escena de la vida «yanqui» con todas las maravillas de su técnica y organización, ¿qué diría?, ¿rectificaría su criterio? Es de sospechar que no. Todo ese aspecto de ultramodernidad americana le parecería simplemente un resultado mecánico de la cultura europea al ser transportada a un medio más fácil, pero bajo él vería en el alma americana un tipo de espiritualidad primitiva, un comienzo de algo original y no europeo. En suma, lo que estimaría de América sería

276 Ibid.

${ }^{277}$ Cfr. ORTEGA Y GASSET, J. Meditación de nuestro tiempo. Op. cit. p. 257. 
precisamente sus dotes de nueva y saludable barbarie. De éstas y no de su técnica europea, mera representación del Viejo Mundo, dependería, en su opinión, el nuevo estadio de la evolución espiritual que América está llamada a representar" 279.

El final del prólogo para franceses de La rebelión de las masas es determinante para entender el tema. Allí, con la intención de mostrar que son los primeros capítulos de $\mathrm{La}$ rebelión de las masas los que más han caducado, por haber cambiado la situación, la piel del tiempo, y refiriéndose a ellos escribía Ortega: "El lector debería, al leerlos, retrotraerse a los años 1926-1928. Ya ha comenzado la crisis en Europa, pero aún parece una de tantas. Todavía se sienten las gentes en plena seguridad. Todavía gozan de los lujos de la inflación. Y, sobre todo, se pensaba: ¡ahí está América! Era la América de la fabulosa prosperity"280. El europeo equivocó su mirada: veía en América, en Estados Unidos, únicamente la panacea, las posibilidades, el futuro, h técnica. La crisis del 29 o el primitivismo, en forma de estandarización del hombre-masa, romperán esa mirada. Ortega defenderá insistentemente su posición: "El viejo lugar común de que América es el porvenir había nublado un momento su perspicacia [del europeo]. Tuve entonces el coraje de oponerme a semejante desliz, sosteniendo que América, lejos de ser el porvenir, era, en realidad, un remoto pasado, porque era primitivismo. Y, también contra lo que se cree, lo era y lo es mucho más América del Norte que la América del Sur, la hispánica"281. El primitivismo del Norte lo refiere Ortega a la técnica, a la estandarización, al hombre masa; el del sur únicamente a su ausencia de historia.

Ortega no desaprovechará la oportunidad, remitiendo a sus escritos Sobre los Estados Unidos y, previo a éste, el Hegel y América"282. La tesis de Ortega es la ya comentada: América es el futuro porque es primitivismo, porque todavía no es. Pero esa tesis no es de Ortega, sino de Hegel, que el propio Ortega expone mediante citas sin comentar en el "Hegel y América". Años más tarde, Ortega remitirá constantemente a ese artículo, pero

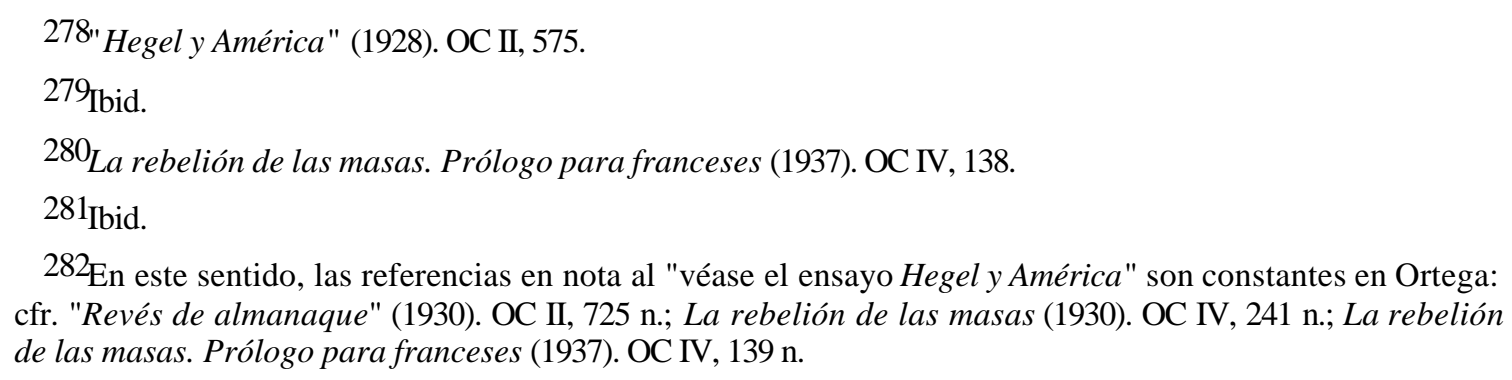

${ }^{282}$ En este sentido, las referencias en nota al "véase el ensayo Hegel y América" son constantes en Ortega: cfr. "Revés de almanaque" (1930). OC II, 725 n.; La rebelión de las masas (1930). OC IV, 241 n.; La rebelión de las masas. Prólogo para franceses (1937). OC IV, $139 \mathrm{n}$. 
haciendo suya la tesis de Hegel, y haciéndola suya con toda coherencia: la está aplicando al momento actual. El "Hegel y América" es un buen ejemplo, quizá el mejor, de la recepción que Ortega hace de otros filósofos: en este caso, ni siquiera comenta las ideas que aparecen en los textos citados de Hegel, sino que ya lo hará más tarde, en otros textos, en otros contextos, con sus propios temas, con sus propios objetivos. Es cierto que ese "tuve entonces el coraje de oponerme..." no es del todo correcto; debería haber escrito: "tuve entonces el coraje de utilizar a Hegel que...". América como el remoto pasado es la tesis de Hegel, que el propio Ortega ha detallado acudiendo a Schelling; el primitivismo de América es el que muestra Hegel, pero en Ortega ese primitivismo remite además al del hombre-masa.

Detallando los contextos, entonces, Ortega toma de Hegel el carácter de primitivismo para América, pero amplía el sentido: América todavía no es historia, todavía no le ha pasado nada. A la vez, ese primitivismo tiene dos significados: el positivo, el caudal de posibilidades, la historia por delante, y el negativo, ese primitivismo de la estandarización, de la desaparición de individualidades, de la ausencia de historia, de hombre-masa 283 . El primitivismo, en el sentido de las posibilidades, de todavía no, el nuevo barbarismo, según escribía Ortega sobre Hegel, será el futuro de América: su posibilidad de crear historia, de hacer vida, de ampliar mundo y realidad; pero el primitivismo, en el sentido del hombre masa, de la técnica estandarizada sin una historia detrás que ayude a dirigirla, será para Ortega el carácter negativo: "América es fuerte por su juventud, que se ha puesto al servicio del mandamiento contemporáneo «técnica», como podía haberse puesto al servicio del budismo si éste fuese la orden del día. Pero América no hace con esto sino comenzar su historia. [...] Yo siempre, con miedo a exagerar, he sostenido que era un pueblo primitivo camuflado por los últimos inventos"284. Ese primitivismo procede de la lectura de Hegel,

\footnotetext{
${ }^{283}$ En esos capítulos de La rebelión de las masas en torno al primitivismo, "Primitivismo y ténica", y "Primitivismo e historia", Ortega ha insistido en ese carácter primitivo del hombre actual, del hombre masa. Con ello, de nuevo, si se une en la referencia al primitivismo americano, se ve la conexión entre el tiempo nuevo y América, con las diferencias apuntadas: el americano no tiene historia, el europeo tiene demasiada; el primitivismo del hombre-masa, con todo, es igual para ambos: "El hombre hoy dominante es un primitivo, un Naturmensch emergiendo en medio de un mundo civilizado". La rebelión de las masas (1930). OC IV, 196. Ese hombre primitivo en la referencia alemana del Naturmensch ya lo presentó Ortega en el "Hegel y América", comentando las relaciones de la historia y la naturaleza, de la prehistoria como contexto del hombre natural, del salvaje: cfr. "Hegel y América" (1928). OC II, 569.
}

${ }^{284}$ La rebelión de las masas (1930). OC IV, 241. 
el camuflaje es la recepción, la aplicación de la idea que Ortega toma en Hegel a una nueva situación: la situación de América como "paraíso de las masas"285.

Cuando Ortega en 1932, en 'Sobre los Estados Unidos", el artículo que une en lo que refiere a esta temática el "Hegel y América" y las ideas expuestas en La rebelión de las masas, incluyendo el prólogo para franceses, insista, en torno al concepto de hombre colonial, en esta serie de contenidos, aclarará todos los contextos: "América no es todavía. [...] Aún no ha comenzado su historia. Vive la prehistoria de sí mismo'286. Todo eso aparecía ya en Hegel, incluso el noch nicht, el todavía no, era el carácter determinante de América como futuro: "Por esta razón le parece todo el continente un «todavía no», una madrugada de humanidad"287. Pero para Ortega la situación ha cambiado: las miradas se han dirigido de Europa a América, a su técnica, a su pragmatismo, y esto ha sido un error. Europa no tiene que imitar a América, porque esa técnica que parece encumbrarla procede de la vieja Europa.

Es más: es América la que tendrá que mirar a Europa, en tanto es ésta la que tiene historia, la que tiene pasado, aunque esa historia la haya conducido a la serie de caracteres irrespetuosos del tiempo nuevo para con el pasado. Lo que debe traerse Europa de América es su juventud, el caudal de posibilidades, precisamente lo que buscará personalmente Ortega; el problema es que esa juventud es difícil de imitar: "De aquí que me pareciese imperdonable la confusión padecida por Europa al creer que América podía representar una norma nueva de vida. Es como si el viejo, ante la nueva generación, dijese: «¡Diablo, estos chicos han inventado una cosa inaudita y formidable: los veinte años!» En efecto, esto es lo único que nos sería conveniente imitar de América, su mocedad, pero es al mismo tiempo lo que, desgraciadamente, no se puede imitar. En cambio, Norteamérica va a comenzar ahora a imitarnos en lo más fundamental: a hacer historia, a entrar en las angustias que a todo pueblo esperan más allá de la etapa primitiva"288. Es la conexión de juventud e historia, de límites abiertos y limitaciones cerradas lo que interesaba a Ortega, la relación

\footnotetext{
285 Ibid. p. 222.

286" Sobre los Estados Unidos" (1932). OC IV, 378.

287" Hegel y América" (1928). OC II, 572.

288" Sobre los Estados Unidos" (1932). OC IV, 378-379.
} 
entre la modernidad y el primitivismo, la necesidad de encontrar guías capaces de encauzar la inseguridad del tiempo nuevo.

No la técnica, no la prosperity americana interesan a Ortega, sino su carácter abierto, su ausencia de historia. El talante que esa ausencia ejerce es el mismo que se ha producido en Europa precisamente por la causa contraria, por la abundancia de historia, por el cansancio del tiempo viejo que Ortega se esfuerza en superar. Por esto, el carácter que más le interesará a Ortega de América, de un modo general, es el tema del colonialismo, y, más en concreto, uno de sus rasgos definitorios, el del anacronismo, anacronismo entre modernidad y primitivismo.

\subsubsection{El colonialismo}

"No es exagerado afirmar que Hegel ve a América -en su geología, en su fauna, en sus indios y [...] en su retoño colonial- como una niñez perdurable de la Ecumene"289. Podría decirse que en torno al tema del colonialismo se sitúan, de un modo u otro, todos los demás aspectos de la relación de Ortega con América. El contexto es amplio. Ya en 1916, en su primera conferencia en Buenos Aires, recuerda, ante un pueblo formado por colonizaciones europeas, que el origen de la filosofía fue el de ser una aventura colonial 290.

Pero Ortega no está refiriendo a la colonización, sino a la vida, a la existencia colonial: "no se trata de la «colonización», que es lo menos interesante y el preámbulo de lo demás: se trata de de la «existencia colonial» después de la estricta colonización"291. Esa existencia, vida colonial se caracteriza en primer lugar por ser únicamente etapa, periodo hacia otra, la vida autóctona, y, en este sentido, América se situaría en el estadio de estar a punto de abandonar su carácter colonial, aunque esto no impida su definición previa como

289" Hegel y América" (1928). OC II, 572. Tan poco exagerado es afirmarlo que ya lo afirma el propio Hegel: "So stehen die Amerikaner da als unverständige Kinder". HEGEL, Vorlesungen über die Philosophie der Weltgeschichte. Op. cit. p. 193.

290Cfr. ORTEGA Y GASSET, J. Meditación de nuestro tiempo. Op. cit. p 39. Sobre la filosofía como aventura colonial, ver además: "Sobre los Estados Unidos" (1932). OC IV, 371; "Meditación del pueblo joven" (1939). OC VIII, 398; Origen y epílogo de la filosofía (1946). OC IX, 411; Notas de trabajo. Epílogo... Ed. J.L. Molinuevo. Madrid: Alianza / Fundación José Ortega y Gasset, 1994, p. 240, nota 370.

291"Sobre los Estados Unidos" (1932). OC IV, 371. 
"carencia de autoctonías"292. Pero el rasgo determinante, el rasgo que interesa del tema y que amplía las connotaciones es otro: es el tema del anacronismo de la vida colonial.

Ese anacronismo lo expresa Ortega del modo siguiente: "Este factor de anacronismo es el que da todo su valor al carácter de no-autoctonía anejo a la «vida colonial». Sólo que aquí el anacronismo es inverso: hombres de pueblos viejos y muy avanzados en el proceso de su civilización caen en tierras menos civilizadas, es decir, históricamente más jóvenes. David se acuesta con la Sunamita. El colonizador se rejuvenece de modo automático"293. En Hegel había leído Ortega: "Auch ein Zufluchtsort ist dieser Boden geworden, wo sich der Auswurf von Europa hingemacht hat. In der Tat bietet diese Auswanderung viele Vorteile dar, denn die Auswandernden haben vieles abgestreift, was ihnen in der Heimat beengend sein konnte, und bringen den Schatz des europäisches Selbstgefühles und der europäisches Kultur mit ohne die Lasten desselben; und für die, welche anstrengend arbeiten wollen und in Europa die Quellen dazu nicht finden, ist in Amerika allerdings ein Schauplatz eröffnet"294.

Si para Hegel el viaje era de ida, de Europa a América, para Ortega ese viaje incluye también la vuelta, el regreso. Ortega, en su relación con América, siempre expresará esta ida y vuelta 295 . El anacronismo implica los caracteres de rejuvenecimiento, el pueblo viejo que se rejuvenece en el nuevo, pero también los caracteres negativos de la juventud: la prepotencia... y el primitivismo. El colonial es siempre un retroceso hacia el primitivismo

${ }^{292}$ Es el "hecho maravilloso" que Ortega enunciaba en sus conferencias de Buenos Aires en 1928: "El hecho maravilloso, único en la historia y que lleva el enorme nombre de América es la carencia de autoctonías". Meditación de nuestro tiempo. Las conferencias de Buenos Aires, 1916 y 1928 . Op. cit. pp. 258259.

293"Sobre los Estados Unidos" (1932). OC IV, 373.

${ }^{294}$ HEGEL, Vorlesungen über die Philosophie der Weltgeschichte. Op. cit. p. 195. Traducción: "Estos territorios se han convertido de ese modo en lugar de refugio, adonde van a parar las barreduras de Europa. En realidad esta emigración ofrece grandes ventajas; porque los emigrantes han suprimido muchas cosas que en su patria resultaban constrictivas y han llevado allá el tesoro del sentimiento europeo y de la cultura europea, sin las cargas que la oprimen. Para todos aquellos que quieran trabajar con energía y no encuentren en Europa labor a propósito, es, sin duda, América un excelente refugio". HEGEL, Lecciones sobre la filosofía de la historia universal. Op. cit. p. 173.

295" Meditación del pueblo joven" (1939). OC VIII, 401: "He venido, por lo pronto, a traer lo que tenía unas veces poco, otras como ahora mucho- a traer eso, pero también a llevarme, a llevarme lo que hay aquí, lo que verdaderamente hay aquí, a pesar de que los argentinos hacen cuanto pueden para que no lo haya: juventud, el famoso divino tesoro". 
del pueblo joven, pero conservando la modernidad que ha traído consigo. El anacronismo es esta unión de primitivismo y modernidad.

Pero es precisamente ese anacronismo el que rompe limitaciones, el que se muestra en el carácter límite entre lo nuevo y lo viejo, y las ventajas de ambos. El colonial siempre une las posibilidades de lo joven con la limitación del destino que impone lo ya hecho, lo pasado. Esta es la conexión de Europa y América para Ortega, la unión de una limitación con su superación, "porque, no se le dé vueltas, vida colonial quiere decir, ante todo, vida ex abundantia, e historia, vida precaria, vida bajo la presión inexorable de un destino limitado"296. Esta vida ex abundantia es la misma que la que mantiene el mundo nuevo en Europa, aunque, con la distinción explícita de que Europa ha perdido su sombra, de que es precisamente su pasado el que le ha conducido a la ausencia de pasado, a la constante disponibilidad y juventud del tiempo nuevo. Es por ello por lo que, cuando Ortega en la Meditación del pueblo joven vuelva a repetir los textos de Sobre los Estados Unidos le añadirá al carácter de anacronismo su mejor talante, el de disparar energía, el de posibilitar fuerza viva: "Este anacronismo entre la vida externa modernísima y la vida interna elementalizada es constitutivo de la vida colonial y es, a la par, su mayor tesoro, su mayor encanto. Ese desnivel entre lo uno y lo otro liberta, como todo desnivel, energía, dispara fuerza viva" 297 .

La pretensión de Ortega es unir los dos caracteres, el de la fuerza viva de la juventud, con la modernidad que ha perdido su pasado, con la Europa vieja que ha adquirido la conciencia del tiempo nuevo, unirlos en una modernidad alternativa que parta de la fidelidad a lo real y de todos los rasgos de la nueva sensibilidad: ser conscientes de un pasado, pero para hacer posible un futuro, para saber dirigir ese futuro. En este sentido, la vida colonial va mucho más allá de remitir únicamente a América. Su anacronismo, el de la conjunción de modernidad y primitivismo, es también el que, adquiriendo los caracteres del tiempo nuevo, debe dirigir la renovación: la integración de pasado y futuro, de las posibilidades y la experiencia para saberlas llevar por el cauce correcto. La vida colonial, como expresión de un espacio límite entre pasado y futuro, expresaría la exigencia del tiempo nuevo: ser capaces de convertir las limitaciones que cierran en límites que abren.

296" Sobre los Estados Unidos" (1932). OC IV, 372. 


\subsubsection{La emigración}

"Para que un Estado adquiera las condiciones de existencia de un verdadero Estado es preciso que no se vea sujeto a una emigración constante", escribe Hegel y cita Ortega 298. Hegel insiste en que en América todos los ciudadanos son emigrantes europeos, y en que la emigración ofrece todas las ventajas de suprimir aquello que en la patria resultaba constrictivo, pudiendo llevar a América el "tesoro del sentimiento y la cultura europeas", sin las cargas históricas que los oprimen.

Ortega es consciente de que Hegel, además de mostrar las ventajas que pueda incluir la emigración, no olvida el carácter de primitivismo, de inactualidad, de ausencia de historia que caracterizaría a América: "Cuando pasa a considerar los nuevos Estados surgidos de la emigración europea, Hegel mantiene este punto de vista. No se deja arrastrar por el dato primario de que esos Estados vivan de un material humano procedente de Europa y, por tanto -habría de pensarse-, plenamente actual"299. Ortega admite estos caracteres que Hegel remite a América, pero la temática de la emigración en Ortega implica otros sentidos. Y no sólo por la conexión de España y América, por la emigración española y la insistencia de Ortega en la necesidad de aumentar todo tipo de contactos entre España y los pueblos americanos, sino por tesis filósoficas claves, entre ellas, la del hombre como sustancial emigrante. Todas ellas pueden resumirse en una: la emigración como el afán por superar limitaciones.

Que América es la "emigración pura" ya lo había afirmado Ortega en el 28 en Buenos Aires, pero mostrando una exigencia: esa emigración no se entenderá mientras "no se haga en serio la fenomenología y la biología de la gran emigración" 300 . Y lo fundamental de la emigración no es que ciertos países o tierras atraigan y susciten todo tipo de sueños en los

297" Meditación del pueblo joven" (1939). OC VIII, 400-401.

298"Hegel y América" (1928). OC II, 574. El original de Hegel se encuentra en: HEGEL, Vorlesungen über die Philosophie der Weltgeschichte. Op. cit. p. 199.

299" Hegel y América" (1928). OC II, 572.

300Meditación de nuestro tiempo. Las conferencias de Buenos Aires, 1916 y 1928. Op. cit. p. 259. 
individuos que llegan hasta ellos, sino, al contrario, "que los retengan"301. La emigración es un fenómeno de retención, no de atracción. Es por esto por lo que Ortega no busca para América un nacionalismo de pasado, de raíces, de tipo europeo, sino, todo lo contrario, un nacionalismo de futuro, basado en el poder de retención, en el poder de América para crear, no para repetir.

Ese nacionalismo futuro, y no pasado, no cerrado, sino abierto, precisamente al estar basado en la ausencia de autoctonías, un nacionalismo por tanto de límites y no de limitaciones es el que quería Ortega encontrar en América: "un nacionalismo más ágil, más aéreo y que anida en el futuro"302. Un nacionalismo de futuro es un nacionalismo que convierte su espacio en espacio límite, abierto y creado por contactos, no por la cerrazón de unas raíces pasadas, de tipo romántico, que lo repitan como nacionalismo europeo, limitador, concluso. Ese nacionalismo de futuro, de proyecto, de límites y no sólo de limitaciones es el que Ortega también deseaba para España.

El papel del emigrante determina este nacionalismo futuro. $\mathrm{Su}$ función es la de posibilitar el ascenso del nivel vital, la de conseguir basar la unidad en pluralidades y no en unitarismos, en límites y no en limitaciones, la del impulso por la superación, el abandono de lo caduco, lo que ya no da más de sí. El contexto sobrepasa, de este modo, el tema de América: ya el arte mismo era pensado en su misión de evasión, de mostrar la posibilidad del hombre para escapar de sí mismo, para explotar su instinto de exploración, el afán de fuga, "de pájaro emigrante atraído por toda palpitación de horizontes"303. El hombre es por esencia la potencialidad de elegir un proyecto de vida, elegir un paisaje que le permita iniciar su ideal, su programa vital: no hay que olvidar que el hombre "es un animal trashumante, que hay en él siempre una potencia migratoria"304. Se trata de la definición del hombre como "sustancial emigrante"305: su ser no es fijo, no tiene naturaleza, sino historia, es la potencialidad de un progreso que debe conservar un pasado.

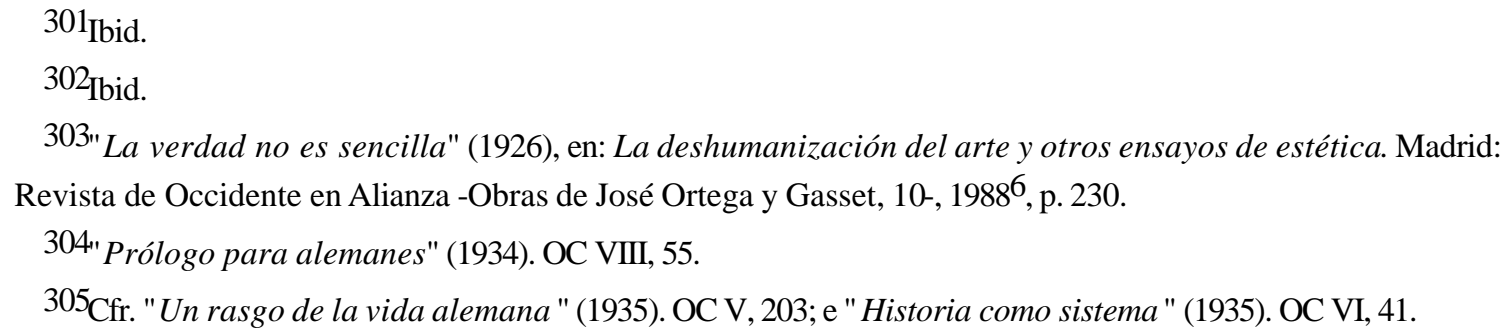


El único límite que constriñe al hombre es el pasado, sólo el pretérito le limita el futuro. Las ansias de progreso, de capacidad para mostrar su potencialidad ilimitada, las intenciones de futuro, vienen limitadas por el pasado, pero es precisamente éste el que, a la vez, lo convierte en entidad progresiva: "el progreso exige, junto a la capacidad de no ser hoy lo que ayer se fue, la de conservar eso de ayer y acumularlo"306. Este es el sentido que explica la relación con América en las pretensiones de Ortega: América no tiene pasado, no tiene historia, es todo futuro, y no debe intentar crearse un pretérito ficticio a través de un pasado que no es suyo. El europeo, por contra, es todo pasado, éste lo limita, lo constriñe. Traer hasta él la juventud, la potencia ilimitada de América sólo será beneficiosa en cuanto consiga hacerlo sin olvidar su pasado. El futuro de América y el pasado de Europa, en su conjunción, en la unión de la juventud de la pre-historia y la vejez de la historia, es la que debe guiar el talante del tiempo nuevo: unir la experiencia con las expectativas de futuro.

En este sentido, el emigrante, el emigrante concreto que llega hasta América y del que deben ser eliminados sus caracteres negativos ("la exclusiva mira de hacer fortuna"307), y el emigrante en sentido general, el hombre como sustancial emigrante que constantemente busca sus opciones de futuro, que en su carácter histórico, de progreso, se mueve en la búsqueda de un paisaje propio, un ideal, un proyecto de vida, incluye todos los rasgos de futuro que deben guiar a la nueva sensibilidad. El emigrante que busca la tierra prometida lo hace al ser retenido por un paisaje que le concede los caracteres del ideal, del proyecto ansiado. Pero esa retención no es detenida, sino que debe ser re-creada, constituida con las intenciones de futuro que trae ese emigrante que ya ha vivido un pasado, ya ha huido de un pasado, pero no lo ha olvidado. La unión de futuro y pasado es la que explica el carácter general de la relación entre Europa y América; la conexión positiva, que elimine los talantes de olvido de pasado o de creación de uno ficticio, pero se base decididamente en crear proyectos de futuro, afecta tanto al nacionalismo del futuro, tan añorado por Ortega, como, en general, a la nueva sensibilidad. Es en esa unión de futuro y pasado donde se superan las limitaciones, se superan en un sentido hegeliano: se toma conciencia de las del pasado, pero se las dirige constantemente hacia un futuro.

306" Un rasgo de la vida alemana" (1935). OC V, 203.

307" El hombre a la defensiva" (1929). OC II, 651. 
El hombre como sustancial emigrante adquiere conciencia tanto de sus limitaciones como de las posibilidades de superación. Se sostiene sobre el límite entre pasado y futuro. El arte como perpetua evasión dota al hombre de un carácter único: el de la emigración íntima y constante, el de la conciencia de la posibilidad de salir fuera de sí, de superar su propio mundo. La razón histórica, el hombre que es progreso, que emigra de paisaje en paisaje hasta que encuentra su proyecto de vida, que no es inmóvil, natural, sino esencialmente móvil, histórico, realiza vitalmente esos caracteres de evasión, una evasión hacia un futuro que, sin embargo, no olvida su pasado. El emigrante en América no sólo lleva su pasado europeo, sino que incluye el poder de retención, la fuerza que sobre él ejerce el paisaje nuevo, más que nuevo, futuro. En el límite entre ambas posturas, en el límite entre pasado y futuro, en lo que Ortega llamará el anacronismo de la vida colonial, se juega tanto la relación con América como los caracteres más determinantes de la nueva sensibilidad.

Ese anacronismo es el que determina el carácter límite, el anacronismo entre el primitivismo americano y sus posibilidades de futuro, el anacronismo entre pasado y futuro. Ortega ya había dejado lo suficientemente claro que no quería renunciar ni a uno ni a otro. En 1916, en el contexto del primer viaje a Argentina, comparaba Ortega el futuro de América con el pasado de Azorín, y escribía: "En tanto, pues, que mi alma orienta su proa hacia América, que es el porvenir, meditemos un poco a este poeta del pasado. ¡Pasado, porvenir! Ya he dicho que para mí la vida no tiene sentido si no es como una aspiración de no renunciar a nada"308.

La serie de caracteres que dirigen el acercamiento de Ortega al tema de América siempre estarán dirigidos, de un modo un otro, por el afán de conjuntar límites y limitaciones, futuro y pasado, primitivismo y potencialidad de posibilidades. El nacionalismo futuro, la existencia colonial, el anacronismo, el emigrante como carácter sustancial del hombre, todos ellos son muestras del talante que rige esa nueva sensibilidad que buscaba Ortega. Todos ellos expresan la situación en el límite entre las limitaciones y su superación, implican la necesidad de conservar un pasado dirigido hacia unas intenciones efectivas de futuro, de mundo nuevo, de ampliación de realidad. La conexión entre Europa y América es 
la conexión entre el pasado que debe ser conservado y el futuro que debe ser posibilitado, creado, sostenido, es una conexión, entonces, que supera el propio tema de América.

308" Azorín: primores de lo vulgar" (1916). OC II, 158. 


\subsection{Historia y densidad de población}

En el contexto concreto del "Hegel y América" resta el final. Las citas que Ortega ha tomado de Hegel y que sólo adquieren un sentido al salir del mismo artículo, conducen hasta cierta ley histórica. Una ley que sería difícil de aceptar por el propio Hegel, pero que tiene un truco o, mejor, dos: primero, la conexión con los temas explícitos a tratar en 'En el centenario de Hegel", y, segundo, la conexión con el final de la "Meditación del pueblo joven". Esa ley la expresa Ortega del modo siguiente:

"Entrevemos una ley fundamental de la historia que Hegel no ha formulado nunca por separado. Por lo visto, para que el espíritu se recoja sobre sí mismo y abandone ese aspecto de naturaleza que primero adoptó, es preciso que los hombres no encuentren ante sí grandes espacios libres, sino que, al contrario, vivan apretados. Por tanto, la historia o espiritualización del Universo es función de la densidad de población. La humanidad desparramada no segrega espíritu: es menester que se haga especialmente compacta, que se aprieten unos contra otros los individuos. Sometida a presión, la humanidad comienza a rezumar espiritualidad y la aventura propiamente histórica se inicia. Sólo ante dificultades en la vida «natural», cuya medida hallamos en la holgura de territorio, se dispara el proceso cultural" 309 .

Ortega acaba de citar el texto de Hegel que más arriba iniciaba mi comentario del tema de la emigración: "Dass eine Staat die Existenz eines Staates bekommen könne, dazu gehört, dass er nicht auf fortwährende Auswanderung bedacht sein, sondern dass sich die ackerbauende Klasse nicht mehr nach aussen drängen kann, vielmehr sich in sich zurückdrängt, sich zu Städten und städtischen Gewerben zusammenfasst"310. Para Hegel, sólo cuando la posibilidad de extenderse, de tender a nuevas tierras, sea superada y comience la concentración en ciudades e industrias, podrá formarse un sistema civil, y, con ello, un Estado. Sólo cuando, como en Europa, ya no quede una salida natural para la población, sino que esa naturaleza abierta haya sido superada, el espacio abierto esté lleno y la sociedad se concentre en sí misma, podrá América formar un Estado, y, con ello, entrar en la historia. Ortega entiende estos caracteres a partir del carácter de la densidad de

\section{9" Hegel y América" (1928). OC II, 575.}

310HEGEL, Vorlesungen über die Philosophie der Weltgeschichte. Op. cit. p. 198. Traducción: "Para que un Estado adquiera las condiciones de existencia de un verdadero Estado, es preciso que no se vea sujeto a una emigración constante, sino que la clase agricultora, imposibilitada de extenderse hacia afuera, tenga que concentrarse en ciudades e industrias urbanas.". HEGEL, Lecciones sobre la filosofía de la historia universal. Op. cit. p. 176. 
población: la humanidad desparramada deviene compacta, la cultura se inicia con la superación de las dificultades de la vida cultural.

Es cierto, como afirma Albizu, que Hegel no admitiría la idea de Ortega como ley histórica: no podría hacerlo porque supondría basar el inicio de la historia en caracteres geográficos, naturales 311 . Pero para entenderla como ley histórica hay que salir de Hegel y recaer sobre Ortega. El tema afecta a la relación entre raturaleza y cultura: la cultura como medio para enfrentarse a los problemas que al hombre le presenta la vida, la cultura para salir del estado de continua amenaza que plantea la naturaleza, para solucionar la cuestión de las necesidades naturales, la cultura como lo que el hombre añade a la naturaleza, o, utilizando una frase del Ortega joven, "cultura es lo que no cabe dentro de la Naturaleza"312.

El tema afecta también a la cuestión de la convivencia que veíamos más arriba comentando el final de 'La «Filosofía de la historia de Hegel» y la historiología" y afecta al tema de la relación entre geografía e historia que expondrá Ortega en "En el centenario de Hegel" y que veremos en el capítulo siguiente: la relación entre tiempo y espacio en la historia, el tema del paisaje, el tema mismo de la limitación en la historia, etc. Afecta del mismo modo al tema de la atención que constantemente, en unos contextos y otros, utiliza Ortega: la atención única a la naturaleza no permite al hombre concentrarse en sí mismo, no le permite ensimismarse, y, con ello, hacer posible una cultura, una filosofía, una teoría o, sin más, crear una sociedad 313 .

Pero limitándonos al tema de América, para entender esa, según las palabras de Ortega, "teoría general nunca expuesta por Hegel, pero fácilmente destilable del contexto"314, hay

311 ALBIZU, E. "Ortega, Hegel y el pensamiento latinoamericano actual", en: Sur, no 2, Buenos Aires, 1983, p. 7: "La ingenuidad que consiste en hacer de lo histórico un resultado de la densidad de población, lo que contradice axiomas hegelianos, pues entonces la esencia de la historia se concentra en un fenómeno natural, geográfico".

312" La conservación de la cultura" (1908). OC X, 46.

313 También en Hegel ha encontrado Ortega la exposición concisa de ese tema: "Die Gewalt der Elemente ist zu gross, als dass der Mensch aus dem Kampfe mit ihnen herauskäme, als dass er mächtig genug wäre, seine geistige Freiheit gegen die Macht der Natur geltend zu machen. [...] Der Mensch ist beständig darauf gewiesen, seine Aufmerksamkeit auf die Natur zu richten". HEGEL, Vorlesungen über die Philosophie der Weltgeschichte. Op. cit. p. 181. El texto se encuentra subrayado fuertemente por Ortega en el ejempar que maneja, y citado en el "En el centenario de Hegel" (1931). OC V, 427.

314" Hegel y América" (1928). OC II, 574. 
que acudir al final de la "Meditación del pueblo joven". Allí Ortega, sin mencionar a Hegel, escribe lo siguiente, casi repitiendo el texto del "Hegel y América" y los párrafos del propio Hegel:

"Hay que apurarse, argentinos. El tiempo corre y la vida colonial, probablemente, termina ahora, aún en sus formas más avanzadas, para América. Como está en la agonía la economía colonial, así el resto de esta forma de vida. Y con la vida colonial termina el vivir ex abundantia -las glebas se van llenando de hombres. La población se densifica -ya no hay tanta buena tierra libre, ya se ha averiguado que gran parte de esa tierra libre no es buena. Mientras hay tierra de sobra la historia no podía empezar. Cuando el espacio sobra ante el hombre reina aún la geografía que es prehistoria. La prehistoria es el paraíso, es la vida de la campaña, y del hombre en él como un detalle. La prehistoria es más que historia, paisaje. La vida colonial tiene, por eso, un delicioso carácter bucólico -es el campo, el campo abundante en derredor de unos pocos hombres. Pero ahora va a empezar la historia de América en todo el rigor de la palabra. Esa primera juventud que es la adolescencia termina, la cuesta se inicia. Adán sale del paraíso y comienza su peregrinación. Buena suerte, argentinos, en esa historia que para ustedes comienza"315.

A partir de esta lectura, hecha diez años más tarde, que Ortega efectúa de su propia ley histórica presentada en el "Hegel y América", adquieren conexión la serie de temas tratados y se inician las temáticas que aparecerán en "En el centenario de Hegel". La historia regida en función de la densidad de población es más importante de lo que parece. En el fondo se encuentra el constante afán de Ortega por unir individualidades, unir caracteres, mostrar que la unidad sólo puede adquirir sentido a través de la pluralidad, no del unitarismo de una idea, o de una persona. El vivir apretados, el ataque a la humanidad desparramada, además, no remite únicamente a los individuos, sino también a los pueblos, a las naciones. Sólo en la pluralidad de las miradas será posible agotar la multitud de perspectivas, sólo en la conjunción de proyectos de vida será posible el progreso en esos mismos proyectos. La constante insistencia en la conexión de España con Europa, la constante insistencia en la relación con América, ambas son muestras de ese afán de luchar contra el "cada uno por su lado". Es el talante de conjunción de limitaciones a través de la apertura que posibilita tratarlas a cada una como límite.

La humanidad compacta, unida, sea en lo referente a los individuos, sea en lo referente a los pueblos, sea en lo referente a las épocas, expresa la continuidad de una discontinuidad, la conjunción de individualidades para aumentar el proyecto de vida de cada una de esas

315" Meditación del pueblo joven" (1939). OC VIII, 406. 
individualidades. Es en la unidad abierta de las particularidades donde se inicia la historia, donde se inicia el progreso que verdaderamente posibilite dar sentido a cada una de ellas. Si en ese vivir compacto se inicia la historia, también supone ese inicio el final de la vida colonial. Entiéndase bien: el final de la vida colonial como colonialismo, como dependencia de ideas ajenas. Finaliza el colonialismo pero se inicia la historia, y, con ella, el carácter más propio de la existencia colonial: la conjunción de futuro y pasado en un anacronismo que permita sostener el presente sobre la experiencia de pasado y las posibilidades de futuro. Termina la vida ex abundantia, pero en el sentido de los recursos, de las tierras no explotadas; comienza, con la historia, con la razón histórica y vital que le da sentido, la vida ex abundantia de las posibilidades, de los proyectos de vida. Con la historia comienzan las aventuras: la aventura histórica es precisamente eso, aventura.

La juventud como carácter del tiempo nuevo permanece, pero su proyecto de vida sólo adquirirá sentido en la unidad compacta de las particularidades, sean naciones o individuos. $\mathrm{Si}$ se supera el carácter negativo de la prehistoria, de la geografía como paisaje, con esa misma superación se inicia su carácter positivo: el de convertir el paisaje en un proyecto, el de convertirlo en un ideal que hay que crear, que hay que hacer. Crear el paisaje propio como crear la limitación propia. Con la historia se inicia la cuesta, los problemas, pero también las aventuras y los proyectos de paisaje, de creación de un marco propio que se encuentre a sí mismo a través de los contactos con las particularidades. Con la historia adquiere verdadero sentido la categoría del descontento. Pero en el sentido visto más arriba.

Ortega insistía en que en la mujer argentina "he visto desprenderse de su alma, como vaho, un sublime, divino descontento. La historia humana es obra del descontento"316, en que "el alma criolla está llena de promesas heridas, sufre radicalmente de un divino descontento"317, en que el americano en general "siente en el fondo de su vida manar querulante un hontanar de tristeza, de desolación, de descontento, de extraña insatisfacción"318. Ese descontento lo afirmaba Ortega en el 16, en el 29 y en el 39, por tanto, recorre toda la relación de Ortega con América. Si siempre lo ha referido a los caracteres del pueblo joven, abierto a toda la serie de posibilidades, sólo adquiriría

316" Impresiones de un viajero" (1916). OC VIII, 370.

317"La Pampa... promesas" (1929). OC II, 639. 
verdaderamente su sentido cuando ese pueblo joven se haya concebido como tal, cuando haya desaparecido la faceta negativa de la vida colonial y únicamente permanezca la positiva, la de la conjunción de pasado y futuro. El descontento como emoción idealista, que aparecía más arriba, sólo es posible cuando la historia ha comenzado, cuando esa historia adquiere el carácter vital de la biografía, de la pluralidad de historias posibles, de proyectos de vida posibles.

Esa pluralidad remite a la insatisfacción por no poder abarcarlo todo, por no ær capaz de plenificar todas las aspiraciones, pero también a la necesidad de unión con las particularidades para que los proyectos amplíen su sentido. Al terminar la adolescencia de América se inicia su historia, y con ella su pasado, su presente futuro $\$$ une a su pasado nuevo. La prehistoria como paisaje adquiere el sentido del paisaje efectivamente creado, no sencillamente encontrado en la abundancia de espacio. Esa creación de paisaje, de espacio, afecta tanto a América como a Europa, como a la circunstancia donde se desenvuelve el proyecto de vida de cada individuo. Es esa misma creación de una limitación la que requiere, en sus exigencias de henchimiento, la existencia compacta con otros proyectos, otros paisajes. Es esa misma creación la que dará verdadero sentido a la relación entre geografía e historia. Si ahora la prehistoria es paisaje, en sentido negativo, si ahora reina la geografía al sobrar el espacio, en "En el centenario de Hegel" "la nación es espíritu mineralizado y animalizado; por tanto, adscrito a un lugar, a un paisaje. La historia con su enjambre de pueblos brota de la geografía"319. Será una geografía estético-histórica, en tanto el paisaje no sólo será hallado, sino constantemente creado, sostenido.

318" Meditación del pueblo joven" (1939). OC VIII, 402.

319" En el centenario de Hegel" (1931). OC V, 423. 


\section{4. "En el centenario de Hegel"}

Los dos textos anteriores sobre Hegel, 'La «Filosofía de la historia de Hegel» y la historiología" y el "Hegel y América", están escritos en el mismo año, 1928. "En el centenario de Hegel", por su parte, fue una conferencia ofrecida en el Instituto Internacional de Señoritas dos años más tarde, en 1931. El talante ha cambiado. En este momento Ortega utiliza a Hegel, lo recibe, para referirlo, de un modo mucho más explícito que en los dos artículos anteriores, a sus propias teorías. Los contextos serán sobre todo dos, primero la relación entre el concepto hegeliano de espíritu y el orteguiano de vida, y, segundo, la relación entre geografía e historia. Ambos han sido iniciados en los dos artículos anteriores, pero sólo ahora los tratará Ortega de un modo detenido.

Por las notas de trabajo se percibe claramente que la lectura de Hegel la llevó a cabo Ortega de un modo unitario, por lo menos en lo que refiere a los tres artículos y los aspectos tratados en ellos. En las notas de trabajo no se distingue la diferencia de dos años que los separa. Pero si en las notas no se notan esos dos años, sí que lo hacen en los mismos textos: sosteniendo "En el centenario de Hegel" se encuentran las temáticas que Ortega ha tratado en esos dos años, sobre todo las que han sido expuestas de un modo lo suficientemente unitario (aunque ya hayan sido iniciadas en años anteriores) en el curso ¿Qué es filosofía?.

En 'En el centenario de Hegel" aparecerá en relación con Hegel la referencia a aspectos de la teoría de la vida que Ortega ha tratado en ¿Qué es filosofía? Al ser esto así, el artículo se constituye como el más interesante de los tres que Ortega escribió sobre Hegel: en él va aclarar explícitamente, dejando en cierto modo en segundo término el tema de la historia, la relación receptiva que mantiene con Hegel. Y lo va a hacer en dos sentidos, primero en la conexión entre espíritu y vida, y, segundo, en aquello que ya inició en el "Hegel y América" y que sólo ahora adquirirá un talante puramente orteguiano: el tema de la geografía.

Ese tema de la geografía no aparecerá examinado únicamente en relación con la historia, y, con ello, con Hegel, sino también con aspectos puramente orteguianos que recorren el conjunto de su filosofía. Esos aspectos son el tema del paisaje y el tema de la limitación. La conexión con toda la primera parte de mi trabajo revertirá ahora sobre la recepción explícita de Hegel por Ortega a través de un artículo basado directamente en Hegel. Concretando, 
por un lado se situará la relación entre espíritu y vida, ratada a partir de teorías puramente orteguianas ya expuestas en textos anteriores; por el otro, la relación entre historia y geografía, que si en el "Hegel y América" fue únicamente iniciada y dedicada al tema de América, ahora se dirigirá al conjunto del tema y se concentrará en dos aspectos, el paisaje y la limitación. Para entender la conexión entre ambas secciones es importante concretar el tema del Volksgeist y el concepto de espíritu objetivo, que, aunque ambos han aparecido ya en varias ocasiones, sólo ahora alcanzarán un sentido determinado en torno a la recepción por Ortega de los escritos sobre Hegel

En general, entonces, en este último artículo de los escritos sobre Hegel, Ortega utilizará ideas y aspectos, incluso textos completos, que ya ha expuesto en los otros dos. Pero el talante es distinto. Ahora Ortega hará confluir esas ideas, de un modo mucho más claro que en los otros artículos, sobre sus propios intereses. Si el primero se mantenía alrededor de la idea de la razón en la historia y el segundo en torno al tema de América y del futuro, este tercero, aunque Ortega continuará insistiendo en el marco de la historia, se centrará en la idea de vida y en el tema del paisaje. 


\subsection{Vida y espíritu}

Ortega comienza "En el centenario de Hegel" del mismo modo que concluyó "La «Filosofía de la historia de Hegel» y la historiología": mediante la conexión de vida individual, vida colectiva o convivencia, e historia. Por un lado, "a cada cual le pasa su vida -es decir, la serie de hechos que la integran. En todos y cada uno de ellos está, solapado, el Mismo. Yo soy el Mismo, el punto de identidad o mismidad latente bajo la diversidad e inconexión aparente de los hechos que urden mi vida"; por el otro, "los hechos de mi vida no terminan en ella, en su órbita individual, sino que actúan sobre la órbita de otras vidas como la mía, penetran en ellas produciendo múltiples efectos. Y viceversa, lo que a otros les pasa -su vida- rezuma sobre la mía"320. Por un lado, entonces, el individuo y la vida individual, por el otro la convivencia, la sociedad. La vida individual y la vida social son dos perspectivas distintas, modos diferentes de ver los acontecimientos. Aunque la relación entre ambas será siempre del nivel más alto, esto es, no podrán separarse en ningún momento, las perspectivas son diferentes: lo que me sucede en mi individualidad, lo que me sucede en mi convivencia, lo que sucede en la vida social, en la sociedad.

A esas dos perspectivas se une una tercera, la historia. El individuo muere y otras vidas suceden a la suya, la sociedad de ahora se prolonga en la futura y continúa a la pasada: "nos encontramos ante un nuevo tropel de hechos -los históricos- enormemente más rico, multiforme, caótico, que el atribuible a la vida individual o a la sociedad de hoy. En suma, nos encontramos con el rumor innumerable de la historia universal" 321 . La historia intenta darle un sentido, encontrar una razón que nos permita comprender la serie de hechos pasados que han conducido a un presente y remiten a un futuro, pero la cuestión es quién o qué rige ese sentido, esto es, buscar el Mismo de la vida histórica, como el individuo, el yo, lo era de la individual. Este es el modo como Ortega introduce a Hegel: "La Filosofía de la historia Universal es el golpe de nudillos que da Hegel sobre los fenómenos del destino humano. Al buscar el Mismo de la historia, su substrato y sujeto, tiene que buscar también, como antes indiqué, una nueva perspectiva, distinta de la individual y de la vida social. Ahora se trata de la vida histórico-universal que comprende aquellas otras dos formas de

320" En el centenario de Hegel" (1931). OC V, 413-414.

321 Ibid. p. 415. 
vida; es decir, que la perspectiva histórico-universal que incluye la perspectiva individual y la social, es la perspectiva integral de lo humano"322.

No es casual que el tema de la relación entre vida individual, vida social y vida histórica concluya el primer artículo e inicie el tercero de los escritos sobre Hegel. La explicación no es ni de "ahorro de trabajo", esto es, de aprovechamiento de ideas usadas, ni tampoco de un supuesto afán "sistemático" que conjunte finales de unos textos con inicios de otros, sino que remite al propio modo de Ortega de entender la historia. La historia, concebida a partir de la razón vital y la razón histórica, en todo momento remitirá a la necesidad de atender a ella para saber cómo actuar, cómo desenvolverse en la vida, sea ésta individual o social. Que Ortega culmine uno y comience otro de los artículos sobre Hegel tratando el vínculo de la historia con la vida individual y la social supera el marco de la relación con Hegel, de hecho determina ya esa misma relación, en tanto se sostiene sobre el concepto de historia como vida histórica, en conexión con la vida individual y la vida social. Ortega, desde el inicio, entonces, pone sus cartas sobre la mesa: lo que está en juego es el carácter vital de la historia, y con ese talante se dirige hasta Hegel, más ahora, en 1931, después de los cursos sobre ¿Qué es conocimiento? y ¿Qué es filosofía?, incluso después de La rebelión de las masas.

En la historia se trata de encontrar ese Mismo, ese algo permanente que explique la incesante variación de hechos. Ortega examina brevemente distintos métodos, distintas formas de interpretación de la historia que, dependiendo de la base sobre la que se asiente cada cual, expliquen los hechos de un modo u otro. Puede hablarse de la interpretación económica de Marx, de la bélica, que el propio Ortega ha examinado en "La interpretación bélica de la historia", incluso de la interpretación hidrológica y la interpretación sideral. Todas ellas son verdad en algún sentido, pero ninguna lo es del todo: son verdades parciales, perspectivas, que se centran en unos caracteres determinados y olvidan los demás. Ortega ya lleva tiempo presentando su teoría de la perspectiva, en todos los sentidos, y, de un modo u otro y siempre que aparezca en el contexto de la historia, hay que recordar que uno de los modos de entenderla consiste en partir de aquella cita de Goethe que tanto gustaba a Ortega: "Sólo entre todos los hombres llega a ser vivido lo humano", esto es, la pluralidad frente a todo tipo de unitarismo, la conversión de la limitación cerrada 
en dulce frontera, la unidad abierta, de perspectivas dispuestas a su conexión con otras, frente al carácter cerrado de todo exclusivismo absolutista. La perspectiva histórica como "perspectiva integral de lo humano", que Ortega remitía a Hegel y su filosofía de la historia, conecta de este modo con la idea que toma de Goethe. Es la conexión entre historia y perspectiva, pero también, como veremos en la última sección, la referencia al tema del cosmopolitismo.

Que Ortega comience presentando esas diversas perspectivas de la historia, con la intención de situarlas ante la perspectiva absoluta, del espíritu, que intentará Hegel, ya es indicio de por dónde continuará el análisis: al espíritu va a enfrentarle Ortega su propio concepto de vida, pero con un esquema propio, en tanto que en ese enfrentamiento, primero, se definirán y criticarán determinados caracteres del espíritu y, segundo, la vida se apropiará de todo aquello que de él le sea útil. El encuentro entre el carácter parcial de esas perspectivas y la teoría de Hegel lo expresa Ortega del modo siguiente:

"Esas teorías sobre la historia son verdades abstractas, por tanto parciales. Son vistas tomadas arbitrariamente sobre la realidad. Toda vista es verdadera, puesto que nos da algo de la cosa. Pero como la hemos tomado desde un punto de vista cualquiera, sin dejar de ser verdadera resulta arbitraria. Lo arbitrario no es tanto la vista como el punto de vista. / Esta es la máxima preocupación de Hegel: encontrar un punto de vista que no sea uno cualquiera, sino que sea aquel único desde el cual se descubre la verdad entera, la verdad absoluta. Sea nuestro punto de vista no el nuestro, sino precisamente el universal o absoluto. / Este abandono de nuestro punto de vista y este esfuerzo por instalarnos en lo absoluto y mirar desde él todo y cada cosa es para Hegel la filosofía. No discutamos ahora si esto es factible. Mi tema no es la metafísica de Hegel, sino su Metafísica de la historia"323.

No es del todo cierto que su tema sea únicamente la metafísica de la historia de Hegel, incluso podría decirse que esa metafísica de la historia va a pasar a segundo plano. Lo que realmente interesa a Ortega es situar su concepto de vida fente al hegeliano de espíritu. Si ahora evita el enfrentamiento entre ese punto de vista absoluto y su teoría de la perspectiva, únicamente lo hace por dos razones: primero porque su interés está ahora en el concepto de espíritu y, segundo, porque ese enfrentamiento lo viene llevando a cabo desde hace años y textos. De hecho, como ya hemos visto, uno de los marcos ineludibles de la superación del idealismo es la sustitución de cualquier tipo de unitarismo por la pluralidad de perspectivas, de ideas, de historias, de vidas, la sustitución de una unidad unitaria, por una unidad plural.

323Ibid. p. 419 
Es en este momento cuando comienza lo realmente interesante del artículo. El modo de llegar hasta aquí por parte de Ortega ya incluye las primeras pistas, los primeros tanteos: de un modo u otro, casi a escondidas, ha comenzado con el concepto de vida y ha continuado con la teoría de la perspectiva. Con ambos aspectos acude a la teoría de Hegel: en la filosofía de Hegel, esa realidad fundamental que superaría la parcialidad de bs perspectivas es lo absoluto, la lógica le ha conducido hasta eso absoluto y, bajo su gobierno, se dirigirá a la historia y a la naturaleza. La historia, en concreto, quedará subsumida bajo el imperio de lo absoluto, Hegel no irá hasta los hechos para intentar descubrir la verdad oculta en ellos, sino que llega ya con el esquema preconcebido, con la intención de saber si la historia se adapta a la filosofía, a la realidad absoluta que ha encontrado en su lógica. Esa realidad absoluta es el espíritu, y todo lo demás no será otra cosa más que manifestación de ese espíritu.

Todo esto, como ya se ha indicado, contradice para Ortega la pretensión fundamental de la nueva sensibilidad: la fidelidad a las cosas. Pero, con todo, hay aspectos cruciales que Ortega no pasará por alto. En este momento la cuestión es: "¿qué es el espíritu? No nos engañemos: el Espíritu en Hegel es una enormidad en todos los sentidos de la palabra: una enorme verdad, un enorme error y una enorme complicación"324. La pregunta que plantea Ortega ha sido contestada dos veces: una en el texto publicado, otra en un apéndice inédito editado por Garagorri con el título de "Reflexividad" y que el propio Ortega desechó 325 . Ese apéndice corresponde a las páginas que, en el manuscrito de la conferencia, continuaban al texto de esa pregunta citada, y que más tarde, en la publicación, fueron sustituidas por las editadas.

En el texto publicado, la clave la presenta el concepto de vida; en el apéndice el tema del pensamiento. Ambos contextos están íntimamente relacionados, pero el hecho de que en ese apéndice no haya referencia alguna a la vida, esto es, a la teoría particular de Ortega, exige intentar explicar precisamente por qué fue desechado. Lo que editó Ortega fue la relación entre el espíritu y la vida; lo que desechó fue el análisis del espíritu basado

324Ibid. p. 420.

325"Apéndice: La reflexividad", en: Kant - Hegel - Scheler. Madrid: Revista de Occidente en Alianza Obras de José Ortega y Gasset, 23-, 1983, pp. 119-124. 
exclusivamente en el concepto de reflexividad, sin que ésta remitiera también a la vida. Es necesario ir por partes, comenzando por la relación entre espíritu y vida.

Ortega utiliza al propio Hegel para unir espíritu y vida: "Se han llamado espíritu tantas cosas, que hoy no nos sirve esta deliciosa palabra para nada pulcro. Hegel mismo vaciló mucho antes de decidirse por esta terminología. En su juventud prefería hablar de «vida». Hoy le acompañaríamos en esta preferencia. ¿Por qué?"326. Pero Ortega no va a relacionar los conceptos hegelianos de espíritu y vida, sino el espíritu de Hegel y el concepto orteguiano de vida. Es más, esa conexión con el Hegel joven, más que haberla descubierto por sí mismo en la lectura de Hegel, la ha encontrado a través de los estudios que ha manejado, sobre todo en Kroner. Puede afirmarse que Ortega lee los textos del joven Hegel (y me refiero sobre todo al Differenzschrift) después de haber leído la Filosofía de la historia y los estudios manejados, de hecho muy mediatizado por ambos, incluso puede decirse que estudia el concepto hegeliano de vida después de haber expuesto su propia teoría. Entre esos estudios no sólo se encuentra Kroner, sino también Dilthey y su Jugendgeschichte Hegels, aunque Dilthey, más que en la referencia directa a Hegel, afectará al tema general de la conexión entre historia y vida, y supone un momento posterior a éste del encuentro con Hegel.

Gran parte de los textos e ideas que Ortega toma del Differenzschrift coincidirán con las citas que transcribe Kroner, incluida la referencia de que el Hegel joven "prefería hablar de vida". Por ejemplo, y de un modo general, atendiendo únicamente a la conexión entre espíritu y vida, en Kroner ha leído Ortega (y subrayado con fuerza en su ejemplar) textos como los siguientes: "die Aufgabe der Philosophie besteht darin «...das Endliche in das Unendliche, als Leben zu setzen». Das Leben ist die Totalität, der höchste Gegenstand der Philosophie, dasselbe, was Hegel später (und auch schon in den Jugendschriften) Geist nennt", o: "In dem Begriffe des Lebens vereinigt sich die Subjektivität der Vernunft mit der Objektivität ihres Wirkens, vereinigt sich die Idealität des Denkens mit der Realität des geschichtlichen Seins [...]. Geist bezeichnet mehr die subjektive, Leben mehr die objektive Seite dessen, worin er das Absolute erblickt"327.

326" En el centenario de Hegel" (1928). OC V, 420.

${ }^{327}$ KRONER, R. Von Kant bis Hegel. Bd. II: Von der Naturphilosophie zur Philosophie des Geistes. Tübingen: Mohr, 1921, pp. 145 y 147, respectivamente. Traducción: "La tarea de la filosofía consiste en 
Ambos párrafos se encuentran en el capítulo del Kroner sobre el Differenzschrift de Hegel. Las citas que transcribe Kroner son casi las mismas que subraya Ortega en su ejemplar de la obra de Hegel, haciendo hincapié en una, la primera de las de Kroner: "Die Aufgabe der Philosophie besteht aber darin, diese Voraussetzungen zu vereinen, das Sein in das Nichtsein - als Werden, die Entzweiung in das Absolute - als dessen Erscheinung, das Endliche in das Unendliche - als Leben zu setzen"328.

Pero Ortega no utiliza el concepto hegeliano de vida, ni éste del joven Hegel, ni tampoco el que aparecerá en la tercera parte de la Lehre vom Begriff de la Lógica. Su interés no es ése. Ortega, simplemente, manifiesta que en su juventud Hegel utilizaba el concepto de vida, y lo aprovecha para conectar espíritu y vida, pero a partir de su propio concepto de vida, no del de Hegel. Que esa referencia al joven Hegel la ha tomado de Kroner y de otros estudios es más o menos clara ${ }^{329}$, pero Ortega se salta el concepto hegeliano de vida. De un modo concreto: el interés explícito de Ortega es utilizar ciertos caracteres del concepto hegeliano de espíritu para el suyo de vida, no conectar éste con el concepto de vida de Hegel; conectar el espíritu hegeliano con el concepto orteguiano de vida a través de ciertos caracteres comunes, de cierta identificación en los modos de actuación o de desarrollo de

«...poner lo finito en lo infinito, como vida». La vida es la totalidad, el más alto objeto de la filosofía, el mismo que Hegel más tarde (y ya también en los escritos de juventud) llama espíritu" y "En el concepto de vida se reúne la subjetividad de la razón con la objetividad de su actuación, la idealidad del pensamiento con la realidad del ser histórico [...]. Espíritu designa más la parte subjetiva, vida la objetiva de éste, donde él descubre lo absoluto".

${ }^{328}$ HEGEL, Differenz des Fichteschen und Schellingschen Systems der Philosophie, en: Erste Drückschriften. Sämtliche Werke I. Hrsg. G. Lasson. Leipzig: Meiner, 1928, p. 16. Traducción: "La tarea de la filosofía consiste en unificar estos presupuestos, en poner el ser en el no-ser -como devenir-, la escisión en lo absoluto -como su manifestación-, lo finito en lo infinito -como vida-". HEGEL, Diferencia entre los sistemas de filosofía de Fichte y Schelling. Ed. M. C. Paredes. Madrid: Tecnos, 1990, p. 24.

${ }^{329}$ En Dilthey, por ejemplo, ha leído: "Hegel bestimmt den Charakter aller Wirklichkeit durch den Begriff des Lebens. Leben ist bei ihm die Beziehung der Teile zum Ganzen, nach welcher diese isoliert vom Ganzen weder existieren noch gedacht werden können". DILTHEY, W. Die Jugendgeschichte Hegels und andere Abhandlungen zur Geschichte des deutschen Idealismus. Gesammelte Schriften. IV Band. Leipzig und Berlin: Teubner, $1925^{2}$, p. 138 ; en Schilling-Wollny, remitiendo directamente a los mismos textos del Differenzschrift que encuentra en Kroner (KRONER, R. Von Kant bis Hegel. Op. cit. p. 147): "Hegel sagt: «Betrachten wir die besondere Form näher, welche eine Philosophie trägt, so sehen wir sie einer Seits aus der lebendigen Originalität des Geistes entspringen»". SCHILLINGWOLLNY, K. Hegels Wissenschaft von der Wirklichkeit und ihre Quellen. I. Band: Begriffliche Vorgeschichte der Hegelschen Methode. München: Ernst Reinhardt, 1929, p. 160; en Heimann ha manejado sobre todo el capítulo titulado "Das Leben als Produkt einer Doppelbewegung von aussen nach innen und von innen nach aussen". HEIMANN, B. System und Methode in Hegels Philosophie. Leipzig: Meiner, 1927. Valgan estos textos como muestra, habiendo tomado únicamente aquellos de los que se encuentran en la biblioteca de Ortega que, por las fechas, éste podía haber 
ambos. Esos caracteres comunes los centra Ortega en la idea de reflexividad, de conocerse a sí mismo tanto del espíritu como de la vida.

leído antes del 31, y que contienen los párrafos citados subrayados y anotados por el propio Ortega. De todos modos, la referencia explícita es Kroner. 


\subsection{Reflexividad del espíritu y reflexividad de la vida}

La conexión entre el concepto hegeliano de espíritu y el orteguiano de vida se establece a partir del carácter de reflexividad. Ortega lo expone del modo siguiente:

"El atributo principal del Espíritu en Hegel es conocerse a sí mismo. Es, pues, una realidad que consiste en comprensión, pero lo comprendido es ella misma. Lo cual supone que es, a la vez, incomprensión, porque de otro modo no consistiría en un movimiento y esfuerzo y faena para hacerse transparente a sí misma. Tiene, pues, dos haces: por uno es constante problema para sí, por otro es interpretación de ese problema. ¿No es esto b característico de la vida humana? ¿No es nuestro vivir sentirse cada cual sumergido en un absoluto problema? [...] La vida no es el sujeto solo, sino su enfronte con lo demás, con el terrible y absoluto «otro» que es el mundo donde al vivir nos encontramos náufragos. No creo que haya imagen más adecuada de la vida que esta del naufragio. Porque no se trata de que a nuestra vida le acontezca un día u otro naufragar, sino que ella misma es desde luego y siempre hallarse inmerso en un elemento negativo, que por sí mismo no nos lleva, sino, al contrario, nos anula. De aquí que vivir obligue constante y esencialmente a ejecutar actos para sostenerse en ese elemento o, lo que es igual, para convertirlo en medio positivo. Y de éstos, el fundamental y primario es formarse una idea de sí misma, ponerse en claro sobre qué sea ese elemento en que a ratos flotamos, a ratos nos hundimos, y qué sea nuestra pobre persona náufraga en él. Todos nuestros demás actos surgen ya dentro de esa interpretación de la vida y van inspirados por ella" 330 .

La conexión que establece Ortega entre su concepto de vida y el espíritu hegeliano se basa en el esfuerzo de comprensión por conocerse a sí mismos. Se trata de la conjunción en ambos de dos caracteres: por un lado el ser constante problema para sí, por el otro ser eterna interpretación de ese problema. Ambos consisten en llegar a la transparencia de sí, y se diferenciarían en el final: el espíritu hegeliano concluye su desarrollo con la plena conciencia de sí mismo, la vida es siempre bgro parcial de ese resultado: "Una vida que en absoluto no se comprendiese y aclarase a sí misma, sucumbiría. Por otra parte, una vida que se viese con plena claridad a sí misma, sin tiniebla alguna, sin rincón de problema, sería la absoluta felicidad. Donde no hay problema no hay angustia, pero donde no hay angustia no hay vida humana. Por esto la vida humana no puede ser lo que Hegel llama «espíritu», sino sólo movimiento y estación hacia él; afán de transparencia, parcial iluminación, constante descubrimiento y averiguación, mas por lo mismo nunca plenaria claridad"331. La vida

330" En el centenario de Hegel" (1931). OC V, 420-421.

${ }^{331}$ Ibid. p. $422-423$. 
humana coincidiría con el espíritu en el esfuerzo por llegar hasta sí mismo, pero no en el final: la vida humana sería, en el proceso de su desarrollo, un espíritu sin final. Coinciden en el carácter de reflexividad, de esfuerzo por llegar hasta sí mismos, pero no en el resultado.

Este carácter de reflexividad, de saberse o conocerse a sí, Ortega ya lo ha examinado, aunque sin referir a Hegel. Además de la distinción de finales, también ha mostrado las diferencias de contenido: el espíritu en su desarrollo es un acercamiento a sí mismo, una superación conservadora de momentos que le conducirá a la transparencia de sí; la vida busca una interpretación de sí misma para saber a qué atenerse, saber cuál es el destino de cada vida para poder adaptarse a él, y para ello hay que llevar a cabo una interpretación, una concepción particular de vida. La vida pretende hacerse una idea de sí misma para saber desenvolverse en la circunstancia, en el mundo que se le abre y le causa problemas, cuestiones, que solicitan una respuesta; el espíritu lleva a cabo un proceso similar de autoconocimiento con el fin de llegar hasta sí mismo. La vida siempre se mantiene en el juego con un extraño, el mundo; el espíritu mantiene esa extrañeza, su exterioridad, como paso hasta sí. Que Ortega está partiendo de una interpretación clásica de Hegel es evidente: no está tan claro que el espíritu finalice su recorrido, que no exija precisamente dejar abierto su proceso. Pero a Ortega, antes incluso que las referencias a la similitud con el desarrollo del espíritu, le interesa ese concepto de reflexividad.

Al comienzo de "Abenjaldún nos revela el secreto", en 1927, describía Ortega los mismos caracteres que ahora ha encontrado en el espíritu acudiendo a un binomio, que expresaría esos "dos haces" que en este momento remite a Hegel: reflexividad y transitividad. La vida es siempre realidad exclusiva, propia, individual, pero, a la vez, es el enfrentamiento con un extraño, hs cosas en torno, el mundo; es un movimiento constante hacia dentro y hacia fuera. La vida se mueve desde su intimidad hasta el objeto que la llena, que está "fuera", pero ese "fuera" es constantemente interiorizado, individualizado. Se trata de salir de sí a las cosas, para traerse a éstas hacia sí. El contexto es el de la superación del subjetivismo, el de la necesaria integración de sujeto y objeto, de intimidad y mundo, a través del concepto de vida.

Es en el marco de esa integración donde se exige la conjunción de reflexividad y transitividad: "vivir es un movimiento circular que va de dentro a fuera y desde fuera otra 
vez a dentro. Vivir es un verbo, a la par, transitivo y reflexivo: vivirse a sí mismo en tanto en cuanto vivimos con las cosas"332. De nuevo, entonces, lo que realmente interesa a Ortega del espíritu hegeliano es el dinamismo, la tensión, el esfuerzo que supone la constante salida, el extrañamiento de sí, y la constante re-entrada. Pero marcando las diferencias: en Ortega, la vida es el enfrentamiento con un verdadero extraño, real; en el espíritu hegeliano ese extraño es manifestación o disfraz oculto de sí mismo: "Todo lo que no sea francamente espíritu tendrá que ser manifestación disfrazada del espíritu. En la medida en que no «parezca» ser Espíritu su realidad será pura apariencia, ilusión óptica no arbitraria, sino fundada en la necesidad que el Espíritu tiene de jugar al escondite consigo mismo"333. El juego de la vida también es el del escondite, pero no únicamente consigo misma, sino con el extraño real que es el mundo.

Nos encontramos, de nuevo, ante los caracteres de dinamismo y agilidad que más arriba referían también a Fichte. Es la ambigua, hegeliana, superación del idealismo que lleva a cabo Ortega: los caracteres de la vida (y eniendo claro que es ésta, en la integración de sujeto y objeto, la que para Ortega supera el subjetivismo) asumen, asimilan, conservan, formas muy propias de autores y temáticas habitualmente consideradas como clásicos del idealismo. Ortega, incluso en el tema de la superación del idealismo, no abandona en ningún momento el carácter de recepción. Con respecto a Hegel y el tema del espíritu, en las notas de trabajo es todavía más explícito: "la vida se caracteriza por ser lo que él dice del espíritu «lo que vuelve siempre sobre sí mismo», «descansa en sí, se sostiene - tiene en sí su propio centro de gravitación»"334. Ortega llega hasta Hegel con su concepto de vida ya listo, ya enunciado. Si lo coloca ahora en relación con el espíritu, esa relación debe entenderse siempre en términos de recepción: no se trata únicamente de llegar hasta Hegel, sino de llegar hasta él llevando ya los medios que determinarán el contacto.

Tanto en el curso ¿Qué es conocimiento? como en el de ¿Qué es filosofía?, Ortega ha presentado ya los caracteres de reflexividad de la vida. En ¿Qué es filosofía? aparece el pensamiento cartesiano basado en los caracteres de reflexividad y la posterior

332" Abenjaldún nos revela el secreto (Pensamientos sobre África menor)" (1927). OC II, 667.

333" En el centenario de Hegel" (1931). OC V, 421-420.

${ }^{334}$ Archivo de la "Fundación José Ortega y Gasset", Carpetilla "Hegel: filosofía de la historia". Conjunto de notas titulado "Detalles históricos". 
conceptualización de ese pensamiento como conciencia: la conciencia del subjetivismo idealista $\mathbf{e}$ mantiene en su reflexividad, en su ser para sí, en su intimidad. La pregunta que planteará Ortega es la que rige su intento de superación del idealismo: "Descubrir tan extraña realidad como la conciencia ¿no implica volverse de espalda a la vida, no es bmar una actitud perfectamente opuesta a la que al vivir nos es natural?"335. La radical soledad de esa conciencia subjetivo-idealista se vuelve contra la vida, que es ser para otro, encontrarse frente a frente con un extraño, con el mundo. Esta es la superación hegeliana del idealismo: superar la soledad de la intimidad pero sin perder esta intimidad, mostrar la necesaria conjunción de sujeto y objeto, de intimidad y mundo. La vida será la encargada de llevar a cabo esa conjunción: la vida es encuentro con d mundo, es necesaria unión de intimidad y exterioridad, de dentro y fuera.

Cuando Ortega continúe el curso ¿Qué es filosofía? con las lecciones que Garagorri ha titulado como ¿Qué es conocimiento? concretará la idea de un modo determinante a través del concepto de ejecutividad. Sin referir a Hegel, Ortega va a llevar a cabo un planteamiento importante: atacar el carácter de reflexión de sí de la conciencia -en tanto siempre, aunque sea auto-conciencia, se mostrará como la referencia a un objetoprecisamente para afirmar el carácter de reflexividad de la vida, esto es, el mismo carácter que ahora está mostrando en el espíritu de Hegel. El argumento es el siguiente: "El error o insuficiencia de todo idealismo es partir de que la mente o conciencia se refleja en sí misma, de la Selbstbewusstsein. No hay tal Selbstbewusstsein. El acto de conciencia reflejante no es él mismo reflejado, sino siempre otro; luego ni hay tal reflexión sensu stricto ni hay un sí MISMO. La Bewusstsein como todo lo que es objetivante se disocia de su objeto, y esto igualmente cuando el objeto es otro o es ella misma. La verdadera "reflexión en sí mismo" se da sólo en la vida"336. Son los caracteres de ejecutividad que veíamos más arriba: la vida es ser para sí, pero no puesta como objeto, sino como operando, como siendo, con lo que la reflexión no es objetivadora, sino operante, sustentándose a sí

335 ¿Qué es filosofía? (1929). OC VII, 373.

336. ¿Qué es conocimiento? Madrid: Revista de Occidente en Alianza -Obras de José Ortega y Gasset, 25-, 1984, p. 13. 
misma, ejecutándose, "la vida es para sí porque es por su propio esfuerzo; es lo que de sí haga"337 y ese hacerse se lleva a cabo en el encuentro con un mundo.

Cuando más arriba mencionaba que el ser para sí no volvía a aparecer en la filosofía de Ortega me refería precisamente a esto: si reaparece es convertido en reflexividad, en el ejecutarse a sí mismos de la vida y del espíritu, no en los caracteres hegelianos de la lógica del Dasein. De otro modo: este carácter de para sí que refiere a la vida es el de reflexividad en la forma de esfuerzo, de ejecutarse, de dinamismo, que conjunta vida y espíritu en el artículo sobre Hegel. Para Ortega, tanto h vida como el espíritu son su propio esfuerzo para hacerse a sí mismos. En lo que refiere a la vida, tanto en el plano gnoseológico de la conexión entre intimidad y externidad, sujeto y objeto, como en el efectivo, vital, de la relación entre vida y mundo, yo y mi circunstancia. La reflexividad que en "En el centenario de Hegel" reúne espíritu y vida se constituye superando los caracteres de reflexión de la conciencia, esto es, de vuelta hacia sí, al conjuntarlos con los modos de la salida a un mundo, hacia fuera, que exije precisamente tener una idea de sí para poder desenvolverse en esa salida. El esfuerzo que supone tanto el juego de salidas y re-entradas, como la necesaria posesión de una idea, de una interpretación, de una teoría que consiga llevar a buen puerto ese juego, constituye el dinamismo, la tensión, la heroicidad que conllevan tanto espíritu como vida, aunque sus contenidos y desarrollos sean diferentes.

Es por ello por lo que Ortega utiliza en este momento la metáfora del naufragio, metáfora que recorre de principio a fin su filosofía en sentidos varios, y que, en el que nos ocupa ahora, también se encuentra en ¿Qué es filosofía?: "Nuestra vida empieza por ser la perpetua sorpresa de existir, sin nuestra anuencia previa, náufragos, en un orbe impremeditado"338. Ese naufragio es la metáfora del esfuerzo que realiza la vida consigo misma, en su enfrentamiento con el mundo, y es también, para Ortega, sinónimo de la tensión, del trabajo del espíritu en su lucha por salir de sí y volver a sí. El esfuerzo de la vida para superar limitaciones, para sostenerse a flote mediante los restos que se desprenden de ese mismo naufragio; el esfuerzo dinámico del espíritu para llegar plenamente hasta sí mismo.

\footnotetext{
337 Ibid. p. 16.

338. ¿Qué es filosofía? (1929). OC VII, 417.
} 
Es el carácter de dinamismo el que interesa a Ortega, la conexión de intimidad y reflexividad, mostrar que vivir "es un verbo transitivo"339, pero, precisamente porque lo es, porque se sitúa ante el mundo, porque se mantiene en el intento de efectivizar un destino propio en el enfrentamiento con la circunstancia, porque es constante dirigirse a un otro, es también un verbo reflexivo. De aquí la importancia del ejecutarse, del hacerse como definición de la vida: son concreciones de la conjunción entre transitividad y reflexividad. La reflexividad que en este momento Ortega refiere a la vida se caracteriza precisamente por superar el carácter subjetivo de reflexión, de autoconciencia: es una reflexividad transitiva.

Además, si lo que está en juego es la superación de la reflexión (de la conciencia) a través de la reflexividad (de la vida), esta reflexividad no es sólo transitiva, sino también entitativa. La reflexión supera el marco de la conciencia para, en el de la vida, referirse a todo lo que la ocupa. Esta es la conversión del ser para sí lógico, que aparecía más arriba conteniendo las relaciones con un otro, la solidaridad de los contactos, en ser para sí vital. En la vida todo es en su ejecución, en su hacerse como actuando, siendo, participando en el mundo: "Vivir, existir yo, es existir dentro de una universal presencia cuyo «sujeto» no soy yo propiamente sino que yo participo de ella, como el mundo. La reflexión no es, pues, en mi = conciencia, sino «reflexión en sí» de todo. La realidad «vida» es un ámbito de reflexión en sí, donde todo es absolutamente «siendo para sí»"340.

El "para mî" vital es la reflexividad de la vida, la presencia de actuación constante de la vida consigo misma: "es una presencia entitativa y no de objeto ante sujeto. [...] El "existir algo para mî" es un "contar yo con" ello. Mi vida es contar yo conmigo y, a la vez, con algo que no soy yo y que llamaremos lo Otro = circunstancia o Mundo"341. En esta reflexividad transitiva y entitativa es en la que está pensando Ortega cuando conecta el espíritu de Hegel y su concepto de vida. Es por ello por lo que ambos aspectos coinciden en el esfuerzo, en el dinamismo, en la constante actuación, pero no en el final: la vida siempre será "parcial iluminación", en tanto que la actuación no concluirá nunca y en tanto que la interpretación

339" El hombre a la defensiva" (1929). OC II, 655. Sobre ese carácter transitivo de la vida, bajo la forma de la vida como "el hecho cósmico del altruismo", ver también El tema de nuestro tiempo (1923). OC III, 187.

${ }^{340}$ ¿Qué es conocimiento? Op. cit. p. 20.

${ }^{341}$ Ibid. p. 55. 
o aclaración de los problemas que permitan el desenvolverse en ella serán siempre parciales, nunca plenos.

En el apéndice no publicado, y titulado por Garagorri precisamente "La reflexividad", Ortega, en vez de conectar el carácter reflexivo, dinámico, del espíritu con d de la vida, presenta el ataque a Hegel en el contexto de la superación del idealismo ("Hegel brota en la tradición filosófica del idealismo"342), esto es, se referirá a la reflexión de la conciencia, a la reflexividad del pensamiento, no a la de la vida. En el apéndice también se parte del carácter de reflexividad, de que el principal rasgo del espíritu es conocerse a sí mismo, pero aquí no está la "sustitución de su «espíritu» por nuestra «vida»"343, sino el "tal vez fuera más útil sustituirlo por cualquiera de estas dos: mente o pensamiento'344. Ortega analizará el pensamiento como conciencia de sí, como reflexividad, pero no aplicado ni al espíritu ni a la vida, con la intención de llegar a la conclusión habitual: para que haya pensamiento, para que sea posible esa conciencia de sí, es necesario que haya lo que no es pensamiento, las cosas, "sólo cuando pienso una cosa existe pensamiento, y sólo entonces puedo darme cuenta de que pienso"345. A la reflexividad del pensamiento precede entonces la idea de que hay cosas, objetos de pensamiento, incluidas las cosas más opuestas al pensamiento, las materiales.

A partir de este momento el apéndice continúa por los mismos cauces que el ensayo publicado, aunque de un modo mas breve y contando con que el manuscrito está incompleto. Centrándonos en esa idea de reflexividad, lo que ha sustituido Ortega por lo publicado es la caracterización del espíritu como pensamiento, y éste como reflexión de sí. A esa caracterización le opone Ortega su crítica de la prioridad del objeto, o, utilizando aquella tesis que procedía de la "extraña" traducción de Hegel, el "pensamos con las cosas". ¿Por qué Ortega cambió este desarrollo por el publicado, basado en la conexión receptiva de espíritu y vida? Pues, sencillamente, porque lo expuesto en el apéndice no le servía para su concepto de vida de un modo positivo, esto es, si en el apéndice Ortega lleva a cabo una

342"Apéndice: La reflexividad", en: Kant - Hegel -Scheler. Op. cit. p. 119.

343" En el centenario de Hegel" (1931). OC V, 421-420.

344" Apéndice: La reflexividad", en: Kant - Hegel-Scheler. Op. cit. p. 119.

345 Ibid. p. 121. 
crítica (en el contexto del tema de la reflexividad), en lo publicado lleva a cabo una recepción.

La crítica a la reflexividad en lo que refiere al pensamiento, a la conciencia, es decir, la reflexividad como reflexión, ya la ha expuesto tanto en los cursos sobre ¿Qué es filosofía? como en las lecciones ¿Qué es conocimiento?, y ha mostrado el paso siguiente: el paso de la crítica de la reflexión hasta la afirmación del carácter transitivo y entitativo de la reflexividad de la vida. En el texto publicado que sustituyó en 'En el centenario de Hegel" a ese apéndice Ortega ya cuenta con esa parte, con la negativa, de crítica: ya ha tratado en innumerables ocasiones el tema de la superación del idealismo. Ahora lo que le interesa es la recepción de parte de sus temas, entre ellos, este carácter de la reflexividad dinámica del espíritu hegeliano. La superación siempre será hegeliana, de negación, pero también de conservación, "el espíritu, por su esencia misma, es, a la par, lo más cruel y lo más tierno o generoso. [...] Superar es heredar y añadir"346.

En el texto publicado únicamente aparece la parte "positiva", el carácter de recepción, no la "negativa", de crítica. Se trata de aprovechar caracteres, de recibir a Hegel, no de insistir en el talante crítico de la superación. $\mathrm{O}$, de otro modo: en el texto publicado a Ortega, en realidad, le interesaba que el protagonismo lo tuviera su concepto de vida, no el hegeliano de espíritu. Si ante el carácter de reflexividad hay que mantener siempre las dos direcciones (reflexividad sí, pero no sólo: superación de la intimidad subjetiva, pero superación hegeliana, esto es, mantener esta intimidad junto a la apertura al mundo), con lo que el talante es siempre de por sí ambiguo, en las notas de trabajo se ve esta ambigüedad de un modo más claro.

Por un lado, escribía Ortega, "hay que superar la idea del Espíritu - la reflexividad"347, pero, por el otro, la unión en la vida de reflexividad y trascendencia, del saberse con el trascenderse, implican la cautela ante el tema, da que pensar: "La conciencia no es autoconciencia aunque pueda serlo. La conciencia abierta al mundo: no hay conciencia sin ser de que soy consciente. La reflexividad un caso particular de esto. Sin embargo, pensar

\footnotetext{
346. ¿ué es filosofía? (1929). OC VII, 421.

${ }^{347}$ Archivo de la "Fundación José Ortega y Gasset", Carpetilla "Hegel: filosofía de la historia". Conjunto de notas titulado "Detalles históricos".
} 
sobre este punto: la vida como reflexividad o el ser para sí"348. Esta vida como reflexividad la pensó Ortega en los escritos comentados, concordando incluso en los términos elegidos, $\mathrm{y}$, con respecto a Hegel, en "En el centenario de Hegel". El contexto siempre es el mismo: superar la conciencia como (únicamente) reflexión de sí para llegar a la vida como reflexividad transitiva o transitividad refleja.

348Archivo de la "Fundación José Ortega y Gasset", Carpetilla "Hegel: Dialéctica". 


\subsection{La reflexividad del Estado}

El tema de la reflexividad implica una segunda parte, una parte que corre el riesgo de ser entendida sólo parcialmente si no se tienen en cuenta las ideas propias de Ortega. El artículo sobre Hegel, en el fondo, está dividido en tres secciones temáticas: la reflexividad (de espíritu y vida, de conexión entre espíritu y vida), el Estado (el espíritu objetivo, la libertad, el Volksgeist) y el paisaje (la geografía, la limitación, la nación). El paso del tema de la reflexividad en relación con el espíritu y la vida, al tema del Estado, es en cierto modo extraño. Acudiendo a Hegel es fácil de explicar: el espíritu en la historia procede condensándose en los grandes pueblos, cada uno de éstos es "una interpretación de sí mismo que el espíritu ensaya"349. Del mismo modo que la vida es interpretación de sí misma, el espíritu en la historia es una interpretación de sí a través de sus concreciones y ensayos en los espíritus nacionales.

Sin embargo, ¿dónde queda el paso a ese tema partiendo no de Hegel, sino de los caracteres de la vida que ha presentado Ortega, la reflexividad de vida y no la del espíritu? Pues queda, por un lado, en la temática de la interpretación: la vida se interpreta a sí misma, el espíritu se interpreta a través de los espíritus nacionales. De hecho era ésta una de las cosas que más interesaban a Ortega de Hegel, el momento en el que los pueblos son concebidos como sensibilidades vitales, como interpretaciones y justificaciones de vida: "Que cada época o pueblo es en definitiva una nueva «idea» o sensibilidad de la vida"350, o, como lo expone en el artículo, "cada uno de los grandes pueblos ha consistido en ser una nueva interpretación. Por eso, porque va «inspirado» por una idea unitaria y original, consigue llegar a una fuerte disciplina e imponerse durante una época en la historia universal"351. A Ortega, más incluso que el hecho de que sean los grandes pueblos los que

\footnotetext{
349" En el centenario de Hegel" (1931). OC V, 423.

350 Archivo de la "Fundación José Ortega y Gasset", Carpetilla "Hegel: filosofía de la historia". Conjunto de notas titulado "Detalles históricos".
}

351"En el centenario de Hegel" (1931). OC V, 421. Es de este modo como interpreta Ortega la idea hegeliana de que cada pueblo sólo puede ser una vez dominante en la historia universal. Para Ortega, ese pueblo particular se impone porque tiene una idea unitaria y original de vida; para Hegel, porque "sólo una función puede serle encomendada en el proceso del espíritu": "Welthistorisch kann ein Volk nur einmal das herrschende sein, weil ihm im Prozesse des Geistes nur ein Geschäft übertragen sein kann". HEGEL, Vorlesungen über die Philosophie der Weltgeschichte. Op. cit. p. 163. Ortega no escatima las críticas a esta idea de Hegel: "Por eso en la historia no ha triunfado en cada época más que un pueblo: porque sólo en él 
muestran la pluralidad de sensibilidades vitales, de interpretaciones de vida, le interesa sobre todo esa pluralidad misma, esto es, la capacidad de la historia para presentarse desplegando la pluralidad de vidas, la pluralidad de limitaciones, de sensibilidades diversas en el modo de ver el mundo.

Pero, por otro lado, está la conexión entre el Estado y la reflexividad, según la interpretación de Ortega. Esa interpretación no se encuentra en el artículo sobre Hegel, sino, de un modo explícito, en un párrafo de 'El hombre a la defensiva", artículo de 1929, publicado en el contexto del tema de América (o, mejor, de Argentina), en el contexto temporal de todos los escritos que estamos comentando. Allí escribía Ortega: "En el Estado la nación se mira a sí misma, o, dicho de otra forma, lo que el Estado sea en una nación, simboliza la idea que esa nación tiene de sí misma. En este punto no lay inconveniente en aceptar la tesis de Hegel, previa extirpación de sus raíces metafísicas. El Estado es la reflexividad nacional"352. Más arriba aparecían las críticas de Ortega al concepto hegeliano de Estado, así como la teoría orteguiana de la relación entre Estado y nación. La conexión que se establece ahora entre Estado y nación remite a esas temáticas, pero mediadas por el concepto de reflexividad, una reflexividad extirpada de sus raíces metafísicas, es decir, una reflexividad vital.

El Estado como reflexividad nacional debe ser entendido en los términos de Ortega, no en los de Hegel. El contexto en el que aparece esa tesis se sitúa en el comentario de Ortega a la idea de Estado que encontró en Argentina. Ésta iría por delante de la realidad social del país, con lo que se produce un anacronismo entre los dos polos, que muestra, por un lado, la gran idea que el pueblo argentino tiene de sí mismo, pero, por el otro, la valoración exagerada de la idea de Estado, que puede conducir a consecuencias peligrosas, el peligro del estatismo. Esa exageración Argentina la habría recibido de la situación actual europea, la situación del año 29, que ha olvidado que "no hay nada más peligroso para una nación o conjunto de ellas, que pasar la raya en la intervención y atoritarismo del Estado"353. Ante esta situación Ortega presenta su tesis del Estado como reflexividad vital de la nación.

actuaba el Espíritu, que lo necesitaba como un peldaño para su genial ascensión hasta la pura idea de sí mismo. Una vez que ha usado de ese pueblo, el Espíritu lo abandona, y el pobre pueblo triunfante un día queda anulado históricamente". "En el centenario de Hegel" (1931). OC V, 423.

352" El hombre a la defensiva" (1929). OC II, 643-644.

353 Ibid. p. 646. 
El Estado simboliza la idea que la nación tiene de sí misma, pero siempre que haya sido la nación, a través del dinamismo y la tensión de su vitalidad, la que haya llevado hasta ese Estado determinado. La reflexividad vital que rige la relación entre Estado y nación se basa en los caracteres que Ortega ha encontrado en el espíritu y conectado con los de la vida: la agilidad, el esfuerzo, la inquietud, los rasgos transitivos de la reflexividad. La vitalidad de la nación debe ser previa a la idea del Estado. El Estado como reflexividad nacional debe ser entendido en los conceptos dinámicos de la reflexividad vital: el Estado como dinamismo nacional, el Estado como tensión y esfuerzo de la nación, "en la historia triunfa la vitalidad de las naciones, no la perfección formal de los Estados"354. Esa vitalidad es la que se encuentra bajo la reflexividad nacional extirpada de raíces metáfisicas: esa vitalidad de la nación, de la sociedad, es la reflexividad ágil y dinámica que debe guiar al Estado.

Ortega, aunque haya admitido para su concepto de vida ciertos caracteres del espíritu hegeliano, no pasará por alto la crítica al estatismo que según él se encontraba en Hegel. En las notas de trabajo, hablando de la hegeliana razón de Estado, escribe únicamente una frase: "su maquiavelismo, su inmoralismo en beneficio del estatismo"355 y en 1931 (el año, por tanto, de 'En el centenario de Hegel"), en el discurso pronunciado en las Cortes Constituyentes el 4 de septiembre, mostrando la necesidad de dotar al Estado con armas fuertes para enfrentarse a poderes nuevos en el momento, las grandes organizaciones financieras y económicas, decía: "Frente a esos poderes, hasta ahora desconocidos en la historia, es menester pertrechar de armas fuertes al Estado, para que se defienda de ellos y los sojuzgue. Esto, como todo, tiene su riesgo: la vida es riesgo, y es peligro; esto puede llevar al estatismo, a la estatolatría y a que el poder público aplaste al individuo. Si esta ocasión llega, el Estado morirá"356. Ya lo había mostrado en La rebelión de las masas, en la crítica feroz al estatismo y al intervencionismo del Estado en el capítulo "El mayor peligro, el Estado".

Partiendo de estos temas es como hay que llegar hasta lo que he considerado la segunda sección temática del artículo sobre Hegel, una sección que se situaría alrededor de los caracteres de Volksgeist y espíritu objetivo. Aunque estos conceptos vienen apareciendo

\footnotetext{
354 Mirabeau o el político (1927). OC III, 631.

355Archivo de la "Fundación José Ortega y Gasset", Carpetilla "Hegel - Filosofía de la historia".
} 
desde el comienzo en contextos determinados, la situación ahora adquiere un sentido especial, en tanto Ortega los analiza, primero, en el marco de la relación entre geografía e historia, y, segundo, explícitamente dirigido por sus propias teorías. Del mismo modo que ha utilizado el concepto hegeliano de espíritu para ponerlo en contacto con el suyo de vida, ahora llevará a cabo un procedimiento similar en torno a esta serie de temas.

356 Rectificación de la República (1931). OC XI, 376. 


\subsection{El Volksgeist}

La vida es interpretación de sí misma. Intenta encontrar ideas, teorías, culturas, ciencias, etc., que le permitan sostenerse y actuar en el mundo, un mundo que le causa constantemente problemas. El espíritu también es interpretación de sí mismo, pero no para saber a qué atenerse en la vida; en la interpretación del espíritu se muestran los distintos estadios en los que progresa hasta su llegada a sí. Tales interpretaciones son los pueblos, y su desarrollo aparece manifestado en la historia universal. El espíritu ha tenido que superar su extrañamiento en la naturaleza, su estar fuera de sí. La naturaleza es el sometimiento al aquí y ahora, a las leyes del espacio-tiempo; el espíritu es ubicuo y eterno, no un estar-ahí, sino un estar en sí y sobre sí.

Por todo ello, como ya insistía Ortega en el artículo sobre América, la naturaleza es esencial pre-historia, el escenario donde el espíritu y la razón se han perdido y tratan constantemente de regresar a sí mismos: "en esta peregrinación del espíritu por la naturaleza queda calificado por ella, influido por dla, y en este proceso terrenal del Espíritu consiste para Hegel la historia"357. El espíritu se multiplica en los distintos pueblos al ser cribado por la naturaleza: el espíritu se naturaliza, nace, se nacionaliza, al adscribirse a un territorio, a un espacio, "al hacerse «nacional» el Espíritu «nace» -y porque nace, muere, como un animal. Nat-uraleza es lo que nace"358.

De este modo introduce Ortega, a través de la relación entre espíritu y naturaleza, el tema de la geografía en la historia, del paisaje, pero también, aunque únicamente de pasada, insinuado, el concepto del Volksgeist: "Esta es la famosa idea del Volksgeist, del «espíritu nacional», que constituye, sin duda, una de las creaciones más originales del romanticismo alemán (Herder, Fichte, Schelling, la escuela histórica). El personaje único -Espíritu- se pluraliza en los «espíritus nacionales» de los grandes pueblos verdaderamente históricos -y no prehistóricos o «naturales»-: China, Egipto, India, Persia, Grecia, etc." 359 . No deja de ser extraño que Ortega no trate de un modo más detenido el concepto de Volksgeist en este

357" En el centenario de Hegel" (1931). OC V, 423.

358 Ibid.

359 Ibid. 
artículo, y no sólo por el interés explícito de Ortega por el tema, sino también porque en las notas de trabajo se muestra en innumerables ocasiones.

El Volksgeist ya ha aparecido varias veces en este trabajo, situado en distintos contextos temporales y temáticos de la biografía filosófica de Ortega: el Volksgeist como huella nacionalista del romanticismo, como sensibilidad vital, como muestra de la plenitud particularizada, etc. En el fondo se encuentra siempre la ambiguiedad de Ortega ante el concepto: por un lado el ataque a sus referencias nacionalistas, por el otro la afirmación de su sentido diferencial, particular, de una manera concreta de situarse en la vida. $\mathrm{O}$, de otro modo, el ataque al Volksgeist como limitación restrictiva, frente a su defensa como limitación positiva, la limitación que incluye el sentido de límite y la posibilidad de ver más allá de su propia sombra. Es el juego de limitaciones que, "curiosamente", Ortega expresará al final del artículo utilizando, en el contexto del paisaje, las tres configuraciones topográficas que toma de Hegel: meseta, valle y costa. Puede decirse que la intención de Ortega (que comentaré de un modo detenido más adelante) está clara: al presentar el concepto de espíritu nacional, o el de nación, o el de Estado, en el contexto del tema del paisaje, y, con él, de los juegos de límites y limitaciones, pretende aludir al talante positivo, abierto, integrador, de esos conceptos, no a la crítica al estatismo. De nuevo, entonces, la recepción en lugar de la crítica.

Aunque ahora aparezca de un modo muy breve, el concepto de Volksgeist es uno de los que más le interesaban a Ortega en la filosofía de la historia de Hegel. Y al lado del Volksgeist, el concepto de espíritu objetivo, el Estado o la vida social (Ortega entenderá por espíritu objetivo unas veces directamente el Estado, otras la sociedad; el rasgo común es ser todo aquello que supera y determina al espíritu subjetivo, al sujeto individual; de este modo, Ortega llegará incluso a definir el espíritu objetivo como "la cultura de Spengler"360). En las notas de trabajo es claro al respecto. Primero critica el imperialismo del espíritu, el plano metafísico que domina toda la filosofía de la historia de Hegel, para después escribir: "Mas tras ese plano metafísico hay lo verdaderamente rico y fecundo de la filosofía de la historia de Hegel. Son una serie de planos intermedios entre ése y la simple historiografía o filología. Conceptos como el de espíritu objetivo que hace posible el de

\footnotetext{
360Archivo de la "Fundación José Ortega y Gasset", Carpetilla "Hegel: Filosofía de la historia". Conjunto de notas titulado "Más teoría general, con puntos críticos".
} 
Volksgeist"361. Podría afirmarse una "ley histórica" dentro de la exposición filosófica de Ortega: cuanto más le interesa un tema o un concepto de un determinado autor, menos lo expone, y no con la intención de ocultarlo, de esconder sus "fuentes", sino con el fino propósito de utilizarlo convertido a sus propios términos e intereses, esto es, de recibirlo.

El concepto de Volksgeist merece un examen especial, porque puede decirse que tiene una historia propia a lo largo de la filosofía de Ortega. En el artículo sobre Hegel se limita a afirmar que es una de las ideas más originales del romanticismo alemán, y, sin embargo, ese originalidad sólo puede ser entendida desde dos puntos: en relación a Hegel, desde las notas de trabajo y en relación a la teoría filosófica de Ortega en general, desde el resto de sus obras.

Por lo que respecta a Hegel, Ortega entiende el Volksgeist sobre todo en relación con el aspecto geográfico de la historia, el contexto donde se desarrolla el artículo "En el centenario de Hegel". Ortega entiende el Volksgeist, el espíritu del pueblo, también como espíritu nacional, al insistir en la relación en Hegel de pueblo y nación, que parte de la diversificación del espíritu en sus particularidades al ser tamizado por la naturaleza. Es este carácter de particularización, de pluralidad de las sensibilidades, de las distintas manifestaciones del Volksgeist lo que realmente interesa a Ortega, dejando aparte el sentido hegeliano de que esas manifestaciones no son más que niveles en el progreso del espíritu hacia su conciencia de sí. De este modo, Ortega lee las palabras de Hegel: "...jedes Volk, das die Repräsentation einer besondern Stufe der Entwickelung des Geistes ist, eine Nation ist; ihre natïrliche Beschaffenheit entspricht dem, was das geistige Prinzip in der Reihe der geistigen Gestaltugen ist"362. Lee esas palabras, pero las recibe de un modo determinado: el Volksgeist es sensibilidad vital, no es espíritu de raza, sino que es "sobre-étnico"363, cada pueblo es la unidad de su Geist, su tierra, su raza, su materia, no el efecto de ellos.

El concepto hegeliano de Volksgeist, que de un modo u otro remite a los niveles o estadios en el desarrollo del espíritu, en Ortega adquiere el rango de particularidad

\footnotetext{
361 Archivo de la "Fundación José Ortega y Gasset", Carpetilla "Hegel - Filosofía de la historia".

362HEGEL, Vorlesungen über die Philosophie der Weltgeschichte. Op. cit. p. 179. Traducción: "Todo pueblo, siendo la representación de un grado particular en la evolución del espíritu, es una nación; su contextura natural corresponde a lo que el principio espiritual significa en la serie de las formas espirituales". HEGEL, Lecciones sobre la filosofía de la historia universal. Op. cit. p. 162.

363 Archivo de la "Fundación José Ortega y Gasset", Carpetilla "Hegel - Filosofía de la historia".
} 
concreta, determinada, no de simple evolución hacia otro estadio. Es el carácter que veíamos más arriba: cada evolución particular incluye su propia norma de perfección, cada sensibilidad vital es propia, singular, particular, y no únicamente un momento hacia otra. Cada pueblo tiene un fin propio, un ideal, un proyecto, existe una plenitud de los tiempos, en plural, no únicamente la unicidad hegeliana del tiempo pleno. Es precisamente por esto, como veremos, por lo que Ortega une los conceptos de pueblo o nación y su paisaje. No se trata de simples caracteres geográficos, sino del ideal particularizado, las perfecciones propias a las que tiende cada sensibilidad vital, "la tierra prometida es el paisaje prometido"364, el paisaje no es un espacio hecho, es un espacio a hacer, un ideal. En este sentido se entenderá la estética política del paisaje.

Para Ortega, el concepto hegeliano del Volksgeist se puede resumir en una sola frase: "Volksgeist: insuficiente, pero realidad"365. La realidad refiere a su carácter de espíritu particularizado, de sensibilidad vital propia de cada pueblo, de pluralidad en los modos de acercarse al mundo. La insuficiencia refiere a que Hegel sólo atiende al Estado y la religión, a que olvida la realidad vital sobre la que éstos se asientan, a que pasa por alto la realidad histórica del individuo y la vida individual, a que, en el fondo, entiende las sensibilidades vitales como trayectos en la formación del espíritu, no como singularidades propias y particulares. En general, el Volksgeist como sensibilidad vital es admitido por Ortega, pero en su sentido en vez de en el de Hegel. Éste atendería únicamente a la evolución de los distintos niveles en el desarrollo del espíritu, a Ortega le interesaría mucho más atender a la evolución propia, a la evolución inferior de cada sensibilidad vital, de cada Volksgeist, atender a la realidad-vida sobre la que se sostiene: "Historiológicamente sería de más interés que insistiese Hegel sobre los estadios de la evolución inferior de un Volksgeist, cosa que no hace"366.

El carácter de Volksgeist como sensibilidad vital implica entender el concepto no como fuente, como explicación de las distintas particularidades de pueblos o naciones, sino como producto, como resultado. La sensibilidad vital, sostenida por el ideal o norma de

\footnotetext{
364" En el centenario de Hegel" (1931). OC V, 425.

365Archivo de la "Fundación José Ortega y Gasset", Carpetilla "Hegel - Filosofía de la historia".

366Archivo de la "Fundación José Ortega y Gasset", Carpetilla "Hegel: Filosofía de la historia". Conjunto de notas titulado "Defectos de dinámica".
} 
perfección particular que hay que hacer, que es futuro y no pasado, explica el carácter de resultado, el carácter de producto que supone el Volksgeist. Entre otra serie de notas de trabajo, realizadas por Ortega sin duda para el tema del nacionalismo, de la nación, con la referencia explícita a Meinecke y que son, en concreto, las notas que darán lugar a la Meditación de Europa, se encuentra una que lleva por título directamente Volksgeist". Son notas de una época muy posterior a las que estamos manejando, pero en la referencia a Hegel que aparece junto al tema del Volksgeist puede verse que el modo de entenderlo por Ortega parte ya de la lectura de Hegel que está llevando a cabo en estos años, finales de los veinte principios de los treinta.

En esas notas explicita Ortega el carácter de producto, de resultado, del Volksgeist, y remite directamente a Rosenzweig y su Hegel und der Staat, mostrando la conexión entre el Volksgeist y el "esprit national" de los franceses. Allí ha leído Ortega: "der Volksgeist erscheint ihm als Erzeugnis, als die sichtbare lebendige Gesamtheit einer nationalen Gesittung. [...] Denn der Volksgeist als Ergebnis - das trifft zusammen mit Montesquieus Bestimmnung des Esprit general" 367. El tema es importante porque muestra cómo, para Ortega, el Volksgeist, no es la causa latente y misteriosa de las formas de vida de un pueblo, sino el resultado, el producto de los proyectos dinámicos, ideales, que ese pueblo mantiene. Ortega admite el carácter de libertad del Estado en su conformación como progreso de la historia, del espíritu, pero niega, como ya hemos visto, el carácter transhistórico, absoluto de esa libertad, y la remite al dinamismo y agilidad, a la tensión que debe incluir un pueblo en sus proyectos, en sus ideales.

Es ese dinamismo el que precisamente une los caracteres históricos, la conjunción de pasado y futuro de ese pueblo, así como los rasgos de agilidad y esfuerzo que ha encontrado en el concepto hegeliano de espíritu. Escribe Ortega: "Lo que existe es la voluntad nacional de que en continuidad con las determinaciones de su pasado se constituya la nación en un Estado históricamente deseable, ejemplar - en este sentido,

367ROSENZWEIG, F. Hegel und der Staat. München und Berlin: Oldenbourg, 1920, p. 23. Traducción: "El Volksgeist se le muestra [a Hegel] como producto, como la totalidad viva manifiesta de una civilización nacional. [...] El Volksgeist como resultado coincide con la determinación del Esprit general por parte de Montesquieu". 
perfecto"368. Este carácter ideal en el proyecto, en lo deseable, que explica los caracteres de dinamismo y agilidad de la nación, se encuentra ya en el tratamiento del Volksgeist en la lectura de Hegel: el Volksgeist como sensibilidad vital se asienta en los caracteres de futuro, de ideal a realizar, que constituyen el sentido propio, particular, de esa sensibilidad.

A partir de estas temáticas se entiende la evolución de Ortega en su idea del concepto de Volksgeist. El fondo siempre será la ambiguiedad en la recepción: por un lado la crítica a los talantes nacionalistas, por el otro la afirmación de la pluralidad de las sensibilidades vitales, que deben incluir tanto su limitación como su límite, la apertura de esa limitación. De otro modo: el concepto de Volksgeist en la recepción de Ortega siempre debe ser entendido al lado de los ideales de proyecto, de los programas de futuro; el Volksgeist no es causa de nada, sino unidad de todos los caracteres que determinan una sensibilidad vital, el Volksgeist no está nunca finalizado, sino que hay que hacerlo constantemente, del mismo modo que toda sensibilidad vital en el contexto de un pueblo parte siempre de sus talantes de futuro. El concepto de "nacionalismo futuro" que mostraba Ortega en las lecciones del 28 en Buenos Aires estará constantemente en la base.

Es por esto por lo que, en 1930, un año antes del artículo sobre Hegel y comentando el concepto de ideología, presenta Ortega al Volksgeist en relación, primero, con el carácter evolutivo de la razón en la historia, y, segundo, con la justificación de la pluralidad y singularidad de las opiniones o sensibilidades de vida: "Al mostrar cómo la razón, sin perder su última unidad, vive evolutivamente, toma diferentes aspectos en épocas y pueblos, justifica la pluralidad de opiniones. Cada «espíritu popular»-Volksgeist- posee una ideología propia inexorable e inalienable"369. Las referencias a Hegel en ese texto son claras. Y las intenciones de Ortega también: si lo que realmente le interesa del concepto de Volksgeist es el carácter plural y particularizado, singular pero abierto, de las pueblos, de las épocas, de las sensibilidades vitales, se trata de quedarse únicamente con ese sentido, desprendiendo al Volksgeist de todo talante nacionalista. En este contexto, Ortega concretará todo el tratamiento del Volksgeist romántico-nacionalista que veíamos en la

\footnotetext{
368Archivo de la "Fundación José Ortega y Gasset", Carpetilla "Volksgeist, Meinecke, etc.". Rollo 11, caja 8. 369" No ser hombre de partido" (1930). OC IV, 82.
} 
primera sección, en las primeras apariciones del término en la filosofía de Ortega. Se tratará de afirmar el carácter plural, no el restrictivo.

El final del trayecto en esa evolución del concepto de Volksgeist en la filosofía de Ortega aparecerá en el Toynbee, cuando directamente afirme que el espíritu nacional "no era nada que tuviera que ver con el «nacionalismo»"370. Antes de llegar hasta ahí, Ortega ha ampliado el concepto de Volksgeist, remitiendo más que a Hegel a la escuela histórica, y mostrando (e insistiendo en ello) que la idea no es originaria del romanticismo alemán, sino del esprit des nations francés 371 (más arriba he mencionado las referencias de Ortega a Rosenzweig en este sentido). La idea la utiliza Ortega para criticar la supuesta originalidad de la escuela histórica, pero también para alcanzar un punto en que el Volksgeist quede exento de los talantes nacionalistas y basado únicamente en caracteres de sensibilidad vital y pluralidad de opiniones, siempre abiertas al contacto; llegar a un punto en el que el Volksgeist se asiente nada más y nada menos que en el universalismo, no en el nacionalismo.

El interés de Ortega por criticar la supuesta originalidad de la escuela histórica no es un simple ataque por cuestiones de diferencia en el modo de entender la historia (las diferencias que he presentado en el análisis de 'La «Filosofía de la historia» de Hegel y la historiología"), sino también para mostrar que el concepto de Volksgeist tiene su origen precisamente "en el siglo menos nacionalista de toda la historia europea, a saber, en el siglo XVIII, y dentro de él por el hombre más universalista que ha habido nunca, a saber: por Francisco Arouet, dicho Voltaire. Aquella idea goza, en efecto, su primera epifanía en el título de su obra famosa: Essai sur l'histoire générale et sur les moeurs et l'esprit des

\footnotetext{
370 Una interpretación de la historia universal. En torno a Toynbee (1948-1949, curso). OC IX, 235.

371"Guillermo Dilthey y la idea de la vida" (1933). OC VI, 182: "Para no tomar sino un ejemplo, ¿cuál es el pensamiento de Savigny? El derecho es fundamentalmente derecho consuetudinario -moeurs, diría Voltaire- que emana de un «espíritu nacional»-Volksgeist-Voltaire diría esprit des nations. Por eso he indicado antes que la «escuela histórica», en última instancia, no añade ningún principio al siglo XVIII, y surge, más bien, por una operación de resta: desentenderse de la raison"; La rebelión de las masas. Prólogo para franceses (1937). OC IV, 126 n.: "El término Volksgeist muestra demasiado claramente que es la traducción del volteriano esprit des nations"; El hombre y la gente (1949-50). OC VII, 199: "No se ha subrayado debidamente cómo ese concepto alemán del espíritu nacional no es sino el heredero de la idea que lanzó sugestivamente Voltaire en su genial obra, titulada: Essai sur l'histoire générale et sur les moeurs et l'esprit des nations. El Volksgeist es el espíritu de la nación".
} 
nations. Los franceses no hicieron, por lo pronto, otra cosa que traducir literalmente esprit des nations por Volksgeist" 372 .

Hasta este punto llegarán, entonces, los tratamientos del Volksgeist, iniciados en las dos primeras décadas del siglo alrededor de la temática de la relación España-Europa, proseguidos en la lectura de Hegel y la constitución del Volksgeist como sensibilidad vital, y culminados ahora, en los años cuarenta, remitiendo al universalismo de la pluralidad de opiniones, de limitaciones, de sensibilidades vitales en los modos de ver el mundo. Esos tratamientos constituyen en su desarrollo la muestra de la necesaria conversión para Ortega de la limitación cerrada en limitación-límite, limitación, pero plural, basada en un proyecto de futuro, asentada en los contactos, en el universalismo de las múltiples vistas particulares.

372Una interpretación de la historia universal. En torno a Toynbee (1948-49, curso). OC IX, 236. 


\subsection{El espíritu objetivo}

El tema del Volksgeist, en lo que respecta exclusivamente a Hegel, tiene un compañero temático ineludible: el concepto de espíritu objetivo. El espíritu objetivo une en la recepción de Hegel por Ortega el tratamiento del Volksgeist, del Estado y de la prioridad de lo real ante el sujeto. No se trata únicamente del descubrimiento de lo social como ámbito que debe mantenerse al lado de la realidad histórica de los individuos, sino también de la afirmación del carácter objetivo de lo que hasta entonces había sido concebido como objetivado, es decir, en el fondo, como subjetivo. Es así como recibirá Ortega el espíritu objetivo hegeliano: "Que el individuo vive de actualizar en sí lo que es objetivo"373. El tema remitirá en Ortega, aunque no lo hará explícito, a la relación de individuo y sociedad, a la conexión de ideas y creencias (no hay que olvidar que "En el centenario de Hegel" fue introducido por Ortega en el volumen Ideas y creencias) y, en general, a todo aquello objetivo, externo, de vida social e histórica, que determina la vida individual.

Para analizar el concepto de espíritu objetivo, de nuevo, hay que acudir más que al artículo sobre Hegel, al apéndice eliminado. El tema que une ambos contextos es el concepto de Estado, y es éste el que realmente aparece en 'En el centenario de Hegel". Si con el Volksgeist Ortega pretende mostrar el talante de sensibilidad vital que se encuentra en su base, con el de espíritu objetivo presentará la serie de interpretaciones del espíritu en su manifestación histórica no en conexión con los espíritus nacionales, con el Volksgeist, sino directamente con el concepto de Estado: "Fuera de cada individuo hay una realidad que no es material sino espiritual y que por otra parte no es ningún sujeto individual: es el Estado. El Estado es espíritu pero objetivo. Cada pueblo es un espíritu objetivo, es decir, un sistema de ideas jurídicas, morales, científicas, artísticas del cual beben los individuos, en el cual se informan. La realidad del Espíritu subjetivo, del hombre individual, no está en él sino en el espíritu de su pueblo"374. Esa es la conexión entre el espíritu objetivo y el espíritu del pueblo. El interés de analizar el espíritu objetivo después del concepto del

\footnotetext{
373Archivo de la "Fundación José Ortega y Gasset", Carpetilla "Hegel: filosofía de la historia". Conjunto de notas titulado "Detalles históricos".

374"Apéndice: La historiología", en: Kant - Hegel - Scheler. Madrid: Revista de Occidente en Alianza Obras de José Ortega y Gasset, 23-, 1983, p. 123.
} 
Volksgeist tiene, ahora, una razón concreta: el espíritu objetivo conduce directamente al tema de la limitación.

Más arriba indiqué que, en el fondo, la temática que subyace al concepto del espíritu objetivo en Ortega es el problema de la libertad. También han sido examinadas las críticas de Ortega a todo tipo de estatismo. En este momento confluyen todas las referencias. Teniendo en cuenta todo lo visto (la crítica a la Libertad con mayúscula, la libertad vital que presenta Ortega, la relación del espíritu objetivo con el "pensamos con las cosas", la crítica al estatismo, etc.), es preciso acudir al tratamiento explícito del tema centrado en el contexto de la limitación.

Ortega insiste en que para Hegel la historia es el progreso en la conciencia de libertad 375 . El tema ha aparecido también en el "Hegel y América": para Hegel, la verdadera libertad es la del que se manda a sí mismo, no la del que simplemente se libera de algo. Libre es el que se da a sí mismo la ley, y esto únicamente puede hacerlo el Estado376. Por ello, el espíritu no aparece en el mundo teniendo realidad efectiva más que en la forma de Estado: los individuos históricos para Hegel son los pueblos, mientras que los individuos singulares no son históricos. En este contexto se presenta la bidireccionalidad de la recepción del concepto de espíritu objetivo por parte de Ortega: por un lado se critica esa desaparición del individuo, por el otro se apoya la idea de que, en el fondo, el individuo está determinado por el contorno social, objetivo. La explicación es sencilla: se critica la desaparición del individuo en la filosofía de la historia hegeliana, se comparte la idea de que el individuo particular constantemente actualiza lo objetivo.

La libertad, en Hegel, corresponde únicamente al Estado porque éste se determina a sí mismo. El individuo, por su parte, está constantemente atravesado por el espíritu objetivo: "La individualidad del sujeto es una idea parcial. Cree cada cual consistir en sí mismo pero nuestras ideas, preferencias, deseos, normas nos vienen, en su inmensa mayoría, impuestas

375HEGEL, Vorlesungen über die Philosophie der Weltgeschichte. Op. cit. p. 135: "Die Weltgeschichte stellt nun den Stufengang der Entwicklung der Prinzips dar, dessen Gehalt das Bewusstsein der Freiheit ist".

376 Ortega en este momento está teniendo en cuenta tanto la Filosofía de la historia como la Filosofía del derecho: "...die Idee der Freiheit wahrhaft nur als der Staat ist". HEGEL, Grundlinien der Philosophie des Rechts. Hrsg. G. Lasson. Leipzig: Meiner, 1928, § 57, p. 62. De todos modos, su interés, más que referirse a los contenidos de la filosofía del derecho de Hegel, filosofía del espíritu objetivo, se centran precisamente en el hecho de que el espíritu pueda ser objetivo, esto es, en la relación entre algo externo, social, comunitario, estatal, y algo individual constantemente determinado por ello. 
por el contorno social" 377 . Esta tesis la admitirá Ortega, la tesis de que constantemente vivimos de ideas, convicciones, normas, etc., que nos preceden, que se refieren a la constitución objetiva de la vida social e histórica, pero no admitirá la consecuencia de Hegel: que de esa tesis se deduzca que sólo es libre el Estado, y que lo es porque se determina a sí mismo. Por ello, afirmará Ortega, "Hegel combate la idea, a un tiempo inglesa y mediterránea, de la libertad que nos hace pensar en un mero «libertarse de», en un movimiento de evasión y fuga"378. A partir de aquí se entiende la crítica de Ortega que veíamos más arriba: la crítica a la libertad como autodeterminación, como soledad, como limitarse a sí mismo, y también a partir de aquí surge el tema de la limitación en relación con el de la libertad.

Si la idea mediterránea de la libertad es un movimiento de evasión, y la de Hegel un movimiento inverso, de vuelta a sí, de ensimismamiento, Ortega afirmará la libertad en la pluralidad, libertad como estatuto del ser en pluralidad, en los contactos, en los juegos de límites y limitaciones:

\footnotetext{
"Para los alemanes, un poco asiáticos siempre, panteístas, libertad es un negarse a sí mismo, un limitarse a sí mismo o autodeterminarse. Ahora bien, yo no puedo limitarme a mí mismo si no es aceptando algo distinto de mí que me limite; por tanto, aceptando en mí a lo demás, a los demás, llenándome con lo otro, con los otros, integrándome, desindividualizándome, generalizándome; en suma, fundiéndome con lo que queda fuera de mí, con los prójimos de mi pueblo y formando con ellos la unidad colectiva de una nación"379.
}

En ese texto, Ortega concreta las dos direcciones en su recepción del espíritu objetivo. Por un lado, "acepto lo demás", acepto las cosas, las veo frente a mí, limitándome, y les presento mis respetos, mi fidelidad, no pretendo situarlas en mi interior, no pretendo subjetivarlas; por el otro, "acepto a los demás", que me limitan, me constriñen, pero a la vez me permiten generalizarme, integrarme en un pueblo, en una misma sensibilidad vital. Es la constante crítica de Ortega en las notas de trabajo: el espíritu objetivo es perfecto... siempre que no se entienda objetivo como objetivado, refiriendo eso objetivo tanto a las cosas, a la realidad, a la relación del sujeto con los objetos, como a lo social, al constante influjo de lo

377" Apéndice: La historiología", en: Kant - Hegel-Scheler. Op. cit. p. 123.

378" En el centenario de Hegel" (1931). OC V, 426.

379" Apéndice: La historiología", en: Kant - Hegel-Scheler. Op. cit. p. 124. 
general. Por esto escribía Ortega en las notas de trabajo: "No me gusta término: espíritu objetivo. Objetivo: existe para un sujeto"380. Constantemente se vive actualizando lo objetivo, pero no negándole su condición de objetivo, de externo a mí. Ortega, entonces, entiende el espíritu objetivo no refiriéndolo únicamente al Estado, a lo social, a eso que me precede y determina, sino también en relación con la realidad objetiva misma. Es por ello por lo que más arriba entendíamos el "pensamos con las cosas" en referencia al espíritu objetivo.

A partir del espíritu objetivo y de la relación hegeliana entre Estado, libertad e historia, Ortega presenta, entonces, una teoría propia de la limitación que, en el fondo, determinará el resto del artículo sobre Hegel, esas referencias a las constituciones topográficas de meseta, valle y costa. La tesis de Ortega es la que he venido mostrando desde el comienzo: la limitación implica siempre algo externo, sea un objeto, sea un individuo, sea la realidad social, que me limita, y el juego consiste en aceptar esa limitación superándola al convertirla en límite, al posibilitar la integración y la generalización con lo otro y con los otros. Es la unidad de individualidad y generalidad que pretendía Ortega con el concepto de vida, unidad que para él Hegel no consiguió alcanzar. En ¿Qué es filosofía? lo mostraba de un modo explícito: "«Mi vida», aplíquese este nombre a mi caso o al de cada uno de ustedes, es un concepto que desde luego implica lo individual; de donde resulta que hemos encontrado una idea rarísima que es a la par «general» e «individual». [...] El mismo Hegel, que quiso buscar algo parecido, no lo logró: su «universal concreto» es, a la postre, universal y no verdaderamente, radicalmente concreto, no es individual"381.

Hay que tener en cuenta, además, que, si en el texto citado Ortega remite únicamente a la superación de la limitación al fundirme con los otros en la unidad colectiva de una nación, el tema debe ser ampliado a la fusión precisamente entre naciones. La superación de la limitación nacional, el henchimiento de esa limitación, a través de la fusión con las otras. Es el universalismo que culminaba la evolución en el pensamiento del Volksgeist. El nacionalismo como limitación deviene limitación positiva, limitación-límite, al mantener la fusión con lo otro que lo limita, con eso objetivo que de ningún modo puede subsumirse bajo los intereses particularistas, sean de un sujeto para con las cosas, sean de una nación

380Archivo de la "Fundación José Ortega y Gasset", Carpetilla "Hegel - Filosofía de la historia". 
para con las otras. Al confluir, en la recepción que Ortega lleva a cabo del concepto de espíritu djetivo, por un lado la determinación de lo objetivo como lo social o el Estado, con la determinación de lo objetivo como realidad objetiva misma, por el otro, entonces confluyen también el universalismo con el que concluía el concepto de Volksgeist, o la fusión de limitaciones nacionales que se desprendía de la teoría de la libertad, por un lado, y ese otro universalismo, el principio de pantonomía o ley de totalidad, que mostraba Ortega en ¿Qué es filosofía?, por el otro.

Esa ley de totalidad decía que el filósofo pretenderá buscar siempre la verdad última de cada cosa, lo que cada cosa es en función de las demás. No es casual, entonces, que con ese principio de pantonomía, de universalismo, Ortega refiera a lo que él llama filosofía romántica: "El principio de pantonomía o universalismo sólo ha encontrado atención adecuada en algún momento del alma antigua y en el breve periodo filosófico que va de Kant a Hegel, la filosofía romántica"382. El universalismo, el afán hacia el todo, se presenta como un afán intelectual, pero también, en Ortega, como ese afán político de unidad de naciones e individualidades. Es el afán por negar todo tipo de exclusivismo, pero hacerlo afirmando las limitaciones en sus contactos: no perder particularidades, pero tampoco sus conexiones, los deseos de comunidad, de conjunción de miradas.

La afirmación del universalismo conduce a la definición del filósofo como "especialista en universos" 383 , pero esa definición también correspondería a Ortega en múltiples contextos: la conexión de perspectivas, la conexión de individuos, la conexión de naciones, la conexión de todo tipo de limitaciones... El nacionalismo futuro que aparecía más arriba es éste, el que afirma la limitación propia al negar todo tipo de exclusivismo y mantener todo su afán en el contacto con el resto de sensibilidades vitales.

El conjunto de estos temas concretos, del Volksgeist y el espíritu objetivo en sus componentes de universalismo y superación de limitaciones restrictivas, permite entender de un modo mucho más amplio la última sección temática de "En el centenario de Hegel", la parte que, centrada en el tema del paisaje y de la relación entre geografía e historia, analiza las tres configuraciones topográficas que presenta Hegel, meseta, valle y costa. El

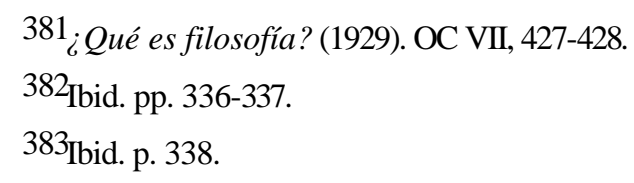


espíritu nacional conduce a la conexión de historia y geografía, a la interpretación del espíritu en sus momentos históricos, los pueblos, asentados sobre un territorio, sobre un espacio, sobre un paisaje. Al mostrar Ortega al Volksgeist y al espíritu objetivo, en su forma de Estado, como la plasmación de una sensibilidad vital en un espacio, incluirá con ello la temática de la superación de limitaciones, el universalismo que se desprende de ambos, en el contexto del tema del paisaje, con lo que se muestra la conexión con toda la primera sección del trabajo.

La geografía, entonces, en torno al tema del paisaje, presentará la parte positiva de la evolución en el concepto de limitación, evolución que concluirá en un límite inquieto que permita la superación de la propia Imitación. Ese límite inquieto lo encontrará Ortega en el tratamiento hegeliano de los pueblos asentados en las costas, al lado del mar, principio natural de lo inquieto. Pero si en Hegel estos caracteres topográficos responden a categorías histórico-geográficas definidas, en Ortega deben ser entendidos como metáforas de los juegos de límites y limitaciones, como metáforas de ese nacionalismo como limitación restrictiva convertido en limitación como límite. El tema del paisaje será el encargado de mostrar ese desarrollo, con lo que las connotaciones histórico-geográficas de Hegel pasarán a entenderse en Ortega en la base de una estética política de superación de limitaciones: el paisaje manifestando su capacidad para superarse a sí mismo al exigir el propio ideal, el propio carácter de futuro sobre el que se sostiene.

Ortega ha presentado el tema del Estado y del Volksgeist, ha dejado ver la crítica al estatismo y la consolidación del Volksgeist como sensibilidad vital. Al concluir el artículo con los juegos de límites y limitaciones que se sitúan al lado del tema del paisaje, mostrará la parte positiva, la recepción universalista y superadora de limitaciones. Que Ortega utilice esa relación entre meseta, valle y costa, y, con ellos, la relación entre un pueblo y su espacio, su paisaje, no pretende únicamente mostrar algo "bonito", o "curioso", de la filosofía de la historia de Hegel. Los intereses de Ortega son más profundos: se trata de la conversión de todo tipo de limitación en límite, del juego que concede el tema del paisaje al incluir siempre la percepturitio de Leibniz, las connotaciones de futuro que lo determinan.

Si se tiene en cuenta todo lo mostrado alrededor de los conceptos de Volksgeist y espíritu objetivo, así como la recepción del concepto hegeliano de espíritu al unirlo con el orteguiano de vida, podrá afirmarse que el final de "En el centenario de Hegel" es la 
postulación a través del propio Hegel de la estética política de la limitación que viene apareciendo desde el inicio. El tema del paisaje volverá a ser fundamental, pero ahora analizado a partir de las relaciones entre geografía e historia que Ortega encuentra en Hegel. De nuevo aparecerán paisajes, afinidades simbólicas, límites y limitaciones, paisajes como tierras prometidas, etc., toda la serie de temáticas que ya surgían en la primera sección alrededor del no escrito Ensayo sobre la limitación. En este momento, esas temáticas se reunirán con la remisión explícita a Hegel en uno de los artículos publicados, "En el centenario de Hegel". 


\subsection{La geografía estético-histórica de la limitación}

En la primera sección, comentando los escritos sobre el paisaje en el contexto de las dos primeras décadas del siglo, aparecían los caracteres determinantes que en torno al paisaje y la limitación presentaba Ortega desde el inicio de su filosofía. El paisaje era definido, con Leibniz, como percepturitio, con todas las connotaciones de futuro que esto supone; aparecía el paisaje en la necesidad de henchir la limitación propia, de su aceptación como patriotismo, pero mediante una aceptación que supone la ampliación, en tanto la fidelidad al paisaje implica también la fidelidad a su necesario contacto con otras limitaciones; aparecía el paisaje en sus connotaciones de paisaje prometido, de paisaje que hay que hacer, que hay que construir. Todo ello se situaba en el marco del tema de España y la relación con Europa, en especial, además, en el contexto de la primera guerra.

Ahora, en 'En el centenario de Hegel", muchos de esos caracteres permanecerán, pero el contexto ha cambiado. El marco es mucho más general: se establece en torno a las relaciones entre geografía e historia, es decir, en palabras de Ortega, la afinidad de un pueblo con su territorio, con el espacio que ocupa. El paisaje, en este momento, completa la serie de caracteres que Ortega presentaba en los escritos alrededor del año 10. Con lo visto en los capítulos anteriores, en especial el tema de la inquietud, de la agilidad que implican vida y espíritu, así como los caracteres universalistas que, en la lectura de Ortega, se desprenden tanto del Volksgeist como del concepto de espíritu objetivo, Ortega va a utilizar a Hegel para expresar una relación entre paisaje y limitación que supera la referencia al propio Hegel y que remite tanto al concepto de paisaje en el tratamiento llevado a cabo en aquellos textos alrededor de "Temas del Escorial", como a temáticas que Ortega ha iniciado en años posteriores y que ahora mostrarán su desarrollo en torno a este marco.

El contexto explícito en Hegel es el de la conexión entre historia y geografía. Ortega incluso titula así la sección, "Historia y geografía". Esto no tendría por qué llamar la atención, teniendo en cuenta que el capítulo de la Filosofía de la historia al que se va a dedicar Ortega es "Der Naturzusammenhang oder die geographische Grundlage der Weltgeschichte", y, sin embargo, tiene su importancia, por una razón explícita: diez años antes del artículo sobre Hegel, Ortega ha colocado el mismo título a una sección de "Temas de viaje". Ahí ha tratado los mismos temas, la relación entre geografía e historia, pero con 
una intención explícita: España. Si en el artículo sobre Hegel la sección se inicia con la dominación que el espíritu ejerce en la historia tal como la entiende Hegel, en "Temas de viaje" Ortega tiene unos intereses más cercanos: "No, la aridez climatológica de la Península no justifica la historia de España"384.

Para completar el recorrido hay que presentar otras dos referencias. La primera es un capítulo de la "Introducción a un «Don Juan»" titulado "La «razón geográfica» y una variación sobre Toledo"385, donde Ortega insiste en la afinidad entre cada forma de vida y su paisaje. La segunda aparecerá años más tarde, en el Toynbee, cuando Ortega, comentando el tema de las emigraciones y la relación del hombre con su espacio geográfico, se cite a sí mismo remitiendo tanto a "Temas de viaje", como a "En el centenario de Hegel"386. Ortega afirmará la prioridad respecto a Toynbee en el tratamiento del tema, aunque no referirá a Hegel. No es necesario: ya lo ha hecho en el artículo que nos ocupa.

Con esta serie de referencias, y antes de comenzar su examen, pueden presentarse una serie de pautas que dirijan el desarrollo. En primer lugar hay que afirmar que el hilo conductor que une todos los contextos es el concepto de paisaje. En segundo, que, aunque no aparezca en el artículo sobre Hegel de un modo explícito, el tema de España no se abandonará en ningún momento. Tercero, que no hay que olvidar que, para Ortega, siempre que aparece el concepto de paisaje, a su lado se muestran las connotaciones de futuro, de percepturitio, de ideal, de tarea futura, paisaje que hay que hacer. Y cuarto, que el conjunto del tema, además de las referencias históricas y geográficas, tiene unas connotaciones políticas fáciles de detectar, connotaciones políticas que, al situarse, de nuevo, en torno al tema del paisaje, conducirán a esa estética política de la limitación que se basa en la constante afirmación y superación de las limitaciones. Equipados con estos medios puede, de un modo muy determinado, recibirse la recepción que Ortega hace de Hegel en este tema.

La relación entre naturaleza y espíritu en la filosofía de Hegel se establece como la conexión entre dos momentos del despliegue del espíritu: su estar fuera de sí y su ser en sí,

384" Temas de viaje" (1922). OC II, 371.

385" Introducción a un «Don Juan»" (1921). OC IV, 128 
para sí. El hombre, la vida humana, se situaría en el límite entre ambos momentos, oscilando entre naturaleza y espíritu, entre estar fuera de sí y estar en sí: "Esto que Hegel insinúa se advierte muy bien en el hombre, que es, a la par, término de la Naturaleza e iniciación del Espíritu. Realidad fronteriza y oscilante, el hombre es unas veces lo uno, y otras, lo otro"387. Ortega tiene un interés especial en afirmar esa naturaleza fronteriza del hombre y volverá a incidir sobre ello unas páginas más adelante 388 , aunque es consciente de que para Hegel, el hombre, precisamente porque es espíritu, debe "sacudirse lo natural"389.

Ese interés no responde únicamente a las causas de ensimismamiento y alteración, esto es, de unión en el hombre de necesaria atención a lo natural y, también necesaria, salida o evasión de eso natural para recaer sobre sí. El hombre como realidad fronteriza se sitúa en un espacio límite que le permite la movilidad, el dinamismo exigido por la vida. Ese espacio límite mantiene el mismo carácter oscilante en su conceptualización como espacio geográfico, y es a éste al que se dirige ahora Ortega: se dirige hacia el tema del paisaje entendido como límite oscilante partiendo del hombre precisamente como realidad fronteriza.

Para Hegel, el despliegue del espíritu en la historia aparece tamizado por la naturaleza, con lo que se produce su multiplicación en los distintos espíritus nacionales. Mediante esta relación entre naturaleza y nación surge el tema del paisaje en la lectura de Ortega: "La nación es espíritu mineralizado y animalizado; por tanto, adscrito a un lugar, a un paisaje"390. Es a partir de este tema cuando habrá que abandonar por un momento al propio Hegel y continuar únicamente con Ortega: al sustituir las connotaciones geográficas que afirmaba Hegel por el concepto de paisaje, éste debe remitirse ya únicamente a Ortega. Es decir: Hegel habla de geografía, Ortega de geografía... y de paisaje. Ese concepto de

386 Una interpretación de la historia universal. En torno a Toynbee (1948-1949, curso). OC IX, 204 ss.

387" En el centenario de Hegel" (1931). OC V, 422.

388"Recuérdese que, para Hegel, es el hombre una realidad oscilante entre la Naturaleza y el Espíritu, entre el «estar fuera de sí» y el «estar sobre sí»". "En el centenario de Hegel" (1931). OC V, 426.

389HEGEL, Vorlesungen über die Philosophie der Weltgeschichte. Op. cit. p. 35: "Der Mensch dagegen muss sich selbst zu dem machen, was er sein soll; er muss sich alles erst selbst erwerben, eben weil er Geist ist; er muss das Natürliche abschütteln. Der Geist ist also sein eigenes Resultat".

390"En el centenario de Hegel" (1931). OC V, 422. 
paisaje es el de Ortega, con lo que el examen que lleva a cabo de la relación entre geografía e historia en la teoría de Hegel se presenta totalmente determinado por un concepto, el de paisaje, que será entendido con las connotaciones de la teoría propia de Ortega. Esta es la recepción: a la geografía de Hegel se le añade el paisaje de Ortega.

Ortega afirma que el tema ya lo trató en el "Hegel y América" y que ahora "me interesa tomar la cuestión en toda su generalidad'391. No es del todo cierto: más que tomarla en toda su generalidad, el interés estriba en entenderla a partir de su propio concepto de paisaje. Así, cuando Hegel expone la idea de que las condiciones naturales no son la causa de un cierto modo de ser espiritual, esto es, de que no hay que hablar del influjo causal entre tierra y nación, Ortega admitirá la tesis de Hegel, pero muestra lo que para sus intereses supone la insuficiencia de esa tesis. Para Hegel, cada pueblo es una determinada configuración del espíritu; con ello, sus peculiaridades serían de orden espiritual, no originadas por peculiaridades geográficas, étnicas, etc., y Ortega añade: "Pero a esa peculiaridad espiritual o modo de ser corresponde la peculiaridad de la Naturaleza en la región donde el pueblo se forma. Hegel no aventura más. Se contenta con hablar de «correspondencia» para designar relación entre pueblo y contorno físico"392.

En cierto sentido, Ortega invierte el esquema teórico de Hegel. Es verdad que las condiciones geográficas no determinan la historia de un pueblo, que con el mismo material geográfico y antropológico se producen historias diferentes, que además hay que contar con las emigraciones, es decir, con el movimiento de los pueblos hacia los lugares donde crean su historia, donde se hacen a sí mismos. Pero, precisamente por todo esto, la pregunta no está en saber si la geografía o el "terruño" determina la historia del pueblo que lo habita, sino en concretar por qué un pueblo, con la movilidad que se le permite y se le supone (de ahí la importancia de las emigraciones, como vimos más arriba), se adscribe a un paisaje y no a otro.

Este es el momento en el que Ortega se separa de Hegel: ya no se está hablando de geografía propiamente dicha, sino de geografía como paisaje, no de la relación entre geografía e historia, sino de la de paisaje e historia. Para llegar hasta aquí es para lo que ha utilizado Ortega a Hegel:

${ }^{391}$ Ibid. p. 423. 
"Si nos atenemos, pues, al rigor de los hechos, lo que importa comprender es por qué un pueblo que se desplaza se detiene de pronto y se adscribe a un paisaje. Es como un hombre que avanza entre las mujeres y de pronto queda prendido, prendado de una. Es vano acudir, como se suele, con consideraciones utilitarias que sucumben siempre entre contradicciones de los hechos. Hay que acabar por reconocer una afinidad entre el alma de un pueblo y el estilo de su paisaje. Por eso se fija aquél en éste: porque le gusta. Para mí, pues, existe una relación simbólica entre nación y territorio. Los pueblos emigran en busca de su paisaje afín, que en el secreto fondo de su alma les ha sido prometido por Dios. La tierra prometida es el paisaje prometido. / Hegel no interpreta así la correspondencia entre geografía y cultura. Pero no anda muy lejos de ello"393.

Ortega admite la importancia del tema en el tratamiento de Hegel, pero más que en el contenido mismo se fija en cómo le permitirá a él continuarlo, en cómo utilizarlo para llegar a esa afinidad simbólica. En las notas de lectura sobre este capítulo de la Filosofía de la historia de Hegel se muestra de un modo claro que Ortega está uniendo las dos cosas, la lectura de Hegel con su teoría de la afinidad simbólica. Y es ésta la que realmente le interesa: "Es admirable la interpretación de las relaciones entre geografía y cultura relación predominantemente simbólica y de afinidad entre una tierra y un pueblo", escribe ${ }^{394}$. Es una afinidad de estilo, pero no únicamente de coincidencia en un sentido de detención, de pasado, de algo que estaba ahí, esperando, hasta que yo llegara: el paisaje prometido primero hay que encontrarlo, pero después hacerlo propio, re-construirlo.

La afinidad simbólica es una afinidad estética, pero de estética política. Un pueblo se fija en el paisaje "porque le gusta", pero ese gusto no es un simple deleite por el contorno: "gusta" porque se encuentran en él las posibilidades de un futuro, porque se ve que incluye la potencialidad de hacer historia, gusta porque es tarea futura, gusta, precisamente, porque hay que hacerlo, convertirlo en paisaje propio. A esto remite la afinidad simbólica: es una estética histórica y política, en tanto ese paisaje encontrado, prometido, es afín porque permite llenarlo con un pasado y construirlo como futuro, re-construirlo como paisaje propio, como nación y pueblo futuros, concretando las limitaciones y los límites.

La clave para entender todo esto consiste en volver atrás, recordar cómo viene Ortega exponiendo el concepto de paisaje: no se trata únicamente de un movimiento en la historia,

\footnotetext{
392Ibid. p. 424.

393 Ibid. p. 425.
} 
no se trata únicamente de explicar las emigraciones o los movimientos de los pueblos, sino también de hacer la composición de lugar de Ignacio de Loyola, esto es, ver los espacios como paisajes, porque sólo así adquieren caracteres cercanos, eficaces. El concepto de paisaje une en Ortega presente, pasado y futuro, une cercanía y lejanía, une afinidad estética y tarea política. No se trata únicamente de encontrar un paisaje que todavía no hemos visto, sino también de ver como paisaje el espacio sobre el que nos encontramos. La tierra prometida puede ser la que ya tenemos, si la convertimos en paisaje y, con él, recogemos todas las posibilidades: paisaje que hay que hacer, paisaje que hay que ampliar, paisaje que hay que conocer. De nuevo la estética espacial, pero ahora el espacio aparece directamente en conexión con la historia y la tarea de futuro: el espacio también hay que hacerlo, la afinidad simbólica es de complemento, de realización, de imperativo.

Cuando, diez años antes respecto a En el centenario de Hegel", presentaba ya Ortega esa afinidad simbólica entre vida y paisaje, mostraba el momento previo. Si ahora en el artículo sobre Hegel aparece el paisaje como paisaje prometido, futuro, antes se había afirmado esa identidad de estilo en un sentido ya forjado, con la promesa ya alcanzada, pero que constantemente se mantiene como promesa, que "pugna por realizarse", un presente que es futuro y un futuro que es presente: "Late, pues, en cada localidad un posible destino humano, que parece en todo instante pugnar por realizarse y actúa como un imperativo atmosférico sobre la raza que lo habita. A su vez, cada forma típica de vida humana proyecta ante sí el complemento de un paisaje afín"395. La tierra prometida ya está en el paisaje propio: es la razón geográfica, topográfica, que explica el estilo de vida preformado en cada paisaje, pero que exige también los caracteres futuros, de tarea, que tal razón supone, en tanto la plenitud del paisaje ideal implica la necesidad de trabajarla, de causarla, de hacerla.

El hombre elige su paisaje, pero esa elección no es únicamente histórico-geográfica, con remisión a una búsqueda, a una emigración efectiva. El lombre elige su paisaje también en el sentido de convertir su espacio en paisaje, conformarlo como tierra prometida. Ortega volverá a insistir en ello en el "Prólogo para alemanes": "Todo pueblo lleva dentro de sí un

\footnotetext{
394Archivo de la "Fundación José Ortega y Gasset", Carpetilla "Hegel: filosofía de la historia". Conjunto de notas titulado "Detalles históricos".

395" Introducción a un «Don Juan»" (1921). OC VI, 129.
} 
«paisaje prometido» y yerra peregrino por el haz de la tierra hasta que lo encuentra"396, pero ese errar puede ser inmóvil, y ese paisaje prometido puede ser aquél sobre el que se encuentra, sólo que todavía no convertido en paisaje, en tarea, en esfuerzo dinámico por hacer de él un paisaje prometido. La historia como "una fuga de tierra en tierra, una emigración hacia la tierra prometida"397, hacia la vida ideal, que presentaba Ortega en el "Abenjaldún..." puede iniciarse ya en la tierra propia, en tanto comience a instalarse en ella ese ideal al que tender. Es la conexión de Ortega con la vida individual: ésta también debe orientarse por un ideal, por una vocación, por un destino propio, pero ese ideal hay que hacerlo, crearlo, mantenerlo, no sólo encontrarlo. La emigración, en todos los sentidos, el hombre como esencial emigrante, puede llevarse a cabo sin moverse del mismo espacio, pero para ello este espacio debe ser entendido en el sentido de estética espacial, en el sentido de paisaje, de unión de presente y futuro.

De este modo vuelven a recaer todas las ideas expuestas sobre el tema de España. La remisión de Ortega a "Temas de viaje" ("Hace años, perescrutando yo el mismo problema..."398) no supone únicamente la explicación de por qué a Ortega le ha interesado el capítulo de Hegel sobre la relación entre geografía e historia, sino también la inclusión implícita del tema de España en 'En el centenario de Hegel". En "Temas de viaje" insistía Ortega en que el clima o la tierra española, en general la serie de condiciones geográficas, ni justifican ni pueden utilizarse como justificación para explicar la historia de España, esa historia que Ortega se empeña en reescribir, en rehacer, precisamente para que pueda tener carácter de futuro. No han sido la geografía o el clima los que han determinado la situación española, sino los españoles mismos: "En comparación con la influencia que los españoles hemos tenido sobre nosotros mismos, el influjo del clima es estrictamente desdeñable"399. El clima o la geografía pueden influir, pero no determinar, es más, su misión está en implicar una reacción, un poder de transformación que convierta esa geografía en historia, en potencia histórica.

396" Prólogo para alemanes" (1934). OC VIII, 55.

397"Abenjaldún nos revela el secreto (Pensamientos sobre África menor)" (1927). OC II, 682.

398" En el centenario de Hegel" (1931). OC V, 424.

399" Temas de viaje" (1922). OC II, 372. 
Este es el sentido importante ahora, el de la geografía como incitación: "la geografía no arrastra la historia: solamente la incita"400. Incitación, excitación, el mismo carácter que define al ideal, "el ideal es un órgano de toda vida encargado de excitarla"401. En este sentido concuerdan el ideal y el paisaje, y no únicamente como paisaje a encontrar, como tarea emigratoria, sino como ideal a realizar en el propio paisaje aceptado. No encontrar un espacio en el paisaje, sino un paisaje en el espacio, no encontrar un paisaje ideal, sino un ideal en el paisaje: "Cada raza lleva en su alma primitiva un ideal de paisaje que se esfuerza por realizar dentro del marco geográfico del contorno'402.

El ideal de paisaje, entonces, la tierra prometida, supera el afán de búsqueda en tierras lejanas, e incluye ya el esfuerzo por encontrarlo, por realizarlo, en el marco geográfico propio. Esta es la estética política del paisaje: crear el ideal, crear el paisaje, re-crear la historia que implicará un futuro. Eso es lo que faltaba en España, definirlo era el afán de Ortega. Cuando llega a la Filosofía de la historia de Hegel ya viene cargado con esta intención: la tierra prometida es el paisaje prometido, pero hay que ser capaces de encontrar ese paisaje en esa tierra, encontrar la tierra como paisaje.

La afinidad simbólica entre nación y territorio es, así, una afinidad dinámica, de inquietud y agilidad en el esfuerzo por realizar el ideal de paisaje, las mismas agilidad e inquietud que conectaban espíritu y vida. Es por ello por lo que la relación simbólica remite a la teoría del símbolo como muestra de la ampliación, de las posibilidades de crecimiento y superación de la limitación que veíamos en la primera sección en conexión con el arte. La afinidad simbólica no es únicamente una afinidad representativa, sustitutoria, sino que implica las potencialidades de idealidad y mejora. El paisaje en su sentido estético-político, el de la configuración de un ideal en el espacio propio, el de símbolo dinámico y esforzado, explica esa "inspiración histórica" de cada pueblo que menciona Ortega: "Hay un factor que podríamos llamar «la inspiración histórica del pueblo», que no puede explicarse zoológicamente. Y ese factor es el decisivo en sus destinos"403. Esa inspiración histórica es la que se constituye en el paisaje propio al ser constituido como paisaje prometido, como

\footnotetext{
400 Ibid. p. 372.

401"Epílogo al libro De Francesca a Beatrice" (1924). OC III, 325.

402" Temas de viaje" (1922). OC II, 373.
} 
ideal a realizar. Cumplir el destino histórico propio sólo es posible si del espacio geográfico se ha hecho un paisaje, si del paisaje se ha hecho un ideal, si del ideal una tarea futura, una incitación a su realización.

La relación entre espacio e historia, o, directamente, entre espacio y tiempo en la historia, adquiere su explicación a través de esta serie de caracteres del paisaje. Cuando Ortega en las notas de trabajo se pregunte: ¿Cabe en la historia la fusión de tiempo y espacio en la física?"404, parezca contestarse con Hegel en el "Hegel y América": "El espacio es una categoría geográfica y no histórica"405 y culmine el recorrido en "Sobre los Estados Unidos": "La inseparabilidad de espacio y tiempo que la Física actual nos enseña vale también para la historia y la geografía'406, es necesario tener en cuenta que para entender esa inseparabilidad hay que acudir a los caracteres de ideal, de tarea futura, a realizar, que implica el concepto de paisaje. En el paisaje se unen espacio y tiempo en la historia: el paisaje remite a un espacio, pero ese espacio hay que idealizarlo, convertirlo en tarea, en destino, dotarlo con los caracteres de futuro. Y, hacia el pasado, la tarea es de recreación de la historia, de volver a escribirla, para llegar a entender el paisaje propio y poder dotarlo con los talantes de futuro.

Cuando Ortega en el Toynbee se cite a sí mismo, transcribiendo amplios textos tanto de "Temas de viaje" como de "En el centenario de Hegel", y vuelva al tema del paisaje, en concreto a la relación entre el hombre y la tierra, mostrará de nuevo la importancia del ideal de vida, de presión sobre el contorno que ejerce el proyecto de existencia. Es éste, con todos los caracteres de futuro, de programa, de tarea a realizar, el que dirige la relación con el espacio geográfico: "La tierra actúa sobre el hombre, no directamente causando sus acciones, sino indirectamente planteándole problemas. [...] Parto, desde luego, del hombre y digo que el proyecto de existencia, la peculiar idea o ideal de la vida que lleva un pueblo dentro de sí mismo, en cada una de sus épocas, oprime el contorno'407. El contorno

\footnotetext{
403" En el centenario de Hegel" (1931). OC V, 424.

${ }^{404}$ Archivo de la "Fundación José Ortega y Gasset", Carpetilla "Hegel: Filosofía de la historia". Conjunto de notas titulado "Teoría general de Hegel".

405" Hegel y América" (1928). OC II, 575.

406" Sobre los Estados Unidos" (1932). OC IV, 373.

407 Una interpretación de la historia universal. En torno a Toynbee (1948-1949, curso). OC IX, 206.
} 
responde planteando dificultades, pero también ofreciendo facilidades (en este contexto de los años cuarenta Ortega piensa sobre todo en la técnica). Ambas vienen definidas por el proyecto, por el ideal de vida elegido, y ese ideal es ya el paisaje ideal al que se tiende.

El paisaje creado, convertido en tarea a realizar, oprime ya la relación con el contorno. El proyecto elegido conecta así espacio y tiempo, y muestra las limitaciones o facilidades que ofrece el espacio para la realización futura del ideal. La geografía como incitación, que plantea problemas y a la vez los determina por el proyecto elegido, por el ideal a realizar, se constituye como paisaje al ser éste el que une en su contenido tanto el espacio como su propio carácter de ideal, de paisaje prometido.

Esta unión en el paisaje de espacio e ideal, de espacio y tiempo (entendido éste sobre todo en el sentido de tarea futura), implica los caracteres de ampliación, de contacto, de superación de las limitaciones propias. Implica la necesaria salida de sí para conseguir cumplimentar su plenitud, su ideal. Es de este modo como, de nuevo, el tema del paisaje vuelve a constituirse como un problema de relaciones entre límites y limitaciones. Para buscar los modos de exposición de esa relación acude Ortega en "En el centenario de Hegel" al examen de las tres configuraciones topográficas que presentaba Hegel: meseta, valle y costa. 


\subsection{Los tres paisajes}

Al inicio del trabajo aparecían las referencias que, partiendo del no escrito "Ensayo sobre la limitación", llegaban por un lado hasta Hegel y por el otro hasta el tema del paisaje. Ahora esas referencias se reúnen en este contexto, el paisaje hallado por Ortega a partir de su lectura del tema de la geografía en la Filosofía de la historia, los límites y limitaciones a partir de su interpretación de esas tres configuraciones topográficas que muestra Hegel. Es por ello por lo que la exposición de esos tres conceptos, meseta, valle y costa, debe ser entendida con toda la carga simbólica y metafórica necesaria, situando en el fondo toda la serie de temáticas que vienen apareciendo.

Si el objetivo de Ortega, como afirmaba en aquella nota de trabajo, no consiste en exponer a Hegel, sino ver cómo los problemas, los temas de Ortega, aparecen en él, tampoco este tratamiento de las tres configuraciones topográficas puede ser una simple exposición. Al estar basado de un modo explícito en el tema de la limitación, las relaciones entre meseta, valle y costa deben ser analizadas partiendo de todos los caracteres que han venido siendo presentados alrededor de los juegos de limitaciones.

Ortega no esconde su entusiasmo al leer a Hegel en este momento: "En la Filosofía de la historia Universal brotan súbitamente altos surtidores de espléndida poesía, géiseres cálidos, irisados, que se alzan sobre el horizonte lunar de su gélida dialéctica. Así, en este lugar: ¿Qué delicia oír que de pronto se nos habla -corroborando con un gesto romántico hacia significaciones infinitas- del «principio de la meseta, el privilegio del valle, el principio de la costa»'408. Pero, sobre todo, y es lo más importante, le entusiasman las posibilidades que ofrece: "La mente nos queda repentinamente fecundada por el polen de estas palabras y germina en ilimitadas posibilidades de pensamiento'409. Es a esas posibilidades a las que nos tenemos que referir, porque Ortega en el texto no permite verlas tan fácilmente. Y, para ello, lo primero que hay que tener en cuenta es la conexión con la teoría del paisaje expuesta más arriba, pues, y es importante, Ortega no olvida recalcar que

408" En el centenario de Hegel" (1931). OC V, 425.

${ }^{409}$ Ibid. pp. 425-426. 
los tres tipos de tierra serían "lo que yo llamaría tres paisajes"410. Es la conexión con el paisaje la que realmente ofrece las ilimitadas posibilidades de pensamiento.

La división en los tres paisajes procede en Hegel de la relación entre la tierra y el agua. La meseta (Hochland: no será casual que Ortega prefiera traducir el término por "meseta", en lugar de "altiplanicie", como hace Gaos) es la aridez; el valle es obra del río; y la costa, la tierra en relación explícita con el mar 411 . A cada uno de los tres paisajes corresponde una manifestación concreta del espíritu, o, sin más, una forma concreta de Estado. El contexto general está sostenido sobre la relación con la naturaleza: en las zonas de la naturaleza donde ésta exige la constante atención de los individuos no puede haber historia, el hombre no puede ocuparse de sí mismo. El hombre sólo llega a manifestarse como tal en aquellas condiciones de paisaje que no son demasiado exigentes (como la tórrida o la gélida 412 ), o que han sido ya lo suficientemente humanizadas, controladas, con lo que el hombre puede concentrarse en sí mismo y aislarse frente a la naturaleza. El proceso de libertad del espíritu como ser para sí se desarrolla en esta dirección: la libertad sólo es posible en la medida que el espíritu logra evadirse de la naturaleza. Éste es el contexto en el que Hegel expone su teoría de los tres paisajes.

La meseta, la altiplanicie, tiene su tipo vital en el nomadismo. Es una tierra seca, pobre, que "no está limitada por ninguna contención espacial"413. El nómada no está encadenado al suelo, no sabe nada de los principios de convivencia. Su vida es vagabundear de un lugar a otro, está asentada sobre un principio flotante, vacilante 414 (como lo era el del símbolo),

410 Ibid. p. 425.

411 La referencia exacta en Hegel de la relación entre el mar y los tres paisajes es la siguiente: "Das allgemeine Verhältnis der Naturbestimmtheit, worauf es in der Geschichte ankommt, ist das Verhältnis von Meer und Land. Mit Bezug auf das Land ergeben sich drei grundlegende Unterschiede. Wir finden erstens Hochländer ohne Bewässerung, zweitens Talbildungen, die von Strömen bewässert sind, und drittens Künstenländer. Diese drei Momente sind die wesentlichsten, die sich dem unterscheidenden Begriffe darbieten und auf die wir die weiteren Bestimmungen alle reduzieren können". HEGEL, Vorlesungen über die Philosophie der Weltgeschichte. Op. cit. p. 183.

412 HEGEL, Vorlesungen über die Philosophie der Weltgeschichte. Op. cit. p. 181: "Der Mensch gebraucht die Natur zu seinen Zwecken; wo aber die Natur zu mächtig ist, da bietet sie sich nicht zu Mitteln dar. Die heisse Zone und die kalte sind als solche nicht Schauplatz der Weltgeschichte. Diese Extreme sind von dieser Seite freien Geiste ausgeschlossen".

413 "En el centenario de Hegel" (1928). OC V, 428.

414 HEGEL, Vorlesungen über die Philosophie der Weltgeschichte. Op. cit. p. 183: "Das schwebende, schwankende Prinzip". 
que le impide fijarse a un punto estable. Su inquietud, su vagabundeo, se limita a un círculo concreto, aunque ese círculo siempre puede ser superado: "Das Herumschweifen der Nomaden ist nur formell, weil es in einförmige Kreise beschränkt ist. Diese Beschränkung ist aber nur faktisch; es ist Möglichkeit vorhanden, sich abzuscheiden. Der Boden ist nicht bebaut, und ich kann ihn überall wiederfinden; daher kann ein Impuls äusserer oder innerer Art die Völker weitertreiben. Doch liegt der Geist der Unruhe nicht eigentlich in ihnen"415. No habita en el nómada el espíritu de la inquietud porque éste sólo puede darse en la forma consciente, cuando el espíritu ha adquirido la manifestación en la forma de libertad, de Estado.

El nómada se mantiene en un simple ir y venir, su inquietud no es la verdaderamente espiritual: en sus condiciones de vida no es posible una convivencia estable, no es posible la formación de una ley o un Estado, de un orden. Su inquietud es completamente indeterminada, no es la inquietud de un espacio propio, limitado. Así, aunque también, y sobre todo, el espíritu es inquietud, el nómada no alcanza ese carácter, en tanto su inquietud más que inquietud es vagabundeo, errancia. Por ello, "en la meseta, pues, tenemos el germen de lo espiritual, su aparición embrionaria, nada más"416.

La vida del nómada no implica la verdadera inquietud, su limitación no mantiene la dialéctica de superaciones: es constante vacilación, constante permanencia en el límite, pero no aglutina, en tanto no es capaz de convivencia estable, límite y limitación. La meseta exige la constante vida del nómada en el límite (por un lado, su vida "queda encerrada en su localidad'417; por otro, son movilidad constante), y, sin embargo, no tienen limitaciones, no tienen un espacio propio a partir del cual conjugar límites y limitaciones: la meseta "es la independencia inconcreta de lo que no tiene límites y no es nada determinado'418.

\footnotetext{
415Ibid. Traducción: "El vagabundaje de los nómadas es sólo formal, porque se limita a un círculo uniforme. Mas esta limitación lo es sólo de hecho; pues siempre existe la posibilidad de romperla. El suelo no está cultivado; puede hallarlo el nómada en todas partes; por eso un impulso exterior o interior puede inducir a los pueblos a trasladarse a otro lugar. No obstante, no alienta en ellos propiamente el espíritu de la inquietud". HEGEL, Lecciones sobre la filosofía de la historia universal. Op. cit. p. 165.

416" En el centenario de Hegel" (1928). OC V, 428.

417"Es bleibt ein in sich durch seine Lokalität abgeschlossenes Leben". HEGEL, Vorlesungen über die Philosophie der Weltgeschichte. Op. cit. p. 183.

418" En el centenario de Hegel" (1928). OC V, 428.
} 
La meseta culmina en laderas, donde los ríos han formado valles. Si la meseta era ausencia de limitaciones, y precisamente por ello constante vida en el límite de los nómadas que la habitan, "el valle es una unidad conclusa, cerrada en sí, independiente"419. La meseta era siempre igual a sí misma, sin limitaciones espaciales que la diferenciaran y estructuraran. El valle tiene un estructura concreta, el río y sus dos riberas. La tierra es fértil, surge la agricultura, y con ella la propiedad, las normas jurídicas, las diferencias de clase. La agricultura exige el apego a la tierra, ésta no puede ser abandonada, con lo que "el valle obliga a la convivencia, que es, a su vez, imposible sin modos generales de conducta, es decir, sin Estado'420. Surgen los centros de cultura, la independencia, pero no hacia fuera, como era la del nómada, que siempre podía moverse de un lado a otro, sino hacia dentro, en la forma de cultura interior. Surge el derecho, surge el arte, la invención, al exigirse constantemente la capacidad para crear nuevos instrumentos, surge la necesidad de gobierno, de Estado.

Todo ello se inicia en la limitación que supone el apego a la tierra: "el valle fija el hombre al terruño: lo limita"421, o, en palabras de Hegel, "das Bedürfnis der Werkzeuge, die Notwendigkeit des Aufbewahrens führen zur Sesshaftigkeit, zur Beschränkung auf diesen Boden"422. Esa limitación, aunque permite la creación de las leyes, del derecho, del Estado, de la convivencia, etc., implica también la dependencia de un sistema poco variado de condiciones. Si el nómada permanecía en el límite, sin limitaciones, con el valle surge la limitación, pero sin el límite, sin la salida hacia fuera de sí. En la dialéctica de limitación y superación de limitaciones a cada uno les falta algo, al primero el espacio propio, la limitación, al segundo la conversión de esa limitación en límite, que permita la superación. Las culturas de los valles son casos de limitación, no de límite.

Los ejemplos son las grandes culturas fluviales de la historia, China, Egipto. Su organización interna llega a ser altísima, su desarrollo asombroso, pero son culturas hiératicas, revertidas siempre sobre el interior, sobre sí mismas: "De aquí que estas

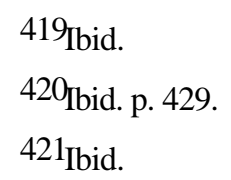


civilizaciones fluviales hayan girado eternamente sobre sí mismas, recluidas en un repertorio de temas, de modos, de intentos, de normas. Son culturas «hieráticas», es decir, rígidas" 423 . O, de otro modo, la inquietud únicamente es interna, como únicamente era externa la del nómada. La limitación originada en el valle es una limitación que sólo muy ocasionalmente posibilita la salida hacia fuera de sí, no permite su conversión en límite: le falta el otro momento de la dialéctica de la limitación, la superación de ésta.

Si la meseta es límite sin limitación y el valle limitación sin límite, el tercer paisaje, la costa, la integración de tierra y mar, implica la conjunción de ambos. El mar es el principio liberador, de contacto, de superación de limitaciones, respecto a la tierra asentada a su lado. El mar es el límite móvil de una tierra como limitación. En este momento, en el tercer paisaje, confluyen bs dos momentos de la dialéctica de la limitación. Y la referencia no es únicamente de límites y limitaciones, sino también de metáfora general de la vida en el sentido de Ortega. Éste cita un amplio texto de Hegel que determina el análisis. Ortega excluye del texto algunas frases, así como realiza una traducción propia, no siguiendo a Gaos. Es conveniente citar el texto original, más amplio que el de Ortega, y mantener en nota tanto la traducción de Gaos como la de Ortega:

"Das Meer begründet überhaupt eine eigene Lebensweise. Das unbestimmte Element gibt uns die Vorstellung des Unbeschränkten und Unendlichen, und indem der Mensch sich in diesem Unendlichen fühlt, so ermutigt ihn dies zum Hinaus über das Beschränkte. Das Meer ist selbst das Grenzenlose und leidet keine ruhige Einschränkung in Städten wie das Binnenland. Das Land, die Talebene fixiert den Menschen an den Boden; er kommt dadurch in eine unendliche Menge von Abhängigkeiten. Aber das Meer führt ihn über diese beschränkten Kreise hinaus. Das Meer erweckt den Mut; es lädt den Menschen zur Eroberung, zum Raub, aber auch zum Gewinn und Erwerb ein. Die Arbeit des Erwerbs bezieht sich auf jene Besonderheit der Zwecke, die man das Bedürfnis nennt. Die Arbeit für dies Bedürfnis bringt nun mit sich, dass die Individuen sich in diesen Kreis des Erwerbes eingraben. Führt sie aber der Erwerb auf das Meer, so wird das Verhältnis verwandelt. Die das Meer befahren, wollen und können wohl auch dort gewinnen, erwerben; aber das Mittel schliesst unmittelbar das Gegenteil dessen, wozu es erwählt wird, in

422HEGEL, Vorlesungen über die Philosophie der Weltgeschichte. Op. cit. p. 185. Traducción: "La necesidad de instrumentos y de almacenes conducen a la vida sedentaria, implican la necesidad de atenerse a este suelo". HEGEL, Lecciones sobre la filosofía de la historia universal. Op. cit. p. 167.

423" En el centenario de Hegel" (1928). OC V, 428. 
sich, nämlich die Gefähr: es ist in der Weise verkehrt, dass sie ihr Leben und Eigentum gerade in Gefahr des Verlustes setzen"424.

A la transcripción, parcial e "interesada", recibida, de ese texto de Hegel por parte de Ortega, éste añade un breve pero crucial comentario, con el que concluye 'En el centenario de Hegel", y con el que Ortega deja que seamos nosotros realmente los que llevemos a cabo aquellas "ilimitadas posibilidades de pensamiento" que mostraba más arriba. El comentario de Ortega a la cita de Hegel dice: "La vida marítima es un constante riesgo de perderse a sí misma. Es libre ante sí misma e implica serenidad y astucia incesantes. Por todo ello tiene un claro sentido de creación y fue dondequiera el mar el gran educador para la libertad. El mar es un perpetuo «más allá de la limitación de la tierra». Es el verdadero «espíritu», que de su movimiento elemental pasa a las almas de sus moradores y hace del existir una permanente creación. El principio supremo constitutivo del espíritu fue expresado un día por alguien con monumental ingenuidad: «Es necesario navegar, pero no es necesario vivir»'425. Ese comentario es el final del artículo. Habría que añadirle otra idea de Hegel

\footnotetext{
${ }^{424}$ HEGEL, Vorlesungen über die Philosophie der Weltgeschichte. Op. cit. p. 188. Gaos traduce: "El mar engendra, en general, una manera propia de vivir. Este elemento indeterminado nos da la representación de lo ilimitado e infinito; y al sentirse el hombre en esta infinitud, anímase a trascender de lo limitado. El mar es lo limitado [errata o despiste de Gaos: debe decir "ilimitado", Grenzenlose]; no tolera circunscribirse tranquilamente a las ciudades, como el interior. La tierra, el valle, fija el hombre al terruño y lo sitúa en una multitud de dependencias. Pero el mar lo saca de este círculo limitado. El mar alienta al valor; invita al hombre a la conquista, a la rapiña, pero también a la adquisición y la ganancia. La labor de adquisición se refiere a la particularidad de los fines, llamada necesidad. Ahora bien, el trabajo encaminado a satisfacer estas necesidades implica que los individuos se entierran en este círculo de la adquisición. Mas si el afán de provecho les impulsa a surcar las aguas del mar, entonces la relación se invierte. Los que navegan quieren y pueden cosechar ganancias; pero el medio de que se valen implica inmediatamente lo contrario de aquello para que ha sido tomado; implica peligro y resulta contrario a lo que con él busca el hombre, por cuanto éste pone su vida y su fortuna en grave peligro". HEGEL, Lecciones sobre la filosofía de la historia universal .Op. cit. p. 168. Ortega, por su parte, traduce y transcribe lo siguiente: "El mar da lugar siempre a un peculiar tipo de vida. El indeterminado elemento nos da una imagen de lo ilimitado e infinito, y al sentirse el hombre en él se anima al más allá sobre toda limitación. El mar suscita el valor: incita al hombre a la conquista y la rapiña; pero también a la ganancia y la industria. El trabajo industrioso se refiere a aquella clase de fines que se llaman necesidades. El esfuerzo para satisfacer estas necesidades trae consigo, empero, que el hombre quede enterrado en este oficio. Mas, cuando la industria pasa por el mar, la relación se transforma. Los que navegan pretenden ciertamente ganar, lucrarse, satisfacer sus necesidades; pero el medio para ello incluye en este caso lo contrario del propósito con que se eligió, a saber: el peligro". "En el centenario de Hegel" (1928). OC V, 429.
}

425" En el centenario de Hegel" (1928). OC V, 429. 
que Ortega encontró en la Filosofía del derecho: "Alle grossen, in sich strebenden Nationen sich zum Meere drängen" 426 .

Si ésta es la exposición de los tres paisajes, y sabemos que a Ortega no le interesaba la "exposición" de Hegel, sino "ver cómo nuestros problemas aparecen en él", ahora se trata de encontrar esos problemas encubiertos, encubiertos porque Ortega en este momento no los hace explícitos. El tema tiene dos direcciones estrechamente unidas: por un lado todo lo referente al paisaje, al espacio, a las relaciones entre pueblos y naciones, en general, a la dialéctica de la limitación. Por el otro, el tema de la vida como peligro, aludiendo explícitamente al final del artículo: la relación entre la vida y el espíritu en el marco de la inquietud, de la agilidad, la relación con el mar, conociendo las connotaciones metáforicas que tiene el tema en la filosofía de Ortega (y conectando así con el comienzo del artículo, la exposición por parte de Ortega de la relación entre vida y espíritu a través de la metáfora del naufragio). En general, las dos direcciones, y por ello están indisolublemente unidas, son el paisaje y la vida, los dos temas que subyacen a todo el artículo.

426 HEGEL, Grundlinien der Philosophie des Rechts. Op. cit. § 247, p. 190. Traducción: "Toda nación grande y pujante tiende hacia el mar". HEGEL, Principios de la filosofía del derecho. Trad. J.L. Vernal. Barcelona: Edhasa, 1988, p. 311. 


\subsection{Los tres paisajes y la limitación}

Si por un momento se dejan a un lado las conceptualizaciones explícitas de los tres paisajes, la dialéctica de límite y limitación que posibilitan se determinaría de un modo concreto. La dialéctica de la limitación a partir del paisaje quedaría, entonces, como sigue: en un primer momento surge un espacio no detenido por ninguna limitación. Es un puro espacio-límite, precisamente porque carece de limitaciones. La inquietud que en él se produce no es suya, sino de los individuos que lo habitan: no es un paisaje móvil, un espacio móvil, pero sí permite la movilidad e inquietud de sus inquilinos. Se trata del primer momento de la dialéctica: límite sin limitación.

El segundo momento se constituye como la aparición de la limitación, una limitación en forma de Estado, de convivencia, de ley. El espacio está limitado, es una unidad conclusa, que revierte constantemente en su interior y que carece del carácter de límite que supondría la apertura de esa limitación hacia fuera. Si el primer momento es la ausencia de limitación y la constitución unilateral del carácter de límite, éste segundo es d inverso: afirmación de la limitación y ausencia de la superación de ésta que supone su conversión en límite.

El tercer momento reúne los dos primeros. Es la expresión de la dialéctica de la limitación, la conjunción de límites y limitaciones. Aparece una limitación abierta, que a los caracteres inmóviles y hacia dentro implicados en el momento anterior les añade la movilidad y apertura de su constante conversión en límite. Es una limitación en contacto explícito con la ilimitación, permitida por la posibilidad de relaciones que potencia el carácter de apertura, de límite. La limitación constantemente se muestra superándose a sí misma, sin perder sus caracteres propios, particulares, pero siendo éstos ampliados y aumentados mediante el contacto con otras limitaciones, con otros caracteres. Si el primer momento era expresión del límite y el segundo de la limitación, este tercero presenta una limitación para el límite y un límite para la limitación.

Esta sería la conjunción de límite y limitación que permite la teoría del paisaje, desde Hegel recibido por Ortega. Ahora se trata de mostrar la aplicación concreta a las intenciones de éste. Si la dialéctica de la limitación presentada se origina en una teoría del paisaje, es necesario partir del concepto de paisaje que utiliza Ortega, el que viene siendo expresado desde el comienzo y que refiere a la estética política. En este sentido, el paisaje 
debe remitir a pueblos, a naciones, con el contexto del nacionalismo en el fondo. Es el nacionalismo futuro, el nacionalismo que es más nacional que nacionalista, y que encuentra en el paisaje el concepto perfecto para expresar los talantes de futuro, de percepturitio, de ampliación y crecimiento. Este nacionalismo tiende ya al carácter universalista al unir límite y limitación en su propia definición. Se trata de afirmar las diferencias, la limitación, pero no convertirlas en exclusivismos, con lo que exigen su necesaria ampliación por contacto, por unión con otras particularidades. Es el momento en que la limitación incluye su carácter de límite: la unidad de las diferencias a través del carácter abierto de esas diferencias, de la limitación que constituyen.

Esta unión de limitación y límite, de limitación e ilimitación a través del límite, es la que expone Ortega mediante el tercer paisaje de Hegel, la conjunción de tierra y mar, la conjunción de limitación e ilimitación, de diferencia particular, como todo paisaje, pero de diferencia abierta, como todo límite, como todo paisaje entendido como límite móvil. El momento exacto no es ni la ausencia de limitaciones en el espacio de la meseta, ni la limitación únicamente interna del valle, sino la conjunción de la limitación e ilimitación en el paisaje de la costa. Esa es la metáfora del paisaje marítimo: unir la particularidad diferenciadora de la limitación con la remisión al futuro, a lo ilimitado, a las posibilidades, unir la "firmeza de la tierra" y el carácter inquieto, errabundo, de la vida marina 427 . El mar, el agua, no separa las diferencias, sino que las une, como vio Ortega en Hegel: "Das Wasser ist in der Tat das Vereinigende"428, o "Dass die Flüsse keine natürlichen Grenzen sind, [...] sondern sie und ebenso die Meere vielmehr die Menschen verbinden" 429.

El tema de España sigue estando en el fondo, y no únicamente la referencia a América, la relación necesaria que España debe mantener con los pueblos americanos, como constantemente ha insistido Ortega y como llevó a la práctica en sus viajes, viajes siempre

\footnotetext{
${ }^{427}$ Ese es el final del capítulo en Hegel: "In diesen drei Naturbeschaffenheiten zeigt sich die wesentliche Bedingtheit des Völkerlebens durch die Natur. Am stärksten charakterisieren sich das binnenländische und das küstenländische Prinzip gegeneinander. Der höher ausgebildete Staat vereinigt die Verschiedenheiten beider in sich: die Festigkeit des Binnenlandes mit dem schweifenden Charakter der Zufälligkeit im Küstenleben". HEGEL, Vorlesungen über die Philosophie der Weltgeschichte. Op. cit. p. 189.
}

428HEGEL, Vorlesungen über die Philosophie der Weltgeschichte. Op. cit. p. 186. Traducción: "El agua es lo que une". HEGEL, Lecciones sobre la filosofía de la historia universal. Op. cit. p. 167.

${ }^{429}$ HEGEL, Grundlinien der Philosophie des Rechts. Op. cit. § 247, p. 190. Traducción: "Los ríos no son fronteras naturales, [...] sino que, por el contrario, al igual que los mares, unen a los hombres". HEGEL, Principios de la filosofía del derecho. Op. cit. p. 311. 
de ida y vuelta, de lo que Ortega llevaba y lo que Ortega traía. No sólo a América sino también a la situación concreta de España. Quince años antes de "En el centenario de Hegel" escribió Ortega un texto que incluía la relación entre dos paisajes, el paisaje de la meseta y el paisaje asturiano, la meseta y el valle. No eran tres paisajes, como ahora con Hegel, sino únicamente dos: "De Madrid a Asturias o los dos paisajes". Cuando Ortega, ahora, con Hegel, traduce constantemente Hochland por "meseta" ya está pensando en la meseta castellana, y por eso decía más arriba que la traducción no era casual.

La meseta que Ortega encuentra en Hegel, que no está limitada por ninguna contención espacial, que camina en línea recta, para él era algo muy cercano: "¡Caballero, en Castilla no hay curvas!"430, exclamaba en el texto de 1915. En ese escrito, Ortega cura sus nervios tensos, tirantes, de la meseta, donde "vivir es dispararse", con el paisaje asturiano, con el valle. El límite entre ambos paisajes son los puertos de montaña, lugares de elección: "No son León-Castilla, no son Asturias. Son sitios para elegir entre lo uno y lo otro'431. Ortega defiende su paisaje castellano frente al habitualmente preferido, el verde del valle. Son simples diferencias de mirada, dos paisajes diferentes.

La ausencia de obstáculo, de contención espacial del Hochland la había expresado Ortega acudiendo a la mirada castellana: "En Castilla, mirar suele ser disparar la flecha visual al infinito; ni al salir de la pupila ni en el resto de su trayectoria encuentra obstáculo alguno'432. El carácter unitario, compacto, del valle, donde nace la propiedad, la convivencia, el Estado, según lo expuesto por Hegel, también los había presentado Ortega a su modo en el cambio del paisaje castellano al asturiano: "Ahora, en cambio, vamos hacia un paisaje que pide ser mirado con ojos de propietario", porque "en este paisaje el vacío no existe; de un extremo a otro todo forma una unidad compacta y tangible"433.

En ese texto del 15, sin olvidar ni las diferencias temporales ni las temáticas ni las intencionales con respecto a "En el centenario de Hegel", Ortega exponía una tesis integradora de España precisamente a partir de las diferencias: "Si hace nueve centurias fue la misión de Castilla reducir a unidad las variedades peninsulares, acaso sea su menester de

\footnotetext{
430" De Madrid a Asturias o los dos paisajes" (1915). OC II, 251.

${ }^{431}$ Ibid. p. 252.

432 Ibid. p. 254.
} 
hogaño hacer que la vida española retorne de esa unidad a una variedad más fuerte y fecunda que la primitiva. Mira y quiere la diversidad en torno tuyo, que puede ser espléndida. Digna de la antigua es esta tu nueva misión de empujar a los pueblos para que cada cual cobre la voluntad de sí mismo'434. Era una integración a partir de las diferencias, a partir de la conjunción de miradas diversas, de paisajes. Ahora, con Hegel y la dialéctica de la limitación expuesta, esa misión no refiere únicamente a España.

Ahora se trata de unir la limitación general de cada particularidad, con la ilimitación que permite su conformarse como límite, como contacto. La relación entre tierra y mar simboliza esta conjunción de límites y limitaciones: la nación fuerte, como expresaba Hegel en la Filosofía del derecho y recogía Ortega, tiende hacia el mar, y esa tendencia, en Ortega, debe tomarse tanto en el sentido literal (tendencia hacia América) como en el metafórico (unión de la limitación de la tierra con la ilimitación de posibilidades simbolizada por el mar; el paisaje como límite móvil, como conjunción de límite y limitación).

Ortega no olvida que España es un país mediterráneo, que incluye en sí misma los tres paisajes, y que, hacia el exterior, hacia América y hacia Europa, la limitación de su particularidad debe sostenerse junto a la salida de sí misma, junto a la ilimitación de posibilidades que ofrece el mar entendido como metáfora. La integración a partir de la diferencia, sea en lo referente a España, sea en lo referente a cualquier tipo de limitación, se mantiene tanto en los dos paisajes del texto del 15 como en los tres del texto sobre Hegel. Es la misma estética política que parte del paisaje: conjunción de miradas, conjunción de diversidades, conjunción de limitaciones, conjunción de paisajes manteniendo éstos su voluntad de diferencia, de limitación, pero incluyendo su carácter de límite. La tendencia hacia el universalismo que ya se mostraba en la lectura del Volksgeist adquiere ahora su sentido a través de la dialéctica de la limitación.

Pero esta dialéctica de la limitación incluye un segundo momento, basado casi exclusivamente en el tercer paisaje. El mar como superación de toda limitación, que en un primer sentido refiere a esa conjunción de limitación e ilimitación en las naciones, en los Estados, tiene para Ortega un significado especial. Un significado no tanto basado en el

\footnotetext{
433 Ibid. pp. 258-259.

434 Ibid. p. 255.
} 
carácter de superación de limitaciones, como en el de peligro, el de la ausencia de firmeza y de seguridad que tradicionalmente ha conllevado el mar. El mar como metáfora incluye las dos referencias, la de ilimitación y la de peligro. Si la primera puede ser entendida en relación con el talante universalista, con la conjuncion de particularidades, de limitaciones, la segunda debe ponerse en contacto con la teoría general de la vida en Ortega. Con ello, el artículo sobre Hegel adquiere un carácter circular: la conexión de espíritu y vida con que se iniciaba también aparece ahora al final, la metáfora del naufragio del comienzo aparece ahora como metáfora del mar en general.

Cuando Ortega afirma que la vida marítima implica el riesgo de perderse a sí misma, y que exige la serenidad y astucia necesarias para superar ese riesgo, está expresando exactamente los mismos caracteres que más arriba refería a la vida en general: la vida es naufragio, riesgo constante de naufragio, y por ello exige interpretaciones de vida, actos que posibiliten salir de él. En Ortega, esos actos son todos los modos de cultura, sea la filosofía, la ciencia, la técnica, etc. Pero el primero de ellos es formarse una idea clara de la misma vida, tener una interpretación general de la vida que dirija todos los demás. Es la cultura, la filosofía, como enfrentamiento con el peligro de la vida. Es el "vivid alerta" que sustituye al "vivid en peligro" de Nietzsche 435 : vivid alerta precisamente porque la vida es peligro, el peligro del enfrentamiento con un mundo, con una circunstancia que puede no ser muy amistosa. La vida en su discurrir está llena de peripecias, de aventuras, de riesgos, de peligros, y exige la misma serenidad y astucia que solicita la vida en el mar.

La metáfora del naufragio para ilustrar ese riesgo, ese peligro de la vida en el enfrentamiento con el mundo, implica este segundo momento: el de la serenidad, el de la vida alerta. La vida y el espíritu mantienen el mismo carácter de inquietud; el mar es el símbolo de la inquietud, de la inseguridad. En la vida, esa inseguridad deviene peligro, y exige estar constantemente alerta. Es por ello por lo que el mar es el gran educador, por lo que tiene un sentido explícito de creación, por lo que es el principio supremo del espíritu. La inquietud implica riesgo, pero, de hecho, es el carácter definitorio de la vida. Implica riesgo y al mismo tiempo concede la posibilidad de creación, de interpretación, que permita afrontar los peligros.

${ }^{435}$ Cfr. "Ensimismamiento y alteración" (1939). OC V, 307. 
El mismo tema de la inquietud se ha ido forjando ahora, después de que Ortega lo mostrara como equivalencia entre espíritu y vida, en la dialéctica de los tres paisajes. En el nomadismo la inquietud todavía no era la puramente espiritual, porque no implicaba la referencia a sí: era una inquietud sin rumbo, un vagabundeo que no tenía como sustrato una convivencia estable, un espacio concreto con los caracteres de Estado. En el valle la inquietud era puramente interna, sin referencia a un afuera. Sólo en la costa, entendida como principio liberador, con la conjunción de limitación e ilimitación, aparece esa inquietud simbolizada por el mar, que implica tanto la referencia a sí como la posibilidad de ampliación en los contactos. Es la representación de la inquietud del espíritu, que supone la movilidad con el fin determinado de llegar hasta sí mismo, conocerse, reflejarse. Esta inquietud es también la de la vida, la que conjuga reflexividad y transitividad, la que incluye el peligro y las posibilidades de interpretación para su superación, o, por lo menos, para su mantenimiento como riesgo. El mar, que incluye el carácter de riesgo y el carácter de alerta, simboliza en este sentido tanto el espíritu como la vida.

El final del artículo de Ortega, la ingenuidad del principio "es necesario navegar, pero no es necesario vivir", conjunta todos los caracteres 436 . El principio es ingenuo porque precisamente la vida es ya navegación, porque incluye peligros y riesgos, pero también creaciones y alertas, porque incluye limitaciones y espacios cerrados, pero también límites y posibilidades de ampliación. Es el momento en el que paisaje y vida confluyen, la unión de límites y limitaciones, la unión de riesgos y posibilidades de superación. El mar como "perpetuo más allá de la limitación de la tierra" expresa tanto los caracteres de estética política, la movilidad del paisaje y de las naciones en su unión de límites y limitaciones, como los de la teoría general de la vida en Ortega, la conjunción de las posibilidades de creación e interpretación en la limitación propia, por un lado, y los momentos de riesgo e inseguridad en el límite, en la superación de la limitación, por el otro.

\footnotetext{
436 En ¿Qué es filosofía? utiliza Ortega el mismo principio para mostrar la relación entre vida y filosofía: "¿No fuera más prudente excusarla -dedicras no más a vivir y prescindir del filosofar? Para el viejo héroe romano, por el contrario, era necesario navegar y no era necesario vivir. Siempre se dividirán los hombres en estas dos clases, de las cuales forman la mejor aquéllos para quienes precisamente lo superfluo es lo necesario". ¿Qué es filosofía? (1929). OC VII, 328.
} 


\section{EL FINAL DE LA RECEPCIÓN: DIALÉCTICA Y EUROPA (1931-1950)}

\section{Introducción}

El tercer artículo de Ortega sobre Hegel, "En el centenario de Hegel", fue escrito en 1931. Ortega no volverá a publicar ningún otro texto explícitamente dedicado a Hegel, pero su recepción no culmina ni en ese año ni en los temas que ha tratado en los tres artículos. La recepción proseguirá en tres sentidos:

- En primer lugar, Ortega continuará utilizando de un modo concreto los contenidos e ideas que ha examinado en los tres artículos. Aplicados a los nuevos objetivos y temas expuestos en sus textos de los años treinta y cuarenta, de un modo muy especial en el contexto de la historia, de la historia en general y de la historia de la filosofía en particular, los contenidos de las notas de lectura sobre Hegel y su concreción en los tres artículos publicados continuarán apareciendo. En general, Ortega no modificará su lectura. La ambigüedad de la recepción se mantendrá y no habrá excesivos cambios en el tratamiento que reciben las apariciones de Hegel, sean explícitas o implícitas, que tengan que ver con los tres artículos. Ortega incluso repetirá textos o se citará a sí mismo utilizando lo expuesto en los tres escritos sobre Hegel.

Pero, si en un primer sentido puede decirse que no habrá más novedades en las ideas de Ortega sobre Hegel, y que las modificaciones se producirán con la aplicación de esas ideas, procedentes de los tres artículos, a los nuevos contextos e intereses, en los otros dos sentidos sí que se llevará a cabo una ampliación en la recepción. El segundo sentido afecta a un tema concreto, la dialéctica; el tercero se sitúa en el contexto de los años cuarenta, en los escritos sobre Europa y la idea de nación.

- La dialéctica es el tema que une los escritos sobre Hegel con la continuación de la recepción a partir de ellos. En los tres artículos publicados no aparecía el tema de la dialéctica en sentido explícito, pero por las notas de trabajo es fácil ver que representaba uno de los mayores intereses de Ortega: una de las carpetillas sobre Hegel llevará el título concreto de "Hegel: Dialéctica" y, aunque las notas que contiene fueran escritas con las 
demás sobre Hegel en el contexto del final de los años veinte, su aplicación tendrá que esperar más de una década, hasta los años cuarenta, hasta las notas para Epílogo... y Origen y epílogo de la filosofía (en lo que concierne a los textos publicados, pues una de las lecciones de Ortega sobre Hegel en el año 28 en Buenos Aires llevará precisamente el título de "Dialéctica e intuición", título que refiere directamente a los contenidos de las notas).

El tema de la dialéctica afectará a todos los marcos. Ortega ofrecerá una teoría de la dialéctica propia, una dialéctica real (utilizando la expresión de Dilthey), pero la presencia de Hegel será determinante, en las dos direcciones, h negativa y la positiva. La dialéctica representará la integración de la serie de continuidades y discontinuidades que refieren tanto a la realidad, como a la historia, como a la conciencia, como, de un modo muy concreto, a la historia de la filosofía. El talante general supondrá la afirmación de una serie de rasgos globalizadores, integradores, colaboradores, que se mantendrán siempre en un sentido abierto y nunca totalitario. Ese será el marco que rija la relación con Hegel: se admitirá la dialéctica en su juego de continuidades y discontinuidades, pero no un final en el desarrollo, no el imperialismo del espíritu o del absoluto que para Ortega dirigía la dialéctica hegeliana.

La dialéctica, en un sentido muy general, determinará el desarrollo de gran parte de los temas que definen los intereses de Ortega a partir de los años veinte y comienzos de los treinta. Representará el marco de una teoría que, afectando directamente al tema de la historia, se mostrará en la afirmación de diferencias y particularidades, por un lado, y la remisión a un todo, a un conjunto que muestre la continuidad de las discontinuidades, por el otro. Se tratará constantemente de presentar la conexión de las diferencias, de las limitaciones, que, manteniendo una exposición determinada de la relación límite-limitación, afectará a todos los contextos. La continuidad y la discontinuidad, la serie de limitaciones y su conjunción a partir de su conversión en límites, aparecerá en la teoría de la historia, de la historia de la filosofía, de la relación entre aspectos de lo real y sus vistas o conceptualizaciones, o, de un modo muy concreto, en las ideas sobre Europa y la idea de nación.

- Este es el tercer sentido en el que se amplía la recepción de Hegel: el tema de Europa y la idea de nación. Se sitúa en un contexto explícito, los escritos de los años cuarenta alrededor de la Meditación de Europa, pero únicamente será posible vislumbrar la 
presencia de Hegel a partir de las notas de trabajo. El tema afectará al concepto de nación, de nacionalismo, a la relación dialéctica entre las distintas limitaciones nacionales y al carácter móvil, dinámico, que mantendrá el proyecto ultranacional europeo. La dialéctica de la limitación tendrá en este contexto el final de su aparición: referirá a las relaciones explícitas entre naciones, a los juegos de fronteras que mostrarán el carácter dinámico, nunca cerrado, de la ultranación europea en su lucha contra los nacionalismos particularistas.

En estos dos últimos sentidos, el que remite a la dialéctica y d que concierne al tema de Europa, los caracteres estéticos tendrán una presencia ineludible. En la dialéctica, la continuidad de fragmentos, la continuidad de la discontinuidad, mostrará la aparición de una estética sugestiva basada en la relación entre dialéctica e intuición. En el tema de Europa, esa estética sugestiva, referida de un modo explícito al tema de la continuidad simbólica y dialéctica de los fragmentos, tendrá su exposición en el tema concreto de la frontera. La meditación de Ortega sobre Europa se rige por una dialéctica de la frontera muy especial, que tendrá su expresión estética en los escritos de los mismos años sobre Velázquez. La frontera política entre las naciones y la frontera estética de las figuras en los cuadros de Velázquez estarán definidas por el mismo talante abierto, impreciso, equívoco, que permitirá la integración de las discontinuidades en un fondo común.

De un modo general, el final de la recepción de Hegel por Ortega tendrá dos temas principales, la dialéctica y Europa, y mantendrá los dos hilos argumentativos que han guiado la recepción desde el inicio, la dinámica que supone la relación entre limitación y límite, y la conexión con el contexto estético. Los juegos de límites y limitaciones afectarán explícitamente a la continuidad dialéctica de discontinuidades y a la relación entre Europa como ultranación y sus diferencias, las distintas nacionalidades.

La conexión entre el tema de la dialéctica y el tema de Europa se mostrará precisamente a partir de esta dinámica: la que permite la relación entre las particularidades diferenciales como limitaciones y la referencia constante de unas a otras como límites. Las singularidades dinamizadas en el movimiento dialéctico (las épocas y vigencias históricas, los distintos sistemas filosóficos, los aspectos de cosa, etc.) y las nacionalidades refiriendo al fondo ultranacional europeo, mantendrán ambas el mismo carácter: el carácter limitador 
que confiere un talante propio, concreto, a cada diferencia, y el carácter límite que muestra la continuidad entre ellas.

La estética sugestiva que surgirá en el contexto de la dialéctica, y la serie de márgenes flotantes, de fronteras estéticas, que aparecerá en conexión explícita con el tema de Europa, no mostrarán únicamente la referencia estética en los dos momentos, sino que, del mismo modo, continuarán el sentido seguido desde el inicio como hilo conductor: el hilo marcado por la estética de límites y limitaciones. La sección final de la recepción de Hegel por Ortega mantendrá, con esto, la presencia conjunta de los tres polos que han guiado la recepción en su conjunto: la relación entre Hegel y Ortega en temas concretos, en este caso la dialéctica y Europa, la referencia estética que se desprende de esos temas y la conjunción de ambos aspectos en la dinámica ofrecida por la conexión entre límite y limitación. Hegel, estética y limitación, situados alrededor del tema de la dialéctica y de Europa, concluirán la recepción de la recepción de Hegel por Ortega. 


\section{La dialéctica}

El tema de la dialéctica en Ortega se presenta definido por el talante de convivencia y colaboración entre las particularidades. Un talante que no será cerrado, circular, como el de la dialéctica hegeliana, sino que permanecerá abierto, progresando en línea recta y no en círculo, como el sistema de Hegel. De todos modos, la relación entre la dialéctica de Hegel y la de Ortega es determinante para entender el contexto. Una de las lecciones del año 28 en Argentina tendrá como título "Dialéctica e intuición", y las notas preparatorias de esa lección permanecen en el archivo de la "Fundación José Ortega y Gasset" en una carpetilla titulada "Dialéctica". Esas notas, cuyos contenidos no aparecerán en textos publicados hasta los años cuarenta, mostrarán de un modo detallado tanto la relación, mantenida siempre en términos de recepción, entre Hegel y Ortega con respecto a este tema, como la conexión entre textos e ideas de los años veinte con otros que refieren de modo concreto a los años cuarenta. En esas notas estará basada gran parte del desarrollo del tema a examinar.

El concepto de "dialéctica" en Ortega tiene una historia particular. Se inicia con una serie de pretensiones de totalidad, de no renunciar a nada, que, en el fondo, llegarán hasta su conclusión. Ese afán de totalidad presentará a la dialéctica en el comienzo de su historia en la filosofía de Ortega refiriendo al tema del arte, el arte entendido como expresión de la totalidad. Junto a este afán de totalidad, de exclusión de toda exclusión, aparecerá el talante integrador, el que muestra la solidaridad de las limitaciones, niega la primacía de lo eterno y se mantiene como dialéctica socrática, colaboradora, conversadora.

Pero a este comienzo de la historia de la dialéctica inmediatamente se le unen nuevos caracteres. En primer lugar, y recorriendo todo el contexto, el de la continuidad de la historia, el del movimiento dialéctico de la historia, cuyo sentido intentará ofrecer la razón histórica. Ésta mostrará una dialéctica histórica que se definirá en contraposición explícita a la dialéctica conceptual, a la dialéctica lógica de la razón pura. Las críticas a Hegel, en el sentido de su operación mágica sobre la historia, serán determinantes en este sentido. Sin embargo, junto a las críticas también aparecen los méritos, los méritos que Ortega presenta en la conexión entre Hegel y Dilthey referente a la continuidad de la conciencia, en la que no se permite la independencia o primacía del conocimiento. La integración en este caso 
será de los distintos ámbitos de la conciencia, y será una primera exposición de los talantes de continuidad que regirán constantemente el tema de la dialéctica.

Con este marco se iniciará en Ortega el encuentro con Hegel. A la continuidad de la conciencia y de la historia seguirá en el desarrollo del tema de la dialéctica la continuidad de pensamiento y realidad. Aparecerá una teoría del pensar como yuxtapensar, que Ortega inicia en las notas de lectura sobre Hegel y que, recogida parcialmente en ¿Qué es filosofía? sin remitir al tema de la dialéctica, no volverá a aparecer hasta los textos de los años cuarenta, hasta el proyecto inacabado de Epílogo... La continuidad del pensamiento se mostrará basada en la continuidad misma de lo real, en el carácter histórico y dialéctico que afecta a todos los marcos.

La relación con Hegel partirá de esos caracteres. Ortega en ningún momento admitirá el rasgo de conclusión, de definitividad que acompaña en su lectura la dialéctica sistemática hegeliana. La dialéctica en Ortega siempre estará abierta, expresará la continuidad en todos los marcos, los rasgos de posibilidad de ampliación, de perfeccionamiento. La conexión se establece entre dialéctica e historia de la filosofía, en tanto ésta iría exponiendo en sus distintos momentos, en sus distintos sistemas, vistas o aspectos parciales del universo o la totalidad que tiene como objeto.

En este sentido, el que une la continuidad de lo real y del pensar en su integración de fragmentos y de particularidades con la continuidad de la propia historia de la filosofía, aparecerá el tema del error, entendido no en un carácter negativo, sino en el positivo de fragmentación, de verdad incompleta. El tema del error es determinante en el contexto de la dialéctica, porque muestra la conexión entre ésta y la historia de la filosofía, conexión que, en el fondo, dirige el desarrollo del concepto de dialéctica en Ortega. El error aparecerá remitiendo a incompletudes, a parcialidades, a aspectos de cosa, de realidad.

Este tema, el de los aspectos o fragmentos de lo real, será la innovación de Ortega en los años cuarenta frente a los textos y notas de épocas anteriores. Con todo, volverá a asentarse en una idea conocida: la cosa como maestro del hombre, el "pensamos con las cosas" de Hegel. De nuevo, Hegel situado en el centro de la dialéctica de Ortega. La conexión se mostrará incluso en el afán de totalidad que iniciaba el tema: la renuncia a no renunciar será expuesta en los años cuarenta cuando Ortega se defina a sí mismo como "filósofo del todo para el todo". 
Ese afán de totalidad, basado en los rasgos propios de la dialéctica real, la dialéctica de Ortega, se sostiene ahora sobre la integración de aspectos, sobre la continuidad siempre abierta de particularidades. Esa continuidad, que refiere tanto al pensamiento, como a lo real, como a la historia, y muy en concreto a la historia de la filosofía, exigirá un pensamiento intuitivo, basado en la presencia inmediata de las cosas, que integre concepto y realidad. Será un pensamiento pleno, completo, sintético, que, partiendo de la cosa "como maestro del hombre", no renuncie con todo a su mismo título de pensamiento.

En este último sentido, el pensar intuitivo, sintético, dialéctico, mostrará su exposición en los rasgos de un pensar sugestivo que, basado en la constante remisión de unos aspectos o limitaciones a otros, unirá la sugestión de la dialéctica con la sugestión del propio lenguaje filosófico: unos aspectos sugieren otros, unos conceptos sugieren otros. La filosofía adquirirá, así, en la conexión de dialéctica e intuición, el rango de un pensamiento poético, sugestivo, metafórico. En este pensamiento sugestivo, la constante creación de realidad, de paisaje, de perspectiva, aparecerá remitiendo, por un lado, a los caracteres de continuidad de la dialéctica real, la dialéctica propia de Ortega, y, por el otro, al propio lenguaje y pensamiento filosóficos, que en la dialéctica de su historia progresan en línea recta en el descubrimiento y ampliación de nuevos aspectos de realidad. 


\section{1. "Dialéctica e intuición": Buenos Aires, 1928}

Si hay algo que llama la atención en los tres escritos de Ortega sobre Hegel, eso es que no aparezca en ninguno de ellos el tema de la dialéctica. Y no sólo llama la atención al tener en cuenta que para Ortega la dialéctica llegará a ser, sobre todo en los escritos de los años cuarenta, una de las claves centrales de su filosofía, sino también, y sobre todo, porque entre las notas de trabajo sobre Hegel se encuentra una carpetilla titulada así, "Dialéctica", que incluye las conexiones y las diferencias entre lo que el propio Ortega quería de la dialéctica y la dialéctica hegeliana. Esa carpetilla, además de incluir los puntos determinantes para entender la dialéctica de Ortega, contiene multitud de referencias a temas (la intuición, la continuidad de ser y pensamiento, la fragmentariedad, etc.) que aparecerán junto al examen del tema de la dialéctica sobre todo en Origen y epílogo de la filosofía y en las notas de trabajo para Epílogo..., el proyectado libro "definitivo" de Ortega (que reelaboraría otro también únicamente proyectado, la Aurora de la razón histórica), escritos ambos de los años cuarenta.

Con todo, esas mismas notas de la carpetilla "Dialéctica", además de remitir a temas que sobrepasan los aspectos tratados en los artículos sobre Hegel, incluyen tanto las referencias a éstos como la continuidad con los mismos temas. De otro modo: la carpetilla titulada "Dialéctica" incluye tanto la conexión con los escritos sobre Hegel editados al final de los años veinte, como la referencia a temáticas posteriores, concretamente de los años cuarenta, centradas explícitamente en el tema de la dialéctica.

Ante esto pueden presentarse dos opciones explicativas: 1. Las notas de la carpetilla "Dialéctica" fueron escritas por Ortega mas de diez años después, con respecto anto a los artículos sobre Hegel como a las notas sobre las que éstos se sostenían. Esto querría decir que Ortega habría vuelto explícitamente a Hegel, alrededor de los años cuarenta, para detenerse únicamente en el tema de la dialéctica. 2. Las notas sobre la dialéctica de Hegel, y, con ellas, las ideas y teorías de Ortega que contienen, fueron escritas a la vez que los artículos publicados sobre Hegel y las notas de trabajo que les corresponden. No habría, entonces, discontinuidad entre los temas: Ortega, al estudiar a Hegel, llevó a cabo tanto el tratamiento del tema de la historia, y del futuro, y de la geografía o el paisaje, y de la conexión entre espíritu (en Hegel) y vida (en Ortega), esto es, los temas que aparecen en los 
escritos publicados, como el examen muy concreto del tema de la dialéctica. Ortega, entonces, al centrarse en los años cuarenta en el tema de la dialéctica no habría vuelto a leer de un modo detenido a Hegel para llevar a cabo la exposición de ese tema, sino que ya lo tenía hecho: donde volvió Ortega fue a sus notas de trabajo sobre Hegel.

La segunda opción es la correcta. Pero, si es así, ¿por qué Ortega retrasó en más de diez años la utilización de sus apuntes sobre la dialéctica de Hegel? Y, además, ¿cómo sabemos que esa segunda pción es realmente la correcta? A finales de los años veinte, Ortega ya tenía estudiado (y, por las notas, muy avanzado en la exposición) el tema de la dialéctica, pero sólo será diez años más tarde aproximadamente cuando realmente lo utilice. Puede concretarse más aún: ese tratamiento de la dialéctica no fue publicado, pero quizá sí expuesto... en Buenos Aires en el año 28.

En el segundo viaje a Argentina, además de las conferencias en la Sociedad de Amigos del Arte tituladas Meditación de nuestro tiempo, ofreció Ortega una serie de cuatro lecciones en la Facultad de Filosofía y Letras de Buenos Aires. La información sobre las primeras es detallada, de hecho han sido editadas recientemente por Molinuevo 437 , pero no ocurre igual con las segundas. Medin, al igual que Molinuevo en la introducción a Meditación de nuestro tiempo, dice que esas conferencias en la Facultad de Filosofía trataron sobre el tema "¿Qué es la ciencia, qué es la filosofía?"438; de nuevo Molinuevo, en el prólogo a su reciente edición de textos de El Espectador, precisa la información y las presenta expresamente dedicadas a Hegel ${ }^{439}$; Marta Campomar, por su parte, afirma que

${ }^{437}$ ORTEGA Y GASSET, J. Meditación de nuestro tiempo. Las conferencias de Buenos Aires, 1916 y 1928. Ed. J.L. Molinuevo. Madrid: F.C.E., 1996.

438 MEDIN, T. Ortega y Gasset en la cultura hispanoamericana. México: F.C.E., 1994, p. 96: "El 25 de agosto de 1928 Ortega llega a Buenos Aires, a los 45 años de edad, gracias a la invitación de la sociedad Amigos del Arte, la Institución Cultural Española, la Sociedad de Conferencias y la Facultad de Filosofía y Letras de la Universidad de Buenos Aires. También en esta oportunidad, como en la anterior visita, Ortega dictará sus conferencias en dos ámbitos diferentes: en la Facultad de Filosofía y Letras cuatro conferencias sobre el tema «¿Que es la ciencia y qué es la filosofía?», y en los Amigos del Arte cinco conferencias alrededor del tema de nuestra vida". MOLINUEVO, J.L. Introducción, en: ORTEGA Y GASSET, J. Meditación de nuestro tiempo. Op. cit. p. 24: "Invitado por la Sociedad de Amigos del Arte, desarrolla un ciclo de cinco conferencias sobre «Meditación de nuestro tiempo», y otro de cuatro en la Facultad de Filosofía y Letras de la Universidad de Buenos Aires, sobre el tema «¿Qué es la ciencia, qué es la filosofía?»".

439MOlinUEVO, J.L. Prólogo, en: ORTEGA Y GASSET, J. El Espectador. Madrid: Edaf, 1998, pp. 2021: "En el año 1928 Ortega realiza su segundo viaje a la Argentina. Da una serie de conferencias en la Sociedad de Amigos del Arte con el título Meditación de nuestro tiempo, y en la Facultad de Filosofía y Letras sobre Hegel". 
esas lecciones trataban sobre Hegel y la historia 440 . Entre los tres mencionan tres temas de esas cuatro lecciones: qué es filosofía, Hegel y la historia. Les falta uno: la dialéctica 441. Entre las notas de trabajo sobre Hegel se encuentra la siguiente:

"Título de las conferencias.

Cuatro lecciones de filosofía

I. ¿Qué es filosofía?

II. Dialéctica e intuición

III. La "filosofía de la historia de Hegel"

IV. La historiología".442

Esas cuatro lecciones sólo pueden ser las del 28 en la Facultad de Filosofía y Letras de Buenos Aires, o, por lo menos, la pretensión que tenía Ortega en un principio. Con todo, la pregunta sigue siendo la misma. La cuestión sobre qué es la filosofía se encuentra iniciada en las lecciones de Meditación de nuestro tiempo y explícitamente tratada en la obra clásica de Ortega; el examen de la filosofía de la historia de Hegel y la historiología corresponde al prólogo a la Filosofía de la historia de Hegel. Además, el hecho de ofrecer las lecciones sobre Hegel en Argentina ya ha sido explicado en el comentario al "Hegel y América": no sólo el tema de la historia interesaba a Ortega, también el de América y el del futuro. Pero, ¿qué ha pasado con esa segunda lección, "Dialéctica e intuición"? ¿por qué no fue publicada por Ortega en algún artículo o formando parte de alguna obra de la misma época, alrededor de 1928 ?

Las notas que dieron origen a esa lección son las d la carpetilla "Dialéctica", por tanto, previas al año 28. Su exposición en textos publicados, sobre todo en Origen y epílogo de la filosofía y en Epílogo..., en cambio, tendrá que esperar más de diez años: ¿por qué? Porque Ortega, aunque ya tenía un concepto bastante detallado de su dialéctica y del modo de

440CAMPOMAR, M. 'Los viajes de Ortega a la Argentina y la Institución Cultura Española", en: V.V.A.A. (J.L. Molinuevo, coor.), Ortega y la Argentina. México: F.C.E., 1997, p. 141: "En este segundo viaje, en Amigos del Arte, Ortega dio una serie de conferencias sobre «Qué es nuestra vida» y en la Facultad, sobre Hegel y la historia".

${ }^{441}$ Es cierto que Molinuevo lo menciona comentando el "Hegel y América", aunque sin remitir explícitamente al contenido de las lecciones ofrecidas en la Facultad de Filosofía: "También es decisivo el concepto de dialéctica, ya que Ortega sostiene una concepción no conclusiva de la misma, manteniendo la tensión de la tesis y la antítesis, pero sin una síntesis conclusiva". MOLINUEVO, J.L. Prólogo, en: ORTEGA Y GASSET, J. El Espectador. Op. cit. p. 21. 
entender la de Hegel, todavía carecía de algunos temas primordiales que la constituirán como su dialéctica, la realmente propia de Ortega, la que llamará, partiendo de Dilthey, dialéctica real ${ }^{443}$. Esta dialéctica real no sólo debe entenderse en conexión, positiva y negativa, con la de Hegel, sino que, además, dos de las tesis principales sobre las que se apoya, la del pensar como yuxtapensar y la de la prioridad del objeto, el "pensamos con las cosas", se iniciarán, como mostraré, precisamente en Hegel.

Además, la dialéctica real continuará manteniendo la relación con el pensar intuitivo, que ya se inicia tanto en el título de esa segunda lección del 28, como en las notas que la sostienen. El tema de la intuición llegará también de un modo explícito hasta Epílogo..., tanto en conexión con la dialéctica, como en sí mismo, con unos caracteres propios que detallaré más adelante. Los temas que le faltaban a Ortega para poder enunciar su dialéctica se referirán, sobre todo, a la conexión explícita entre historia y filosofía, a la teoría de los aspectos, a la confluencia de la serie dialéctica en el pensamiento y en lo real mismo, y estas ideas únicamente serán enunciadas de un modo amplio en los textos de los años cuarenta y en los de los años treinta que conducen hasta ellos.

De todos modos, no hay que olvidar en ningún momento que, para poder entender el desarrollo del tema, es necesario conocer la situación cronológica donde se inicia el tratamiento de la dialéctica: las notas de lectura para los artículos sobre Hegel (y, sobre todo, lo que subyace a ellos, lo que ya he comentado en el examen de esos artículos: el porqué del acercamiento de Ortega a Hegel en un determinado momento), así como el contexto de las lecciones del 28 en Argentina. Cuando Ortega, en los años cuarenta en Origen y epílogo de la filosofía, afirme: "Dejo para otro trabajo una exposición que precise lo que hay de común (muy poco) y lo que hay de divergente (todo el resto) entre el uso de este término [dialéctica] en la obra de Hegel y en las páginas de este libro'444, hay que tener en cuenta dos cosas: que no está tan claro que eso común sea "muy poco", y que ese "otro trabajo", sea cuál sea, en lo referente a la dialéctica de Hegel ya lo había iniciado

\footnotetext{
${ }^{442}$ Archivo de la "Fundación José Ortega y Gasset", Carpetilla "Hegel: Dialéctica".

443" Historia como sistema" (1935). OC VI, 41: "Es la Realdialektik con que en un rincón de sus papeles soñaba Dilthey".

${ }^{444}$ Origen y epílogo de la filosofía (1946). OC IX, 375 n.
} 
Ortega en notas de trabajo desde los años veinte, desde esas notas de la carpetilla "Dialéctica".

Para entender este proceso hay que seguir diversos pasos. En primer lugar, ver cómo se ha desarrollado el tema de la dialéctica desde sus inicios, antes de llegar a Hegel y mucho antes de la explicitación como dialéctica real; en segundo, cómo ha quedado situado Hegel en la filosofía de Ortega en general, después de los tres artículos publicados; y, en tercero, y de modo general, cuáles son los contextos y las intenciones de Ortega que le conducirán hasta el tema de la dialéctica. Una vez concretados estos puntos, podrá analizarse de un modo lo suficientemente detallado el tema de la dialéctica en los textos de los años cuarenta. 


\subsection{Estética dialéctica y dialéctica de la colaboración}

En 1911 aparecen dos referencias a la dialéctica en las obras de Ortega cuyo significado, en el fondo, se mantendrá hasta el final. Los contextos cambiarán, también los temas y las intenciones, pero no así el talante general. La primera de esas dos referencias es aquélla, ya comentada (en el capítulo "Mediterranismo, cultura fronteriza y nacionalismo"), que presentaba Ortega para definir la estatua del guerrero en la catedral de Sigüenza: "La historia nos garantiza su coraje varonil. La escultura ha conservado su sonrisa dialéctica. ¿Será posible? ¿Ha habido alguien que haya unido el coraje a la dialéctica?"445. El contexto era el de la integración, el de la reunión del hombre mediterráneo y el hombre gótico, de España y Europa, y la dialéctica remitía únicamente al carácter de ciencia, de cultura, que definía al hombre del norte en oposición al hombre del sur. La base de todo ello era la necesidad de integrar ambos talantes, el afán de totalidad, de preferir no preferir: "La vida cobra sentido cuando se hace de ella una aspiración a no renunciar a nada'446.

También en el mismo año, en el 'Vejamen del orador", Ortega refiere a los inicios de la filosofía, a la dialéctica socrática. Frente al discurso, frente a la soledad del orador, ensaya Sócrates el diálogo. La conversación no puede avanzar si no se produce poco a poco una coincidencia, una aproximación que identifique los pasos teóricos que sigue cada uno de los conversadores: "La verdad los transubstancia y de dos se hacen un solo hombre, el Hombre. Así la filosofía se llamó primero dialéctica"447. El diálogo, la dialéctica, unifica, identifica; el orador, por su parte, se atiene en su monólogo únicamente al momento, a la circunstancia momentánea. El problema surge al intentar determinar esa circunstancia concreta:

"Mas ¿qué son las circunstancias? ¿Son sólo estas cien personas, estos cincuenta minutos, esta menuda cuestión? Toda circunstancia está encajada en otra más amplia; ¿por qué pensar que me rodean sólo diez metros de espacio? ¿Y lo que circundan estos diez metros? ¡Grave olvido, mísera torpeza, no hacerse cargo sino de unas pocas circunstancias, cuando en verdad nos rodea todo! / Yo no simpatizo con el loco y

\footnotetext{
445" Tierras de Castilla. Notas de andar y ver" (1911). OC II, 47.

446 Ibid. p. 46.

447" Vejamen del Orador" (1911). OC I, 563.
} 
el místico: alcanza todo mi entusiasmo el hombre que se hace cargo de las circunstancias, con tal que no se olvide ninguna" 448 .

En la primera sección del trabajo aparecía el tratamiento contextualizado de los temas que subyacen a ese párrafo citado: la circunstancia, los talantes panteístas del joven Ortega, etc. Ahora debe hacerse únicamente en relación con el tema de la dialéctica: la unificación e identificación que la filosofía obtiene en el diálogo y en la consecución de la verdad remite a una teoría de la continuidad de las circunstancias ("toda circunstancia está encajada en otra más amplia") que se constituye como un afán de totalidad, de intento por alcanzar el todo. El pensamiento se produce siempre a través de una continuidad de limitaciones a partir de la cual éstas quedan dinamizadas, parcializadas en su carácter de limitación y, a la vez, justificadas en su movilidad mediante la asunción del carácter de límite que permite el contacto con otras limitaciones. En estos primeros escritos de Ortega la referencia es únicamente a circunstancias; mucho más adelante, la continuidad remitirá a la historia, a la vida, al pensamiento, a la filosofía...

Las dos primeras apariciones de la dialéctica en la obra publicada de Ortega, ambas en 1911, se sitúan, por lo tanto, una junto a la aspiración a no renunciar a nada y otra junto al entusiasmo por el hombre que no olvida ninguna circunstancia, que se hace cargo de todas. Esto no es casual. No lo es en lo que refiere al tema de la dialéctica en general, como veremos, pero tampoco lo es en su conexión con un aspecto esencial, la conexión entre la dialéctica y el arte. El afán de totalidad, de no renunciar a nada, alcanza su máxima expresión en el arte. Desde el comienzo de su filosofía ha sido el arte para Ortega el punto de vista de la totalidad. En la vida, la totalidad es imposible, pero no en el arte: en éste, el artista se propone conseguir "la ficción de la totalidad; ya que no podemos tener todas y cada una de las cosas, logremos siquiera la forma de la totalidad'449. En la base de esta tesis se encuentran todos los temas ya examinados: el afán de ampliación, de crecimiento, la conjunción de ética y estética con ello (querer ser más, querer ser mejor), el imperativo de vida múltiple, la existencia metafórica, etc., o, en una sola expresión, el imperativo de no renunciar a nada.

\footnotetext{
448 Ibid. pp. 563-564.

449" Adán en el paraíso" (1910). OC I, 484.
} 
Es este afán de totalidad, de no renunciar a nada, el que se constituye como un sentimiento dialéctico de la vida: se aspira a la unificación en la totalidad a través de una concordancia de los opuestos, a través de esa existencia metafórica, del arte como metáfora, en la que se trata de conseguir el todo sin dejar de ser uno mismo. Todas esas figuras jánicas, bifrontes, ambiguas (los dii consentes, los dióscuros, el centauro...) expresan la dialéctica del arte. La unión de estética y ética se establece en este primer momento como el afán dialéctico en el que el impulso de totalidad, de no renunciar a nada, se traduce en solidaridad (el diálogo dialéctico, el diálogo entre circunstancias). Es una dialéctica de limitaciones que, por un lado, conduce a h totalidad ficcional del arte, y, por el otro, a los talantes éticos y políticos de la solidaridad, de la convivencia, de querer ser mejor.

El sentimiento dialéctico para Ortega, desde los inicios hasta el final de su filosofía, expresará siempre y en todos los ámbitos la conjunción de limitaciones, de fragmentos, de individualidades, basada en el aspecto de continuidad, de diálogo o de convivencia entre esas mismas particularidades. La dialéctica se constituirá como una dialéctica vital, histórica, real, en la que el talante de solidaridad entre las particularidades aparecerá como el hilo común que une todas las referencias. En este sentido, la remisión a la estética, al arte como afán de totalidad, en su expresión de una estética política o ética, de ethos, se mantendrá también en el tema de la dialéctica.

Si los caracteres dialécticos de colaboración y continuidad entre las particularidades, por tanto, se mostrarán desde el inicio y referirán al sentido vital e histórico de la dialéctica, la confrontación con Hegel se producirá, en realidad, antes de que Ortega haya comenzado a estudiar de un modo detenido la dialéctica de éste. Cuando en 1919, en "Leyendo «Le petit Pierre» de Anatole France", critique Ortega los caracteres eternos, infinitos, sobrehumanos, que se alejan en el arte de lo vital y terreno, y muestre su preferencia por un "arte más saturado de vida que se sabe hijo de un tiempo y con él destinado a transcurrir" 450 , frente a las intenciones de eternidad del arte griego, está mostrando ya los inicios de una dialéctica vital e histórica que tendrá su contrapunto en la hegeliana.

Después de la postulación de un arte vital, y la generalización que sobrepasa el ámbito del arte y conduce a los talantes generales de nueva sensibilidad, de fidelidad al tiempo

450" Leyendo «Le petit Pierre» de Anatole France" (1919). OC II, 231. 
propio $^{451}$, la crítica a todo tipo de eternidad enfrenta la dialéctica platónica, y ya la hegeliana en el fondo, al sentido vital que afirmará Ortega: "Esta sobrestima de las cosas llamadas eternas, que nos dejó en herencia Platón, me parece entre perversa y pueril, resto de la antigua y naciente dialéctica. Veo en ella la apoteosis de fáciles esquemas y una subversión de los débiles contra el destino grandioso de la vida'452. La dialéctica de la teoría platónica expresando la "sobrestima de lo eterno", frente al destino finito, limitado, de la vida. Muy cerca en el blanco de esas críticas se encuentra Hegel y el idealismo que intenta superar Ortega, el de los edificios eternos, que olvida que, del mismo modo que existe una melancolía de las ruinas, hay también una melancolía de lo eterno.

En estas primeras apariciones del tema de la dialéctica en la filosofía de Ortega, por un lado se muestran las referencias al preferir no preferir, al afán de totalidad, y, por el otro, el carácter vital de ese afán, negando los talantes de eternidad. En el centro de ambos momentos, o, mejor, como resultado de su conjunción, una conjunción que exprese la totalidad vital, histórica, la unificación de las limitaciones sin que cada una pierda su carácter propio, se encuentra la serie de rasgos que presentan a la dialéctica como colaboración, como diálogo entre particularidades. Para mostrar estos rasgos acudirá Ortega a la dialéctica socrático-platónica, incidiendo únicamente en estos caracteres de particularización integradora. Antes ha criticado la "sobrestima" de lo eterno que dejó en herencia Platón, ahora se basará únicamente en el talante conversador y afable de su dialéctica.

En 1921, en 'Pepe Tudela vuelve a la Mesta" incide Ortega (comentando los rasgos de la ciudad clásica, opuesta al instinto doméstico en tanto que la casa griega, en el fondo, se construye para salir de ella, para salir a la ciudad y reunirse con otros que también han salido de sus casas) en el carácter de sociabilidad, de convivencia que definía al mundo griego: "Un sentimiento de insuficiencia dentro del círculo doméstico, un afán de romper éste, de hacer nuestra vida tangente a otras vidas, de convivencia, de trato, de sociabilidad ultradoméstica, engendra la urbe antigua"453. Se trataba entonces de un instinto de

\footnotetext{
451"Aprendamos a preferir lo corruptible a b inmutable, la trémula mudanza de la existencia a la esquemática y lívida eternidad. Seamos de nuestro día: mozos al tiempo debido". Ibid. pp. 231-232.

452 Ibid. p. 232.

453" Pepe Tudela vuelve a la Mesta" (1921). OC II, 331.
} 
colaboración, de conversación, que lleva a basar la vida antigua en el logos, en la palabra, en la disputa, con lo que "la ciencia suprema que descubrieron fue llamada «dialéctica», que quiere decir conversación"454. Una conversación que se muestra en la integración de parcialidades e individualidades y que más que conversación se constituye como colaboración. Sólo tres años más tarde respecto a esos dos últimos textos citados muestra Ortega realmente a quién se enfrenta ese pensamiento como diálogo, como convivencia y colaboración iniciado con la dialéctica platónica y socrática:

"El monólogo largo y de una pieza, la macrología, se ha fragmentado en mínimos trozos, se hace micrología y se reparte entre dos. Así nace el diálogo y con él la dialéctica. El pensamiento honesto es siempre en tal sentido dialéctica. Y la dialéctica es colaboración. / La vida intelectual española cruza ahora por una etapa de audaz monologuismo"455.

"El griego no supo nunca estar solo. Para él, vivir era formalmente convivir. [...] Por eso el «modo de pensar» filosófico fue llamado desde Platón «dialéctica»'456, escribirá Ortega más de veinte años después del texto citado y comentando los mismos caracteres. Las bases de la intención de Ortega ya están expuestas, sin embargo, mucho tiempo antes: la dialéctica como colaboración se enfrenta al carácter monologuista de la vida intelectual española del momento. La filosofía, de nuevo, utilizada con unos objetivos muy concretos, los de la crítica a la situación española. Pero las dos direcciones permanecerán indisolublemente unidas: por un lado el ataque al monologuismo hispano, por el otro esa micrología, ese pensamiento fragmentado que caracteriza la dialéctica. Esta micrología de los fragmentos, que, al mantenerse en un carácter dialéctico remitirá constantemente al afán de continuidad, al impulso de totalidad, permanecerá también en la dialéctica real de Ortega, aunque en ésta, como se verá, la continuidad de la fragmentariedad referirá a pensamiento y realidad.

Los rasgos de solidaridad y colaboración que Ortega encuentra en la dialéctica socráticoplatónica llegarán hasta la exposición de su dialéctica real en los años cuarenta. La continuidad y convivencia como expresión del diálogo y de la colaboración en la búsqueda del sentido, de la verdad, reunirán las referencias que en este momento únicamente

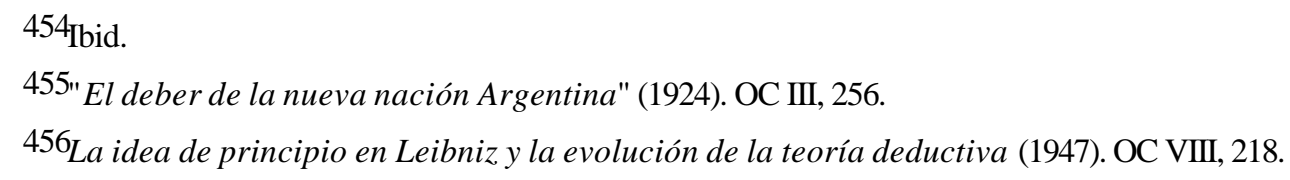


insinúan: la continuidad de la historia, la convivencia de la vida, del "vivir es convivir". Cuando Ortega pueda integrar toda esta serie de caracteres con los de la continuidad del pensamiento y de lo real, continuidad y discontinuidad, en tanto será continuidad de la fragmentación, entonces podrá desplegar su teoría de la dialéctica real. Para llegar hasta ahí necesitará antes, por un lado, constituir de un modo lo suficientemente detallado su teoría de la vida y de la historia, y con ambas, por el otro, enfrentarse a la dialéctica de Hegel.

El inicio del tema de la dialéctica se constituye, entonces, como un afán de totalidad y de no renunciar a nada que conecta explícitamente con el tema del arte. Del mismo modo, comienzan a concretarse los rasgos vitales de esa dialéctica, que se enfrentaría a todo tipo de "eternidades". De la relación entre ambos aspectos resulta el acercamiento de Ortega a la dialéctica griega y sus caracteres de convivencia, de solidaridad, de continuidad de la fragmentación. Esta serie de rasgos llegará hasta el final, hasta la dialéctica real expuesta en los años cuarenta. Previamente, sin embargo, tendrá que acudir al enfrentamiento con Hegel, enfrentamiento que, como se verá, aparece de nuevo con todos los caracteres de ambiguiedad que vienen mostrándose desde el comienzo en la recepción de Hegel por Ortega. En este caso, esa ambigüedad será fácil de presentar: crítica dura a la dialéctica hegeliana, y, sin embargo, apoyo de la dialéctica real en dos rasgos que Ortega ha encontrado en Hegel: la continuidad del pensamiento, el yuxtapensar, y el "pensamos con las cosas". Antes de llegar hasta ahí, Ortega intentará definir su crítica: la suya no pretende ser una dialéctica conceptual o lógica, sino una dialéctica real e histórica. 


\subsection{Dialéctica histórica}

Ortega comienza su relación con el tema de la dialéctica postulando el afán de totalidad, de no renunciar a nada, insinuando la relación con la vida, y mostrando los talantes de convivencia y colaboración. Cuando lee a Hegel en los años veinte escribe las notas de trabajo sobre la dialéctica hegeliana y presenta los inicios de su dialéctica real, que seguramente fueran expuestos en la lección segunda de las ofrecidas en la Facultad de Filosofía de Buenos Aires en 1928. Esos aspectos, tanto las críticas a Hegel como su propia dialéctica, sólo serán recogidos de un modo explícito en los textos de los años cuarenta, cuando Ortega haya completado la serie de contenidos que formarán la dialéctica real.

La cuestión es ahora la siguiente: qué ocurre exactamente, en lo que concierne a Hegel y al tema general de la dialéctica, durante los años treinta, esto es, el contexto en el que Ortega ya ha escrito los artículos sobre Hegel (así como las notas de trabajo, incluidas las de la carpetilla "Dialéctica"), pero todavía faltan más de diez años hasta llegar a Epílogo... y a Origen y epílogo de la filosofía. Si se quiere concretar más: qué ocurre exactamente en lo que concierne a Hegel y a la dialéctica desde ¿Qué es filosofía? hasta las obras de los años cuarenta.

En lo que atañe a la dialéctica, las referencias explícitas en las obras publicadas son pocas, aunque ya estuvieran escritas esas notas sobre la dialéctica desde final de los años veinte. No así las implícitas, las que remiten a los temas que Ortega inicia ahora, y que sólo si se tienen en cuenta los caracteres de la dialéctica real expuesta en los años cuarenta podrán entenderse como los pasos previos que Ortega está llevando a cabo. Las referencias explícitas en las obras publicadas remiten únicamente a dos caracteres que pueden presentarse como "dos dialécticas" particulares: la dialéctica vital y la dialéctica histórica, esto es, la conexión de la dialéctica con la razón histórica y la razón vital. En las lecciones En torno a Galileo lo expresaba Ortega de este modo (el párrafo lo cité completo más arriba en el contexto de la relación entre Hegel y Schlegel): "La realidad histórica, el destino humano avanza dialécticamente, si bien esa esencial dialéctica de la vida no es, como creía Hegel, una dialéctica conceptual, de razón pura, sino precisamente la dialéctica de una razón mucho más amplia, honda y rica que la pura - a saber, la de la vida, la de la 
razón viviente' 457 . El enfrentamiento se produce entre la razón lógica de Hegel y la razón vital e histórica de Ortega, y el contexto es el del prólogo a la Filosofía de la historia, que veíamos más arriba.

La dialéctica histórica es el movimiento, la continuidad de la historia, la relación entre las diferentes particularidades (sea en forma de épocas, de creencias, de generaciones...) a lo largo del tiempo, la conexión entre un pasado, un presente y un futuro. La misión de la razón histórica, del logos que confiere sentido a los hechos históricos, sería explicar esa dialéctica. Es una dialéctica histórica constituida como una dialéctica de la razón vital, en tanto se mantendrá en el juego de perspectivas, de individualidades, de proyectos de futuro. De ahí el enfrentamiento con Hegel, con la dialéctica conceptual de Hegel. En el "Hegel y América" hacía Ortega una mención muy breve de esa dialéctica conceptual. Allí escribía: "La Lógica de Hegel desarrolla este proceso ideal, que, de etapa en etapa, aclara ante sí mismo, desvela y revela al Espíritu. El concepto con que empezamos se perfecciona en otro; éste, a su vez, en otro, y así, sucesivamente, en cadena de diamante, en disciplina dialéctica, que nos aprisiona, para al cabo dotarnos de la suma libertad'458. Es el enfrentamiento ya presentado: el enfrentamiento entre la dialéctica conceptual y la dialéctica histórico-vital es el enfrentamiento de la razón conceptual, pura, y la razón histórico-vital.

El objetivo de Ortega es concederle carácter vital e histórico a la razón pura, unir "razón y peripecia", teniendo muy en cuenta que la peripecia, la vicisitud, la aventura histórica, surge de la naturaleza propia de las cosas, uniendo con ello historia y vida, y confiriéndole a ambas el carácter objetivo, real, que solicitan. Ortega muestra la exigencia de unir razón y peripecias contraponiendo su razón histórica a la razón pura. Esta razón pura es definida explícitamente como dialéctica conceptual, atendiendo ahora a Platón en vez de a Hegel, y el enfrentamiento con la razón histórica sería el tema primordial para una meditación del presente: "¡Menudo tema, amigos, para una meditación del presente: someter a careo y hacer hablar, la una contra la otra, estas dos formidables potencias históricas: la razón y la peripecia o vicisitud! En realidad, se trata de dos formas de la razón: una, la razón pura que «parte de conceptos, procede mediante conceptos y termina en conceptos»-así define

\section{${ }^{457}$ En torno a Galileo (1933). OC V, 137.}


Platón la dialéctica-, y otra, la razón histórica, que sale a nuestro encuentro de la peripecia misma, que brota fulminante de la naturaleza de las cosas' 459 .

La dialéctica conceptual es la forma de la razón pura, y parte, procede y termina en conceptos; la dialéctica histórico-vital atiende a la naturaleza de las cosas, en la historia a las pericecias mismas, en la vida a los hechos individuales. Es otra de las expresiones del enfrentamiento entre la dialéctica conceptual y la dialéctica real: el concepto frente a la cosa. La dialéctica histórica avanza atendiendo a individualidades, a hechos, a peripecias, a objetos; la dialéctica conceptual, por su parte, se mantiene en la rigidez del concepto, anticipa en éste lo que únicamente sucede en la cosa, entendido esto en referencia tanto a la razón en la historia como a la lógica hegelianas. La dialéctica histórica y vital muestra la plenitud real de sus momentos; la dialéctica conceptual los determina, los crea.

Alrededor de 1935 insistirá Ortega en estos caracteres, en distintos escritos y contextos, aunque siempre con una base similar. De hecho, hasta llegar a los años cuarenta no aparecen más referencias a la dialéctica en la filosofía de Ortega que en este momento, en torno a 1935. No es casual. 1935 es el año de Historia como sistema, pero también el del último curso (1935/1936) profesado por Ortega en h Universidad de Madrid. Ese curso, en sus primeras lecciones, consistió en la exposición de las páginas iniciales de Ideas y creencias, que fueron así incorporadas al curso como introducción. En su edición de Ideas y creencias, Garagorri ha publicado algunas partes del manuscrito preparatorio para las lecciones posteriores de ese último curso. Entre esos papeles se encuentran unas páginas (de la lección del 3 de marzo del 36) tituladas por el editor "La paradoja de Hegel".

Ése es el texto importante para nuestro tema, el que conecta con las notas de la carpetilla "Dialéctica" y permite ver la relación entre Hegel, la dialéctica y escritos de los años anteriores a 1935/36, sobre todo ¿Qué es filosofía?. Los temas que aparecerán en este contexto serán muy similares a los que se tratarán en los textos concretos de los años cuarenta sobre la dialéctica. Se demostrará así que realmente Ortega ya tenía escritas las notas sobre la dialéctica bastante tiempo antes de los años cuarenta, y que si no las había utilizado era porque le faltaban una serie de contenidos para él determinantes, como lo serán "la serie dialéctica", la teoría de los aspectos, etc.

458" Hegel y América" (1928). OC II, 565.

${ }^{459}$ Del Imperio Romano (1940). OC VI, 56. 
Ya en 1933, en la introducción al curso "¿Qué es la técnica?", el curso que luego quedaría conformado en la obra publicada como Meditación de la técnica, justificaba Ortega el momento presente insistiendo en la imposibilidad de suprimir algunos de los estadios de la vida histórica. La vida individual o colectiva embarcada en los hechos, creencias, ideas, de una determinada época es precisamente la experiencia histórica. Sólo si estamos embarcados hasta el fondo podrán verse los inconvenientes o limitaciones de esa experiencia, lo que dará lugar al surgimiento de una nueva experiencia histórica encadenada dialécticamente con la anterior. Una experiencia no efectivizada en su momento, sea en la vida individual o en la histórica, siempre reclamará sus derechos. Esto no quiere decir que todas las experiencias históricas tengan el mismo valor, ni mucho menos, pero sí que todas son necesarias e insustituibles para entender la historia, por la razón de que "la historia humana, vista en su auténtica intimidad es una serie de experiencias encadenadas, una dialéctica de experiencias" 460 .

La intención "práctica" que explica la importancia para Ortega de resaltar ahora ese aspecto refiere a la situación europea de esos años. "La Europa de hoy no es más que la Europa de hoy", escribe: queda intacta toda esperanza para el futuro. En este sentido, la lectura orteguiana de la historia, basada en una dialéctica histórica y en una razón en la historia, explicita los componentes hegelianos asumidos, a pesar de las diferencias entre la dialéctica conceptual y la razón pura, frente a la dialéctica histórica y la razón históricovital.

Ortega ha insistido en que la historia avanza dialécticamente, aunque esa dialéctica no es la de Hegel, y, sin embargo, en el mismo sentido que ese texto de la primera lección del curso sobre la técnica, "cada experiencia vital es ineludible. Si no se hace hasta su raíz, queda indigesta y no permite que quedemos francos y alertas para la nueva. Porque la nueva consiste siempre en evitar los límites y defectos de todas las anteriores, especialmente de la recién hecha. Esta dialéctica de experiencias forma la cadena de la trayectoria humana, en que -como Hegel decía barrocamente- cada eslabón está borracho y tiene que apoyarse en el que le precede y en el que le sigue, borracho de entusiasmo,

460" ¿Qué es la técnica? Introducción: la universidad y la técnica", en: ORTEGA Y GASSET, J. Meditación de la técnica y otros ensayos sobre ciencia y filosofía. Madrid: Revista de Occidente en Alianza, 1996 -3ª reimp.- (Obras de José Ortega y Gasset, 21), p. 18. 
primero; luego de pena"461. Ocurre exactamente igual que con el tema de la razón en la historia. Ortega admite la razón en la historia, pero no los caracteres hegelianos de esa razón; ahora, Ortega admite la dialéctica histórica, pero no los caracteres hegelianos de esa dialéctica.

En Historia como sistema se concretan las diferencias. De hecho, Historia como sistema es el lugar donde aparece por vez primera el término "dialéctica real", así como su origen en Dilthey (origen que Ortega no volverá a mencionar). La conexión es la de historia y vida. El ser del hombre es un pasar y un pasarle: inventa un programa de vida para adecuarse lo mejor posible a las dificultades que le plantea su circunstancia, ensaya ese programa, el personaje imaginario que ha decidido ser, $\mathrm{y}$, al hacerlo, percibe las insuficiencias y limitaciones de ese ensayo. El hombre como personaje, tanto en la vida individual como en la histórica, comienza con la ilusión, con el entusiasmo, y concluye con la limitación, con la insuficiencia, que le lleva a idear otro programa vital que mejore el anterior. Ese momento sigue actuando en el anterior, conservado, en sentido hegeliano. Esta es la dialéctica vital e histórica, así como su conexión con la dialéctica real:

"El hombre «va siendo» y «des-siendo» - viviendo. Va acumulando ser -el pasado-: se va haciendo un ser en la serie dialéctica de sus experiencias. Esta dialéctica no es de la razón lógica, sino precisamente de la histórica - es la Realdialektik con que en un rincón de sus papeles soñaba Dilthey [...] ¿En qué consiste esta dialéctica que no tolera las fáciles anticipaciones de la dialéctica lógica? ¡Ah! Eso es lo que hay que averiguar sobre los hechos. Hay que averiguar cuál es esa serie, cuáles son sus estadios y en qué consiste el nexo entre los sucesivos. Esta averiguación es lo que se llamaría historia, si la historia se propusiese averiguar eso, esto es, convertirse en razón histórica" 462.

En nota insiste Ortega en algo importante: la razón histórica es, como la física, "una razón a posteriori'463, es decir, no anticipa, no se sitúa en un ámbito previo y superior, sino que parte de los hechos, de las vidas, de los objetos. Es por ello por lo que encuentra todas las posibilidades de futuro en el hombre abiertas, ilimitadas, y las limitaciones únicamente en el pasado. Este es el sentido en el que el hombre no tiene naturaleza, sino

\footnotetext{
461" Un rasgo de la vida alemana" (1935). OC V, 190. La alusión a Hegel recuerda aquel texto ya citado que tomaba Ortega del prólogo a la Fenomenología: "Das Wahre ist so der bacchantische Taumel, an dem kein Glied nicht trunken ist". HEGEL, Phänomenologie des Geistes. Jubiläumsausgabe, Hrsg. G. Lasson. Leipzig: Verlag der Dürr'schen Buchhandlung, 1907, p. 31.

462" Historia como sistema" (1935). OC VI, 40-41.

463 Ibid. p. $41 \mathrm{n}$.
} 
que tiene historia. Lo que la naturaleza es a las cosas es al hombre la historia. La vida no se rige por una línea marcada, fija, sino que está abierta a toda posibilidad de futuro.

El único momento que presenta esos caracteres rígidos, que determina y pre-establece, que demarca, es el pasado. Esta fuerza del pasado es la que conforma a la historia como sistema, la cadena dialéctica de experiencias vitales estrechamente entrelazadas. Entender un momento histórico supone entender el resto de la historia, fijar un momento en la historia significa fijarlo en función de toda la historia, "ni más ni menos que en la Lógica de Hegel cada concepto vale sólo por el hueco que le dejan los demás"464. La historia es ciencia sistemática de la vida, $\mathrm{y}$, por ello, es ciencia del presente: el pasado queda siempre situado en función del presente y de las posibilidades del futuro; el pasado, la historia, sosteniendo nuestro hoy. No hay actio in distans: "el pasado soy yo -se entiende, mi vida'465 y, con ello, tampoco hay anticipación en la dialéctica histórica, la anticipación que corresponde a la dialéctica lógica.

La dialéctica histórica no hace anticipaciones, la dialéctica conceptual, hegeliana, se basa en ellas, procede mágicamente sobre la historia: "Dialéctica, movimiento, experiencia de un concepto y paso al otro en virtud de aquella experiencia. Esta serie de experiencias es anticipada en la lógica y en la idea, que es Seelenführer, Wahrheit des Völker: Weltführer. Nosotros no podemos hacer esa anticipación"466. La dialéctica histórica queda determinada por una razón histórica y vital a posteriori, basada en las peripecias, en los hechos históricos, en las cosas. La dialéctica conceptual, por contra, introduce en la historia una razón ajena, forastera: "Una razón forastera, como Hegel, que inyecta en la historia el formalismo de su lógica"467. Si la dialéctica y la razón históricas se inician a posteriori, externamente, ateniéndose a los hechos y a las cosas y sin anticipar, sin preestablecer el movimiento, la lógica y la historia hegelianas, por su parte, aparecen dirigidas por un movimiento ficcional y, en el fondo, estático, que determina su discurrir. Es el movimiento del espíritu: "En Hegel, el movimiento del espíritu es pura ficción, porque es un 
movimiento interno al espíritu, cuya consistencia es en su verdad fija, estática y preestablecida" 468 .

En este contexto se mueve el enfrentamiento entre la dialéctica de Hegel y la de Ortega en los textos publicados. El fondo es el mismo que el que más arriba aparecía en la relación entre la razón histórica de Ortega, la historiología, y la razón lógica hegeliana. Los caracteres de la crítica en los textos de estos años remiten continuamente al carácter de prestidigitación, de actuación mágica sobre la historia y la realidad olvidando la vida individual y los caracteres de futuro, olvidando la vida como realidad radical y situando Ortega sus ataques siempre en el marco de la superación del idealismo. Las expresiones de esa crítica son explícitas: el furor teutonicus, la ausencia de bon sens, en el año 32469; la prestidigitación, el soborno a la realidad, así como la falta de prudencia, de mesura, el "nabucodonosorismo", en el 34470; o la congelación de la historia en el 42, aunque Ortega admita que esa fue la primera forma adoptada por la razón en la historia, por el sentido histórico 471 . Pero este momento crítico es únicamente una parte, la negativa. Falta la segunda, la positiva, y ésta es más difícil de rastrear. Esta parte positiva afecta al tema de la dialéctica en concreto, superando en cierta medida su expresión como dialéctica histórica, marco en el que se mueven las críticas.

\footnotetext{
468Ibid. p. 31.

469" Pidiendo un Goethe desde dentro" (1932). OC IV, 412: "¿Qué es sino Sturm prodigioso la filosofía postkantiana! Pero el alemán no suele ser sino Sturm - es desmesurado. Su modo de ser lo que es queda exorbitado por el furor teutonicus. ¡Imagínese un momento -por no hablar de los poetas- que Fichte, Schelling, Hegel, hubieran gozado además de bon sens".

470" Prólogo para alemanes" (1934). OC VIII, 29: "Hegel, que es uno de los cuatro o cinco mayores filósofos del planeta Tierra, fue acaso el más imprudente. [...] La evidente falta de mesura en Hegel, su nabucodonosorismo, aniquiló la filosofía. La historia del hegelianismo es la historia de Nabucodonosor". Ibid. p. 38: "Junto al mayor genio filosófico se da, en estos hombres, sin intermisión, el prestidigitador. Hegel es, a un tiempo, Aristóteles y Houdin. Con su genio sobornaban a la realidad para que aceptase el yugo de su doctrina".

471" Prólogo a "Historia de la filosofía», de Émile Bréhier (Ideas para una historia de la filosofía)" (1942). OC VI, 417: "Hegel y Comte ordenan el proceso evolutivo del pasado humano en vista de un término absoluto que es su propia filosofía como filosofía definitiva. Pero esto es congelar la historia, detenerla, como Josué parece que hizo con el sol. Considerar definitiva una filosofía es separarla del proceso histórico, colocarla fuera del tiempo. Y esta fue la limitación de la forma primera que adoptó el «sentido histórico»".
} 


\subsection{Dilthey y la continuidad de la conciencia}

Al final de los años veinte Ortega comienza a leer a Dilthey. Llega a decir que el retraso en su lectura le ha hecho perder diez años de vida intelectual. En Dilthey encuentra la conexión entre historia y vida que venía presentando desde hace tiempo, con lo que Dilthey aparece enfrentado para Ortega tanto respecto a la escuela histórica como al propio Hegel y el idealismo en su conjunto. Sin embargo, Dilthey no habría llegado nunca a constituir plenamente su idea, a tener la claridad y seguridad necesarias en su pensamiento para poder formar rigurosamente su sistema. La ruptura del paralelismo con Ortega, según éste, consiste en que Dilthey permaneció en la razón histórica, mientras que el propio Ortega habría dado un paso más: la conjunción de razón histórica y razón vital. Para Ortega, Dilthey nunca habría llegado a descubrir plenamente el nuevo racionalismo de la vida.

En 1933 comienza a publicar Ortega 'Guillermo Dilthey y la idea de la vida". En ese texto, tanto expone a Dilthey como pretende hacerle decir lo que "debería haber dicho". El tema de la vida, de la historia, de la razón vital e histórica, d enfrentamiento con la escuela histórica y con el trascendentalismo, etc., los temas clásicos de Ortega, aparecerán en ese texto en la recepción de Dilthey que lleva a cabo Ortega. Sin embargo, el tema principal del escrito sobre Dilthey subyace a todos ellos. Es el tema que conduce directamente hasta la dialéctica: el tema de la continuidad de la conciencia y de la historia, de la historia en general y de la historia de la filosofía en particular.

El enfrentamiento se produce, de nuevo, entre la razón pura y la razón histórica. Ortega, con Dilthey, en este momento encuentra el contrapunto en Kant, no en Hegel. Para Kant, las condiciones de posibilidad de la experiencia son una construcción intelectual, no se dan en la experiencia. La actitud de Dilthey, por contra, sería de radical empirismo: no se trata de buscar las condiciones de posibilidad de la experiencia, sino sus condiciones de realidad y facticidad. No se trata de perseguir una hipotética conciencia trascendental, sino de mantenerse en la efectiva conciencia empírica. El problema de Kant y sus antecesores consistía en creer que el conocimiento era un compartimiento estanco, una zona de la conciencia impermeable a las demás. Es el prejuicio del intelectualismo. El paso decisivo de Dilthey habría consistido en mostrar que no tiene sentido saltar por encima de la conciencia, que los hechos de conciencia deben tomarse según ellos se presentan. 
En este punto del desarrollo, Ortega se reúne con Dilthey... y con Hegel. Los hechos de conciencia deben tomarse según se presentan, y "lo más obvio y claro en todo hecho de conciencia es que se presenta siempre y constitutivamente en conexión con otros hechos de conciencia. [...] Lo más esencial del hecho de conciencia es que se da en complexo, conexión, interdependencia y contexto con otros hechos de conciencia. Esta es un conjunto en que todo anda trabado"472. Es la conciencia como Zusammenhang, el término que constantemente utiliza Dilthey. Los hechos de la conciencia cognoscente no son impermeables a la conciencia volitiva y sentimental, el conocimiento depende de la voluntad y del sentimiento, como éstos de aquél. Es el gran enfrentamiento de Dilthey con Kant y con toda la tradición intelectualista: "el conocimiento no se explica por sí solo, sino como miembro de la conciencia humana total" 473 . Los principios de conocimiento no flotan en el vacío, no son sin fundamento, sino que se apoyan en otras partes de la conciencia, así como éstas en ellos. Con ello, la conciencia queda constituida como un sistema circular y cerrado donde todo encontraría su explicación.

La conciencia, entonces, como conexión, como continuidad entre las distintos hechos, intelectuales, volitivos, sentimentales, etc. Este es el sentido en el que Ortega ve la afinidad entre Dilthey y Hegel. El radical empirismo con el que comenzaba Dilthey le conduce a lo mismo que llevaba a Hegel su radical logicismo, "a saber: la condición cíclica de la conciencia, no haber nada en nuestra mente que sea comienzo en seco o término abrupto, que sea discontinuo, sino que todo en ella viene de algo y va a algo - en suma, la estricta continuidad de la conciencia humana. Si Colón no se hubiera anticipado en lo del huevo, el huevo de Colón sería esto"474. La continuidad de la conciencia une en este momento a Hegel y a Dilthey. Pero Ortega está mezclando temas. La continuidad de la conciencia que le interesa de Dilthey es la que reúne conocimiento, sentimiento, voluntad, etc.; la continuidad que remite a Hegel se encontrará en el contexto particular del pensamiento y del conocimiento (y será examinada a continuación, en el contexto de esa "paradoja de Hegel"). La conjunción de ambas aparecerá explícitamente en el tema de la dialéctica. Pero falta una tercera continuidad: la de la historia y la vida, la de la historia de la filosofía.

472" Guillermo Dilthey y la idea de la vida" (1933-1934). OC VI, 192.

473Ibid. p. 193. 
La ciencia que estudie la conciencia como continuidad de conocimiento, sentimiento, voluntad, etc., tendrá que ser para Dilthey primero psicología, pero, al tener como objeto la estructura general de la conciencia, esto es, la vida real de la conciencia, esa ciencia será la auténtica filosofía. Deberá ser una investigación de la naturaleza total humana, sin parcializaciones ni abstracciones, con lo que la filosofía se establecerá como intento de posesión de toda la realidad humana. Para ello tendrá que acudir a la historia, con el fin de mostrar la situación de cada momento humano en esa totalidad. Es la dialéctica histórica que examinaba en la sección anterior: todo lo humano es relativo a un tiempo, con lo que el hombre es relatividad, historicidad, y será necesario postular una ciencia fundamental sobre la que se sostenga esa conciencia histórica de lo humano. Esa ciencia será la filosofía.

Por la sección anterior, sabemos que la dialéctica histórica implica que historia, en último sentido, es historia universal: todo presente procede de un pasado y se dirige hacia un futuro, todo pasado es reconstrucción desde un presente, todo futuro es proyecto o programa de vida. A lo largo de la historia se han ido forjando los saberes y filosofías más diversas y, sin embargo, del mismo modo que la conciencia se mantiene en la continuidad de sus hechos, también la filosofía implica la conexión de sus particularidades. La filosofía tiene la totalidad como tema, pero la autonomía como modo. Es la conexión de filosofía e historia que Ortega necesita. La filosofía, por el hecho de que lo son el hombre y la vida, es necesariamente histórica, aunque en cada una de sus particularidades pretenda la totalidad. Ese carácter histórico implica que la primera función del filósofo sea tomar conciencia de su lugar histórico, de su tiempo y momento desde el que filosofa.

El filósofo acude a la historia de la filosofía para saber cómo ha llegado hasta ahí, de dónde procede, cuál es su situación: trata de reconstruir su propia historia. En ese sentido, y Ortega cita a Dilthey, toda filosofía comienza por ser su propia historia, por ser propedéutica para la filosofía sistemática. En este momento, de nuevo, Ortega encuentra la conexión entre Dilthey y Hegel. En nota, escribe:

"Véase de nuevo cómo Dilthey, por el camino del más radical empirismo, llega a las mismas posiciones de Hegel. También para éste la filosofía comienza por una propedéutica, la «fenomenología del espíritu», cuya faena consiste en llevar la mente desde la actitud más ingenua y primaria -la que cree encontrar la

474Ibid. p. 193 n. 
verdad en lo sensible, viendo, tocando, oyendo- hasta la actitud plenamente filosófica -la conciencia como dialéctica. Estas formas escolares de la conciencia son, a la vez, para Hegel, etapas de la historia"475.

Pensar es ya partir de ideas determinadas, incluir la serie de ensayos efectuados en el pasado. El intelecto no es individual, sino que se constituye en la herencia de lo histórico. Por ello, la filosofía debe renunciar a todo tipo de intelectualismo, de "construcción definitiva y a-histórica"476 que detenga el tiempo mediante puros conceptos. En vez de ello, su tarea debe consistir en acercarse a las cosas, a la realidad fáctica, no construir mediante la conciencia. Esa crítica a la filosofía como construcción definitiva ya aparecía más arriba, en el contexto de la dialéctica histórica, explícitamente dirigida a Hegel. Ahora y a pesar de ello, Ortega, aunque en cierto modo al margen, siempre en nota, insinuado, sin explicitar demasiado, intenta reunir a Hegel y a Dilthey en aspectos concretos.

¿Cuál es realmente la intención de Ortega en esta reunión Hegel-Dilthey? Remite al tema de la dialéctica. Ortega ya ha visto la continuidad, la omnímoda conexión de la conciencia; también ha visto esa conexión, esa continuidad, en la vida, en la historia y en la historia de la filosofía. Le falta la continuidad del pensamiento, del conocimiento. Esa es la continuidad que encuentra en Hegel, la conciencia como dialéctica que aparecía en el texto citado y que era mostrada como la actitud plenamente filosófica. Es la continuidad del pensamiento sostenida por la continuidad de lo real. En este momento, la dialéctica de Hegel se reunirá con aquella "máxima averiguación de Hegel", el "pensamos con las cosas". Ambos caracteres constituirán la dialéctica real expuesta en los años cuarenta, que, por tanto, tiene sus orígenes en ideas y contenidos de escritos muy anteriores, con las notas de la carpetilla "Dialéctica" en el fondo.

\footnotetext{
475 Ibid. p. 203.

476Ibid. p. 208.
} 


\subsection{La paradoja de Hegel}

"La paradoja de Hegel" es el título colocado por Garagorri a ese apéndice que incluye en su edición de Ideas y creencias y que corresponde a la lección profesada por Ortega el tres de marzo de 1936. En ese texto, Ortega explica caracteres determinantes para su teoría de la dialéctica. Se inicia con la limitación que supone todo concepto: "El concepto «esta habitación», como todo concepto, significa una determinación, una limitación. Esta habitación es una cosa y el edificio que la rodea, en general, todo el resto del espacio, es otra. Cuando decimos «esta habitación» nos referimos a esta porción limitada de espacio y dejamos fuera de nuestro concepto, excluimos el resto del espacio'477. Ahora bien, la habitación, sin el resto de espacio que la sostiene y determina no tiene realidad. «Esta habitación», sin todo lo demás del cosmos, del resto del espacio, es irreal: "La realidad no es de ella sola, sino de ella junto con lo demás, con toda la materia cósmica o naturaleza'478. La conexión de esta teoría con aquel texto de 1911 citado más arriba es evidente $^{479}$, pero las intenciones han cambiado. Ahora se trata de afirmar el carácter dialéctico del pensamiento, asentado sobre la dialéctica de lo real.

Es el momento en el que surge la paradoja: todo concepto, al consistir en pensar algo determinado, por un lado se contrapone a lo que queda fuera de él, y, por el otro, exige eso que queda fuera, lo necesita para tener realidad. Así, "para ajustarse a la realidad de una cosa tengo que pensarla a ésta justamente con su contradicción. [...] Para pensar una cosa hay siempre que yuxtapensar su otra cosa, su contracosa; porque, en rigor, la cosa entera se compone de su concepto y del de su enemiga"480. No puedo pensar "izquierda" sin pensar "derecha", no puedo pensar A sin yuxtapensar no-A, porque sólo sobre el fondo de los segundos adquieren realidad, se perfilan y delimitan los primeros. Para Ortega, esta es la paradoja que introdujo Hegel en la filosofía:

477" La paradoja de Hegel", en: ORTEGA Y GASSET, J. Ideas y creencias (y otros ensayos de filosofía). Madrid: Revista de Occidente en Alianza, 1993 -1ª reimp.- (Obras de José Ortega y Gasset, 29), p. 75.

478 Ibid.

479 "Vejamen del Orador" (1911). OC I, 563: "¿Por qué pensar que me rodean sólo diez metros de espacio? ¿Y lo que circundan estos diez metros?".

480" La paradoja de Hegel". Op. cit. p. 75. 
"Desde el punto de vista del pensamiento esto es contradecirse. Pero desde el punto de la realidad esto es ajustarse a ella. Y si verdad significa adaptación del pensamiento a lo real todo pensar verdadero consistirá en abandonar su punto de vista y aceptar el punto de vista de la cosa misma. En suma, que el decir verdadero es contradecirse. Esta es la formidable paradoja que introdujo Hegel en la filosofía. / Llegó a ella porque Filosofía es la urgente pregunta sobre qué sea no esto o aquello sino el todo de cuanto hay: el Universo. Pero al tratar de pensar el Universo no arribamos nunca a un último concepto. Ese mismo concepto de Universo no es sino la contraposición al concepto de Multiverso, el del todo frente y contra las partes. Cuando digo universo quiero decir aquello que no es parte, trozo de otro algo, lo que no deja fuera de sí nada, lo que excluye la pluralidad y no puede estar limitado por cosa alguna junto a él, en suma, lo absoluto" 481 .

Este texto y las ideas que contiene son claves por varias razones: porque muestra las conexiones con textos de años anteriores, especialmente ¿Qué es filosofía?, porque determina los caracteres de la dialéctica real, porque permite ver cuál es exactamente el papel de Hegel en la dialéctica de Ortega, porque demuestra, al conectar tanto con escritos de años anteriores, como con los de los años cuarenta, como con las notas de la carpetilla "Dialéctica", que Ortega ya tenía su teoría de la dialéctica muy avanzada desde los años veinte, porque, en general, permite ver la recepción de Hegel por Ortega en un marco que supera el de la historia, etc. Pero para examinar todo esto hay que ir por partes. En primer lugar, ¿de dónde tomó Ortega la idea de Hegel?

Dicho de un modo concreto, la idea de Hegel, tal como la recibe Ortega, no la tomó directamente ni de los textos de Hegel, ni de una idea general sobre su filosofía, sino de los estudios, o, mejor, de un estudio con nombre propio: Kroner. En Kroner encontró Ortega los textos de Hegel que necesitaba, todos ellos en el mismo capítulo del segundo volumen de Von Kant bis Hegel y que Ortega recibe con unas intenciones muy determinadas. Ese capítulo de la obra de Kroner se inicia ya con la afirmación que buscaba Ortega: "Die Hegelsche Philosophie ist nicht nur Identitäts-, sie ist auch Widerspruchs- Philosophie" 482. Ortega busca sobre todo dos cosas (como veremos por las notas): la unión de análisis y síntesis en el pensamiento, contra la prioridad de lo analítico y la crítica al racionalismo, y la explicitación del pensamiento de la contradicción como elemento esencial del concepto.

$$
\text { 481 Ibid. pp. 75-76. }
$$

${ }^{482}$ KRONER, R. Von Kant bis Hegel. Bd. II: Von der Naturphilosophie zur Philosophie des Geistes. Tübingen: Mohr, 1921, p. 319. Traducción: "La filosofía de Hegel no es únicamente filosofía de la identidad, sino también filosofía de la contradicción". 
En este sentido, en Kroner lee Ortega: "Das spekulative Denken ist analytisch und synthetisch zugleich, deshalb entwickelt es sich aus dem sich selbst verneinenden und aufhebenden Satze des Widerspruchs. Die Rationalisten verkannten die gegenseitige Bedingtheit des analytischen und synthetischen Denkens, weil sie das Prinzip der Identität nur als dasjenige der formalen Logik verstanden"483, y, en nota, citado por Kroner, encuentra el texto de Hegel que necesitaba:

"Das formelle Denken aber macht sich die Identität zum Gesetze, lässt den widersprechenden Inhalt, den es vor sich hat, in die Sphäre der Vorstellung, in Raum und Zeit herabfallen, worin das Widersprechende im Neben- und Nacheinander aussereinander gehalten wird und so ohne die gegenseitige Burührung vor das Bewusstsein tritt. Es macht sich darüber den bestimmten Grundsatz, dass der Widerspruch nicht denkbar sei; in der Tat aber ist das Denken des Widerspruchs das wesentliche Moment des Begriffes" 484 .

El "decir verdadero es contradecirse" de Ortega remite a este pensar la contradicción como "wesentliche Moment des Begriffes", de Hegel. Kroner transcribe el texto de Hegel y lo completa con un comentario que a Ortega le interesaba de un modo concreto: "Der spekulative Widerspruch begreift und rechtfertigt erst, was die Vernunftkritik nicht begreifen und nicht rechtfertigen konnte: den synthetischen Charakter des analytischen Denken"485. La pregunta ahora es saber para qué necesita Ortega esta serie de ideas, cómo las recibe y con qué fines. Para ello, hay que regresar a la paradoja de Hegel.

Si los conceptos son limitaciones de una realidad mucho más compleja, una realidad que incluye cada cosa en relación con su contradicción, con su otro, con el resto de cosas, entonces el pensamiento conceptual es contradicción, pues supone limitaciones que la realidad no acepta si además no incluyen, junto a su carácter particular, limitador, la

\footnotetext{
483Ibid. p. 322. Traducción: "El pensamiento especulativo es analítico y sintético a la vez, por lo que se desarrolla a partir del principio de contradicción, que se niega y se supera a sí mismo. Los racionalistas ignoraban la condicionalidad recíproca del pensami ento analítico y sintético, pues entendían el principio de identidad únicamente referido a la lógica formal".

${ }^{484}$ HEGEL, G.W.F. Wissenschaft der Logik, II. Frankfurt/M.: Suhrkamp, $1990^{2}$ (Ed. MoldenhauerMichel), -Werke, 6 pp. 562-563. Traducción: "El pensar formal hace de la identidad su ley. El contenido que se contradice, que tiene ante sí, lo deja caer en la esfera de la representación, en el espacio y el tiempo, donde los momentos que se contradicen se hallan uno fuera del otro en su estar uno al lado delotro y uno después del otro, y se presentan así ante la conciencia sin el recíproco contacto. El pensar formal se crea a este respecto el principio determinado de que la contradicción no es pensable; pero en realidad, el pensamiento de la contradicción es el momento esencial del concepto".

485KRONER, R. Von Kant bis Hegel. Bd. II. Op. cit. p. 336. Traducción: "La contradicción especulativa conceptualiza y justifica aquello que la crítica de la razón no podía ni conceptualizar ni justificar: el carácter sintético del pensar analítico".
} 
condición de límite, esto es, de referir a otras limitaciones. El problema es del pensamiento, no de lo real. Éste asume su carácter contradictorio, "todas las cosas reales son contradictorias si se las analiza un poco'486, la realidad es dialéctica por esencia: toda cosa exige yuxtapensar su contracosa, el universo exige su multiverso. Es la limitación del concepto la que no puede adaptarse a esta realidad dialéctica y contradictoria, pero no puede hacerlo únicamente desde una dialéctica conceptual que limite, que anticipe o apriorice esa realidad.

La exigencia es la de la vuelta a las cosas, el pensamos con las cosas como máxima averiguación de Hegel, o, como aparece ahora en "La paradoja de Hegel", aceptar el punto de vista de la cosa misma. Ese pensamiento que acepta el punto de vista de la cosa, como contradicción, también acepta el de la misma vida, pues también la vida es contradicción, es eso y aquello, esto y lo otro, racional e irracional: "La vida es, sin duda, contradictoria, es lo uno y lo otro -de otro modo sería íntegramente racional. Ello revela que contradecirse no es una objeción para la vida porque ésta no consiste en decir y decirse"487. Ese adoptar el punto de vista de la cosa, por tanto, no sólo refiere a la conexión entre pensamiento y realidad, sino también al carácter dialéctico y contradictorio de la vida.

La vida tiene un origen trágico, dialéctico, pues trata de llevar a cabo un proyecto en un mundo que no ha sido elegido, trata de realizar un yo en un no-yo. Si en "La paradoja de Hegel" escribía Ortega que pensar una cosa exige pensar también su enemiga, su contracosa, también la vida exige la dialéctica, en este caso trágica, de realizar un yo en un contra-yo, también la vida es hallarse entregado al enemigo: "Toda vida es trágica en su esencia: porque es contradicción, porque es tener que realizar mi vocación que soy yo en lo que no soy yo, en el mundo, en el contra-yo. En este sentido, puede decirse que la vida es traición esencial y enajenación: vivir es hallarse entregado al enemigo, al mundo'488.

La realidad dialéctica, en el fondo, la viene presentando Ortega desde el comienzo de su filosofía: remite a la conexión de circunstancias y de perspectivas, remite a todo el juego de relaciones que encontrábamos en el campo del arte, remite a la serie de talantes de

486" Sobre el fascismo" (1925), en: El Espectador - VI(1927). OC II, 497.

487" El estilo de una vida (Notas de trabajo)". Antología y edición de J.L. Molinuevo. En: Revista de Occidente, $\mathrm{n}^{\circ}$ 132, mayo 1992, p. 66. 
integración que han aparecido en todas las épocas y contextos, remite en general a la relación entre vida y mundo. La conclusión de Ortega es la siguiente: a esa realidad dialéctica debe corresponderle un pensamiento dialéctico que no sea lógico, analítico, sino que parta de las mismas cosas, un pensamiento que sea yuxtapensamiento, pero que no implique una dialéctica conceptual, sino real, en tanto que "la ley del pensar está en las cosas"489.

Se trata de conseguir una dialéctica que sea capaz de integrar los caracteres contradictorios de vida y realidad, que reúna la dialéctica de la historia (e historia de la filosofía), la de la vida y la de la ealidad, y que muestre ese contradictorio yuxtapensar con los talantes integradores de la continuidad. Esta es la causa de que Ortega esperara hasta los años cuarenta para exponer su teoría de la dialéctica: para expresar de un modo lo suficientemente detallado la integración de vida, historia, pensamiento y realidad en los caracteres dialécticos de continuidad y de colaboración iniciados en la prioridad de la vida y las cosas. En este sentido, ese yuxtapensar que aparece ahora expresando la contradicción de lo real llegará en sus talantes integradores hasta el final de la filosofía de Ortega 490 , aunque se ha iniciado mucho antes:

"Lo esencial de la dialéctica, cualquiera que ella sea, está en que el pensamiento de un concepto nos lleva por necesidad a pensar otro. Esta necesidad sentida ya en el concepto A de pensar el concepto B (por ejemplo, al pensar un color hay que pensar un soporte ontológico de él) es lo sintético. Ahora bien, esto no pasa sólo en la contradicción sino en todo concepto bien pensado. Todo pensar implica un yuxtapensar. Y esta necesidad viene del objeto y su estructura, no del sujeto. Toda determinación es fragmento (momento diría Hegel) y el ser es continuo"491.

El yuxtapensar y el multiverso que aparecen ahora al lado de Hegel y en las notas de trabajo sobre la dialéctica, Ortega ya los había examinado en ¿Qué es filosofía? Mostraba

488 ¿ué es conocimiento? Madrid: Revista de Occidente en Alianza -Obras de José Ortega y Gasset, 25-, 1984, p. 138.

${ }^{489}$ Archivo de la "Fundación José Ortega y Gasset", Carpetilla "Hegel: Dialéctica".

490En 1947 define Ortega el yuxtapensar con los mismos caracteres que está utilizando ahora en torno a Hegel: "Llamo así [yuxtapensar] a todo «pensar por añadidura» sobre lo que efectivamente se piensa en cada caso. El yuxtapensar puede ser analítico o sintético. Al pensar la derecha, yuxtapensamos analíticamente la izquierda. Al pensar «blancura», yuxtapienso sintéticamente «extensión», porque el color no puede darse sino extendiéndose sobre una superficie". La idea de principio en Leibniz y la evolución de la teoría deductiva (1947). OC VIII, 185 n.

491Archivo de la "Fundación José Ortega y Gasset", Carpetilla "Hegel: Dialéctica". 
allí el enfrentamiento entre la ciencia y la filosofía, entre el imperialismo de la física que había humillado a la filosofía en el siglo anterior y la filosofía que comienza a renacer en un determinado momento. Las ciencias aceptan sus limitaciones y devienen independientes, pero para que haya progreso deben conectarse, y ese carácter integrador es misión del filósofo. De hecho, es su propio objeto, su no parcialización, su no especialización, el que produce la vuelta a la filosofía: la filosofía como conocimiento del universo, cuando ese apetito por el universo proviene de la situación general del hombre en la vida, es decir, la necesaria relación entre hombre y mundo.

La filosofía es el conocimiento del universo y "entiendo por universo «todo cuanto hay» [...]. [Al filósofo] le interesa la totalidad de cuanto hay, $\mathrm{y}$, consecuentemente, de cada cosa lo que ella es frente y junto a las demás, su puesto, papel y rango en el conjunto de todas las cosas -diríamos la vida pública de cada cosa, lo que representa y vale en la soberana publicidad de la existencia universal"492. Del mismo modo que para conocer un hecho histórico hay que conocer su situación en la historia universal, para conocer una cosa hay que situarla en sus relaciones, en su lugar en la existencia universal. Pero cuando el filósofo inicia su investigación del universo se encuentra que no sabe nada: busca todo y obtiene partes, incluso cuando encuentra algo ignora también "si eso que hay será, en efecto, un todo, es decir, Universo, o si por ventura cuanto hay forma más bien diversos todos, si es Multiverso' 493 .

Ignora el filósofo además si eso que quizá encuentre será cognoscible o no, si podrá llegar a ser objeto de su pensamiento. Puede que nuestras facultades sean limitadas, puede que el universo, el objeto de la filosofía, sea irracional. Por ello, se exige un conocimiento que supere la definición clásica de adecuación cosa-pensamiento, y postule la reciprocidad, la comunicación mutua: ni prioridad para el ser ni para el pensar, sino afirmación de la situación intermedia, la de la razón vital, que muestra que no todo es lógico, no todo es racional, y se adapta al punto de vista de las cosas.

La filosofía como afán de universo, como necesaria al intelecto para posibilitarle al hombre la vida en el mundo, no sólo duda ante la posibilidad de que el universo sea multiverso, sino que, además, cada vez que encuentra algo, eso se le muestra como trozo o

492 ¿Qué es filosofía? (1929). OC VII, 319. 
fragmento de algo más amplio: "Todo lo que es y está ahí, cuanto nos es dado, presente, patente, es por su esencia mero trozo, pedazo, fragmento, muñón. Y no podemos verlo sin prever y echar de menos la porción que falta'494. Es el mismo esquema de la continuidad del ser y del yuxtapensar que aparece tanto en la carpetilla "Dialéctica", como en "La paradoja de Hegel". Ortega incluso utiliza el mismo ejemplo, el de la imposibilidad de pensar un color sin la extensión.

En las notas sobre la dialéctica, las mismas ideas de ese texto se expresan del modo siguiente: "Todo "saber" (= pensar e intuir) es evolutivo. Lo que en él propiamente pensamos es tomado de un continuo más amplio que él, trascendente de él, del cual quedan en lo tomado los muñones y le da un carácter fragmentario. De aquí que necesite todo saber integrarse y para ello "pensar más que lo ya pensado" traspensar o discurrir"495. La pretensión de Ortega es la reunión de la dialéctica de lo real y del pensamiento, con la dialéctica de ideas, con la necesaria integración en la filosofía de su carácter histórico (continuidad), con su objetivo y pretensión de universalidad (totalidad). El continuo afecta tanto a lo real como al pensamiento, como a la historia, como a la vida, como a la filosofía: es siempre la continuidad de discontinuidades, el afán de los fragmentos por afirmar tanto su particularidad como sus constantes remisiones a fuera de sí.

Es el fervor de las cosas, que implica el fervor de las ideas, el fervor de lo real que implica la necesidad de la filosofía, la exigencia de unir lo "junto" y lo "separado": "Son cosas que no van unas con otras sino todas juntas - pero a la vez separadas. Este fervor de las ideas es siempre superior a todo"496. La conexión se produce, así, entre filosofía y realidad: se trata de pensar más que lo ya pensado, de traspensar o discurrir, porque el fervor de las ideas responde al carácter fragmentario de lo real, que implica la constante anticipación de otros fragmentos. Es el carácter histórico y dialéctico de lo real el que muestra la necesidad de la filosofía, definida en el intento de adecuación a ambos caracteres.

\footnotetext{
493Ibid. p. 320.

${ }^{494}$ Ibid. p. 330

495 Archivo de la "Fundación José Ortega y Gasset", Carpetilla "Hegel: Dialéctica".

496Archivo de la "Fundación José Ortega y Gasset", Carpetilla "Hegel: Dialéctica".
} 
El esquema general es el mismo, aunque en ¿Qué es filosofía? no aparezca todavía la referencia a la dialéctica: "Si tomamos un objeto cualquiera de cuantos hallamos en el mundo y nos fijamos bien en lo que poseemos al tenerlo delante, pronto caeremos en la cuenta de que es sólo fragmento y que por serlo nos fuerza a pensar en otra realidad que lo completa"497. Este pensamiento que implica pensar en la completación, que lleva a anticipar lo que falta, pero no la anticipación lógica conceptual, sino la que se inicia precisamente en las cosas, es lo que encontrará Ortega como esencial en la dialéctica de Hegel. El concepto como fragmento que implica su continuación, por el hecho de que la realidad misma es por esencia continua, y que siempre se presenta en fragmentos: "Lo esencial de la dialéctica no es la trinidad del paso o vals de tres pasos, ni siquiera la contradicción directa sino sólo la indirecta que se origina en que todo concepto es fragmentario y por tanto no es lo que él por sí es, a saber, lo que le falta, y en el va

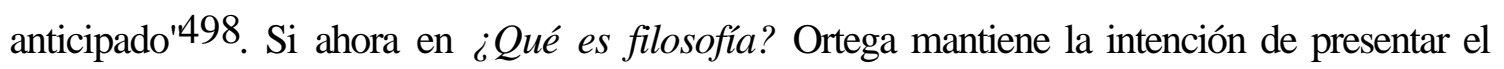
ser fundamental de la filosofía, mostrar la relación entre vida y mundo a través del filósofo como "especialista en universos", en los textos e ideas sobre la dialéctica los mismos caracteres afectarán a la realidad y al pensamiento: la continuidad del ser, la continuidad del pensamiento, la continuidad de la filosofía y de su historia.

Así se estable la conexión entre dialéctica histórica y dialéctica real, entre la aceptación del punto de vista de las cosas y la afirmación de su carácter fragmentario, entre la dialéctica como colaboración y la dialéctica estética que se mantenía en las pretensiones de totalidad, de afán por crear universos propios. Esta conexión entre los distintos aspectos donde tiene lugar el mecanismo dialéctico es la clave del tema.

En ¿Qué es filosofía? el carácter de fragmentariedad de lo real remite al fondo de cada cosa, al mundo, el mundo del que todo es sólo pedazo, el mundo al que tendrá que enfrentarse la vida individual en su circunstancia. Esa remisión supone una ley general: "presente algo, está siempre compresente el mundo'499 y, por ello, todo pensar es yuxtapensar, todo concepto exige su continuación. El propio mundo en general es

\footnotetext{
497 ¿Qué es filosofía? (1929). OC VII, 331.

498 Archivo de la "Fundación José Ortega y Gasset", Carpetilla "Hegel: Dialéctica".

${ }^{499}$ ¿Qué es filosofía? (1929). OC VII, 332.
} 
fragmento, pues no se explica a sí mismo, sino que reclama su fundamento, su situación en una totalidad: reclama su propio ser.

La filosofía tiene como misión encontrar ese ser fundamental, crear una integración, una interpretación de vida y de mundo, hallar el ser, que es el eterno ausente, que únicamente deja el hueco de su presencia, que no es nunca dado, sino constantemente buscado. "El mundo que hallamos es, pero, a la vez, no se basta a sí mismo, no sustenta su propio ser, grita lo que le falta, proclama su no-ser y nos obliga a filosofar; porque esto es filosofar, buscar al mundo su integridad, completarlo en Universo y a la parte construirle un todo donde se aloje y descanse. Es el mundo un objeto insuficiente y fragmentario, un objeto fundado en algo que no es él, que no es lo dado. Ese algo tiene, pues, una misión sensu stricto fundamentadora, es el ser fundamental"500. Esta es la conexión en ¿Qué es filosofía? de los caracteres de fragmentariedad y la filosofía: la filosofía, como especialista en universos, trata de encontrar un ser que integre las partes, que fundamente los fragmentos en una totalidad.

El afán universalista de la filosofía, el principio de pantonomía, la filosofía como pensamiento integral que Ortega encontraba en Hegel, esa es la conexión que se produce ahora entre el carácter fragmentario de lo real y su necesario afán de totalidad. No aparece el tema de la dialéctica, pero sí los contenidos que lo determinarán más adelante y que ya se encuentran en las notas de trabajo. La continuidad de la conciencia que aparecía en el texto sobre Dilthey uniendo conocimiento, sentimiento, voluntad, etc. aparece ahora referida explícitamente a $\mathbf{b}$ continuidad de las cosas y a la del pensamiento. Cada cosa remite a un mundo, cada cosa remite a otras cosas; cada concepto remite a otro, obliga a yuxtapensar incluso su contradictorio. El avance que se produce en la anticipación, en la implicación que cada fragmento realiza en la indicación hacia su otro, es el movimiento dialéctico. Ese movimiento es el que Ortega pretende mostrar como la continuidad conjuntiva de pensamiento, historia, vida y realidad, y es el que da origen a su tratamiento de la dialéctica en los años cuarenta.

500 Ibid. p. 333. 


\section{6. "Lo absoluto es objeto"}

En ¿Qué es filosofía?, el tema de la fragmentariedad del mundo y de las cosas conduce a la afirmación de la filosofía como búsqueda del fundamento que integre las partes, los fragmentos. En el tema de la dialéctica del pensamiento y lo real, el proceso se detiene en un momento previo, el momento en que los fragmentos, sean referentes a la cosa o al concepto, exigen la continuación en sus referencias a otras particularidades, en sus deseos de ampliación. Se reúnen así el proceso de continuidad de la conciencia que Ortega encontraba en Dilthey y el afán de totalidad y colaboración que iniciaba el tratamiento de la dialéctica, con el tema concreto de la continuidad de pensamiento y realidad y la filosofía como especialista en universos.

La dialéctica afecta a cada uno de esos contextos, y la intención de Ortega es unirlos todos. Esa unión de los distintos marcos dialécticos quedaría expresada del modo siguiente: vida, historia y realidad incluyen tal carácter dialéctico de continuidad y contradicción entre las particularidades, que exige un pensamiento dialéctico asentado en el punto de vista de las cosas y las bases vitales e históricas sobre las que se sostiene. Ese pensamiento dialéctico implica y explica el afán de totalidad, de universalismo, que significa la filosofía, y, a la vez, los caracteres de integración, de colaboración y conversación entre los fragmentos, caracteres que afectan a todos los niveles.

De este modo, las pretensiones de totalidad de la filosofía, y la afirmación de la particularidad en los fragmentos que llenan cada marco (vida, historia, pensamiento, realidad), se constituyen en el sentido de la dialéctica entre límite y limitación que viene presentándose desde el comienzo: el carácter fragmentario anticipa su continuación, el fragmento como limitación, sea de vida, historia, pensamiento o realidad, deviene carácter límite en el momento en que su propia particularidad remite a otras particularidades. El conjunto de la dialéctica de limitación y límite, extendiéndose a los contextos generales donde ha sido presentada, se constituye ahora en torno al tratamiento de Ortega de la dialéctica en general. La clave continúa siendo la conciencia de que el afán de integración, de impulso de totalidad y colaboración entre los diversos fragmentos y particularidades, afecta a marcos filósoficos, históricos, políticos y estéticos. 
Esta conjunción entre el tema de la dialéctica y la relación límite-limitación inicia, además, la explicación concreta de la conexión entre la dialéctica hegeliana y la de Ortega. Esta conexión no es sencilla, aunque Ortega insista en que su dialéctica tiene muy poco que ver con la hegeliana. En "La paradoja de Hegel" ha admitido el valor de la idea de Hegel, tal como el propio Ortega la entiende, de que todo concepto es limitación (hasta aquí llegarían, entonces, las referencias en Meditaciones del Quijote a la unión de concepto y límite) y contradice el movimiento real de la cosa, que implica constantemente la conexión con su otro, incluido su contradictorio.

En las notas de trabajo sobre la dialéctica puede verse que ése es realmente el tema principal para Ortega, la conexión entre pensamiento y realidad, a través del carácter sintético de la dialéctica (de ahí la importancia de los textos que encontraba en Kroner): "Los conceptos dados al análisis no tienen por sí valor objetivo. Su atribución a la cosa es ya el prototipo de la síntesis. Síntesis es la identificación del pensar y del ser"501. Y por esto la identificación del pensar sintético con el pensar dialéctico en los textos de los años cuarenta, explicada a partir de los temas y contenidos que ya se inician ahora, en concreto dos, el yuxtapensamiento y la aceptación del punto de vista de la cosa: "El concepto «esferoide» no implica pero sí complica el pensamiento «espacio en torno». Este es el pensar sintético o dialéctico"502, escribe Ortega, y, en las notas de trabajo: "Nuevo sentido de síntesis y análisis - análisis es intra-concepto - Concepto = Sujeto. Síntesis es transconcepto: trans-sujeto. Objeto es lo que regula la síntesis, el fundamento de la síntesis"503. El objeto como regulador de la síntesis superando la dialéctica conceptual y el subjetivismo. Por un lado el yuxtapensamiento, por el otro la prioridad del objeto, el "pensamos con las cosas".

Si esos dos temas Ortega los toma en su recepción de Hegel, el yuxtapensar en el tema del paradoja, de la continuidad tanto del ser como del pensamiento, y la aceptación del punto de vista de la cosa proveniente incluso del "pensamos con las cosas" como máxima averiguación de Hegel, ¿cómo se explica realmente la conexión de Ortega con la dialéctica hegeliana? Si Ortega admite, es más, necesita la afirmación de las determinaciones no

\footnotetext{
501Archivo de la "Fundación José Ortega y Gasset", Carpetilla "Hegel: Dialéctica".

${ }^{502}$ Origen y epílogo de la filosofía (1946). OC IX, 351.
} 
como limitación, sino también remitiendo a un progreso, a un desarrollo; si se trata de ver ese progreso en lo real mismo, no en lo puesto exteriormente por el sujeto; si el objetivo consiste en partir del punto de vista de las cosas, todo esto ya lo tenía en la dialéctica de Hegel.

En este sentido, hay en la Filosofía del derecho una definición de la dialéctica que aglutina todos los caracteres. En el ejemplar manejado por Ortega, el párrafo se encuentra subrayado al margen, en el propio texto, con más de una línea... La importancia de esa definición de la dialéctica es determinante para Ortega, teniendo en cuenta además que el tema de la limitación aparece en su centro. Escribe Hegel:

"Das bewegende Prinzip des Begriffs, als die Besonderungen des Allgemeinen nicht nur auflösend, sondern auch hervorbringend, heisse ich die Dialektik - Dialektik also nicht in dem Sinne, dass sie einen dem Gefühl, dem unmittelbaren Bewusstsein überhaupt gegebenen Gegenstand, Satz usf. auflöst, verwirrt, herüber- und hinüberführt und es nur mit Herleiten seines Gegenteils zu tun hat - eine negative Weise, wie sie häufig auch bei Platon erscheint. Sie kann so das Gegenteil einer Vorstellung, oder entschieden wie der alte Skeptizismus den Widerspruch derselben, oder auch matter Weise eine Annäherung zur Wahrheit, eine moderne Halbheit, als ihr letztes Resultat ansehen. Die höhere Dialektik des Begriffes ist, die Bestimmung nicht bloss als Schranke und Gegenteil, sondern aus ihr den positiven Inhalt und Resultat hervorzubringen und aufzufassen, als wodurch sie allein Entwicklung und immanentes Fortschreiten ist. Diese Dialektik ist dann nicht äusseres Tun eines subjektiven Denkens, sondern die eigene Seele des Inhalts, die organisch ihre Zweige und Früchte hervortreibt. Dieser Entwicklung der Idee als eigener Tätigkeit ihrer Vernunft sieht das Denken als subjektives, ohne seinerseits eine Zutat hinzuzufügen, nur zu. Etwas vernünftig betrachten heisst, nicht an den Gegenstand von aussen her eine Vernunft hinzubringen und ihn dadurch bearbeiten, sondern der Gegenstand ist für sich selbst vernünftig; hier ist es der Geist in seiner Freiheit, die höchste Spitze der selbstbewussten Vernunft, die sich Wirklichkeit gibt und als existierende Welt erzeugt; die Wissenschaft hat nur das Geschäft, diese eigene Arbeit der Vernunft der Sache zum Bewusstsein zu bringen"504.

\section{Archivo de la "Fundación José Ortega y Gasset", Carpetilla "Hegel: Dialéctica".}

${ }^{504}$ HEGEL, Grundlinien der Philosophie des Rechts. Hrsg. G. Lasson. Leipzig: Meiner, 1928, § 31, pp. $44-$ 45. Traducción: "Llamo dialéctica al principio motor del concepto, que disuelve pero también produce las particularidades de lo universal. No se trata pues de la dialéctica en el sentido negativo, que aparece frecuentemente en Platón, que disuelve, confunde y lleva de aquí para allá los objetos o proposiciones dados a la conciencia inmediata o al sentimiento, y sólo se preocupa de deducir su contrario. Siguiendo este procedimiento, se podrá considerar que el resultado último es llegar a lo opuesto de una representación dada, a su contradicción si se actúa de un modo decidido -como en el antiguo escepticismo -, o a un acercamiento a la verdad, medianía típicamente moderna, si se lo hace con mayor debilidad. La más elevada dialéctica del concepto consiste en no considerar la determinación como límite y opuesto, sino en producir a partir de ella el contenido positivo y el resultado, único procedimiento mediante el cual la dialéctica es desarrollo y progreso inmanente. No es por lo tanto la acción exterior de un pensar subjetivo, sino el alma propia del contenido lo 
La dialéctica como principio motor del concepto, la determinación superando los caracteres limitadores, el desarrollo dialéctico como progreso en la conjunción de particularidades, el pensamiento subjetivo que no agrega nada al desarrollo de la idea, la racionalidad del objeto en sí mismo y la ausencia de razón externa procedente del sujeto, la tarea de la ciencia llevando a la conciencia la razón de la cosa y no creando desde ella misma esa razón. Estos caracteres, traducidos a la filosofía de Ortega y pasados por el tamiz de su recepción, van a permanecer todos en su dialéctica real, a pesar de su empeño en separarse de la hegeliana. Ortega toma esos caracteres y los aplica, y con ello los determina, los modifica, a su propia filosofía, pero el fondo permanece intocable: la dialéctica como fuente de los avances en la integración de fragmentos, la limitación que incluirá su condición de límite, el progreso dialéctico convertido en dialéctica histórica, la dialéctica de lo real y nunca agregada por el sujeto, la razón en el objeto mismo, la filosofía como aceptación del punto de vista de las cosas.

El papel exigido a aquella extraña traducción de Ortega que aparecía en el prólogo a la Filosofía de la historia, "la razón determinada es la cosa", se muestra ahora, en el contexto de la dialéctica, como el propio trabajo de la razón de la cosa, como el objeto que es por sí mismo racional. Ortega eliminará los rasgos que le molestan de Hegel: el imperialismo del espíritu, el carácter lógico de la razón, el progreso en realidad ya concluido en el inicio, etc. Sin embargo, los caracteres de yuxtapensamiento y la serie de ideas que aglutina el "pensamos con las cosas", permanecerán de un modo u otro. Si esto es así, si esto es lo que realmente interesa a Ortega de la dialéctica hegeliana, rasgos no precisamente secundarios, ¿qué es realmente lo que separa a Hegel de Ortega?

Ortega insiste en que no puede admitir la anticipación lógica que efectúa la dialéctica conceptual, en que su dialéctica real supera todo subjetivismo y postulación de la razón pura-lógica, en que el sistema y el imperialismo del espíritu determina toda la dialéctica hegeliana. Es lo que viene afirmando constantemente desde sus primeros encuentros con Hegel. En las notas de trabajo lo expresa del modo siguiente:

que hace crecer orgánicamente sus ramas y sus frutos. El pensamiento, en cuanto subjetivo, contempla este desarrollo de la idea como la actividad propia de su razón, sin agregar nada por su parte. Considerar algo racionalmente no quiere decir acercar la razón al objeto desde fuera y elaborarlo por medio de ella, sino que el objeto es por sí mismo racional; aquí está el espíritu en su libertad, la más alta cumbre de la razón autoconsciente que se da realidad y se produce como mundo existente. La tarea de la ciencia es llevar a la 
"Lo inteligible es un organismo, un cuerpo sistemático. Todo en él es parte del todo y es lo que es como tal. Cada concepto absoluto lo es en función del todo como su limitación o concreción. Toda verdad es limitación funcional de la Verdad y está formando parte viva o particularización interna de ésta que es, por tanto, substancia de todas, generalidad inclusiva y concreta de ellas. / Podría así indicarse nuestra distancia de Hegel: Para topar con algo absoluto necesitan los postkantianos postular un sistema absoluto. Ningún objeto lo es por sí, sino en función del todo que sólo existe como postulado correlato de un "saber absoluto" - Este sólo puede ser un saberse y por consecuencia el "todo" aquel, el objeto absoluto sólo puede ser lo que sea capaz de saberse - un sujeto. [...] Queda el cosmos como aspiración y obligación y problema pero no como postulado. Para nosotros lo absoluto es objeto - Y nuestro trato con él es experiencia (absoluta) y no precario sistematismo" 505.

"Para nosotros lo absoluto es objeto", mostrado ahora como diferencia con Hegel, y, sin embargo, el "pensamos con las cosas" y el "aceptar el punto de vista de la cosa" han sido constantemente afirmados como lo común con él. Ortega acepta esos caracteres, pero al extraerlos de su contexto, éstos y su aceptación sólo pueden explicarse junto a las críticas a Hegel. Esas críticas se basan en la "distancia" que plantea la nota transcrita: Ortega niega toda pretensión de absoluto, acepta el "yuxtapensar" y el "pensamos con las cosas", pero únicamente asentados en el contexto vital, histórico y real, nunca en el del sistematismo absolutista que les da sentido en Hegel. Para Ortega, el proceso de Hegel sigue tres pasos: 1. toda determinación es fragmento, 2. ese fragmento sólo tiene significación en función del todo y de su final, el saber absoluto, y 3. ese saber absoluto, objeto absoluto, sólo puede ser lo que es capaz de saberse, esto es, un sujeto. Ortega admite los caracteres de continuidad y de integración de los fragmentos, pero no su explicación a partir de un sistema absoluto regido por el imperativo del subjetivismo.

Para Ortega, el trato con los fragmentos es de experiencia, de filosofía de la razón vital, es un trato cercano, cortés, no el sistematismo dirigido por un sujeto absoluto. Se admiten las verdades y las parcialidades, pero en su sentido histórico, el sentido de aspiración y problema, manteniendo ambos caracteres la remisión a un continuo, un continuo que no permite ni postulados definitivos ni verdades definitivas: "Según esto toda verdad parcial y todo concepto es punto de un continuo integral de verdades positivas. No hay en sí ninguna

conciencia este trabajo propio de la razón de la cosa". HEGEL, Principios de la filosofía del derecho. Trad. J.L. Vernal. Barcelona: Edhasa, 1988, pp. 92-93.

505Archivo de la "Fundación José Ortega y Gasset", Carpetilla "Hegel: Dialéctica". 
primera o in-mediata sino que toda verdad es mediata y se llegará a ella mediante un proceso" 506 .

En Ortega, la dialéctica es real e histórica precisamente porque admite la evolución, el continuo, pero niega el sentido detenido que hace de los fragmentos únicamente disculpas para llegar al final absoluto. El carácter evolutivo de la filosofía y de lo real, del ser, permite constantemente el paso de un momento a otro, pero no detiene el desarrollo, no determina su movimiento: "Merced a ese carácter evolutivo del saber - porque continuo del ser - pasamos de todo punto del ser a los demás, de un plano a otro, de un orden a otro, de un orbe a otro"507. El sentido de aspiración y de ampliación es el que mueve el continuo del ser y del saber, pero esa aspiración no opera mágicamente, no está dirigida, sino que se rige por los carácteres histórico-vitales de lo real mismo.

La dialéctica de Ortega, implicadas en su desarrollo estas diferencias y similitudes con la hegeliana, no es menos amplia que la de Hegel, sino, por el contrario, mucho más radical. Y lo es porque se inicia en el carácter histórico, dialéctico, de la vida y de lo real mismo, un carácter dialéctico que precisamente por ello, por vital y real, no admite ningún tipo de directriz extraña, absoluta, ajena a la propia dialéctica. La dialéctica en Ortega es todo menos un método: no dirige movimientos o desarrollos, sino que se inicia en el sentido esencialmente dialéctico de las mismas cosas, su referencia a fuera de sí, su afán por superar las limitaciones. Es una dialéctica constitutiva: la realidad, la vida, la historia, el pensamiento no "se mueven" con un ritmo dialéctico, sino que ellos mismos son dialécticos, en tanto se sostienen originariamente sobre el carácter de indefinitividad, de finitud, de conexión de límites y limitaciones.

El carácter evolutivo del saber respondiendo a la continuidad del ser se explica a partir de este sentido, el sentido cercano, íntimo y necesario de la filosofía y su objeto, la condición vital y humana de la dialéctica. De ello se desprende que, en principio, todo ser es asequible, por lo menos en sus carácteres vitales, reales: "Otra ventaja de la continuidad del ser y en consecuencia del pensar es que todo ser es en principio asequible" 508 . Hay un camino continuo entre el objeto y el pensamiento que intenta captarlo, la continuidad que

\footnotetext{
506Archivo de la "Fundación José Ortega y Gasset", Carpetilla "Hegel: Dialéctica".

${ }^{507}$ Archivo de la "Fundación José Ortega y Gasset", Carpetilla "Hegel: Dialéctica".
} 
determina el carácter real y vital de los fragmentos. Otro problema es que el objeto sea cognoscible o no.

La filosofía, en este sentido dialéctico e histórico de su despliegue, se adapta al carácter contradictorio, imperfecto, nunca concluso, de su objeto: la vida, la realidad, las cosas. La perpetua aproximación, movimiento de progreso que afecta a todos los niveles, y la negación de los caracteres definitivos, expresando así el significado fragmentario de las particularidades un sentido positivo y nunca negativo, un sentido de progreso, vital, humano, reúnen a la filosofía con la finitud de sus objetos. La efectividad imperfecta y contradictoria de vida y realidad adquieren de este modo, a través de su propia dialéctica, la adecuación a la filosofía que las piensa. Ortega no admite la perfección, la definitividad, en ninguno de sus términos. Es una cuestión que le plantea a Hegel. En el fondo es su crítica, la crítica a la ausencia de futuro implicada por la rigidez de un sistema sostenido por su final, por su carácter absoluto.

En el parágrafo 216 de la Filosofía del derecho, Hegel comenta la complicación que para la legislación supone el hecho de que a menudo se exija la perfección, el carácter "intocable" de los códigos y no se permitan las modificaciones ulteriores. El tema es de una actualidad manifiesta. Ortega lee el parágrafo de Hegel y subraya el siguiente texto:

"An ein Gesetzbuch die Vollendung zu fordern, dass es ein absolut fertiges, keiner weiteren Fortbestimmung fähiges sein solle - eine Forderung, welche vornehmlich eine deutsche Krankheit ist -, und aus dem Grunde, weil es nicht so vollendet werden könne, es nicht zu etwas sogenanntem Unvollkommenen, d.h. nicht zur Wirklichkeit kommen zu lassen, beruht beides auf der Misskennung der Natur endlicher Gegenstände, wie das Privatrecht ist, als in denen die sogenannte Vollkommenheit das Perennieren der Annäherung ist"509.

Al margen de ese párrafo, escrito de puño y letra por Ortega, puede leerse en su ejemplar: "¿Y una filosofía?". No es una pregunta, sino un reproche. El reproche a la propia filosofía de Hegel, sostenida por los caracteres definitivos y con pretensiones de plenitud de

\footnotetext{
508Archivo de la "Fundación José Ortega y Gasset", Carpetilla "Hegel: Dialéctica".
}

509HEGEL, Grundlinien der Philosophie des Rechts. Op. cit. § 216, pp. 175. Traducción: "Exigir de un código la perfección, que sea algo absolutamente determinado [errata o fallo de traducción: debería decir "terminado"; fertiges: concluido, dispuesto], que no pueda admitir ninguna determinación ulterior -exigencia que es especialmente una enfermedad alemana- y a causa de que no puede llegar a esa perfección no dejarlo alcanzar lo que se llama imperfecto, es decir, la realidad efectiva, son dos opiniones que se basan en el desconocimiento de la naturaleza de los objetos finitos tales como el derecho privado, en los cuales la llamada perfección es una perpetua aproximación". HEGEL, Principios de la filosofía del derecho. Op. cit. p. 289. 
su sistema. Es uno de los rasgos vitales e históricos de la nueva sensibilidad, la anulación de toda pretensión de definitividad. Ortega comparte las ideas de Hegel en ese párrafo de la Filosofía del derecho, que refieren únicamente a los códigos, a los libros de leyes, y las lanza, ampliando su contexto, precisamente contra el propio Hegel. La perpetua aproximación viene exigida por la propia naturaleza de los objetos finitos. No se trata ahora de la metáfora de la circunferencia y el polígono del Cusano, sino del carácter dialéctico de esos objetos, que constantemente remiten a más allá de sí.

La realidad efectiva es Unvollkommene, imperfecta, en el sentido de no concluida, indefinitiva, el sentido dialéctico de su posible perfección, su posible mejora en la remisión a otras imperfecciones. Es la teoría del descontento que precisamente iniciaba La «Filosofía de la historia de Hegel» y la historiología, la insatisfacción provocada por "lo incompleto e imperfecto de cuanto da la realidad"510. Ahora aparece en su figura dialéctica: el fragmento mostrando y admitiendo su imperfección permite el avance en la continuidad, en la remisión a su completamiento, nunca pleno. En este contexto, de nuevo, la dialéctica abierta, histórica, de Ortega, deja ver su talante ético y político: el afán de progreso, de mejora, el ideal como impulso, como divino descontento, y nunca como plenitud. "A la perfección no se llega nunca en nada, y acaso ella existe para que no se le llegue nunca"511. Pero este mismo talante dialéctico no remite únicamente a caracteres éticos, sino también estéticos, como veremos.

No es casual que en los años cuarenta, junto al tema de la dialéctica, Ortega critique los caracteres perfectos, precisos, terminados de las cosas, mediante la pintura de Velázquez. La dialéctica adquirirá de ese modo la connotación estética del fragmento como imprecisión, imperfección, in-definitividad, que se adecúa plenamente al carácter impreciso de la propia realidad: "El «naturalismo» de Velázquez consiste en no querer que las cosas sean más que lo que son [...]. Le repugna que el hombre se proponga fingir a las cosas una perfección que ellas no poseen. [...] Velázquez descubre que en su realidad, es decir, en tanto que visibles, los cuerpos son imprecisos"512. Las cosas no poseen una perfección, sino que flotan en un margen de imprecisión y nunca terminan en un perfil riguroso, o, de

510" La «Filosofía de la historia» de Hegel y la historiología" (1928). OC IV, 521.

511"A Veinte años de caza mayor, del Conde de Yebes" (1942). OC VI, 470. 
otro modo, la realidad "no está nunca acabada"513, es Unvollkommene. Esa realidad estética que no está nunca acabada tiene su connotación filosófica en el carácter dialéctico de lo real. El proceso será siempre el mismo: aceptar el punto de vista del objeto, el "pensamos con las cosas", pero partiendo del carácter dialéctico, contradictorio, inconcluso, de lo propiamente real.

De este modo, la dialéctica conjugará en su final, en los textos de los años cuarenta la unificación de caracteres filosóficos, estéticos y políticos. Si en los escritos de Ortega en esos años por un lado aparece el tema de la dialéctica, por el otro, en la Meditación de Europa, las referencias a límites y limitaciones en el contexto del tema del nacionalismo y Europa, y, en último término, los escritos sobre Velázquez mostrando la imprecisión e indefinitividad de lo real, la conjunción de los tres aspectos adquirirá un marco común. Es el marco que, iniciado en la aceptación del punto de vista del objeto, en los caracteres dialécticos del yuxtapensamiento y en la dialéctica histórica y vital, aglutinará la serie de caracteres en torno a los talantes de integración, de colaboración, de aceptación de limitaciones e imprecisiones mediante la continuidad que ellas mismas suponen. El tema del límite y la limitación, de este modo, llegará en Ortega hasta el final de sus escritos uniendo filosofía, estética y política, y la dialéctica será su forma de expresión.

Pero previamente a la conjunción de estética y política en los años cuarenta, es necesario examinar cómo aparece de modo concreto la dialéctica en la misma época. Se ha mostrado el trayecto que conduce hasta aquí, la dialéctica real en su conexión con Hegel y con textos de años anteriores. Ahora se trata de ver exactamente cuál es la exposición del tema sobre todo en dos obras, Origen y epílogo de la filosofía y las notas para Epílogo... El contexto será completado con la teoría de los aspectos y los juegos de series dialécticas, aunque el inicio de ambos, incluso puede decirse que bastante más que el inicio, ya ha sido llevado a cabo en años anteriores. La aparición del tema tendrá lugar en este momento no sólo porque Ortega puede ya conectar perfectamente todos los contextos de la dialéctica, sino también porque se situarán en torno a un tema concreto, que viene siendo examinado desde hace años y que ahora, por la intención que regía las dos obras, podrá tratarse de un modo determinado: la conexión de historia y filosofía, la historia de la filosofía.

512"Introducción a Velázquez" (1943). OC VIII, 478-479.

513 Ibid. p. 479. 


\subsection{El pasado filosófico: la historia de la filosofía}

En 1943 Julián Marías, por mediación del hijo de Ortega, solicita a éste un epílogo para la segunda edición de su Historia de la filosofía, que ya llevaba un prólogo de Zubiri. Ortega, acabada la guerra española y comenzada la segunda mundial, ha decidido en ese año poner casa en Lisboa. La petición de redactar el epílogo se le presenta insertada en su propia reflexión sobre la filosofía y su historia, y puede decirse que ese epílogo es una continuación del prólogo que ha escrito en el año 42 a la historia de la filosofía de Bréhier. Pero la redacción del epílogo a Marías comienza a retrasarse. Por las notas de trabajo 514 conocemos diversos planes, distintas estructuras, incluso varios índices y borradores de trabajo de ese epílogo. De lo que ha comenzado como un epílogo va a nacer un libro. En el plan del año 43 Ortega reproduce el esquema del curso de Buenos Aires en el año 40 sobre la razón histórica, en el siguiente plan aparecen ya elementos del curso dado en Lisboa en el 44, también sobre la razón histórica.

En el año 45 Ortega comunica a Marías su intención de separar una parte del epílogo con el título El origen de la filosofía. En el plan del año 46 puede verse que la referencia al tema del origen es predominante, pero, al final, no fue redactado ni el epílogo a la Historia de la filosofía de Marías, ni tampoco el libro que llevaría ese nombre, El origen de la filosofía. Quedaron algunos manuscritos fragmentarios, otros que serían reutilizados por Ortega y multitud de notas de trabajo. El material se fue acumulando e incrementando. Ortega lo utilizó en diversas publicaciones de esos años, pero la esperanza de publicar el libro definitivo como fondo quedó truncada. En el año 60, Garagorri editó los manuscritos fragmentarios inéditos bajo el título de Origen y epílogo de la filosofía; en el 94, Molinuevo recoge, bajo el título de Epílogo..., las notas de trabajo, iniciadas en el año 43, en las que se apoya el proyecto de Ortega.

Tanto en Origen y epílogo de la filosofía como en las notas de trabajo, el tema de la dialéctica adquiere una importancia determinante. El fondo que aglutina el proyecto es el de la historia de la filosofía. Una historia que es tanto de la filosofía como de la pre-filosofía, que muestra el interés de Ortega por el pensamiento mágico y mítico, y que se presenta

514 ORTEGA Y GASSET, J. Notas de trabajo. Epílogo... Ed. J.L. Molinuevo. Madrid: Alianza/Fundación José Ortega y Gasset, 1994. 
como una historia del pensar en la que la continuidad de los momentos, la razón histórica de su desarrollo, aparecerá fundiendo límites y superando fronteras entre los distintos modos de enfrentarse al mundo. La dialéctica, de este modo, no referirá únicamente a la continuidad de la filosofía o del pensamiento y su historia, sino, sobre todo, a un pensar dialéctico o intuitivo, sintético, que, siguiendo el proceso presentado en los capítulos anteriores, reunirá los caracteres dialécticos de pensamiento, vida, historia y realidad, y mostrará de un modo explícito la conexión con las notas sobre la dialéctica hegeliana tomadas al final de los años veinte.

El tema de la lección segunda de las ofrecidas en el 28 en la Facultad de Filosofía de Buenos Aires, "Dialéctica e intuición", aparecerá ahora como un pensar dialéctico intuitivo, un modo de desarrollo en el que el decir se convertirá en un sugerir. En las notas de trabajo sobre Hegel se muestra que "lo esencial de la dialéctica, cualquiera que ella sea, está en que el pensamiento de un concepto nos lleva por necesidad a pensar otro"515, con todos los caracteres del yuxtapensamiento en la base, el continuo del concepto asentado sobre el continuo del ser. Entre las notas de trabajo para Epílogo... hay una titulada por Ortega "Mi dialéctica". En ella afirma que "no es un pensar en conceptos (lógicos) sino un pensar en visiones", y continúa: "por eso es secundario (y tal vez no necesario) que los conceptos en que ese pensar-ver se enuncia sean precisos. Basta con que sean sugestivos" 516.

En Origen y epílogo de la filosofía, transcribe Ortega el fragmento 93 de Heráclito: "El Señor, a quien el oráculo que hay en Delfos pertenece, ni declara ni oculta, sino que sugiere". Es la alabanza de Heráclito al método adoptado por Apolo en sus pronunciamientos délficos, porque en su manifestación por señales, por signos, puede expresar mejor que con una declaración explícita la naturaleza de la verdad subyaciente, la del logos. Ortega le añade un comentario al fragmento: "Conste que aquí -en el umbral venerable y creador de la filosofía se nos propone el «sugerir» como el modo de decir propio a la filosofía" 517 . La necesidad que llevaba de un concepto a otro en las notas de trabajo sobre Hegel se reunirá ahora con los caracteres de sugerencia, de evocación. En la base se encuentra el pensar intuitivo que determinará la dialéctica de Ortega en este

\footnotetext{
515Archivo de la "Fundación José Ortega y Gasset", Carpetilla "Hegel: Dialéctica".

${ }^{516}{ }_{\text {Epílogo..., p. 66, nota } 64 .}$
} 
momento. Explicar este desarrollo del tema, así como la conexión con los textos e ideas de años anteriores ya examinados, es el objetivo de los siguientes capítulos.

El proceso se sitúa ahora en torno a tres contextos: el pasado filosófico, los aspectos y la cosa entera, y las series dialécticas. El pasado filosófico exige al tenerlo presente la necesidad de su continuación. Muestra que no es posible quedarnos en él, que no hay ningún sistema filosófico entre los formulados que nos parezca suficientemente verdad. La mirada hacia atrás provoca una mirada hacia adelante, el pasado se reúne en el presente con su continuación en un futuro: se dispara la serie dialéctica de pensamientos. Esa serie no está ligada por un pensar analítico, que remita al momento posterior porque éste, en el fondo, ya estaba implícito en el anterior, sino que exige el yuxtapensar en el sentido de la dialéctica real. Es un pensar sintético o dialéctico, en el que cada pensamiento complica e impone pensar el siguiente al mostrar su carácter fragmentario, particular:

"En el pensar sintético no es que podamos, es que tenemos, velis nolis, que yuxtaponer un nuevo concepto. Diríamos que aquí la evidencia del nexo entre dos conceptos es anterior a haber pensado el segundo, puesto que es ella quien nos lleva imperativamente a él. La dialéctica es la obligación de seguir pensando, y esto no es una manera de decir, sino una efe ctiva realidad. Es el hecho mismo de la condición humana, pues el hombre, en efecto, no tiene más remedio que «seguir pensando» porque siempre se encuentra con que no ha pensado nada «por completo» sino que necesita integrar lo ya pensado, so pena de advertir que es como si no hubiera pensado nada y, en consecuencia, de sentirse perdido" 518 .

La conexión con todo lo visto más arriba es clara: son los caracteres de integración, de yuxtapensamiento, a partir de la incompletud de cada momento, los que rigen el desarrollo. La dialéctica como obligación, como efectiva realidad al mostrarse como necesidad del hombre en la vida, es la que supera el carácter analítico para quedarse con el sintético. El pensar sintético implica y complica, no complementa, como el analítico. De aquí la importancia de aquellas ideas que Ortega encontraba en Kroner, y que se muestran ahora en la serie dialéctica de pensamientos en el contexto de la continuidad sintética de la historia de la filosofía.

Es el pensar sintético el que interesa a Ortega, no el analítico, en tanto busca la implicación, no la complementación, y esto procede ya de las notas de trabajo sobre la

518 Ibid. p. 352. 
dialéctica de Hegel: "Pensar analítico no es implicación sino complementación"519. En las notas de trabajo para Epílogo... se muestra el mismo carácter, especialmente en dos notas tituladas explícitamente "Complicación" y "Pensar analítico y sintético": la serie dialéctica es una secuencia continua de pensamientos, en tanto "resulta que el pensar sintético es el pensar continuo"520. La necesidad de seguir pensando como definición de la dialéctica exige ese carácter sintético de la continuidad y la complicación: "sólo la complicación o dialéctica puede fundar últimamente la verdad [...]. El pensar analítico no se basta a sí mismo y emerge últimamente en el "otro mundo" que es el pensar sintético'521. Lo que se encuentra en el fondo es aquello que ya aparecía en las notas sobre la dialéctica de Hegel: la síntesis es la integración de pensamiento y realidad, esto es, la dialéctica como realidad efectiva, objetiva, mientras que "los conceptos dados al análisis no tienen por si valor objetivo" 522 .

Ahora bien, la serie dialéctica de pensamientos que significa la historia de la filosofía muestra tanto su continuidad como su discontinuidad. Cada uno de nosotros, cada sistema filosófico, cada particularidad, se detiene en un determinado punto de la serie dialéctica. La serie continúa, pero las particularidades se detienen, sea por la incapacidad para continuar el desarrollo, sea por los rasgos finitos del hombre. Esto es lo que explica que el pasado filosófico, en un primer momento, aparezca como el conjunto de los errores.

Pero el tema del error en la serie dialéctica del pasado filosófico presenta cuatro momentos: en el primero "la historia de la filosofía nos descubre prima facie el pasado como el mundo muerto de los errores" 523 ; en el segundo "el pasado nos aparece como el arsenal y el tesoro de los errores" 524 , en tanto cada filosofía recoge los errores de las anteriores y se asegura, por lo menos, no caer en ellos; en el tercero, "se nos revela el pasado filosófico como la ingente melodía de experiencias intelectuales por las que el

519Archivo de la "Fundación José Ortega y Gasset", Carpetilla "Hegel: Dialéctica".

${ }^{520}$ Epílogo..., p. 113, nota 150.

${ }^{521}$ Epílogo..., p. 114, nota 151.

522 Archivo de la "Fundación José Ortega y Gasset", Carpetilla "Hegel: Dialéctica".

${ }^{523}$ Origen y epílogo de la filosofía (1946). OC IX, 354.

524 Ibid. 
hombre ha ido pasando"525, pues el error absoluto es imposible: los errores filosóficos no son errores, sino verdades insuficientes, parciales, incompletas, que se detuvieron en un determinado punto y que son "superadas en otras más complejas, es lo que Hegel llamaba Aufhebung, término que yo vierto con el de «absorción». Lo absorbido desaparece en el absorbente y, por lo mismo, a la vez que abolido, es conservado'526.

En este punto, Ortega admite el carácter de Aufhebung, de absorción, pero únicamente en su contexto, ya que "en Hegel es, además, una tesis conexa con todo su sistema, y en cuanto tal no tiene nada que ver con lo dicho arriba, como no debe ponerse tampoco la dialéctica hegeliana cuando he hablado y siga hablando de «serie dialéctica»"527. La dialéctica de Ortega muestra, en su adaptación al carácter incompleto e imperfecto de lo real, la parcialidad e insuficiencia de las verdades del pensamiento, pero siempre en sentido positivo. Es una continuidad, una integración, que completa, pero no tiene la pretensión de superioridad, de "quedar por encima", como la hegeliana, que parte ya para superar, que es extremismo dialéctico: "la dialéctica hegeliana es un mecanismo intelectual en que se educa e hipertrofia un mecánico afán de "quedar encima". El pensamiento en ella - una vez aprendido de Hegel y, por tanto, mecanizado- parte ya para superar. No le interesan los "estadios" -tesis, antítesis-: éstos son sólo trampolín y pretexto a uno superior. Así llega Hegel a ser el Dios. El discípulo tiene que seguir superando. Hay que superar a Hegel... y la serie, la película recomienza. Habrá que superar a Dios -superar lo insuperable- este es el extremismo'528. Pero no todo es tan sencillo, no todo es tan crítico con Hegel, como hemos visto en los capítulos anteriores y como se seguirá viendo ahora, incluido el tema del error.

En la serie dialéctica del pasado filosófico falta un auarto momento: "esas experiencias hechas hay que rehacerlas siempre de nuevo, bien que con la benéfica facilidad de haberlas recibido ya hechas. No quedan, pues, a nuestra espalda, sino que nuestra filosofía actual es,

\footnotetext{
525Ibid. p. 360.

$526_{\text {Ibid. p. } 359 .}$

527 Ibid.

${ }^{528}{ }_{\text {Epílogo..., p. } 65, \text { nota } 62 .}$
} 
en gran parte, la reviviscencia en el hoy de todo ayer filosófico"529. La filosofía actual se sostiene sobre los hombros de las anteriores, la filosofía presente hace renacer las anteriores, viene determinada por ellas, del mismo modo que el hombre conserva en su vida el pretérito, lo acumula, y, con él, va haciendo su presente y su futuro. También la filosofía integra sus errores, su pasado, los integra como verdades parciales e incompletas, aprende de ellos, e inicia nuevos ensayos teniendo en cuenta los anteriores. Con todo esto, el tema del error exige un comentario más detenido, porque no es cierto que Hegel desaparezca de la teoría.

Pero previamente a desarrollar el tema del error es necesario concretar el tema de la historia de la filosofía. La pretensión de Ortega, utilizando caracteres del propio Hegel y conjuntándolos con su dialéctica real, implica precisamente alcanzar una historia de la filosofía distinta de la hegeliana, una historia que no consista en llegar a un término absoluto, una historia idealista. Por ello las críticas a Hegel y Comte en el capítulo final (capítulo determinante) del prólogo al Bréhier. Ese capítulo, titulado "La historia que «termina» y no acaba" condiciona los caracteres de la nueva historia de la filosofía: "Hegel y Comte ordenan el proceso evolutivo del pasado humano en vista de un término absoluto que es su propia filosofía como filosofía definitiva", pero, "nuestra óptica es muy diferente de la de Hegel y Comte. No pensamos, no necesitamos pensar que nuestra filosofía sea la definitiva"530. En este sentido h crítica. Pero hay que recordar, primero, que la categoría de in-definitividad Ortega la encontraba en Hegel ${ }^{531}$, y, segundo, que en el parágrafo 216 de la Filosofía del derecho, ya citado, Ortega tenía un ejemplo muy claro de la incompletud, Unvollkommenheit, de lo real y, precisamente por ello, como veíamos más arriba, le reprochaba a Hegel al margen del texto: "¿Y una filosofía?".

De nuevo la recepción: superación de la filosofía de la historia hegeliana, idealista, que tiende a una meta definitiva, pero llevándola a cabo mediante caracteres hegelianos. La nueva historia de la filosofía que pretende Ortega se basa en sumergir toda filosofía,

${ }^{529}$ Origen y epílogo de la filosofía (1946). OC IX, 361.

530" Prólogo a «Historia de la filosofía», de Émile Bréhier (Ideas para una historia de la filosofía)" (1942). OC VI, 417.

531"La "infinitud verdadera" nos descubre que ese modo de ser aparte, $d a$-limitado o finito-no es un modo de ser de-finitivo, sino, al revés, in-definitivo. [...]. De lo cual resulta que en verdad nada finito es 
incluida la nuestra, en el flujo de la historia. La historia queda definida como historia de los errores, pero no porque haya una verdad absoluta frente a la cual efectuar la comparación, sino porque toda "verdad implica siempre, más o menos, error -que es el error a que cada época tiene derecho y a que está obligada"532. La necesidad del error proviene de que otros tiempos lo cometieron para que el nuestro pueda evitarlo. Cada filosofía es la verdadera, pero no porque sea la definitiva, sino porque, llevando en su interior las anteriores, es la filosofía del tiempo propio, del tiempo nuevo. "La filosofía es así historia de la filosofía y viceversa"533, se adapta al carácter siempre incompleto del tiempo nuevo, al utopismo humano, que impide exigir cualquier tipo de realización plena.

Críticas a una historia de la filosofía hegeliana que pretende conducir a una meta definitiva. Frente a ella, la negación de toda definitividad: la inclusión del pasado en el presente, pero con la asunción de la nueva sensibilidad que imposibilita toda pretensión de conclusión. Nuestro tiempo, nuestra filosofía particular, la de cada momento histórico, es el eslabón de una cadena que no concluye, la "cadena báquica «cuyos miembros están todos ebrios» -decía Hegel y tiende la mano al eslabón futuro, lo anuncia, postula y prepara"534.

Así concluye Ortega el prólogo al Bréhier, contra la historia de la filosofía hegeliana utilizando caracteres hegelianos... tamizados por la recepción de Ortega: los miembros están borrachos, tienden la mano a sus compañeros, pero en Hegel esos momentos tienen una dirección precisa que concluye en su llegada al momento definitivo, el absoluto, el espíritu, la filosofía definitiva, mientras que en Ortega cada momento remite a su situación en el tiempo propio, a la necesaria historicidad e incompletud de todo lo real. Los errores están estrechamente unidos a las verdades: entre ambos definen el carácter indefinitivo de todo tiempo y toda filosofía, incluidos, sobre todo, los nuestros.

suficientemente". Archivo de la "Fundación José Ortega y Gasset", Carpetilla "Hegel - Filosofía de la historia".

532" Prólogo a «Historia de la filosofía», de Émile Bréhier (Ideas para una historia de la filosofía)" (1942). OC VI, 417.

533 Ibid. p. 418.

${ }^{534}$ Ibid. La referencia a Hegel ya ha sido mostrada más arriba: "Das Wahre ist so der bacchantische Taumel, an dem kein Glied nicht trunken ist". HEGEL, Phänomenologie des Geistes. Jubiläumsausgabe, Hrsg. G. Lasson. Leipzig: Verlag der Dürr'schen Buchhandlung, 1907, p. 31. 


\subsection{El tema del error}

La conexión entre historia y error se explicita de un modo claro ya en Ideas y creencias, así como la conexión con el hombre y la vida:

"El hombre está condenado a ser novelista. El posible acierto de sus fantasmagorías será todo lo imposible que se quiera; pero, aun así, ésa es la única probabilidad con que el hombre cuenta para subsistir. La prueba es tan arriesgada que ésta es la hora en que todavía no ha conseguido con holgada suficiencia resolver su problema y estar en lo cierto o acertar. Y lo poco que en este orden ha conseguido ha costado milenios y milenios y lo ha logrado a fuerza de errores, es decir, de embarcarse en fantasías absurdas, que fueron como callejones sin salida de que tuvo que retirarse maltrecho. Pero esos errores, experimentados como tales, son los únicos points de repere que tiene, son lo único verdaderamente logrado y consolidado. Sabe hoy que, por lo menos, esas figuras de mundo por él imaginadas en el pasado no son la realidad. A fuerza de errar se va acotando el área del posible acierto. De aquí la importancia de conservar los errores, y esto es la historia. En la existencia individual lo llamamos "experiencia de la vida" y tiene el inconveniente de que es poco aprovechable porque el mismo sujeto tiene que errar primero, para acertar luego, y el luego es, a veces, ya demasiado tarde. Pero en la historia fue un tiempo pasado quien erró y nuestro tiempo quien puede aprovechar la experiencia" 535 .

La historia, entonces, como conservación de los errores. La memoria de los errores... para evitarlos, para no romper la continuidad con el pasado sino, todo lo contrario, partir de esa continuidad acumulando, asumiendo y aprovechando lo ya hecho. Es por esto por lo que Ortega, en las notas de Epílogo... escribe que "el mundo muerto de los errores se desenmascara como pasado viviente - vive en nosotros y no por generosidad nuestra sino porque somos el pasado aunque no sólo el pasado. El viviente es superviviente" 536 . El hombre es viviente y superviviente porque es una entidad histórica, porque no es naturaleza, sino historia, y, como realidad histórica, esto es, no definitiva, no sólo asume y juega con sus errores pasados, sino que él mismo es un error. Se trata, con ello, de tomar conciencia histórica, es decir, de ser capaces de vernos como un error, "y como eso -ser siempre, por lo pronto y relativamente, un error- es la verdad del hombre, sólo la conciencia histórica puede ponerle en su verdad y salvarle"537. La conciencia histórica

535"Ideas y creencias" (1934). OC V, 405.

${ }^{536}$ Epílogo..., p. 51, nota 37.

537" Miseria y esplendor de la traducción" (1937). OC V, 459. 
salva dejando constancia de los errores, la verdad que la historia concede al hombre es la verdad del error, la verdad de que es histórico, de que comete, ha cometido y cometerá errores.

Ahora bien, si esto es así, el hombre, en primer lugar y de un modo muy general, debe poder mostrarse como "posibilidad de acierto y error"538, y, en segundo lugar, los errores tienen que ser aceptados como necesarios, pues son constitutivos de hombre, historia y vida. Y esto implica que no sólo es ineludible la aceptación de los errores, sino que, además y sobre todo, es necesario aprender a jugar con ellos, aprender a apoyarnos en ellos. Los errores son necesarios como impulso, como medios de progreso, y es por ello por lo que Ortega hace suya la idea de Hegel: "Hegel encontró una idea que refleja muy lindamente nuestra difícil situación, un imperativo que nos propone mezclar acertadamente la modestia y el orgullo: Tened -dice- el valor de equivocaros" 539 , la idea ya comentada procedente del primer Espectador. De otro modo, "como Hegel dice: «el miedo a errar es ya un error y si se analiza se descubre en su fondo un miedo a la verdad»" 540 .

El pasado como historia de los errores es entendido a partir de estos supuestos no sólo ya en contraposición a una verdad absoluta, sino, además, tomando conciencia de que toda verdad, o todo acierto, o todo progreso, implica siempre algún error, es verdad parcial. Esos son los errores necesarios, los errores que requieren el valor de equivocarse, y que se muestran como ineludibles si es que queremos no volver a cometerlos.

La necesidad del error, en este contexto de la historia, lo presenta como instrumento. La historia crece con los errores, los pule, los asume, los critica: los supera, aunque sea, normalmente, para caer en otros. El error pasado, el pasado en general, "se va, por decirlo así, cotidianamente suicidando, desprestigiando y arruinando"541, los errores en sí mismos adquieren progresivamente el valor que les correspondía por la valentía que supusieron, el atreverse a errar. Ese valor conlleva su desaparición como errores y su traspaso a

${ }^{538}$ Epílogo..., p. 309, nota 481.

539" Verdad y perspectiva" (1916). OC II, 21. Hasta El hombre y la gente llega el "osar equivocarnos" de Hegel: cfr. El hombre y la gente (1949-50). OC VII, 177.

540 ¿Qué es filosofía? (1929). OC VII, 328. La idea la toma de la Fenomenología: "Diese Furcht zu irren schon der Irrtum selbst ist". HEGEL, Phänomenologie des Geistes. Jubiläumsausgabe. Hrsg. G. Lasson. Leipzig: Verlag der Dürr'schen Buchhandlung, 1907, p. 51.

541 Origen y epílogo de la filosofía (1946). OC IX, 353. 
instrumentos o medios para alcanzar cierta verdad, con lo que el progresivo suicidio del pasado es también el suicidio del error, o, mejor, de la parte negativa del error. Los errores pasan a ser instrumentos de la verdad, con lo que el pretérito deviene tesoro de los errores, y ya no mundo muerto de los errores. A partir de esta conexión entre error y verdad en el contexto del progreso y de la historia, en la que el error se muestra como instrumento de la verdad, aparece el error absoluto como imposible. "Baste insinuar lo imposible que es un error absoluto. Es éste tan incomprensible que nos hace caer de bruces sobre otro espeluznante enigma: la insensatez. El problema del error y el de la demencia se involucran mutuamente" 542 .

En las notas de trabajo explicita Ortega de dónde procede esta imposibilidad del error absoluto: "Añadir a lo que digo al principio del error en cita lo de Aristóteles, Met., I, 1 que "ningún pensador... puede errar por completo la verdad", y lo que sigue que es perfecto" 543 . No es el libro I de la Metafísica, sino el II, justamente el comienzo del libro. El texto exacto de Aristóteles del que parte Ortega es, entonces: "La investigación de la verdad es, en un sentido, difícil; pero, en otro fácil. Lo prueba el hecho de que nadie pueda alcanzarla dignamente, ni yerra por completo, sino que cada uno dice algo acerca de la Naturaleza; individualmente, no es nada, o es poco, lo que contribuye a ella; pero de todos reunidos se forma una magnitud apreciable"544. A ello se le añade la idea que toma del Differenzschrift de Hegel: "Diese Seite, von velcher das Erkennen ein Trennen und ihr Produkt ein Endliches ist, macht jedes Wissen zu einen Beschräknten, und damit zu einer Falschheit: aber insofern jedes Wissen zugleich eine Identität ist, insofern gibt es keinen absoluten Irrtum" 545 .

542Ibid. p. 358.

${ }^{543}$ Epílogo..., p. 40, nota 21.

${ }^{544}$ ARISTÓTELES, Metafísica. A 993 a 30. En la edición de García Yebra: ARISTÓTELES, Metafísica. Madrid: Gredos, $1982^{2}$, p. 84.

545HEGEL, Differenz des Fichteschen und Schellingschen Systems der Philosophie, en: Erste Drückschriften. Sämtliche Werke I. Hrsg. G. Lasson. Leipzig: Meiner, 1928, p. 76. Traducción: "Este aspecto, bajo el cual el conocer es un separar y su producto algo finito, hace de todo saber algo limitado y, por consiguiente, una falsedad; pero, en la medida en que todo saber es al mismo tiempo una identidad, no hay error absoluto". HEGEL, Diferencia entre los sistemas de filosofía de Fichte y Schelling. Ed. M. C. Paredes. Madrid: Tecnos, 1990, p. 113. 
Son de agradecer las opiniones que podemos compartir, que tomamos como verdad, pero también las más superficiales o incluso erróneas. Son de agradecer ambas porque de las primeras quizá tomemos verdades o doctrinas, pero éstas sólo han llegado a existir como tales por medio de las segundas. Con esto, es imposible el error absoluto, y no únicamente debido a la idea clásica, y que repite Ortega de un modo insistente, de que reconocer un error es ya una verdad, o el comienzo de una verdad. El error absoluto es imposible no sólo, tampoco, debido a su carácter de instrumento, o medio necesario para alcanzar la verdad. El error absoluto es imposible porque eso que, en un futuro, o desde otra situación o perspectiva, es considerado como error no lo era en el momento y la circunstancia en que fue enunciado. Respondía a una serie de urgencias, y solucionaba determinadas cuestiones que en ese momento o situación se consideraban importantes. Lo que ocurre es que, pasando el tiempo, si nos referimos a la historia, o cambiando de circunstancia o perspectiva, si pensamos en un contexto general, las connotaciones cambian, las necesidades se modifican, las vistas son distintas, las situaciones vitales son diferentes.

El error absoluto es imposible porque ese error es una actividad humana, exigida por determinadas circunstancias, y "no es verosímil que ninguna actividad normal del hombre consista en un esencial error"546. No hay errores esenciales, sino aciertos insuficientes, o, directamente, "a la postre se revela que no era error porque no fuese verdad, sino porque era una verdad insuficiente"547. Esto no refiere únicamente a ámbitos históricos, esto es, al error como instrumento para conseguir la verdad y a la continuidad en la serie dialéctica, sino, además, a cambios de contexto o de perspectiva: el error como verdad insuficiente que será continuada por otra teoría, por otro pensador, remite también a la incompletud, considerada desde este momento o esta situación, de la perspectiva a partir de la cual nació aquel error o verdad insuficiente. Esa es la conexión entre el tema de los errores en el contexto del pasado filosófico y la serie dialéctica de aspectos, que veremos a continuación.

546" La elección en amor" (1927). OC V, 613.

${ }^{547}$ Origen y epílogo de la filosofía (1946). OC IX, 358. 
El contexto en el que Ortega está analizando estos temas es el de la historia de la filosofía, pero es utilizable para cualquier contexto histórico 548 . Las verdades mancas, incompletas, desaparecen asimiladas por otras más completas, en un procedimiento de Aufhebung, de "absorción": aquello incompleto queda abolido, pero también conservado. El error, como verdad incompleta o parcial, aparece "teniendo razón en parte", con lo que "esas verdades insuficientes o parciales son experiencias de pensamiento que, en torno a la Realidad, es preciso hacer. Cada una de ellas es una «vía» o «camino»-methodos- por el cual se recorre un trecho de la verdad y se contempla uno de sus lados. Pero llega un punto en que por ese camino no se puede llegar a más. Es forzoso ensayar otro distinto. Para ello, para que sea distinto, hay que tener en cuenta el primero y, en este sentido, es una continuación de aquel con cambio de dirección"549.

La clave está, en esa "continuación con cambio de dirección". Se reúne el marco histórico con el juego de aspectos. Los errores, además de considerarse verdades insuficientes o incompletas, remitirían directamente a contextos distintos, a aspectos distintos, a "direcciones" distintas. En este sentido se recuperaría esa ausencia de esencial error en las actividades humanas. No sólo en el sentido progresivo de las verdades insuficientes, del error como instrumento y medio para la verdad, sino también en el sentido de multitud de aspectos o ensayos que, desde el orgulloso punto de vista particular pueden entender como erróneos o incompletos a los demás, pero que la humildad del conjunto muestra el carácter parcial e insuficiente de cada uno.

Aparece en este sentido otro modo de ver el tema del error, el que lo conecta con el carácter viajero de la vía o camino, del methodos, y que es otro modo de mostrar el sentido positivo del error, el error como cambio de perspectiva. Escribe Ortega, ante sus dificultades para definir el paisaje de la Pampa: "Me atrevería a sostener que la manera de colaborar un extraño en el conocimiento de nuestro país es precisamente por medio de sus errores. No siendo probable que ponga la flecha en el blanco sino, en el mejor caso, que forme opiniones desdibujadas, sin perspectivas ni buen coyuntamiento, debemos aprovechar esta misma monstruosidad. Si se quiere una expresión paradójica hela aquí: la

548"Esto que acontece con el pasado filosófico no es sino un ejemplo de lo que acontece con todo pretérito humano". Ibid. p. 361.

549 Ibid. p. 359. 
verdad del viajero es su error"550. El error que el viajero comete en sus opiniones sobre el país extraño deben tener una causa, deben ser posibilitadas por algo que, desde el punto de vista del viajero, se encuentre en esa tierra que le resulta extraña. ¿Por qué ha desdibujado la realidad en tal dirección y no en tal otra? A poco interesante que sea el alma del extraño por fuerza debe interesarnos la línea de su error. [...] Inclinémonos con lupa sobre ese polvillo mental, seguros de que en el error del viajero encontraremos siempre, más acusado que en nuestra propia experiencia, un pedazo de la auténtica verdad"551.

El error del viajero no es error, sino perspectiva distinta, punto de vista diferente. La pluralidad de miradas se muestra en este contexto del viaje fortaleciendo la noción del error como simple incompletud o parcialidad. La verdad del error del viajero presenta al error como verdad, descubriendo aspectos que los lugareños no ven por estar demasiado cerca, o, simplemente, equivocándose en su interpretación por mirar el paisaje desde una circunstancia vital diferente. De este modo, la teoría del error en el pasado filósofico, continuada en su situación en el marco general de la vida y del hombre, remite a la teoría de los aspectos, a la serie dialéctica que conduce el tema del pasado filosófico hasta el marco de los aspectos de la cosa, los aspectos y la cosa entera. Es la conjunción de dialéctica histórica y dialéctica real.

550" La Pampa... promesas" (1929). OC II, 640.

551 Ibid. p. 641. 


\subsection{Los aspectos}

Que el tema de los aspectos no aparezca en ningún momento en las notas de trabajo sobre la dialéctica de Hegel, es prueba de que esas notas son muy anteriores a las de Epílogo... Es la distancia que separa, por lo menos, el año 28 y las conferencias en Buenos Aires, del comienzo en el 43 de las notas para Epílogo..., aunque, como venimos viendo, la continuidad en el pensamiento de Ortega sea evidente: en el año 43 Ortega comienza la recogida de las notas, pero muchas de ellas han sido escritas en años anteriores. Los aspectos no pueden ser entendidos únicamente como una nueva versión de la teoría de la perspectiva o del punto de vista, sino que tienen un contexto fijo: el de la dialéctica, la dialéctica de lo real. Por la misma razón se entiende su conexión con el tema del pasado filosófico y la teoría del error.

Los errores no son únicamente verdades parciales, incompletas, sino que también remiten a vistas determinadas, a aspectos concretos, que exigen su continuación con otros mediante su propia insuficiencia: "el origen de los más frecuentes errores es que nos contentamos con confirmar ese primer carácter real del aspecto o idea en vez de buscar su integración en el carácter decisivo de realidad'552. El pasado filosófico presenta en sus diversos sistemas distintos aspectos de realidad y exige su continuidad dialéctica en otros sistemas, en otros pensamientos. Esa necesidad no es gratuita, sino que responde al carácter mismo de lo real.

Cada cosa, cada realidad, reclama ser vista completa. Cada uno de sus lados, de sus aspectos, de sus caras, tira de nosotros para que prosigamos la visión. Es la realidad misma, en su ofrecerse siempre incompleta, la que "es causa de que pasemos de un aspecto a otro, quien nos obliga a desplazarnos"553. En cada momento, tenemos de la realidad sólo un cierto número de vistas, que se van acumulando; esas vistas son aspectos de las cosas. La

552Epílogo..., pp. 60-61, nota 52. En la expresión definitiva de ese párrafo en Origen y epílogo de la filosofía remite Ortega explícit amente al talante dialéctico, al "tener siempre más aspectos": "Esta es la causa más frecuente de nuestros errores porque nos lleva a creer que asegurarnos de si una idea es verdad se reduce a confirmar ese único carácter «real» de la idea que es enunciar un «auténtico aspecto» -a no buscar su integración confrontando la idea no sólo con el «aspecto» que ella enuncia, sino con el decisivo carácter de la realidad que es «ser entera» y, por lo mismo, tener siempre «más aspectos»". Origen y epílogo de la filosofía (1946). OC IX, 376.

${ }^{553}$ Origen y epílogo de la filosofía (1946). OC IX, 368. 
conexión se dará entre la vista (concepto o pensamiento) y el aspecto (de la cosa, de lo real), entre los dos momentos de cuyas denominaciones huye Ortega, sujeto y objeto. De aquí la afirmación del carácter sintético como unión de pensamiento y realidad, y no el analítico que únicamente permanece en el concepto.

Pero antes de continuar el desarrollo del tema, Ortega deja ver la base sobre la que se sostiene la teoría de los aspectos, la dialéctica de lo real. Es lo que llama un protofenómeno, en el sentido de Goethe, "y a ella debo, literalmente, toda una dimensión de mi doctrina: que es la cosa el maestro del hombre" 554 . La sensibilidad para las cosas, el tomar el punto de vista de los objetos, la prioridad de lo real, etc., todos los contextos que, situados en torno a la superación del idealismo y a la fundamentación de la propia filosofía de Ortega desde sus comienzos, han sido considerados como caracteres determinantes de la nueva sensibilidad, convergen ahora en esa idea, la cosa como el maestro del hombre. Ortega acompaña el texto de una nota a pie de página, muy importante para nuestro tema: "Véase una insinuación de ella en mi ensayo "La «Filosofía de la historia de Hegel» y la historiología"555. Esa insinuación es el "pensamos con las cosas" como máxima averiguación de Hegel, iniciada en la extraña traducción de "la razón determinada es la cosa".

Después de todo tipo de críticas a la dialéctica hegeliana, Ortega muestra que la prioridad de lo real sobre la que se sostiene su dialéctica, se inicia en el propio Hegel. Esta es la ambigüedad de la recepción. No sólo gran parte de lo referente al yuxtapensamiento lo hemos encontrado en las notas sobre Hegel, sino que, además, la parte propia de la dialéctica de Ortega, la que remite a su carácter de realidad, refiere también de forma explícita a su lectura del propio Hegel. En este sentido, la teoría de los aspectos no puede entenderse fuera del contexto de la dialéctica, pero tampoco fuera de la recepción general de Hegel por Ortega.

La explicación es la que viene presentándose: Ortega admite, utiliza y necesita a Hegel, pero siempre que aquello que toma de él sea extraído del contexto sistemático hegeliano; lo que Ortega admite, utiliza y necesita es su propia recepción de Hegel. Son los dos polos de la ambigüedad de la recepción: por un lado el "pensamos con las cosas" como máxima ${ }^{554}$ Ibid. 
averiguación de Hegel y base de gran parte de la teoría de Ortega, pero también, por el otro, la crítica al propio Hegel mediante la afirmación del mismo carácter: "para nosotros, lo absoluto es objeto"556 y el acercamiento a ese objeto es de experiencia, de historia, de vida, no de sistematismo y espiritualismo absolutos.

Pensamiento como yuxtapensamiento, el "pensamos con las cosas", la confluencia con el carácter de pantonomía, del interés por el todo, tales caracteres reúnen de un modo explícito a Hegel y Ortega. Que el tema de la dialéctica sea utilizado para hacer confluir esa serie de rasgos no es casual. Se trata de la dialéctica como integración, como afán de completud, apetito de universo. Cada particularidad siempre remite a otras, cada limitación exige su contacto con sus vecinas, cada fragmento solicita su continuación.

Es este mismo tema el que muestra a Ortega como filósofo "del todo y para el todo", el que lo conecta con el propio Hegel y las pretensiones de totalidad (una totalidad en Ortega siempre abierta, progresiva, dialéctica) de Comte, Aristóteles o Leibniz. Es la confidencia que el propio Ortega ofrece en las notas de trabajo como el secreto de su vida: "Wie Hegel, Comte, Aristóteles, Leibniz ich bin ein Philosoph aus dem Ganzen und zum Ganzen. Deswegen kann ich nicht Parteimensch werden, deswegen müsste mich alles interessieren Erst jetzt verstehe ich dies Geheimnis - Geheimnis für mich - meines Lebens"557. No puede ser hombre de partido, no puede renunciar a otros aspectos, a otras limitaciones, y, aun así, ese müsste indica que quizá no es demasiado lo que ofrezca el interés suficiente.

La teoría de los aspectos muestra el talante de totalidad, de integración, la conexión de continuidad y discontinuidad en lo real mismo. El pensamiento recorre la realidad discontinuamente, mediante las limitaciones del concepto. Pero la reunión de pensamiento y realidad explicita tal discontinuidad en ambos marcos: "a cada paso tomamos una «vista» sobre ella y estas vistas son, de un lado -el sensu stricto intelectual, los «conceptos» o «nociones» o «ideas»; de otro -el intuitivo, los «aspectos» correlativos de la cosa"558. Por

555Ibid. p. 368 n.

556 Archivo de la "Fundación José Ortega y Gasset", Carpetilla "Hegel: Dialéctica".

${ }^{557}$ Epílogo..., p. 116, nota 158. Traducción: "Como Hegel, Comte, Aristóteles, Leibniz, yo soy un filósofo desde el todo y para el todo. Por ello no puedo ser hombre de partido, por ello debería interesarme todo. Sólo ahora entiendo este secreto -secreto para mí - de mi vida".

${ }^{558}$ Origen y epílogo de la filosofía (1946). OC IX, 368. 
un lado, las vistas en la limitación del concepto; por el otro, los aspectos en el carácter fragmentario y sugestivo de la intuición.

Esas vistas son las que lleva a cabo el hombre en la historia, sea de la filosofía, sea su propia historia vital. Corresponden a los aspectos de cosa, pero siempre son limitadas, finitas, por el propio carácter vital del hombre, en tanto el aspecto pertenece a la cosa, pero también al sujeto, a unos ojos, a una vista, "a un mirar que por lo pronto es punto de vista (limitación)" 559 . En los juegos de vistas y aspectos se muestra la conexión de pensamiento y realidad que Ortega ha venido presentando desde el inicio del tema de la dialéctica con la prioridad de lo sintético sobre lo analítico. El aspecto pertenece a la cosa, pero no hay aspecto si alguien no mira esa cosa: el aspecto es una respuesta, y, con ello, depende de la índole del vivente, del que cuestiona.

Se trata de la reunión explícita de sujeto y objeto: "el «aspecto» es la «cara que nos pone» la realidad. La pone ella pero nos la pone a nosotros"560. Si pudiesen integrarse todos los aspectos tendríamos la cosa entera, pero eso es imposible, con lo que tendremos que contentarnos con aspectos, con fragmentos, y no con la cosa misma. Lo que por parte de lo real es aspecto, por parte del hombre es la vista tomada sobre la cosa. En este sentido, "vista" es el término orteguiano para evitar utilizar "idea" o "concepto". Con todo, la limitación es la misma que la que encontrábamos en "La paradoja de Hegel": las vistas siempre limitan, ofrecen sólo una parte, pero su sentido dialéctico solicita la integración de los aspectos que muestran, "integramos los aspectos, no los abandonamos" 561 .

El avance se encuentra ahora en que Ortega muestra que la propia realidad es discontinua, que por el hecho de estar basada en la síntesis de pensamiento y cosa, de hombre y realidad, ofrece únicamente aspectos, fragmentos, discontinuidades que insistentemente solicitan su continuación: "pertenece a la Realidad tener «aspectos», «respectos»y, en general, «perspectiva», ya que pertenece a la Realidad que el hombre esté

${ }^{559}$ Epílogo..., p. 62, nota 54.

560 Origen y epílogo de la filosofía (1946). OC IX, 370.

${ }^{561}$ Epílogo..., p. 61, nota 54. 
ante ella y la vea"562. Es la propia sintetización de pensamiento y realidad la que exige el carácter dialéctico.

Esta es la conexión entre la teoría de la perspectiva y el tema de la dialéctica. Los términos perspectiva y conocimiento son casi sinónimos, "casi son equivalentes" 563 , precisamente porque se parte de la reunión sintética y dialéctica de pensamiento y realidad. Es el hombre el que mira el aspecto, el que piensa el fragmento que ofrece lo real, y, con ello, el resultado siempre expresará una perspectiva, un paisaje, una vista propia procedente del aspecto determinado. Del hecho de que el conocimiento sea perspectiva, esto es, la reunión de vistas y aspectos, se deduce que éste no es únicamente un "«modus cognoscentis», sino una positiva modificación de lo conocido"564. Es el conocimiento como traducción, como interpretación, en el resultado que reúne en la perspectiva propia el aspecto de lo real y la vista particular. La dialéctica real de Ortega tiene como objetivo, tanto en su marco histórico, como en el filosófico y el vital, constituir la enunciación de las distintas vistas, mostrar la continuidad de lo fragmentario, la continuación que solicitan los aspectos entendidos como fragmentos.

Al sustituir Ortega en este momento las referencias a conceptos por las "vistas", ofrece la posibilidad de entender el carácter dialéctico del pensamiento en su necesaria integración con la propia dialéctica de lo real. Es por ello que en el mismo año, en el 46, insista en criticar la dialéctica conceptual de Hegel y afirme el carácter real de la suya. Lo hace en la conferencia sobre el teatro: "La «dialéctica» famosa original de Hegel es, en verdad, miserable. En ella el «movimiento del concepto» procede mecánicamente de contradicción en contradicción, es decir, va movido el pensar por un ciego formalismo lógico. El «pensar dialéctico» que empleo como modo intelectual y a que el texto se refiere va movilizado por una dialéctica real, en que es la cosa misma quien va empujando al pensamiento y obligándole a coincidir con ella"565. Y también en la "Reviviscencia de los cuadros": "Esta

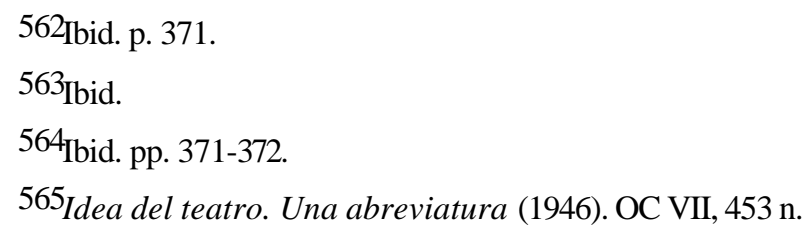


dialéctica no es de conceptos, sino real; no es del logos, sino de la cosa misma"566. No sólo está criticando la dialéctica hegeliana, sino también el propio carácter del "concepto", como limitación, en el sentido de "La paradoja de Hegel". Con las vistas y aspectos puede mostrar la adecuación de la fragmentación, de la limitación, de la discontinuidad, con los talantes dialécticos de ampliación, de límite, de continuación, y puede hacerlo porque parte de la conexión del mismo carácter en pensamiento, las vistas, y realidad, los aspectos.

La diferencia real con Hegel no se encuentra en el propio movimiento dialéctico, sino en el sistema absolutista sobre el que descansa la dialéctica hegeliana. La crítica se refiere al sistema dialéctico como "ventrilocuo del Absoluto"567. En Ortega, cada cosa se presenta bajo un aspecto que conduce a otro, y este a otro, y así sucesivamente. La integración de todos los aspectos expresaría la realidad completa de la cosa. Ortega muestra el proceso en cuatro pasos: 1. detenernos ante cada aspecto y tomar de él una vista, 2. seguir pensando, pasar a un aspecto continuo, 3. conservar los aspectos vistos manteniéndolos presentes, y, 4. integrarlos en una vista lo suficientemente total para cada tema en cuestión. En este momento, la serie dialéctica se constituye en la necesidad de la continuidad, esto es, de la exigencia de cada aspecto para ser continuado por el siguiente: "todo el quid está en que cada «vista» de un «aspecto» reclama que avancemos para ver otro'568, teniendo claro que "la contigüidad «lógica» de las «vistas» (vulgo, conceptos) proviene de la contigüidad real de los «aspectos»"569.

Por mucho que Ortega insista en sus diferencias con la dialéctica hegeliana ${ }^{570}$, por las notas de trabajo y por el examen llevado a cabo más arriba, sabemos que esos caracteres él mismo los ha visto en la teoría de Hegel. Ortega acepta caracteres internos del sistema, pero no el sistema hegeliano mismo. Es por ello por lo que insiste en mostrar que "el pensar

566" La reviviscencia de los cuadros" (1946). OC VIII, 504.

${ }^{567}$ Origen y epílogo de la filosofía (1946). OC IX, 374.

568Ibid. p. 375.

569 Ibid.

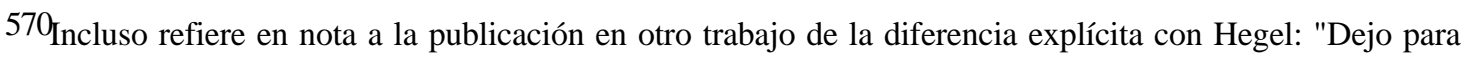
otro trabajo una exposición que precise lo que hay de común (muy poco) y lo que hay de divergente (todo el resto) entre el uso de este término en la obra de Hegel y en las páginas de este libro". Origen y epílogo de la filosofía (1946). OC IX, 375, n. 
dialéctico marcha sólo en línea recta"571, teniendo presente el carácter circular del sistema hegeliano. Muchos de los rasgos de la dialéctica real, incluidos el yuxtapensamiento, la continuidad, el "pensamos con las cosas", etc., provienen del propio Hegel, pero Ortega no admite su situación en un sistema cerrado y basado en el imperialismo del absoluto. Su teoría de la razón histórica y de la razón vital no puede aceptarlo, a pesar de que aspectos determinantes de su dialéctica real se inicien en su propia recepción de Hegel.

Sorprendentemente, Ortega afirma que el tema de la series dialécticas o continuidad de vistas en el pensamiento y aspectos en lo real, no es más que un método de trabajo, "de donde resulta que el término tremendo, prometedor de profundidades, descubre a la postre su humildísima condición de mero instrumento de catalogación, para no olvidarse el autor, y de guía, para perderse el lector"572. Es mucho más que eso. La conexión de pensamiento y realidad que se establece a partir de los caracteres sintéticos y dialécticos remiten al conjunto de la filosofía de Ortega. El talante de integración y continuación, de ampliación de fragmentos, de remisión de unas perspectivas o particularidades a otras, o, en general, la conexión recíproca de límite y limitación, hacen de la dialéctica un marco que supera ampliamente el sentido de simple y "humildísimo" método. El carácter integrador permite conectar la dialéctica vital, histórica, epistemológica y ontológica, con lo que, con la dialéctica real en la base, el contexto general de la teoría de Ortega adquiere la reunión de sus diversas vistas.

571 Ibid. p. 375.

${ }^{572}$ Origen y epílogo de la filosofía (1946). OC IX, 376. 


\subsection{El pensamiento intuitivo}

En la dialéctica real, todo aspecto y todo pensamiento trasciende de sí mismo para remitir a su continuación, a su ampliación: "Esta trascendencia de todo pensamiento, concepto, sobre sí mismo está representada por la intuición, que es un tener el mundo pero aún no es saberlo"573. La intuición que tiene un mundo, pero aún no lo sabe, es el pensar intuitivo o sintético que dirige la dialéctica real. Intuye un mundo: la intuición remite a los aspectos, a los fragmentos o particularidades ("el intuitivo, los «aspectos»"574), pero aún no lo sabe: le falta su intelección, el concepto (el sentido "intelectual, los «conceptos»"575). La tesis de Ortega se basa en la integración de ambos sentidos. Se rechazará el pensar lógico de la filosofía griega, sostenido por el predominio del logos, pero

no se abandonará el concepto: a los conceptos se les pide "que sean sugestivos"576, que permitan esa trascendencia dialéctica que conecta las limitaciones. La sugestión y la intuición mantendrán una dialéctica integradora que no excluye el concepto, pero sí su primacía: "Se acabó la primacía del logos, del decir presuntuoso, que cree valer por sí mismo'577.

El pensar sintético y dialéctico se constituirá de este modo como un pensar intuitivo, que, siendo intuitivo, en ningún caso pretende dejar de ser pensamiento. Por ello, el objetivo es la suma de intuición y abstracción, el pensar íntegro que Ortega presenta como su nueva idea del pensar: "Mi nueva idea del pensar en que, por vez primera, se toma en serio que el pensar es, a la vez, intuición y concepto, de suerte que uno y otro de sus actos se reclaman mutuamente y sólo son auténtico pensar copulador"578, o, de otro modo, "el auténtico logos es la unidad de ambas cosas: abstracción en la intuición'579. Ortega ya había iniciado su idea en las notas sobre Hegel, al insistir en la reunión de vida e intuición,

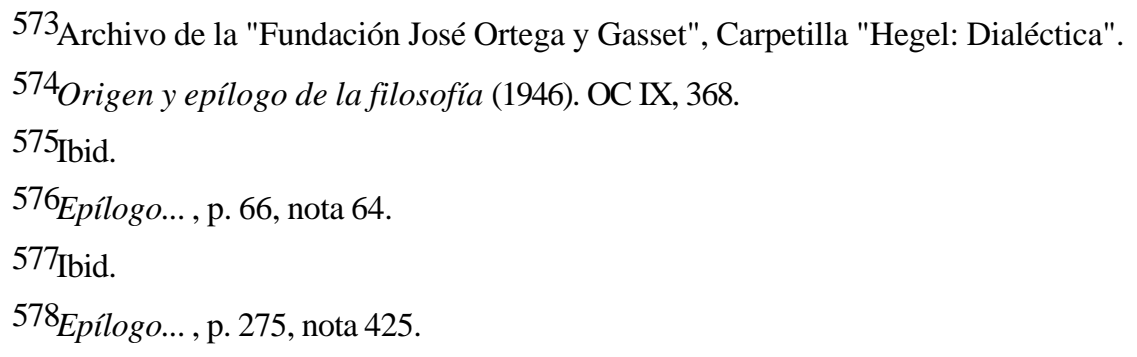


por un lado, y forma y pensamiento, por el otro. Es su carácter de "tercero en discordia", frente a cualquier tipo de sensualismo o logicismo: "somos un tercero en discordia: las formas: los form-anschauer - no distinguimos entre intuición y pensar"580. Esta nota, citada más arriba, adquiere ahora un nuevo sentido, al situarse explícitamente en el contexto de la dialéctica.

La lección segunda de las ofrecidas en el año 28 en Argentina sobre Hegel llevaba el título de "Dialéctica e intuición", y corresponde a las notas de la carpetilla titulada "Dialéctica". En las notas para Epílogo... y en Origen y epílogo de la filosofía, sobre todo en las primeras, el tema de la intuición adquiere una importancia determinante. Ortega vuelve a sus notas sobre Hegel, en reunión directa de las tomadas alrededor del año 28 (la carpetilla "Dialéctica") con las del 43 (las notas para Epílogo...). De lo que se trata ahora es de saber exactamente cómo queda situada la relación dialéctica-intuición con el referente hegeliano, en el marco de las nuevas ideas iniciadas en el año 43 con el proyecto de Epílogo...

El tema de la intuición no aparece en los tres escritos publicados sobre Hegel. Sin embargo, por las notas de la carpetilla "Dialéctica", por el título de la segunda conferencia profesada en Buenos Aires y por las referencias al concepto de "intuición" en ¿Qué es filosofía?, es posible conocer cómo entendía Ortega el tema. En las notas de trabajo sobre Hegel, presenta de un modo explícito su idea. Escribe: "En Hegel, el entendimiento piensa positivamente - la razón no piensa, al contrario, niega el pensamiento y le obliga con su negación a pensar más, a volver sobre sí. Es, pues, la razón una extraña conciencia intuitiva [...] y que presenta la cosa íntegra al pensar desintegrante y parcial analítico. ¿No es esto lo que yo llamo vida?"581. Para Ortega, la razón en Hegel se opone al pensamiento en el sentido de que presenta la cosa y exige al pensamiento la continuación de su despliegue, de su pensar, en un proceso dialéctico evolutivo sostenido por el continuo de lo real. La unión de razón y pensamiento la ofrecería el espíritu: "la razón presenta la cosa, la opone al pensamiento: el Geist une ambos momentos"582. En el fondo se encuentra la tesis del

${ }^{579}$ Epílogo..., p. 253, nota 396.

580 Archivo de la "Fundación José Ortega y Gasset", Carpetilla "Hegel - Filosofía de la historia".

581 Archivo de la "Fundación José Ortega y Gasset", Carpetilla "Hegel: Dialéctica".

582 Ibid. 
"pensamos con la cosas" que presentaba en "La «Filosofía de la historia de Hegel» y la historiología". La razón es entendida en el carácter de intuición, de referencia inmediata a la cosa, que supera en su operar sintético el carácter analítico, conceptual, y refiere a la integración de ambos momentos.

Ortega, y de ahí la conexión con "lo que yo llamo vida", interpreta ahora la razón hegeliana en términos de su razón vital. La vida, en la conexión explícita de pensamiento y realidad, de hombre y mundo, integra ambos momentos y se muestra en los caracteres de esa conciencia intuitiva que, por un lado, es pensamiento, conciencia, y, por el otro, refiere a los aspectos, a lo real, a la cosa. Toma de Hegel ese sentido del "pensamos con las cosas", de la conexión entre razón y cosa, pero también el tema del concepto como limitación de lo real, el pensamiento como contradicción, que presentaba en "La paradoja de Hegel". Este es el momento en el que Ortega se separa de Hegel, el momento en que percibe que la limitación de los conceptos en Hegel únicamente se supera en su referencia a la totalidad, a lo absoluto. La dialéctica real no permite esa finalización. Este sería el sentido negativo del concepto hegeliano de intuición para Ortega: "La intuición en Hegel es referir los conceptos limitados de la reflexión [...] a lo absoluto o totalidad - se unen en ésta. (Vease Kroner)"583. La referencia a Kroner que tiene en mente Ortega (determinable por las propias notas de trabajo y subrayada en el ejemplar que maneja) es lo suficientemente explícita: "[...] ein Angeschautes, d. h. ein Glied der Totalität"584.

De nuevo, a Ortega le interesa el proceso de Hegel, pero no su final. Le interesa el proceso evolutivo, dialéctico, sintético, así como la conexión de pensamiento y realidad y el carácter intuitivo de ese proceso. Esa es la recepción de Hegel, que inmediatamente Ortega remite a sus intereses particulares: "Hegel ve la posibilidad de fundar una síntesis a priori en pura intuición"585. El objetivo está en conseguir la integración de pensamiento analítico o conceptual y pensamiento sintético o intuitivo, y esa integración exige los caracteres de dialéctica real que parte precisamente de la conexión entre el continuo del ser y el continuo del pensar. Por ello, cuando en las notas para Epílogo... remita al "pensar como "Wissen"

583 Ibid.

584KRONER, R. Von Kant bis Hegel. Bd. II: Von der Naturphilosophie zur Philosophie des Geistes. Tübingen: Mohr, 1921, p. 159. Traducción: "un intuido, es decir, un miembro de la totalidad".

585Archivo de la "Fundación José Ortega y Gasset", Carpetilla "Hegel: Dialéctica". 
en Hegel"586, y muestre que los tres momentos dialécticos hegelianos vienen determinados por el carácter intuitivo de la tesis y la síntesis, añadirá a la nota: "Esencial conexión entre pensar e intuición"587. De un modo general, entonces, lo que pretende Ortega con la reunión de dialéctica e intuición en Hegel es conducir a la integración de pensamiento y realidad sostenida en la dialéctica real. Todo esto puede verse de un modo más completo si, como ayuda para la interpretación de las notas de trabajo sobre la dialéctica en los años veinte, se le añade la lectura de la intuición en ¿Qué es filosofía?

Ortega siempre entenderá el concepto de "intuición" como presencia inmediata de la cosa. De ahí la importancia de la intuición en sus pretensiones de unir pensamiento y realidad, concepto y cosa. Que la intuición será siempre entendida del mismo modo puede probarse de un modo fácil: mostrando la definición que ofrece en ¿Qué es filosofía? y la que aparecerá en Origen y epílogo de la filosofía. Así, respectivamente: "intuición es la cosa menos mística y menos mágica del mundo: significa estrictamente aquel estado mental en que un objeto nos sea presente"588, y: "tener presente la cosa, es decir, intuición"589. La reunión de pensamiento y realidad a través de la continuidad de vistas y aspectos ofrecida por la dialéctica real mostrará, de este modo, la necesaria integración de pensamiento e intuición.

El pensar intuitivo es el que, manteniendo sus caracteres de pensamiento, de concepto, de idea, no se separa en ningún momento del punto de vista de la cosa, de su presencia inmediata: el pensar intuitivo, expuesto en los años cuarenta por Ortega, será la expresión del "pensamos con las cosas" como máxima averiguación de Hegel, presentado en el texto sobre Hegel del final de los años veinte. La reunión en Hegel de dialéctica e intuición tenía para Ortega únicamente esta intención: mostrar la conexión de pensamiento y realidad a través del carácter evolutivo, dialéctico, del carácter de continuidad que afecta a ambos. La intuición como presencia inmediata de la cosa exigirá este desarrollo evolutivo en el que quedan integrados pensamiento y realidad. De este modo, la dialéctica real se mostrará en

\footnotetext{
586Epílogo..., p. 297, nota 466.

587 Ibid.

588. Qué es filosofía? (1929). OC VII, 352-353.

${ }^{589}$ Origen y epílogo de la filosofía (1946). OC IX, 368.
} 
la crítica a la dialéctica conceptual hegeliana, pero partiendo de la recepción que Ortega efectúa del propio Hegel.

En ¿Qué es filosofía? la relación de la intuición con la teoría de los aspectos, que únicamente aparecerá en los años cuarenta de forma definitiva, mantiene ya una primera lectura. Se trata de mostrar la filosofía como la exigencia de verdades evidentes, que sólo pueden serlo si el acercamiento a las cosas es de presencia inmediata. Esa presencia inmediata de la cosa es la que ofrece la intuición. Ofrece la presencia inmediata, pero únicamente de partes, de fragmentos, y "en todo momento podremos añadir una nueva visión a lo que ya hemos visto de una cosa"590, la intuición siempre podrá ser perfeccionada. Es el mismo contexto que unirá la continuidad del ser y la continuidad del pensar en la dialéctica real, iniciada en las notas sobre Hegel y mostrada explícitamente en Origen y epílogo de la filosofía y en las notas para Epílogo... La "intuición" que en estos textos aparece remitiendo a los aspectos, se muestra ya en ¿Qué es filosofía? expresando el carácter que conjunta los dos momentos, el de parcialidad y continua posibilidad de ampliación, y el de presencia inmediata de la cosa. Es el pensar intuitivo en la conexión de pensamiento y realidad dialécticos.

Por todo ello, cuando Ortega insista en el Leibniz en el pensar sintético o intuitivo, ambos en su significado de "pensamos con las cosas", de presencia inmediata de la cosa, volverá a mostrarlos en su conexión con la evidencia ("en vez de evidencia se ha solido hablar de «intuición»"591), y en referencia explícita a Husserl, pero también en la conexión con la intuición pura como remisión al objeto, y en referencia explícita a Kant ("en Kant, la pureza de su idea «intuición pura» no se refiere a la intuición, sino al objeto"592). La conexión de ambos, Husserl y Kant, tamizada por Ortega, aparecerá explícitamente en una de las notas de Epílogo..., al mostrar la conexión de abstracción e intuición, pensamiento o concepto y objeto, a través de un único aspecto, la sensación pura: "La intuición sería la «sensación» pura - que es lo que es en Kant y Husserl" 593. Esa sensación pura debe ser

590 ¿Qué es filosofía? (1929). OC VII, 354.

${ }^{591}$ La idea de principio en Leibniz y la evolución de la teoría deductiva (1947). OC VIII, 68.

592 Ibid. p. 137.

${ }^{593}$ Epílogo..., p. 253 , nota 396. 
entendida en términos de Ortega: la sensación pura como integración de pensamiento y realidad en la adecuación de abstracción e intuición 594.

${ }^{594}$ De hecho, esta adecuación de abstracción e intuición era la que realmente le interesaba a Ortega de Husserl: "la dualidad interna del logos, del pensar: este es intuición y abstracción. Hasta Husserl nadie ha visto como lados constitutivos de todo pensar esas dos funciones". Epílogo..., p. 279, nota 431. El tema de la intuición en Husserl siempre interesó a Ortega de un modo determinante, pero, de hecho, nunca lo trató detenidamente en textos publicados. Ya en 1913, en el Congreso de la Asociación Española para el Progreso de las Ciencias, escribía: "Muy varias y hondas son las discusiones que motiva este nuevo principio de la intuición, establecido por Husserl. Su misma novedad hace que todavía no se vean bien claros sus límites y su constitución. Yo me contento con iniciar entre nosotros el tema". "Sensación, construcción e intuición" (1913). OC XII, 498. Más de treinta años después, en el Leibniz, Ortega continúa reconociendo los méritos de Husserl, pero sin admitirlos totalmente... y sin concretar el tema: "En un término tan decisivo como éste nadie había procurado una aclaración controlable hasta Husserl. Pero no he dicho que la de éste sea suficiente, ni voy ahora a desarrollar en su integridad el problema de la intuición". La idea de principio en Leibniz y la evolución de la teoría deductiva (1947). OC VIII, 134. 


\subsection{Estética sugestiva}

El pensar intuitivo, como expresión de la presencia inmediata de la cosa, permite a Ortega conjuntar las referencias a los distintos momentos de la dialéctica: la conexión de pensamiento y realidad, la intelección que supone la reunión de intuición y abstracción, y la trasmisión en una dialéctica histórica de la filosofía que exprese la continuidad de lo real en sus fragmentos. Es en este sentido en el que se muestra como pensar completo, con todos los talantes integradores que supone, un pensar completo que, en su referencia inmediata a la cosa, a lo real, es también pensar verdadero: "El pensar verdadero se caracteriza porque es a la vez visible (intuible), inteligible y transmisible - Es el pensar completo: intuición"595. Pero este pensar intuitivo, en sus referencias al carácter dialéctico, a la cosa y al concepto que se muestran en fragmentos y remit en a su continuación, no es únicamente intuitivo, sino también sugestivo. Es lo que Ortega solicita a los conceptos, que han adquirido un nuevo valor al caer la primacía del logos y ser sustituida por un pensamiento intuitivo basado en el trato directo con las cosas.

En este sentido, la intuición adquiriría los carácteres móviles del talante dialéctico ampliando su significado. No se trataría únicamente de la intuición como presencia inmediata de la cosa, de la intuición como expresión del carácter sintético que aglutina pensamiento y realidad superando el marco lógico del concepto, sino también de "intuición" en el sentido de vislumbre, de presentimiento. La intuición de la cosa, al remitir a la presencia inmediata de un aspecto concreto, exige instantáneamente la continuidad de la serie dialéctica, vislumbra, presiente su continuación.

Esa continuación no se establece únicamente en el marco de la dialéctica real, de la continuidad de los fragmentos de cosa, sino también en la dialéctica histórica que confiere sentido a esa continuidad de los aspectos: la continuidad de la historia de la filosofía, de los distintos sistemas que se han centrado en determinado aspecto o determinada vista de la realidad, del universo. En este sentido, entonces, la intuición adquiere los caracteres de sugestión. Es lo único que Ortega le pide a los conceptos, después de haber cedido su

${ }^{595} 5_{\text {Epílogo..., p. } 263, \text { nota } 415 .}$ 
primacía y verse obligados a la integración con lo real, a la integración de pensamiento y realidad a través de la intuición sintética y dialéctica: que sean sugestivos.

En la dialéctica real, la integración de vistas (conceptos) y aspectos (de cosa) supone la aparición de un pensamiento siempre en perspectiva, un conocimiento como traducción e interpretación en el que la necesaria relación de hombre y mundo convierte todo ver en un mirar. La intuición, en tanto muestra la presencia inmediata de la cosa, y el pensamiento, en tanto se adecúa a esa presencia y a la continuación de su incompletud, de su insuficiencia, no sólo refieren a la atención determinada de cada vista, esto es, al pensamiento regido por la atención, por la particularización de la mirada, sino también a los caracteres propios de esa mirada. La vista que es una mirada no responde únicamente a rasgos atencionales, de exigencias en la relación hombre-mundo o pensamiento-realidad, sino también a la sugerencia, a la ampliación, al carácter de trascendencia y anticipación que supone esa mirada.

La mirada intuitiva sugiere su particularidad, pero también su capacidad de remitir a otras miradas; sugiere una búsqueda concreta, un proyecto, pero también una acción, un hacer: "el intelecto busca algo en lo intuido (que es primitivamente el "mundo", por ejemplo el paisaje en el animal -hombre). Es, pues, sobre el área del ver la acción del mirar. El ver es pasivo: el mirar es un hacer, pues, es un buscar, y, además, es anticipación de lo que se busca. Supone, a su vez, un proyecto como toda acción: se mira por algo y para algo"596. La vista deviene mirada, mirada que es acción, que es creación concreta. Es mirada sugestiva tanto en su referencia a otras miradas, como en la permanencia en sí misma creando y actuando, creando paisaje, actuando en un proyecto. Un ver que es un mirar, un decir que es un sugerir, que siempre amplía y crea, particulariza y construye.

En este sentido la filosofía se supera a sí misma: su terminología lógica y conceptual clásica exige ser sustituida por un pensar poético, sugerente, metafórico, en el que las referencias conduzcan directamente hasta las cosas, pero también a sus caracteres de trascendencia, de superar significados habituales: "No es, pues, por su sentido = sentido tradicional o establecido - por lo que fue elegida la palabra aquella ni por lo que nosotros podemos entenderla sino por lo que nos "sugiere", es decir, por su virtud poética. Cada

${ }^{596}$ Epílogo..., p. 277, nota 428. 
nuevo término es una metáfora"597. El decir filosófico como un sugerir, como nueva intuición, como aumento en la serie dialéctica de aspectos, aglutina ambos sentidos, el del lenguaje, y el de lo real: ambos estás sostenidos por la base de continuidad, de ampliación de los fragmentos, de las novedades que ya sugiere, que ya crea cada mirada, sea particular, individual, sea la mirada de todo un sistema filosófico.

Es por ello por lo que la metáfora, en este contexto de las notas para Epílogo... no se muestra únicamente trasladando cada imagen, cada palabra, de un sentido a otro, sino que también nos mueve y transporta a nosotros mismos: tenemos una nueva intuición, un nuevo sentido, una nueva vista, y lo expresamos mediante una metáfora que supere el antiguo sentido. Por ello, "en una última instancia, en la metáfora los metaforizados o trasladados somos nosotros"598. Es la conexión de este pensamiento metaforizante o sugerente con la dialéctica real, con la ampliación de aspectos, con la continuidad de la historia de la filosofía, con el carácter sugestivo de los conceptos, la "enorme sugestividad'599 de los términos que brotan en nosotros, que expresan intuiciones nuevas y muestran el carácter creador del propio lenguaje.

Los aspectos exigiendo el carácter de vista, de mirada en todo pensar; la dialéctica real filosófica mostrando la continuidad de las distintas incompletudes; el sentido poético o sugestivo que no afecta únicamente al lenguaje, sino también a las mismas cosas en su sentido aspectual, en su sentido de remitir constantemente a más allá de sí. Todo ello posibilita un arte sugestivo, en el que los rasgos de continuidad aparecen refiriendo al carácter simbólico y metafórico de todo sugerir. El pensar en visiones, en miradas, hace de los conceptos dialécticas sugerencias y los muestra en el marco del lenguaje poético, definido precisamente por "ser muy sugestivo'600, por mantener la virtud poética de lo que cada término sugiere.

${ }^{597}$ Epílogo..., p. 100, nota 132.

598 Ibid.

${ }^{599}$ Epílogo..., p. 102, nota 134.

${ }^{600}{ }_{\text {Epílogo..., p. } 52, \text { nota } 38 .}$ 
La metáfora en general mantiene el mismo rasgo, es un "decir que es sugerir"601, una representación simbólica en la que no se cubre nunca con exactitud la idea, por el hecho de que toda idea, vista o concepto, refiere al carácter aspectual de lo real, a la incompletud y limitación de pensamiento y realidad. "Toda expresión es metáfora"602, es sugerencia, referencia a más allá de sí, por el hecho de que la función expresiva misma, sea el lenguaje, sea la vista conceptual que remite a un aspecto de realidad concreto, es "la causa de toda sugestión" 603 . Con ello, con la situación metafórica, simbólica y sugestiva de cada vista o aspecto, sostenida ahora por la dialéctica intuitiva y sintética de la continuidad, se entiende "el «sugerir» como el modo de decir propio a la filosofía'604. Y no sólo explica esto la referencia a la dialéctica real, sino también el interés de Ortega por el pensar mítico y mágico en relación con el origen de la filosofía. No se trata únicamente de mostrar los caracteres de la pre-filosofía, sino también de presentar que esos marcos se sostienen sobre el carácter de sugestión que, con la expresión poética, metafórica, regresa ahora a la filosofía como nueva sensibilidad.

La dialéctica real piensa en visiones, y ofrece a los conceptos su nueva misión de sugerir, pero es que también el pensar mitológico era un "pensar visionario"605, un pensar que no sólo nos ofrece sugestiones, sino que partía del mismo carácter de sugestión. El primitivo entiende el mundo como si cada cosa fuese otro hombre, basando su actuación en ruegos, en plegarias, en "el soborno de esas fuerzas invisibles" 606 que determinan su vida. Por ello "la técnica «sugestiva» (mágica?) del primitivo'607, porque se sostiene sobre el carácter de trascendencia de todo aquello que se le ofrece en la realidad.

El logos mítico, frente al logos preciso de la tradición lógica, conceptual, logicista, presenta su talante de sugestión al mostrarse como "difuso, impreciso, imagen de borde flotante y fundante con otras. De aquí, la interpenetración de los «conceptos» en el pensar

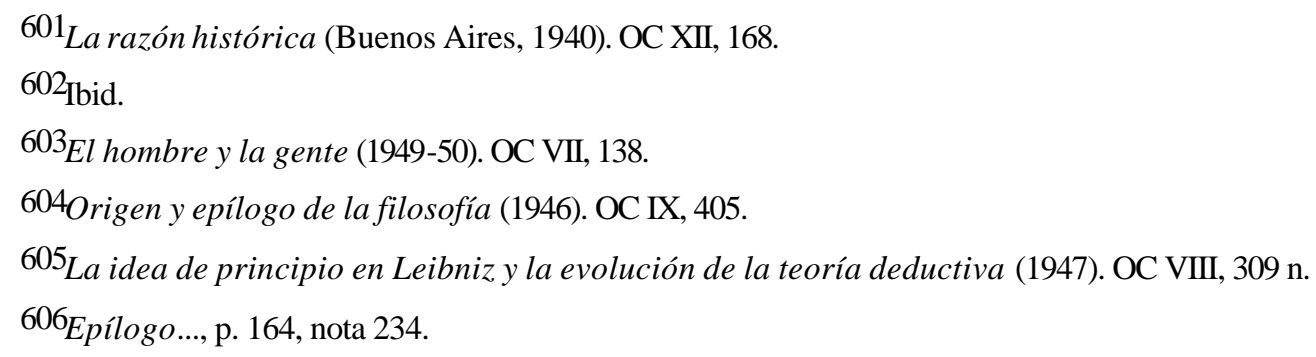


mítico, frente a la exclusión, incompenetrabilidad y choque de los «lógicos»'608. En el momento en que la nueva sensibilidad supera el marco logicista de la primacía del logos, en el momento en que la dialéctica real se apoya en el talante sintético e intuitivo, integrador de pensamiento y realidad, esos caracteres de interpenetración de los conceptos, de la afirmación de bordes difusos e imprecisos en las vistas y en lo real mismo, adquirirán un novedoso papel fundamental.

Ya no se tratará de la ausencia de lógica, de la carencia del concepto, como en el primitivo, sino de la superación de su dominio exclusivo. La dialéctica real e intuitiva exigirá el carácter sugestivo de sus particularidades (vistas, aspectos), los bordes serán precisos en cada una, pero también imprecisos, flotantes, al referir constantemente a su continuación. También las figuras de Velázquez tendrán márgenes imprecisos, también el interés se concentrará en la interpenetración de los conceptos, de las limitaciones. Es el carácter flotante que expresa la reunión de límite y limitación. Si en este momento se ha sostenido sobre el modo de actuación de la dialéctica real, el proceso proseguirá hasta el tema de Europa y del arte en estos años cuarenta.

Los bordes flotantes se referirán a las fronteras de las naciones, a la necesaria superación del nacionalismo agresivo, también a España en particular como tierra fronteriza, recuperando ideas iniciadas por Ortega con aquella cultura fronteriza de Meditaciones $^{609}$. Ahora el contexto se ha ampliado a todos los marcos, la interpenetrabilidad de las particularidades y la exclusión de toda exclusión afectan tanto a la dialéctica real, como a las ideas sobre Europa, como al arte de Velázquez. El proceso de integración de particularidades, iniciado por Ortega desde sus primeros escritos, mostrará ahora su desarrollo final.

${ }^{607}$ Ibid.

${ }^{608}$ Epílogo..., p. 165, nota 239.

609MQ, 155. 


\section{Estética política de la limitación}

El proyecto inacabado de Epílogo... se inicia en 1943, cuando Marías solicita a Ortega la redacción del texto para su Historia de la filosofía. Durará varios años, ypuede decirse que marca el desarrollo de toda una década, la de los cuarenta. Esos años son determinantes para entender la filosofía de Ortega en general: los años del final de la guerra mundial, del regreso de Ortega a España después del exilio, de textos y lecciones claves en su filosofía. El hilo direccional que aglutina los contenidos es el de la colaboración de las particularidades, el de la integración de las diversas limitaciones, que, iniciado en el contexto de la dialéctica, continuará hasta el tema de Europa y la idea de nación, pasando por los escritos estéticos sobre Velázquez.

En el año 39 Ortega ha efectuado su tercer viaje a Argentina. En el 40 pronuncia en Buenos Aires el curso sobre la razón histórica. En el 42 regresa a Europa y se instala en Lisboa. En el 43 escribe la primera introducción a Velázquez (escribirá dos más, en el 47 y en el 54). En el 44 ofrece el ciclo de conferencias en la Universidad de Lisboa titulado, de nuevo, "Sobre la razón histórica". En mayo del 46 realiza su reaparición en público en El Ateneo madrileño con la conferencia sobre la idea del teatro (un mes antes la había pronunciado en Lisboa). En el 47 escribe el Leibniz, en el 48 ofrece el curso sobre Toynbee, en el 49 pronuncia las conferencias sobre Goethe en Aspen y en Hamburgo y escribe la Meditación de Europa, en el 50 profesa el curso sobre El hombre y la gente.

En estos años se produce un doble acercamiento a Hegel, un acercamiento que supone la vuelta tanto a las notas tomadas en su lectura de los años veinte, como a temas iniciados muchos años antes y que superan la referencia a Hegel. El doble acercamiento ya ha sido examinado en su primer momento, el tema de la dialéctica, pero resta el segundo, que se producirá en torno a la idea de Europa y el tema de la nación. Con todo y de nuevo, la presencia de Hegel en ese tema sólo es visible desde las notas de trabajo. En el texto publicado de la Meditación de Europa, Hegel aparece sólo una vez, con un tema conocido, refiriendo a las ruinas que ofrece la historia si volvemos la vista hacia el pasado 610 . El contexto ahora será el de Europa, las ruinas las dejadas por la segunda guerra mundial, que

${ }^{610}$ Cfr. Meditación de Europa (1949). OC IX, 252. 
incluyen su reverso: "tras de las ruinas se oculta el rejuvenecimiento"611. Pero si es ésa, a primera vista, su única participación en el texto publicado, la interpretación se modifica al acudir a las notas de trabajo.

El tema que se encuentra en la base de la Meditación de Europa es el de la nación y el nacionalismo, el de la relación de Europa con sus naciones. Volverán a aparecer contextos que Ortega iniciaba en años muy tempranos, desde el tema del europeísmo y la conexión España-Europa, pero ahora su exposición incluirá, en primer lugar, toda la filosofía que Ortega ha venido desarrollando hasta estos años, y, en segundo, las connotaciones de la situación histórica europea, la Europa de postguerra. Si el tema es el del nacionalismo, en este momento Ortega tendrá, entre la serie de referentes filosóficos que siempre acompañan a sus tratamientos de los temas, uno muy concreto: Meinecke y su Weltbürgertum und Nationalstaat612. Meinecke sí que aparecerá de modo explícito en la Meditación de Europa y escritos afines.

En el archivo de la "Fundación José Ortega y Gasset" se encuentran una serie de carpetillas que contienen los apuntes de Ortega tanto en lo referente a Meinecke como a la serie de temas que definirán la Meditación de Europa. Esas carpetillas tienen títulos lo suficientemente explícitos: "Meinecke - Cosmopolitismo y nacionalidad", "Volkgeist, Meinecke, etc.", "Nación, Europa, etc.". En esas notas la presencia de Hegel es muy importante, tanto que permite ver su situación concreta, a primera vista inexistente, en el texto publicado de la Meditación de Europa.

Si en este sentido puede decirse que la referencia a Hegel en los escritos sobre Europa y la idea de nación de los años cuarenta supone el final de la recepción de Hegel por Ortega, el acudir a estos escritos para concluir este trabajo no obedece únicamente a la referencia a Hegel. El tema de la nación y del nacionalismo incluye aquel otro que lo ha acompañado constantemente desde el inicio: el tema de la limitación, de los límites, de las fronteras. De nuevo confluirán las dos vertientes, Hegel y la limitación, la política de la limitación y del límite.

$611_{\text {Ibid. p. } 253 .}$

612La referencia completa es: MEINECKE, F. Weltbürgertum und Nationalstaat. Studien zur Genesis des deutschen Nationalstaates. München und Berlin: Oldenbourg, 19287. Utilizo el mismo ejemplar que manejó Ortega: los subrayados y anotaciones de Ortega al margen son numerosísimos y determinantes para entender el tema. 
Por un lado Hegel, por el otro, con el tema del nacionalismo, el de la limitación y las fronteras. Resta un tercer momento para poder completar la conjunción que, de un modo u otro, ha regido el conjunto del trabajo: el arte, la estética. En los mismos años en que Ortega está llevando a cabo el proyecto de Epílogo... y las referencias a Europa y la idea de nación, ha iniciado también un tema concreto: Velázquez. En las figuras de Velázquez, Ortega encontrará los bordes difusos, los márgenes flotantes que permiten la conexión de las limitaciones convirtiéndolas en puro límite, puro margen indeciso. La "apertura estética de fronteras" que suponen las figuras de Velázquez aparecerá de un modo muy similar en el tema del nacionalismo mediante una "apertura política".

De nuevo, la conjunción se establecerá a través de una estética política de la limitación en la que Hegel ocupará un papel principal. El tema, con todo, superará la referencia al propio Hegel y se establecerá como conclusión del trabajo. Esa superación de la referencia a Hegel implicará otro aspecto que no aparece en estos años por casualidad: el tema de España como finis terrae, como tierra fronteriza. Los temas iniciados en los primeros años de la filosofía de Ortega vuelven a mostrarse ahora en esta década de los cuarenta.

España como tierra de frontera, el pueblo mediterráneo, con una limitación propia que debe ser permeable a otras limitaciones, el nacionalismo como henchimiento de la limitación, el nacionalismo abierto y futuro, basado en los talantes de convivencia, todos ellos son temas que fueron examinados en los escritos de Ortega de los primeros años. Ahora se trata de interpretarlos en estos textos de los años cuarenta. Con ellos se llegará al final tanto de la recepción de Hegel por Ortega, como de la estética política de la limitación. El recorrido se muestra guiado por el mismo hilo conductor desde el comienzo: la salvación de los españoles por la estética, que aparecía en aquella carta a Rosa Spottorno en 1907613 , llega hasta el final del proceso en la forma de la estética de la limitación. La conjunción de estética y política en la estética de la limitación aparece, así, como el hilo conductor que recorre desde el inicio hasta el final el pensamiento de Ortega en la interpretación que se viene llevando a cabo.

\footnotetext{
613 "Nuestra salvación tiene que estar en una fórmula cultural que sea a un tiempo política y asimismo que sea estética". Cartas de un joven español (1891-1908). Madrid: El Arquero, 1991 (Ed. Soledad Ortega), carta 181, p. 570.
} 


\subsection{La Meditación de Europa desde La rebelión de las masas}

De Europa meditatio quaedam es la conferencia que Ortega pronunció en Berlín en 1949. El texto fue revisado y ampliado a partir de esa fecha, con el propósito de llegar a formar un libro que debería ser publicado inmediatamente en Alemania. Pero Ortega no acabo su redacción y el manuscrito apareció inconcluso entre sus papeles inéditos. Ese manuscrito es el que fue editado como Meditación de Europa. El objetivo que dirige el texto es mostrar el anacronismo de la idea de nacionalidad como integradora de las sociedades europeas del momento, anacronismo que choca, precisamente, con la fértil idea de convivencia y sentimiento aglutinante que había guiado a los pueblos europeos en épocas pasadas.

Partes y temas del texto fueron utilizados en los años que rodean a su redacción: en el ciclo de lecciones de Munich en el 51 titulado "Die Idee der Nation und die deutsche Jugend", en las conferencias también en Munich dos años más tarde "Gibt es ein europäisches Kulturbewusstsein?" y "De nación a provincia de Europa", en la última intervención en público, la conferencia ofrecida en Venecia en 1955 titulada "Il Medio Evo e l'Idea di Nazione", etc. Si las ideas que forman la Meditación de Europa ya no dejarían de ser utilizadas y matizadas por Ortega hasta sus años finales, la procedencia de esas ideas tiene un referente inequívoco: los dos textos que acompañaron en los años treinta a $L a$ rebelión de las masas, el 'Prólogo para franceses" del año 37 y el 'Epílogo para ingleses", del 38, con el artículo que lo completa, "En cuanto al pacifismo...", escrito en el año anterior.

A partir de La rebelión de las masas, después del éxito obtenido por el libro a todos los niveles, Ortega pensó continuamente en la actualización de las ideas que en él había presentado, con el contexto de las dos guerras en el fondo, la española y la segunda mundial europea. El prólogo y el epílogo fueron una primera muestra de esa intención, pensar los cambios ocurridos desde la publicación del libro hasta los años 37 y 38, en plena guerra española y a punto de comenzar la europea. En junio del año 51, durante su estancia en Inglaterra para recibir la investidura de Doctor en la Universidad de Glasgow, fue instado Ortega a dar una conferencia sobre el libro y vuelve a examinar la actualidad de La rebelión 
de las masas 614 . Pero, en lo que concierne de modo explícito al tema de Europa y la idea de nación, únicamente en la Meditación de Europa, incluidos los textos que la rodean, presentó Ortega su interpretación de la situación actual, los años posteriores a la guerra mundial.

El prólogo y el epílogo a La rebelión de las masas mostraban el significado en 1937 de las ideas expuestas por Ortega años antes en la propia obra, la idea de la supernación europea, los Estados Unidos de Europa que, en la conjunción de unidad y pluralidad, reunirían la convivencia europea con las diferenciaciones nacionales y volverían a dinamizar el continente: "Sólo la decisión de construir una gran nación con el grupo de los pueblos continentales volvería a entonar la pulsación de Europa"615. La Meditación de Europa, por su parte, es el intento de explicar y aplicar esta idea, de mostrar su sentido, después de la segunda guerra mundial. La situación ya no es la del final de los años treinta, sino la del de los cuarenta, con Europa en plena postguerra.

Por todo ello, la Meditación de Europa debe leerse teniendo muy presente el prólogo y el epílogo a La rebelión de las masas. Ortega citará párrafos y páginas completos del "Prólogo para franceses" y de "En cuanto al pacifismo..."616, y en las notas de trabajo aparece de un modo explícito esa unión: "Berlín. De Europa meditatio quaedam. Con el prefacio y el epílogo"617. Ese prefacio y ese epílogo remiten a los escritos para La rebelión de las masas. De lo que se trata ahora es de mostrar la presencia de Hegel en este contexto, así como la situación a la que llega la dialéctica entre límites y limitaciones en el contorno del tema de la nación y el nacionalismo.

La tesis de Ortega sobre Europa y sus naciones mantuvo constante el mismo hilo conductor: la afirmación de una unidad europea sostenida por la dinamicidad que produce

\footnotetext{
${ }^{614}$ Es el segundo apéndice incluido por Garagorri en su edición de la obra: "Sobre la rebelión de las masas", en: ORTEGA Y GASSET, J. La rebelión de las masas. Madrid: Revista de Occidente en Alianza Obras de José Ortega y Gasset, 2-, 1994¹1, p. 281.

615 La rebelión de las masas (1930). OC IV, 160.

616 Las páginas concretas que transcribe Ortega, con ligeras modificaciones, son: desde La rebelión de las masas. Prólogo para franceses (1937). OC IV, 116-118, hasta: Meditación de Europa (1949). OC IX, 255257; y desde: La rebelión de las masas. Epílogo para ingleses - En cuanto al pacifismo... (1937-1938). OC IV, 297-309, hasta: Meditación de Europa (1949). OC IX, 304-313.
}

617Archivo de la "Fundación José Ortega y Gasset", Carpetilla "Nación, Europa, etc.". 
la relación entre las diferencias, entre las naciones, la "fertil variedad de situaciones" 618 , la pluralidad continental. Si en el prólogo y el epílogo a La Rebelión de las masas se trataba de justificar esa idea en los preámbulos de la segunda guerra mundial, defendiendo y aclarando lo expuesto en los capítulos finales de la obra, cuando podría parecer que esa idea habría dejado de mantener su sentido, en la Meditación de Europa, en el contexto de la postguerra, Ortega continuará mostrando, quizá de un modo más radical que en los textos de los años treinta, la vigencia de su idea. La diferencia consistirá en que en la Meditación de Europa el tema adquirirá una mayor ampliación y concreción, centrado en la idea de nación y el problema del nacionalismo. Pero la tesis general permanecerá, y lo hará no sólo sin entrar en contradición con los propios hechos históricos, sino precisamente apoyada en ellos.

La sociedad europea, como convivencia entre las naciones, habría precedido a la particularización de los propios pueblos. Las naciones europeas presentan homogeneidad y unificación en sus vigencias, en sus costumbres, en sus modos de ver el mundo, y cada principio uniforme hace fertilizar la diversificación. Se trata de una dialéctica de homogeneidad y diversidad. La conciencia europea de sociedad global se ha mantenido siempre, aunque sea de un modo más leve que las distintas conciencias nacionales. Para los pueblos europeos, vivir ha sido siempre la actuación en un espacio común, vivir era convivir con los demás, aunque la convivencia tomara unas veces el aspecto pacífico y otras el combativo. Europa es un espacio histórico de convivencia, una sociedad: "Los pueblos europeos son desde hace mucho tiempo una sociedad, una colectividad, en el mismo sentido que tienen estas palabras aplicadas a cada una de las naciones que integran aquélla. Esa sociedad manifiesta todos los atributos de tal: hay costumbres europeas, usos europeos, opinión pública europea, derecho europeo, poder público europeo"619.

Esos caracteres unificadores muestran un poder público, un equilibrio europeo, que no tiene la forma solidificada de Estado, sino que parte de la dialéctica entre una homogeneidad de vigencias y una pluralidad de particularidades, las naciones. La fantasía, y Ortega lo afirma ya en el 37, no es la unidad europea, sino la "creencia de que Francia,

${ }^{618}$ La rebelión de las masas. Prólogo para franceses (1937). OC IV, 130.

619 Ibid. 118. El mismo se texto se encuentra en Meditación de Europa (1949). OC IX, 257. 
Alemania, Italia o España son realidades sustantivas e independientes"620. Europa es el equilibrio entre sus particularidades, la unidad dinámica que se sostiene sobre la existencia de una pluralidad, "en vez de imaginarnos las naciones europeas como una serie de sociedades exentas, imaginemos una sociedad única -Europa-, dentro de la cual se han producido grumos o núcleos de condensación más intensa"621.

Europa ha sido siempre un ámbito social unitario, en el que, como en toda sociedad, rigen determinadas vigencias colectivas, determinados principios comunes que definen un modo concreto de ver el mundo, "Europa ha sido siempre un ámbito social unitario, sin fronteras absolutas ni discontinuidades, porque nunca ha faltado ese fondo o tesoro de «vigencias colectivas»'622. El problema surge cuando el índice de socialización varía, cuando los principios dejan de tener vigencia, cuando los vínculos de socialización que mantenían unida esa sociedad o convivencia europea desaparecen como tales. Entonces ya no hay unidad de particularidades, sino particularidades luchando por su diferenciación, diversidad sin el principio homogéneo de integración.

Llega un momento en que Europa se desocializa, en que pierde las instancias comunes que rigen la convivencia. "Europa está hoy desocializada", y esto puede afirmarlo Ortega en el 37 y en el 49623, faltan los principios de convivencia, las vigencias colectivas, el auténtico poder social anónimo independiente de todo grupo o individuo determinado. La guerra ha comenzado en realidad antes de iniciarse, "la pura verdad es que, desde hace años, Europa se halla en estado de guerra, en un estado de guerra sustancialmente más radical que todo su pasado'624. En la transcripción de ese texto en el año 49, Ortega añade: "Yo decía esto en 1937'625. Aparecen los nacionalismos, los totalitarismos, las luchas entre pueblos continuando las luchas en el interior de cada nación. Los principios colectivos europeos conferían cohesión interna a la unidad, pero también a cada nación, a cada

${ }^{620}$ La rebelión de las masas. Prólogo para franceses (1937). OC IV, 120.

${ }^{621}$ La rebelión de las masas. Epílogo para ingleses - En cuanto al pacifismo... (1937-1938). OC IV, 296.

622Ibid. p. 297

${ }^{623}$ La rebelión de las masas. Epílogo para ingleses - En cuanto al pacifismo... (1937-1938). OC IV, 299; Meditación de Europa (1949). OC IX, 306.

${ }^{624}$ La rebelión de las masas. Epílogo para ingleses - En cuanto al pacifismo... (1937-1938). OC IV, 299

625 Meditación de Europa (1949). OC IX, 306. 
particularidad. Al desaparecer esas vigencias sociales desaparece la cohesión unitaria y la particular. Surge primero el distanciamiento entre los pueblos, luego la agresión. 


\subsection{Mobilis in mobile}

En el año 49, hablando en Munich, ante el pueblo derrotado, Ortega no dejará de insistir en el aspecto que explica los problemas europeos: la ausencia de principios colectivos dessocializó Europa, la dividió en particularidades inconexas. Naciones que antes habían mantenido la unidad y particularidad concedida por la vigencia común, en un momento dado dejan de tener principios por los que regirse. Desapareció el dinamismo que confería la relación entre unidad y pluralidad. La guerra sería en parte consecuencia de esa situación. Después de ella, la creación de principios nuevos, de vigencias colectivas adecuadas a los tiempos y que vuelvan a integrar las diferentes nacionalidades europeas, se muestra como la primera condición de subsistencia. Ha desaparecido una Europa, hay que hacer otra, y para ello debe partirse del carácter de sociedad europea que siempre ha permanecido, con nuevos principios adecuados a la movilidad de los tiempos.

Nueva Europa con nuevos principios colectivos que integren las particularidades, ése era el objetivo de Ortega, y llevarlo a cabo sin olvidar que esa figura, "Europa", ya existe, no es únicamente un futuro utópico. Se aprovecha el carácter de convivencia, de unidad, que siempre ha subsistido, que ha mantenido a las naciones europeas integradas sin desvirtuar su carácter diferencial, pero con nuevos principios aglutinantes 626 . No se puede admitir la inmutabilidad, la permanencia, la eternidad de las vigencias: las derrotas y las ruinas deben ser aprovechadas, el reverso de la ruina es el rejuvenecimiento.

El hombre y la realidad son móviles, dinámicos, son históricos, y por ello lo es toda sociedad: "Nosotros ponemos la proa hacia una cultura, la única adecuada a un ente como el hombre, que en medio de un mundo en constante movimiento es él mismo móvil. Sea nuestro lema: Mobilis in mobile'627. Esa movilidad es la de la realidad histórica, la del hombre, la de la vida, la de la sociedad. Es también la movilidad, el dinamismo que integra la pluralidad de los diversos pueblos europeos en la unidad de una convivencia, de unos principios y costumbres que han sido siempre comunes.

\footnotetext{
626"Es, pues, un estricto error pensar que Europa es una figura utópica que acaso en el futuro se logre realizar. No; Europa no es sólo ni tanto futuro como algo que está ahí ya desde un remoto pasado; más aún, que existe con anterioridad a las naciones hoy tan claramente perfiladas. Lo que sí será preciso es dar a esa realidad tan vetusta una nueva forma". Meditación de Europa (1949). OC IX, 258.
} 
En las notas de rabajo, escribe Ortega: "Hegel y Europa. Ver en su Philosophie des Rechts como interpreta la efectiva participación de las naciones en una vida europea"628. Por las propias notas, y sabiendo que el referente explícito en este momento, en lo que remite al acopio de textos e ideas, es Meinecke, se puede afirmar que el texto de la Filosofía del derecho que Ortega tiene en mente es el agregado al parágrafo 339. Allí escribía Hegel: "Die europäischen Nationen bilden eine Familie nach dem allgemeinen Prinzipe ihrer Gesetzgebung, ihrer Sitten, ihrer Bildung'629. Pero esa "familia" europea no se sostiene únicamente por caracteres de semejanza. Criticando a Hegel y al propio Meinecke escribe Ortega en sus notas: "Hay que atacar la idea de Hegel, Ranke y Meinecke según la cual hay - selbstverständlich- una "europäische Gemeinschachtlichkeit" - pero que consiste sólo en semejanza - also für einem Driten, der Beobachter"630. No se trata únicamente de una conexión de vida por simple vecindad u originario parentesco entre las naciones europeas 631 , sino de la homogeneidad que supone la convivencia bajo una serie de principios y vigencias comunes. No se trata únicamente de compartir un espacio territorial, sino de que ese espacio es espacio de vigencias comunes, de un modo único de enfrentarse al mundo.

El dinamismo se produce por la dialéctica de homogeneidad y diversidad de las particularidades. Es un dinamismo de los pueblos, pero también de las vigencias colectivas.

${ }^{627}$ Meditación de Europa (1949). OC IX, 255.

628 Archivo de la "Fundación José Ortega y Gasset", Carpetilla "Volkgeist, Meinecke, etc".

629 Ortega toma la idea directamente de Meinecke. La edición castellana traduce: "Por el principio general de su legislación, sus costumbres, su cultura, las naciones europeas componen una familia". HEGEL, Principios de la filosofía del derecho. Trad. J.L. Vernal. Barcelona: Edhasa, 1988, p. 419. El texto completo de Meinecke donde aparece esa referencia a Hegel, texto subrayado por Ortega con dos líneas rojas al margen de su ejemplar, es el siguiente: "Wohl wusste und betonte er zugleich, dass es insbesondere unter den europäischen Nationen eine familienhafte Gemeinschaft gäbe, die auch auf ihr völkerrechtliches Verhältnis untereinander einwirke und ihren reinen, rücksichtslosen Interessenkampf mildere. Aber diese Milderung der Machtkämpfe bedeutet, so müssen wir ihn verstehen, keine Fesselung der autonomen Machtpolitik der einzelnen Staatspersönlichkeiten, sie ist vielmehr eine ungezwungene Folge der europäischen Kulturgemeinschaft, des «allgemeinen Prinzips ihrer Gesetzgebung, ihrer Sitten, ihrer Bildung»". MEI NECKE, F. Weltbürgertum und Nationalstaat. Op. cit. p. 282.

${ }^{630}$ Archivo de la "Fundación José Ortega y Gasset", Carpetilla "Nación, Europa, etc".

${ }^{631} \mathrm{El}$ texto de Meinecke, sobre Ranke y Hegel, que Ortega comenta con esa nota (el texto se encuentra subrayado con tres gruesas líneas al margen, acompañadas de una gran interrogación), dice: "Ranke wusste, wie Hegel, sehr wohl, dass es auch im Leben der Staaten untereinander eine «europäische Gemeinschaftlichkeit» gab, die aber das natürliche Ergebnis ursprünglicher Verwandtschaft und nachbarlichen Zusammenlebens war". MEINECKE, F. Weltbürgertum und Nationalstaat. Op. cit. p. 306. 
El problema surgió cuando la movilidad de los pueblos, de sus intereses y contactos, de su vida, no se vio acompañada por la movilidad de los principios colectivos. De hecho, ésta es la tesis que subyace a En cuanto al pacifismo... El pacifismo inglés habría fracasado porque partía de una idea demasiado simple, creer que la guerra provenía de las pasiones humanas y que era posible desterrarla sin más. Para Ortega, la guerra es un modo de solucionar conflictos entre los hombres que, para ser evitado, exige tener otro modo que lleve a cabo la misma misión. El pacifismo debería haber sido sustituido por una una nueva técnica jurídica, por un derecho internacional que regulara las relaciones entre los pueblos. Pero ese derecho no existía, no estaba listo para enfrentarse a la nueva situación.

El fracaso de la Sociedad de Naciones para Ortega se basó en que carecía, por el hecho de que éste no existía, de un derecho objetivo que regulara la convivencia entre los pueblos 632 . La realidad y la historia son móviles, pero el derecho es estático: "El hombre necesita un derecho dinámico, un derecho plástico y en movimiento, capaz de acompañar a la historia en sus metamorfosis"633, y para que exista ese derecho es necesario que antes se dé una sociedad. No hay derecho en un vacío social. Por ello la insistencia de Ortega en la necesidad de una sociedad europea, basada en todo su fondo histórico, de pasado, pero sostenida por caracteres de empresa, de futuro.

Esa crítica al derecho estático, y con ella a todo inmovilidad, ya la había visto Ortega en Hegel, y la había utilizado precisamente contra la filosofía de Hegel. Era la crítica de Ortega a la definitividad, al carácter concluso, estático, de cualquier marco. En el parágrafo 216 de la Filosofía del derecho había visto la versión de Hegel: "Der Umfang der Gesetze soll einerseits ein fertiges, geschlossenes Ganzes sein, andererseits ist er das fortgehende Bedürfnis neuer gesetzlicher Bestimmungen"634. Ortega no lo aplica únicamente a la

\footnotetext{
632"La Sociedad de Naciones fue un gigantesco aparato jurídico creado para un derecho inexistente. Su vacío de justicia se llenó fraudulentamente con la sempiterna diplomacia, que al disfrazarse de derecho contribuyó a la universal desmoralización". La rebelión de las masas. Epílogo para ingleses - En cuanto al pacifismo... (1937-1938). OC IV, 291.

633Ibid. p. 293.

${ }^{634}$ HEGEL, Grundlinien der Philosophie des Rechts. Hrsg. G. Lasson. Leipzig: Meiner, 1928, § 216, p. 175. Traducción: "El ámbito de las leyes debe ser por una parte una totalidad cerrada y terminada, mientras que por otra es la continua necesidad de nuevas determinaciones legales". HEGEL, Principios de la filosofía del derecho. Op. cit. p. 289.
} 
necesaria reforma particular de los códigos, sino al marco general de la movilidad de la realidad histórica, del dinamismo de hombre, vida y sociedad.

La situación en su conjunto se sostiene sobre unos caracteres de movimiento, de dinamicidad, que afectan a todos los contextos: el dinamismo de la realidad histórica, del hombre y la vida, el dinamismo de la dialéctica entre la homogeneidad y la diversidad de las naciones europeas 635 , la necesaria dinamización del derecho, el dinamismo que debe definir el proyecto de futuro de todo pueblo, de toda nación. Ese carácter dinámico y dialéctico se define por su actividad. La dinamicidad es sobre todo actividad, el dinamismo de algo que es proyecto, que hay que hacer: la realidad histórica se presenta con un rasgo esencial, "el de ser una realidad que hay que hacer, que es obra humana, no proceso de la naturaleza"636, por lo que "la nación no nace, sino que se hace"637. Se trata de la constante dialéctica entre pasado y futuro, entre la tradición y la agilidad, la dialéctica entre el ser inercial, receptivo, tradicional y el ser "ágil, emprendedor, afrontador de problemas" 638 .

Es la definición del hombre como ser ágil, que refiere a la reine Agilität de Fichte y a la Vis activa de Leibniz ${ }^{639}$, pero también a Hegel. Lo vimos más arriba en aquella definición de las notas de trabajo, la conciencia como agilidad e inquietud: "La conciencia es agilidad, por tanto, inquietud. [...] El ser ágil - frente al ser inerte"640. Vuelve a aparecer ahora, en

\footnotetext{
635En una de las notas de trabajo escribe Ortega: "Europa y naciones. Una de las perspectivas más fértiles bajo las que debiera escribirse la historia de Occidente fuera la de una lucha entre la sociedad europea y las sociedades nacionales. Unas veces puede más aquélla, otras éstas. Es el dinamismo natural de algo que consiste a la vez en ser unidad y pluralidad". Archivo de la "Fundación José Ortega y Gasset", Carpetilla "Volkgeist, Meinecke, etc". La nota fue utilizada por Ortega, por ejemplo, para su prólogo al libro de Haller. Así, el texto definitivo de esa nota en un escrito publicado es el siguiente: "La historia europea no ha consistido sólo en las luchas de unos pueblos occidentales con otros, sino que además ha habido una lucha, llena de vicisitudes, entre unas o varias o todas la naciones europeas y Europa en cuanto unidad indiferenciada y envolvente. A veces es la pluralidad de las naciones quien predomina sobre su unidad subterránea; otras es, por el contrario, la unidad europea quien somete a muy acusada homogeneidad las figuras divergentes de aquéllas". "La sociedad europea. Prólogo a: J. Haller, "Las épocas de la historia alemana»" (1941). OC IX, 324.

636" La sociedad europea. Prólogo a: J. Haller, «Las épocas de la historia alemana»" (1941). OC IX, 321. 637 Ibid.

638 Meditación de Europa (1949). OC IX, 278.

${ }^{639}$ Cfr. Meditación de Europa (1949). OC IX, 278-279 n.

${ }^{640}$ Archivo de la "Fundación José Ortega y Gasset", Carpetilla "Hegel: filosofía de la historia". Conjunto de notas titulado "Detalles históricos".
} 
algo que Hegel no habría advertido y que sin embargo ya estaba implícito en su distinción entre nación y Estado. La nación es algo que existe, que está ahí; el Estado es voluntad, la autodeterminación del Espíritu en su búsqueda de la libertad, "porque no hay voluntad si no se es libre"641. Para Ortega la nación no nace, no sólo "está ahí", sino que es proyecto dinámico que hay que hacer. Al conjuntarse con el Estado como voluntad, con la movilidad del espíritu, Hegel ya habría propuesto esa dialéctica de inercialidad y agilidad.

La clave está en mostrar que inercialidad y agilidad no son dos aspectos separados, uno referido a la nación, otro al Estado, sino que ambos son momentos de la nación en su conjunción de proyecto de futuro y recepción de una tradición: "Sin embargo, hay una nota muy fina y honda en esta distinción: la nación [...] es algo que existe, el Estado es voluntad. No advierte [Hegel] que ambos son momentos de la nación: su inercialidad y su agilidad'642. La conexión de inercialidad y agilidad afecta a todos los contextos. Es el carácter de mobilis in mobile que define la realidad histórica. El dinamismo dialéctico de las particularidades, las naciones, en el marco común de la sociedad europea, procede de la necesidad de un proyecto de futuro, un proyecto integrador y móvil que diferencie modos, pero aglutine objetivos. La inercialidad y agilidad no afecta únicamente a las naciones, sino también al conjunto de Europa: la inercialidad de su tradición, de su pasado común como sociedad homogénea, y la agilidad concedida por el carácter dialéctico de las relaciones entre sus distintos pueblos.

Son los mismos caracteres de convivencia y continuidad de fragmentos que aparecían en el contexto general de la dialéctica. La crítica a Hegel será la misma. Si en la dialéctica no podía admitirse ningún final o definitividad del movimiento, ahora, la explicación de la separación que Hegel efectúa entre Estado y nación, entre inercialidad y agilidad, responde a las mismas causas: "la razón de separarlos en Hegel es que con la voluntad los hombres de un país aspiran a que su Estado sea el Estado ideal - es decir, a que su pueblo o su "nación" participe en valores trascendentes a la historia, universales, absolutos" 643 , pero esos valores transhistóricos, universales y absolutos no existen. La dinámica dialéctica entre los distintos pueblos europeos, apoyada en un proyecto común de futuro, que debe ser

641"En el centenario de Hegel" (1931). OC V, 426.

${ }^{642}$ Archivo de la "Fundación José Ortega y Gasset", Carpetilla "Volkgeist, Meinecke, etc". 
creado, hecho, imposibilita esa trascendencia de la aspiración. Las naciones europeas no tienden a la idealización de valores trascendentes a la historia, sino a la convivencia y pluralidad de las particularidades.

El carácter dinámico, de mobilis in mobile, es causa y consecuencia de la misma idea: "una nación no puede ser nunca una sola. Al estricto y no vagoroso concepto de nación pertenece ineludiblemente la pluralidad"644. El carácter "vagoroso" es el de ese Estado que aspira a Estado ideal645, a mantenerse único en su diferenciación, sin definir ésta mediante el carácter homogéneo y unitario de la serie de principios y proyectos comunes que comparte con otras naciones. Únicamente olvidando este sentido surge el nacionalismo como problema, el nacionalismo no futuro, no de proyecto, sino el nacionalismo agresivo. El nacionalismo olvida que una nación no puede ser nunca sola, pero también que la base previa conjuntiva es la dinamicidad de las relaciones entre particularidades.

${ }^{643}$ Archivo de la "Fundación José Ortega y Gasset", Carpetilla "Volkgeist, Meinecke, etc".

644 Meditación de Europa (1949). OC IX, 262.

645 Divinización insensata por parte de Hegel, así llamaba Ortega en los años cuarenta a esta idealización del Estado: "Hegel [...] lo diviniza [al Estado] como un misticismo insensato". Del Imperio Romano (1940). OC VI, 74. 


\subsection{Ortega versus Meinecke: el fondo ultranacional}

El manuscrito publicado de la Meditación de Europa concluye con uno de los párrafos transcritos de En cuanto al pacifismo... La reanudación y conclusión propias de la Meditación no han sido halladas entre los inéditos de Ortega. El texto culmina criticando la injerencia de las opiniones de unas naciones sobre otras (en el contexto del Epílogo para ingleses, las opiniones, infundadas, según Ortega, sobre la guerra española), y postulando la necesaria regulación de las relaciones entre las naciones a través de la "formidable dictadura de las buenas maneras". El párrafo final es el siguiente:

"Esto [la regulación de la opinión de un pueblo sobre otro] supone estar de acuerdo sobre un principio básico. Sobre éste: que los pueblos, que las naciones existen. Ahora bien: el viejo y barato «internacionalismo», que ha engendrado las presentes angustias, pensaba, en el fondo, lo contrario.

Ninguna de sus doctrinas y actuaciones es comprensible si no se descubre en su raíz el desconocimiento de lo que es una nación y de que eso que son las naciones constituye una formidable realidad situada en el mundo y con que hay que contar. Era un curioso internacionalismo aquel que en sus cuentas olvidaba siempre el detalle de que hay naciones" 646 .

Las críticas de Ortega al internacionalismo regulan su interpretación del nacionalismo y la teoría del cosmopolitismo. Tienen una intención muy determinada: negar la postulación de un Europa como inter-nación, y afirmar su carácter como ultra-nación. Europa como ultranación en ningún momento se enfrentará al carácter particular y propio de cada diferencia nacional. Las diferencias, las limitaciones, las naciones existen en la forma de una intimidad, de un sistema de secretos: "un pueblo es, como una persona, aunque de otro modo y por otras razones, una intimidad - por tanto, un sistema de secretos que no puede ser descubierto, sin más desde fuera"647. No se trata de la eliminar ese carácter diferencial, entre otras cosas porque no se puede, porque las diferencias nacionales permanecerán e intentar anularlas supondría el nacimiento de nacionalismos agresivos, "sino de integrarlas, dejando al Occidente todo su rico relieve"648.

${ }^{646}$ La rebelión de las masas. Epílogo para ingleses - En cuanto al pacifismo... (1937-1938). OC IV, 308309; Meditación de Europa (1949). OC IX, 313.

${ }^{647}$ La rebelión de las masas. Epílogo para ingleses - En cuanto al pacifismo... (1937-1938). OC IV, 308; Meditación de Europa (1949). OC IX, 312.

${ }^{648}$ La rebelión de las masas. Epílogo para ingleses - En cuanto al pacifismo... (1937-1938). OC IV, 309. 
La integración no sólo no elimina los caracteres diferenciales, sino que, además, permite ver la realidad completa de cada nación: "No se ha visto, pues, la realidad completa de una nación europea si se la ve como algo que concluye en sí mismo. No; cada una de estas naciones levanta su peculiar perfil, como una protuberancia orográfica, sobre un nivel de convivencia básica que es la realidad europea"649. Únicamente cuando el carácter limitador se integra con su función de límite y permite mostrar la situación en un conjunto, en un todo, en este caso Europa, es posible ver la realidad completa. Es la dinámica entre h unidad y la pluralidad la que permite definir los destinos de las naciones europeas. Europa como ultranación se inicia en esa unidad, superando el carácter de internación 650 . Supera el internacionalismo porque éste pasaba por alto las diferencias nacionales, las distintas particularidades, e implica un carácter de trascendencia que remite al conjunto, o, en la filosofía, al universo. Es la definición de Ultrar que ofrecía Ortega en las notas para Epílogo...: "Es el trascender por excelencia - el ir al universo"651. La filosofía como afán de universo conecta con esta ultranación que aglutina límites y limitaciones, homogeneidad y diferencia.

La conjunción entre la ultranación y la ultrafilosofía se sostiene sobre el dinamismo que los define. La ultranación subraya la dialéctica dinámica de unidad europea y diferencias nacionales, el dinamismo del proyecto de futuro, siempre indefinitivo, que confiera sentido a esa dialéctica de unidad y diferencia; la ultrafilosofía niega el carácter definitivo de toda filosofía, "está hecha de una atmósfera de jovialidad, alciónica, olímpica"652, y se sostiene sobre la continuidad dialéctica de sus aspectos, sobre la superación de la propia filosofía en su sentido excluyente al entenderla como un modo más de enfrentarse a los problemas que el mundo plantea: "Insinuar que la Filosofía no puede ser una definitiva posición del

649" La sociedad europea. Prólogo a: J. Haller, «Las épocas de la historia alemana»" (1941). OC IX, 321.

650 En el curso sobre la razón histórica de Buenos Aires, en 1940, presenta de nuevo Ortega el enfrentamiento: "Lo que hoy se está fraguando en el mundo es una nueva forma de colectividad, que no es ciertamente la «internación» o «internacionalidad», la cual no existe ni puede existir como colectividad [...], sino que se está fraguando una serie de «ultranaciones»". Sobre la razón histórica (Buenos Aires, 1940). OC XII, 221.

651 Notas de trabajo. Epílogo... Ed. J.L. Molinuevo. Madrid: Alianza/Fundación José Ortega y Gasset, 1994, p. 91, nota 91.

652Ibid. pp. 178-179, nota 254. 
hombre. Vistas hacia una ultrafilosofía"653. También la filosofía es un instrumento, un ensayo, una limitación que puede superarse algún día, y no sólo cada uno de los distintos sistemas, sino la filosofía en general654. El Ultrar como conjunción de filosofía y ultranación afirma particularidades y unidades, y niega cualquier tipo de definitividad, sea una nación, sea un sistema, sea la filosofía en general. Es la dialéctica del error que veíamos más arriba.

El significado dialéctico de los aspectos muestra la conjunción de límites y limitaciones. Las diferencias nacionales definen modos concretos de sensibilidad, de intimidad; no se trata de vivir la sensibilidad ajena, de intentar poseerla, sino de aceptarla como tal diferencia, aceptar las limitaciones. Es el nuevo sentido, en el contexto de la ultranación, de la frase de Goethe que constantemente cita Ortega, el "nur alle Menschen leben das Menschliche", con lo que se muestra la conexión con el tema de la perspectiva en el contexto de los primeros años de la filosofía de Ortega. En una de las notas de trabajo escribe:

"Todo pueblo mirado desde otro parece por lo pronto irritante. Y es que eso que llamamos un puebloes un ensayo de ser hombre dentro de unas limitaciones determinadas. Porque la vida no puede ser vivida en todas sus posibilidades. Existir es decidirse a ser de un cierto modo previa renuncia a ser de otros. Cada pueblo se embarca resueltamente en un sistema de renuncias para poder ser con cierta plenitud un reducido número de formas. El otro pueblo ve primero del nuestro sólo nuestros límites, que, claro está, no coinciden con los suyos y la idea de tener que vivir suscrito en esa figura geométrica que no es la nuestra nos enoja. Pero todo se arregla cuando advertimos que la cuestión no es ésa: que no se trata de que nosotros tengamos que vivir en la figura del otro sino, al contrario, en dejarle a él vivir y ser ese otro poliedro en que ha preferido instalarse. Nur alle Menschen leben das Menschliche" 655.

653 Ibid. pp. 338-339, nota 542.

${ }^{654}$ Esa insinuación que presenta Ortega en las notas para Epílogo... la hizo explícita en el Leibniz: "Se ha experimentado el instrumento «filosofía». En esa experimentación se han ido ensayando los modos diversos de hacer funcionar aquel instrumento. Cada nuevo ensayo aprovechaba los anteriores. Sobre todo, aprovechaba los errores, las limitaciones de los anteriores. Merced a esto cabe hablar de que la his toria de la Filosofía describe el progreso en el filosofar. Este progreso puede consistir, a la postre, en que otro buen día descubramos que no sólo este o el otro «modo de pensar» filosófico era limitado, y por tanto erróneo, sino que, en absoluto, el filosofar, todo filosofar, es una limitación, una insuficiencia, un error, y que es menester inaugurar otra manera de afrontar intelectualmente el Universo que no sea ni una de las anteriores a la filosofía, ni sea esta misma". La idea de principio en Leibniz y la evolución de la teoría deductiva (1947). OC VIII, 270.

655 Archivo de la "Fundación José Ortega y Gasset", Carpetilla "Volkgeist, Meinecke, etc". El referente de esta nota en los textos publicados, de un modo mucho más breve, se encuentra en el "Epílogo para ingleses". Allí escribía Ortega: "No hay pueblo que, mirado desde otro, no resulte insoportable. [...] Y es que las 
Pero si esto es así, si se trata de afirmar el talante de universalidad, de continuidad a partir de las diferencias y particularidades, ¿cómo aparece ahora Hegel, al que Ortega ha criticado por activa y por pasiva de estatismo y de germen de nacionalismo agresivo? Ortega cambia su perspectiva. Ya no se trata de ver a Hegel en el contexto de la divinización del Estado, o en el de la "perniciosa aproximación a Hegel" que afirmaba en Temas del Escorial, sino de mostrarlo viviendo la historia universal, negándole incluso los caracteres de nacionalismo: "Hegel no consigue ser nacionalista ni casi nacional. Hegel no puede vivir sólo Alemania: vive la historia universal"656. El contexto es el de la reunión de nacionalismo futuro, positivo, abierto, y cosmopolitismo, integrador de diferencias, que se encuentra en la base del Ortega de estos años. Es ese marco el que explica el carácter de ultranación como afán de proyecto para Europa.

El carácter de ultranación enfrentado al internacionalismo tiene una base explícita, en lo que concierne a la Meditación de Europa: los textos e ideas que Ortega tomó de Meinecke, textos e ideas que Ortega recibe de un modo determinado, sin ocultar tanto su valor como las críticas al propio Meinecke en su tesis general657. La idea que define esas críticas es explícita: "procede Meinecke cegado por la convicción de que la nacionalidad es la última y superior forma histórica de colectividad' 658 , es decir, Meinecke habría permitido ver a Ortega el fondo ultranacional que sustentaba la idea de Europa, pero él mismo no lo habría visto: "los árboles nacionales europeos no dejan ver el bosque Europa a este egregio, magistral historiador"659. Ortega toma los textos que transcribe Meinecke, pero su

virtudes de un pueblo, como las de un hombre, van montadas y, en cierta manera, consolidadas sobre sus defectos y limitaciones". La rebelión de las masas. Epílogo para ingleses - En cuanto al pacifismo... (19371938). OC IV, 283.

656Archivo de la "Fundación José Ortega y Gasset", Carpetilla "Volkgeist, Meinecke, etc".

${ }^{657} \mathrm{El}$ contacto de Ortega con Meinecke refiere explícitamente en este momento a Weltbürgertum und Nationalstaat. Su recepción la aclara en nota: "Como el libro de Meinecke es un guía insuperable, por sus datos a la vez abundantes y selectísimos, para seguir el proceso formativo de la conciencia nacional alemana en su última fase, me servirá de hilo conductor en torno al cual enrrollo mis propios juicios, que son muy diferentes a los de Meinecke". Meditación de Europa (1949). OC IX, 290 n.

658 Meditación de Europa (1949). OC IX, 298.

${ }^{659}$ Meditación de Europa (1949). OC IX, 299. En nota se disculpa Ortega por no conocer otras obras de Meinecke donde éste se separaría del fondo nacionalista: "Me apresuro a advertir que esta ceguera se manifiesta en el citado libro publicado en 1907. En cambio, su Staatsräson, que es de 1924, está, me parece, escrito con otra perspectiva. En la pag. 448 (Die Idee der Staatsräson, segunda edición, 1925) rechaza aquella ceguera nacional-ista. Seguramente en estudios publicados entre ambas fechas, pero que yo, pobre de mí, no conozco, se halla ya corregida aquella inicial oftalmía". Ibid. p. 299 n. 
intención es la de utilizarlos para sostener con bases históricas el fondo ultranacional europeo, en ningún caso defender el talante nacionalista de Meinecke.

Ortega utiliza textos e ideas de Müller, Humboldt, Stein, Gneisenau, Niebuhr, etc., donde éstos muestran el intento de sostener la nacionalidad alemana sobre el bloque histórico de Europa, con un fin explicativo muy distinto al de Meinecke. Para éste, esas ideas respondían a "ideas impolítico-universalistas, es decir, cosmopolitas, tipo siglo XVIII"660; para Ortega, sin embargo, son muestra de que la colectividad ultranacional europea ha sido defendida constantemente: ninguna nación europea ha podido desarrollarse de un modo pleno sin el "fondo ultra o supranacional, que era precisamente la realidad total europea'661. Un buen ejemplo es la distinta lectura de Humboldt que realizan Ortega y Meinecke (lectura basada en los mismos textos, los que cita el propio Meinecke).

La tesis de Humboldt, con sus propias palabras, sería: "Man muss auf keine Weise den wahren und eigentlichen Zweck des Bundes vergessen, insofern er mit der europäisches Politik zusammenhängt' 662 . Al margen de ese texto escribe Ortega en su ejemplar de la obra de Meinecke: "Fondo ultranacional, ¡Estupendo!" y en sus notas de lectura sobre el mismo texto: "Estupendo párrafo de Humboldt donde se ve que reconoce sólo ser posible y deseable un Bundestaat alemán en función del equilibrio europeo, es decir, de un fondo ultranacional"663. Comentando esas ideas de Humboldt escribe Meinecke el texto que Ortega traduce en su Meditación de Europa:

"Also auch er hat den grossen Gedanken der nationalen Autonomie für Deutschland, den er als einer der ersten zu begrifflicher Schärfe brachte, nicht konsequent festgehalten, auch er ist von dem Glauben nicht

\footnotetext{
660Ibid. p. 299. El texto concreto de Meinecke al que se refiere Ortega dice: "[...] Sein [de Humboldt] nationalpolitisches Ideal gedämpft wurde durch Ideen, die aus der weltbürgerlichen Bildung des 18 . Jahrhunderts stammten, durch jene Vorstellung von dem Berufe der Deutschen zur Kultur- und Menscheitsnation". MEINECKE, F. Weltbürgertum und Nationalstaat. Op. cit. p. 203. Al margen, escrito de puño y letra de Ortega en su ejemplar de la obra, puede leerse: "No: es conciencia realista de la necesidad de fondo ultranacional".

661 Meditación de Europa (1949). OC IX, 299.

662Citado en: MEINECKE, F. Weltbürgertum und Nationalstaat. Op. cit. p. 202. Traducción: "De ningún modo se puede olvidar la finalidad propia y verdadera de la federación, en tanto conecta con la política europea".

663Archivo de la "Fundación José Ortega y Gasset", Carpetilla "Meinecke - Cosmopolitismo y nacionalidad".
} 
ganz losgekommen, dass es übernationale Gemeinsamkeiten im Staatsleben gebe, auf die man politisch bauen, auf die man auch das Dasein der eigenen Nation mit gründen könne"664.

En las notas de lectura sobre ese texto escribe Ortega: "Ojo! Aquí parece que Meinecke ignora que la nación sólo puede ser y existir sobre un fondo nutricio y regulador de comunidad de naciones"665. Para Ortega, una nación no puede ser nunca sola, sus limitaciones implican siempre el carácter de límite, que remite al fondo ultranacional sobre el que se sostiene. La nacionalidad como "forma más perfecta de vida colectiva"666 es un anacronismo que carece de fertilidad, de proyecto de futuro: las naciones europeas únicamente evitarán la disgregación, la des-socialización que mantienen si se superan "a sí mismas como naciones'667, como únicamente naciones, y se las conduce a afirmar sus rasgos diferenciales en el fondo de una ultranacionalidad homogénea con un proyecto europeo de futuro. La creación continua de la nación, la continuidad en su proyecto de futuro, sólo tiene sentido si el proyecto conjunta los intereses de sus vecinas, si la nacionalidad abierta y progresiva se muestra yendo más allá de sí misma y, con ello, superando todo carácter nacionalista agresivo.

La conjunción de unidad europea y diferencialidad de sus naciones produce la dinamicidad que constituye los proyectos de futuro, del marco homogéneo, pero en sus diferentes aspectos, adecuándose a las distintas intimidades, a los distintos modos de ver el mundo. El paso de la nacionalidad al nacionalismo únicamente se produce cuando el talante nacional se convierte en programa político, cuando la conciencia de nacionalidad es extremada "para poder alcoholizar a las masas"668. Esa conciencia es previa, y existe siempre, la conciencia de la diferenciación y limitación propia, la conciencia de

664 MEINECKE, F. Weltbürgertum und Nationalstaat. Op. cit. p. 200. La traducción del propio Ortega dice: "Así, pues, tampoco él se atuvo de modo consecuente al gran pensamiento de una autonomía nacional para Alemania, que él fue uno de los primeros en exponer con agudeza conceptual; tampoco él pudo desprenderse totalmente de la creencia de que hay comunidades supranacionales en la vida del Estado sobre las cuales se puede construir políticamente, sobre las que se puede incluso fundar la existencia de la propia nación". Meditación de Europa (1949). OC IX, 299.

665Archivo de la "Fundación José Ortega y Gasset", Carpetilla "Meinecke - Cosmopolitismo y nacionalidad".

666 Meditación de Europa (1949). OC IX, 265.

667 Ibid.

668Ibid. p. 292. 
intimidad669. Cada nación es una intimidad propia, definida por sus limitaciones y secretos, difícil de conocer y de entender, como lo es cada persona, pero eso no significa que afirmar y defender tal intimidad implique la agresión, el nacionalismo agresivo. El talante íntimo, nacional, se sostiene sobre el proyecto global de ultranación y, con él, de humanismo y cosmopolitismo.

${ }^{669}$ La idea de la nación como intimidad tiene en Ortega unas bases históricas concretas, referentes a la noción clásica del Estado nacional como persona. En esas bases Ortega encuentra la ampliación de su propia teoría: desde el comienzo de su filosofía ha mostrado la definición de todo pueblo como intimidad, como repertorio de secretos. Ahora puede ampliar el sentido, en tanto no se trata únicamente de que la nación sea persona, sino de que es persona porque es intimidad. En uno de los apéndices añadidos por Garagorri a la Meditación escribe: "El Estado nacional es, en efecto, una persona porque es una intimidad". "Nacionalismoy cosmopolitismo", en: Europa y la idea de nación (y otros ensayos sobre los problemas del hombre contemporáneo). Madrid: Revista de Occidente en Alianza -Obras de José Ortega y Gasset, 26-, 1985, p. 117. Los procecentes históricos los encuentra Ortega en su lectura de Meinecke, por ejemplo en Adam Müller ("Er [der Staat] ist eine Person selbst", citado en: MEINECKE, F. Weltbürgertum und Nationalstaat. Op. cit. p. 149. El mismo aspecto aparece ya tratado en el manuscrito de la Meditación: Meditación de Europa (1949). OC IX, 304). El caso de Müller es especialmente importante para Ortega: "Este hombre que valía en su tiempo como un extremista del nacionalismo y que en estos últimos años era considerado como un precursor del hipernacionalismo, nos revela su percepción completamente diáfana de que la diferencia entre las naciones occidentales y las antiguas Ciudades-Estado estriba en que aquéllas no pueden existir sino referidas a un fondo común europeo". "Nacionalismo y cosmopolitismo". Op. cit. p. 119. Ortega puede afirmar esto al leer en Meinecke el siguiente texto de Müller (y el texto lo subraya Ortega con tres gruesas líneas en su ejemplar): "Der grosse Föderalismus europäischer Völker, welcher dereinst kommen wird, so wahr wir leben wird auch deutsche Farben tragen; denn alles Grosse, Gründliche und Ewige in allen europäischen Institutionen ist ja deutsch". Citado en: MEINECKE, F. Weltbürgertum und Nationalstaat. Op. cit. pp. 155156. A Ortega no le interesan esos "deutsche Farben", sino el federalismo de los pueblos europeos que le precede. 


\subsection{Fichte y el cosmopolitismo}

La conjunción de nacionalidad y cosmopolitismo es la conexión de limitación y límite, la afirmación de fronteras, pero de fronteras abiertas. Este es el programa que mantenía Ortega: su nacionalismo futuro es el del proyecto humanista y ultranacional, europeo, de futuro, con todos los caracteres de dinamismo y agilidad que presentan los dos marcos, el del proyecto, y el de la dialéctica unidad-diferencia. Es por ello por lo que, en este momento, el referente principal para Ortega es Fichte. Fichte habría sido el primero en sentir pasionalmente la nación alemana, y, sin embargo:

"El pueblo alemán -piensa Fichte- tiene que ser radicalmente, con frenesí, el pueblo alemán- pero lo característico de este pueblo es ser el «pueblo de la Humanidad». Nótese lo que esto significa. Fichte se siente hasta la médula patriota, «nacional». Pero su modo de sentirse nacional es el que yo llamaba «ser agilidad», esto es, ver su nación proyectada sobre el porvenir como el mejor programa de ser hombre que cabe, por tanto, por Humanismo, Universalismo o Cosmopolitismo. Hay que ser alemán porque ser alemán significa ser la Humanidad. Al revés, pues, que los hipernacionalismos recientes, que querían hacer alemana a la Humanidad"670.

Ortega, en este momento concreto de la Meditación de Europa, tiene en mente el sexto capítulo de la obra de Meinecke, "Fichte und die Idee des deutschen Nationalstaates", y sobre todo un texto de Fichte citado por Meinecke, con el comentario de éste (el texto de Fichte, sin el comentario de Meinecke, lo cita Ortega a pie de página en la Meditación):

"...Wird er Patriot, bleibt aber Kosmopolit, «indem der letzte Zweck aller Nationalbildung doch immer der ist, dass diese Bildung sich verbreite über das Geschlecht». Diese Nationalbildung ist also noch gar nichts Individuelles, ist noch keine Nationalbildung in geschichtlichem Sinne, sondern ist nichts mehr und nichts weniger als höchste menschliche Bildung überhaupt. Die deutsche Nation ist es allerdings gewesen, die die Kraft hatte, sie zu erzeugen" 671 .

En las notas de trabajo escribe Ortega sobre ese texto de Fichte que cita Meinecke: "El cosmopolitismo de Fichte en esta fecha consiste en que un pueblo extienda su modo de vida

670Meditación de Europa (1949). OC IX, 303.

671 MEINECKE, F. Weltbürgertum und Nationalstaat. Op. cit. pp. 98-99. Traducción: "Es patriota, pero también cosmopolita, «en tanto el fin último de toda cultura nacional es siempre que esta cultura se extienda por todo el género humano». Esta cultura nacional no es todavía algo individual, no es una cultura nacional en sentido histórico, sino nada más y nada menos que la más alta cultura humana en general. En todo caso, ha sido la nación alemana la que ha tenido la fuerza para crearla". 
por toda la humanidad"672. En la propia Meditación, sobre el mismo texto, dice: "Para mí esta «fórmula» de Fichte, exactamente entendida, es la más clara expresión vivida -y en este sentido, no teórica- de lo que en pura teoría intentan las páginas anteriores presentar como la definición formal de lo que es una nación"673. Una nación es, con Fichte y superando el talante nacionalista de Meinecke, una nitimidad que pretende extenderse por toda la humanidad, esto es, recorrer con su diferencia y limitación propia toda la humanidad, aceptando las diferencias ajenas y ampliándose (extendiéndose) con ellas.

La clave está en la nota de trabajo: lo que se extiende es un modo de vida, una intimidad, y la extensión no significa pretender que ese modo de vida o intimidad sea el que deba definir la humanidad entera, sino, al contrario, que se amplíe en sus contactos con el resto de modos de vida. Se trata de extender la diferencia, la limitación propia, por la ultranación homogénea, pero no pretender con ello que esa homogeneidad general sea la de la limitación propia. Por esto la insistencia de Ortega en defender el talante diferencial de cada nación, de cada intimidad, y por esto la afirmación de los caracteres de homogeneidad a partir de la agilidad que representa la presencia de un proyecto de futuro. Se trata de ampliar la limitación propia, pero hacerlo mediante el contacto con otras limitaciones.

De este modo conectan las teorías de Ortega en 1915 (el patriotismo como la fidelidad al paisaje propio, el henchimiento de la limitación como "la única manera de llegar más allá de nuestra limitación"674) con las de los años cuarenta: la nación es la intimidad diferencial más propia, que amplía su vista del mundo, su modo de vida, en el contacto dialéctico y dinámico con los del resto de la humanidad. Ortega definiéndose a sí mismo en las notas de trabajo para Epílogo... como "Philosoph aus dem Ganzen und zum Ganzen" debe entenderse también en este contexto: el todo que le interesa es el que reúne de un modo dialéctico e integrador el conjunto de las diferencias y particularidades. El todo, la ultranación, la homogeneidad, el cosmopolitismo, entendidos en su conjunto como rasgos globalizadores, parten siempre de la continuidad de las particularidades, de la necesaria conjunción de vistas y aspectos para vivir la vida entera. Este es el contacto indisoluble

672Archivo de la "Fundación José Ortega y Gasset", Carpetilla "Meinecke - Cosmopolitismo y nacionalidad".

${ }^{673}$ Meditación de Europa (1949). OC IX, 303, n. 
entre el tema de la dialéctica y el del cosmopolitismo. Es por ello por lo que no admitirá Ortega en ningún momento los caracteres globalizadores que no permitan las diferencias y la agilidad dinámica.

Un ejemplo de esto último es la crítica a las pretensiones de entender Europa unida mediante la religión. Las críticas a Novalis en este sentido son fuertes. En su ejemplar de La cristiandad o Europa, subraya Ortega: "Nur die Religion kann Europa wieder aufwecken"675. En el capítulo dedicado a Novalis y a Friedrich Schlegel, Meinecke expone la misma idea de Novalis676. Comentando esa idea escribe Ortega en sus notas de trabajo: "Ya en Novalis la monserga de si sólo la religión puede conciliar a los pueblos. La religión o cualquier otra creencia en común!"677. Ortega no puede aceptar esta tesis, porque supondría impedir la dialéctica de homogeneidad y diferencia de las naciones a partir del proyecto de futuro que supone el dinamismo de la ultranación. La crítica de Ortega se dirige a la pretensión de que únicamente sea la religión la que suponga la conciliación. Esa conciliación, la unidad entre las particularidades, se logrará mediante cualquier tipo de identidad de vigencias colectivas, de principios comunes.

No se trata únicamente de reconciliar a los pueblos, sino de mostrarlos como partes de un proyecto común en el que la homogeneidad viene sustentada por las conexiones entre las distintas limitaciones. La intimidad de cada nación es un modo único de ver el mundo, la unidad de las intimidades remite al proyecto común que las dinamiza. En ningún modo se trata de una simple reconciliación detenida, sea mediante la identidad religiosa o cualquier otra similiar.

La intimidad se entiende en el sentido de la nota vista más arriba, con la referencia al nur alle Menschen leben das Menschliche, de Goethe: dejar vivir los modos de vida ajemos, respetar las limitaciones que nos son extrañas, y utilizarlas para ampliar con ellas nuestra diferencialidad propia. El carácter de humanismo y cosmopolitismo concebido en este

674"Temas del Escorial" (1915), en: Notas de andar y ver. Viajes, gentes y países. Madrid: Revista de Occidente en Alianza -Obras de José Ortega y Gasset, 32-, 1988, p. 51.

675NOVALIS, Die Christenheit oder Europa. En: NOVALIS, Schriften, II. Hrsg. J. Minor. Jena: Eugen Diederichs, 1923, p. 43. Traducción: "Únicamente la religión puede despertar de nuevo a Europa".

676Cfr. MEINECKE, F. Weltbürgertum und Nationalstaat. Op. cit. p. 75.

${ }^{677}$ Archivo de la "Fundación José Ortega y Gasset", Carpetilla "Meinecke - Cosmopolitismo y nacionalidad". 
sentido, el sentido que parte de la afirmación de la limitación propia, permite entender la referencia a Hegel que atiende a su relación con la historia universal y pasa por alto el pretendido talante nacionalista: su nacionalismo era un nacionalismo por cosmopolitismo. Esto explica el interés de Ortega por ese nacionalismo alemán de comienzos de siglo.

No interesa el hecho de que sea alemán, sino de que se base exactamente en el carácter de cosmopolitismo, de nacionalismo por cosmopolitismo: "Sólo hacia 1810 se empieza a querer que haya naciones y empieza la idea nacionalista - el -ismo, signo de doctrina - Pero este nacionalismo de 1810, por ejemplo, alemán - (Novalis, Schlegel, Humboldt) no era nacionalista de Alemania sino de todas las naciones. Se quería que las naciones fuesen todas, no más la una que la extraña - porque se creía que la pluralidad divergente de modos de ser hombre era una inmensa riqueza para la humanidad. Es decir que se era nacionalista por humanismo y universalismo'678. Esta es la versión que interesa a Ortega, la riqueza de la divergencia en las distintas vistas para llegar a vivir el mayor número de vidas posible. Trasladado a su situación de postguerra, el marco queda definido a través de los caracteres de ultranación: la ultranación europea afirma las diferencias nacionales, pero se sostiene sobre el fondo común europeo, así como la extensión de éste en otros fondos, por ejemplo el contacto con América, en el que España representa un caso especial.

La dialéctica nación-humanidad, en su expresión de "nación para la humanidad", permite entender también el rasgo de la reine Agilität de Fichte aplicado al contexto hegeliano del carácter dinámico en el continuo dialéctico. La agilidad es tanto la del proyecto de futuro como la que proporciona la dialéctica en el contacto entre particularidad y homogeneidad. La superación de la interpretación de "patriotismo alemán" que lleva a cabo Meinecke en los textos de Fichte tiene para Ortega un carácter explícito: ese patriotismo se admite al tener claro que "previamente Germania se haya hecho Humanidad'679. Es el nacionalismo que es a la par cosmopolitismo y humanismo, el nacionalismo que se inicia en la superación de la nación desde sí misma, superación que la constituye como intimidad más propia: afirmación de la diferencia en su trascendencia de sí, afirmación de la limitación en el henchimiento a partir de su conversión en límite.

${ }^{678}$ Archivo de la "Fundación José Ortega y Gasset", Carpetilla "Volkgeist, Meinecke, etc".

679 Meditación de Europa (1949). OC IX, 303 n. 
La conexión de intimidad y humanismo contiene todos los rasgos abiertos y dinámicos de la dialéctica límite-limitación. Se trata de afirmar una limitación que es constantemente límite, que muestra a las naciones superándose a sí mismas y, con ello, constituyéndose en su forma más plena. La ultranación europeo es la misma que define el cosmopolitismo y el humanismo de Fichte, la que extiende la diferencia propia por toda la humanidad en su respeto por las ajenas, la que muestra a las naciones europeas en su fondo común, pero también saliendo de ese mismo fondo y remitiendo (y España, insisto, sería un caso extremo) por ejemplo a América. En este sentido, el Volksgeist entendido como intimidad, como sensibilidad propia, y partiendo de la superación de la limitación que supone, adquiriría caracteres positivos. La sensibilidad propia, la nación diferenciada y particular en su modo de vida intransferible, únicamente adquiere su propia identidad en la superación de sí misma, en su íntimo trascenderse: la nación únicamente tiene sentido en su relación con el fondo de cosmopolitismo. 


\subsection{Cosmopolitismo contra internacionalismo}

La ultranación es exactamente lo contrario al hipernacionalismo: ultranación es trascender, superar la nación propia y remitirla al fondo común. Los caracteres de cosmopolitismo permiten ver que Ortega tiene en mente el marco europeo, pero que no olvida la ampliación de Europa en general hacia el exterior. Sus propios viajes dan muestra de ello, su propio interés por América. Fichte siendo patriota y a la vez cosmopolita es el ejemplo para Ortega, y no sólo en lo que refiere a naciones, sino también a individuos o ideas. Es siempre el mismo fondo: partir de la limitación propia, respetar la limitación ajena, ampliar la limitación propia en la ajena (y viceversa) mediante el contacto que supone la conversión de limitación en límite.

El cosmopolitismo no afecta únicamente a las naciones, ni siquiera únicamente a espacios. El talante histórico de Ortega no se abandonará en ningún momento. El cosmopolitismo también refiere al pasado, al antepasado, a los pueblos pasados: "adjunto a este cosmopolitismo espacial ha alentado siempre un cosmopolitismo en el tiempo. No basta convivir con los hombres vivientes: se sentía el deseo de tratar a los antepasados. Lo mismo hoy'680. La historia es en sí misma es un conocimiento de los límites del hombre que posibilita su trascendencia 681 , del mismo modo que la nación debe trascenderse a sí misma para mostrar su realidad completa. El afán de universo en la conjunción de vistas, perspectivas, aspectos, sea en la dialéctica histórica, sea en la dialéctica filosófica, sea en la dialéctica de lo real, sea en la dialéctica del fondo ultranacional europeo, es siempre el que dirige la situación en la teoría de Ortega.

Por ello es tan importante el «sólo entre todos los hombres llega a ser vivido lo humano» de Goethe, que debe ser leído junto a la cultura "que se extiende por toda la humanidad" de Fichte. Es esta conexión de Goethe y Fichte la que está determinando la dialéctica de unidad y diferencia en Ortega, y esta dialéctica se aplica a todos los marcos. El cosmopolitismo va mucho más allá de referirse únicamente a naciones, el afán de universo

680"En el desierto, un león más" (1926). OC II, 513.

681" Prólogo a «Historia de la filosofía», de Émile Bréhier (Ideas para una historia de la filosofía)" (1942). OC VI, 388: "Conoce, pues, mediante el rodeo que es la historia, sus propios límites, y esta es la única manera otorgada al hombre de trascenderlos". 
como definición de la filosofía va mucho más allá de referirse únicamente a la filosofía. Es el talante globalizador en la integración y afirmación de diferencias, aplicado a todos los marcos, el que mantiene el hilo conductor. La conexión entre la dialéctica y el cosmopolistismo es determinante: la continuidad dialéctica de aspectos, de vistas, sólo puede entenderse de un modo coherente si se sitúa en conexión con la afirmación de la limitación propia, nacional, en el fondo común de la ultranación europea, y la ultranación europea en el fondo común de la humanidad, el fondo común cosmopolita.

En este sentido, la extensión de la Bildung nacional a través del fondo general de humanidad, de la cultura superando la limitación propia, expresada ahora con Fichte en los años cuarenta, era ya iniciada en años muy tempranos de la vida de Ortega. En 1906 escribía a Unamuno:

"España tiene que desaparecer como pueblo si ha de sobrevivir de alguna manera, cuya única manera es sobrevivir como cultura. [...] Sólo habrá cultura española cuando algunos españoles hagan cultura universal. [...] Toda cultura que lo es, lo es por su valor eterno. Creo que V. me entiende de sobra y me releva de explicar la diferencia entre cultura universal y cultura cosmopolita. Siendo primer supuesto de verdadera cultura la sinceridad, claro que toda cultura eterna y universal es a su vez cultura griega o española o alemana"682.

Los contextos han cambiado. El afán culturalista, la necesidad de cultura para España que definía en esos años tempranos la pretensión de Ortega, no es la misma que la extensión de la limitación propia por el todo de la humanidad que concreta las intenciones de los años cuarenta. Y, sin embargo, el talante cosmopolita permanecerá: España desapareciendo como pueblo y apareciendo como cultura, en el texto de 1906, llegará hasta los escritos de los años cuarenta en el modo de nación que debe trascenderse a sí misma, sin renunciar a su diferencia propia, en el fondo de la ultranación europea y de la humanidad en general. Los contextos son distintos, pero los modos muy similares. El cosmopolitismo de la cultura iniciado en esos primeros años, la cultura universal, llegará hasta su forma definida en los escritos de los cuarenta. En este sentido, puede decirse que el cosmopolitismo tiene una historia particular en la filosofía de Ortega.

En el año 23, en los años posteriores a la primera guerra mundial, ya anunciaba Ortega el nacimiento de un cosmopolitismo que, enfrentado al internacionalismo anterior, partía de

${ }^{682}$ Epistolario completo Ortega-Unamuno. Ed. L. Robles. Madrid: El Arquero, 1987, p. 58, carta VIII. 
la afirmación de las diferencias nacionales: "Antes de la guerra existía, en cambio, un internacionalismo verbal y de gesto, un cosmopolitismo abstracto, engañoso, que nacía previa anulación de las peculiaridades nacionales. Era el cosmopolitismo obrerista, bancario, del Hotel Ritz y sleepingcar. Tras él pervivían los pueblos en rigurosa incomunicación. El cosmopolitismo de hoy es mejor, y en vez de suponer un abandono de los genios y destinos étnicos, significa su reconocimiento y confrontación"683. Este cosmopolitismo presentado en el 23, que parte de la limitación propia, de la conjunción de limitaciones a través de la dialéctica límite-limitación, se mantendrá hasta el final en la teoría de Ortega.

$\mathrm{Al}$ año siguiente, en el 24, en un artículo con el título concreto de "Cosmopolitismo", presentará Ortega el siguiente momento en la historia del cosmopolitismo en su filosofía, un momento que en cierto modo será superado, el cosmopolitismo de las minorías intelectuales en su enfrentamiento con el internacionalismo verbal que ya mencionaba el año anterior: "En el paisaje de la postguerra se acusan entre otros, con creciente claridad, dos fenómenos que al ser enfrontados facilitan su recíproca definición. Uno de ellos es el internacionalismo representado por la Sociedad de las Naciones; otro es el cosmopolitismo de ciertas minorías intelectuales"684.

El internacionalismo habría favorecido todo tipo de nacionalismos, precisamente al tratar de eliminar las diferencias nacionales. Es el fracaso del internacionalismo político, que tendría su contrapunto en el cosmopolitismo intelectual. Los intelectuales, lo más selecto de cada pueblo, abandonan la dominación de la masa y se unen entre ellos. Esa unión coincide con la caída de los principios tradicionales de cultura, con la necesidad de crear otros nuevos que se adecúen a los tiempos. Si no hay principios unitarios de cultura no hay convivencia. El intelectual necesita rescindir su vinculación con las masas y dedicarse únicamente a crear esos principios. Su misión es precisamente de convivencia, aunque se inicie en la soledad; su misión no es mandar, dirigir, sino retirarse humilde a la construcción de principios de cultura, de modos de ver el mundo. Es esa misma misión creadora la que exige el cosmopolitismo intelectual: el "contacto con almas cargadas del mismo o superior potencial dinámico les sirve para confrontar su obra y sostener su

683" Propósitos. Prólogo al primer número de «Revista de Occidente»" (1923). OC VI, 314. 
tensión"685. Sin embargo, este cosmopolitismo intelectual que afirma ahora Ortega, en los años veinte, tendrá un contrapunto en los treinta, cuando el intelectual abandone en cierto sentido su misión explícita y se inmiscuya en las intimidades nacionales que no conoce.

El ejemplo es claro: las críticas de Ortega a Einstein por opinar sobre la guerra española. Esas críticas no deben entenderse en el sentido de apoyo o ataque a alguno de los bandos. Las críticas de Ortega obedecen a su teoría de la nación como intimidad, a la dificultad del extranjero para conocer la intimidad ajena. No hay que olvidar que la verdad del viajero es su error, tanto en sentido positivo como en el negativo. No se abandonará el cosmopolitismo intelectual, pero sí el cosmopolitismo del intelectual que en un momento dado deja de respetar las diferencias e intimidades ajenas.

En el año 26, Ortega continúa afirmando el carácter de homogeneidad, de "alma ecuménica" que supone el cosmopolitismo. Se trata de conocer las diferencias, conocerlas y respetarlas como tales, y, al hacerlo, convivir con ellas, dilatar el alma, como años más adelante afirmará, con Fichte, el ensanchamiento de la limitación propia por (causal y local) la humanidad en general: "El hombre posee un alma ecuménica. Su vida se dilata hasta los confines de lo habitado -es decir, de lo conocido. Cuando no hay cosmopolitismo, se sabe que existen otros hombres, otros pueblos, pero no se convive con ellos"686. Este será el cosmopolitismo que, en la filosofía de Ortega, llegue a explicarse en el fondo de la ultranación europea. Es la conjunción dialéctica de homogeneidad y diferencia que permite entender el interés de Ortega por acudir a las bases históricas donde surgió ese cosmopolitismo. La exposición concreta se halla en las dos páginas finales del "Epílogo para ingleses", al presentar su continuación en "En cuanto al pacifismo...".

Con esto, continuando la particular historia del concepto, en 1938 afirmará su defensa del cosmopolitismo que, iniciado en el enciclopedismo francés del XVIII llegará hasta el último tercio de siglo representando las tesis que particularmente interesan a Ortega: "El cosmopolitismo de Fergusson, Herder, Goethe es lo contrario del actual «internacionalismo». Se nutre, no de la exclusión de las diferencias nacionales, sino, al revés, de entusiasmo hacia ellas. Busca la pluralidad de formas vitales con vistas no a su

684" Cosmopolitismo" (1924). OC IV, 485.

$685_{\text {Ibid. p. } 490 .}$

686" En el desierto, un león más" (1926). OC II, 513. 
anulación, sino a su integración. Lema de él fueron estas palabras de Goethe: «Sólo todos los hombres viven lo humano»'687. La incomprensión de los pueblos europeos entre sí a finales de los años treinta debe superarse acudiendo a la base histórica de convivencia sobre la que se han sostenido siempre. El fenómeno de que unas naciones se conviertan en jueces de otras, de que el desprecio por la diferencia sea la norma al uso o de que la debilidad bélica o económica sea causa para, como poco, el desdén, es algo que no había ocurrido nunca en Europa.

La teoría de Ortega que surgirá del análisis de este fenómeno es la que viene siendo analizada, la que conjunta a Goethe y a Fichte en una extensión de la limitación propia por el fondo de la humanidad, la teoría de la ultranación europea que asuma las diferencias y juegue con la unidad del proyecto de futuro, la dialéctica de límite y limitación que permite ampliar la diferencia propia a partir de los contactos y la agilidad dinámica del proyecto de futuro.

Cuando Ortega, en la conferencia de la Sociedad Vascongada de Amigos del País, en el mismo año que la Meditación de Europa, muestre a Goethe representando el papel de llevar la vida de Alemania "más allá y más arriba de sí -a saber, a los vastos espacios de la gran comunidad occidental" y, con ello, conjuntando de modo explícito el apego a la tierra propia y la ampliación que supone la superación de sí misma, habrá concluido su teoría del cosmopolitismo: "Este movimiento goethiano cosmopolita, que es de signo opuesto, conste, a todo internacionalismo [...], que va del terruño hacia la más amplia unidad, que no abandona a aquél, sino que lo transporta hacia una forma superir de ser hombre"688. Cosmopolitismo de Fichte, que extiende la limitación propia por toda la humanidad; cosmopolitismo de Goethe, que muestra la conjunción de limitaciones al afirmar que únicamente entre todos los hombres es posible vivir lo humano: ambos se reúnen en Ortega a través de una dialéctica de diferencia e identidad que demarca el carácter de la ultranación europea.

Esa ultranación europea muestra a las naciones superándose a sí mismas en sus contactos, y muestra a la propia Europa superándose a sí misma en sus salidas hacia otros modos de vida. Es una dialéctica de limitación y límite en la que las fronteras entre las ${ }^{687}$ La rebelión de las masas. Epílogo para ingleses - En cuanto al pacifismo... (1937-1938). OC IV, 285. 
particularidades unifican sus dos momentos: son limitación concreta, determinada y diferencial, pero también límite flotante, margen indeciso, posibilidad de contacto. El cosmopolitismo y el humanismo, basados en la agilidad para aglutinar totalidad y diferencia, deben presentar una teoría de la frontera en la que el carácter equívoco de ésta coincida con los caracteres diferenciales del territorio que demarca.

688" Goethe y los amigos del país" (1949). OC IX, 611-612. 


\subsection{Fronteras políticas...}

La realidad completa de una nación sólo puede vislumbrarse si se concibe a ésta trascendiéndose a sí misma. Las naciones no concluyen en sí mismas. No son únicamente limitación restrictiva, intimidad cerrada, sino que amplían esa limitación superando el propio carácter limitador como tal. Esto no afecta únicamente a las naciones, sino a todo aquello que pueda ser considerado como limitación: individuos, cosas, aspectos... realidades. Las fronteras nacionales deben ser indecisas, equívocas, cuando esa indecisión no remite al marco geográfico, sino al modo de vida propio, a las limitaciones de la sensibilidad íntima en su salida hacia fuera de sí, en su dialéctica de diferencia y homogeneidad.

Las fronteras adquieren de este modo la conexión de política y estética que se ha venido presentando como estética política de la limitación: las limitaciones fronterizas son también los márgenes indecisos de las figuras que aparecen en los cuadros... en algunos cuadros. Ortega lo mostrará ahora en Velázquez, y no es casual que la época, alrededor de los años cuarenta, de los escritos sobre Velázquez y de los que rodean a la Meditación de Europa sea la misma: se trata de alcanzar dos objetivos, por un lado, reunir el tema de la frontera con la remisión explícita a España, por el otro, mostrar las fronteras abiertas que aparecen en la ultranación en su conexión con los límites imprecisos de determinadas figuras estéticas.

La frontera tendrá dos referencias: primero, el carácter equívoco e indeciso que la presenta como límite, y, segundo, la definición de España como cultura fronteriza, que conecta con Meditaciones del Quijote 689 y su contexto, así como con aspectos examinados en la sección inicial del trabajo (en el capítulo "Mediterranismo, cultura fronteriza y nacionalismo"), pero con todas las diferencias que supone el cambio de marco. Ahora la frontera remitirá a España como tierra de frontera, la cultura fronteriza de finis terrae: "Nuestra meditación sobre Velázquez y la pintura española de su tiempo nos obligará a definir en una dimensión muy concreta ese carácter que la vida española tiene de cultura

${ }^{689} \mathrm{MQ}$, 155: "La cultura salvaje, la cultura sin ayer, sin progresión, sin seguridad; la cultura en perpetua lucha con lo elemental, disputando todos los días la posesión del terreno que ocupan sus plantas. En suma, cultura fronteriza". 
fronteriza y de finis terrae"690. La conexión con Meditaciones y el tema del mediterranismo será fácil de mostrar, pero también será necesario presentar las diferencias. La cultura fronteriza que aparece ahora definiendo a España, en estos años cuarenta, responde a la teoría de la ultranación europea, a la relación explícita de España y Europa, pero entendiendo Europa a partir de los contextos presentados en la Meditación de Europa y la dialéctica de homogeneidad y diferencia, de afirmación de limitaciones propias y ensanchamiento de esa limitación en su extensión por el mundo.

Para entender la cultura fronteriza de los años cuarenta, y poder mostrar con ello tanto las conexiones como las diferencias con la que aparecía en Meditaciones del Quijote, es necesario tratar previamente el tema de la frontera como tal. El análisis tiene un objetivo expreso: mostrar cómo en Ortega coincide un tratamiento político o nacional de la frontera, que incluye en su examen la frontera restrictiva y llega hasta la frontera abierta de la ultranación, con un tratamiento estético, referido en concreto a la pintura, que parte de una demarcación concreta de límites y perfiles y culmina en la indecisión de las figuras que pinta Velázquez. El paralelismo entre ambas direcciones, la política y la estética, expresa una estética política de la frontera en la que ésta se presenta definida por la relación dialéctica de límite y limitación.

La dialéctica política de la frontera supone la afirmación de la intimidad propia, el carácter diferencial, y su expansión trascendente hacia fuera de sí. En el contexto europeo, la particularidad íntima de cada nación se sostiene sobre el fondo ultranacional homogéneo de la convivencia europea. Los caracteres nacionalistas que en un determinado momento mantienen los pueblos europeos presentan el momento negativo de la frontera: su hermetismo. Si la convivencia europea siempre había mostrado las fronteras como polos casi imaginarios, en un cierto momento histórico ese talante abierto desaparece y surge el hermetismo. Es el carácter agresivo que tendrá su exposición más plena en la Segunda Guerra Mundial: "Mientras, hace treinta años, las fronteras eran para el viajero poco más que coluros imaginarios, todos hemos visto cómo se iban rápidamente endureciendo, convirtiéndose en materia córnea, que anulaba la porosidad de las naciones y las hacía

690"Introducción a Velázquez" (1947). OC VIII, 561. Ortega escribió tres "introducciones a Velázquez", en el 43, en el 47 y en el 54. 
herméticas", escribe Ortega en "En cuanto al pacifismo..." y repite en la Meditación de Europa 691 .

Todo pueblo es una intimidad, con sus secretos y limitaciones. No es únicamente el talante nacionalista el que cierra la frontera, sino que el mismo hecho de que unas naciones, olvidando la convivencia común europea, pretendan intervenir, del modo que sea, en la intimidad ajena, supone la conversión de la frontera en aislante: "Esto bastaría a explicar por qué, cuando las naciones europeas parecían más próximas a una superior unificación, han comenzado repentinamente a cerrarse hacia dentro de sí mismas, a hermetizar sus existencias, las unas frente a las otras, y a convertirse las fronteras en escafandras aisladoras"692.

En el momento en que la sociedad europea se presente como ultranación, respetando la limitación y particularidad ajenas, pero manteniendo el fondo común de la homogeneidad que supone un proyecto unitivo de futuro, una empresa en común, en tanto "los europeos no saben vivir si no van lanzados en una gran empresa unitiva"693, las fronteras asumirán su dialéctica de límite y limitación: el principio nacionalizador en el que se basa la ultranación exige la permanencia de la pluralidad de intimidades ("la idea nacional, más puramente dinámica, exige la permanencia activa de ese plural que sido siempre la vida de occidente"694), pero, al mismo tiempo, elude el talante agresivo y hermético al sostener la unidad sobre el proyecto de futuro que supone la nación y la ultranación en su definición como empresa, como proyecto a realizar, realidad que tiene que ser constantemente recreada.

En este momento, las fronteras no obedecerán de ningún modo a caracteres únicamente territoriales. Será la propia fuerza íntima de cada nación la que demarque las fronteras. La frontera es posterior al carácter de empresa, a la intimidad en el proyecto de futuro que supone cada nación. La idea la mostraba ya Ortega en el año 16: "la fuerza íntima de una

${ }^{691}$ La rebelión de las masas. Epílogo para ingleses - En cuanto al pacifismo... (1937-1938). OC IV, 300; Meditación de Europa (1949). OC IX, 307.

${ }^{692}$ La rebelión de las masas. Epílogo para ingleses - En cuanto al pacifismo... (1937-1938). OC IV, 308; Meditación de Europa (1949). OC IX, 312-313.

${ }^{693}$ La rebelión de las masas (1930). OC IV, 272.

694 Ibid. p. 273. 
nación hace que sus fronteras no se conviertan en líneas irrisorias'695. Cuando los caracteres de esa intimidad refieran al talante de empresa, al repertorio de secretos que es cada pueblo, pero sostenido por su proyecto unitivo de futuro, la idea reaparecerá, transformada, en La rebelión de las masas. Las fronteras no serán algo previo a la formación de las nacionalidades, sino que surgirán cuando la unificación política en torno a una empresa haya sido ya lograda: "Las fronteras han servido para consolidar en cada momento la unificación política ya lograda. No han sido, pues, principio de la nación, sino al revés: al principio fueron estorbo, y luego, una vez allanadas, fueron medio material para asegurar la unidad"696. Ese carácter de "estorbo" remite a la empresa de futuro, a la fuerza creadora. Es la expresión que Ortega utiliza en las notas de trabajo: "Las fronteras como estorbos creadores" 697 .

En este sentido, las fonteras nacionales, en primer lugar, son posteriores a los caracteres de empresa de futuro, $y$, en segundo, por el hecho de que las naciones europeas se sostienen sobre el fondo común de la ultranación, con lo que esa empresa es unitiva, conjunta, desaparece el carácter restrictivo de la frontera y deviene expresión de la dialéctica límitelimitación: las fronteras demarcan, limitan, definen la intimidad propia, pero, al mismo tiempo, suponen la ampliación, la extensión de esa limitación por el fondo ultranacional y cosmopolita. Las fronteras pierden su carácter hermético y se sostienen sobre la indecisión, sobre la equivocidad que supone conjuntar la expresión de la intimidad propia, diferencial, con la referencia a su trascendencia, a su salida hacia fuera de sí.

Insistirá Ortega en este carácter equívoco de la frontera, en el marco de los años cuarenta que define el tema en este momento. Será afirmado en distintas obras y contextos, pero siempre en estos años y siempre expresando el carácter irónico de la frontera en su misión de integrar la diferencia propia y la referencia a la homogeneidad, a la superación de la limitación. Aparecerá en el año 40 en Buenos Aires: "La frontera es algo en que una realidad termina y otra empieza. Por eso suele ser línea equívoca y ambigua, lugar de

695" Azorín: primores de lo vulgar" (1916). OC II, 183.

${ }^{696}$ La rebelión de las masas (1930). OC IV, 272.

${ }^{697}$ Archivo de la "Fundación José Ortega y Gasset", Carpetilla "Nación, Europa, etc.". 
confusión, terreno de combates que luego cuentan sonoros, los romances fronterizos" 698 ; lo hará también en el año 43: "Tienen las fronteras un sino irónico. Están destinadas a separar dos mundos, pero el hecho es que quienes las habitan de uno y otro lado acaban por hacerse homogéneos"699; y reaparecerá en el Toynbee, mostrando el carácter móvil y amenazado del limes romano: "Frontera quiere decir algo así como perfil, y el perfil es lo que está siempre en cada cosa más amenazado, más expuesto"700. Es lo que está más amenazado porque es la primera expresión de una intimidad, lo que se encuentra manifestando en un momento inicial la particularidad propia. Es lo más amenazado porque se encuentra de cara al exterior, remitiendo a más allá de sí, a su contacto con otras limitaciones. Se trata del perfil como línea equívoca que mostraba Ortega en aquél texto ya citado del "Esquema de Salomé"701.

En la dialéctica política de la frontera, situada en el marco de la relación entre nación y ultranación, las fronteras muestran en un determinado momento el carácter hermético, aislante, que separa a unas naciones de otras y las mantiene en el fondo de nacionalismo agresivo situado en torno a los enfrentamientos europeos entre naciones. Ese carácter negativo de la frontera se supera al afirmar la ultranación europea, la necesaria e histórica convivencia entre las naciones, que las muestra en su constante referencia a más allá de sí, a la trascendencia que conllevan las relaciones entre los pueblos. Surge con ello una frontera abierta, nunca exclusiva, que, aunque expresa la intimidad particular y diferencial de cada pueblo, se mantiene sobre el fondo común de trascendencia que impide el hermetismo de las naciones. En el momento negativo, la frontera presenta su carácter hermético, aislante, demarcador; en el momento positivo, la frontera presenta el talante abierto que supone la dialéctica de límite y limitación: afirmación de la intimidad propia, pero necesidad de extender esa particularidad por el marco general de la ultranación, por el marco cosmopolita de la humanidad en general.

${ }^{698}$ La razón histórica (Buenos Aires, 1940). OC XII, 211.

699" Prólogo a «Aventuras del capitán Alonso de Contreras»" (1943). OC VI, 499.

$7^{700}$ Una interpretación de la historia universal. En torno a Toynbee (1948-49, curso). OC IX, 45-46. Con el análisis de ese limes en el Imperio Romano comienza precisamente Trías su Lógica del límite. Cfr. TRÍAS, E. Lógica del límite. Barcelona: Destino, 1991, pp. 15 ss. 
En el contexto estético, concretamente referido a la pintura, esos dos momentos no expresan un carácter negativo y otro positivo, sino dos modos de entender las figuras que, en el primer caso, las muestra fuertemente demarcadas, delimitadas, y, en el segundo, las expone con los márgenes imprecisos y equívocos del límite irónico. Este segundo estilo lo encontrará Ortega en Velázquez, en sus escritos de los años cuarenta, y no será casual que ese modo de pintura lo trate Ortega precisamente en el mismo contexto epocal que los textos en torno a la Meditación de Europa. La frontera abierta de la ultranación conectará con el margen impreciso de las figuras en los cuadros de Velázquez.

701"El equívoco propio de todo lo que es término y extremo; así, el perfil de los cuerpos, que es línea en que terminan, no se sabe bien si les pertenece a ellos o al espacio circundante que los limita". "Esquema de Salomé" (1921). OC II, 360. 


\section{7. ...y fronteras estéticas}

Es posible mostrar con nombres propios y contextos epocales precisos la diferencia de modos de pintura en lo que refiere al límite, al perfil. El límite demarcador, las figuras expuestas con un perfil riguroso, aparecerán en los hermanos Zubiaurre y en textos de los años veinte. El margen impreciso y la realidad nunca completa, siempre indefinitiva, aparecerá en Velázquez en los años cuarenta. El mismo talante de indefinitividad, por tanto, se mostrará en el tema del arte, en el tema de la nación y la ultranación y, no hay que olvidarlo, en el tema de la dialéctica.

Velázquez, ultranación y dialéctica, tres de los aspectos determinantes que definen los escritos e intereses de Ortega en los años cuarenta. No será casual que el mismo carácter de indefinitividad les afecte a los tres, y no hay que olvidar tampoco que ese carácter apareció por primera vez en este trabajo con una de las notas de lectura sobre Hegel, aquélla en la que Ortega mostraba el descubrimiento que le supuso la infinitud verdadera: "La "infinitud verdadera" nos descubre que ese modo de ser aparte, $d a$-limitado o finito- no es un modo de ser de-finitivo, sino, al revés, in-definitivo. [...]. De lo cual resulta que en verdad nada finito es suficientemente"702.

La pintura de los hermanos Zubiaurre, con un párrafo que aparecía citado en parte más arriba en otro contexto (el del tema general del arte en los escritos de los años veinte, y su relación con la dialéctica de límite y limitación), la definía Ortega del modo siguiente:

"El impresionismo nacido de una antipatía hacia las cosas atomiza las formas en puros reflejos: de una jarra, de una faz, de un edificio, pintará sólo la masa cromática amorfa. El primitivo, entusiasta del mundo que le rodea, sigue un camino opuesto: hará abstracción de los reflejos que deforman el cuerpo de cada objeto, y como si la pupila fuera una mano, la deslizará sobre la superficie, no admitiendo confusión ni vaguedad en los contornos. / En los Zubiaurre retoña una vez más esta intención artística de los primitivos flamencos e italianos. Les importa mucho cada cosa, y como el perfil representa la demarcación de fronteras entre unas y otras, se han hecho pintores de perfiles, de siluetas. Puede decirse que la parte de nosotros mismos donde más enérgicamente nos hallamos es nuestro perfil. Viene éste a ser la línea de batalla que constantemente oponemos al resto del mundo, presto siempre a aniquilarnos, a borrar nuestra singularidad"703.

702 Archivo de la "Fundación José Ortega y Gasset", Carpetilla "Hegel - Filosofía de la historia". 703" Los hermanos Zubiaurre" (1920). OC II, 270. 
El perfil como demarcación de fronteras rigurosas, las fronteras mostrando únicamente el carácter diferencial, hermético, de cada figura. Sólo tres años más tarde insistirá Ortega en el carácter del perfil como frontera rigurosa, "bien definida", como "inequívoco dintorno o forma externa que, como una frontera bien definida, le [a toda cosa] separa o aísla de todas las demás"704. Llegará a afirmar, incluso, que "sin límites no hay dibujo ni fisonomía"705, y, en el tema general del arte nuevo, será síntoma de pulcritud mental la negación de toda confusión de fronteras: "Es un síntoma de pulcritud mental querer que las fronteras entre las cosas estén bien demarcadas"706, una pulcritud que defiende Ortega en un contexto determinado: no confundir nunca lo que es con lo que debe ser, lo real con el ideal abstracto.

Las fronteras, los perfiles, los límites, en su sentido hermético de demarcar las individualidades, remarcar el carácter diferencial de cada singularidad y no permitir la confusión de fronteras. Las limitaciones expresan únicamente su carácter propio, diferencial, remitiendo hacia sí mismas antes que hacia fuera de sí. Más arriba veíamos, comentando el mismo texto de Ortega sobre la pintura de los Zubiaurre, que ya en ese momento está presente la dialéctica de límite y limitación. Ahora interesa presentar únicamente el carácter restrictivo y hermético de la frontera, de los contornos de sus figuras. En el arte de los hermanos Zubiaurre, la pretensión de exteriorizar intimidades, de mostrar secretos, parte de esa demarcación de fronteras que supone el perfil como línea de batalla opuesta al mundo.

Pero llega un momento, en el contexto de los años cuarenta, en el que domina el carácter de la indefinitividad. Sea en el tema de la dialéctica, sea en el tema de la ultranación, sea en el tema de la pintura. Ya no se admitirán los perfiles que únicamente demarcan los contornos rigurosos, ya no se admitirá la precisión de ese perfil. La pulcritud que en esos años veinte aniquilaba todo tipo de confusión tendrá un margen muy estrecho. En los años cuarenta, Ortega ha mostrado la continuidad de los aspectos, de las particularidades, en todos los marcos. Incluso la filosofía en general no se admite como modo definitivo, único, de acercarse al mundo

704" Tiempo, distancia y forma en el arte de Proust" (1923). OC II, 705.

705" Góngora, 1627-1927" (1927). OC III, 587. 
En sus estudios sobre la mitología, sobre el logos mágico y el primitivo, encuentra Ortega un "principio de la confusión"707 que niega la permanencia detenida. Es el principio del logos mágico, en el que el carácter metafórico constantemente trasciende los términos como tales: "Lo mismo que el ser de una cosa comunica y se con-funde con el de otra - cada palabra tiende a trascender su propio sentido y representar el sentido de otra existente ya o aún no existente. Es, pues, un estado de máxima hiperestesia en la función metafórica del lenguaje, que es el poder lingüístico de «con-fusión» correlato de un mundo de con-fusiones"708. Ortega no defenderá ese principio fuera de su marco propio, no lo desprenderá nunca de su carácter de logos mágico, no intentará hacerlo presente, actual.

Para Ortega las metáforas no confunden, sino que suponen "un mundo de distintos (= no confusos)"709. No habrá confusión, pero sí continuidad en los aspectos, en los distintos modos de ver el mundo. Continuidad en el sentido de continuación, de permitir las diferencias, pero mostrando su conexión con otras. Es la indefinitividad de la dialéctica, la que muestra las comunicaciones entre los fragmentos, sean éstos aspectos de cosa, sistemas filosóficos, naciones, o, en general, modos de ver el mundo. Nada hay definitivo: las naciones en su diferencialidad remiten al fondo homogéneo ultranacional, nunca concluyen en sí mismas; los aspectos son por definición la superación de sí mismos, la expresión de una incompletud que remite a su perfeccionamiento en otros aspectos; los sistemas filosóficos se muestran como verdades parciales en la dialéctica histórica de la filosofía; la filosofía en general puede encontrar un punto en el que sea superada como modo único de enfrentarse al mundo. Todos ellos son rasgos de la filosofía de Ortega sobre todo en los años cuarenta: la dialéctica, la ultranación, las conexiones de indefinitividades, la necesaria reunión de finitudes para ver el conjunto de lo humano.

Al ser esto así, las figuras de los cuadros que interesen ahora a Ortega no pueden ser las de los perfiles rigurosos y demarcadores precisos de individualidad. Deben ser fronteras imprecisas, ambiguas, que muestren toda la ironía que supone la superación de la limitación

\footnotetext{
706 La deshumanización del arte (1925). OC III, 371.

707"Hemos salido al «principio del pensar sintético mágico» del que se derivarán todas sus categorías: el Ente es «todo lo que tiene que ver con él» o principio de la «confusión»". Notas de trabajo. Epílogo... Ed. J.L. Molinuevo. Madrid: Alianza/Fundación José Ortega y Gasset, 1994, p. 150, nota 207.

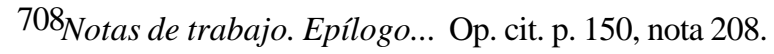


propia en la referencia a más allá de sí. Esa imprecisión es la que presentan las figuras de Velázquez, y el texto que determina el tema, para mostrar de un modo claro la diferencia, debe ser leído junto al anterior que definía el arte de los hermanos Zubiaurre. Es un texto que Ortega repite casi literalmente en la 'Introducción a Velázquez" del 43 y en la del 54, y expresa toda la serie de ironías, de equivocidades, de ambigüedades que, en el tema de la pintura, definirá la frontera abierta defendida en estos años cuarenta, la frontera abierta que, en el contexto de la dialéctica o en el de la ultranación, presenta la indefinitividad de toda realidad. Escribe Ortega:

"El «naturalismo» de Velázquez consiste en no querer que las cosas sean más que lo que son. De aquí su profunda antipatía por Rafael. Le repugna que el hombre se proponga fingir a las cosas una perfección que ellas no poseen. Esos añadidos, esas correcciones que nuestra imaginación arroja sobre ellas le parecen una falta de respeto a las cosas y una puerilidad. Ser idealista es deformar la realidad conforme a nuestro deseo. Esto lleva en la pintura a perfeccionar los cuerpos precisándolos. Pero Velázquez descubre que en su realidad, es decir, en tanto que visibles, los cuerpos son imprecisos. Ya Tiziano había advertido algo de esto. Las cosas en su realidad son «poco más o menos», son sólo aproximadamente ellas mismas, no terminan en un perfil riguroso, no tienen superficies inequívocas y pulidas, sino que flotan en un margen de imprecisión que es su verdadera presencia. La precisión de una cosa es su leyenda. Lo más legendario que los hombres han inventado es la geometría. / [...] El efecto aéreo de sus figuras se debe simplemente a esa venturosa indecisión de perfil y superficie en que las deja. A sus contemporáneos les parecía que no estaban «acabadas» de pintar, y a ello se debe que Velázquez no fuese en su tiempo popular. Había hecho el descubrimiento más impopular: que la realidad se diferencia del mito en que no está nunca acabada"710.

La frontera abierta e indecisa de las particularidades en el fondo ultranacional tiene en su expresión pictórica este carácter de las figuras de Velázquez. En este contexto, no se trata de un momento negativo frente a otro positivo (como lo eran las fronteras herméticas frente a las porosas), pero no deja de ser importante que en los mismos años cuarenta el carácter de indefinitividad sea expuesto en la dialéctica, en la ultranación y en la pintura. Que Ortega elija a Velázquez tendrá la intención particular, como veremos, de referirlo al tema de España, al tema de la cultura fronteriza, pero, en el marco individual de las fronteras, de

\footnotetext{
709 Ibid.

710" Introducción a Velázquez" (1943). OC VIII, 478-479. El texto, con algunas variantes y más breve, se encuentra también al final de la introducción del 54: Cfr. "Introducción a Velázquez" (1954). OC VIII, 652.
} 
los límites abiertos, esa imposibilidad de mostrar los perfiles rigurosos presenta la conexión entre todos los marcos tratados.

Los hermanos Zubiaurre pretendían mostrar la realidad plena, individual de cada objeto. Por ello "se han hecho pintores de perfiles", porque "el perfil representa la demarcación de fonteras", demarcación rigurosa de fronteras. Ahora, la realidad misma de las cosas impide su culminación en un perfil riguroso. La realidad misma es dialéctica, es siempre inconclusa, se presenta o aparece en aspectos, en indefinitividades, y esa realidad en el momento de su aparición es la que pinta Velázquez, "ese momento de la realidad que consiste en presentársenos"711. Es difícil entender esta teoría que Ortega remite ahora a Velázquez sin tener en cuenta el tema completo de la dialéctica visto más arriba. Y no sólo este tema es necesario, sino también el del tratamiento político de la ultranación en su mostrar los límites abiertos de las particularidades, que implican la intimidad propia, pero lo hacen precisamente presentándola trascendiendóse a sí misma.

La equivocidad de la frontera 10 responde únicamente a su definición como tal, sino que remite al carácter dialéctico de lo real. La frontera es imprecisa, indecisa, equívoca, pero es que "yo no creo más que en el equívoco, porque la realidad misma es ella equívoca y toda simplificación y todo lo que pretenda ser inequívoco es adulteración o falsificación de la realidad, es lugar común, aspaviento, postura y frase"712. La indecisión estética de las figuras de Velázquez expresa de este modo la realidad más propia, la que no deviene deformada por el deseo, pretendidamente completa, perfecta. La perfección, como vimos en la referencia a la dialéctica de Hegel, no remite a la plenitud o culminación, sino al perfeccionamiento. La imprecisión de las figuras de Velázquez expresa constantemente su incompletud, su imperfección, y por ello las expresa "en su realidad".

711"Introducción a Velázquez" (1943). OC VIII, 478.

712" La razón histórica" (Lisboa, 1944). OC XII, 276. 


\subsection{Imprecisión y descontento}

Del mismo modo que la realidad plena de cada nación únicamente se muestra en su salida hacia fuera de sí, en la frontera que expresa la individualidad propia, pero también el sentido de límite que la pone en contacto con su fondo ultranacional, con las demás limitaciones, y, con ello, su frontera es siempre imprecisa, indecisa, permaneciendo en un margen flotante, las figuras de Velázquez muestran a las cosas en su realidad al negarle las superficies inequívocas. No hay precisiones e inequivocidades.

La dialéctica muestra la indefinitividad de los fragmentos, la ultranación presenta el carácter de trascendencia de sí de cada particularidad, ahora las figuras de Velázquez expresan su esencia más real precisamente al flotar en el margen de imprecisión. Las figuras no están nunca acabadas, porque lo real mismo no está nunca acabado, es unvollkommene. También lo es el proyecto de perfeccionamiento, de futuro, el programa unitivo que mantiene conectadas las distintas limitaciones nacionales. Se trata constantemente de referir a un más allá, de trascender la limitación propia, y, para ello, las fronteras de esa limitación deben presentarse en el límite, en la indecisión y ambigüedad del límite.

Esta serie de caracteres, que aglutina el sentido de lo presentado hasta este momento, aparecen concretados en el texto sobre Velázquez citado 713 :

- "No querer que las cosas sean más que lo que son". Las cosas (aspectos, naciones, fragmentos) no son más que lo que son, pero, precisamente por eso, sí son más de lo que son. Son lo que son siendo más de lo que son, en tanto discurren en un espacio límite que constantemente posibilita la relación con otras cosas y su virtual ser más, su extensión y ensanchamiento "por toda la humanidad", como expresaba Ortega en el texto citado de Fichte. Las cosas son lo que son siendo en su ampliación.

- "Fingir una perfección que ellas no poseen". Las cosas no poseen una perfección, en el sentido de acabadas, concluidas, pero sí un perfeccionamiento que remite tanto a los contactos como a la constante superación de las limitaciones. La imperfección y el perfeccionamiento se implican esencialmente: hay posibilidad de perfeccionamiento porque

713"Introducción a Velázquez" (1943). OC VIII, 478-479. 
las cosas son por esencia imperfectas. Es el tema de la dialéctica que aparecía más arriba en la referencia al propio Hegel, aquel carácter de imperfección que mostraba precisamente la realidad efectiva ${ }^{714}$. El idealismo deforma la realidad al conferirle una conclusión, una perfección que no posee. La realidad inconclusa, indefinitiva, es la que se presenta en la dialéctica del límite y la limitación y, con ello, muestra el respeto tanto por la limitación ajena como por la finitud o limitación en general, el respeto por la imperfección, por la imprecisión.

- "En su realidad [...] los cuerpos son imprecisos". "Los cuerpos son imprecisos" porque "la realidad misma es ella equívoca", el naturalismo de Velázquez es naturalismo de imprecisión porque la realidad misma es imprecisa, equívoca. Ese equívoco remite en general a la frontera; remite a la ambigüedad de la frontera en la referencia tanto hacia su interior, a lo que limita, como a fuera de sí, a su trascendencia, sea al fondo homogéneo de la ultranación, sea a la relación concreta con cualquier otra limitación.

- "No terminan en un perfil riguroso, [...] flotan en un margen de imprecisión". El margen de imprecisión y la ausencia de perfil riguroso de las cosas es el carácter de límite, el que permite su intimidad propia, pero también su trascendencia: la relación con las demás cosas y la pluralidad de aspectos, de limitaciones, el henchimiento de la limitación propia en las posibilidades de ampliación, implican la quiebra de la precisión y la rigurosidad. La imprecisión tiene sentido positivo, en tanto remite a la superación de las fronteras, de los perfiles restrictivos, a partir del límite ambiguo y equívoco que hace posible afirmar la intimidad propia a partir precisamente de la negación del carácter hermético de esa intimidad. Se mantienen los secretos, pero también la salida hacia otros secretos, otras intimidades.

- "La realidad [...] no está nunca acabada". Por el hecho de que toda realidad es inacabada hay lugar para el perfeccionamiento, para la dialéctica de continuidad que muestra el proyecto de futuro, la dialéctica histórica de la continuación. Lo imperfecto, lo inacabado, exige el henchimiento de la limitación propia y la ampliación de realidad. La realidad nunca es acabada, por eso las cosas son lo que son siendo más de lo que son. Son inacabadas, imperfectas, tienden a la ampliación y al perfeccionamiento.

\footnotetext{
$714 "$...Weil es nicht so vollendet werden könne, es nicht zu etwas sogenanntem Unvollkommenen, d.h. nicht zur Wirklichkeit kommen zu lassen". HEGEL, Grundlinien der Philosophie des Rechts. Hrsg. G.
} 
Las fronteras rigurosas que mostraban las figuras de los Zubiaurre devienen en Velázquez flotantes márgenes imprecisos. Es la configuración estética de la dialéctica de lo real, pero también de la dialéctica de la ultranación en su conjunción de diferencia y homogeneidad. La política de la ultranación, que no tolera el nacionalismo, que no permite la intimidad hermética sino que la sitúa en su trascendencia de sí, adquiere carácteres estéticos en las figuras de Velázquez: las fronteras políticas abiertas coinciden con las estéticas en sus talantes de imprecisión, de incompletud. La estética política de la limitación muestra en este carácter dialéctico de la indefinitividad, que afecta a todos los marcos, su exposición más plena. Si los hermanos Zubiaurre expresaban la intimidad que busca todo arte a través de la rigurosidad en el perfil de sus figuras, la intimidad que muestran las de Velázquez se sostiene precisamente sobre su referencia a fuera de sí, sobre su esencia siempre indefinitiva. Es una intimidad interna, intima, pero dirigida hacia el exterior, hacia su ampliación: es intimidad limitada, pero también insaciable.

Este es el sentido de otro de los conceptos claves de estos años cuarenta, el Ungenügsamer de Goethe: "Entre los mil epítetos que Goethe dedica a Fausto hay uno que es para mí el preferible. Le llama el Ungenügsamer - el insatisfecho. En efecto, entre todos los seres del Universo tiene el hombre el privilegio de sentir descontento"15. Es la teoría del descontento que ha venido apareciendo en varios contextos, incluido el descontento por los libros de historia que iniciaba "La «Filosofía de la historia» de Hegel y la historiología". El marco en el que sitúa Ortega el tema con la referencia a Goethe, remite a la cultura, a Europa, a la situación del momento. Europa habría vivido de petulancia, de progresismo, de utopismo, de ilusiones, y de lo que se trataría ahora es de aceptar las limitaciones, de nada de sueños delirantes, sino mantenerse adaptado a lo real llevando a cabo un progreso, posible, progreso de perfeccionamiento, que se alejara de todo tipo de idealismo. Junto al Ungenügsamer presenta Ortega la teoría de la Entsagung de Goethe, de la resignación como principio de una nueva cultura.

Esa Entsagung expresa la situación europea del momento. Se trata de construir una nueva Europa que parta de las negatividades, de "sus inexorables limitaciones y en ellas se 
apoye para existir con plenitud"716. Nada de utopismos, nada de perfeccionar idealmente la realidad, como expresaba el texto sobre Velázquez. Se trata de vivir sin ilusiones, de "sentir delicia al contemplar las cosas en su desnuda realidad"717. Partir de las limitaciones supone aceptar el carácter fragmentario y limitado de todo lo real, supone el final de todo utopismo o deseo hueco, supone la afirmación del carácter impreciso y equívoco de lo real. Esa es la clave: se trata de contemplar las cosas en su desnuda realidad, pero esa realidad es siempre imprecisa, con márgenes flotantes, inacabada, imperfecta... y exige su continuación dialéctica con otras imperfecciones.

Europa y sus naciones inician su nuevo camino partiendo de las limitaciones, de la ausencia de utopías, de las desilusiones. Ortega ya lo ha mostrado en el mismo año que la conferencia sobre Goethe en la Meditación de Europa: aceptando las limitaciones propias se verá que éstas son en su trascendencia de sí, en la remisión de cada nación al fondo común europeo y al general cosmopolita. Es por ello por lo que se necesita contemplar las cosas en su desnuda realidad, no sólo para evitar utopías, sino, sobre todo, para utilizar el carácter inacabado, imperfecto, a perfeccionar, de toda realidad.

La dialéctica, la ultranación, las figuras de Velázquez, muestran constantemente las fronteras indecisas entre las particularidades. Expresan así la necesaria conexión de intimidades secretas con referencias a fuera de sí, expresan los caracteres de proyecto, de fronteras nunca herméticas. Expresan que el Ungenügsamer, el insatisfecho, es la remisión al perfeccionamiento que se inicia en la limitación, en la ausencia de utopías. El Ungenügsamer, adjetivo que define a las particularidades en su darse en la dialéctica, en la ultranación o en las figuras imprecisas de Velázquez, no concluye nunca su salida de sí, su tarea de futuro, su proyecto: el Ungenügsamer es el insatisfecho, pero también el insaciable.

$716_{\text {Ibid. }}$

${ }^{71} 7_{\text {Ibid. }}$. 


\subsection{España como finis terrae. Mitos sin amaneramiento}

Europa ha sido mostrada como el fondo de ultranación, que no elimina las diferencias particulares de las naciones, pero que las mantiene superando su propia limitación al remitir constantemente al marco común europeo y a la extensión y ampliación de la finitud propia por toda la humanidad. Las naciones no concluyen en sí mismas, son imperfectas, indefinitivas, las fronteras de su intimidad son siempre móviles, imprecisas, y exigen la relación dialéctica con un exterior que posibilite la continuación de su proyecto. Es la Europa de la ultranación, la que se basa en las relaciones entre las distintas intimidades. Pero, ¿qué ocurre con la intimidad española como tal? ¿cómo despliega su intimidad la limitación española?

El Ungenügsamer de Goethe parte de las limitaciones, de la afirmación de la limitación propia, que al mostrarse como insaciable conecta con el fondo general de relación entre limitaciones, remite al todo: el Ungenügsamer debe entenderse siempre en conexión con el "nur alle Menschen leben das Menschliche". Se trata constantemente de una afirmación de la limitación propia, pero partiendo de que esa limitación es imperfecta, incompleta, es un limitación límite, una limitación fronteriza.

Con Velázquez, Ortega ha mostrado la indecisión del límite que afecta también a las naciones en su fondo de ultranación. La imprecisa frontera política entre naciones, que remite a la intimidad propia, pero a la vez señala la trascendencia de su limitación, adquiere su forma estética en el margen flotante que Velázquez encuentra en las figuras al pintarlas en el momento de su aparición, de su presentársenos. Pero Velázquez no es utilizado únicamente con este fin. Resta la segunda parte.

Ortega continúa su particular historia de España a través del análisis de mitos, de figuras, de personajes, continúa forjando una historia de España que hasta el momento habría sido inédita. Velázquez es un momento determinante en esa historia. Los perfiles de sus figuras son indecisos, expresan por esencia la ironía de la frontera, pero es que también España en general presenta el mismo sino irónico. Es un país fronterizo, mediterráneo, un país límite entre dos continentes, que además, por sus relaciones con América, puede incluso entenderse como país límite no entre dos, sino tres continentes. Si la ultranación europea muestra el carácter fronterizo de las diferentes naciones, que reúnen su intimidad 
propia con el marco móvil de la ampliación, España es un caso extremo: mantiene ese carácter fronterizo de las limitaciones en la ultranación, pero es que ya en sí misma es un pueblo fronterizo. España es una realidad límite, anómala, que se sitúa junto al carácter límite de las demás intimidades europeas: es un límite en el límite.

España es un país de finis terrae, se mantiene como pueblo de frontera, y Ortega acude a Velázquez para mostrarlo. Los márgenes indecisos de sus figuras no expresan únicamente la indecisión de toda realidad, siempre insatisfecha, inacabada, sino también el carácter límite del pueblo de frontera, la cultura fronteriza española. Velázquez descubre en sus figuras que la realidad no está nunca acabada, que su naturaleza es fronteriza por esencia: Velázquez expresa estéticamente la realidad española como finis terrae, como cultura fronteriza. Cumplirá en parte, así, treinta años después, aquel objetivo que presentaba Ortega para una cierta meditación dedicada a la Estética de «Myo Cid», que no fue publicada, y que debería haber incluido "un ensayo panorámico sobre la cultura de España interpretada como cultura fronteriza" 718 .

Si no es casual que en los mismos años coincidan los escritos sobre la dialéctica (aunque ya iniciados con Hegel al final de los años veinte), sobre la ultranación y sobre el sino irónico, indeciso de las fronteras, mucho menos lo es que la reaparición de España como cultura fronteriza, que no había vuelto a mostrarse en Ortega desde Meditaciones del Quijote, tenga lugar precisamente ahora, con Velázquez y junto a la serie de contextos definidos por la indefinitividad, la dialéctica identidad íntima-homogeneidad y el Ungenügsamer. Velázquez mostrará la realidad íntima española, pero lo hace presentándola en su carácter fronterizo, en su posesión de márgenes indecisos.

En la "Introducción a Velázquez" del año 47, después de criticar la incapacidad de los historiadores (en especial Menéndez Pelayo) para expresar lo verdaderamente único, propio, del teatro clásico español, con lo que su historia estaría todavía inédita, Ortega generaliza el tema y escribe:

"Como con la pintura, como con el teatro acontece con las demás dimensiones de nuestra historia. Piensen ustedes... el pueblo español, localizado en el finis terrae del área cultural de Occidente, recogido en la extremidad del cuerpo de la cultura europea, por tanto, pueblo de frontera con otro modo de ser hombre, radicalmente distinto del europeo, con el modo africano... En consecuencia, una forma de

718MQ, 155. 
humanidad infinitamente dramática en que colindan perpetuamente dos inspiraciones y como dos destinos antagónicos, lo que da a nuestras almas esa incomparable tensión, ese ardor emotivo que hace incandescentes y febriles los ojos del hombre español. [...] De aquí lo extraña que ha sido siempre nuestra historia, lo tornasolada y cambiante de color, a la vez atractiva y atroz, dulce y frenética, que ha atraído y atraerá siempre la nostalgia romántica de los hombres del Norte. ¡Qué pena! Esa historia, distinta de todas las demás europeas, está inédita. [...] Nuestra meditación sobre Velázquez y la pintura española nos obligará a definir en una dimensión muy concreta ese carácter que la vida española tiene de cultura fronteriza y de finis terrae" 719 .

La meditación sobre Velázquez mostrará la esencia española como cultura fronteriza y de finis terrae. Ya no se trata únicamente de la cultura fronteriza en los términos de Meditaciones del Quijote, la cultura salvaje, cultura sin ayer que exige el contacto con la cultura europea del concepto. Ahora el objetivo consiste en mostrar la intimidad propia española en su carácter fronterizo, y hacerlo precisamente desde una teoría que, al reunirse con la frontera móvil de las particularidades europeas en la ultranación y con el margen flotante de los perfiles en las figuras de Velázquez, expresa la intimidad española desde su rasgo más particular, más propio, el de ser límite en la conjunción de límites.

Para comentar todo esto es necesario tener en cuenta otras dos ideas. La primera es la definición concreta de la cultura fronteriza y del finis terrae, que Ortega presenta también en sus escritos sobre Velázquez; la segunda es el tipo de relación entre España y Europa que Ortega busca en este contexto. Pueden mostrarse ambas tesis con dos textos concretos, uno de la misma introducción a Velázquez del año 47, otro procedente de una carta a Curtius fechada diez años antes.

El primer texto, escrito en el contexto de la evolución de la pintura que conducirá hasta Velázquez, dice:

"El proceso de evolución seguido por ese área continental que forma la pintura italiana es el normal en todo orden de cultura -trátese del arte, de la técnica, de la ciencia, de la política o de la religión. Ese proceso evolutivo normal ostenta dos caracteres principales. Uno es que los principios e inspiraciones que van a reinar sobre toda esa inmensa área son inventados en un territorio que luego aparecerá como centro. De allí, lentamente, se va extendiendo su dominio a nuevas regiones hasta llegar, por último, a tierras distantes en las cuales detendrá su expansión y que serán el finis terrae, la extrema periferia de aquel área. Con frecuencia estas tierras extremas coinciden con los límites de un continente geográfico. Cuando la tierra que es límite de una cultura no sólo es límite y extremo de ella sino que confina y es frontera con

719" Introducción a Velázquez" (1947). OC VIII, 561. 
otra área cultural de inspiración muy distinta, tenemos la peculiar realidad histórica que debemos sensu stricto llamar «cultura fronteriza». Consecuencia de esta lentitud en la expansión territorial de los principios culturales es que el florecimiento cultural de la periferia sea siempre tardío"720.

Por el texto citado más arriba es fácil deducir la consecuencia: la cultura fronteriza y el finis terrae se refieren de modo explícito a España. Pero resta un tercer texto que permita iniciar el análisis de todos los caracteres. Procede de una carta a Curtius escrita en París el 3 de diciembre de 1937. En esa carta, Ortega muestra la fecundidad que supondría la colaboración con Curtius en temas históricos, y el contexto de esa historia es muy particular. Se trata de la relación entre España y Europa, y la historia conjunta estaría sostenida por el régimen de la reciprocidad: Curtius llegando a España desde fuera, Ortega partiendo desde dentro, mostrando los secretos de la intimidad española 721 . En este marco, escribe Ortega:

"Esta colaboración puede resultar aún más fértil si se resuelve usted a continuar sus trabajos sobre el hecho español. Aunque yo creo -¡de nuevo lo petulante!- que en historia está todo por decir, lo está en mucho mayor grado cuanto se refiere a los fenómenos españoles. Esto resulta de dos causas que convergen: $1^{\circ}$, en España no ha habido propiamente historiadores; $2^{\circ}$, la realidad española es, desde el punto de vista europeo, una realidad anómala. Lo es hasta el punto que representa esencialmente una realidad límite de lo europeo. Esto hace que los fenómenos españoles no puedan ser suficientemente pensados con las categorías habituales de la historia europea y por esto yacen ahí «ignorados» -como cadáveres insepultos. Por otro lado, son éstos total y puramente europeos, precisamente son la variedad más extrema de lo europeo, muy próxima a lo «completamente otro». ¿No sería una gran tarea el ensayo de integrar en la historia europea esta su manifiesta diferencia?" 722.

También en Meditaciones del Quijote insistía Ortega en la necesaria integración de la cultura mediterránea, impresionista, de superficies, con la europea, conceptual, de profundidades: "Yo no propongo ningún abandono, sino todo lo contrario: una integración"723. Se trataba de traer Europa a España; ahora el recorrido se completa: integrar en la historia europea la manifiesta diferencialidad española. Pero los contextos

\section{0"Introducción a Velázquez" (1947). OC VIII, 584.}

${ }^{721}$ ORTEGA Y GASSET, J. Epistolario. Madrid: Revista de Occidente, 1974, p. 105: "Viniendo usted a lo español desde fuera, yo puedo salirle al encuentro partiendo desde dentro, y al saber expreso de usted unir mi saber intuitivo de lo español".

722Ibid. pp. 104-105.

${ }^{723} \mathrm{MQ}, 165$. 
han cambiado. En 1911 definía Ortega el fondo último del alma española con los caracteres del mediterranismo: antipatía por lo trascendente, materialismo extremo, amor a las cosas "en su rudeza material, en su individualidad, en su miseria y sordidez, no quintaesenciadas y traducidas y estilizadas"724. Treinta años más tarde, después de todas las teorías e ideas defendidas por Ortega en esos años, con la superación del idealismo en el centro del desarrollo, aparece con Velázquez la verdadera realidad de las cosas al mostrarlas en la indecisión de sus perfiles, en la indefinitividad de sus caracteres, no precisadas, no estilizadas. Aparece la conexión entre las cosas en su carácter fronterizo y la realidad fronteriza española.

La realidad española, en su carácter propio y diferencial, límite, siempre ha atraído la nostalgia romántica de los hombres del norte, de Europa. Esto tiene una parte positiva y una negativa. La primera refiere al interés propio por una intimidad anómala, extraña, el interés que despierta lo español; la segunda permite deducir de ello la idea diferencial, demasiado diferencial, que han tenido de España el resto de pueblos europeos. Con los deseos de integración, de llevar esa realidad anómala hasta Europa, Ortega mantiene una intención explícita: se trata de extender la intimidad propia, en todos sus caracteres anómalos y fronterizos, pero hacerlo integrándola, superando la lejanía de país exótico con que ha sido habitualmente considerada. En las notas de trabajo, conectando expresamente con esa historia particular expuesta en el texto de la "Introducción a Velázquez", que "ha atraído y atraerá siempre la nostalgia romántica de los hombres del norte", escribe Ortega: "Sensación de España. Antipatía perforada por la erupción de curiosidad, admiración y entusiasmo por ciertas formas, gestos, actitudes, comportamientos españoles. Lo español no ha sido nunca para los extranjeros una cosa más o menos estimable, grata u odiosa - pero normal. Ha sido siempre algo extraordinario, algo que se subían a la cabeza"725. Ortega tratará de mantener el carácter extraordinario, único, pero también de integrarlo en el conjunto de la ultranación: que España continúe subiéndose a la cabeza, pero que deje de ser considerada como lo simplemente exótico, lejano, extraño.

El objetivo es integrar el carácter diferencial de la intimidad española en el conjunto de la ultranación europea, y hacerlo con todos los caracteres que rigen la dialéctica de esa 724" Arte de este mundo y del otro" (1911). OC I, 190. 
ultranación: conexión de pluralidades, pero sin perder en ningún caso la intimidad propia, los rasgos propios y diferenciales. La pregunta que surge es la siguiente: ¿qué ocurre cuando esa intimidad que se pretende extender, acudiendo al carácter límite, fronterizo, que permite la conexión de particularidades en el proyecto unitivo europeo, es ya de por sí una realidad fronteriza, una limitación de finis terrae? ¿cómo integrar una cultura fronteriza, límite, en una ultranación compuesta por intimidades dinamizadas por el carácter dialéctico y abierto de sus fronteras? Mediante la conjunción de los tres textos citados, los dos de la "Introducción a Velázquez" y el procedente de la carta a Curtius, es posible responder a esas cuestiones.

España es el finis terrae de Occidente. Es pueblo de frontera, límite entre Europa y África. Su mediterranismo, su carácter costero, diferencial, se inicia en la conjunción de dos modos de vida radicalmente distintos. La historia de esta realidad límite que es España estaría inédita, inédita porque no ha mostrado ese carácter fronterizo, ambiguo, que presentan sus figuras y sus mitos. Es una historia inédita entre las europeas, pero no sólo porque no haya sido narrada, sino porque no se ha tenido en cuenta su intimidad más plena, la intimidad de un pueblo de frontera. Que la meditación sobre Velázquez exija definir el carácter de España como cultura fronteriza (definición que, explícitamente y referida a España, no efectúa Ortega: la cultura fronteriza únicamente vuelve a aparecer en el texto citado más arriba en segundo lugar) no proviene únicamente de que ello sea necesario para entender a Velázquez, sino también de que el mismo Velázquez, como las demás figuras, mitos, personajes, etc. españoles, presentan los caracteres móviles de la frontera. La estética del perfil móvil que aparece en sus figuras se situaría en este contexto.

Por el hecho de que es finis terrae, la cultura fronteriza española mantiene un florecimiento tardío en lo que respecta al resto de Europa. Es lo que explicaría la necesaria culturización y remisión al concepto que mostraba insistentemente Ortega en sus primeros escritos. Cultura fronteriza es la de los territorios que, además de finalizar un determinado área cultural, limitan con otro distinto. Su florecimiento es tardío con respecto al núcleo de la cultura que finalizan, pero su intimidad propia, sus caracteres diferenciales, se muestran en todo su vigor desde el inicio de su historia. Esa intimidad propia parte precisamente de su situación en un espacio límite. Es por ello que España representa una realidad anómala,

\footnotetext{
725Archivo de la "Fundación José Ortega y Gasset", Carpetilla "Nación, Europa, etc.".
} 
límite, respecto al resto de Occidente, pero eso no significa que, primero, no sea una intimidad tan propia como las demás, $\mathrm{y}$, segundo, no sea esencialmente europea. Es una realidad anómala, en tanto es el límite con un modo de ser hombre "radicalmente distinto del europeo", pero, desde Meditaciones del Quijote, Ortega ha insistido en que el mediterranismo, el talante mediterráneo, es previo a que Europa y África se conformasen como sus términos.

España es una realidad límite, y, por tanto, especial. Por ello no deja de ser europea, pero sí que exige unas categorías diferentes para narrar su historia, categorías diferentes respecto a las habituales en la historia europea. Esas categorías diferenciales exigen acudir a mitos o figuras (sea Don Juan, sean los toros, sean Goya o Velázquez, sea Don Quijote o El Escorial) que de por sí muestran una estética propia, extremada, límite. Para integrarlos con el resto de la historia europea son necesarios los dos caracteres que definen la dialéctica de la ultranación: admitir la intimidad propia, diferencial, y mostrarla abierta en sus referencias. La intimidad española propia únicamente será integrada en Europa, integrada como su manifiesta diferencia, si son analizados desde su carácter único, especial, íntimo (como el de todas las demás intimidades nacionales), pero si, además, se exige que esos mitos colectivos dejen de tener el simple significado exótico que ha mantenido siempre España en la historia europea. Ortega quiere llevar a Europa los mitos españoles, particulares, íntimos, propios, con todo su talante del pueblo fronterizo, extremo de lo europeo, pero exentos de todo amaneramiento.

Este es el modo como la realidad fronteriza española, el pueblo del finis terrae y sus mitos podrán ser integrados en la historia europea, sin perder su intimidad propia, pero evitando su exacerbamiento. Con el amaneramiento, exacerbamiento del mito o figura nacional, primero, no podrán ser integrados en la historia europea, pues siempre serán entendidos como algo puramente exótico, lejano, y no en su sentido de la variedad límite, la variedad fronteriza de lo europeo, límite y fronteriza, pero europea. Y, segundo, pueden causar "el asesinato" del propio pueblo, en este caso España. El tema lo muestra Ortega de un modo claro en las notas de trabajo sobre la Saudade. Integrar en Europa la realidad límite y fronteriza española es integrar sus mitos, sus vigencias, precisamente porque "el 
mito es la etimología (popular) de la realidad presente"726. Será por ello una integración política mediante un modo estético, con lo que, de nuevo, el margen flotante de las figuras de Velázquez, entendido en su expresión de la propia realidad fronteriza española, adquiere un carácter determinante.

Las concreciones epocales continúan mostrando la continuidad de los temas: que durante los años cuarenta, en las notas para Epílogo..., el tema del mito sea una de las claves, o que, durante su estancia en Portugal, proyectase Ortega una Hipótesis a la Saudade: un estudio de mitología, ambas referencias tienen la misma explicación. Se trata de mostrar al mito colectivo, a la vigencia, como expresión propia de la realidad presente de cada pueblo, de cada intimidad. En lo que refiere a España, serán sus mitos los que serán integrados estéticamente en Europa, pero siempre si se lleva a cabo evitando su amaneramiento. Serán la realidad anómala de la cultura fronteriza que Ortega pretendía integrar en la historia europea, la variedad más extrema de lo europeo, pero deben hacerlo expresando su intimidad propia, no su exacerbamiento.

En las notas sobre la Saudade, Ortega concreta el problema, y puede aplicarse de un modo determinado a los mitos españoles, teniendo claro que Ortega está efectuando con el mito portugués un examen externo, el examen de un extranjero que no conoce la intimidad, los secretos portugueses 727 . Cuando el examen refiera al "saber intuitivo de lo español", como le escribe a Curtius, y teniendo claro lo que Ortega entiende por intuición, la intimidad española estará expresada en sus más radicales secretos. Esos secretos son los que expresan los mitos colectivos:

"Estos «mitos colectivos» constituyen la paideia o disciplina de un pueblo. / Pero tienen, como una fisiología o sanidad, una patología. / El mito de que un pueblo vive puede convertirse en su asesino, y matarlo. ¿Por qué? ¿En qué condiciones? / Por lo pronto encuentro esta distinción que acaso pueda ser útil: el mito actúa o a tergo o al frente (inconscientemente o como consciente norma). / Ahora bien, esto último lleva con facilidad al amaneramiento; al reconocer nuestro ser en el Mito, puede propenderse a imitar el Mito, es decir, a imitarse a sí mismo, y ser por duplicado, ser dos veces lo que es, la espontánea y la operada. Le fait que l'on est, est surfait" 728 .

726 Notas de trabajo. Epílogo... Op. cit. p. 209, nota 316.

727ORTEGA Y GASSET, J. Saudade, notas de trabajo. Ed. J.L. Molinuevo. Málaga: Obra Socio Cultural de Unicaja, 1995, p. 3: "No se olvide: yo no conozco ningún secreto de Portugal".

728 Ibid. pp. 8-9. 
El mito colectivo expresa la intimidad propia de un pueblo. Es esa intimidad, en su forma española, la que Ortega quiere llevar hasta Europa. Y quiere llevarla en su carácter más particular: el de su esencia fronteriza, límite, anómala, que exige una historia propia y que hasta ahora ha permanecido inédita. El carácter mediterráneo del español responde a su esencia fronteriza, sus mitos y figuras son todos ellos muestras de ese talante: Velázquez pintando sus figuras con límites imprecisos, Don Juan y Don Quijote como maestros del descontento, los toros en su carácter de fiesta y de drama, etc. Son la variedad más extrema de lo europeo, son una intimidad propia, una limitación particular, que Ortega pretende integrar en la historia europea: el gran ensayo de integrar en Europa su manifiesta diferencia, la intimidad española, diferente, pero europea.

Para que esa intimidad pueda ser integrada en la historia europea sin continuar manteniendo el carácter que le ha acompañado siempre (la extraordinariedad, el exotismo, la lejanía), pero sin perder su diferencialidad propia, los mitos colectivos que la definen deben perder su amaneramiento, su exacerbamiento. Ortega en ningún caso pretende llevar hasta Europa la España de toros y zarzuela en su expresión chabacana. Su propósito es integrar la diferencia española, como intimidad fronteriza, límite, evitando que nuestros propios mitos nos asesinen. Para ello se exige el análisis riguroso de esos mitos, la exposición particular y propia de una intimidad, pero no el exacerbamiento de esa intimidad. La España que Ortega quiere conducir hasta Europa en los años cuarenta es la España como pueblo de frontera que, en sus mitos, permite mostrar su carácter más propio, su estética íntima de la limitación, pero adecuando las intenciones al proyecto común europeo de futuro.

Integrar España en Europa responde a la misma dialéctica de la pluralidad que exige la ultranación. Llevar España hasta Europa supone ampliar la limitación propia en su extensión por el fondo común, pero mostrando esa limitación de un modo nunca exacerbado. Ya el deseo de integrar a España en Europa como su manifiesta diferencia implica la intención de continuar conviviendo en la sociedad común europea de la que siempre, de un modo u otro, ha formado parte. En el contexto de bs años cuarenta, esa integración exige la intimidad seria, propia e íntima, pero también real y abierta, que niegue el más mínimo talante de nacionalismo. Por ello la intención de integrar los mitos españoles en la historia europea, pero también la necesidad de hacerlo sin que ello implique su 
exacerbamiento. La afirmación del mito propio, pero con la eliminación de su amaneramiento, muestra la integración de España en la ultranación a través de su intimidad particular (como todas las demás nacionalidades o limitaciones), pero negando el hermetismo de sus fronteras.

España, como todo pueblo, es un repertorio de secretos, una intimidad personal y difícil de captar desde fuera. Más aún si se tiene en cuenta su realidad anómala, la esencia del pueblo de frontera. Conducir sus mitos hasta Europa, mostrarlos, pero evitando su exageración nacionalista, responde a las exigencias del carácter dialéctico de la ultranación: intimidad propia de las nacionalidades, pero homogeneidad en la convivencia abierta de los pueblos. 


\section{CONCLUSIÓN}

La recepción de Hegel por José Ortega y Gasset acompaña en su desarrollo el conjunto de la filosofía de Ortega. Desde el inicio en los primeros años del siglo, con la aparición del concepto de sistema en el contexto de la polémica con Maeztu, hasta el final en los años cuarenta, alrededor del tema de la dialéctica y el de Europa y la idea de nación, Hegel ha sido utilizado por Ortega en momentos determinantes y con unas intenciones muy precisas. Hegel y el tema del arte, a través de una particular estética de la limitación, han mostrado el progreso de la conjunción entre filosofía, estética y política en las teorías de Ortega.

Hegel y la dialéctica entre límite y limitación han sido presentados como los objetivos del análisis llevado a cabo. La reunión de ambos aspectos, sin embargo, ha posibilitado la superación constante de cada uno tomado de un modo particular, y ha pretendido ofrecer una lectura concreta de la filosofía de Ortega en su conjunto. Esa lectura puede ser determinada mediante tres caracteres generales: 1. En Ortega, la conjunción de particularidades, sea en la historia, en la política o en la realidad misma, se apoya siempre sobre el talante de progreso, de dinamismo, sobre la dialéctica abierta de futuro; 2. El tema de la ampliación, el crecimiento, el henchimiento, la creación de realidad, todos ellos son caracteres determinantes que dirigen la serie de contextos y posibilitan su reunión, su interpretación conjunta; 3. La reunión de estética y política se sostiene sobre esos caracteres: el arte como superación de limitaciones, creando mundos nuevos, superando el marco de lo real aunque partiendo de él, tiene su compañero ineludible en una serie de pretensiones políticas y morales sostenidas no sólo por el afán de proyecto, de progreso, de mejora, sino también por el deseo de superar todo tipo de limitaciones restrictivas, particularistas, y conseguir la integración de las diferencias sin por ello privarlas de su identidad propia.

Los tres rasgos se encuentran unificados por el mismo tema: la conjunción entre las particularidades y el marco común sobre el que se apoyan, afectando esto a todos los contextos y permaneciendo siempre sostenido por rasgos vitales, humanos, iniciados en la sensibilidad para con las cosas y la fidelidad a lo real. A este talante general se debe el interés por Hegel, así como la importancia del tema de la limitación. La recepción de Hegel 
por Ortega, con la ambigüedad que la caracteriza, únicamente puede ser entendida teniendo en cuenta el conjunto de la filosofía de Ortega. Es comprensible el interés por Hegel, en la reunión del sistema con sus determinaciones, en la continuidad de los momentos históricos, en el dinamismo ofrecido por la dialéctica, pero también la necesidad para Ortega de su superación, tal como él entiende a Hegel: el sistema cerrado, la ausencia de futuro en la historia, el imperialismo de la idea, la dialéctica gobernada por el absoluto y el espíritu.

La razón histórica y la razón vital, la serie de rasgos que definen la nueva sensibilidad, la atención a la circunstancia, la situación europea y española en el tiempo nuevo, en la biografía de Ortega, todos ellos son caracteres que explican y determinan la recepción de Hegel, en la parte positiva y en la negativa. El tema de la dialéctica entre el límite y la limitación, la estética de la limitación, se encuentra en el centro del proceso, tanto en lo que refiere a Hegel, como en lo que remite de modo general a la filosofía de Ortega en su conjunto. La estética política del paisaje como limitación y límite, el concepto como limitación aglutinando relaciones, el arte como constante superación de limitaciones, la historia uniendo pasado y futuro y permitiendo al hombre ir más allá de sí mismo en su momento presente, la dialéctica expresada como conjunción de continuidad y discontinuidad, el fondo ultranacional europeo superando las restrictivas limitaciones nacionalistas: cada uno de estos rasgos expresa en un marco determinado la dialéctica entre límite y limitación y define las distint as pretensiones de Ortega en su filosofía.

Los tres objetivos propuestos en la introducción (analizar la relación entre Hegel y Ortega, utilizar para ello un método hermenéutico basado en los caracteres de la estética de la recepción, mostrar una interpretación de Ortega definida por el tema del límite y la limitación, la estética de la limitación), que han guiado el conjunto del trabajo y, en su integración, han solicitado cada uno de los temas tratados, tenían como pretensión inicial mostrar un Ortega adecuado a sus propias teorías: un Ortega como clásico, un Ortega inacabado, siempre por leer, que presenta en sus textos e ideas la ley de excedencia, de decir siempre más de lo que dice, ley que el mismo proponía junto al proyecto de los Principios de una nueva filología. Un Ortega indefinitivo, como lo son todos los aspectos aparecidos junto a la estética de la limitación y junto a la recepción de Hegel. La inconclusión que Ortega encuentra en el clásico, que aplica a Hegel y permite su análisis como recepción, también es posible aplicarla al propio Ortega. Y es posible hacerlo porque, 
en el fondo, Ortega no la remite únicamente a los textos o a los clásicos, sino a la totalidad de aspectos que definen su filosofía.

La vida como realidad radical implica el dinamismo causado por la constante remisión hacia un futuro, por el impulso y el esfuerzo que supone intentar adecuar una vocación a las circunstancias que la rodean. Vida inconclusa de por sí, definida por la tensión del arquero en su esfuerzo. Vida histórica y, como tal, sostenida por las referencias a su superación, a su ampliación y crecimiento en las relaciones con los individuos, con la sociedad, con los momentos históricos. La historia, que conecta pasado, presente y futuro, apoyada en una razón narrativa e histórica que ofrece un logos, un sentido a la pluralidad de hechos, pero que precisamente por ello parte de la pluralidad, de la diferencia e individualidad de los acontecimientos, es la definición misma de la constante superación de limitaciones. Su dialéctica de continuidad y pluralidad, de vida y de muerte, de conjunción de los tiempos, impide la conclusión. Ambos caracteres, la conclusión y la indefinitividad, Ortega los encontraba en Hegel: de ahí la ambigüedad de su relación, el "con Hegel no pero sin él tampoco".

En ningún caso se pretende la eliminación de la diferencia y particularidad de las individualidades. La estética de la limitación, con la dialéctica integradora de límite y limitación, expresa la tarea constructora, progresiva, ampliadora, que define toda la serie de caracteres apostando por la integración de las diferencias y su continuidad, su colaboración, su convivencia. Se constituye como un efecto hermenéutico aplicable a los clásicos y al propio Ortega, la individualidad de las teorías junto a las posibilidades de crecimiento que ofrecen en su recepción, pero también como un efecto de dinamismo que remite a la vitalidad y circunstancialidad de lo real y lo humano. La estética sugestiva, metafórica, simbólica, que crea mundos propios superando limitaciones y permitiendo el henchimiento de lo real, va más allá de sí y remite al conjunto de los talantes políticos de convivencia, de reunión cosmopolita de particularidades.

Y son la salvación en las cosas, la sensibilidad para lo real y la fidelidad a lo cercano las que hacen posible tanto la superación de limitaciones como el deseo integrador y cosmopolita de lo humano. La actualidad de Ortega parte precisamente de aquí, de una fidelidad a las cosas que es fidelidad tanto a ellas mismas como a las posibilidades que ofrecen. Esas posibilidades remiten a su propia historia y narración en una historia de 
objetos, a su carácter simbólico y ampliable en el marco estético, al constante metaforismo que las constituye superando sus limitaciones. La fidelidad a las cosas es también fidelidad a su crecimiento. Ese crecimiento únicamente será posible en la conjunción de vistas y aspectos, en el talante cosmopolita que reúne las miradas. El crecimiento de las cosas significa también el crecimiento de los que las miran.

En las notas de lectura sobre Hegel presentaba Ortega la "hora de la evasión", la superación de subjetivismos y espiritualismos con la afirmación de la salida al mundo. Esa salida al mundo no es un olvido del sujeto, de la razón, de los caracteres modernos por excelencia, no es un olvido, sino, todo lo contrario, el intento de hallarles la única posibilidad que pueden tener en el tiempo nuevo. Esa posibilidad los mantiene vivos dotándolos de nuevos caracteres, adecuándolos a la circunstancia actual: los convierte en razón narrativa, en sujeto siempre indefinitivo, en realidad futura que hay que construir atendiendo a las exigencias de sus objetos, en vida estética que constantemente expresa la superación de las limitaciones, pero que lo hace precisamente al caracterizarse a sí misma como límite, como potencia de crecimiento.

Es una modernidad nueva, una modernidad actual, caracterizada por la indefinitividad tanto de ella misma como época, como de sus propios objetos. No hay un Ortega posmoderno, sino que su modernidad es la más actual en su propio origen, la que supera toda pretensión de conclusión y se constituye en los talantes clásicos, humanistas, integradores y cosmopolitas, posibilitados por la fidelidad a las cosas, a la vida y al hombre. La dialéctica de miradas, la estética de la limitación, que intenta constantemente ampliar la limitación propia sin perder la identidad diferencial de cada vista, se constituye así como el hilo conductor de la filosofía de Ortega. Mostrar la posición de Hegel en esa dialéctica ha sido el objetivo de este trabajo. 


\section{BIBLIOGRAFÍA}

Los criterios que rigen la bibliografía están condicionados por el conjunto del trabajo. Se divide en cinco secciones: 1. Obras de Ortega: contiene la referencia a las obras de Ortega en general, incluyendo las últimas publicaciones de notas y lecciones no presentes en las Obras completas, así como la serie de ediciones consultadas con aparato crítico independiente (introducción, prólogo, notas, etc.). 2. Ediciones de Hegel utilizadas por Ortega: incluye las ediciones de las Obras de Hegel, así como las referencias a obras editadas independientemente de las distintas Werke, presentes en la biblioteca personal de Ortega. 3. Estudios sobre Hegel utilizados por Ortega: inclu ye aquellas obras, específicas sobre Hegel, que se encuentran en la biblioteca personal de Ortega, así como otros textos de carácter general explícitamente utilizados por Ortega en sus escritos sobre Hegel. 4. Bibliografía específica sobre la relación entre Hegel y Ortega: contiene únicamente aquellos textos que estudian de modo explícito la conexión entre Hegel y Ortega. 5. Bibliografía general sobre Ortega.

No se incluyen en la bibliografía ni los estudios sobre Hegel consultados al margen de su recepción por Ortega, ni las referencias a otros autores utilizados como fuente. En ambos casos se remite a las notas a pie de página presentes en el corpus del trabajo.

\section{Obras de Ortega}

Obras completas. Madrid: Alianza-Revista de Occidente, 1983 (12 volúmenes).

Obras de José Ortega y Gasset. Madrid: Revista de Occidente en Alianza Editorial. Colección editada por P. Garagorri. Nuevas ediciones revisadas y ampliadas con textos inéditos.

"Carta a Ricardo Burguete", en: Revista de Occidente, no 108, mayo 1990, pp. 5-11.

"Correspondencia Gerardo Diego-José Ortega y Gasset (1921-1932)", en: Revista de Occidente, no 178, marzo 1996, pp. 5-18. Presentación de M. Márquez.

"El estilo de una vida (Notas de trabajo)", en: Revista de Occidente, $\mathrm{n}^{\circ}$ 132, mayo 1992, pp. 51-68. Antología y edición de J.L. Molinuevo

"Notas a Luis Olariaga", en: Revista de Occidente, n 108, mayo 1990, pp. 37-47.

"Sobre la fenomenología", en: Revista de Occidente, no 108, mayo 1990, pp. 13-28.

"Sobre Cervantes y El Quijote desde el Escorial. (Notas de trabajo de José Ortega y Gasset)", en: Revista de Occidente, $\mathrm{n}^{\circ}$ 156, mayo 1994, pp. 36-54. Presentación de J.L. Molinuevo.

"Tres textos recuperados", en: Revista de Occidente, no 205, mayo 1998, pp. 75-80. Presentación de Laureano Robles.

Cartas de un joven español (1891-1908). Madrid: El Arquero, 1991. Edición y notas de Soledad Ortega. Prólogo de V. Cacho Viu.

Epistolario completo Ortega-Unamuno. Madrid: El Arquero, 1987. Introducción de Soledad Ortega. Edición de Laureano Robles.

Epistolario. Madrid: Revista de Occidente, 1974.

Meditación de nuestro tiempo. Las conferencias de Buenos Aires, 1916 y 1928. México: F.C.E., 1996. Edición e introducción de J.L. Molinuevo.

Notas de trabajo. Epílogo... Madrid: Alianza/Fundación José Ortega y Gasset, 1994. Edición e introducción de J.L. Molinuevo.

Saudade (Notas de trabajo). Málaga: Poesía Circulante, 1995. Edición e introducción de J.L. Molinuevo.

¿Qué es filosofía? Madrid: Alianza Editorial (Biblioteca 30 Aniversario), 1997. Prólogo y Álbum de José Luis Molinuevo. 
El Espectador. Madrid: Edaf, 1998. Prólogo de J.L. Molinuevo.

El sentimiento estético de la vida (Antología). Madrid: Tecnos, 1995. Edición e introducción de J.L. Molinuevo.

Estudios sobre el amor. Madrid: Edaf, 1995. Edición e introducción de J.L. Molinuevo.

La vida alrededor. Meditaciones para entender nuestro tiempo. Madrid: Temas de Hoy, 1998. Edición e introducción de J.L. Molinuevo

La deshumanización del arte y otros ensayos de estética. Madrid: Espasa Calpe, 1993 ( $3^{\text {a }}$ ed.). Prólogo de Valeriano Bozal.

La rebelión de las masas. Madrid: Castalia, 1998. Edición e introducción de Th. Mermall.

Meditaciones sobre la literatura y el arte (La manera española de ver las cosas). Madrid: Castalia, 1988. Edición e introducción de E. Inman Fox.

Meditaciones del Quijote. Madrid: Cátedra, 1984. Edición, introducción y notas de J. Marías.

\section{Ediciones de Hegel utilizadas por Ortega y presentes en su biblioteca personal}

Enciclopedia de las ciencias filosóficas. Trad. Ovejero y Maury. Madrid: Librería General de Victoriano Suárez, 1917.

Enciclopedia delle Scienze Filosofiche in compendio. Trad. B. Croce. Bari: Laterza, 1907.

Encyclopädie der philosophischen Wissenschaften. Hrsg. G. Lasson. Leipzig: Verlag der Dürr'eschen Buchhandlung, 1905. Philosophische Bibliothek, Band 33. 2. Aufl.

Filosofía de la historia universal. Trad. Gaos. Madrid: Revista de Occidente, 1928.

Neue Briefe Hegels und Verwandtes. Hrsg. G. Lasson. Leipzig: Meiner, 1912.

Phänomenologie des Geistes. Jubiläumsausgabe. Hrsg. G. Lasson. Leipzig: Verlag der Dürr'schen Buchhandlung, 1907. Philosophische Bibliothek, Band 114.

Phänomenologie des Geistes. Hrsg. Otto Weiss. Sämtliche Werke. Kritische Gesamtausgabe der Werke Hegels in zwölf Bänden, II. Leipzig: Fritz Eckardt Verlag, 1909.

Phénoménologie de l'Esprit. Trad. J. Hyppolite. Paris: Aubier, 1949.

Sämtliche Werke. Hrsg. G. Lasson. Leipzig: Meiner, 1923 ss.

Sämtliche Werke. Jubiläumsausgabe in 20 Bänden. In neuer Anordnung herausgegeben von H. Glockner. Stuttgart: Frommanns Verlag, 1927-1929.

Vorlesungen über die Philosophie der Geschichte. Hrsg. F. Brunstäd. Leipzig: Reclam.

Werke. Vollständige Ausgabe durch einen Verein von Freunden des Verewigten. Berlin: Verlag von Duncker \& Humblot, 1832 ss.

(Además de estas ediciones, se ha utilizado la "Werkausgabe": Werke in 20 Bänden. Hrsg. Moldenhauer, Michel. Frankfurt/M.: Suhrkamp.)

\section{Estudios complementarios sobre Hegel (específicos y generales) utilizados por Ortega y presentes en su biblioteca personal}

COUSIN, V. Manuel de l'histoire de la philosophie. Paris: Ladrange, $1839^{2}$. 
CROCE, B. Ciò che è vivo e ciò che è morto della filosofia di Hegel. Bari: Laterza, 1907.

DILTHEY, W. Gesammelte Schriften. IV Band. Die Jugendgeschichte Hegels und andere Abhandlungen zur Geschichte des deutschen Idealismus. Leipzig und Berlin: Teubner, $1925\left(2^{\mathrm{a}}\right)$.

FALKENHEIM, H., LEHMAN, R., PFÄNDER, A. Hegel Schopenhauer Nietzsche. Madrid: Revista de Occidente, 1925.

FISCHER, H. Hegels Methode in ihrer ideengeschichtlichen Notwendigkeit. München: C. H. Beck'sche Verlagsbuchhandlung, 1928.

HAERING, Th. Hegel. Sein Wollen und sein Werk. Eine chronologische Entwicklungsgeschichte der Gedanken und der Sprache Hegels. Leipzig und Berlin: Teubner, 1929.

HEIMANN, B. System und Methode in Hegels Philosophie. Leipzig: Meiner, 1927.

KRONER, R. Von Kant bis Hegel. Tübingen: Mohr, 1921.

LASSON, G. Hegels als Geschichtsphilosoph. Leipzig: Meiner, 1920.

LEVY, H. Die Hegel-Renaissance in der deutschen Philosophie mit besonderer Berücksichtigung des Neukantianismus. Philosophische Vorträge veröffentlicht von der Kant-Gesellsachft, 30. Charlottenburg: Pan-Verlag Rolf Heisi, 1927.

LORENZ, O. Geschichtswissenschaft in Hauptrichtungen und Aufgaben. Berlin: Hirze, 1886 (I Band) (II Band 1891).

LOTZE, H. Mikrokosmus. Ideen zur Naturgeschichte und Geschichte der Menschheit. Leipzig: Hirze, 1878. II. Bd. 3 Aufl.

MOOG, W. Hegel y la escuela hegeliana. Madrid: Revista de Occidente, 1931 (trad. J. Gaos).

ROSENZWEIG, F. Hegel und der Staat. München und Berlin: Oldenbourg, 1920.

ROTHACKER, E. Einleitung in die Geisteswissenschaften. Tübingen: Mohr, 1920.

SCHILLING-WOLLNY, K. Hegels Wissenschaft von der Wirklichkeit und ihre Quellen.

I. Band: Begriffliche Vorgeschichte der Hegelschen Methode. München: Ernst Reinhardt, 1929.

SCHOLZ, H. Die Bedeutung der Hegelschen Philosophie für das philosophische Denken der Gegenwart. Philosophische Vorträge veröffentlicht von der Kant-Gesellsachft, 26. Berlin: Reuther \& Reichard, 1921.

STEINBÜCHEL, Th. Das Grundproblem der Hegelschen Philosophie. Erster Band: Die Entdeckung des Geistes. Bonn: Peter Hanstein, 1933.

UEBERWEG, F. Grundriss der Geschichte der Philosophie. Berlin: Ernst Siegfried Mittler und Sohn, $1920^{11}$.

VV.AA. Études sur Hegel. Paris: Librairie Armand Colin, 1931.

WENKE, H. Hegels Theorie des objektiven Geistes. Halle/Saale: Max Niemeyer, 1927.

\section{Bibliografía específica sobre la relación Ortega-Hegel}

ALBIZU, E. "Ortega, Hegel y el pensamiento latinoamericano actual", en: Sur, $\mathrm{n}^{\mathrm{o}} 2$, Buenos Aires, 1983, pp. 5-15. 
CRUZ VÉLEZ, D. "Ortega y su distorsión de la idea hegeliana de América", en: Ortega y Gasset y el destino de América latina. Buenos Aires, 1983, pp. 147-158

HERNÁNDEZ SÁNCHEZ, D. 'La magia y el límite del "debe ser". Una conexión entre España invertebrada y la Ciencia de la lógica", en: LÓPEZ DE LA VIEJA, M. T. (ED.), Política de la vitalidad. España invertebrada de José Ortega y Gasset. Madrid: Tecnos, 1996, pp. 195-204.

INSAUSTI, X. Unamunos und Ortega y Gassets Philosophie und ihre Hegel-Rezeption. San Sebastián: Zorroaga, 1993.

INSAUSTI, X. Die Rezeption der hegelschen Philosophie bei José Ortega y Gasset", en: Hegel-Jahrbuch, 1992, pp. 229-238.

MATE, R. "El Hegel y América de Ortega o la imposible universidad occidental", en: Revista de Occidente, $\mathrm{n}^{\circ}$ 160, 1994, pp. 101-114.

RIAÑO ALONSO, J.J. "Platón y Hegel en la biblioteca: la teoría bibliotecaria de Ortega", en: Boletín de la ANABAD, XLI n 2, 1991, pp. 133-140.

\section{Bibliografía general sobre Ortega}

ABAD PASCUAL, J. Método de la razón vital y su teoría en Ortega y Gasset. Madrid: Tatropoe, 1992.

ABELLÁN, J.L. Ortega y Gasset en la filosofía española. Ensayos de apreciación. Madrid: Tecnos, 1966.

ABELLÁN, J.L. La escuela de Madrid. Un ensayo de filosofía. Madrid: Asamblea de Madrid, 1991.

ACERO, J.J. "La doctrina del conocimiento simbólico en Otega", en: Teorema, vol. XIII / 3-4, 1983, pp. 444-493.

ACEVEDO, J. Sobre la teoría de la historia en Ortega", en: Revista de Filosofía, no 33-34, 1989, pp. 99-105.

AGUILAR, E. "Ortega y la idea de nación", en: Fundación, no 3, 1994, pp. 101-110.

AGUILAR, E. "Ortega y la tradición liberal", en: Libertas, nº 17, 1992, pp. 27-59.

AGUILAR, E. "Historicismo, liberalismo e instituciones: Un aspecto de la crítica de Ortega al racionalismo político", en: Revista de Occidente, n 108, 1989, pp. 85-96.

AGUILAR, E. "Nacionalidad y nacionalismo en el pensamiento de Ortega y Gasset", en: MOLINUEVO, J.L. (coord.), Ortega y la argentina. México: F.C.E., 1997, pp. 95-109.

ÁLVAREZ, Ll. "Ensayo y rigor: el ejemplo de Ortega", en: Revista de Occidente, $\mathrm{n}^{\circ}$ 205, mayo 1998, pp. 25-41.

ÁLVAREZ GÓMEZ, M. "El concepto de cosa en Ortega", en: PAREDES MARTÍN, $\mathrm{M}^{\mathrm{a}}$. C. (ed.), El hombre y su medio. Perspectivas ecológicas desde Ortega y Gasset. Salamanca: Universidad, 1998, pp. 11-110.

ÁLVAREZ GÓMEZ, M. "La "acción pensante" del espectador", en: PAREDES MARTÍN, Ma . C. (Ed.) Ortega y Gasset. Pensamiento y conciencia de crisis. Salamanca: Universidad de Salamanca, 1994, pp. 11-29.

ARANGUREN, J.L. "El Ortega de 1914", en: LÓPEZ DE LA VIEJA, Ma. T. (Ed.), Política y sociedad en José Ortega y Gasset. En torno a "Vieja y nueva política". Anthropos: Barcelona, 1997, pp. 19-21.

ARANGUREN, J.L. La ética de Ortega. Madrid: Taurus, 1958.

ARAYA, G. Claves filológicas para la comprensión de Ortega. Madrid: Gredos, 1971. 
ARAYA, G. "Semántica y etimología en Ortega", en: Revista de Occidente, nº 75, junio 1969, pp. 293-310.

ARGERI, D. "Alle radici del raziovitalismo di Ortega: una rilettura del'Ensajo de estetica a una manera de prologo", en: Giornale di Metafisica, vol. XV, 1993, pp. 261-288.

ARISTA, L. José Ortega y Gasset, pensador de la crisis. Lima: Orellana y Orellana, 1991.

ARROYO POMEDA, J. "L'idée d'une Europe nouvelle chez Ortega y Gasset", en: L'Enseignement Philosophique, vol. 44, no 5, 1993-1994, pp. 32-28.

AUBERT, P. "Un nuevo estilo de discurso político", en: Revista de Occidente, $\mathrm{n}^{\circ}$ 192, 1997, pp. 39-46.

AZAM, G. El modernismo desde dentro. Barcelona: Anthropos, 1989.

BASDEKIS, D. The evolution of Ortega y Gasset as literary critic. Lanham: University Press of America, 1986.

BAYÓN, J. Razón vital y dialéctica en Ortega. Madrid: Revista de Occidente, 1972.

BENAVIDES LUCAS, M. De la ameba al monstruo propicio. Raíces naturalistas del pensamiento de Ortega y Gasset. Madrid: Ediciones de la Universidad Autónoma, 1988.

BOUSOÑO, C. "La estética de Ortega: notas de controversia", en: Cuadernos Hispanoamericanos, $\mathrm{n}^{\mathrm{o}} 322$ y 323, 1977.

BRITT ARREDONDO, Ch. "La modernidad española y el nacionalismo imperial: el quijotismo de Ganivet a Ortega", en: Quimera, no 135, abril 1995, pp. 47-51.

BRITT ARREDONDO, Ch. "Ortega y la dominación del arte", en: Quimera, n 150, septiembre 1996, pp. 56-60.

BURÓN GONZÁLEZ, M. La historia y la naturaleza. Ensayo sobre Ortega. Madrid: Akal, 1992.

CACHO VIU, V. "El compromiso público de Ortega y Gasset en la España de su tiempo", en: MOLINUEVO, J.L. (coord.), Ortega y la argentina. México: F.C.E., 1997, pp. 951-165.

CALVO, C. 'Una relación entre diferentes: Ortega y Gasset y Gramsci", en: LÓPEZ DE LA VIEJA, Ma. T. (Ed.), Política y sociedad en José Ortega y Gasset. En torno a "Vieja y nueva política". Anthropos: Barcelona, 1997, pp. 211-219.

CAMÓN AZNAR, J. "Ortega ante el arte", en: Revista de Filosofía, no 60-61, 1957.

CAMPOMAR, M. "Los viajes de Ortega a la Argentina y la Institución Cultura Española", en: MOLINUEVO, J.L. (coord.), Ortega y la Argentina. México: F.C.E., 1997, pp. 119-149.

CARPINTERO, H. "Ortega y sus complementarios", en: Revista de Occidente, $\mathrm{n}^{\circ}$ 192, 1997, pp. 59-77.

CARVAJAL, J. 'La autodisolución de la vieja política en Ortega", en: LÓPEZ DE LA VIEJA, Ma. T. (Ed.), Política y sociedad en José Ortega y Gasset. En torno a "Vieja y nueva política". Anthropos: Barcelona, 1997, pp. 195-210.

CASCARD, A. La rebelión de las masas: la crítica de Ortega a la modernidad", en: RESINA, J.R. Mythopoesis: literatura, totalidad, ideología. Barcelona: Anthropos, 1994, pp. 213-238

CASTRO FLÓREZ, F. 'La estética española en el siglo XX (Menéndez Pelayo, Ortega y Gasset, D'Ors, Gómez de la Serna, Bergamín y María Zambrano)", en: GIVONE, S. Historia de la estética. Madrid: Tecnos, 1990, pp. 215-267.

CASTRO FLÓREZ, F. 'Las derivas de la irrealidad: episodios del sujeto", en: Revista de Occidente, $\mathrm{n}^{\mathrm{o}} 168,1995$, pp. 61-74. 
CAVANA, M ${ }^{\mathrm{a}}$ L. Der Konflikt zwischen dem Begriff des Individuums und der Geschlechtertheorie bei Georg Simmel und José Ortega y Gasset. Pfaffenweiler: Centaurus, 1991.

CEREZO GALÁN, P. "Ideología y mito en España invertebrada", en: LÓPEZ DE LA VIEJA, Ma T. (Ed.), Política de la vitalidad. España invertebrada de José Ortega y Gasset. Madrid: Tecnos, 1996, pp. 115-131.

CEREZO GALÁN, P. "Experimentos de nueva España", en: LÓPEZ DE LA VIEJA, M". T. (Ed.), Política y sociedad en José Ortega y Gasset. En torno a "Vieja y nueva política". Anthropos: Barcelona, 1997, pp. 101-120.

CEREZO GALÁN, P. "De la crisis de la razón a la razón histórica", en: VV.AA. Historia, Literatura y Pensamiento. Estudios en homenaje a María Dolores Gómez. Molleda. Salamanca: Universidad/Narcea, 1990, pp. 307-343.

CEREZO GALÁN, P. "Meditaciones del Quijote o el estilo del héroe", en: MOLINUEVO, J.L. (coord.), Ortega y la argentina. México: F.C.E., 1997, pp. 27-48

CEREZO GALÁN, P. "Ortega y la generación de 1914: un proyecto de ilustración", en: Revista de Occidente, $\mathrm{n}^{\circ}$ 156, 1994, 5-33.

CEREZO GALÁN, P. La voluntad de aventura. Aproximamiento crítico al pensamiento de Ortega y Gasset. Barcelona: Ariel, 1984.

CHAMIZO DOMÍNGUEZ, P.J. "La teoría orteguiana de la metáfora", en: Actas del VI seminario de historia de la filosofía española e iberoamericana. Salamanca, 1990, pp. 463469.

CSEJTEI, D. 'El cartesianismo de la vida: la influencia de Descartes sobre la filosofía madura de Ortega y Gasset", en: Teorema, vol. 14, n 1, 1996, pp. 87-104.

CUESTA ABAD, J.M". "Ausencias platónicas: una hermenéutica de lo siniestro en Ortega", en: Revista de Occidente, no 168, 1995, pp. 101-116.

CURTIUS, E. R. 'Ortega y Gasset (I: 1924; II: 1949)", en: CURTIUS, E.R. Ensayos críticos acerca de la literatura europea. Madrid: Visor, 1989, pp. 219-244.

DELGADO GAL, A. 'El valor de la retórica en Ortega", en: Teorema, vol. XIII / 3-4, 1983, pp. 607-617.

DIAZ, E. Los viejos maestros: la reconstrucción de la razón. Madrid: Alianza, 1994.

DOBSON, A. An Introduction to the Politics and Philosophy of José Ortega y Gasset. Cambridge Univ. Press, 1989.

DUJOVNE, L. La concepción de la historia en la obra de Ortega y Gasset. Buenos Aires: Rueda, 1968.

DURÁN, M. (Ed.), Ortega, hoy. Xalapa: Universidad Veracruzana, 1985.

DUST, P. (Ed.), Ortega y Gasset and the Question of Modernity. Minneapolis: Prisma, 1989.

DUST, P. 'Ortega y el papel de la cultura en la crisis de la tecnología contemporánea", en: Revista de Occidente, no 96, 1989, pp. 5-26.

DUST, P. "Ortega y Gasset y la destrucción del libro (hacia una hermenéutica del discurso orteguiano)", en: Revista de Occidente, no 120, 1991, pp. 83-95.

ECHEVERRÍA, J. "Ortega como estudioso de Aristóteles y Leibniz", en: Teorema, vol. XIII / 3-4, 1983, pp. 431-445.

ELORZA, A. La razón y la sombra. Una lectura política de Ortega y Gasset. Barcelona: Anagrama, 1984.

FERNÁNDEZ, A.M. Teoría de la novela en Unamuno, Ortega y Cortázar. Madrid: Pliegos, 1991. 
FERNÁNDEZ, P.H. La paradoja en Ortega y Gasset. Madrid: Porrúa, 1985.

FERNÁNDEZ, P.H. "Ortega y la paradoja: teoría y tipología", en: Revista de Occidente, $\mathrm{n}^{\circ}$ 60, 1986, pp. 27-48.

FERNAUD, P. 'Ortega y Heidegger", en: Revista de Occidente, $\mathrm{n}^{\circ} 115,1990$, pp. 133136.

FERRATER MORA, J. La filosofía de Ortega y Gasset. Buenos Aires: Sur, 1958.

FERRATER MORA, J. Ortega y Gasset: etapas de una filosofía. Barcelona: Seix Barral, 1973.

FERRER SANTOS, U. "Notas sobre la razón histórica: dos intentos de fundamentación", en: Anuario filosófico. Universidad de Navarra, Volumen XVIII, 1985, $\mathrm{n}^{\circ} 1$, pp. 157-168.

FLÓREZ MIGUEL, C. "Arqueología y hermenéutica en Ortega", en: VV.AA. Historia, Literatura y Pensamiento. Estudios en homenaje a María Dolores Gómez Molleda. Salamanca: Universidad/Narcea, 1990, pp. 439-448.

FLÓREZ MIGUEL, C. "Política y filosofía en Ortega. Teoría orteguiana de la Modernidad", en: LÓPEZ DE LA VIEJA, M ${ }^{\text {a }}$ T. Política y sociedad en José Ortega y Gasset. En torno a "Vieja y nueva política". Anthropos: Barcelona, 1997, 121-140.

FLÓREZ MIGUEL, C. "Ontología de la vida, razón histórica y nacionalismo", en: LÓPEZ DE LA VIEJA, M ${ }^{\mathrm{a}}$ T. (Ed.), Política de la vitalidad. España invertebrada de José Ortega y Gasset. Madrid: Tecnos, 1996, pp. 95-113.

FLÓREZ MIGUEL, C. "Fenomenología y ciencias sociales. Schütz y Ortega", en: Filosofía y sociedad e Incomunicación. Murcia: Universidad, 1983, pp. 109-130.

FLÓREZ MIGUEL, C. "Racionalidad y teoría de la acción en Ortega", en: Studia Zamorensia, $\mathrm{n}^{\circ}$ 4, 1983, pp. 283-301.

FLÓREZ MIGUEL, C. Génesis de la razón histórica. Salamanca: Universidad, 1983.

FLÓREZ, R. "Dos modos de pensamiento: Ortega y Heidegger", en: Cuadernos de Pensamiento, $\mathrm{n}^{\circ}$ 4, 1989, pp. 39-55.

FONCK, B. 'Ortega y Gasset, la presse et le pouvoir sous la dictadure de Primo de Rivera", en: Presse et pouvoir en Espagne: 1868-1975. Madrid: Casa de Velázquez, 1996, pp. 119-135.

FONCK, B. 'Un análisis de España invertebrada en su circunstancia", en: LÓPEZ DE LA VIEJA, M ${ }^{a}$ T. (Ed.), Política de la vitalidad. España invertebrada de José Ortega y Gasset. Madrid: Tecnos, 1996, pp. 63-74.

FOX, I. 'Ortega y Gasset y la manera española de mirar las cosas", en: FOX, I. La invención de España: nacionalismo liberal e identidad nacional. Madrid: Cátedra, 1997, pp. 138-151.

FUSI, J.P. "La cultura de la transición", en: Revista de Occidente, no 122-123, 1991.

GAOS, J. Sobre Ortega y Gasset y otros trabajos de historia de las ideas en España y la América española. México: Imprenta Universitaria, 1957.

GARAGORRI, P. Introducción a Ortega. Madrid: Alianza, 1970.

GARAGORRI, P. Unamuno, Ortega, Zubiri, en la filosofía española. Madrid: Plenitud, 1968.

GARCÍA ALONSO, R. El náufrago ilusionado. La estética de José Ortega y Gasset. Madrid: Siglo XXI, 1997.

GARCÍA ALONSO, R. 'En torno a Ortega y la estética", en: Actas de las II. Jornadas de Hispanismo filosófico. Oviedo: El Basilisco, 1996, pp. 60-61. 
GARCÍA BACCA, D. "Ortega y Gasset o el poder vitamínico de la filosofía", en: GARCÍA BACCA, D. Nueve grandes filósofos contemporáneos y sus temas. Barcelona: Anthropos, 1990, pp. 291-396.

GARCÍA GUAL, C. "De cómo camino de Leibniz Ortega volvió a Aristóteles", en: Revista de Occidente, $\mathrm{n}^{\circ}$ 192, 1997, pp. 78-91.

GARCÍA MAURIÑO, J.M. y FERNÁNDEZ REVUELTA, J.A. Ortega y Gasset: el raciovitalismo. Madrid: Alhambra, 1992.

GARRIGUES, E. 'Ortega y Alemania", en: Revista de Occidente, 132, 1992, pp. 128138.

GIL VILLEGAS, F. Los profetas y el mesías. Lukács y Ortega como precursores de Heidegger en el Zeitgeist de la modernidad. México: F.C.E., 1996.

GÓMEZ DE LIAÑO, I. "Forster, Ortega, Baroja", en: Revista de Occidente, no 192, 1997, pp. 92-116.

GÓMEZ DE LIAÑO, I. "La deshumanización del arte, 1925-1989", en: Revista de Occidente, $\mathrm{n}^{\circ}$ 96, 1989, pp. 57-79.

GRACIA, J. "Formas del estilo en el ensayo español de hoy", en: Revista de Occidente, no 192, 1997, pp. 117-132.

GRAHAM, J.T. A pragmatist philosophy of life in Ortega y Gasset. Columbia: U. of Missouri P., 1994.

GRAHAM, J.T. Theory of history in Ortega y Gasset: the dawn of historical reason. Columbia: U. of Missoury, 1996.

GRAY, R. José Ortega y Gasset. El imperativo de la modernidad. Madrid: Espasa Calpe, 1994.

GUIA, W. Nazioni ed Europa nell'età delle masse: sul pensiero politico di Ortega y Gasset. Pisa-Roma: Instituti editoriali e poligrafici, 1996.

GULLÓN, R. 'Ortega y la teoría de la novela", en: Letras de Deusto, n 19, 1989, pp. 105-121.

GUY, A. Ortega y Gasset, crítico de Aristóteles. Madrid: Espasa Calpe, 1968.

GUY, A. "Ortega y Bergson", en: Revista de filosofía, 2a serie, VII, 1984, pp. 5-19.

HEIDEGGER, M. "Heidegger y sus alumnos judios (Dos escritos inéditos a Ortega y Gasset", en: Revista de Occidente, n ${ }^{\circ}$ 96, 1989, pp. 103-107.

HENARES, I. "Las ideas estéticas en la Revista de Occidente (1923-1936): apunte crítico", en: Cuadernos de arte de la Universidad de Granada, vol 23, 1992, pp. 517-534.

HERMIDA, P. "El mundo incuestionado (Ortega y Schütz)", en: Revista de Filosofía: 9:15, 1996, pp. 67-95.

HERNÁNDEZ SAAVEDRA, M.A. "La política en su arquetipo. Los modelos ejemplares de España invertebrada", en: LÓPEZ DE LA VIEJA, $\mathrm{M}^{\mathrm{a}} \mathrm{T}$. (Ed.), Política de la vitalidad. España invertebrada de José Ortega y Gasset. Madrid: Tecnos, 1996, pp. 151159.

HERNÁNDEZ SÁNCHEZ, D. 'La teoría del ensayismo: Musil y Ortega", en: Volubilis, nº 5, 1997, pp. 42-56.

HERNÁNDEZ SÁNCHEZ, D. "La ambigüedad del símbolo. Sobre la forma de arte simbólica en la estética de Hegel", en: Daimon. Revista de filosofía, no 14, 1997, pp. 59-68.

HERNÁNDEZ SÁNCHEZ, D. "El silencio y el prójimo. La antropología de Ortega", en: V.V.A.A. Pensar lo humano. Madrid. Iberoamericana, 1997, pp. 63-67.

HOLMES, O. S. Human Reality and the Social World. Ortega's Philosophy of History. Amherst: University of Massachusetts Press, 1975. 
HULL, R. "Ortega y Gasset, phenomenology and Quixote", en: Analecta Husserliana, 41, 1993, pp. 179-190.

INFANTINO, L. Ortega y Gasset. Una introduzione. Roma: Armando editore, 1990.

JIMÉNEZ MORENO, L. "Conciencia de la exigencia personal y de las relaciones sociales. Reflexiones sobre La rebelión de las masas", en: Anales del seminario de historia de la filosofía, V, 1985, pp. 23-53.

JIMÉNEZ MORENO, L. Práctica del saber en filósofos españoles (Gracián, Aranguren, Ortega, d'Ors, Tierno Galván). Barcelona: Anthropos, 1995.

JIMÉNEZ, A.M. 'Génesis de la razón histórica en Ortega y Gasset", en: ABELLÁN, J.L. (coord.), El reto europeo: identidades culturales en el cambio de siglo. Madrid: Trotta, 1994, pp. 299-306.

JIMÉNEZ, J. "El arco de la estética", en: Revista de Occidente, no 168, 1995, pp. 5-22.

JIMÉNEZ, J. (Ed.), El nuevo espectador. Madrid: Fundación Argentaria - Visor Dis., 1998.

KAPLANOV, R. "La idea de Europa en la obra de José Ortega y Gasset", en: VV.AA. España y el mundo. Moscú: Nauka, 1990, pp. 124-132.

KOLPATZIK, A. Technikphilosophische Betrachtungen im Werk Jose Ortega y Gassets. Hamburg: Kovac, 1996.

LAFUENTE FERRARI, E. Ortega y las artes visuales. Madrid: Revista de Occidente, 1974.

LASAGA MEDINA, J. Ortega y Gasset (1883-1955). Madrid: Ediciones del Orto, 1997.

LASAGA MEDINA, J. 'Del deber a la ilusión. (Notas para una ética de Ortega)", en: Isegoría, $\mathrm{n}^{\circ}$ 10, 1994, pp. 158-166.

LASAGA MEDINA, J. 'Don Juan o el héroe del esfuerzo inútil (Sobre el Don Juan de Ortega y Gasset)", en: Revista de Occidente, n 120, pp. 108-126.

LÁZARO CARRETER, F. "Poéticas: Ortega y Gasset. Esbozo de su poética: Ortega y la metáfora", en: LÁZARO CARRETER, F. De poética y poéticas. Madrid: Cátedra, 1990, pp. 95-128.

LÓPEZ DE LA VIEJA, M․ T. (Ed.), Política y sociedad en José Ortega y Gasset. En torno a "Vieja y nueva política". Anthropos: Barcelona, 1997.

LÓPEZ DE LA VIEJA, M. T. "Nacionalidad y cuerpo político", en: LÓPEZ DE LA VIEJA, Ma T. (Ed.), Política de la vitalidad. España invertebrada de José Ortega y Gasset. Madrid: Tecnos, 1996, pp. 133-149.

LÓPEZ FRÍAS, F. Ética y política. En torno al pensamiento de J. Ortega y Gasset. Barcelona: Publicaciones Universitarias, 1985.

LÓPEZ DE LA VIEJA, Ma.T. (Ed.), Política de la vitalidad. España invertebrada de José Ortega y Gasset. Madrid: Tecnos, 1996.

LÓPEZ DE LA VIEJA, Mª T. 'Élites sin privilegio", en: LÓPEZ DE LA VIEJA, Ma ${ }^{\mathrm{a}}$ T. (Ed.), Política y sociedad en José Ortega y Gasset. En torno a "Vieja y nueva política". Anthropos: Barcelona, 1997, pp. 141-166.

LÓPEZ FRÍAS, F. "Ortega y Gasset. On being liberal in Spain", en: Analecta Husserliana, $\mathrm{n}^{\circ} 29,1990$, pp. 149-166.

LORENZO ALQUEZAR, R. "Ortega y Gasset y los inicios de la vanguardia artística española", en: Endoxa. Series filosóficas, n 1, 1993, pp. 309-340.

LUBAR, R.S. 'Ortega y Greenberg frente al arte moderno y la cultura de masas", en: Revista de Occidente, $\mathrm{n}^{\circ}$ 168, 1995, pp. 23-41. 
LYNCH, E. "La perspectiva y la crítica del conocimiento (Sobre Ortega y Gasset)", en: LYNCH, E. El merodeador. Tentativas sobre filosofía y literatura. Barcelona: Anagrama, 1990, pp. 53-76

MARÍAS, J. Ortega. Circunstancia y vocación. Madrid: Revista de Occidente, 1960.

MARÍAS, J. Las trayectorias. Alianza: Madrid, 1983.

MARÍAS, J. El lugar del peligro, en: Obras de Julián Marías. Madrid: Revista de Occidente, 1982, Volumen IX.

MARÍAS, J. La Escuela de Madrid, estudios de filosofía española. Buenos Aires: Emecé, 1959.

MARÍAS, J. Ortega y tres antípodas: un ejemplo de intriga intelectual. Madrid: Revista de Occidente, 1960.

MARÍAS, J. Ortega ante Goethe. Madrid: Taurus, 1961.

MARÍAS, J. Acerca de Ortega. Madrid: Espasa-Calpe, 1991.

MARICHAL, J. El secreto de España. Madrid: Taurus, 1996.

MARICHAL, J. Teoría e historia del ensayismo hispánico. Madrid: Alianza, 1974.

MARICHAL, J. Los intelectuales y la política (Unamuno, Ortega, Azaña y Negrín). Madrid: Residencia de Estudiantes, 1990.

MÁRQUEZ PADORNO, M. 'Polémica en torno a un prólogo. Araquistáin y la cuarta edición de España invertebrada", en: LÓPEZ DE LA VIEJA, M ${ }^{\mathrm{a}}$ T. (Ed.), Política de la vitalidad. España invertebrada de José Ortega y Gasset. Madrid: Tecnos, 1996, pp. 188193.

MARTÍN, F. J. Ortega contro Heidegger. Romanzo e poesia", en: Rivista di Estetica, 48, anno XXXIV, XXXV, 94-95, pp. 41-58.

MARTÍN, M. José Ortega y Gasset. Madrid: Rueda, 1996.

MARVAL McNAIR, N. de, (Ed.), José Ortega y Gasset: Proceedings of the "Espectador Universal", International Interdisciplinary Conference. New York: Greenwood, 1987.

MASSA RINCÓN, F. J. El concepto de «naturaleza» en Ortega y Gasset. Historia de una inadaptación. Barcelona: Editeuro, 1996.

MATE, R. "De la invertebración de España al ocaso de Europa", en: LÓPEZ DE LA VIEJA, M ${ }^{\mathrm{a}}$ T. (Ed.), Política de la vitalidad. España invertebrada de José Ortega y Gasset. Madrid: Tecnos, 1996, pp. 173-186.

McCLINTOCK, R. O. 'Ortega o el estilista como educador", en: Revista de Occidente, $\mathrm{n}^{\mathrm{o}} 75$, junio 1969 , pp. 267-292.

MEDIN, T. Ortega y Gasset en la cultura hispanoamericana. México: F.C.E., 1994.

MENÉNDEZ ALZAMORA, M. "España invertebrada en el devenir político de José Ortega y Gasset", en: LÓPEZ DE LA VIEJA, Ma T. (Ed.), Política de la vitalidad. España invertebrada de José Ortega y Gasset. Madrid: Tecnos, 1996, pp. 161-169.

MENÉNDEZ ALZAMORA, M. "Vieja y nueva política y el semanario España en el nacimiento de la Generación del 14", en: LÓPEZ DE LA VIEJA, Mª T. (Ed.), Política y sociedad en José Ortega y Gasset. En torno a "Vieja y nueva política". Anthropos: Barcelona, 1997, pp. 185-194.

MEREGALLI, F. Introduzione a Ortega y Gasset. Roma: Laterza, 1995.

MEREGALLI, F. "Ortega en Venecia", en: El País, 5-I-1996, p. 14.

MERMALL, Th. "Abstracto/concreto: clave retórica para la comprensión de Ortega", en: Revista Canadiense de Estudios Hispánicos, Vol. XXI, 1, 1996, pp. 181-190. 
MERMALL, Th. "El paisaje pedagógico de Ortega y Gasset", en: Aporia, $\mathrm{n}^{\mathrm{o}}$ 21-24, 1983/4, pp. 109-123.

MERMALL, Th. "Entre epistema y doxa: el trasfondo retórico de la razón vital", en: Revista Hispánica Moderna, año XLVII, 1994, pp. 72-85.

MERMALL, Th. "How to do things with rhetoric: the uses of argument in Larra, Unamuno and Ortega", en: Siglo XX/20th. Century, vol. 11, no 1/2, 1993, pp. 155-179.

MERMALL, Th. 'Un postmoderno inteligible: en torno al estilo filosófico de Ortega y Gasset", en: Revista de Occidente, 192, 1997, pp. 47-58.

MOLINUEVO, J.L. "Fichte y Ortega (II). Héroes o ciudadanos. El mito de Don Quijote", en: Daimon. Revista de Filosofía, no 9, 1994, pp. 341-358.

MOLINUEVO, J.L. "La deshumanización del arte en clave de futuro pasado", en: Revista de Occidente, $\mathrm{n}^{\circ}$ 168, 1995, pp. 43-60.

MOLINUEVO, J.L. (Coord.), Ortega y la argentina. México: F.C.E., 1997.

MOLINUEVO, J.L. "Ortega y la Argentina: la modernidad alternativa", en: MOLINUEVO, J.L. (coord.), Ortega y la argentina. México: F.C.E., 1997, pp. 95-109.

MOLINUEVO, J.L. 'Cohen y el pueblo de los pensadores y poetas", en: Volubilis, $\mathrm{n}^{\circ} 4$, 1996, pp. 22-34.

MOLINUEVO, J.L. La crisis del socialismo ético", en: LÓPEZ DE LA VIEJA, Ma. T. (Ed.), Política y sociedad en José Ortega y Gasset. En torno a "Vieja y nueva política". Anthropos: Barcelona, 1997, pp. 23-50.

MOLINUEVO, J.L. Higiene de los (propios) ideales", en: LÓPEZ DE LA VIEJA, Ma T. (Ed.), Política de la vitalidad. España invertebrada de José Ortega y Gasset. Madrid: Tecnos, 1996, pp. 77-94.

MOLINUEVO, J.L. "Ortega sin Weimar (1914-1918)", en: Revista de Occidente, ${ }^{\circ}$ 156, 1994, pp. 55-76.

MOLINUEVO, J.L. El idealismo de Ortega. Madrid: Narcea, 1984.

MOLINUEVO, J.L. "Salvar a Fichte en Ortega", en: Azafea, III, 1990, pp. 103-150.

MOLINUEVO, J.L. "Literatura y filosofía en Ortega y Gasset", en: Revista de Occidente, $\mathrm{n}^{\circ}$ 132, 1992, pp. 69-94.

MORALES, A. "Vieja y nueva política. La circunstancia histórica", en: LÓPEZ DE LA VIEJA, Ma. T. (Ed.), Política y sociedad en José Ortega y Gasset. En torno a "Vieja y nueva política". Anthropos: Barcelona, 1997, pp. 69-100.

MORALES, A. 'El contexto historiográfico de España invertebrada: La "interpretación castellana" de la Historia de España", en: LÓPEZ DE LA VIEJA, M ${ }^{\mathrm{a}} \mathrm{T}$. (Ed.), Política de la vitalidad. España invertebrada de José Ortega y Gasset. Madrid: Tecnos, 1996, pp. 3562.

MORÁN, G. El maestro en el erial. Ortega y Gasset y la cultura del franquismo. Barcelona: Tusquets, 1998.

MORENO HERNÁNDEZ, C. "Ortega, el ensayo y el hipertexto", en: Revista de Occidente, $\mathrm{n}^{\circ}$ 205, mayo 1998, pp. 55-74.

MORÓN ARROYO, C. El sistema de Ortega y Gasset. Madrid: Alcalá, 1968.

MOSCOVICI, S. La era de las masas. México: F.C.E., 1985.

MUGUERZA, J. 'La incierta aurora de la razón histórica", en: MUGUERZA, J. Desde la perplejidad. Ensayos sobre la ética, la razón y el diálogo. Madrid: F.C.E., 1990, pp. 477-490.

NAVARRO CORDÓN, J.M. Meditación del arte", en: Revista de Occidente, $\mathrm{n}^{\circ}$ 156, 1994, 87-101. 
OLASO, E. de, "Ríos de ideas en cauces de creencias", en: MOLINUEVO, J.L. (coord.), Ortega y la argentina. México: F.C.E., 1997, pp. 13-25.

ORRINGER, N. 'La rebelión de las masas como antropología", en: Aporía, n 12, 1981, pp. 3-20.

ORRINGER, N. Ortega y sus fuentes germánicas. Madrid: Gredos, 1979.

ORTEGA, M. Ortega y Gasset, mi padre. Planeta: Madrid, 1983.

ORTEGA, S. José Ortega y Gasset: Imágenes de una vida 1883-1955. Madrid: Ministerio de Educación y Ciencia / Fundación José Ortega y Gasset, 1983.

OUIMETTE, V. José Ortega y Gasset. Twayne: New York, 1982.

OUIMETTE, V. "Liberalismo e democrazia in Ortega y Gasset", en: Mondoperario, $\mathrm{n}^{\circ}$ 42, 1989, pp. 100-107.

PAREDES MARTÍN, M ${ }^{a}$ C. (Ed.) El hombre y su medio. Perspectivas ecológicas desde Ortega y Gasset. Salamanca: Universidad, 1998.

PAREDES MARTÍN, M ${ }^{\mathrm{a}}$ C. (Ed.) Ortega y Gasset. Pensamiento y conciencia de crisis. Salamanca: Universidad, 1994.

PASCUAL, J. A. 'Ortega entre literatos y lingüistas", en: LÓPEZ DE LA VIEJA, Ma. T. (Ed.), Política y sociedad en José Ortega y Gasset. En torno a "Vieja y nueva política". Anthropos: Barcelona, 1997, pp. 51-68.

PIERRE, Ch. 'Ortega en el ámbito cultural europeo", en: Revista de Occidente, $\mathrm{n}^{\circ} 120$, 1991, pp. 59-72.

PINTOR RAMOS, A. 'Heidegger en la filosofía española: la eficacia de Heidegger en las filosofías de Ortega y Zubiri", en: Naturaleza y Gracia, vol. 38, n 1-2, 1991, pp. 153187.

POSER, H. "Ortega: una reflexión sobre los principios y el nuevo modo de pensar", en: Revista de Occidente, $\mathrm{n}^{\circ}$ 132, 1992, pp. 95-105.

PRATA, L. M. "Superación del idealimo en España invertebrada", en: LÓPEZ DE LA VIEJA, Ma T. (Ed.), Política de la vitalidad. España invertebrada de José Ortega y Gasset. Madrid: Tecnos, 1996, pp. 205-210.

PRESAS, M. "El hombre, ese eterno novelista", en: MOLINUEVO, J.L. (coord.), Ortega y la argentina. México: F.C.E., 1997, pp. 109-117.

PUCCI, D. "Ortega's approach to husserlian phenomenology", en: Analecta Husserliana, 36, 1991, pp. 387-394.

RAIMONDI, E. 'Ortega, la novela, Manzoni", en: Revista de Occidente, ${ }^{\circ}{ }^{\circ} 168,1995$, pp. 93-100.

RALEY, H. "Literature as Philosophic Analogue in José Ortega y Gasset", en: VV.AA. Estudios en homenaje a Enrique Ruiz-Fornells. Erie, Asociación de Licenciados y Doctores Españoles en Estados Unidos, 1990, pp. 519-525.

RALEY, H. Ortega y Gasset, filósofo de la unidad europea. Madrid: Revista de Occidente, 1977.

RALEY, H. "Phenomenological life. A new look at the philosophical enterprise in Ortega y Gasset", en: Analecta Husserliana, n² 29, 1990, pp. 93-104.

REDONDO, G. Las empresas políticas de Ortega y Gasset, I y II . Madrid: Rialp, 1970.

REGALADO GARCÍA, A. El laberinto de la razón: Ortega y Heidegger. Madrid: Alianza, 1990.

ROBLES, L. "A propósito de tres cartas de María Zambrano a Ortega", en: Philosophica Malacitana, vol. IV, 1991, pp. 231-239. 
RODRÍGUEZ HUÉSCAR, A. La innovación metafísica de Ortega. Madrid: Ministerio de Educación y Ciencia, 1982.

RODRÍGUEZ HUÉSCAR, A. Perspectiva y verdad. El problema de la verdad en Ortega. Madrid: Revista de Occidente, 1966.

RODRÍGUEZ HUÉSCAR, A. Semblanza de Ortega. Barcelona: Anthropos, 1994.

RODRÍGUEZ HUÉSCAR, A. "Reflexiones sobre Ortega y la política", en: Revista de Occidente, $\mathrm{n}^{\circ} 72,1987$, pp. 5-28.

ROJAS BEZ, J. 'Visión de América en Ortega y Gasset", en: Comunicaçôes filosóficas, vol. 2., n ${ }^{\circ}$ 1, 1991, pp. 9-26.

ROMANO, V. José Ortega y Gasset publicista. Madrid: Akal, 1976.

ROSALES, J. M.. 'Sobre política y reformismo cívico. A partir de Ortega", en: LÓPEZ DE LA VIEJA, M.. T. (Ed.), Política y sociedad en José Ortega y Gasset. En torno a "Vieja y nueva política". Anthropos: Barcelona, 1997, pp. 167-184.

RUPP, St. 'Ortega, Heidegger, and beginning again in Don Quixote", en: Comparative Literature Studies, vol. 28, no 1, 1991, pp. 36-50.

SALAS FERNÁNDEZ, T. "Sobre el concepto de novela deshumanizada: aportación a la teoría orteguiana de la novela", en: Revista Analecta Malacitana, 1992, pp. 82-85.

SALAS, J. de, Razón y legitimidad en Leibniz. Una interpretación desde Ortega. Madrid: Tecnos, 1994.

SALAS, J. de, "De Meditaciones del Quijote a España invertebrada: la imagen de España en Ortega", en: Memoria Académica 1993-94. Madrid: Instituto Fe y Secularidad, 1994, pp. 41-48.

SALAS, J. de, "Sobre la génesis de las Meditaciones del Quijote", en: Revista de Occidente, $\mathrm{n}^{\circ}$ 156, 1994, 77-86.

SALAS, J. de, "Ortega lector de Nietzsche: las Meditaciones del Quijote frente a las Meditaciones intempestivas II", en: De orbis Hispani Linguis Literis Historia moribus. Frankfurt: Domus Editoria Europaea, 1994, pp. 877-904.

SALMERÓN, F. Las mocedades de Ortega. México: Universidad Autónoma, 1983.

SAN MARTÍN, J. "Ortega, filosofía alemana y postmodernidad", en: Agora, no 10, 1991, pp. 13-34.

SAN MARTÍN, J. Ensayos sobre Ortega. Madrid: U.N.E.D., 1994.

SAN MARTÍN, J. (ed.), Ortega y la fenomenología. Actas de la $1^{a}$ Semana Española de Fenomenología. Madrid: U.N.E.D., 1982.

SÁNCHEZ CÁMARA, I. La teoría de la minoría selecta en el pensamiento de Ortega. Madrid: Tecnos, 1986.

SÁNCHEZ CÁMARA, I. "El liberalismo de Ortega y Gasset", en: Revista de Occidente, $\mathrm{n}^{\circ}$ 108, 1990, pp. 71-84.

SÁNCHEZ CÁMARA, I. 'El intelectual y la política en la obra de Ortega", en: Revista de Occidente, $\mathrm{n}^{\circ}$ 72, 1987, pp. 98-112.

SÁNCHEZ DE LA YNCERA, I. "La sociología ante el problema generacional. Anotaciones al trabajo de Karl Mannheim", en: Revista Española de Investigaciones Sociológicas, 62, 1993.

SANTERVAS, R. "Maeztu y Ortega. Dos formas de regeneracionismo: El poder y la ciencia", en: Revista de Occidente, n ${ }^{\circ}$ 66, 1989, pp. 80-102.

SAVIGNANO, A. Introduzione a Ortega y Gasset. Roma: Laterza, 1996.

SENABRE, R. "Ortega y Gasset y la Generación del 27", en: Cuadernos Hispanoamericanos, n 514-515, 1993, pp. 197-207. 
SENABRE, R. Lengua y estilo de Ortega y Gasset. Salamanca: Acta Salmanticensia, 1964.

SILVER, Ph. W. 'Ortega y la revertebración de España", en: LÓPEZ DE LA VIEJA, M. T. (Ed.), Política de la vitalidad. España invertebrada de José Ortega y Gasset. Madrid: Tecnos, 1996, pp. 17-33.

SOBEJANO, G. Nietzsche en España. Madrid: Gredos, 1967.

TUSSELL, J. Los intelectuales y la República. Madrid: Nerea, 1990.

TUTTLE, H. "Some issues in Ortega y Gasset's critique of Heidegger's doctrine of sein", en: Southwest Philosophical Studies, 1991, pp. 96-103.

TUTTLE, H. The Crowd is Untruth: The Existential Critique of Mass Society in the Thought of Kierkegaard, Nietzsche, Heidegger, and Ortega y Gasset. New York: Lang, 1996.

VAN REE, H. Ortega y el humanismo moderno: la conformación de los modelos de análisis cultural. Zaragoza: Universidad, 1997.

VIRGILI, C. "Malcolm Lowry y Ortega: el hombre como novelista de sí mismo", en: Revista de Occidente, $\mathrm{n}^{\circ}$ 96, 1989, pp. 45-56.

VV.AA. Ortega y su tiempo. Madrid: Ministerio de Cultura/Fundación José Ortega y Gasset, 1990.

VV.AA. Estudios sobre la creencia en Ortega. Madrid: Seminario de Estudios Orteguianos II, 1994.

VV.AA. A los 80 años de las "Meditaciones del Quijote" de Ortega. Una visión de España desde el Escorial. San Lorenzo de El Escorial: Concejalía de cultura, 1993. 